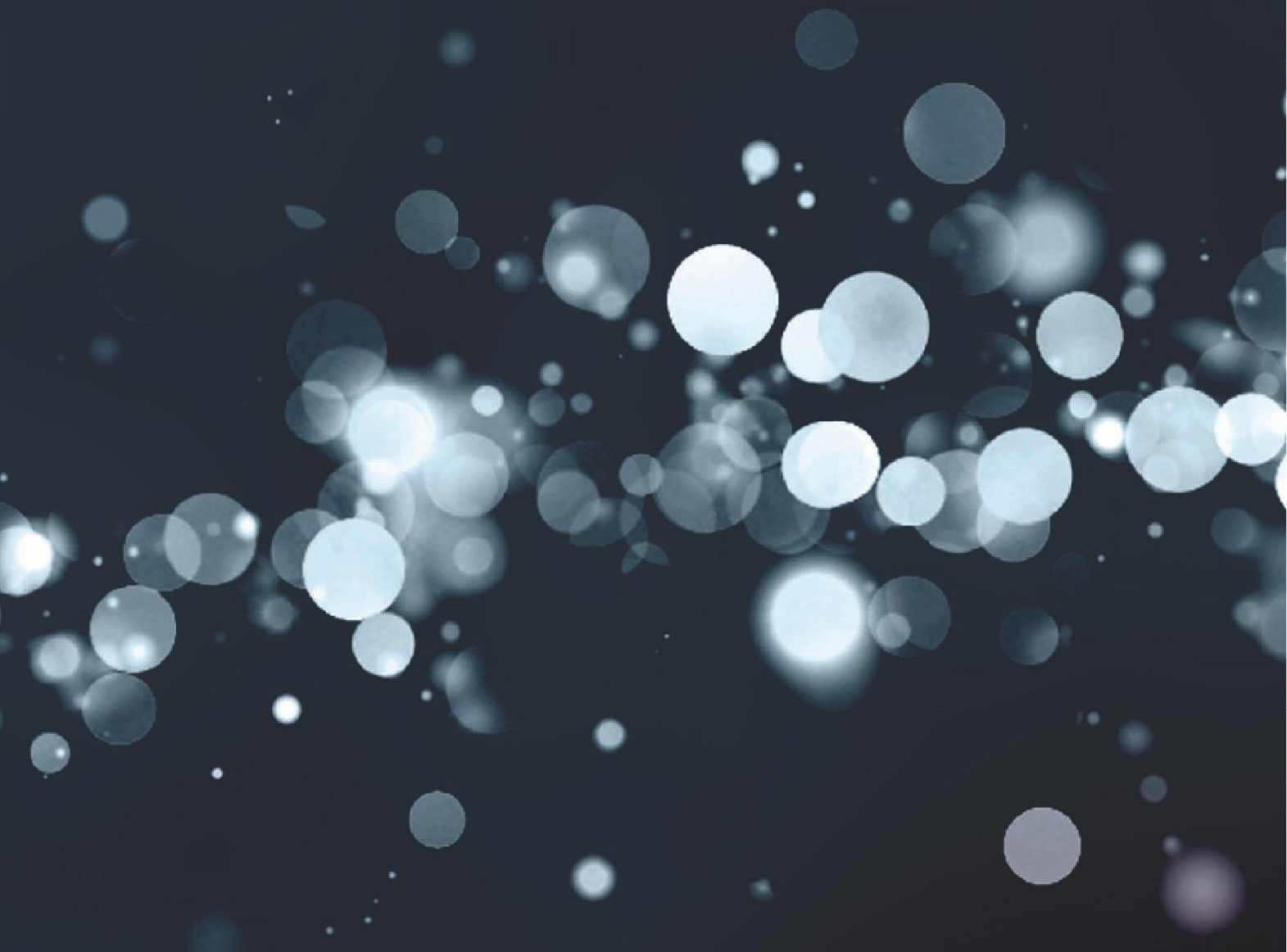

\title{
HYPER-CROSS-LINKED, HYBRID MEMBRANES VIA INTERFACIAL POLYMERIZATION
}

MICHIEL RAAIJMAKERS 



\section{HYPER-CROSS-LINKED, HYBRID MEMBRANES VIA INTERFACIAL POLYMERIZATION}




\section{Promotiecommissie:}

prof. dr. ir. J.W.M. Hilgenkamp (Voorzitter) Universiteit Twente

prof. dr. ir. Nieck E. Benes (Promotor) Universiteit Twente

prof. dr. ir. Arian Nijmeijer (Promotor) Universiteit Twente

prof. dr. Matthias Wessling

RWTH Aachen

dr. Anne Julbe

Institut Européen des Membranes

prof. dr. ir. Theo Dingemans

Technische Universiteit Delft

prof. dr. Jorge Gascon

Technische Universiteit Delft

dr. ir. Mark Hempenius

Universiteit Twente

prof. dr. ir. Jeroen Cornelissen

Universiteit Twente

Omslagontwerp door Inge Nahuis

Hyper-cross-linked, hybrid membranes via interfacial polymerization

ISBN: 978-90-365-3967-8

DOI: $10.3990 / 1.9789036539678$

URL: http://dx.doi.org/10.3990/1.9789036539678

Printed by: Ipskamp Drukkers, Enschede

(C) Copyright 2015 Michiel J.T. Raaijmakers 


\title{
HYPER-CROSS-LINKED, HYBRID MEMBRANES VIA INTERFACIAL POLYMERIZATION
}

\author{
PROEFSCHRIFT
}

\author{
ter verkrijging van \\ de graad van doctor aan de Universiteit Twente, \\ op gezag van de rector magnificus, \\ prof. dr. H. Brinksma, \\ volgens besluit van het College voor Promoties \\ in het openbaar te verdedigen \\ op vrijdag 2 oktober 2015 om 16:45 uur
}

door

Michiel Jozef Thomas Raaijmakers geboren op 11 mei 1987 te Geldrop, Nederland 
Dit proefschrift is goedgekeurd door de promotoren:

prof. dr. ir. Nieck E. Benes (Promotor)

prof. dr. ir. Arian Nijmeijer (Promotor) 

This work is financially supported by the University of Twente, Inorganic Membranes Chair, and the European Union's Seventh Framework Programme for research, technological development and demonstration under CARENA grant agreement no. 263007 


\section{Table of contents}

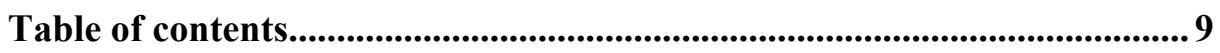

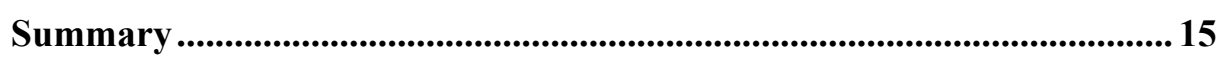

Samenvatting ........................................................................................................ 18

Chapter 1 Hybrid membranes via interfacial polymerization .................... 21

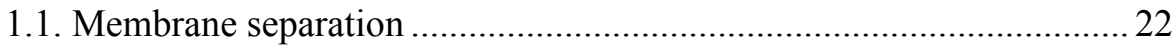

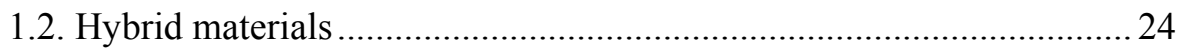

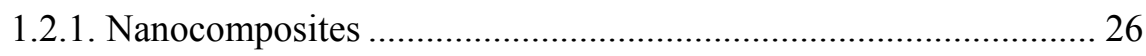

1.2.2. Covalent hybrid materials ............................................................. 27

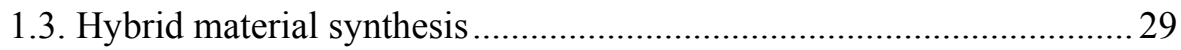

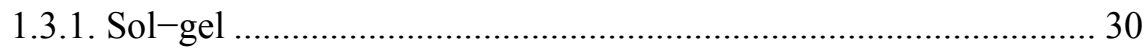

1.3.2. Step polymerization.................................................................. 30

1.4. Current trends in interfacial polymerization chemistry ......................... 31

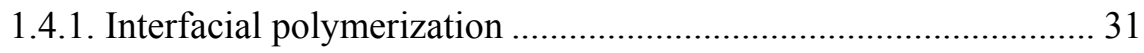

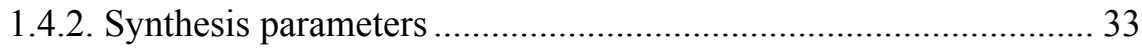

1.4.3. Monomer concentration, reactivity, and solubility....................... 34

1.4.4. Interfaces suitable for interfacial polymerization.......................... 37

1.4.5. Supported and free-standing layers via interfacial polymerization 38

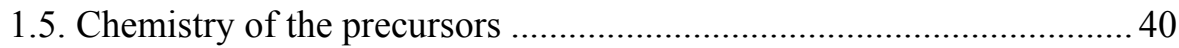

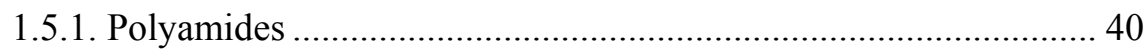

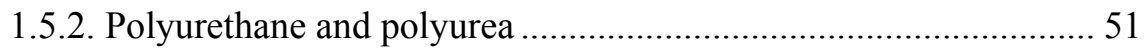

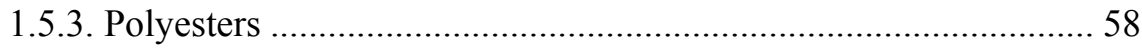

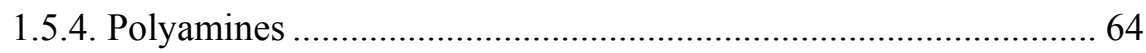

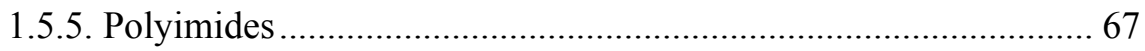

1.5.6. Conductive polymers..................................................................... 71

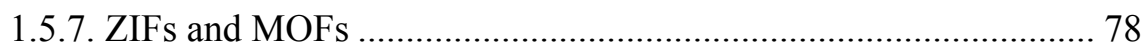

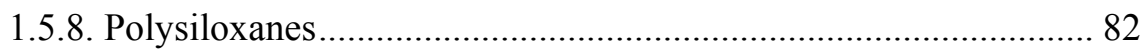




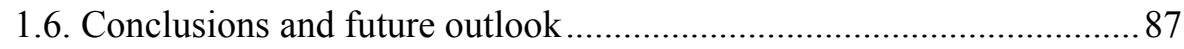

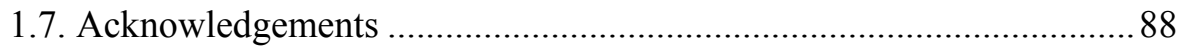

1.8. Thesis outline

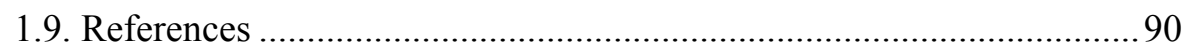

Chapter 2 Sieving of hot gases by hyper-cross-linked nanoscale-hybrid

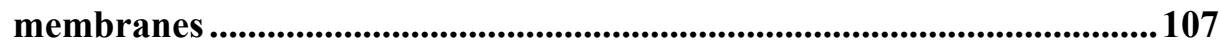

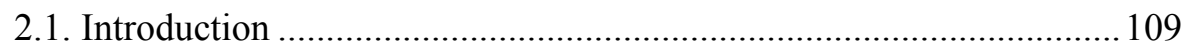

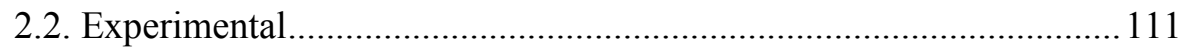

2.2.1. Synthesis of poly(POSS-imide)s via interfacial polymerization. 111

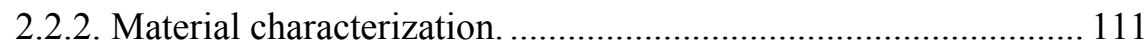

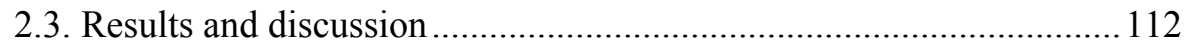

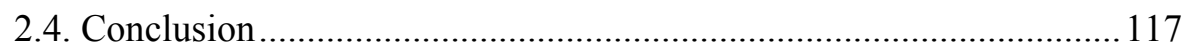

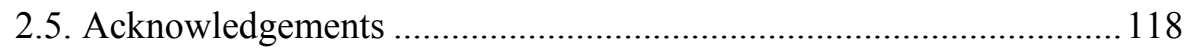

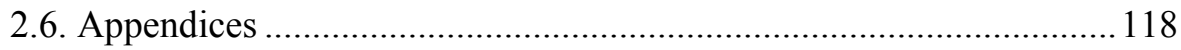

2.6.1. Poly(POSS-imide) synthesis....................................................... 118

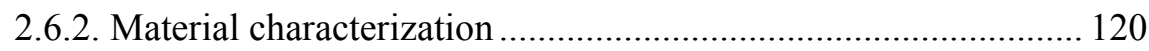

2.6.3. Membrane single gas permeation experiments........................... 126

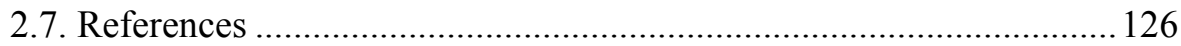

Chapter 3 Hybrid poly(POSS-imide)s with tailored inter-cage spacing for sieving of hot gases.................................................................................................129

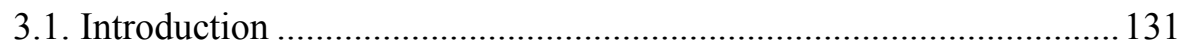

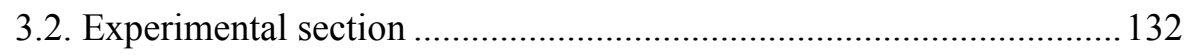

3.2.1. Synthesis of poly(POSS-imide)s via interfacial polymerization. 132

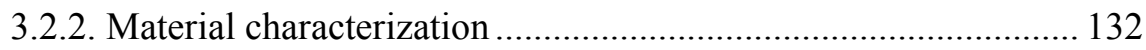

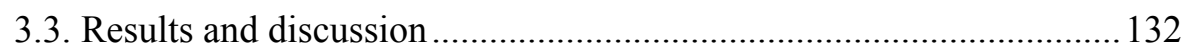

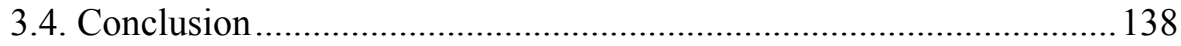

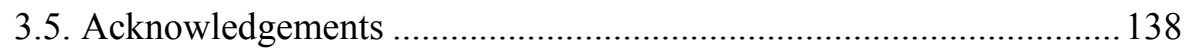

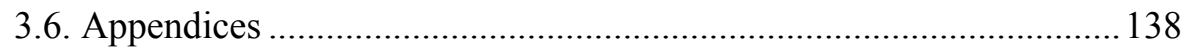

3.6.1. Poly(POSS-imide) layer preparation ........................................... 138 
3.6.2. Material characterization

3.7. References .....

Chapter 4 Thermal imidization kinetics of ultrathin films of hybrid poly(POSS-imide)s 153

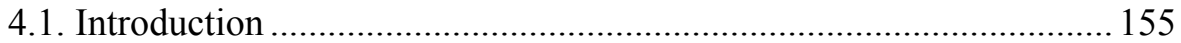

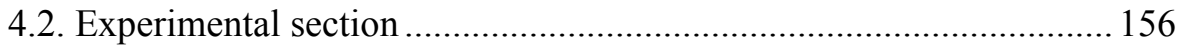

4.2.1. Synthesis of poly[POSS-(amic acid)]s by interfacial

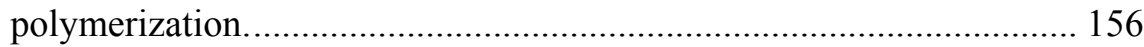

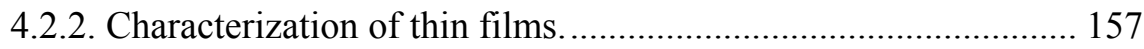

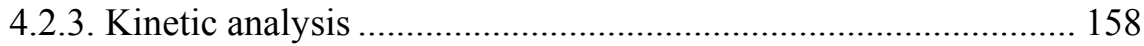

4.2.4. Characterization of thin films by thermo-ellipsometric analysis (TEA) 158

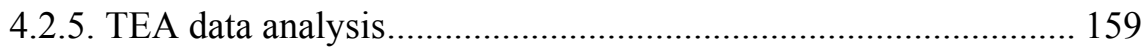

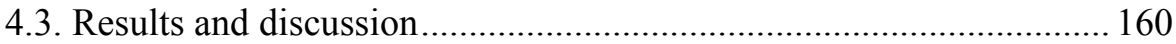

4.3.1. Imidization and thermal stability of the poly[POSS-(amic acid)]

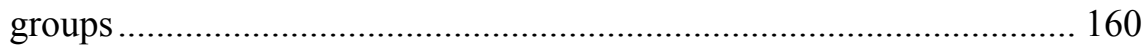

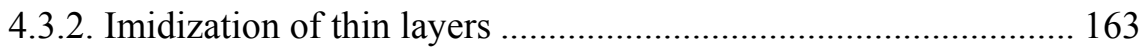

4.3.3. Density change upon imidization ................................................ 166

4.3.4. Kinetic analysis of the reactions by isoconversional and

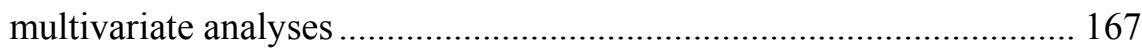

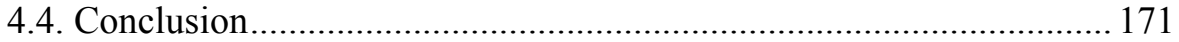

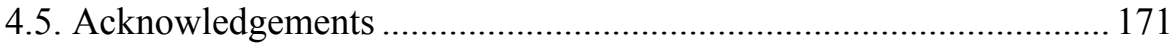

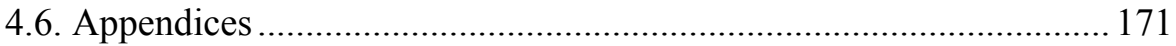

4.6.1. Conversion processes during thermal imidization ...................... 171

4.6.2. Thickness and refractive indices ............................................. 173

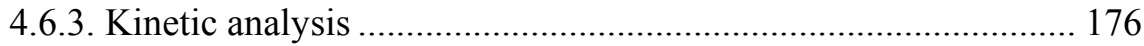

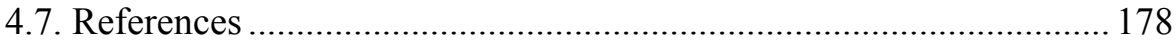

Chapter 5 Sorption behavior of compressed $\mathrm{CO}_{2}$ and $\mathrm{CH}_{4}$ in ultrathin hybrid poly(POSS-imide) layers ................................................................. 181

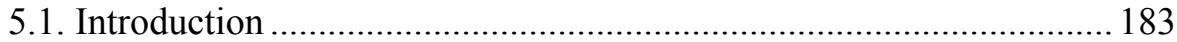




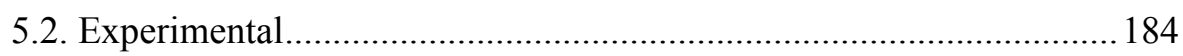

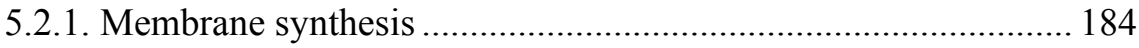

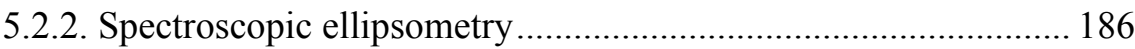

5.2.3. Spectroscopic ellipsometry - high pressure $\mathrm{CO}_{2}$ sorption........... 187

5.2.4. Magnetic suspension balance …………………….................... 188

5.2.5. X-ray photoelectron spectroscopy …………................................. 189

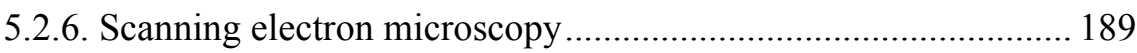

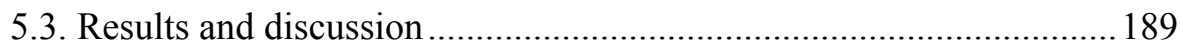

5.3.1. $\mathrm{CO}_{2}$ and $\mathrm{CH}_{4}$ sorption isotherms - high pressure ellipsometry ... 193

5.3.2. $\mathrm{CO}_{2}$ and $\mathrm{CH}_{4}$ partial molar volume and penetrant induced dynamics 200

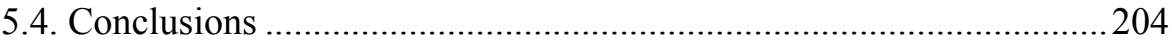

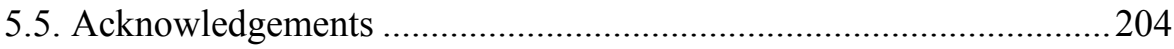

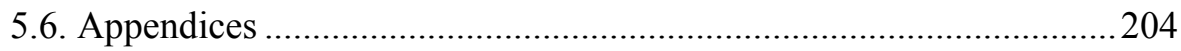

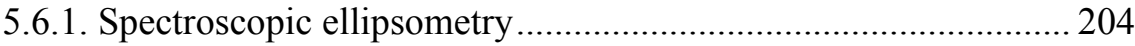

5.6.2. X-ray photoelectron spectroscopy ……………………................ 205

5.6.3. $\mathrm{CO}_{2}$ sorption measurements measured by a magnetic suspension

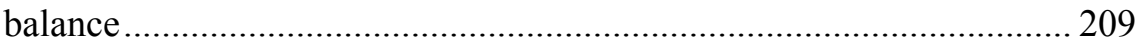

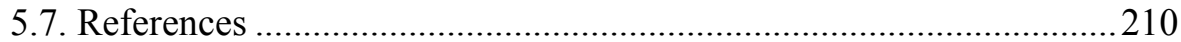

Chapter 6 High pressure $\mathrm{CO}_{2}$ permeation behavior of hybrid poly(POSSimide)s...................................................................................................................2215

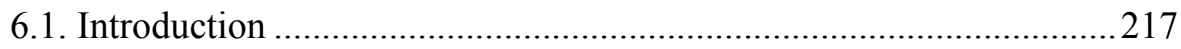

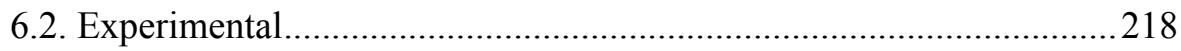

6.2.1. Poly(POSS-imide) membrane synthesis...................................... 218

6.2.2. Membrane characterization ......................................................... 218

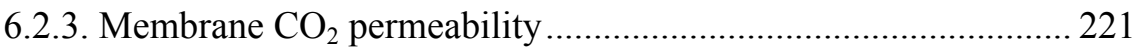

6.2.4. Thickness, refractive index and $\mathrm{CO}_{2}$ concentrations ................... 222

6.2.5. Apparent gas molar volumes ...................................................... 226

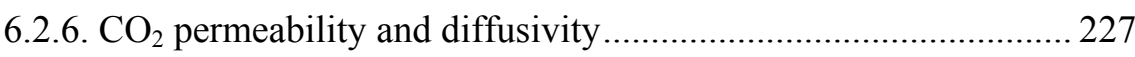




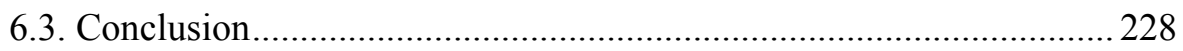

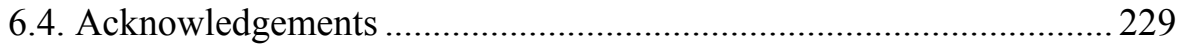

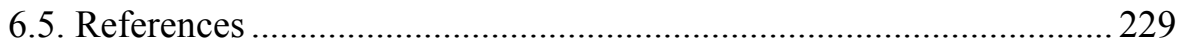

Chapter 7 Enzymatically-active, ultrathin pepsin membranes................ 233

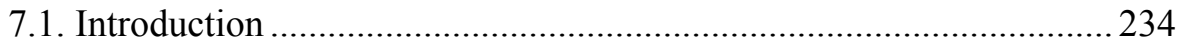

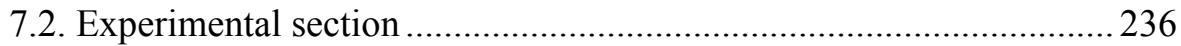

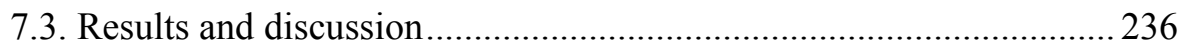

7.3.1. Pepsin film formation.................................................................. 236

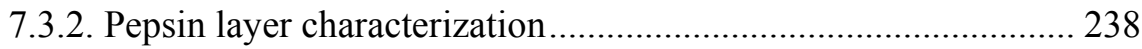

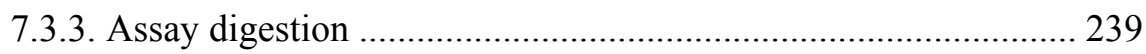

7.3.4. Pepsin layer membrane performance .......................................... 241

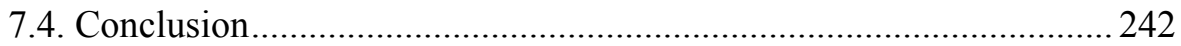

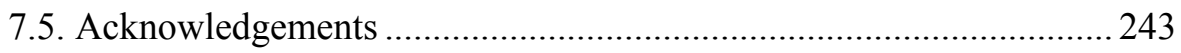

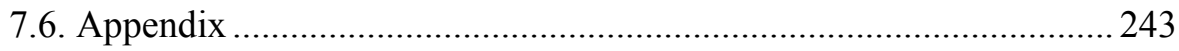

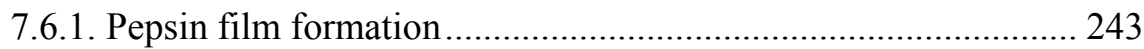

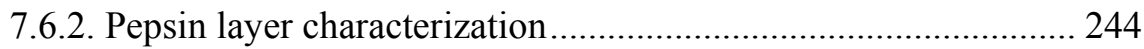

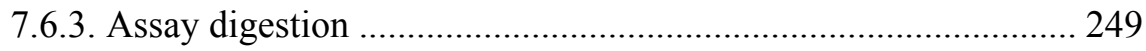

7.6.4. Pepsin layer membrane performance .......................................... 253

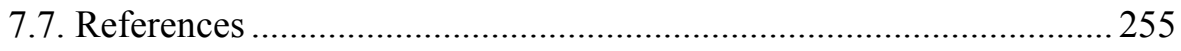

Chapter 8 Fluorescent protein thin films via interfacial polymerization 257

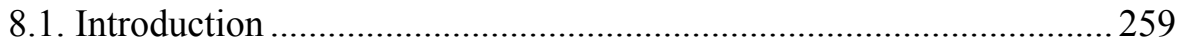

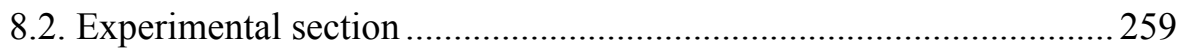

8.2.1. Fluorescence Recovery After Photobleaching ............................ 261

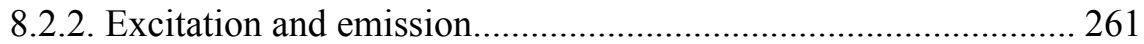

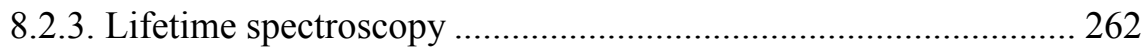

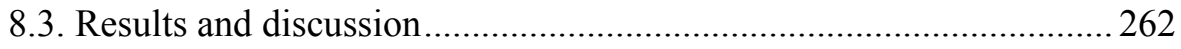

8.3.1. Fluorescence recovery after photobleaching ............................... 262

8.3.2. Fluorescence spectroscopy; excitation and emission ................... 263 


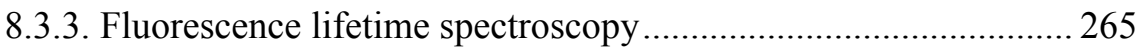

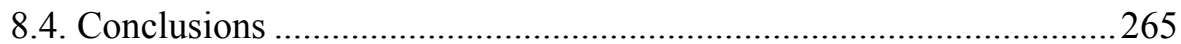

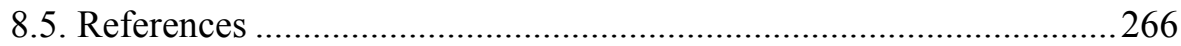

Chapter 9 Reflections \& Perspectives.......................................................269

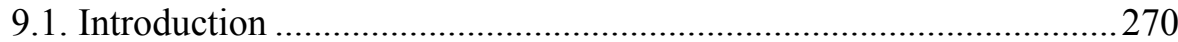

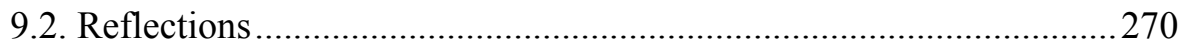

9.2.1. Reflections on hyper-cross-linked, hybrid materials ................... 270

9.2.2. Reflections on structure-property relationships........................... 271

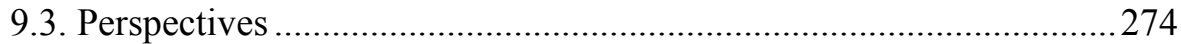

9.3.1. Membrane material design for gas separation applications......... 274

9.3.2. Structure-property-performance relationships............................. 277

9.3.3. Scale-up the membrane production process …............................. 280

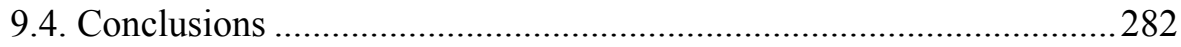

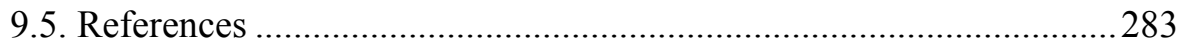

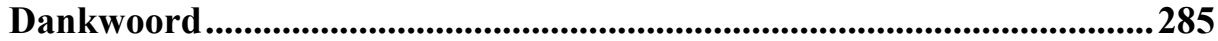

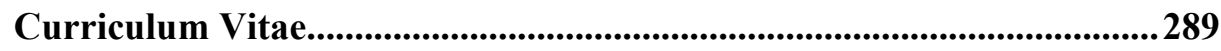

List of publications .........................................................................................291 


\section{Summary}

Hyper-cross-linked hybrid membranes consist of covalent networks of alternating organic and inorganic, or biological groups. Here, such hybrid networks have been prepared via interfacial polymerization. The structureproperty relationships of the hybrid networks depend strongly on the type, size and flexibility of the constituents.

The introductory Chapter 1 defines the characteristics of glassy membranes and hybrid materials and gives an overview of the common synthesis methods and suitable precursors that are used for synthesis of hybrid materials. In particular, the possibilities of using interfacial polymerization as a synthesis method for ultrathin hybrid films are examined. The chapter identifies a wide range of polymer chemistries that can be prepared via interfacial polymerization, and discusses the (dis)advantages of the precursors and polymer products in a review on the current trends in interfacial polymerization chemistry. The increasing number of hybrid inorganic organic, biological hybrid and nanocomposite materials that are prepared via interfacial polymerization underline the suitability of the synthesis approach for ultrathin hybrid membrane development.

In Chapter 2, reports for the first time a facile method for forming hybrid inorganic-organic networks of alternating polyhedral oligomeric silsesquioxane (POSS) and aromatic imide groups. The poly(POSS imide) membranes are formed by a polycondensation reaction that results in the formation of a poly[POSS-(amic acid)] layer, followed by a heat treatment to convert the amic acid groups to cyclic imides. The homogeneous distribution of POSS cages and imide bridges is demonstrated by atomic force microscopy measurements. The hybrid network characteristics are expressed by the size sieving permselectivities at temperatures up to $300{ }^{\circ} \mathrm{C}$. In addition, the membranes show $\mathrm{CO}_{2} / \mathrm{CH}_{4}$ permselectivities of around 60 for temperatures up to $100^{\circ} \mathrm{C}$.

In Chapter 3, the preparation of poly(POSS-imide)s via interfacial polymerization is extended towards other precursors. The length and flexibility of the imide bridge that connects the POSS cages determines the gas separation performance at elevated temperatures. Poly(POSS-imide)s with short, rigid imide bridges show high $\mathrm{H}_{2} / \mathrm{N}_{2}$ permselectivities between $40-100$ for temperatures between $50-300{ }^{\circ} \mathrm{C}$. Long, flexible imide bridges show lower permselectivities, particularly at higher temperatures, but display larger gas 
permeabilities for all gases. The tailored membrane performance allows for facile optimization of the membrane properties with respect to the requirements of the membrane process.

Chapter 4 provides new insights in the thermal imidization procedure that is required to convert the poly[POSS-(amic acid)] precursor into a poly(POSS imide). The thermal imidization occurs at temperatures between $150-350{ }^{\circ} \mathrm{C}$. During the imidization step, the shrinkage of the material shows an inverse relation with the length of the organic bridging group. In addition to the thermal imidization, a thermally stimulated silanol condensation is detected, that originates from partially opened POSS cages. Whereas a comparable mass loss is recorded for the five different bridging groups with different lengths, a lower shrinkage is recorded for the shorter organic linkers compared to longer organic bridging because of the hampered network mobility of short linkers. The thermal imidization follows a decelerating reaction mechanism and shows a higher activation energy than the imidization of purely organic polyimides. The distinct imidization kinetics underline the strongly different characteristics of the hyper-cross-linked hybrid materials.

In Chapter 5, the $\mathrm{CO}_{2}$ and $\mathrm{CH}_{4}$ sorption behavior of ultrathin, fluoroalkanefunctionalized poly(POSS imide)s is presented. The sorption capacity strongly correlates to the fluorine content in the hybrid materials, which can be tailored by using different monomer reactant concentrations in the solutions used for interfacial polymerization. The high $\mathrm{CO}_{2}$ sorption originates from the affinity that is provided by the fluoroalkane groups. Moreover, the high gas sorption capacity is due to the high content of free spaces in the hybrid network and the flexible response of the network in a compressed gas atmosphere. At high gas concentrations in the poly(POSS-imide), the apparent molar volume of the sorbed gas molecules starts to resemble that of the fluid phase.

Chapter 6 couples the $\mathrm{CO}_{2}$ sorption and permeability of fluoroalkane functionalized poly(POSS-imide)s. The permeability increases with increasing concentrations of sorbed gas, due to an increase in $\mathrm{CO}_{2}$ solubility as well as diffusivity coefficient. The increased diffusivity originates from the flexible response of the network to the exposure to the compressed gas. At higher $\mathrm{CO}_{2}$ pressures, the interaction of the $\mathrm{CO}_{2}$ molecules with the network decreases, which is reflected by the increased apparent molar volume.

Chapter 7 presents ultrathin, cross-linked pepsin membranes that are prepared via interfacial polymerization. The presented pepsin membrane layers allow 
for simultaneous enzymatic conversion and selective removal of digestion products. The pepsin activity in the layers remains after more than a day of contact with an assay solution, and demonstrates similar activity in a second digestion run. The persistent activity demonstrates that the cross-linking of pepsin into an all-protein film effectively prevent autolysis-induced deactivation. Moreover, the combination of high water fluxes and molecular retention of the pepsin layer allows for expeditious transport of solutes to the surface, where digestion can occur.

Chapter 8 illustrates that preparation of an all-protein layer via interfacial polymerization can be extended to fluorescent proteins such as EGFP and mRFP. The limited recovery of fluorescence after photobleaching illustrates the high degree of protein immobilization upon cross-linking. The emission and excitation spectra of the proteins are similar before and after cross-linking, indicating that denaturation of the protein structure is limited. A decrease in the lifetime of the fluorescence does imply that quenching occurs in the protein layers.

Chapter 9 reflects on the results that have been presented in this thesis, and provides guidelines for future development of hybrid network polymers for membrane applications. The perspectives focus on membrane material development, characterization of the structure-property-performance relationships of ultrathin membrane films and production of ultrathin membrane layers on tubular and hollow fiber supports for large-scale applications. 


\section{Samenvatting}

Hyperverknoopte hybride membranen bestaan uit covalent gebonden netwerken van organische groepen alternerend met anorganische of biologische groepen. In dit proefschrift wordt een verhandeling gegeven van dergelijke hybride netwerken, die bereid zijn door middel van grensvlakpolymerisatie. De structuur-eigenschap-correlaties van de hybride netwerken zijn sterk afhankelijk van de grootte, flexibiliteit en chemische samenstelling van de subgroepen.

Hoofdstuk 1 beschouwt de eigenschappen van glasachtige membranen en hybride materialen, en geeft een overzicht van de processen en precursoren die geschikt zijn voor de synthese van hybride materialen. Met name de mogelijkheden om grensvlakpolymerisatie als synthesemethode voor ultradunne hybride films zijn onderzocht. Het hoofdstuk geeft een breed scala aan polymeertypes die bereid kunnen worden via grensvlakpolymerisatie, en bespreekt de voor- en nadelen van de precursoren en polymeer types aan de hand van huidige trends in de chemie van grensvlakpolymerisatie. De geschiktheid van deze synthesebenadering voor ultradunne hybride membraanontwikkeling wordt onderstreept door het toenemende aantal hybride anorganisch-organisch, biologisch-hybride en nanocomposiet materialen die zijn bereid via grensvlakpolymerisatie.

In Hoofdstuk 2 wordt, voor het eerst, door middel van grensvlakpolymerisatie een ultradunne laag gemaakt, bestaande uit polyedrisch-oligomerisch silsesquioxaan (POSS) kooien die covalent gebrugd zijn door imidegroepen. Deze zogenaamde poly(POSS-imide) membranen worden gevormd door een polycondensatiereactie die resulteert in de vorming van een poly[POSS(amidocarbonzuur)] laag, gevolgd door een warmtebehandeling om de amidocarbonzuurgroepen om te zetten naar cyclische imides. De homogene verdeling van POSS kooien en imidebruggen wordt aangetoond door atoomkrachtmicroscopiemetingen. De kenmerken van het hybride netwerk komen tot uiting in de selectieve scheiding van gassen bij temperaturen tot $300{ }^{\circ} \mathrm{C}$. Daarnaast vertonen de membranen een 60 maal hogere permselectiviteit voor het transport van $\mathrm{CO}_{2}$ in verhouding tot $\mathrm{CH}_{4}$ voor temperaturen tot $100{ }^{\circ} \mathrm{C}$.

In Hoofdstuk 3 wordt de bereiding van poly(POSS-imide)s via grensvlakpolymerisatie uitgebreid naar andere bruggroepen. De lengte en flexibiliteit van imidegroepen die de POSS kooien verbinden, bepaalt de 
gasscheidingseigenschappen bij verhoogde temperaturen. Poly(POSS-imide)s met korte, rigide imidebruggen vertonen een 40-100 maal hogere permselectiviteit voor het transport van $\mathrm{H}_{2}$ in verhouding tot $\mathrm{N}_{2}$ bij temperaturen tussen $50-300{ }^{\circ} \mathrm{C}$. Lange, flexibele imidebruggen vertonen een lagere selectiviteit, vooral bij hogere temperaturen, maar hebben een hogere doorlaatbaarheid voor alle gassen. De mogelijkheid om te kiezen tussen de verschillende imidebruggen maakt het mogelijk de membraaneigenschappen te optimaliseren naar de eisen van het membraanproces.

Hoofdstuk 4 geeft nieuwe inzichten in de thermische imidisatie procedure die nodig is om de poly[POSS-(amidocarbonzuur)] precursor om te zetten naar een poly(POSS-imide). De thermische imidisering treedt op bij temperaturen tussen 150-350 ${ }^{\circ} \mathrm{C}$. Tijdens de imidiseringstap houdt de krimp van het materiaal een invers verband met de lengte van de organische bruggroep. Parallel aan de thermische imidisering werd een thermisch-geactiveerde silanolcondensatie ten gevolge van partieel geopende POSS-kooien waargenomen. Terwijl een vergelijkbaar massaverlies werd geregistreerd voor de vijf verschillende brugvormende groepen met verschillende lengten, belemmeren kortere organische bruggroepen de netwerkmobiliteit, wat resulteert in een lagere krimp in vergelijking met langere organische bruggroepen. De thermische imidisering laat een afremmende reactiesnelheid zien en heeft een hogere activeringsenergie dan de imidisering van een puur organisch polyimide. De verschillen tussen de imidiseringkinetiek onderstreept de sterk afwijkende eigenschappen van het hyperverknoopte hybride netwerkmateriaal ten opzichte van haar organische tegenhanger.

Hoofdstuk 5 presenteert het $\mathrm{CO}_{2}$ - en $\mathrm{CH}_{4}$-sorptiegedrag van ultradunne, fluoralkaan-gefunctionaliseerde poly(POSS-imide)s. De gassorptiecapaciteit correleert sterk met het fluorgehalte in de hybride materialen, dat aangepast kan worden door de concentratie van het monomeerreactant in de oplossing die wordt gebruikt voor de grensvlakpolymerisatie te variëren. De hoge $\mathrm{CO}_{2}$ sorptie is afkomstig van de $\mathrm{CO}_{2}$ affiniteit van de fluoralkaan groepen. Daarbovenop is de hoge gassorptiecapaciteit een gevolg van het hoge gehalte aan vrije ruimte in het hybride netwerk en de rekbaarheid van het netwerk onder hoge druk. Bij hoge gasconcentraties in het poly(POSS-imide) komt het schijnbare molair volume van de gesorbeerde gasmoleculen overeen met die van een vloeibaar gas. 
Hoofdstuk 6 koppelt het $\mathrm{CO}_{2}$-sorptie- en permeabiliteitsgedrag van fluoroalkaan-gefunctionaliseerde poly(POSS-imide)s. De permeabiliteit wordt hoger naarmate de concentratie van gesorbeerd gas stijgt, mede door een toename in de oplosbaarheid en diffusiecoëfficiënt van het gas. De toename in diffusie is een gevolg van de flexibele respons van het netwerk onder blootstelling aan hoge gasdruk. De interactie van de $\mathrm{CO}_{2}$ moleculen met het netwerk nemen af bij een hogere $\mathrm{CO}_{2}$ druk., wat tot uiting komt door de grotere schijnbare molair volumes van het gesorbeerde gas.

Hoofdstuk 7 presenteert ultradunne, pepsine netwerkmembranen die zijn bereid via grensvlakpolymerisatie. De pepsine membraanlagen zorgen voor een gelijktijdige enzymatische omzetting en selectieve verwijdering van producten. De pepsine-activiteit van de lagen houdt stand na langer dan een dag contact met een testoplossing, en toont vergelijkbare resultaten in de eerste en een tweede activiteitstest. De aanhoudende activiteit toont aan dat de verknoping van pepsine in een proteïne netwerk effectief de deactivatie van de laag door middel van autolyse voorkomt. De combinatie van een hoge waterdoorlaatbaarheid en hoge retentie van opgeloste stoffen zorgt ervoor dat de opgeloste stoffen zich verzamelen aan het oppervlak van de pepsine membrane, waar de enzymatische omzetting gebeurt.

Hoofdstuk 8 illustreert dat de bereiding van volledig proteïne netwerken via grensvlakpolymerisatie kan worden uitgebreid naar fluorescente proteïnen zoals EGFP en mRFP. Het beperkte herstel van fluorescentie na bleking door licht illustreert de hoge immobilisatiegraad van de proteïne. De emissie- en excitatiespectra van de eiwitten voor en na verknoping zijn vergelijkbaar, wat aangeeft dat de proteïnes slechts beperkt denatureren. De afname in de levensduur van de fluorescentie impliceert dat uitdoving van de fluorescentie in de proteïne netwerken plaatsvindt.

Het laatste hoofdstuk 9 reflecteert op de resultaten die zijn beschreven in dit proefschrift, en geeft richtlijnen voor de toekomstige ontwikkeling van hybride netwerkpolymeren voor membraantoepassingen. Een vooruitblik wordt gegeven op membraanmateriaalontwikkeling, karakterisering van de structuureigenschappen-prestatiecorrelaties van ultradunne membraanlagen en productie van ultradunne membraanlagen op buisvormige en holle vezel dragers voor grootschalige toepassingen. 


\section{Chapter 1 \\ Hybrid membranes via interfacial polymerization}

A part of this chapter has been submitted for publication as: Raaijmakers, M.J.T., Benes, N.E. Current trends in interfacial polymerization chemistry. 


\subsection{Membrane separation}

Membrane separation is a technology that allows for the selective separation of one or more components from a mixture. The membrane material acts as a barrier that selectively permeates one of the components over the others. Membrane performance is commonly expressed in terms of permeability and selectivity. The permeance is the rate at which a component passes through a membrane of a certain thickness. The membrane permselectivity is the ratio of the permeances of two pure components. The membrane selectivity, given by the ratio of the permeances of the components in a mixture, can differ significantly from the permselectivity and depends on the material properties and process operating conditions. A membrane with high selectivity and permeance is desirable; the separation process will require less precious membrane surface area and potentially yields higher product purities.

Membranes can be either porous or dense. Porous membranes are used on a large scale in ultrafiltration and microfiltration processes. ${ }^{1}$ The pore size distribution and membrane surface charge governs which components are retained by the membrane. The size of the pores can be in between $1 \mathrm{~nm}-10$ $\mu \mathrm{m}$, depending on size of the molecules or particles that need to be retained. Porous membranes are currently only used for liquid separation and purification processes, ${ }^{2}$ although they have been used to separate gases decades ago. ${ }^{1}$

Dense membranes do not have any discrete pores. Instead, transport through a dense membrane occurs via dissolution of a component into the membrane matrix, followed by diffusive transport of the component through the layer. The mechanism of separation by a dense membrane is based on differences in solubility and/or diffusivity of the permeating components. In rubbery dense membranes solubility differences dictate the membrane selectivity for low molecular weight components. ${ }^{3}$ The liquid-like properties of a rubbery membrane allow for fast diffusion of all soluble components. The solubility of components can differ significantly, and depends on the degree of component condensability and affinity towards the membrane material. ${ }^{3}$ A component with a higher condensability, such as butane, will have a higher solubility, and hence a higher permeability, compared to a poorly condensable component such as methane. ${ }^{4,5}$ Rubbery membranes are particularly useful for separation of mixtures with small amounts of contaminants, such as aqueous streams with small fractions of volatile organic components ${ }^{6-8}$ or recovery of hydrocarbons. ${ }^{9,} 10$ 
In glassy dense membranes, the difference in diffusivity governs the selectivity. Permeation occurs via the space between the (polymeric or inorganic) chains, that is commonly considered to be either excess free volume (EFV) or microporous elements. ${ }^{11-17}$ The degree of permeability is determined by the size and amount of the elements that are trapped in the glassy matrix of the dense layer. ${ }^{18,19}$ Small molecules such as hydrogen rapidly pass through the glassy matrix, while diffusion of larger molecules is hampered by the rigid network. Glassy membranes can differentiate between gases with small differences in molecule size, and are therefore considered promising candidate materials for gas separation applications. Nonetheless, membrane application in large-scale gas separation processes is limited by a lack of membrane materials with performance in relevant process conditions.

The performance of a membrane separation process is governed by both the process operating conditions, and the membrane material properties. From a process perspective, the driving force for permeation is related to the difference in chemical potential between the feed and permeate side of the membrane. From a material's perspective, differences in permeability originate from differences in solubility and diffusivity of the components in the membrane matrix. However, the degree of solubility and diffusivity often depends on the driving force (pressure, concentration, ...) and operating conditions (temperature, $\mathrm{pH}, \ldots$ ). Therefore, the membrane material properties need to be tailored to fit the process operating requirements. This thesis deals with the design of glassy materials that have tailored membrane properties, and the study of their performance at relevant process conditions. Both gas separation and nanofiltration applications will be addressed.

Dense (glassy) membrane systems generally consist of a porous substrate with a dense polymeric separation layer. ${ }^{20-22}$ Conventional polymeric membranes are mechanically stable, versatile, easy to process and relatively cheap. However, even in the case of state-of-the-art membranes, the molecular sieving performance subsides at high temperatures, ${ }^{23-25}$ in presence of penetrants at high pressures, ${ }^{26-29}$ or in harsh chemical environments. ${ }^{30,}{ }^{31}$ The development of highly permeable polymers has brought about new classes of membranes, including polymers of intrinsic microporosity (PIMs), ${ }^{14-17}$ thermally rearranged (TR) polymers, ${ }^{32-35}$ polyethers ${ }^{36}$ and substituted polyacetylenes. ${ }^{37}$ Their high EFV contributes to a high permeability in combination with excellent selectivities. In terms of membrane performance (i.e., permeability and selectivity), these membranes may well approach the 
ideal separation layer. However, particularly the high EFV polymeric membranes suffer from penetrant-induced changes such as plasticization and physical ageing, as a result of increased macromolecular dynamics. ${ }^{38}$ Moreover, the changes of membrane performance in time are particularly pronounced for ultrathin films that suffer from nano-confinement effects and accelerated aging. ${ }^{38-47}$ The dilemma of every membrane scientist therefore remains: how to come up with a material that has a high permeability and selectivity, which maintains its performance at relevant operating conditions (i.e., temperature, pressure, penetrant) and reliably operates over a long period of time.

In this respect, inorganic membranes offer interesting prospects. Inorganic membranes are stable at much higher temperatures and are less prone to penetrant-induced changes. The stability of inorganic membranes is related to the rigid nature of the inorganic backbone. Although the markets are still relatively small, Mitsui ${ }^{48}$ and the Energy Research Centre of the Netherlands ${ }^{49}$ have successfully commercialized inorganic membranes for pervaporation applications. In addition, metal membranes (palladium) are currently in pilot plant testing phase for gas separation applications. ${ }^{50,}{ }^{51}$ Nonetheless, widespread implementation of inorganic membranes is hampered by the lack of stable, cheap, easy-to-process, defect-free inorganic layers. Moreover, the cost price for ceramic supports remains high, while they offer a low specific surface area compared to polymer hollow fibers or spiral-wound modules. To overcome the drawbacks of both organic and inorganic materials, the best of both should be incorporated in one material; large-scale, defect-free processability in combination with stable membrane performance at the relevant process conditions. Such a synergistic combination of material properties can be attained by using hybrid materials.

\subsection{Hybrid materials}

Hybrid materials represent a class of materials that combine two or more chemically and physically different constituents in one material. The synergistic combination of the constituents allows for the design of materials with properties that are distinct from their individual counterparts. Hybrid materials allow for the design of materials that, for example, combine electronic, photonic, and catalytic nanoparticle properties, with molecular sensing and catalytic biomaterial properties. ${ }^{52}$ In addition, many hybrid materials are designed to have the flexibility of a polymer combined with the 
mechanical toughness of a ceramic ${ }^{53}$ or to combine the rigidity of an inorganic network with the chemical affinity of organic groups. ${ }^{54,55}$

The term hybrid is mainly used when a material combines organic and inorganic constituents. In general, the organic constituent is considered to be the more flexible, cheaper and more easily processable component. The inorganic constituent, often either a metal or metal oxide, acts as the more rigid framework element. In case a biological constituent is included in a hybrid material, it is often referred to as bio(logical) hybrid, ${ }^{56,57}$ hybrid biopolymer ${ }^{58}$ or bionanocomposite. ${ }^{59}$ The development of methods that incorporate inorganic, organic, and even biological constituents in a single material has resulted in the synthesis of numerous novel, multifunctional materials. $^{60}$

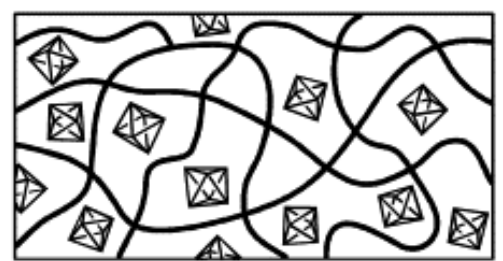

a)

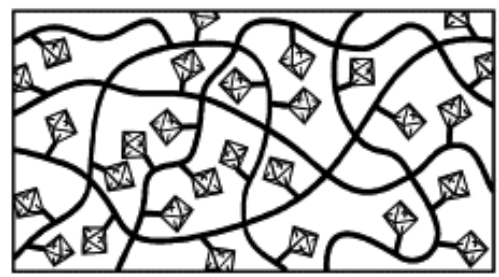

c)

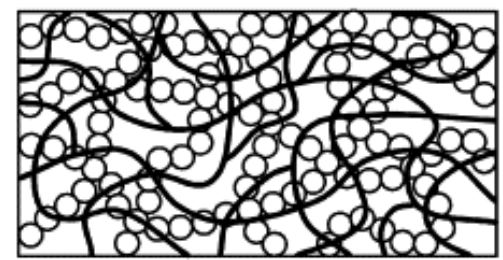

b)

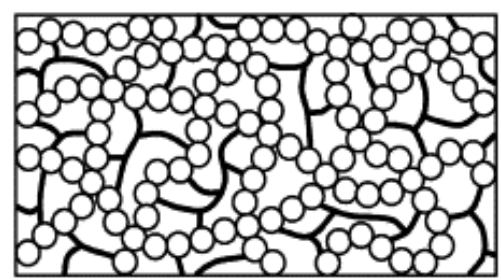

d)

Figure 1-1. Different classes of hybrid organic-inorganic materials. (a) inorganic particles dispersed in a polymer, (b) interpenetrating networks (IPNs), (c) inorganic groups tethered to a polymer main chain. (d) covalently-bonded network of inorganic and organic groups. ${ }^{61}$ Copyright 2003. Adapted with permission from Elsevier Science Ltd..

Figure 1-1 shows the different types of (inorganic-organic) hybrid materials that are recognized as such in literature. The term hybrid is commonly used to denote materials that combine constituents with length-scales of the individual constituents ranging from $\AA$ up to several $\mu \mathrm{m}$. The synergistic properties of a hybrid material depend to a great extent on these length-scales: materials that combine inorganic and organic groups on a nanoscale level will show 
completely distinct properties from a material that is merely a physical dispersion of inorganic particles in an organic matrix.

\subsubsection{Nanocomposites}

Nanocomposites, shown in Figure 1-1(a), are physical dispersions of inorganic particles in a polymer matrix. Particularly in membrane science and composite materials science, the combination of inorganic particles in a polymer matrix is regularly denoted as "hybrid". ${ }^{62-66}$ Although such materials do combine two constituents in one material, the physical properties will in general be in between those of the two individual constituents. Examples of this class include polymer modification by dispersing polyhedral oligomeric silsesquioxanes (POSS), ${ }^{67,68}$ zeolite $^{69}$ or silica ${ }^{70-72}$ particles in the polymeric phase during processing. Conductive properties of POSS and silica particles are used to improve the proton conductivity of proton exchange membranes for fuel cell applications. ${ }^{73-76}$ Improved material properties include increased degradation temperature, glass transition temperature $\left(T_{g}\right)$ and polymer rigidity of POSS ${ }^{77-80}$ and silica filled materials. ${ }^{81-83}$ In addition, better membrane separation properties are achieved by an increase in EFV and affinity separation properties. ${ }^{73}, 84,85$ However, addition of particles does not necessarily result in a combination of these effects: ${ }^{86}$ materials that show an increased EFV, often show a reduction in $T_{g}{ }^{87}$ The introduction of affinity domains and additional particle-polymer interface are considered as the main reasons for these material property changes. The main drawback of particle dispersions is the strong tendency towards agglomeration or phase demixing during processing, in particular for high surface area particles with strong interparticle interaction. ${ }^{88-90}$ Improved dispersion stability can be accomplished by particle surface modification, although this potentially renders the implementation of affinity domains ineffective.

Completely distinct properties can only be attained by integrating two or more constituents at the nano-length scale. One way to obtain higher loading homogeneous hybrid materials is by simultaneous polymerization of the inorganic and organic phase. The (semi)-interpenetrating character of the polymeric and inorganic network, as shown in Figure 1-1(b), allows for synthesis of materials with excellent thermo-mechanical properties. Most (semi)-interpenetrating networks are produced by a simultaneous (radical) polymerization reaction and a sol-gel synthesis ${ }^{53,}$ 91-93 Although some interpenetrating networks are cross-linked, most of the interactions between 
the two components is based on non-covalent bonding types such as Van der Waals forces. ${ }^{94-96}$

\subsubsection{Covalent hybrid materials}

Covalent bonding between the inorganic and organic moieties, as shown in Figure 1-1(c) and (d), on a nanoscale level results in materials that have structure-properties and physicochemical behavior that is distinct from their individual constituents. The formation of inorganic-organic hybrid, covalent networks can be accomplished by tethering inorganic constituents to a polymer main chain, cross-linking of the polymer network with inorganic groups, or incorporating the inorganic constituent in the main chain. ${ }^{67,68,97-99}$ The degree of branching, or network formation, depends on the number of reactive groups on both organic and inorganic precursors. The two types of precursors that are used in this thesis are polyhedral oligomeric silsesquioxanes (POSS) and proteins. POSS are silicon oxide nano-building blocks with the general structural formula $\mathrm{R}_{n} \mathrm{Si}_{n} \mathrm{O}_{1.5 n}(n=6,8,10,12) .{ }^{100}$ POSS has been applied in nanocomposites, catalysis, biomaterials, optics, and coating technologies ${ }^{67,101-}$ ${ }^{103}$ Figure 1-2 shows the schematic structure formula of a POSS molecule with $n=8$, and some commonly used functional groups (R) for the synthesis of hybrid materials.
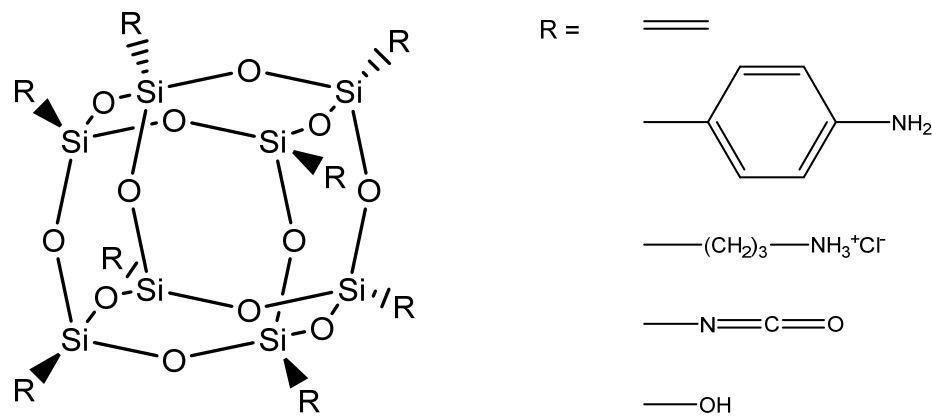

Figure 1-2. The general features of POSS with $n=8$

POSS molecules are synthesized via hydrolysis and condensation reactions of chloro- or alkoxysilanes $\left(\mathrm{RSiX}_{3}\right)$. The cubic, polyhedral $(n=8)$ species are preferentially formed in case a single $\mathrm{RSiX}_{3}$ precursor is used, although formation of ladder $(n=8)$ and non-polyhedral $(n=10,12)$ by-products is common.$^{67}$ Post-treatment of the non-polyhedral silsesquioxanes can be used to yield polyhedral $(n=10,12)$ structures. ${ }^{104}$ POSS molecules with various functional groups are available, due to the large availability of 
organo-functionalized silanes. ${ }^{103}$ The inorganic-organic functionality of POSS classifies them as hybrid materials. The large number of reactive groups on each POSS cage allows for network formation in three dimensions. ${ }^{105-109}$ POSS based hybrid layers have been prepared by step-polymerization ${ }^{107}$, sol-gel processing ${ }^{110}$ and interfacial polymerization. ${ }^{111}$

Proteins are a class of biomacromolecules that consist of amino acid subunits. Protein properties depend on the number and type of amino acids, as well as the structural conformation in a given environment. The unique architecture of proteins is expressed in functionalities such as enzymatic activity, ${ }^{112}$ fluorescence, ${ }^{112}$ transport channel properties, ${ }^{113}$ specific recognition of molecules, ${ }^{114}$ adhesive and other mechanical properties, ${ }^{115}$ and more. The amino acids groups of proteins can form non-covalent and covalent bonds with other molecules, and are therefore potentially suitable for the formation of biological hybrid materials.

Examples of different hybrid inorganic-organic and biological hybrid network materials are given in Figure 1-3.

(a)

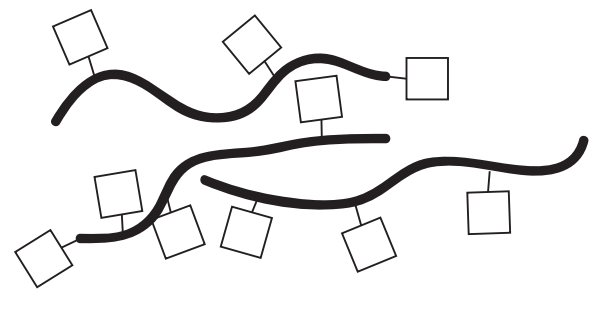

(c)

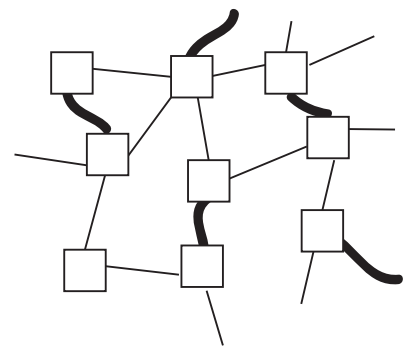

(b)

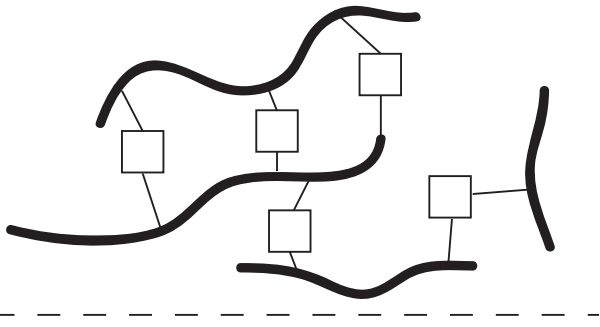

(d)

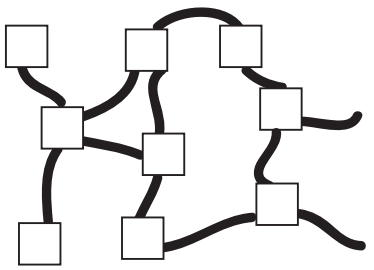

Figure 1-3. Different types of covalently-bonded hybrid organic-inorganic materials. (a) side- or end-group tethered inorganic groups on a polymer chain (b) polymer networks cross-linked by inorganic groups (c) sol-gel-based hybrid silica networks (d) alternating networks of organic and inorganic constituents. 
Polymers that are tethered with inorganic groups such as POSS, as shown in Figure 1-3(a), have a relatively low degree of network formation. Tethering pendant side or end-groups usually results in distortion of the polymer chain organization, and increased rigidity of the network. ${ }^{116-119}$ In prevalent cases, slightly increased $T_{g}$ values are observed. ${ }^{86}$ However, high loading of tethered groups may also lead to the formation of self-organized domains that result in very high EFV and lowered $T_{g}$ values. ${ }^{120-122}$ Although the tethering of side- and end-groups is an effective modification method, calculations suggest that the influence of the inorganic constituent is most pronounced if the number of covalent bonds between the organic and inorganic groups is larger. ${ }^{67,}{ }^{123}$ Examples include hybrid cross-linked materials, as shown in Figure 1-3(b-d).

Figure 1-3(b) shows a schematic representation of a cross-linked hybrid material. Cross-linking with inorganic groups such as POSS is generally done by co-polymerization of the inorganic precursor and (pre-)polymer in solution. POSS cross-linked materials generally display improved mechanical properties and significant increases in $T_{g .}{ }^{124,125}$

Figure 1-3(c) shows a hybrid network prepared using sol-gel synthesis. Commonly, bi- or multifunctional siloxane precursors containing an organic functional group are used, such as 1,2-bis(triethoxysilyl)ethane (BTESE), 3-glycidoxypropyltrimethoxysilane and 3-aminopropyltrimethoxysilane. ${ }^{61,126-}$ ${ }^{129}$ Depending on the reaction conditions, high degrees of branching can be obtained. ${ }^{130}$ Generally, the influence of pendant organic groups are different from organic groups as bridging constituent. ${ }^{131}$ Alkoxysilanes with built-in organic bridge are available, and have been successfully applied for synthesis of membranes for vapor ${ }^{132}$ and gas separation. ${ }^{133}$

Figure 1-3(d) shows a network that consists of alternating organic and inorganic constituents, prepared using multi-functional precursors such as POSS, dendrimers and proteins. The large number of reactive groups on these precursors allows for covalent bond formation in three dimensions. The multifunctional character of these precursors are used as a platform for material synthesis for membrane applications. In this thesis, a number of hybrid network materials have been prepared via interfacial polymerization.

\subsection{Hybrid material synthesis}

Hybrid material synthesis can be accomplished via polymerization of suitable inorganic and organic precursors in one or more suitable solvent phases. The most common methods used for hybrid material synthesis include sol-gel 
synthesis and step polymerization. In this thesis, interfacial polymerization has been explored as an alternative route for preparation of hybrid network materials.

\subsubsection{Sol-gel}

Most of the early work on inorganic-organic hybrid materials has been done using sol-gel approaches. ${ }^{134-138}$ The sol-gel method involves the preparation of a stable sol, a colloidal suspension of particles in a liquid. The class of precursors mainly used in sol-gel processing are the alkoxides of transition metals such as silicon, because they are readily hydrolyzed in the presence of water. ${ }^{130}$ During the hydrolysis step an alkoxide bonded to a metal atom is replaced by a hydroxyl group. Subsequently, condensation between the hydroxyl groups can occur, resulting in the formation of a metal oxide network.

Hybrid materials can be obtained by using sol-gel precursors that have pendant or bridged organic groups. Example precursors often used in sol-gel chemistry for membrane applications include 1,2-bis(triethoxysilyl)ethane (BTESE) and 1,2-bis(triethoxysilyl)methane (BTESM), but a wide variety of organic bridges can be used to obtain different membrane functionalities. ${ }^{139}, 140$ In addition, surface modification has been done by increasing hydrophobicity with increasing fluorine content ${ }^{54}$ and increasing $\mathrm{CO}_{2}$ sorption with tertiary, secondary and primary amine group content. ${ }^{55}$

\subsubsection{Step polymerization}

Step polymerization $(n$-mer $+m$-mer $=(n+m)$-mer $)$ of hybrid materials is often done in aprotic polar solvents. ${ }^{109,}{ }^{141}$ The reaction can be achieved by living polymerization techniques, such as ring-opening polymerization and living free-radical polymerization or coupling reactions such as click chemistry and hydrosilylation. ${ }^{105,}{ }^{142}$ Commonly, reaction times of several hours at elevated temperatures are used to obtain hybrid polymers with sufficiently high molecular weights. ${ }^{123}$ Because the solubility of the hybrid network depends on the molecular weight and degree of branching, careful control of the reaction conditions is required to allow for further processing of the materials. The advantages of step-polymerization include the careful control of the molecular weight (distribution) and wide range of chemistries that can be used for polymer synthesis. ${ }^{103}$ Drawbacks of highly cross-linked networks is their brittleness after evaporation of the solvent, and cracking can occur due to shrinkage induced stresses in the layers. ${ }^{143}$ 


\subsection{Current trends in interfacial polymerization chemistry}

Interfacial polymerization is an enabling technique for the large-scale production of ultrathin layers, hollow nanospheres and nanofibers. The availability of a wide range of suitable monomer reactants allows for the synthesis of an impressive collection of polymers, including polyamides, polyurethanes, polyureas, polyanilines, polyimides, and polycarbonates. In addition, the technique has been used to prepare defect-free, ultrathin films of metal organic frameworks, organic-inorganic hybrids, and bio-hybrids. This review provides an overview of the chemistry that is used in interfacial polymerization, discusses the (dis)advantages of derived material types, and assesses the future prospects for synthesis of ultrathin functional materials via interfacial polymerization.

\subsubsection{Interfacial polymerization}

Interfacial polymerization is a technique that allows for the synthesis of ultrathin functional layers, capsules or fibers, at the interface between two phases. Commonly, the polymerization is a polycondensation reaction between two highly reactive monomers that are dissolved in two immiscible liquids. ${ }^{144}$ Alternatively, one of the phases only contains a reaction initiator or a catalyst (e.g., a strong oxidizing agent ${ }^{145}$ ), or acts as the reactive monomer by itself (e.g., water as reactant ${ }^{146}$ ). In some studies, ultraviolet light is employed for a photopolymerization at the interface. ${ }^{147-149}$ In all cases, the separation of monomer precursors in two phases results in the localized reaction and formation of a polymer. Figure 1-4 shows a schematic of an interfacial polymerization reaction between monomer reactants $\mathrm{A}$ and $\mathrm{B}$.

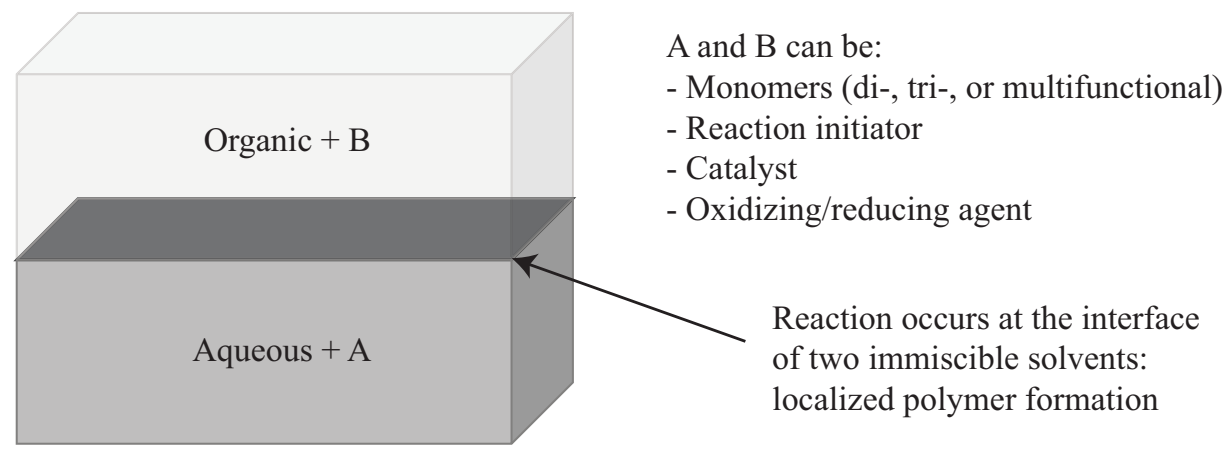

Figure 1-4. Schematic of an interfacial polymerization reaction. 
Because the polymer formation is confined to the interface, reactants will more likely encounter the growing polymer chain instead of other monomers. As a result, as compared to bulk polymerization, higher molecular weights can be obtained at mild reaction conditions. ${ }^{150}$ Precipitation of the polymer at the interface might occur at a given molecular weight range, resulting in polydispersities that are distinct from bulk polymerization. ${ }^{151}$

The properties of the formed polymer depend, to a great extent, on the reactivity and (local) concentration of the monomers, the stability of the solvent interface and the number of reactive groups on each of the monomers. ${ }^{152-156}$ Interfacial polymerization involves the reaction of di-, tri- or multi-functionalized monomers. ${ }^{144,157,158}$ Usually, one of the phases contains a nucleophile reactant (i.e., amines, alcohols, ...) and the other contains an electrophile reactant (i.e., acid chlorides, isocyanates, ...). Because most of the electrophilic monomers used for interfacial polymerization are susceptible to reaction with water, they are commonly dissolved in the organic phase. The reaction of two di-functional monomers results in formation of a linear polymer chain. Examples of linear polymers include the synthesis of polyamides (e.g., nylon ${ }^{159}$ ) and polycarbonates. ${ }^{160}$ Syntheses with large yields are performed by either by stirring to create more liquid-liquid interface or by continuous removal of the formed polymer from the interface. The resulting high molecular weight linear polymers can be dissolved again for further processing. Only for some polymers, such as polyaniline, the synthesized linear polymers are used as synthesized and are not redissolved.
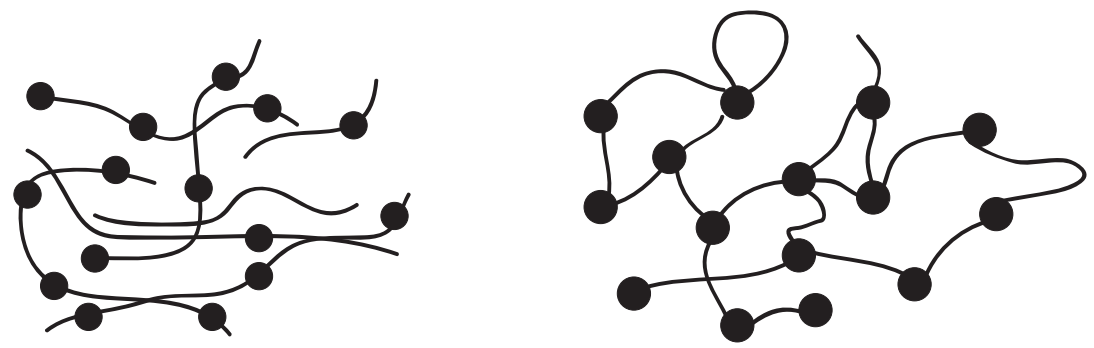

Figure 1-5. Schematic of (left) a linear polymer and (right) a polymer network prepared by interfacial polymerization. The ball and chain represent the different functional segments of the polymer main chain. 
The production of branched polymers requires at least one precursor with three or more reactive functional groups. The degree of branching and cross-linked network formation depends on the number and reactivity of the functional groups. The properties of such polymer networks are completely distinct from linear polymers. Figure 1-5 shows a schematic representation of a linear polymer (left) and a polymer network prepared by interfacial polymerization (right). Linear polymers have properties that depend, to a large extent, on their chemistry, chain-chain interactions and molecular weight distribution. Because each polymer chain has freedom of movement, polymer chain dynamics occur over a range of time-scales. Even glassy polymers, that display slow chain dynamics due to the rigid nature of their polymer chains, inherently display chain reorganizations. On the other hand, polymers prepared by interfacial polymerization potentially consist of networks of semi-infinite molecular weight that moderate such polymer reorganizations. This is reflected by the poor solubility in any type of solvent, the absence of any crystallinity, and the distinct layer morphology of branched polymers prepared via interfacial polymerization. In particular such branched and network polymers are applied in the configuration that is obtained upon interfacial polymerization. This review focusses on interfacial polymerization that is used for synthesis of structures and layers with large lateral dimensions and small thicknesses. This excludes materials that are redissolved after preparation, because they are not used in the same configuration as is achieved by interfacial polymerization.

\subsubsection{Synthesis parameters}

Interfacial polymerization reactions generally result in fast polymer chain growth and polymer precipitation at the liquid-liquid interface. The properties of the polymer depend on a large number of parameters. Polymer properties that can be varied using these reaction parameters include: molecular weight, polydispersity, degree of branching or cross-linking, residual group content, shape (fibrils, capsules, layers), thickness, density, layer roughness, component (membrane) transport, mechanical strength, ${ }^{157}$ and stimuli responsive properties. ${ }^{161,}{ }^{162}$ Figure 1-6 gives an overview of the most important synthesis parameters that influence the properties of the formed polymer, and coupling between these parameters. Several of the most important parameters will be discussed in detail here in this review. 


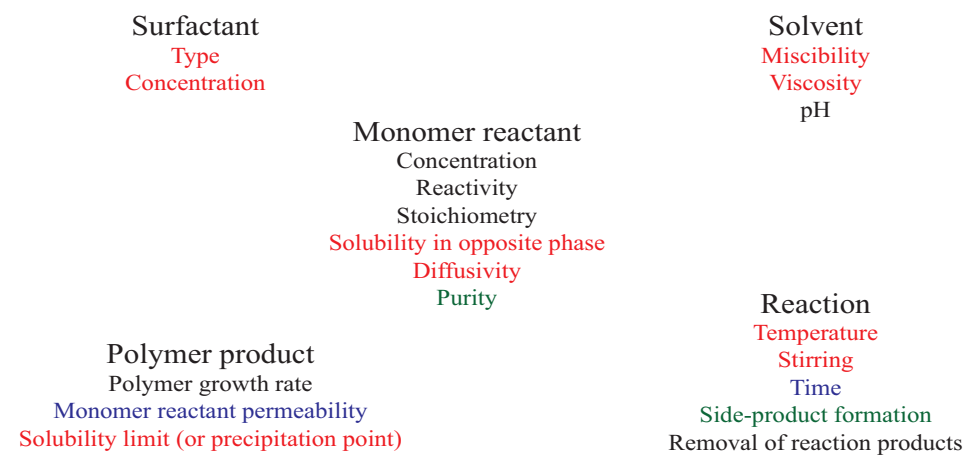

Figure 1-6. Overview of the synthesis parameters that determine the nature of the polymer formation during interfacial polymerization. The synthesis parameters are categorized by color and type of parameter. The colors indicate a strong interdependency of the parameters. For example, the solvent miscibility and viscosity will influence the monomer diffusivity and solubility in the opposite phase. Stirring, addition of a surfactant and temperature will influence the solubility as well. The concentration, reactivity, stoichiometry, solvent $\mathrm{pH}$ and removal of reaction products will influence the polymer growth rate. Reactant purity can result in sideproduct formation. The interdependency is not limited to the colors shown here: diffusivity is for example also coupled to the monomer reactant permeability.

\subsubsection{Monomer concentration, reactivity, and solubility}

The nature of the localized layer formation is determined mainly by the nature of the two monomer reactants that are dissolved in the aqueous and the organic phase, respectively. Monomers with a high reactivity allow for film formation in a matter of min or even seconds. Diffusion limitations of monomer reactants upon film formation decelerate the film growth, typically restricting film thicknesses to the sub- $\mu \mathrm{m}$ range. Although film growth decelerates upon film formation, the properties can still change with longer reaction times due to continued covalent bond formation and material densification. ${ }^{163}$ Lower reactant reactivities commonly result in thicker films, with thicknesses than can go up to several $\mu \mathrm{m}$. Layers produced by interfacial polymerization are inherently defect-free, because monomer diffusion in areas without layer formation allows for continued polymer growth. In addition, the potentially unlimited lateral dimensions of an interface of two immiscible phases enables synthesis of ultrathin layers with similarly large areas. The prospect of large surface areas of ultrathin, defect-free films are two of the key aspects that 
underline the attractiveness of interfacial polymerization as a layer synthesis technique.

In contrast to polymerization in a single solvent, the reactant stoichiometry of the monomers during interfacial polymerization is not necessarily in agreement with the final composition of the polymer. Instead, the reactant stoichiometry at the interface is a function of the monomer reactivities, concentrations, diffusivities and solubilities in either phase. Hence, each individual combination of monomers requires an optimization of reactant concentrations. Empirical data of the influence of reaction conditions on molecular weight, ${ }^{159,160,164,165}$ surface roughness, ${ }^{166,167}$ layer thickness, ${ }^{163}$ and (membrane) material performance, provides general guidelines for sensible reaction conditions. In general, a high monomer reactivity and low solubility in the opposite phase are required to obtain dense, well-defined films.

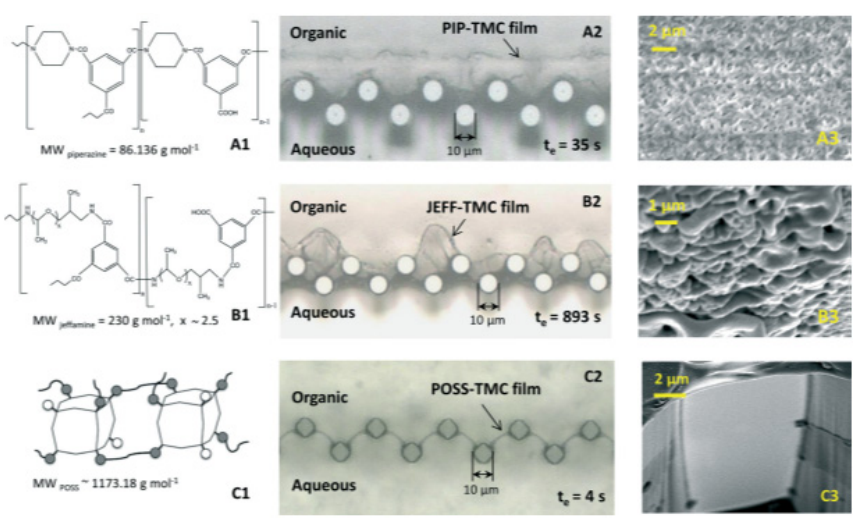

Figure 1-7. Optical microscopy images of a piperazine (top panels), Jeffamine (middle panels) and POSS (bottom panels) based interfacial polymerization layers, formed in a microchannel. ${ }^{168}$ Copyright 2015. Adapted with permission from the Royal Society of Chemistry.

A high solubility of one of the reactants in the other phase may lead to the formation of more corrugated films. ${ }^{168}$ Film morphology depends on the type of reactants used for interfacial polymerization. This is illustrated by optical microscopy images of films prepared with different aqueous phase precursors, in a microchannel, shown in Figure 1-7. The layers show distinct thicknesses and morphologies, which is due to the difference of the amine (aq. phase) reactivity and solubility in the opposite organic phase. The large differences between the layer morphologies and the thicknesses underline that the type of reactant affects both the physical and chemical properties of the material. In 
case both reactants solubilize in the opposite phase, their concentration can be used to obtain diffusion controlled reaction either in the organic phase or the aqueous phase. ${ }^{163}$ A low organic reactant concentration results in layer formation that is controlled by the diffusion in the organic layer. At high organic reactant concentrations, the monomer diffusion of the aqueous phase will predominate.

Interfacial polymerization membranes commonly have a gradient in the chemical composition, charge and number of residual groups as function of the layer thickness. The composition of the unreacted residual groups depends on which of the monomers are supplied in excess. On the aqueous side, excess of e.g. amine groups results in residual amine groups, while on the organic side excess acid chloride monomers result in formation of residual carboxylic acid groups. Depending on the size, concentration, diffusivity and solubility, one type of residual groups might be prevalent. However, in many interfacial polymerization layers, both monomer reactants can remain as partially unreacted residual groups. Post functionalization by cross-linking or endcapping reagents can be used to change the composition of the layers. Unreacted residual groups can post-functionalized by stepwise contacting with reactant solutions, as an additional treatment after the conventional interfacial polymerization procedure. ${ }^{169}$ Another example employs the stepwise addition of the reactant solutions to a support fixed on a spin coater, although such an approach is not easily scalable for large surface area applications. ${ }^{170}$ Usually, post-functionalization only results in a changed surface composition of the layers. The slow monomer diffusion in the layers complicates postfunctionalization throughout the layer. To overcome the diffusion limitations of post-functionalization, end-capping reagents are added to one of the monomer solutions, including 3,5-diaminobenzoic acid (BA) and o-aminobenzoic acid-triethylamine (o-ABA-TEA) salt, that increase the hydrophilicity. ${ }^{171}$ The drawback of the latter approach is that the degree of network formation is inherently lower as compared to conventional interfacial polymerization.

A number of models have been developed to predict the growth of interfacial polymerization layers. ${ }^{172-175}$ Many attempts have been made to predict the reaction-diffusion behaviour of the components responsible for thin film formation. This resulted in the availability of various models that all focus on different assumptions and key parameters, and as such there is no consensus on the location, size and direction of the actual reaction zone. Three different 
modelling approaches can be identified. In the first modelling approach, the reaction initially occurs at the interface and from there it grows into the organic phase. A second approach places the reaction zone in the organic phase and lets it shift further into the organic phase as the film is growing. The third approach involves determining a steady reaction zone with a finite thickness in which the reaction takes place and the polymer film is formed. An overview of the different models is given by Dhurmal et al. ${ }^{176}$

\subsubsection{Interfaces suitable for interfacial polymerization}

The interface is key for controlling the localized polymerization reaction. Most commonly, an aqueous phase and a hexane phase are used. Hexane and water mix very poorly, and provide a very stable interface. Alternative combinations can be made with methanol, acetonitrile, nitromethane, formamide, dimethylformamide or dimethylsulfoxide instead of the aqueous phase and cyclohexane, hexane and higher alkenes, chloroform, dichloromethane, higher alcohols such as octanol, xylene and toluene as the organic phase. ${ }^{177}$ Although the solvent combinations are not miscible, small amounts of solvent can dissolve in either phase. ${ }^{177}$ The exchange of solvent at the interface potentially disturbs the reaction zone and changes the solubility of the monomer reactants in either phase. The liquid phase mixing is not necessarily a drawback; the diffuse reaction zone can promote layer growth. Moreover, in many interfacial polymerization syntheses an additional surfactant is used to improve the materials properties. ${ }^{152,}$ 178, 179 For example, for interfacial polymerized polyamide membranes, surfactants are beneficial for the flux. ${ }^{180}$ Commonly, the enhanced flux is ascribed to the increased roughness and hence surface area. ${ }^{166}$ In other work, the flux increase has been attributed by the combination of a higher roughness and a higher excess free volume content that allows for faster water permeation. ${ }^{181}$

Interfacial polymerization is not limited to the combination of two liquid phases. Alternative approaches include vapor-liquid interfacial polymerization (VLIP) via supercritical $\mathrm{CO}_{2}$ to supply vapor phase reactant ${ }^{182}$ and vaporizing of the reactant with an inert gas stream to induce a polymerization reaction at a stable aqueous interface on a hydrophobic support. ${ }^{183}$ In addition, it is possible to perform solid-liquid interfacial polymerization by freezing interfacial polymerization. ${ }^{184}$ Here, the crystallization of the solvents is accompanied by the formation of a layer of monomer reactants on the outside of the crystal. One of the monomer reactants (pyrrole) is still liquid, and can diffuse to the oxidant and dopant on the ice surface. 


\subsubsection{Supported and free-standing layers via interfacial polymerization}

Most interfacial polymerization layers are prepared on top of a porous support, because the mechanical strength of sub- $\mu \mathrm{m}$ thin free-standing films not sufficient for many applications. The properties of the support are important for the characteristics of the interfacial polymerization layer. The pore size and hydrophobicity have more practical implications for the reaction. When the aqueous phase is used to wet the porous substrate, the stability of the interface of the water that fills the pores depends on the pore size. Very small pores provide a stable interface, but are more difficult to pre-wet. Too large pores might suffer from loss of wetting and fast evaporation of the liquid that fills the pores. In general, pores with a size below $100 \mathrm{~nm}$ are considered as suitable for interfacial polymerization reactions. For larger pores defects can occur, simply because there will be no liquid-liquid interface in an empty pore.

The support hydrophobicity has a similar influence on wetting as the pore size. Hydrophobic supports often require a pre-wetting step with a surfactant solution and the wetting liquid in hydrophobic supports might be confined to the pores. Hydrophilic supports are wetted more easily, and might have a thin wetting layer (of water) on top of the support. Therefore the location of the interface might be distinct for hydrophobic and hydrophilic supports.

When preparing a supported membrane via interfacial polymerization, the following practical steps are commonly employed:

1. Pre-wetting of the support by a surfactant solution.

2. Pre-wetting of the support by the monomer reactant solution.

3. Removal of excess liquid from the surface using a roller or by evaporation under an atmosphere.

4. Interfacial reaction on the support by static contact or active flow of the organic phase.

5. Removal of the organic phase from the surface by washing with excess solvent.

6. Removal of the aqueous phase from the pores by solvent exchange and/or evaporation.

7. Drying to remove residual solvent, or storage in a suitable liquid.

The pre-wetting step is commonly done by forcing a liquid flow through the support, by means of a pressure difference. Sufficient time must be used for pre-wetting of the support, as residual surfactant can influence the stability of the interface and layer formation. The removal of the aqueous phase often 
requires a solvent exchange step. When water is directly evaporated from the pore, pore collapse might occur due to the large negative Laplace pressure upon water evaporation. Therefore a low surface tension solvent is often used to replace the aqueous phase and to remove any residual, unreacted monomers. Commonly, the pores of the support are wetted with the aqueous phase. However, it is possible to use the organic phase to wet the support instead. ${ }^{185}$ The main difficulty with such an approach is maintaining a stable interface at the surface of the porous support.

Free-standing films can be prepared by simply contacting two phases containing monomer reactants. Usually this is done to prepare micro- or nanocapsules. For small particle dimensions, even small layer thicknesses provide sufficient mechanical strength. When preparing capsules via interfacial polymerization, the following practical steps are commonly employed:

1. Preparation of a stable emulsion by mixing and ultrasonic treatment or the preparation of droplets via microfluidic devices. Commonly, surfactants such as sodium dodecyl sulfate are added as emulsion stabilizers. ${ }^{177,}{ }^{186-188}$ Usually, only one of the phases contains a monomer reactant. In some cases both reactants are present, and the capsules are removed as they are formed. ${ }^{189}$

2. Addition (at once or dropwise) of a solution of the other monomer reactant. This can be during stirring and/or ultrasonic treatment. In a microfluidic device the monomer solution can simply be added at a location downstream, where the droplets are stable.

3. Removal of monomer reactants by washing in excess solvent.

4. Concentration of particles by settling, solvent evaporation, solvent exchange or centrifugal separation.

5. Drying to remove residual solvent, or storage in a suitable liquid.

Preparation of capsules via interfacial polymerization requires the addition of surfactants to obtain a stable emulsion with a narrow size distribution. The size of the capsules is determined by the stirring rate at which the emulsion is prepared. ${ }^{190}$ The addition of surfactants is known to change the nature of the interfacial polymerization reaction, and characteristics of the synthesized material. This is because the surfactant does not only stabilize the emulsion, but can also results in self-assembly of monomers at the interface. Examples include the interfacial polymerization of aniline by ammonium 
peroxydisulfate. Addition of cetyltrimethylammonium bromide (CTAB) could be used to tune the polyaniline from one-dimensional nanoneedles or nanowires with a network structure $(50-100 \mathrm{~nm}$ in diameter) to three-dimensional hollow microspheres $(\sim 400 \mathrm{~nm}$ outer diameter $)$ via a combination of self-assembly and interfacial polymerization.

\subsection{Chemistry of the precursors}

Most polymers that are prepared via interfacial polymerization are polyamides. The successful commercial application of aromatic polyamides in membrane applications has surged research towards improved interfacial polymerization based layers with improved (water) permeabilities, anti-fouling properties and retention of solutes. Nonetheless, the chemistry used for interfacial polymerization is certainly not limited to polyamides. Other materials prepared by interfacial polymerization include poly(bio-amides), polyesters, polyamines, polysiloxanes, polyimides, polyanilines and other conducting polymer analogues, polyurethanes and polyureas, and hybrid inorganic-organic materials such as metal organic frameworks ${ }^{191}$ or POSS based network materials. ${ }^{192}$ Here, we provide an overview of new materials prepared by interfacial polymerization and their properties. This review shows that interfacial polymerization has a large unexploited potential for the design of novel, ultrathin functional films

\subsubsection{Polyamides}

\section{Polyamide chemistry}

Polyamide chemistry is prevalent in interfacial polymerization based materials. Preparation of composite aromatic polyamide membranes via interfacial polymerization has been the main enabling technology for membrane-based seawater desalination and water purification. In general, polyamides are formed by the reaction between acid chlorides and di-, tri-, or polyamines.

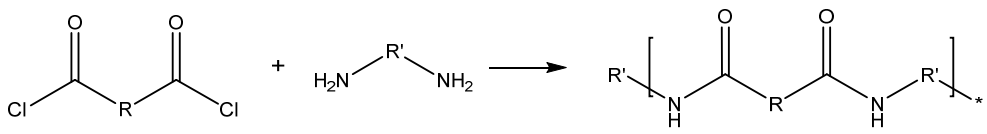

Polyamide formation can result in the release of hydrogen chloride. The formation of hydrogen chloride can locally change the reactivity of the monomer reactants in the aqueous phase. Often, a base such as sodium hydroxide or trimethylamine is added to consume the produced acid and to 
improve the reactivity of the amine reactant. In some cases, a strong base is required to make the aqueous phase monomer reactive. ${ }^{111}$

After interfacial polymerization, a large number of residual carboxylic acid and amine groups can remain in the polyamide. Post treatment to reduce the number of carboxylic acid groups on the membrane by washing with an amine solution. Both aliphatic and aromatic precursors are used for the preparation of polyamides. Commonly, aromatic polyamides are favored over aliphatic polyamides because of their higher degree of chain rigidity, more hydrophobic nature and better performance in membrane applications. Aromatic polyamides are known to be stable at $\mathrm{pH}$ ranging from 2-10, and are therefore used in a broad range of applications. ${ }^{193,194}$ Drawbacks of polyamides include their limited stability towards chlorine treatment that is used in membrane applications to remove fouling. ${ }^{195,} 196$ The development of chlorine-tolerant membranes is important because it directly reduces the costs of membrane replacement, backwashing chemicals, and energy to overcome the additional osmotic pressure. Stability of polyamide membranes is improved by changing the monomer precursors used for interfacial polymerization, ${ }^{197,}{ }^{198}$ or by chemical post-modification. ${ }^{199}$ In addition, the chemical composition of the polyamide is varied to prevent fouling effects, consequently reducing the need for harsh chemical cleaning. ${ }^{199}$ A number of polyamides show excellent stability and membrane performance in harsh chemical solvents such as dimethylformamide. ${ }^{200}$

An excellent review on the historical and current developments of reverse osmosis membranes is given by Lee et al.. ${ }^{201}$ They give an overview of the most important monomer precursors that are used for interfacial polymerization of polyamides, and a list of commercial membranes and their performance. Hermans et al. gives an overview of the membrane performance of different layers prepared by interfacial polymerization in solvent resistant nanofiltration applications. ${ }^{202}$ Lau et al. and Misdan et al. have reviewed thin film composite membranes for aqueous applications, including many examples of interfacial polymerization based membranes. ${ }^{179,}{ }^{203}$ A complete, recent overview of monomer precursors that are used for the synthesis of polyamides for membrane applications, including a variety of di- and multifunctional amines and acid chlorides, is given by Ismail et al.. ${ }^{204}$ In the present review, the overview of polyamides prepared via interfacial polymerization will be limited to the different types of polyamides. This overview, shown in Table 1-1, includes common precursors for aromatic and aliphatic polyamides, 
poly(piperazine-amide)s and poly(sulfon-amide)s. Almost all membranes prepared by interfacial polymerization are exclusively produced by the reaction of trimesoyl chloride (TMC) in the organic phase with either mphenylene diamine (MPD) or piperazine (pip) in the aqueous phase. Because common polyamides are covered by several reviews, this review will instead focus on novel polyamide (inorganic-organic) composites, hybrid inorganicorganic polyamides and bio-hybrid polyamides.

Table 1-1. Polyamides types and the most commonly used precursors used for preparation via interfacial polymerization, and the most important characteristics of the polyamide. In bold: the reactant names and main polymer application.

\begin{tabular}{|c|c|c|c|c|}
\hline Polyamide type & $\begin{array}{l}\text { Aq. phase } \\
\text { reactant }\end{array}$ & $\begin{array}{l}\text { Org. phase } \\
\text { reactant }\end{array}$ & Application & Ref. \\
\hline Aromatic polyamides & $\begin{array}{l}\text { Meta-phenylene } \\
\text { diamine } \\
\text { Para-phenylene } \\
\text { diamine. }\end{array}$ & $\begin{array}{l}\text { Trimesoyl } \\
\text { chloride }\end{array}$ & $\begin{array}{l}\text { Membranes } \\
\text { mainly for } \\
\text { reverse osmosis } \\
\text { and } \\
\text { nanofiltration. } \\
\text { High degree of } \\
\text { hydrogen bonding. } \\
\text { High thermal, } \\
\text { mechanical } \\
\text { stability and poor } \\
\text { solubility. }\end{array}$ & $\begin{array}{l}153,156,197, \\
205-212\end{array}$ \\
\hline $\begin{array}{l}\text { Aliphatic polyamides } \\
\text { Nylon } 6,6\end{array}$ & $\begin{array}{l}\text { Hexamethylene } \\
\text { diamine }\end{array}$ & Cyclohexane- & $\begin{array}{l}\text { Linear aliphatic } \\
\text { polyamides are } \\
\text { mainly prepared } \\
\text { and re-dissolved } \\
\text { for further } \\
\text { processing. }\end{array}$ & $195,213,214$ \\
\hline
\end{tabular}




\begin{tabular}{|c|c|c|c|c|}
\hline & $\begin{array}{l}\text { Poly(ethylene } \\
\text { imine) }\end{array}$ & $\begin{array}{l}1,3,5- \\
\text { tricarbonyl } \\
\text { chloride }\end{array}$ & $\begin{array}{l}\text { Branched aliphatic } \\
\text { polyamides and } \\
\text { aliphatic-aromatic } \\
\text { polyamides have } \\
\text { been prepared for } \\
\text { membrane } \\
\text { nanofiltration } \\
\text { and reverse } \\
\text { osmosis } \\
\text { applications. The } \\
\text { chlorine resistance } \\
\text { of aromatic } \\
\text { polyamides is } \\
\text { considered to be } \\
\text { higher. }\end{array}$ & \\
\hline Poly(piperazine-amide) & Piperazine & $\begin{array}{l}\text { Trimesoyl } \\
\text { chloride }\end{array}$ & $\begin{array}{l}\text { Membrane } \\
\text { reverse osmosis } \\
\text { and } \\
\text { nanofiltration } \\
\text { applications. } \\
\text { Improved } \\
\text { resistance against } \\
\text { chlorine treatment } \\
\text { with respect to } \\
\text { other aromatic } \\
\text { polyamides. }\end{array}$ & $215-218$ \\
\hline Poly(sulfon-amide) & $\begin{array}{l}\text { Meta-phenylene } \\
\text { diamine }\end{array}$ & $\begin{array}{l}\text { Benzene-1,3,5, } \\
\text { trisulphonyl } \\
\text { chloride } \\
\text { Benzene-1,4- } \\
\text { disulphonyl } \\
\text { chloride. }\end{array}$ & $\begin{array}{l}\text { Membrane } \\
\text { reverse osmosis } \\
\text { and } \\
\text { nanofiltration } \\
\text { applications. } \\
\text { Only stable in acid } \\
\text { conditions. In base } \\
\text { conditions the } \\
\text { amide group is } \\
\text { deprotonated. } \\
\text { Hydrophilic } \\
\text { character. }\end{array}$ & $215,219-221$ \\
\hline
\end{tabular}

\section{Polyamide composites}

Composites are physical dispersions of (inorganic) particles in a polymer matrix, with physical properties that are generally in between those of the two individual constituents. Composite layers can be prepared via interfacial 
polymerization by addition of particles to one of the monomer phases. Particles have the tendency to assemble at the interface to minimize the surface energy, moving into the interfacial polymerization reaction zone. Different type of micro- and nanoparticles have been used to prepare composites via interfacial polymerization layers. Examples include zeolites, ${ }^{201}$ 222-225 ceramics (silica ${ }^{71,146}$, titania ${ }^{226}$, mostly from sol-gel), MOFs and ZIFs, ${ }^{227-229}$ carbon nanotubes, ${ }^{230-234}$ proteoliposomes containing water transport proteins, ${ }^{235}$ liquid carriers such as di-(2-ethylhexyl)dithiophosphoric acid, ${ }^{236,237}$ and graphene. ${ }^{232}$ Figure 1-8 shows transmission electron micrographs

Most of the composites are prepared to obtain higher permeances for a selected component. Other advantageous properties include particles that act as antifoulant by reducing bacterial growth. ${ }^{238}$
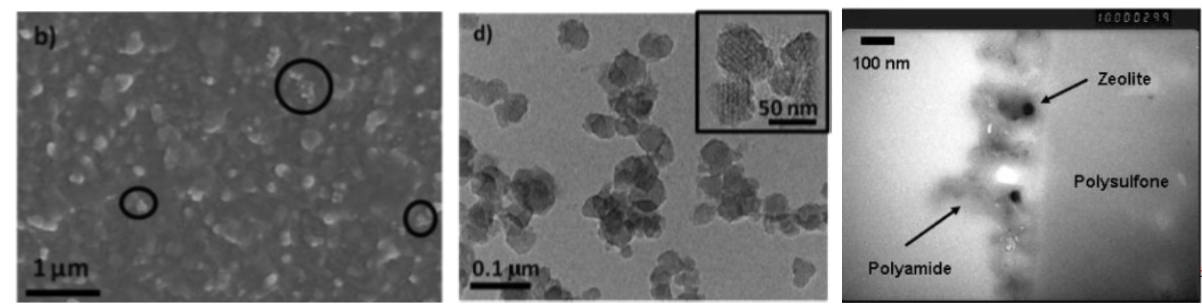

Figure 1-8. (left panel) Scanning electron micrograph of MIL-101(Cr) containing polyamide layer $[0.2$ wt./v.\%)] membrane surface after dimethylformamide dipping, (middle panel) Transmission electron micrograph of detached PA-MIL-101(Cr) thin film surface, where the inset is at a higher magnification. ${ }^{229}$ Copyright 2013. Adapted with permission from the American Chemical Society. (right panel) Transmission electron micrograph of a polyamide layer containing zeolite crystals. ${ }^{69}$ Copyright 2007. Adapted with permission from Elsevier Science Ltd.

\section{Hybrid inorganic-organic polyamides}

Hybrid inorganic-organic polyamides have been prepared via interfacial polymerization by using amine functionalized siloxane precursors. Example precursors include amine functionalized siloxanes that are copolymerized with polyamide precursors ${ }^{239}$ and polyhedral oligomeric silsesquioxanes with amine or ammonia functional groups. ${ }^{111,168,240}$ Table 1-2 shows an overview of the precursors used for hybrid inorganic-organic polyamides. The properties of the hybrid materials are distinct from composites due to the covalent bonds that are formed between the inorganic and organic moieties. ${ }^{239}$ 
Table 1-2. Precursors used for hybrid inorganic-organic polyamides prepared via interfacial polymerization, the reaction conditions, and the applications of the poly(POSS-amide)s. In bold: the reactant names, method of interfacial polymerization, reaction time and temperature and final polymer configuration.

\begin{tabular}{|c|c|c|c|c|}
\hline Aq. phase reactant & $\begin{array}{l}\text { Org. phase } \\
\text { reactant }\end{array}$ & $\begin{array}{l}\text { Reaction } \\
\text { conditions }\end{array}$ & Application & Ref. \\
\hline 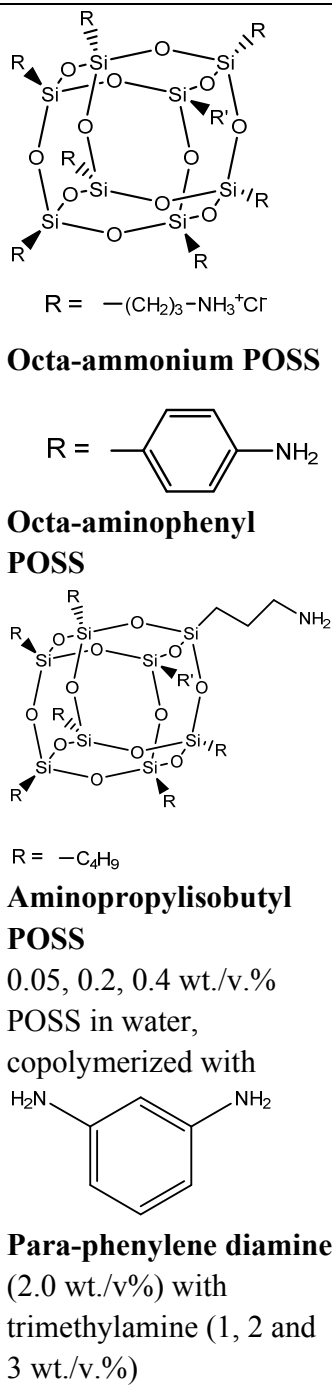 & $\begin{array}{l}\text { Trimesoyl } \\
\text { chloride (0.15 } \\
\text { wt./v.\%) in } \\
\text { hexane }\end{array}$ & $\begin{array}{l}\text { Preparation of the } \\
\text { layer on a PS } 20 \\
\text { support that is } \\
\text { immersed in aq. } \\
\text { solution for } 20 \\
\text { min. Excess water } \\
\text { is removed by } \\
\text { rubber rollers. } \\
\text { Next, the trimesoyl } \\
\text { chloride solution in } \\
\text { hexane is contacted } \\
\text { with the layer for } \\
20-60 \mathrm{~s} \text {. }\end{array}$ & $\begin{array}{l}\text { Membrane } \\
\text { nanofiltration } \\
\text { applications. } \mathrm{NaCl} \\
\text { salt rejection above } \\
98 \% \text { and permeances } \\
\text { between } 27-33 \mathrm{~L} \mathrm{~m}^{-2} \\
\mathrm{~h}^{-1} \text { bar }^{-1} \text { (vs. } 20 \mathrm{~L} \mathrm{~m}^{-2} \\
\mathrm{~h}^{-1} \text { bar }^{-1} \text { for similar } \\
\text { preparation conditions } \\
\text { without addition of } \\
\text { POSS. }\end{array}$ & 240 \\
\hline
\end{tabular}




\begin{tabular}{|c|c|c|c|c|}
\hline $\begin{array}{l}\mathrm{R}=-\left(\mathrm{CH}_{2}\right)_{3}-\mathrm{NH}_{3}{ }^{+} \mathrm{Cr} \\
\mathrm{R}^{\prime}=-\left(\mathrm{CH}_{2}\right)_{3}-\mathrm{NH}_{2} \\
\text { Octa-ammonium POSS } \\
(0.9 \text { wt.\%) in water with } \\
\text { pH 9.9, sodium } \\
\text { hydroxide }(\mathrm{NaOH}) \text { or } \\
\text { triethyl amine (TEA) } \\
\text { adjusted. }\end{array}$ & $\begin{array}{l}\text { Trimesoyl } \\
\text { chloride }(0.05 \\
\text { wt. \%) in } \\
\text { hexane. }\end{array}$ & $\begin{array}{l}\text { Preparation of the } \\
\text { layer on a } \\
\text { polyacrylonitril } \\
\text { (PAN) support. } \\
\text { The aq. solution is } \\
\text { forced through the } \\
\text { support by means } \\
\text { of vacuum for } 30 \\
\text { min. Excess water } \\
\text { is removed by } \\
\text { drying under } \mathrm{N}_{2} \\
\text { atmosphere, } \\
\text { followed by } \\
\text { contacting with the } \\
\text { TMC in hexane } \\
\text { phase for } \mathbf{1 - 5} \text { min. }\end{array}$ & $\begin{array}{l}\text { Membrane } \\
\text { nanofiltration } \\
\text { applications. } \\
9.7 \text {, using } \mathrm{NaOH} \text { as an } \\
\text { additive, the } \\
\text { molecular weight cut } \\
\text { off (MWCO, for the } \\
\text { aqueous PEG solution } \\
\text { is } 200 \mathrm{~g} \mathrm{~mol}^{-1} \text {. For a } \\
\text { solution of } \\
\text { polystyrenes in } \\
\text { toluene the MWCO is } \\
1000 \mathrm{~g} \mathrm{~mol}^{-1} \text {. The } \\
\text { permeances of water } \\
\text { and toluene are } 0.3 \\
\text { and } 0.6 \mathrm{~L} \mathrm{~m}^{-2} \mathrm{~h}^{-1} \text { bar }^{-1} \text {, } \\
\text { respectively. }\end{array}$ & 711,168 \\
\hline $\begin{array}{l}\text { Tetraethylorthosilicate } \\
\text { (TEOS) } \\
\text { silane (APTES, } 1: 1 \text { molar } \\
\text { ratio with TEOS) in water }\end{array}$ & $\begin{array}{l}\text { Adipoyl } \\
\text { chloride } \\
\text { in toluene }\end{array}$ & $\begin{array}{l}\text { Layer preparation } \\
\text { was achieved by } \\
\text { adding the adipoyl } \\
\text { chloride in } \\
\text { toluene solution } \\
\text { and } \\
\text { HMDA/TEOS/AP } \\
\text { TES solution in } \\
\text { water within } 10 \mathrm{~s} \\
\text { while stirring. } \\
\text { After } 90-120 \mathrm{~s} \\
\text { reaction time, the } \\
\text { polymer was } \\
\text { washed and dried } \\
\text { under vacuum at } \\
90^{\circ} \mathrm{C} \text {. Finally, the } \\
\text { polymer was } \\
\text { washed in boiling } \\
\text { methanol and } \\
\text { redried in vacuum. }\end{array}$ & $\begin{array}{l}\text { The polyamide silica } \\
\text { hybrid consists of a } \\
\text { network of silica } \\
\text { particles in the range } \\
\text { of } 30-40 \mathrm{~nm} \text { that are } \\
\text { covalently bonded to } \\
\text { the polyamide. The } \\
\text { bonded silica } \\
\text { nanocomposites } \\
\text { exhibit superior } \\
\text { mechanical stiffness } \\
\text { to the pristine } \\
\text { polyamide and } \\
\text { unbonded, silica } \\
\text { particle functionalized } \\
\text { polyamide. }\end{array}$ & 239 \\
\hline $\begin{array}{l}\text { Nonafluorohexylmethyl } \\
\text { siloxane functionalized } \\
\text { diphenylene diamine } \\
\text { (MPDSi, } 2 \text { wt.\%) in a } \\
\text { water/ethanol 90/10 wt.\% }\end{array}$ & $\begin{array}{l}\text { Trimesoyl } \\
\text { chloride }(0.1 \\
\text { wt.\%) in } \\
\text { hexane }\end{array}$ & $\begin{array}{l}\text { Ultem hollow } \\
\text { fibers were } \\
\text { immersed in } \\
\text { ethanol for } 30 \mathrm{~s} \text {, } \\
\text { and then in water } \\
\text { for } 1 \mathrm{~h} \text {. The fibers } \\
\text { were then } \\
\text { immersed in the } \\
\text { aq. amine solution }\end{array}$ & $\begin{array}{l}\text { Membrane } \\
\text { pervaporation for } \\
\text { water/ethanol } \\
\text { separation. Separation } \\
\text { factors between } 42- \\
108 \text {, with permeances } \\
\text { of about } 2 \mathrm{~kg} \mathrm{~m}^{-2} \mathrm{~h}^{-1} \text {. }\end{array}$ & 241 \\
\hline
\end{tabular}




\begin{tabular}{|l|l|l|l|}
\hline mixture & for 5 min. Excess & \\
& & liquid was & \\
removed by & blotting with paper & & \\
& & tissue. Finally, the & \\
fibers were dipped & & \\
& into the hexane & & \\
& solution for & & \\
& reaction times of & & \\
& $\mathbf{1 , 2}$ or $\mathbf{5}$ min. & & \\
\hline
\end{tabular}

\section{Poly(bio-amide)s}

Poly(bio-amide)s are a class of polyamides that include a biological component, such as amino acids or complete proteins.
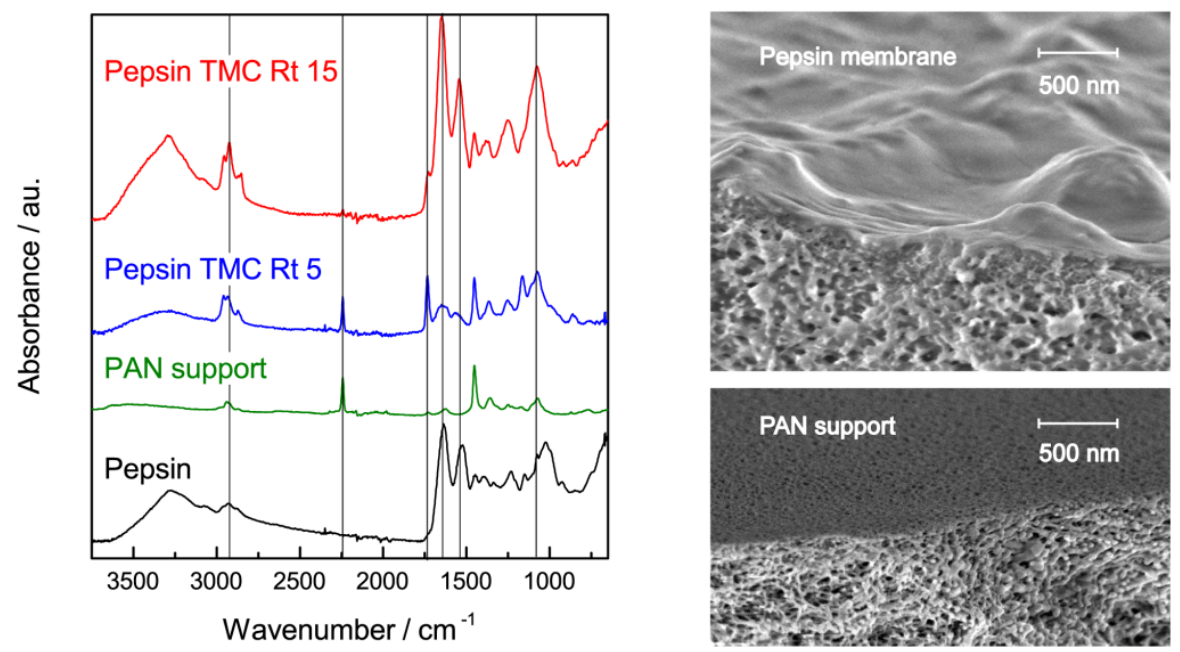

Figure 1-9. (left panel) ATR-FTIR absorbance spectrum of pepsin powder, PAN-PO supported ultrathin pepsin membranes prepared with 5 and 15 min reaction time. The absorbance peaks around $3000-3500 \mathrm{~cm}^{-1}$ represent the different $\mathrm{C}-\mathrm{C}, \mathrm{C}-\mathrm{H}$ and $\mathrm{O}-\mathrm{H}$ bonds present in the pepsin. Amino acid bonds are located at 1650 (N-H bending) and $1540\left(\mathrm{C}=\mathrm{O}\right.$ stretching) $\mathrm{cm}^{-1}$. (right panel) Scanning electron micrograph of a pepsin membrane atop a PAN support (top panel) and a bare PAN support (bottom panel). The pores present on the top side of the PAN support are not visible in the pepsin membrane PAN support. ${ }^{243}$ Copyright 2015. Adapted with permission from John Wiley \& Sons Inc. 
Interfacial polymerization of proteins has been demonstrated by polycondensation of bovine serum albumin ${ }^{162}$ and copolymerization of aquaporin with conventional m-phenyl diamine. ${ }^{235}$ The protein immobilization allows for layer preparation with very high protein concentrations ${ }^{242}$ that potentially have improved protein stability with respect to proteins in solution. Recently, the preservation of the protein function has been demonstrated by interfacially polymerized visible fluorescent proteins (VFP's) and pepsin films, as shown in Figure 1-9. ${ }^{243}$ Table 1-3 shows an overview of the precursors used for the synthesis of poly(bio-amide)s. Trimesoyl chloride is the most commonly used reactant for the organic phase, although the large number of residual carboxylic acid groups in the cross-linked protein films indicates that a large fraction of the acid chloride groups does not form amide bonds. ${ }^{244}$ Poly(bio-amide) based membranes have relatively high molecular weight cut-off values compared to conventional polyamides. Even though the proteins are highly cross-linked, the layers display proteins functionality, biocompatibility and switchable properties.

Table 1-3. Precursors used for poly(bio-amide)s prepared by interfacial polymerization, the reaction conditions, and the applications of the poly(bio-amide) layer. In bold: the reactant names, method of interfacial polymerization, reaction time and temperature and final polymer configuration.

\begin{tabular}{|c|c|c|c|c|}
\hline Aq. phase reactant & $\begin{array}{l}\text { Organic phase } \\
\text { reactant }\end{array}$ & Reaction conditions & Application & Ref. \\
\hline $\begin{array}{l}\text { Bovine serum albumin } \\
\left(\text { structure from }{ }^{245}\right)(5 \text {, } \\
\left.10,20,30 \mathrm{~g} \mathrm{~L}^{-1}\right) \text { in } \\
\text { water with PBS buffer } \\
\text { (pH 7). }\end{array}$ & $\begin{array}{l}\text { Trimesoyl } \\
\text { chloride }(1,2 \text {, } \\
3,4 \text {, and } 5 \mathrm{~g} \mathrm{~L}- \\
\left.{ }^{1}\right) \text { in hexane. }\end{array}$ & $\begin{array}{l}\text { Cross-linked BSA } \\
\text { layers were prepared } \\
\text { by immersing PCTE } \\
\text { substrate membrane in } \\
\text { the aq. BSA solutions } \\
\text { for } 20 \text { min. After } \\
\text { removing excess } \\
\text { solution with filter } \\
\text { paper, the substrates } \\
\text { were immersed into } \\
\text { the TMC solution in } \\
\text { hexane for 5-30 min, } \\
\text { at } \mathbf{2 0 - 8 0}{ }^{\circ} \mathbf{C} \text {. Next, the } \\
\text { cross-linked BSA } \\
\text { layers on PCTE } \\
\text { membranes were } \\
\text { rinsed and stored in } \\
\text { water. }\end{array}$ & $\begin{array}{l}\text { Membrane } \\
\text { nanofiltration } \\
\text { applications. } \\
\text { Rejection of } \\
\text { organic GII and } \\
\text { Congo red (20- } \\
100 \% \text { retention) } \\
\text { and pH responsive } \\
\text { water permeability } \\
\left(\mathrm{pH} 2,110 \mathrm{~L} \mathrm{~h}^{-1} \mathrm{~m}^{-2}\right. \\
\left.\mathrm{bar}^{-1}\right)\left(\mathrm{pH}^{-2}, 80 \mathrm{~L}\right. \\
\left.\mathrm{h}^{-1} \mathrm{~m}^{-2} \mathrm{bar}^{-1}\right)(\mathrm{pH} \\
12,160 \mathrm{~L} \mathrm{~h}^{-1} \mathrm{~m}^{-2} \\
\left.\text { bar }^{-1}\right)\end{array}$ & 162 \\
\hline
\end{tabular}




\begin{tabular}{|c|c|c|c|c|}
\hline $\begin{array}{l}\text { Bovine serum albumin } \\
\text { (structure from }{ }^{245} \text { ) and } \\
\text { Fibrinogen (structure } \\
\text { from }{ }^{246}, 3.8 \mathrm{wt} \% \text { ) in } \\
\text { PBS buffer (pH } \\
\text { adjusted to } 6.0,7.4 \text { and } \\
9.0 \text { ). }\end{array}$ & $\begin{array}{l}\text { Terephthaloyl } \\
\text { chloride (TDC, } \\
1.0 \text { wt.\%) in } \\
\text { xylene }\end{array}$ & $\begin{array}{l}\text { Protein capsules were } \\
\text { formed by pumping } \\
\text { BSA and fibrinogen } \\
\text { solutions in water and } \\
\text { TDC in xylene through } \\
\text { an y-shaped channel to } \\
\text { generate } \\
\text { microdroplets. Instant } \\
\text { layer formation } \\
\text { occurred upon droplet } \\
\text { formation. The } \\
\text { droplets were allowed } \\
\mathbf{2 4} \mathbf{h} \text { to react. }\end{array}$ & $\begin{array}{l}\text { Cross-linked } \\
\text { protein capsules } \\
\text { for cell growth } \\
\text { cultures. Capsules } \\
\text { with diameters of } \\
160-530 \mathrm{~nm} \text { were } \\
\text { obtained. Pore } \\
\text { diameter increased } \\
\text { with increasing pH } \\
\text { of the aq. solution. } \\
\text { At higher pH } \\
\text { values, a smoother } \\
\text { surface was } \\
\text { obtained. }\end{array}$ & 247,248 \\
\hline $\begin{array}{l}\text { Pepsin (structure from } \\
249) \\
(0.46 \text { wt.\%, PBS } \\
\text { buffered pH 7) in water }\end{array}$ & $\begin{array}{l}\text { Trimesoyl } \\
\text { chloride }(0.2 \\
\text { and } 0.5 \mathrm{wt} . \%)\end{array}$ & $\begin{array}{l}\text { Preparation of the } \\
\text { layer on a } \\
\text { polyacrylonitril (PAN) } \\
\text { support. The aq. } \\
\text { solution is forced } \\
\text { through the support by } \\
\text { means of vacuum for } \\
30 \text { min. Excess water } \\
\text { is removed by drying } \\
\text { under } \mathrm{N}_{2} \text { atmosphere, } \\
\text { followed by contacting } \\
\text { with the TMC in } \\
\text { hexane phase for 5-15 } \\
\text { min. }\end{array}$ & $\begin{array}{l}\text { Enzymatically } \\
\text { active pepsin } \\
\text { membrane layer. } \\
\text { (digestion of BSA } \\
\text { and hemoglobin at } \\
\mathrm{pH} 2 \text { ). Clean water } \\
\text { permeability } 50 \mathrm{~L} \\
\mathrm{~h}^{-1} \mathrm{~m}^{-2} \text { bar }^{-1} \text {. } \\
\mathrm{MWCO} \text { values of } \\
10-100 \mathrm{kDa} \text {. }\end{array}$ & 244 \\
\hline $\begin{array}{l}\text { EGFP (left, structure } \\
\text { from }{ }^{250} \text { ) and } \mathbf{m R F P} \\
\text { (right, structure from } \\
\left.{ }^{251}\right)(0.087 \text { wt. } \% \text {, Tris } \\
\text { buffered) in water. }\end{array}$ & $\begin{array}{l}\text { Trimesoyl } \\
\text { chloride }(0.05 \\
\text { wt. } \%) \text { in } \\
\text { hexane }\end{array}$ & $\begin{array}{l}\text { EGFP and mRFP } \\
\text { cross-linked layers } \\
\text { were formed by } \\
\text { contacting the aq. and } \\
\text { hexane solutions for } \mathbf{1 5} \\
\text { min. After removal of } \\
\text { the layer from the } \\
\text { interface using a glass } \\
\text { slide or a spatula, the } \\
\text { film was rinsed and } \\
\text { stored in water. }\end{array}$ & $\begin{array}{l}\text { Fluorescent } \\
\text { activity of EGFP } \\
\text { and mRFP layers. } \\
\text { high degree of } \\
\text { immobilization of } \\
\text { proteins (> 80\%) by } \\
\text { fluorescence } \\
\text { recovery after } \\
\text { photobleaching } \\
\text { measurements. }\end{array}$ & \\
\hline $\begin{array}{l}\left.\text { [D-Lys }{ }^{6}\right]- \text { LH-RH } \\
\text { growth hormone } \\
\text { (Sequence amino acid } \\
\text { Glp-His-Trp-Ser-Tyr- } \\
\text { Lys-Leu-Arg-Pro-Gly- } \\
\mathrm{NH}_{2} \text { ) in water (PBS } \\
\text { buffered, pH 7.4) with }\end{array}$ & $\begin{array}{l}\text { Ethylcyano } \\
\text { acrylate (ECA, } \\
25 \text { v.\%) in }\end{array}$ & $\begin{array}{l}\text { Hollow capsules were } \\
\text { prepared from water- } \\
\text { oil microemulsion, by } \\
\text { stirring the aq. and } \\
\text { ethyloleate solutions at } \\
700 \mathrm{rpm} \text { at } 4^{\circ} \mathrm{C} \text {. The } \\
\text { ECA solution in }\end{array}$ & $\begin{array}{l}\text { Hollow capsules } \\
\text { that allow for } \\
\text { controlled protein } \\
\text { delivery. The } \\
\text { growth hormone } \\
\text { co-polymerizes } \\
\text { with the }\end{array}$ & 252,253 \\
\hline
\end{tabular}




\begin{tabular}{|c|c|c|c|c|}
\hline $\begin{array}{l}\text { surfactants sorbitan } \\
\text { monolaurate (Crill 1) } \\
\text { and ethoxy } 20 \text { sorbitan } \\
\text { mono-oleate (Crillet 4). }\end{array}$ & $\begin{array}{l}\text { chloroform. } \\
\text { Ethyloleate was } \\
\text { used as oil } \\
\text { phase for } \\
\text { microemulsion } \\
\text { formation. }\end{array}$ & $\begin{array}{l}\text { chloroform was added } \\
\text { dropwise under } \\
\text { continued stirring. The } \\
\text { mixture was left } \\
\text { overnight to complete } \\
\text { the polymerization } \\
\text { reaction and to } \\
\text { evaporate the } \\
\text { chloroform. }\end{array}$ & $\begin{array}{l}\text { polymerizing } \\
\text { ethylcyanoacrylate. }\end{array}$ & \\
\hline $\begin{array}{l}\text { Crab protein ( } 2.5 \\
\text { wt. } \%) \text { and soy lechitin } \\
\text { surfactant }(2 \mathrm{wt} . \%) \text { in } \\
\text { water. Carboxymethyl } \\
\text { cellulose in } \mathrm{NaOH}(1 \\
\mathrm{M}) \text { was added to reduce } \\
\text { protein agglomeration. }\end{array}$ & $\begin{array}{l}\text { Mixtures of: } \\
\text { chloride and } \\
\text { chloride } \\
\text { In cyclohexane } \\
\text { / chloroform }\end{array}$ & $\begin{array}{l}\text { Cross-linked protein } \\
\text { capsules were prepared } \\
\text { by emulsifying the aq. } \\
\text { protein solution in } \\
\text { cyclohexane. Capsules } \\
\text { were prepared by } \\
\text { adding trimesoyl } \\
\text { chloride and sebacoyl, } \\
\text { while stirring the } \\
\text { emulsion. After } \mathbf{2 0} \\
\text { min reaction time the } \\
\text { capsules were allowed } \\
\text { to settle over } \mathbf{2 4} \mathbf{h} \text {. } \\
\text { Finally, the capsules } \\
\text { were removed by } \\
\text { centrifugation. }\end{array}$ & $\begin{array}{l}\text { Cross-linked } \\
\text { protein capsules } \\
\text { as a vehicle for } \\
\text { delivery of } \\
\text { nutrients. Higher } \\
\text { degree of protein } \\
\text { stability in the } \\
\text { protein wall in case } \\
\text { more TMC was } \\
\text { used. }\end{array}$ & 242 \\
\hline $\begin{array}{l}\text { Mixture of casein, fish } \\
\text { protein hydrolysate, } \\
\text { octopus meal, dextrin, } \\
\text { emulsified lipids and a } \\
\text { vitamin mixture. }\end{array}$ & $\begin{array}{l}\quad \text { Trimesoyl } \\
\text { chloride ( } 38 \\
\text { wt. \%) in } \\
\text { cyclohexane or } \\
\text { diethyl ether }\end{array}$ & $\begin{array}{l}\text { Cross-linked protein } \\
\text { capsules were prepared } \\
\text { by emulsifying the aq. } \\
\text { protein solution in } \\
\text { cyclohexane. Capsules } \\
\text { were prepared by } \\
\text { adding trimesoyl } \\
\text { chloride in diethyl } \\
\text { ether, while stirring at } \\
1000 \mathrm{rpm} \text {. After } 8 \text { min } \\
\text { reaction time the } \\
\text { capsules were allowed } \\
\text { to settle. Solvent was } \\
\text { removed by decanting } \\
\text { and solvent exchange. }\end{array}$ & $\begin{array}{l}\text { Cross-linked } \\
\text { protein capsules } \\
\text { as a vehicle for } \\
\text { delivery of } \\
\text { nutrients. The } \\
\text { capsules could } \\
\text { substitute live food } \\
\text { during the early } \\
\text { stages of larval } \\
\text { growth. }\end{array}$ & 254,255 \\
\hline
\end{tabular}

\section{Outlook}

Polyamide precursors are and will remain widely used for interfacial polymerization. The relative ease by which amine functionalized precursors 
can be prepared and the high reactivity of the acid chloride reactants allows for design of many polyamides. Recent work on composite, hybrid inorganicorganic and bio-hybrid materials shows that the polyamide chemistry will extend far beyond common aromatic polyamides based on the prevalent combinations of trimesoyl chloride with m-phenylene diamine and piperazine. Particularly the synergistic properties of hybrid polyamides holds much promise for the design of thin, high surface area, defect-free materials with distinct properties.

\subsubsection{Polyurethane and polyurea}

\section{Polyurethane chemistry}

Polyurethanes and polyurea are the most common polymers that are prepared via interfacial polymerization for the synthesis (hollow) nano- and microcapsules. Polyurethanes are formed by the reaction between diisocyanate and a polyol.

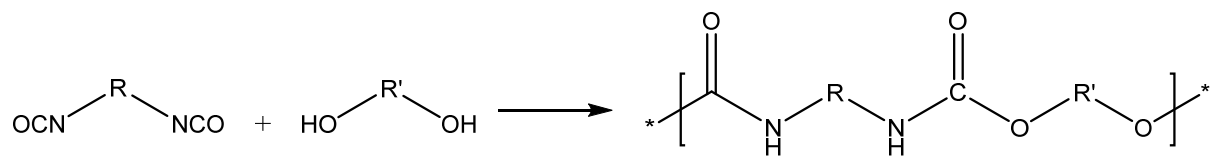

Polyureas are formed by the reaction between dicyanate and diamine groups.

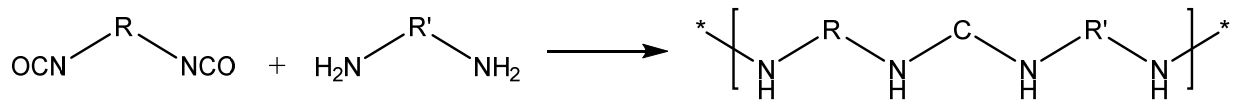

Urea groups are always formed during polyurethane synthesis in a watercontaining system. The side-reaction of isocyanate groups with water results in the formation of an amine. ${ }^{256}$ The amine can subsequently react with other isocyanate groups.
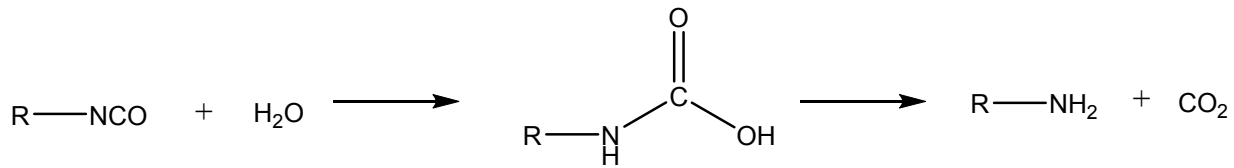

Most polyurethanes and polyureas have a low $T_{g}$, and are rubbery at room temperature. Their rubbery, dense characteristics are ideal for holding a liquid in the core of hollow capsules. The liquid core can be used as a phase change material, ${ }^{257-262}$, catalyst carrier, ${ }^{263-266}$ flame retarding agent, ${ }^{267}$ protective agent for damaged surfaces, ${ }^{268}$ slow release of agrochemicals ${ }^{269-271}$ or the delivery of 
pharmaceuticals. ${ }^{272,273}$ Also, residual, unreacted diisocyanate can be employed as a repair agent in self-healing materials. ${ }^{274}$ The release rate is controlled by the wall thickness and polymer characteristics. ${ }^{275}$ The main advantages of polyurethanes and polyureas are their chemical ${ }^{276}$ and mechanical stability (shell wall moduli of $3.7 \mathrm{GPa}$ are reported, and single capsule normalized maximum strength of 1-10 MPa). ${ }^{274,}{ }^{277}$ In addition, their biocompatibility allows for in-vitro applications. ${ }^{273}$

Polyurethane, polyurea and copolymers of both can be fabricated using a wide range of amine, alcohol and isocyanate precursors. Table 1-4 shows an overview of typical precursors that are used for polyurethane synthesis, the reaction conditions employed for synthesis, and the application of the synthesized polymers. Most common used diisocyanates are diphenylmethane diisocyanate (MDI), toluene diisocyanate (TDI), hexamethylene diisocyanate (HDI) and isophorone diisocyanate (IPDI). Most of the studies on polyurethane and polyurea capsules employ aliphatic polyalcohols and polyamines that are reacted with the aromatic diisocyanates. The $M_{w}$ of the polyamines and polyalcohols ranges from very small molecules such as ethane-1,2-diol to oligomers such as polyethylene glycol (PEG, with $M_{w}$ 's between 200-4200 $\mathrm{g} \mathrm{mol}^{-1}$ ). The size of the capsules depends mainly on the method of dispersion (stirring, ultrasonic treatment, microchannel droplet formation). The size of the capsules becomes smaller with increasing stirring rate. ${ }^{257-259,}{ }^{268}$ In addition, the capsule size depends on the type of reactant. At higher $M_{w}$ 's of di- and polyols, the mean size and yield of the nanocapsules was found to increase. ${ }^{278} \mathrm{In}$ addition, a higher degree of capsule agglomeration was observed when using higher $M_{w}$ precursors.

The main drawback of polyurethane synthesis via interfacial polymerization is the side-reaction of the isocyanate precursor with water, resulting in the formation of amine groups and subsequent formation of urea groups. The properties of the polymer depend on the ratio of urea and urethane groups that is determined by the hydrolysis rate of the isocyanates with respect to the layer formation rate. Urea group formation occurs in particular when the isocyanate solution is contact with water before addition of the aq. phase monomer reactant. The number of isocyanate groups that are converted to amines depends on the time that is used to prepare the emulsion, before the polymerization sets on. Addition of the isocyanate after emulsification can be used to suppress copolymer formation. 
Table 1-4. Precursors used for polyurethanes and polyureas prepared via interfacial polymerization, the reaction conditions, and their applications. In bold: the reactant names, method of interfacial polymerization, reaction time and temperature and final polymer configuration.

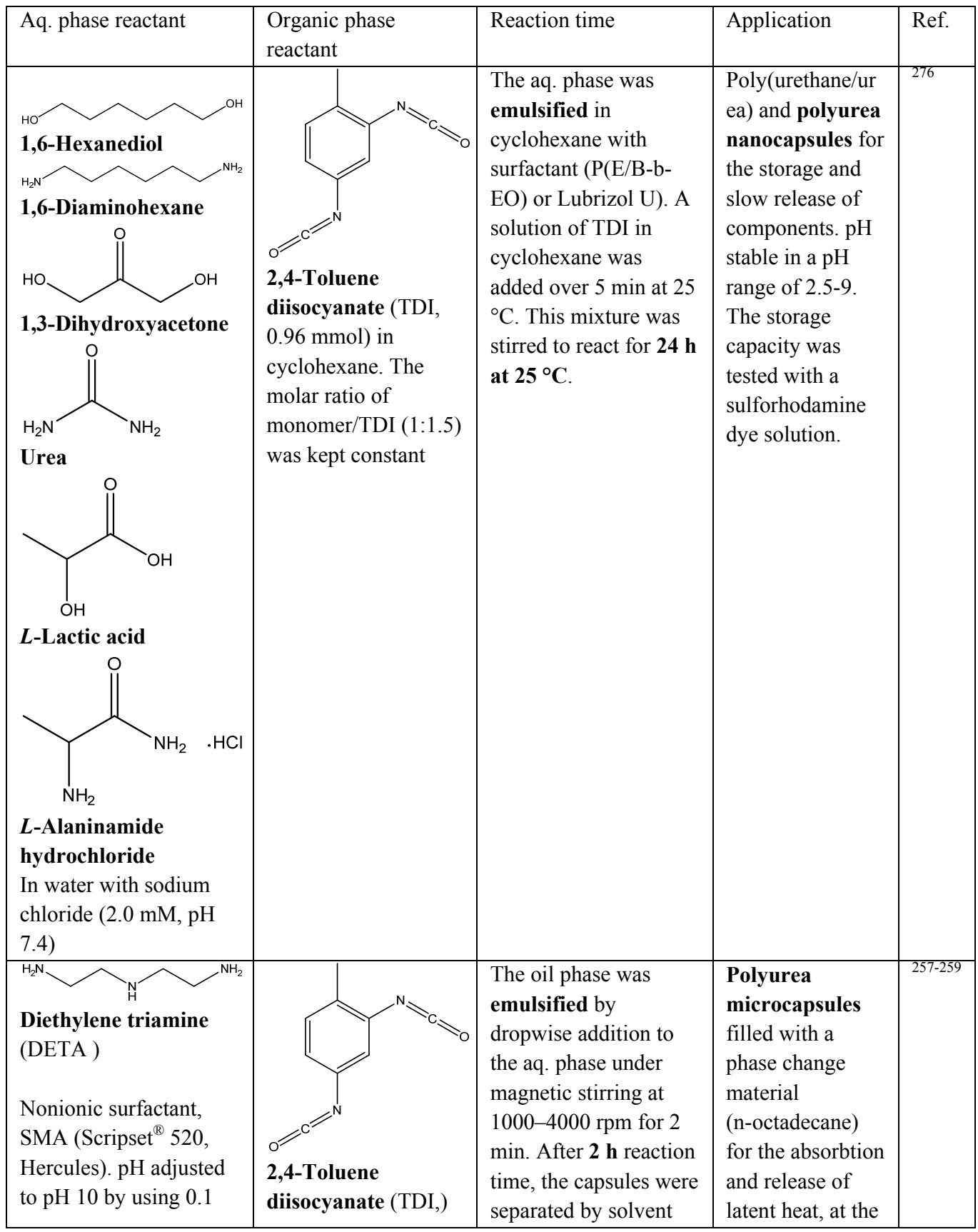




\begin{tabular}{|c|c|c|c|c|}
\hline $\begin{array}{l}\text { mol L } \mathrm{L}^{-1} \mathrm{NaOH} \text {. Molar } \\
\text { ratio of DETA/TDI } \\
\text { varied from } 0.84 \text { to } 1.35\end{array}$ & $\begin{array}{l}\text { in n-octadecane and } \\
20 \mathrm{~mL} \text { of acetone as } \\
\text { an oil phase. }\end{array}$ & $\begin{array}{l}\text { evaporation at } 40^{\circ} \mathrm{C} \\
\text { under reduced } \\
\text { pressure. }\end{array}$ & $\begin{array}{l}\text { melting point of } \\
\text { the liquid core. }\end{array}$ & \\
\hline $\begin{array}{l}\text { Ethane } \\
\text { water. }\end{array}$ & $\begin{array}{l}\text { Tri-isocyanates: } \\
\text { Desmodur L-75 and } \\
\text { Sumidur } \mathrm{N}-3300\end{array}$ & $\begin{array}{l}\text { The emulsion was } \\
\text { prepared by mixing the } \\
\text { oil phase to the water } \\
\text { phase for } 5 \text { min using a } \\
\text { TK Auto Homomixer } \\
\text { (Primix Corporation). } \\
\text { The interfacial } \\
\text { polymerization } \\
\text { reaction was initiated } \\
\text { by heating to } \mathbf{7 5}^{\circ} \mathbf{C} \\
\text { and reaction for } 48 \mathbf{~ h} \text {. }\end{array}$ & $\begin{array}{l}\text { Polyurethane } \\
\text { self-bursting } \\
\text { microcapsules } \\
\text { filled with } \\
\text { pyriproxyfen, an } \\
\text { insect growth } \\
\text { regulator. The } \\
\text { capsules, with } \\
\text { diameters } \\
\text { around, retained } \\
\text { their shape when } \\
\text { suspended in } \\
\text { water, but break } \\
\text { open after the } \\
\text { water is } \\
\text { removed. }\end{array}$ & 269 \\
\hline $\begin{array}{l}\text { Polyethylene glycol } \\
\left(M_{w}=200 \text { and } 400\right) \text { and }\end{array}$ & $\begin{array}{l}\text { 5-Isocyanato-1- } \\
\text { (isocyanatomethyl)- } \\
\text { 1,3,3-trimethyl- } \\
\text { cyclohexane (IDPI) } \\
\text { in saturated medium } \\
\text { chain triglyceride } \\
\text { (MCT) and soybean } \\
\text { oil (SO) }\end{array}$ & $\begin{array}{l}\text { The nano-emulsions } \\
\text { were prepared at } 25^{\circ} \mathrm{C} \\
\text { by phase inversion } \\
\text { composition } \\
\text { emulsification. The } \\
\text { aq. component was } \\
\text { added dropwise under } \\
\text { continuous mixing } \\
\text { with a vibromixer. } \\
\text { Polymerization was } \\
\text { initiated by heating the } \\
\text { emulsion to } 55-80{ }^{\circ} \mathbf{C} \text {. } \\
\text { The polymerization } \\
\text { reaction was stopped } \\
\text { after } \mathbf{4} \mathbf{h} \text { and samples } \\
\text { were kept at } 25^{\circ} \mathrm{C} \text {. }\end{array}$ & $\begin{array}{l}\text { Polyurethane and } \\
\text { polyurea } \\
\text { nanoparticles } \\
\text { with a small } \\
\text { diameter (50-90 } \\
\mathrm{nm} \text { ) for drug } \\
\text { delivery } \\
\text { applications. The } \\
\text { synthesis } \\
\text { required low } \\
\text { concentrations of } \\
\text { IDPI and showed } \\
\text { good } \\
\text { biocompatibility. }\end{array}$ & 273 \\
\hline $\begin{array}{l}\text { Polyamidoamine }\left(0^{\text {th }}\right. \\
\text { generation dendrimer }) \\
(0.005 \mathrm{M}) \text { in water with } \\
1.0 \mathrm{wt} \% \text { of PVA. }\end{array}$ & $\begin{array}{l}\text { 1-Isocyanato-4-[(4- } \\
\text { isocyanatophenyl) } \\
\text { methyl] benzene } \\
\text { (MDI) } 1.5 \mathrm{~g} \text { of MDI } \\
\text { and } 2 \mathrm{~g} \text { of linseed oil } \\
\text { in xylene. }\end{array}$ & $\begin{array}{l}\text { Dispersion of aq. } \\
\text { solution at } 3000,5000, \\
\text { and } 8000 \mathrm{rpm} \text { at } 25^{\circ} \mathrm{C} \\
\text { for } 5 \text { min to obtain } \\
\text { stable emulsion. } \\
\text { Dropwise addition of } \\
\text { PAMAM solution at } \\
300 \mathrm{rpm} \text {. The reaction } \\
\text { was continued for } \mathbf{3 0} \\
\text { min at } 30^{\circ} \mathbf{C} \text { and } \mathbf{1 . 5}\end{array}$ & $\begin{array}{l}\text { Polyurethane } \\
\text { microcapsules } \\
\text { filled with } \\
\text { anticorrosive } \\
\text { agent. mean } \\
\text { diameter in the } \\
\text { range of } 20-300 \\
\mu \mathrm{m} \text {. Polyurea } \\
\text { thermal stability } \\
\text { up to } 380^{\circ} \mathrm{C} \text {. PU }\end{array}$ & 268 \\
\hline
\end{tabular}




\begin{tabular}{|c|c|c|c|c|}
\hline & & $h$ at $45-50^{\circ} \mathrm{C}$. & $\begin{array}{l}\text { coatings on steel } \\
\text { substrate } \\
\text { embedded with } \\
\text { the polyurea } \\
\text { microcapsules } \\
\text { containing } \\
\text { linseed oil } \\
\text { showed corrosion } \\
\text { protection. }\end{array}$ & \\
\hline $\begin{array}{l}\text { 1,4-Butanediol in of } \\
\text { water with arabic gum } \\
\text { and surfactant } 43\end{array}$ & $\begin{array}{l}\text { 5-Isocyanato-1- } \\
\text { (isocyanatomethyl)- } \\
\text { 1,3,3-trimethyl- } \\
\text { cyclohexane (IDPI) } \\
\text { in chlorobenzene. }\end{array}$ & $\begin{array}{l}\text { Emulsification of aq. } \\
\text { solution at } 500-1500 \\
\text { rpm) for } 3 \mathrm{~h} \text {. The } \\
\text { mixture was then } \\
\text { slowly poured into the } \\
\text { arabic gum solution. } \\
\text { At } \mathbf{5 0}{ }^{\circ} \mathbf{C} \text {, the } 1,4- \\
\text { butanediol solution } \\
\text { was slowly added to } \\
\text { the emulsion and } \\
\text { reacted for } \mathbf{4 5} \text { min. } \\
\text { Once cooled to } \\
\text { ambient temperature, } \\
\text { the microcapsule } \\
\text { suspension } \\
\text { was rinsed with } \\
\text { deionized water and } \\
\text { vacuum filtered. }\end{array}$ & $\begin{array}{l}\text { Smooth spherical } \\
\text { polyurethane } \\
\text { microcapsules } \\
\text { of } 40-400 \mu \mathrm{m} \text { in } \\
\text { diameter. The } \\
\text { shell wall } \\
\text { thickness to } \\
\text { diameter ratio is } \\
\text { constant ( } \sim 0.05 \text { ). } \\
\text { High yields } \\
\text { ( 70\%) of a free- } \\
\text { flowing powder } \\
\text { of capsules are } \\
\text { produced with a } \\
\text { liquid core } \\
\text { content of } 70 \\
\text { wt. } \% \text {. The } \\
\text { microcapsules } \\
\text { are stable with } \\
\text { only 10 wt.\% } \\
\text { loss of IPDI } \\
\text { detected after } 6 \\
\text { months storage } \\
\text { under ambient } \\
\text { conditions. }\end{array}$ & 274 \\
\hline $\begin{array}{l}\text { Polyethylene glycol } \\
\left(M_{w}=200,300,400,\right.\end{array}$ & $\begin{array}{l}\text { 5-Isocyanato-1- } \\
\text { (isocyanatomethyl)- } \\
\text { 1,3,3-trimethyl- } \\
\text { cyclohexane (IDPI) } \\
\left(10^{-3} \mathrm{~mol}\right), \alpha-\end{array}$ & $\begin{array}{l}\text { Emulsification by } \\
\text { injection of the organic } \\
\text { phase in an aq. } \\
\text { surfactant solution } \\
\text { under magnetic } \\
\text { stirring, followed by } \\
\text { addition of the aqueous } \\
\text { phase with monomer } \\
\text { reactants. The } \\
\text { magnetic stirring is } \\
\text { maintained for } \mathbf{3} \text { h at } \\
\text { room temperature. }\end{array}$ & $\begin{array}{l}\text { Polyurethane } \\
\text { and poly(ether } \\
\text { urethane) } \\
\text { capsules in the } \\
\text { range of } 150 \text { - } \\
500 \mathrm{~nm} \text {. Drug } \\
\text { carriers for } \alpha \text { - } \\
\text { tocopherol, a } \\
\text { strong } \\
\text { antioxidant that } \\
\text { is used in } \\
\text { medical and }\end{array}$ & 278 \\
\hline
\end{tabular}




\begin{tabular}{|c|c|c|c|c|}
\hline $\begin{array}{l}425,600) \text { in water }(80 \\
\mathrm{ml}), \text { diol or polyether } \\
(10-2 \mathrm{~mol}) \text { and } \\
\text { hydrophilic surfactant } \\
\left(136 \mathrm{mg} \text { Tween }{ }^{2} 20\right) \text {. }\end{array}$ & $\begin{array}{l}\text { tocopherol }(400 \mathrm{mg}) \\
\text { and a lipophilic } \\
\text { surfactant }(86 \mathrm{mg} \\
\text { Span® } 85) \text { in water- } \\
\text { miscible solvent ( } 40 \\
\text { ml acetone) }\end{array}$ & $\begin{array}{l}\text { solvent is removed by } \\
\text { evaporation for } 45 \text { min } \\
\text { under reduced pressure }\end{array}$ & $\begin{array}{l}\text { cosmetic } \\
\text { applications. The } \\
\text { capsules provide } \\
\text { protection of the } \\
\text { active component } \\
\text { from light, heat } \\
\text { and oxygen. }\end{array}$ & \\
\hline $\begin{array}{l}\text { 1,6-Hexanediol }(0.23 \\
\mathrm{M}) \text { in water. } \\
\text { The emulsion is } \\
\text { stabilized with an SDS } \\
\text { solution (3-10 wt. \%) in } \\
\text { water. }\end{array}$ & $\begin{array}{l}\text { 5-Isocyanato-1- } \\
\text { (isocyanatomethyl)- } \\
\mathbf{1 , 3 , 3 - t r i m e t h y l -} \\
\text { cyclohexane (IDPI, } \\
0.43 \mathrm{M} \text { ) in } \\
\text { cyclohexane and } \\
\text { hexadecane as co- } \\
\text { stabilizer. }\end{array}$ & $\begin{array}{l}\text { The mini-emulsion } \\
\text { was prepared by } \\
\text { ultrasonic treatment at } \\
\text { various durations and } \\
\text { amplitudes, combined } \\
\text { with magnetic stirring } \\
\text { at } 500 \mathrm{rpm} \text { ). } \\
\text { Subsequently, the } \\
\text { solution of 1,6- } \\
\text { hexanediol) was added } \\
\text { dropwise for } 1 \text { min } \\
\text { under ultrasonic } \\
\text { treatment at } 20 \% \\
\text { amplitude. The } \\
\text { temperature was then } \\
\text { increased to } \mathbf{4 0 - 6 0}{ }^{\circ} \mathbf{C} \text {, } \\
\text { under magnetic stirring } \\
\text { at } 300 \text { rpm for } \mathbf{4 - 6} \mathbf{h} .\end{array}$ & $\begin{array}{l}\text { Polyurethane } \\
\text { capsules for drug } \\
\text { delivery } \\
\text { applications, with } \\
\text { mean diameters } \\
\text { around } 200 \mathrm{~nm} \text {. } \\
\text { The particles } \\
\text { were filled with } \\
\text { an ibuprofen } \\
\text { solution in } \\
\text { Miglyol } 812 \text {, a } \\
\text { triglyceride oil } \\
\text { used for drug } \\
\text { delivery } \\
\text { applications. }\end{array}$ & $\begin{array}{l}188, \\
272\end{array}$ \\
\hline $\begin{array}{l}\text { Polyvinyl alcohol-co- } \\
\text { vinyl acetate in water }\end{array}$ & $\begin{array}{l}\text { Mixtures of } \\
\text { Diisocyanatohexane } \\
\text { (HMDI) and } \\
\text { (Tri-isocyanate } \\
\text { in ethyl acetate and } \\
\text { dioctyl phthalate. The } \\
\text { weight fractions of } \\
D-110 \mathrm{~N} \text { with respect } \\
\text { to the total monomer } \\
\text { reactants were } 0 \text {, } \\
0.25,0.5,0.75 \text { and } 1 .\end{array}$ & $\begin{array}{l}\text { The organic phase was } \\
\text { poured into a } 5 \text { wt.\% } \\
\text { protective colloid } \\
\text { aqueous solution, and } \\
\text { stirred vigorously at } \\
5000 \text { rpm for } 10 \text { min } \\
\text { on ice with a } \\
\text { homogenizer (HG- } \\
300 \mathrm{D}+\mathrm{K} 12 \mathrm{~S} \text {, } \\
\text { Shuang-Tai Co., } \\
\text { Taiwan). The } \\
\text { suspension was stirred } \\
\text { for another } \mathbf{4} \text { h at } \mathbf{4 0} \\
{ }^{\circ} \mathbf{C} \text { to complete the } \\
\text { layer growth. }\end{array}$ & $\begin{array}{l}\text { Poly(urethane } \\
\text { urea) } \\
\text { microcapsules } \\
\text { (around } 1 \mu \mathrm{m} \\
\text { diameter) for } \\
\text { drug delivery } \\
\text { applications. } \\
\text { Controlled } \\
\text { release of a } \\
\text { yellow oil- } \\
\text { soluble dye was } \\
\text { used to determine } \\
\text { the release } \\
\text { kinetics. A } \\
\text { higher tri- } \\
\text { isocyanate } \\
\text { content resulted } \\
\text { in slower dye } \\
\text { release. }\end{array}$ & $279-281$ \\
\hline
\end{tabular}




\begin{tabular}{|c|c|c|c|c|}
\hline $\begin{array}{l}\text { 2-Amino-2- } \\
\text { (hydroxymethyl)-1,3- } \\
\text { propanediol }\end{array}$ & $\begin{array}{l}\text { 1-Isocyanato-4-[(4- } \\
\text { isocyanatophenyl) } \\
\text { methyl] benzene } \\
\text { (MDI) } \\
\text { Polyhexamethylene } \\
\text { diisocyanate } \\
\text { (Desmodur N 100) } \\
\text { in toluene (B 261, } \\
1 \mathrm{~g} \mathrm{~L}^{-1} \text { ) }\end{array}$ & $\begin{array}{l}\text { A stable inverse } \\
\text { emulsion was formed } \\
\text { by stirring of an } \\
\text { aqueous di- or triols } \\
\text { solution and toluene } \\
\text { containing a stabilizer } \\
\text { at } 300 \mathrm{rpm} \text {. Once the } \\
\text { emulsion was formed, } \\
\text { the stirring rate was } \\
\text { reduced to } 200 \text { rpm } \\
\text { and an isocyanate } \\
\text { solution in toluene was } \\
\text { added. Finally, the } \\
\text { reaction is continued } \\
\text { for several hours in } \\
\text { order to ensure the } \\
\text { wall growth, followed } \\
\text { by washing and } \\
\text { recovery of the } \\
\text { capsules. }\end{array}$ & $\begin{array}{l}\text { Synthesis of } \\
\text { large } \\
\text { polyurethane } \\
\text { capsules with } \\
\text { diameters } \\
\text { between } 50-400 \\
\mu \mathrm{m} \text {, for testing of } \\
\text { mechanical } \\
\text { properties. } \\
\text { The number of } \\
\text { broken capsules } \\
\text { decreased by } \\
\text { using a moderate } \\
\text { amount of cross- } \\
\text { linking agent and } \\
\text { sufficiently long } \\
\text { diols such as } \\
\text { PEG. Longer } \\
\text { diols such as } \\
\text { PEG allow for } \\
\text { more } \\
\text { deformation } \\
\text { without } \\
\text { breakage. }\end{array}$ & 157 \\
\hline
\end{tabular}

\section{Polyurethane and polyurea composites}

Polyurethane and polyurea nanocomposite capsules have been prepared by combining interfacial polymerization with a Pickering emulsion. The Pickering emulsion is prepared by using particles that assemble at the liquidliquid interface, stabilizing the emulsion without the need of additional surfactant. Upon interfacial polymerization, the particles are incorporated in the polymeric shell. Examples of particles that are used include silica (nanopowders with particle size of 5-30 nm or via sol-gel), ${ }^{282-286}$ nanoclay, ${ }^{287}$ magnetic nanoparticles $\left(\mathrm{Fe}_{3} \mathrm{O}_{4}\right),{ }^{288}$ and hollow capsules. ${ }^{289}$ The composites display improved the shelf life of the liquid core (i.e., leaching of the liquid core was slowed down) due to lowered liquid permeabilities and improved the mechanical strength.

\section{Outlook}

Polyurethanes and polyureas prepared via interfacial polymerization are currently mainly used for the synthesis of hollow capsules. However, 
polyurethanes and polyureas prepared via bulk polymerization are used for membrane applications such as gas separation ${ }^{290}$ and the removal of volatile organic components (VOC's) from aqueous streams by pervaporation and vapor permeation. ${ }^{291} \mathrm{Up}$ to date, interfacial polymerization has not been used for such membrane applications. Nonetheless, the preparation of ultrathin, highly cross-linked polyurethane and polyurea rubbers might show potential for solvent nanofiltration and other affinity based separations.

The recent developments in composite polyurethanes prepared by the combination of Pickering emulsion and interfacial polymerization show that the polymer properties can be improved by addition of nanoparticles. Much unexploited potential can be found in the wide variety of fillers used in polyurethane and polyurea nanocomposites prepared by bulk polymerization. ${ }^{292}$ Moreover, in particular capsules can benefit from the addition of particles that impart stimuli-responsive properties on the capsule wall. Examples include conductive or magnetic nanoparticles, heat responsive polymers and light sensitive components that can result in the selective transport of components in and out of the capsules or that can lead to subsequent reactions in the capsule components.

Although currently no hybrid polyurethanes and polyureas are prepared via interfacial polymerization, a large number of amine, hydroxyl and isocyanate precursors are readily available. Examples of hybrid precursors include isocyanate- $-{ }^{293}$ amine-, ${ }^{111}, 192,240,294$ and alcohol-functionalized POSS molecules. ${ }^{295,} 296$ Bio-hybrids can be prepared by using the amino acids of biological components as reactive component, although the high reactivity of isocyanates and their poor biocompatibility might result in loss of protein function.

\subsubsection{Polyesters}

\section{Polyester chemistry}

Interfacial polymerization is not widely used for preparation of polyesters. Of the limited number of studies available in literature, most focus on polyester layer formation for membrane applications such as nanofiltration ${ }^{297-299}$ reverse osmosis ${ }^{300}$ and gas separation. ${ }^{301}$ Polyesters can be prepared from the condensation reaction of acid halides and alcohols. 


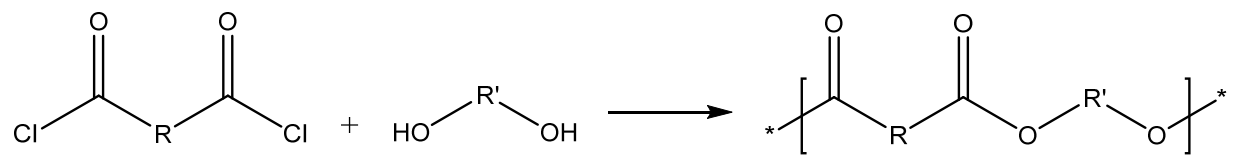

Alternatively, the interfacial polymerization of carboxylic acid and epoxy can be used to synthesize hydroxyesters. ${ }^{302}$

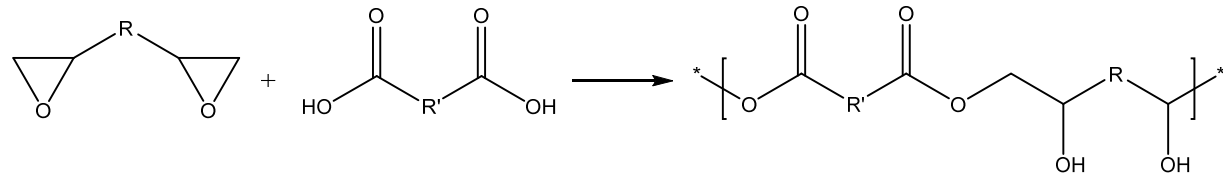

The main drawback of polyesters is their susceptibility to hydrolytic degradation under acid and base conditions, as compared to polyamides. In addition, only limited experimental data is available on polyester fouling resistance, stability against common cleaning agents, and performance at a broad range of relevant process conditions. Lastly, the membrane performance (in terms of permeance and salt rejection) is generally less than that of state-ofthe-art polyamide membranes. Nonetheless, some interesting approaches have been pursued in the preparation of polyesters via interfacial polymerization. Table 1-5 shows the precursors that are used for polyester layer formation, the synthesis conditions and their applications. Trimesoyl chloride, the most used reactant for polyamide membrane preparation, is used as the organic phase monomer. Both aliphatic and aromatic polyols are used. The molecular sizes of these polyols are larger with respect to common diamines used for polyamide preparation, namely meta-phenylene diamine and piperazine. It is almost surprising that simple benzenediols have not yet been employed in polyester synthesis, given the unsurpassed performance of polyamide membranes prepared with short amide bridges.

Table 1-5. Precursors used for polyesters prepared via interfacial polymerization, the reaction conditions, and their applications. In bold: the reactant names, method of interfacial polymerization, reaction time and temperature and final polymer configuration.

\begin{tabular}{|l|l|l|l|l|}
\hline Aq. phase reactant & $\begin{array}{l}\text { Org. phase } \\
\text { reactant }\end{array}$ & Reaction conditions & Application & Ref. \\
\hline $\begin{array}{l}\text { Bisphenol A (BPA, } \\
0.1-2 \text { wt./v.\%) }\end{array}$ & $\begin{array}{l}\text { NFPES10 support } \\
\text { membrane was } \\
\text { immersed in a TMBPA } \\
\text { or BPA aqueous } \\
\text { solution for 15 min. }\end{array}$ & $\begin{array}{l}\text { Membranes } \\
\text { nanofiltration } \\
\text { applications. The } \\
\text { layers exhibited } \\
\text { practically no }\end{array}$ & $\begin{array}{l}298, \\
303, \\
304\end{array}$ \\
\hline
\end{tabular}




\begin{tabular}{|c|c|c|c|c|}
\hline $\begin{array}{l}\text { Tetramethyl } \\
\text { Bisphenol A } \\
\text { (TMBPA) in water. } \\
\text { The pH is adjusted to } \\
11 \text { using } \mathrm{NaOH} \text {. }\end{array}$ & $\begin{array}{l}\text { Trimesoyl } \\
\text { chloride (0.15 } \\
\text { wt./v.\%) in } \\
\text { hexane }\end{array}$ & $\begin{array}{l}\text { The pre-soaked } \\
\text { membrane was taken } \\
\text { out from the aqueous } \\
\text { solution and positioned } \\
\text { vertically for } 2 \text { min to } \\
\text { drain the excess } \\
\text { monomer from the } \\
\text { surface. Subsequently, } \\
\text { the membrane was } \\
\text { dipped in the TMC } \\
\text { solution in hexane for } \\
\mathbf{1 0 ,} \mathbf{3 0} \text { or } \mathbf{6 0} \mathbf{s} \text {. }\end{array}$ & $\begin{array}{l}\text { irreversible fouling } \\
\text { by humic acid } \\
\text { molecules at pH } 7 . \\
\text { Only at } \mathrm{pH} 3 \text {, } \\
\text { irreversible fouling } \\
\text { by humic acid was } \\
\text { observed. }\end{array}$ & \\
\hline $\begin{array}{l}\text { Triethanolamine } \\
\text { and SDS (0.3 } \\
\text { wt./v.\%) in water. } \mathrm{pH} \\
\text { adjusted with of } \\
\mathrm{NaOH} \text { and } \mathrm{Na}_{2} \mathrm{CO}_{3}\end{array}$ & $\begin{array}{l}\text { Trimesoyl } \\
\text { chloride in } \\
\text { hexane }\end{array}$ & $\begin{array}{l}\text { The polysulfone } \\
\text { support membrane was } \\
\text { immersed in the aq. } \\
\text { phase for } 30 \text { min at } 35 \\
{ }^{\circ} \mathrm{C} \text {. A rubber roller was } \\
\text { used to remove any } \\
\text { bubbles from the } \\
\text { surface. Next, the } \\
\text { water solution was } \\
\text { drained and the } \\
\text { support was air-dried } \\
\text { at room temperature. } \\
\text { Finally, the supports } \\
\text { are placed in the } \\
\text { organic phase for up to } \\
\text { 35 min. The } \\
\text { membranes were post- } \\
\text { treated at } 60{ }^{\circ} \mathrm{C} \text { for } 30 \\
\text { min. The final } \\
\text { membranes were } \\
\text { washed and stored in } \\
\text { water. }\end{array}$ & $\begin{array}{l}\text { Membrane } \\
\text { nanofiltration } \\
\text { applications. } \\
\text { Rejection of } \mathrm{Na}_{2} \mathrm{SO}_{4} \\
(82.2 \%), \mathrm{MgSO}_{4} \\
(76.5 \%), \mathrm{NaCl} \\
(42.2 \%) \text { and } \mathrm{MgCl}_{2} \\
(23 \%) . \text { Water flux } \\
\text { around } 10 \mathrm{~L} \mathrm{~m}^{-2} \mathrm{~h}^{-1} \\
\text { bar }{ }^{-1} \text {. Reaction time, } \\
\text { reactant } \\
\text { concentrations were } \\
\text { varied to optimize } \\
\text { membrane } \\
\text { performance. } \\
\text { Addition of multi- } \\
\text { walled carbon } \\
\text { nanotubes resulted } \\
\text { in flux increase } \\
\text { (max increase at } 0.5 \\
\text { g } \mathrm{L}^{-1} \text { in the aq. } \\
\text { solution used for } \\
\text { interfacial } \\
\text { polymerization. }\end{array}$ & $\begin{array}{l}305, \\
306\end{array}$ \\
\hline $\begin{array}{l}\text { Triethanolamine (6 } \\
\text { wt./v.\%) and }\end{array}$ & $\begin{array}{l}\text { Trimesoyl } \\
\text { chloride }(0.6 \\
\text { wt./v.\%) in } \\
\text { hexane }\end{array}$ & $\begin{array}{l}\text { The PSf support was } \\
\text { immersed in the } \\
\text { organic phase for } 30 \\
\text { min. Then, the TMC- } \\
\text { saturated support } \\
\text { membrane was } \\
\text { immersed into the } \\
\text { aqueous phase for } 35 \\
\text { min. Afterwards, the } \\
\text { membrane was put into }\end{array}$ & $\begin{array}{l}\text { Membranes } \\
\text { nanofiltration } \\
\text { applications. The } \\
\text { addition of } \beta-C D \\
\text { increased the } \\
\text { number of } \\
\text { negatively charged } \\
\text { groups, increased } \\
\text { the flux (up to } 2 \\
\text { times with respect }\end{array}$ & 307 \\
\hline
\end{tabular}




\begin{tabular}{|c|c|c|c|c|}
\hline $\begin{array}{l}\text { B-cyclodextrin ( } \beta \text { - } \\
\mathrm{CD} \text { ) and sulfonated } \\
\beta \text {-CD in water with } \\
\mathrm{SDS}(0.3 \text { wt./v.\%). } \\
\mathrm{pH} \text { adjusted with of } \\
\mathrm{NaOH} \text { and } \mathrm{Na}_{2} \mathrm{CO}_{3}\end{array}$ & & $\begin{array}{l}\text { the organic phase } \\
\text { again for } \mathbf{3 5} \text { min. } \\
\text { Finally, the membrane } \\
\text { was subjected to a heat } \\
\text { treatment at } 60^{\circ} \mathrm{C} \text { for } \\
30 \text { min, followed by } \\
\text { soaking the membrane } \\
\text { in an aqueous solution } \\
\text { of SDS }(0.1 \% \text {, w } / \mathrm{v}) \\
\text { with pH } 11 \text { for } 24 \mathrm{~h} \text {. } \\
\text { The final membranes } \\
\text { were washed and } \\
\text { stored in deionized } \\
\text { water. }\end{array}$ & $\begin{array}{l}\text { to the bare } \\
\text { polyester) }\end{array}$ & \\
\hline $\begin{array}{l}\text { Triethanolamine in } \\
\text { water with SDS } \\
(0.3 \text { wt./v.\%) and } \\
\mathrm{LiBr} \text { salt }(0-7 \\
\text { wt./v.\%). The pH } \\
\text { adjusted to } 12 \text { by a } \\
\text { mixture of } \mathrm{NaOH} \\
\text { and } \mathrm{Na}_{2} \mathrm{CO}_{3}\end{array}$ & $\begin{array}{l}\text { Trimesoyl } \\
\text { chloride }(0.2 \\
\text { wt./v. \%) in } \\
\text { hexane }\end{array}$ & $\begin{array}{l}\text { The PSf support } \\
\text { membrane was } \\
\text { immersed in the } \\
\text { aqueous phase for } 30 \\
\text { min at } 35^{\circ} \mathrm{C} \text {. After } \\
\text { removing excess } \\
\text { liquids on the } \\
\text { membrane surface, the } \\
\text { membrane was soaked } \\
\text { in the organic phase } \\
\text { for } 35 \text { min. Finally, the } \\
\text { membrane was post- } \\
\text { treated in an oven at } 60 \\
{ }^{\circ} \mathrm{C} \text { for about } 30 \text { min. } \\
\text { The membranes were } \\
\text { thoroughly washed } \\
\text { with deionized water. }\end{array}$ & $\begin{array}{l}\text { Membrane } \\
\text { nanofiltration } \\
\text { applications. } \mathrm{LiBr} \\
\text { salt influenced the } \\
\mathrm{Na}_{2} \mathrm{SO}_{4} \text { and } \mathrm{MgSO}_{4} \\
\text { rejection and } \\
\text { permeation, by } \\
\text { influencing the layer } \\
\text { formation during } \\
\text { interfacial } \\
\text { polymerization. } 3 \\
\text { wt.\% LiBr gave } \\
\text { highest water flux } \\
\text { improvement. } 1 \\
\text { wt.\% LiBr } \\
\text { dramatically } \\
\text { decreased retention. }\end{array}$ & 308 \\
\hline $\begin{array}{l}\text { Hyperbranched } \\
\text { polyester (HPE, } 2.7 \\
\text { wt. } \% \text { ) in water with } \\
0.3 \text { wt. } \% \text { of SDS. } 2^{\text {nd }} \text {, } \\
3^{\text {rd }} \text {, and } 4^{\text {th }} \text { pseudo- } \\
\text { generation }(16,32 \\
\text { and } 64 \text { terminated } \\
\text { OH-groups, }\end{array}$ & $\begin{array}{l}\text { Trimesoyl } \\
\text { chloride }(0.5 \\
\text { wt. \%) in } \\
\text { hexane. }\end{array}$ & $\begin{array}{l}\text { PAN support } \\
\text { membrane was pre- } \\
\text { wetted by ethanol. The } \\
\text { pre-wetted supports } \\
\text { were then immersed in } \\
\text { the HPE in ethanol } \\
\text { solution for } 40 \text { min } \\
\text { After draining the } \\
\text { excess solution, the } \\
\text { membranes were } \\
\text { submersed in the TMC } \\
\text { solution in hexane for } \\
30 \text { min. Finally, the } \\
\text { membranes were heat } \\
\text { treated at } 80{ }^{\circ} \mathrm{C} \text { for } 20\end{array}$ & $\begin{array}{l}\text { Membrane } \\
\text { nanofiltration } \\
\text { applications. The } \\
\text { membrane surface } \\
\text { displayed a negative } \\
\text { surface and had a } \\
\text { MWCO of 4-6 kDa. } \\
\text { Rejection properties } \\
\text { of the membranes } \\
\text { depended on the dye } \\
\text { charge, dye } \\
\text { concentrations and } \\
\text { salt concentrations. }\end{array}$ & $\begin{array}{l}297, \\
299, \\
309\end{array}$ \\
\hline
\end{tabular}




\begin{tabular}{|c|c|c|c|c|}
\hline respectively). & & $\begin{array}{l}\text { min. The membrane } \\
\text { was preserved in water } \\
\text { for further use. }\end{array}$ & & \\
\hline $\begin{array}{l}\text { Potassium 1,3,5- } \\
\text { benzene } \\
\text { tricarboxylate (1.62 } \\
\text { g) in } 150 \mathrm{~mL} \text { water }\end{array}$ & $\begin{array}{l}\sum_{0}^{\circ} \\
\text { Epoxy resin } \\
(5.465 \mathrm{~g}) \text { in } 50 \\
\mathrm{~mL} \\
\text { toluene }\end{array}$ & $\begin{array}{l}\text { The epoxy in toluene } \\
\text { solution was } \\
\text { emulsified by } \\
\text { dropwise addition to } \\
\text { tetrabutylammonium } \\
\text { hydrogen sulfate } \\
\text { (TBAH, } 3.055 \mathrm{~g} \text { in } 150 \\
\text { mL water, phase } \\
\text { transfer catalyst) in } \\
\text { water under stirring at } \\
700 \text { rpm at } \\
\text { temperatures up to } \\
60{ }^{\circ} \mathrm{C} \text {. Next, the } \\
\text { aqueous phase with } \\
\text { carboxylic acid } \\
\text { monomers was added } \\
\text { dropwise. The reaction } \\
\text { was carried out for } 5 \\
\text { days under reflux, with } \\
\text { stirring ( } 700 \text { rpm) at } 60 \\
{ }^{\circ} \mathrm{C} \text {. The organic phase } \\
\text { was evaporated under } \\
\text { reduced pressure and } \\
\text { further purified in } \\
\text { tetrahydrofuran (THF), } \\
\mathrm{N}-\text { methylpyrrolidone } \\
\text { (NMP) and water. }\end{array}$ & $\begin{array}{l}\text { At lower stirring } \\
\text { rates, } \\
\text { microcapsules in } \\
\text { the range of } 100- \\
400 \mu \mathrm{m} \text { were } \\
\text { obtained. At higher } \\
\text { stirring rates, } \\
\text { microcapsules in the } \\
\text { range of } 10-50 \mu \mathrm{m} \\
\text { were obtained. } \\
\text { Intermolecular } \\
\text { transesterification } \\
\text { was observed as } \\
\text { side reaction. } \\
\text { Capsule } \\
\text { morphology was } \\
\text { influenced by the } \\
\text { cross-linker content. }\end{array}$ & 302 \\
\hline $\begin{array}{l}\text { Diphenolic acid } \\
\text { (DPA, } 0.01 \mathrm{~mol}) \text {, } \\
\mathrm{NaOH}(0.03 \mathrm{~mol}) \text {, } \\
\text { and } \\
\text { tetrabutylammonium } \\
\text { hydrogen sulfate } \\
\text { (TBAC, } 0.117 \mathrm{~g}) \text { in } \\
90 \mathrm{~mL} \text { water. }\end{array}$ & $\begin{array}{l}\text { Isophthaloyl } \\
\text { chloride (IPC, } \\
0.01 \text { mol) in } 50 \\
\mathrm{~mL} \\
\text { dichloromethan } \\
\text { e }\end{array}$ & $\begin{array}{l}\text { IPC in } \\
\text { dichloromethane was } \\
\text { emulsified in the aq. } \\
\text { DPA solution under } \\
\text { stirring at } 400 \mathrm{rpm} \text {. } \\
\text { The reaction was } \\
\text { performed at } 25^{\circ} \mathrm{C} \text { for } \\
\mathbf{1} \mathbf{h} \text {, while adjusting } \\
\text { the pH to around } 3 \\
\text { using sulfuric acid. } \\
\text { The acidified polyester } \\
\text { product, poly(DPA- } \\
\text { IPC), was washed with } \\
\text { deionized water and } \\
\text { acetone. Finally, it was } \\
\text { filtered, and dried at }\end{array}$ & $\begin{array}{l}\text { Microcapsule } \\
\text { synthesis. Shell } \\
\text { growth occurred } \\
\text { towards the core, } \\
\text { gradually increasing } \\
\text { shell thickness. The } \\
\text { viscosity of the } \\
\text { reaction zone and } \\
\text { diffusion rate of } \\
\text { monomers and } \\
\text { oligomers depended } \\
\text { on the miscibility } \\
\text { between the solvent } \\
\text { and the polymer. } \\
\text { Shell growth } \\
\text { depended on solvent }\end{array}$ & 310 \\
\hline
\end{tabular}




\begin{tabular}{|c|c|c|c|c|}
\hline & & $\begin{array}{l}100^{\circ} \mathrm{C} \text { in a vacuum } \\
\text { oven. }\end{array}$ & $\begin{array}{l}\text { type used for } \\
\text { synthesis. }\end{array}$ & \\
\hline $\begin{array}{l}\text { Tannic acid }(0.1-0.5 \\
\mathrm{g} \mathrm{L} \text { ) in water. The } \\
\mathrm{pH} \text { was kept at } 7.0 \\
\text { with } 0.1 \mathrm{M} \\
\text { phosphate buffer } \\
\text { solution. }\end{array}$ & $\begin{array}{l}\quad{ }_{\mathrm{Cl}} \\
\text { Trimesoyl } \\
\text { chloride } \\
(\mathrm{TMC}, 0.1-0.5 \\
\left.\mathrm{g} \mathrm{L}^{-1}\right) \text { in } \\
\text { hexane. }\end{array}$ & $\begin{array}{l}\text { Polyethersulfone } \\
\text { support membranes } \\
\text { were first soaked into } \\
\text { the aqueous tannic acid } \\
\text { solution for about } 10 \\
\text { min. The residual } \\
\text { water on the surface } \\
\text { was drained off using } \\
\text { filter papers. } \\
\text { Subsequently, the } \\
\text { membranes were } \\
\text { immersed into TMC } \\
\text { solution for } 1-15 \text { min. } \\
\text { Excess organic } \\
\text { solution was drained } \\
\text { and the coated surfaces } \\
\text { were air-dried in an } \\
\text { oven at } 20-80{ }^{\circ} \mathrm{C} \text {. } \\
\text { Finally, the } \\
\text { membranes were } \\
\text { washed and stored in } \\
\text { water. }\end{array}$ & $\begin{array}{l}\text { Membrane } \\
\text { nanofiltration } \\
\text { applications. The } \\
\text { permeances were in } \\
\text { between } 13-50 \mathrm{~L} \mathrm{~m}^{-} \\
{ }^{2} \mathrm{~h}^{-1} \text { bar }^{-1} \text {. Orange } \\
\text { GII rejection was } \\
\text { above } 98 \% \text { for all } \\
\text { membranes with a } \\
\text { reaction time above } \\
5 \text { min. Rejection of } \\
\text { monovalent and } \\
\text { divalent salts } \\
\text { increased with } \\
\text { increasing tannic } \\
\text { acid concentration } \\
\text { and decreasing } \\
\text { TMC concentration. }\end{array}$ & 311 \\
\hline
\end{tabular}

\section{Polyester composites}

Only few examples of polyester composites are available in literature. There has been some work on incorporating multi-walled carbon nanotubes to improve the membrane permeance while maintaining high selectivity. ${ }^{306,} 312$ Also, (sulfonated) $\beta$-cyclodextrin has been incorporated in the polymer to change the surface charge for better salt rejection performance. ${ }^{307}$

\section{Outlook}

Polyesters might provide an interesting analogue to polyamides. Differences in layer formation can be expected from the differences in reactivity and solubility of alcohol and amide groups. Further optimization of the choice in polyester precursors might yield membranes with membrane performance that is similar as for aromatic polyamides. Moreover, the distinct surface charge properties, layer morphology and affinity might provide an interesting platform for specific separation applications. 


\subsubsection{Polyamines}

\section{Polyamine chemistry}

The resonance structure of s-triazines provides polymer rigidity, thermal and chemical stability. This is reflected by the $\mathrm{pH}$ stability of nanofiltration membranes based in cyanuric chloride prepared via interfacial polymerization. ${ }^{313}$ Polyamines are prepare by a condensation reaction between a diamine and a di- or trichloride functionalized triazine.

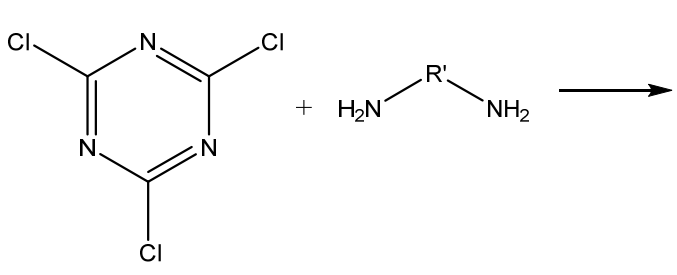<smiles>CP(C)Nc1nc(NNC(C)(C)C)nc(NP(C)(C)(C)C)n1</smiles>

One drawback of di- or trichloride triazines is their decreasing reactivity with the number of chloride group substitutions. ${ }^{314}$ The first chloride group will be substituted easily at room temperature. For the second and third chloride groups, temperatures of $40-60{ }^{\circ} \mathrm{C}$ may be employed to improve the reactivity. Table 1-6 shows an overview of the monomer reactants that have been used to prepare polyamines via interfacial polymerization. Both small monomer reactants such as m-phenylene diamine and large oligomers such as poly(ethylene imine)s have been employed for layer preparation. The concentrations of the polyamines and di- and trichloride triazines are relatively high as compared to polyamide synthesis, which might be due to the lower reactivity of the chloride groups with respect to acid chlorides.

Table 1-6. Precursors used for polyamines prepared via interfacial polymerization, the reaction conditions, and their applications. In bold: the reactant names, method of interfacial polymerization, reaction time and temperature and final polymer configuration.

\begin{tabular}{|l|l|l|l|l|}
\hline Aq. phase reactant & $\begin{array}{l}\text { Org. phase } \\
\text { reactant }\end{array}$ & Reaction conditions & Application \\
\hline Poly(ethylene imine) & Cyanuric & $\begin{array}{l}\text { Hydrophilised } \\
\text { polyethersulfone } \\
\text { (PESf) support } \\
\text { membrane was pre- } \\
\text { wetted by 0.05 wt\% } \\
\text { SDS solution by means }\end{array}$ & $\begin{array}{l}\text { Membrane } \\
\text { applications. Stable } \\
\text { performance in a } \\
\text { pH range of 1-13. }\end{array}$ & 313 \\
\hline
\end{tabular}




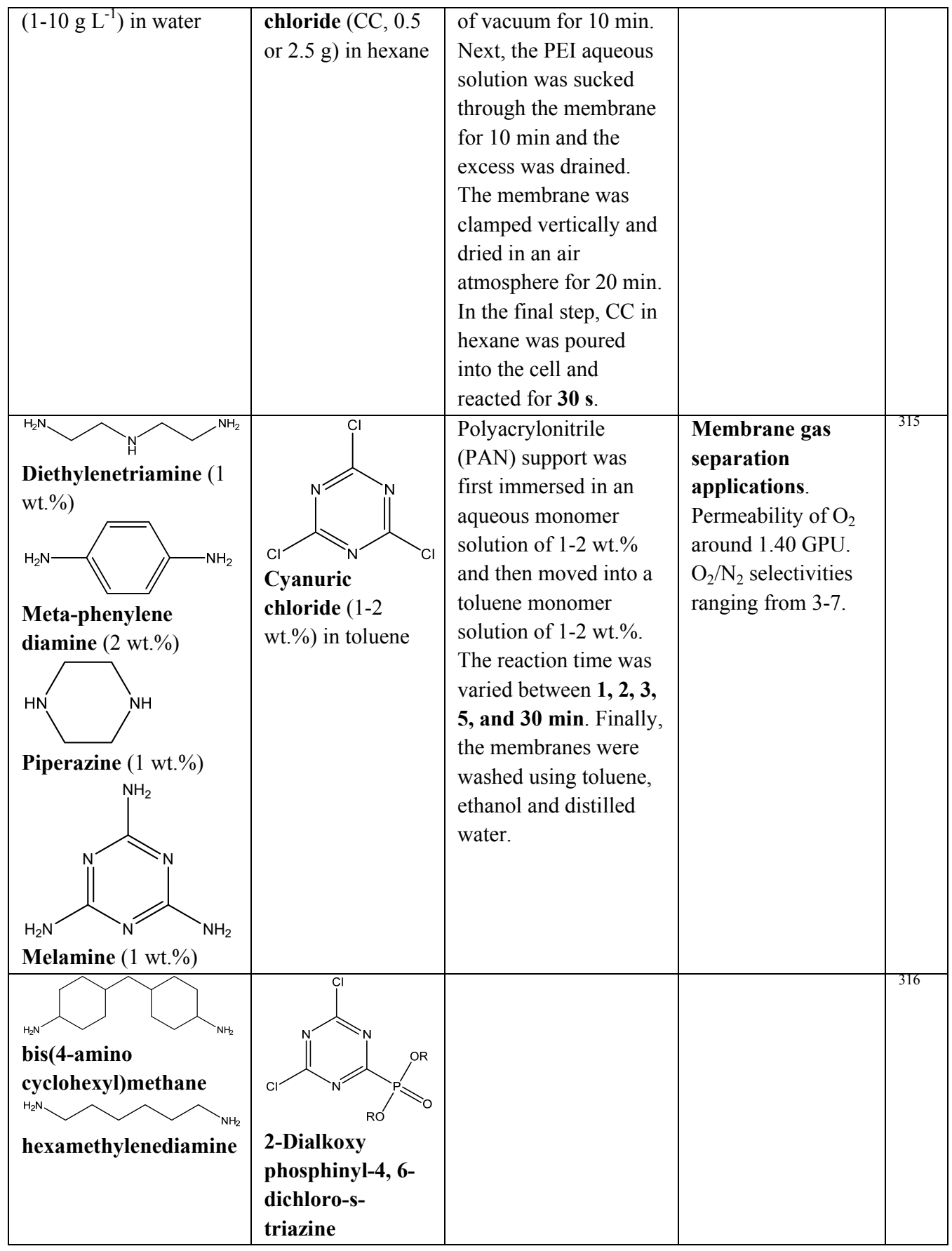




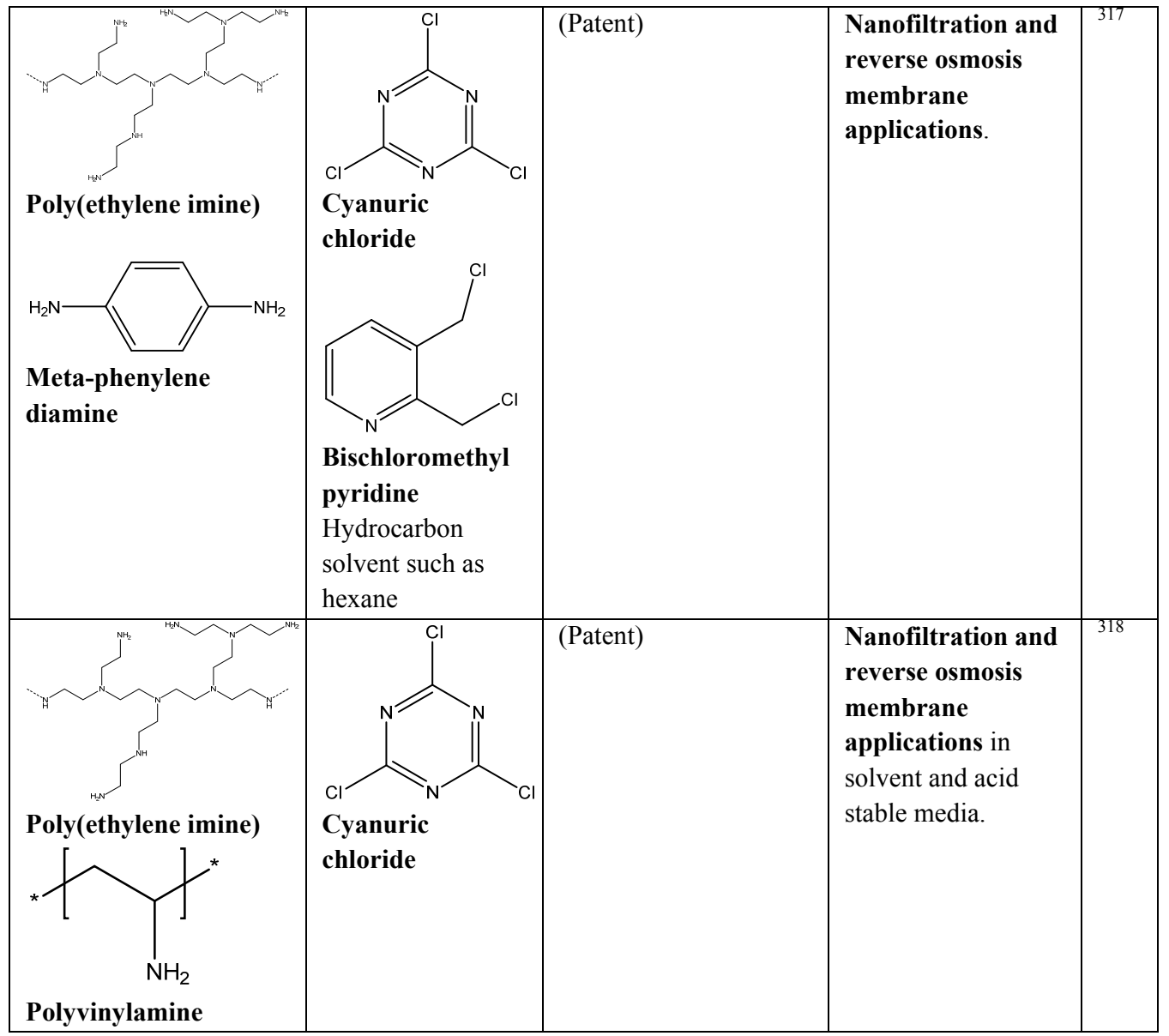

\section{Outlook}

Polyamines prepared from triazines provide a good resistance to harsh chemicals and acid or base media. Demand of clean water will only increase the need for advanced water purification techniques, in particular using membrane nanofiltration and reverse osmosis. The further optimization of the separation performance of polyamine membranes will therefore be an important development for broadening the application range of membrane based water separation. The broad range of polyethylene imine precursors leaves a wide range of possibilities for further material synthesis and membrane performance testing. 


\subsubsection{Polyimides}

\section{Polyimide chemistry}

Polyimides and poly(etherimide)s represent a class of engineering polymers that are characterized by their stability at elevated temperatures, high chemical stability. ${ }^{205}$ Polyimides are widely used as low- $\kappa$ dielectrics, high-temperature plastics, adhesives, photoresists, nonlinear optical materials and membranes. Polyimides are produced by a polymerization reaction that results in a polyamic acid intermediate, followed by thermal or chemical dehydration of the amic acid that results in the formation of imide groups.<smiles>O=C1C(=O)C2c3cc(F)ccc3C(=O)C12</smiles>

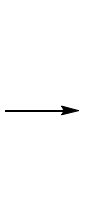<smiles>CNC(=O)c1ccc(Br)cc1C(=O)O</smiles>

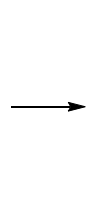<smiles>O=C(c1ccccc1)N1C(=O)c2ccc(Br)cc2C1=O</smiles>

Because the amic acid groups are hydrolytically unstable, the polymer molecular weight might decrease after the reaction is terminated. This effect is particularly pronounced in aprotic polar solvents that are commonly used for bulk polymerization in a single solvent such as N-methyl pyrrolidone. ${ }^{319}$ For poly(amic acid)s prepared via interfacial polymerization, no data on the amic acid group stability is available. Membrane performance data for gas and vapor separation suggest that high performance polyimides can be prepared via interfacial polymerization. ${ }^{192,294,320}$

Other drawbacks include the limited solubility of dianhydride precursors in most apolar solvents. To overcome the solubility issues, alternative precursors such as tetrafunctional acid chlorides ${ }^{205,321,322}$ or acid chloride derivatives of dianhydrides have been used. ${ }^{320}$ In addition, sufficient solubility for interfacial polymerization was observed in toluene. ${ }^{192,294}$ Table 1-7 shows an overview of precursors that are used for polyimide synthesis via interfacial polymerization. 
Table 1-7. Precursors used for polyimides prepared via interfacial polymerization, the reaction conditions, and their applications. In bold: the reactant names, method of interfacial polymerization, reaction time and temperature and final polymer configuration.

\begin{tabular}{|c|c|c|c|c|}
\hline $\begin{array}{l}\text { Aq. phase } \\
\text { reactant }\end{array}$ & Org. phase reactant & Reaction conditions & Application & Ref \\
\hline $\begin{array}{l}\text { Meta- } \\
\text { phenylene } \\
\text { diamine (2 } \\
\text { wt.\%) } \\
\text { diamine (2 } \\
\text { wt.\%) } \\
\mathrm{H}_{2} \mathrm{~N}^{-} \mathrm{H}_{6} \\
\text { mexa } \\
\text { diamine (2 } \\
\text { wt.\%) in water }\end{array}$ & $\begin{array}{l}\text { 2,5-Bis(methoxy } \\
\text { carbonyl) } \\
\text { terephthaloyl } \\
\text { chloride (BMTC, } \\
0.5 \text { wt. } \% \text { ) in toluene }\end{array}$ & $\begin{array}{l}\text { Polysulfone support } \\
\text { membrane was fixed onto } \\
\text { glass plate and immersed in an } \\
\text { aq. diamine solution for } 10 \\
\text { min. Next, excess diamine } \\
\text { solution was removed from } \\
\text { the surface using a rubber } \\
\text { roller and immersed into the } \\
\text { BMTC in toluene solution for } \\
5 \text { min. The membrane was } \\
\text { rinsed with } 50 / 50 \text { (w/w) } \\
\text { ethanol/water solution and } \\
\text { vacuum-dried at } 30^{\circ} \mathrm{C} \text { for } 24 \\
\text { h. Finally, it was cured in a } \\
\text { vacuum oven at various } \\
\text { temperatures }(70,100,150 \text {, } \\
180,210^{\circ} \mathrm{C} \text { ) for } 3 \mathrm{~h} \text {. }\end{array}$ & $\begin{array}{l}\text { Membrane vapor } \\
\text { separation of } \\
\text { ethanol/water } \\
\text { mixtures }(90 / 10 \\
\text { wt./wt.) with a water } \\
\text { permeance of } 1.7 \mathrm{~kg} \\
\mathrm{~m}^{-2} \mathrm{~h}^{-1} \text { and } \\
\text { water/ethanol } \\
\text { selectivity of } 240 .\end{array}$ & 320 \\
\hline $\begin{array}{l}\text { Meta- } \\
\text { phenylene } \\
\text { diamine ( } 2 \\
\text { wt.\%) in water }\end{array}$ & $\begin{array}{l}\mathbf{1 , 2 , 4 , 5} \text {-Benzene } \\
\text { tetraacyl chloride } \\
(0.1 \text { and } 0.05 \text { wt. } \%)\end{array}$ & $\begin{array}{l}\text { Polysulfone support } \\
\text { membrane immersed in aq. } \\
\text { MPD solution. Excess liquid } \\
\text { was removed from the surface } \\
\text { using a rubber roller. The } \\
\text { membrane was then immersed } \\
\text { in an organic solution of BTC } \\
\text { or BTC with TMC for a } \\
\text { predetermined time. The } \\
\text { membranes were thoroughly } \\
\text { rinsed with deionized water } \\
\text { for } 12 \text { h and then immersed in } \\
\text { a TEA or TMHD solution. } \\
\text { Finally, thermal treatment was } \\
\text { applied to convert the } \\
\text { poly(amic acid) to polyimide. }\end{array}$ & $\begin{array}{l}\text { Membrane } \\
\text { nanofiltration } \\
\text { applications. } \mathrm{NaCl} \\
13.9 \text { gfd } 96.7 \% \\
\text { rejection (with } 0.1 \\
\text { wt. } \% \text { BTC) and } 18.8 \\
\text { gfd } 96.7 \% \text { rejection } \\
\text { (with } 0.05 \text { wt.\% } \\
\text { BTC). } \\
\text { Improved chlorine } \\
\text { resistance with } \\
\text { respect to a } \\
\text { polyamide } \\
\text { membrane at } 500 \\
\text { ppm } \mathrm{Cl}_{2} \text { exposure. }\end{array}$ & 205 \\
\hline $\begin{array}{l}\text { 4,4'-methylene } \\
\text { dianiline } \\
\text { Ethylene }\end{array}$ & $1,2,4,5$ '-Benzene & & $\begin{array}{l}\text { Membrane gas } \\
\text { separation } \\
\text { applications. } \\
\mathrm{CO}_{2} / \mathrm{CH}_{4} \\
\text { permselectivities of } \\
20.5 \mathrm{CO}_{2} \text { and } \\
\end{array}$ & $\begin{array}{l}321, \\
322\end{array}$ \\
\hline
\end{tabular}




\begin{tabular}{|l|l|l|l|l|}
\hline diamine & tetracyl chloride & & $\begin{array}{l}\text { permeability } \\
\text { coefficient of } 44 \\
\text { barrer. Film } \\
\text { thicknesses below } \\
20 \mu \mathrm{m} .\end{array}$ \\
\hline
\end{tabular}

\section{Hybrid inorganic-organic polyimides}

Hybrid inorganic-organic polyimides represent a class of materials that allow for combination of rigidity, thermal stability and membrane performance properties. Table 1-8 shows the precursors that are used for the preparation of hybrid polyimides. Dianhydrides and octa-ammonium functionalized POSS have been used as monomers in the interfacial polymerization reaction, resulting in the formation of a range of networks of alternating POSS and imide moieties. The large number of functional groups on the POSS cage are used to obtain a large number of covalent bonds in the hyper-cross-linked network. The length and flexibility of the dianhydride determine the changes during conversion of the amic acid to imide groups via a heat treatment. In addition, the type of dianhydride precursor determines the gas separation properties of the membrane layers. 
Table 1-8. Precursors used for polyimides prepared via interfacial polymerization, the reaction conditions, and their applications. In bold: the reactant names, method of interfacial polymerization, reaction time and temperature and final polymer configuration.

\begin{tabular}{|c|c|c|c|c|}
\hline $\begin{array}{l}\text { Aq. phase } \\
\text { reactant }\end{array}$ & Org. phase reactant & Reaction conditions & Application & Ref. \\
\hline 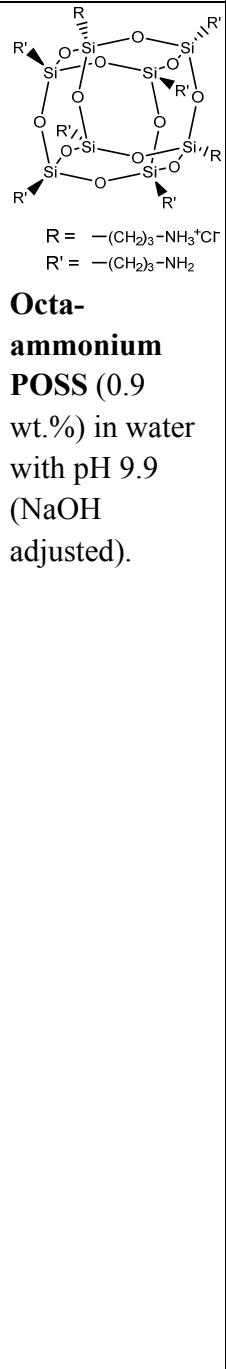 & 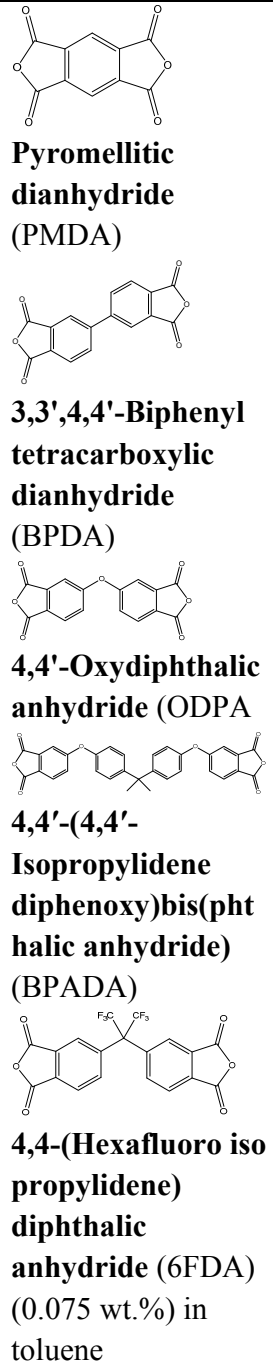 & $\begin{array}{l}\text { Ceramic membranes } \\
(\alpha \text {-alumina discs with a } 3-\mu \mathrm{m} \text { - } \\
\text { thick } \gamma \text {-alumina layer was } \\
\text { pre-wetted under } 0.5 \text { bar } \\
\text { vacuum in the aq. POSS } \\
\text { solution for } 15 \text { min. After } \\
\text { drying in an air atmosphere } \\
\text { for } 15 \text { min, the dianhydride } \\
\text { solution in toluene for } \\
\text { contacted for } \mathbf{5} \text { min. }\end{array}$ & $\begin{array}{l}\text { Membrane gas } \\
\text { separation } \\
\text { applications at 50- } \\
300{ }^{\circ} \mathrm{C} . \mathrm{H}_{2} \\
\text { permeances of } \\
0.2-5 \cdot 10-7 \mathrm{~mol} \\
\mathrm{~m}^{-2} \mathrm{~s}^{-1} \mathrm{~Pa}^{-1}(60- \\
1500 \mathrm{GPU}) \text { and } \\
\mathrm{H}_{2} / \mathrm{N}_{2} \text { selectivities } \\
\text { of } 7-100 \text {. The } \\
\mathrm{H}_{2} / \mathrm{N}_{2} \text { selectivity } \\
\text { was persistently } \\
\text { high at } \\
\text { temperatures up to } \\
300{ }^{\circ} \mathrm{C} \text { for } \\
\text { poly(POSS- } \\
\text { imide)s prepared } \\
\text { using PMDA and } \\
\text { BPDA }\end{array}$ & 192,294 \\
\hline
\end{tabular}

\section{Outlook}

Polyimides prepared via interfacial polymerization are potentially interesting for membrane applications, due to their superior thermomechanical properties and performance in gas separation applications. Although the molecular 
weight of linear polyimides might be limited due to the instability of amic acid bonds in the vicinity of water, highly branched polyimides or hybrid polyimides provide an interesting pathway for novel material development. Further study on the amic acid group stability during interfacial polymerization is required to assess material properties and optimize the synthesis conditions.

\subsubsection{Conductive polymers}

\section{Polyaniline}

Polyaniline layers ${ }^{324-326}$ nanofibers ${ }^{145,327-332}$ and nanoparticles ${ }^{333,334}$ have been prepared via interfacial polymerization. The interfacial synthesis is based on the oxidation of aniline at the interface by a strong oxidizing agent such as ammonium peroxydisulfate, followed by a reaction of the oxidized aniline with another aniline molecule, forming polyaniline.

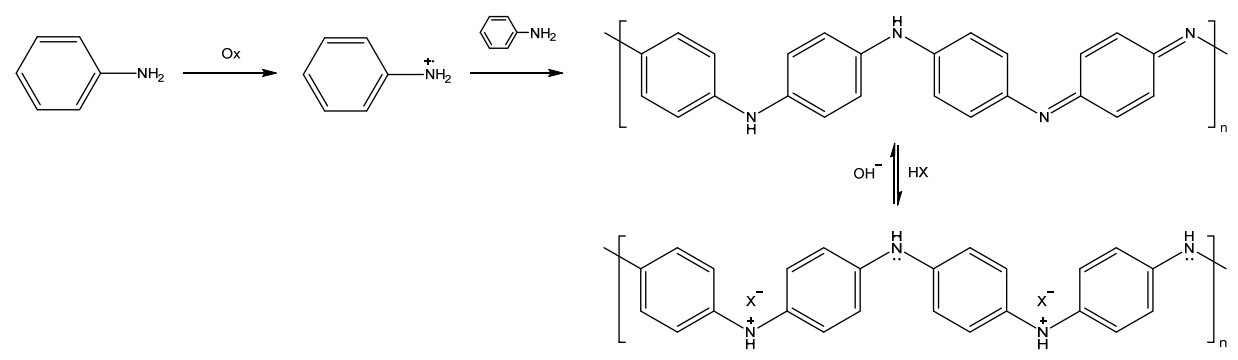

A strong acid is commonly added to the aqueous phase to obtain a doped, conductive emeraldine salt form of polyaniline. The oxidation state of polyaniline is very sensitive to the level of doping, and can therefore be used as a sensor for detection of acids, bases or oxidizing and reducing compounds. Polyaniline nanofibers give larger and faster sensor response than polyaniline films due to the enhanced surface area. ${ }^{335}$ Figure 1-10 shows the typical morphology of polyaniline nanofibers prepared via interfacial polymerization. 


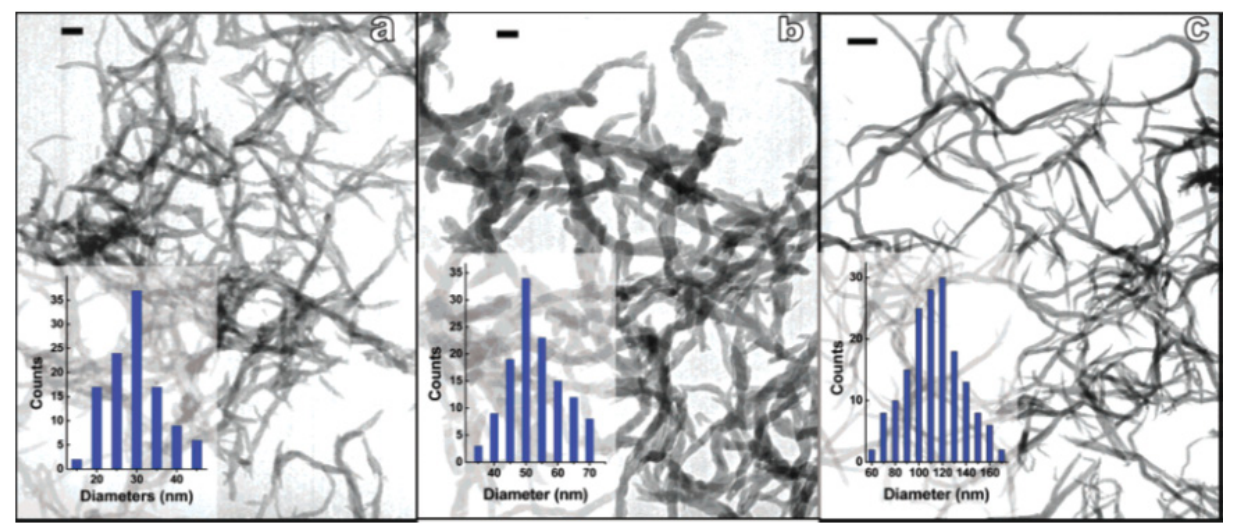

Figure 1-10. Transmission electron microscopy images of polyaniline nanofibers made by using (a) HCl (scale bar $100 \mathrm{~nm}$ ), (b) camphorsulfonic acid (scale bar $100 \mathrm{~nm}$ ), and (c) $\mathrm{HClO}_{4}$ (scale bar $1 \mu \mathrm{m}$ ). The insets show the diameter distributions $(\mathrm{nm})$ of the doped nanofibers (scale bars $\mathbf{5 0 0}$ nm) ${ }^{145}$ Copyright 2004. Adapted with permission from the American Chemical Society.

Table 1-9 shows the precursors, synthesis conditions and applications of polyaniline prepared via interfacial polymerization. Most research on polyaniline synthesis is focused on the synthesis of nanofibers and other nanostructures. The nanofibers are preferred over solid thin film because of the increased surface area that allows for larger electrochemical response of the polymer. The nanofibers can either be coated from solution, of be grown directly on a solid interface that is placed at the interface. ${ }^{328}$ The reaction conditions influence the morphology of the polyaniline nanostructures. ${ }^{336}$ The type of structure that is obtained depends on the organic solvents, acid dopants, concentration of dopants, the reaction time, and the concentration of aniline monomer and oxidant. For example, the length of polyaniline nanofibers was found to increase with acid strength). ${ }^{337}$ A great variety of dopant acids can be used, including hydrochloric, sulfuric, nitric, phosphoric, perchloric, acetic, formic, tartaric, camphorsulfonic, methylsulfonic, ethylsulfonic, or 4-toluenesulfonic acid. 
Table 1-9. Precursors used for polyanilines prepared via interfacial polymerization, the reaction conditions, and their applications. In bold: the reactant names, method of interfacial polymerization, reaction time and temperature and final polymer configuration.

\begin{tabular}{|c|c|c|c|c|}
\hline Aq. phase reactant & $\begin{array}{l}\text { Org. phase } \\
\text { reactant }\end{array}$ & Reaction conditions & Application & Ref \\
\hline 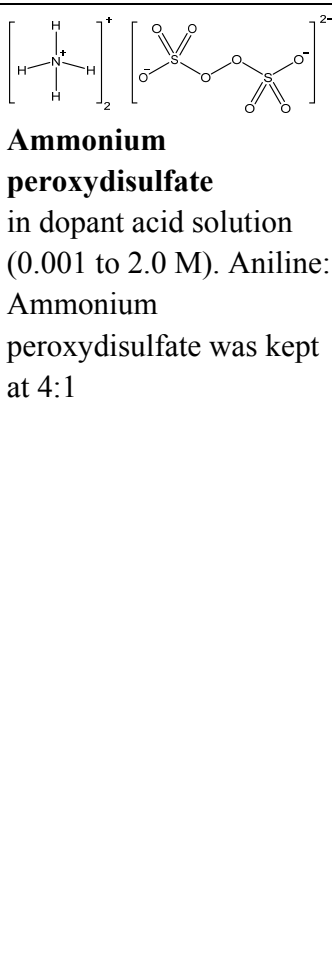 & $\begin{array}{l}\text { Aniline (0.032 to } \\
0.32 \mathrm{M}) \text { in an } \\
\text { organic phase } \\
\text { such as hexane, } \\
\text { benzene, toluene, } \\
\text { xylene, diethyl } \\
\text { ether, carbon } \\
\text { disulfide, carbon } \\
\text { tetrachloride, } \\
\text { chloroform, o- } \\
\text { dichlorobenzene, } \\
\text { or methylene } \\
\text { chloride. }\end{array}$ & $\begin{array}{l}\text { Polyaniline was } \\
\text { formed at the } \\
\text { interface of } \\
\text { ammonium } \\
\text { peroxydisulfate } \\
\text { solution in water and } \\
\text { aniline solution in an } \\
\text { organic phase. } \\
\text { Excess acid and } \\
\text { byproducts were } \\
\text { removed by either } \\
\text { dialysis or filtration. } \\
\text { Doped nanofibers } \\
\text { were obtained by } \\
\text { dialyzing or washing } \\
\text { with water; dedoped } \\
\text { nanofibers were } \\
\text { obtained by } \\
\text { dialyzing or washing } \\
\text { with } 1 \mathrm{M} \text { NH3 } \cdot H 2 O \text {. }\end{array}$ & $\begin{array}{l}\text { Polyaniline } \\
\text { nanofibers } \\
\text { with lengths in } \\
\text { the range of } \\
500 \text { nm to } \\
\text { several } \\
\text { micrometers. } \\
\text { Fiber } \\
\text { diameters } \\
\text { around 30-120 } \\
\text { nm Sensor } \\
\text { applications, } \\
\text { for detection } \\
\text { of acid, base } \\
\text { or redox active } \\
\text { chemicals. } \\
\text { Emeraldine } \\
\text { salt-base } \\
\text { switchable } \\
\text { conductivity. } \\
\text { BET surface } \\
\text { area (around } \\
50 \text { m2 g-1). }\end{array}$ & $\begin{array}{l}145, \\
327, \\
331, \\
338\end{array}$ \\
\hline $\begin{array}{l}\text { Ammonium } \\
\text { peroxydisulfate }(0.009 \text { can be used as } \\
\text { alternative oxidizer, but } \\
\text { requires longer reaction } \\
\text { times (days) }\end{array}$ & $\begin{array}{l}\text { Aniline }(0.2 \mathrm{M}) \text { in } \\
\text { chloroform with } \\
0.01 \mathrm{M} \text { sodium } \\
\text { dodecyl sulfate } \\
\text { (SDS). }\end{array}$ & $\begin{array}{l}\text { Interfacial chemical } \\
\text { oxidation was } \\
\text { performed using } \\
\text { three immiscible } \\
\text { liquids. The lowest } \\
\text { section contained an } \\
\text { aniline in } \\
\text { chloroform solution, } \\
\text { the middle layer the } \\
\text { ammonium } \\
\text { peroxydisulfate } \\
\text { solution in } \mathrm{HCl} \\
\text { solution and the } \\
\text { upper layer } \\
\text { contained } 5 \mathrm{ml} \text { of } \\
\text { toluene which }\end{array}$ & $\begin{array}{l}\text { Electro-active } \\
\text { polyaniline } \\
\text { membrane that } \\
\text { exhibits redox } \\
\text { behavior } \\
\text { similar to } \\
\text { conventional } \\
\text { electro- } \\
\text { deposited } \\
\text { polyaniline. }\end{array}$ & 325 \\
\hline
\end{tabular}




\begin{tabular}{|c|c|c|c|c|}
\hline & & $\begin{array}{l}\text { slowly solubilizes } \\
\text { both the ammonium } \\
\text { peroxydisulfate and } \\
\text { the } \mathrm{HCl} \text { and } \\
\text { quenches the } \\
\text { reaction. }\end{array}$ & & \\
\hline $\begin{array}{l}{\left[{ }_{\text {Ammonium }}\right.} \\
\text { peroxydisulfate }(0.01- \\
0.4 \mathrm{M}) \text { in } 0.5-2 \mathrm{M} \\
\mathrm{H} 2 \mathrm{SO} 4, \mathrm{HCl}, \mathrm{H} 3 \mathrm{PO} 4, \\
\mathrm{HClO} 4,\end{array}$ & $\begin{array}{l}\text { Aniline }(0.1 \mathrm{M}) \text { in } \\
\text { toluene, benzene, } \\
\text { n-hexane, } \mathrm{n} \text { - } \\
\text { hexanol, carbon } \\
\text { tetrachloride, } \\
\text { or chloroform }\end{array}$ & $\begin{array}{l}\text { Polyaniline was } \\
\text { formed at the } \\
\text { interface of } \\
\text { ammonium } \\
\text { peroxydisulfate } \\
\text { solution in water and } \\
\text { aniline solution in an } \\
\text { organic phase. } \\
\text { Polyaniline was } \\
\text { removed from the } \\
\text { interface by } \\
\text { filtration. The } \\
\text { reaction time varied } \\
\text { from } 1-12 \mathrm{~h} \text {. }\end{array}$ & $\begin{array}{l}\text { Polyaniline } \\
\text { nanofibers for } \\
\text { immobilizatio } \\
\mathrm{n} \text { and direct } \\
\text { electrochemist } \\
\text { ry of glucose } \\
\text { oxidase } \\
\text { (GOx). }\end{array}$ & 336 \\
\hline
\end{tabular}

\section{Other conducting polymers}

Polyaniline analogues have been prepared via interfacial polymerization in a comparable manner. Table 1-10 shows the precursors used for the synthesis of polyaniline analogues such as polypyrroles polyindoles, polyphyrins, and polycarbazoles. The oxidant that is used in the aq. phase is commonly either ferric chloride or ammonium peroxydisulphate.

Table 1-10. Precursors used for other conducting polymers such as polypyrrole, polyindole, polyphyrin and polycarbazole prepared via interfacial polymerization, the reaction conditions, and their applications.

In bold: the reactant names, method of interfacial polymerization, reaction time and temperature and final polymer configuration.

\begin{tabular}{|c|c|c|c|c|}
\hline Aq. phase reactant & $\begin{array}{l}\text { Org. phase } \\
\text { reactant }\end{array}$ & Reaction conditions & Application & Ref \\
\hline $\begin{array}{l}\text { Ferrous chloride } \\
\left(\mathrm{FeCl}_{2}, 0.4 \mathrm{M}\right) \text { and } \\
\text { ferric chloride } \\
\left(\mathrm{FeCl}_{3}, 0.5 \mathrm{M}\right) \text { in } \\
\text { water. }\end{array}$ & $\begin{array}{l}\text { Pyrrole in } \\
\text { hexane }\end{array}$ & $\begin{array}{l}\text { Pyrrole in hexane was slowly } \\
\text { added to the aq. solution of } \\
\text { ferrous and ferric chloride. } \\
\text { After removal of the layer by a } \\
\text { glass slide, the polypyrrole film } \\
\text { was washed with methanol to } \\
\text { remove excess reagents. A }\end{array}$ & $\begin{array}{l}\text { Polypyrrole-PDMS } \\
\text { membranes for gas } \\
\text { separation } \\
\text { applications. } \\
\text { (polypyrrole layer } \\
\text { thickness of around } \\
200 \mathrm{~nm} \text { ) Low }\end{array}$ & 339 \\
\hline
\end{tabular}




\begin{tabular}{|c|c|c|c|c|}
\hline & & $\begin{array}{l}\text { solution of PDMS in hexane } \\
\text { was poured over the surface and } \\
\text { left to evaporate for } 24 \mathrm{~h} \text { and } \\
\text { treated at } 80^{\circ} \mathrm{C} \text { for } 15 \mathrm{~min} .\end{array}$ & $\begin{array}{l}\text { polymerization rates } \\
\text { resulted in denser } \\
\text { membranes. } \mathrm{O}_{2} / \mathrm{N}_{2} \\
\text { selectivity of } 17 \text { and } \\
\mathrm{O}_{2} \text { permeability of } 40 \\
\text { barrer. }\end{array}$ & \\
\hline $\begin{array}{l}\text { Ferric chloride } \\
\left(\mathrm{FeCl}_{3}, 3 \mathrm{mM}\right) \text { or } \\
\text { peroxydisulphate } \\
(3 \mathrm{mM}) \text { in water } \\
\text { with Tween } 80 \text { or } \\
\text { Span } 80\left(0 \text { or } 2 \mathrm{~g} \mathrm{~L}^{-}\right. \\
\text {1) surfactants }\end{array}$ & $\begin{array}{l}\text { Pyrrole } \\
(2 \mathrm{mM}) \text { in } \\
\text { chloroform }\end{array}$ & $\begin{array}{l}\text { Free-standing polypyrrole was } \\
\text { prepared by quickly adding the } \\
\text { pyrrole solution in chloroform } \\
\text { to the aq. solution of ferric } \\
\text { chloride or ammonium } \\
\text { peroxydisulphate at } 25 \text { or } 0^{\circ} \mathrm{C} \text {. } \\
\text { After } 8 \mathrm{~h} \text { reaction time, the } \\
\text { polypyrrole was collected by } \\
\text { filtration and washing with } \\
\text { water and ethanol. Finally, the } \\
\text { free-standing films were dried } \\
\text { at } 60^{\circ} \mathrm{C} \text { for } 12 \mathrm{~h} \text { under vacuum. }\end{array}$ & $\begin{array}{l}\text { Free-standing } \\
\text { polypyrrole films for } \\
\text { electrochemical } \\
\text { capacitors. } \\
\text { Polypyrrole prepared } \\
\text { using Tween } 80 \text { was } \\
\text { highly porous. } \\
\text { Polypyrrole prepared } \\
\text { using Span } 80 \text { are } \\
\text { vesicular. }\end{array}$ & 340 \\
\hline $\begin{array}{l}\text { Ammonium } \\
\text { peroxydisulphate } \\
\left(200 \mathrm{~g} \mathrm{~L}^{-1}\right) \text { in water } \\
\text { with sodium } \\
\text { dodecyl benzene } \\
\text { sulfonate (SDBS, } \\
\left.0-100 \mathrm{~g} \mathrm{~L}^{-1}\right) \text { as } \\
\text { surfactant. }\end{array}$ & $\begin{array}{l}\text { Pyrrole } \\
(0.1-0.4 \\
\text { v. } \%) \text { in } \\
\text { toluene }\end{array}$ & $\begin{array}{l}\text { Pyrrole nanocapsules were } \\
\text { prepared by adding the pyrrole } \\
\text { in toluene to an aq. SDBS } \\
\text { solution, while stirring at } 0{ }^{\circ} \mathrm{C} \text {. } \\
\text { Next, the aq. solution of } \\
\text { ammonium peroxydisulphate } \\
\text { was added and the mixture was } \\
\text { stirred at } 400 \mathrm{rpm} \text { for } \mathbf{2 4} \mathbf{h} \text {. } \\
\text { Finally, the pyrrole } \\
\text { nanocapsules were filtered and } \\
\text { washed by water and ethanol. }\end{array}$ & $\begin{array}{l}\text { Polypyrrole } \\
\text { nanocapsule } \\
\text { synthesis. Capsule } \\
\text { diameter in the range } \\
\text { of } 100-200 \mathrm{~nm} \text {. }\end{array}$ & 341 \\
\hline $\begin{array}{l}\text { Ferric nitrate } \\
\left(\mathrm{Fe}\left(\mathrm{NO}_{3}\right)_{3}, 2.0 \mathrm{M}\right) \\
\text { in water. }\end{array}$ & $\begin{array}{l}\text { Pyrrole, } \\
\text { thiophene, } \\
\mathrm{N} \text { - } \\
\text { methylpyrrol } \\
\text { e, aniline. } \\
\text { (vapor } \\
\text { phase) }\end{array}$ & $\begin{array}{l}\text { Polypyrrole is formed at the } \\
\text { surface of an hydrophobized, } \\
\text { anodisc support membrane. The } \\
\text { aq. solution is contacted with } \\
\text { the membrane surface. The } \\
\text { monomer vapor is supplied on } \\
\text { the other side, resulting in layer } \\
\text { formation. }\end{array}$ & $\begin{array}{l}\text { Membrane gas } \\
\text { separation } \\
\text { applications } \\
\text { combined with } \\
\text { switchable polymer } \\
\text { conductivity. Doping } \\
\text { with } \mathrm{HNO}_{3} \text { results in } \\
\text { porous films with } \\
\text { Knudsen selectivity. } \\
\text { Undoped films have a } \\
\text { permeability of } 6.9 \\
\text { barrer and a } \mathrm{CO}_{2} / \mathrm{CH}_{4} \\
\text { selectivity of } 32 .\end{array}$ & 324 \\
\hline
\end{tabular}




\begin{tabular}{|c|c|c|c|c|}
\hline $\begin{array}{l}\text { Copper acetate, } \\
\text { silver nitrate or } \\
\text { mercury acetate as } \\
\text { oxidant in water. }\end{array}$ & $\begin{array}{l}\mathbf{5 , 1 0 , 1 5 , 2 0 -} \\
\text { tetrakis } \\
\text { (r-mercapto } \\
\text { p-tolyl) } \\
\text { porphyrin } \\
(0.3 \mathrm{mM}) \text { in } \\
\text { chloroform }\end{array}$ & $\begin{array}{l}\text { The aq. copper acetate solution } \\
\text { was added to the } \\
\text { mercaptophyrin solution in } \\
\text { chloroform. The solution was } \\
\text { covered to prevent any solvent } \\
\text { evaporation. Film formation at } \\
\text { room temperature occurred } \\
\text { within several hours. Silver } \\
\text { nitrate or mercury acetate } \\
\text { resulted in the formation of a } \\
\text { slurry at the interface. Thiol- } \\
\text { free porphyrins did not show } \\
\text { any film formation. }\end{array}$ & $\begin{array}{l}\text { Robust, free- } \\
\text { standing polyphyrin } \\
\text { films with } \\
\text { thicknesses in the } \\
\text { range } 10 \mathrm{~nm} \text { to } 10 \mu \mathrm{m} \\
\text { The highly- } \\
\text { absorbing, shiny, } \\
\text { purple polymer layers } \\
\text { are amorphous and } \\
\text { retain their ability to } \\
\text { be metalated. } \\
\text { Catalytic activity by } \\
\text { photosensitized } \\
\text { oxidation of a cyclic } \\
\text { thioether. }\end{array}$ & 342 \\
\hline $\begin{array}{l}\text { Ammonium } \\
\text { peroxydisulphate } \\
(1.2 \mathrm{M}) \text { in } \mathrm{HCl}(0.5 \\
\mathrm{M})\end{array}$ & $\begin{array}{l}\text { Carbazole } \\
(60 \mathrm{mM}) \text { in } \\
\text { dichloromet } \\
\text { hane } \\
(\mathrm{DCM})\end{array}$ & $\begin{array}{l}\text { Polycarbazole was prepared by } \\
\text { adding an aq. ammonium } \\
\text { peroxydisulphate solution to the } \\
\text { carbazole solution in DCM at } \\
\text { room temperature. The } \\
\text { optimum yield was } 50 \% \text { in } \mathbf{1 2} \mathbf{~ h} \\
\text { time period. }\end{array}$ & $\begin{array}{l}\text { Polycarbazole } \\
\text { hollow microspheres } \\
\text { with diameters } \\
\text { around } 3-5.5 \mu \mathrm{m} \text { and } \\
\text { wall thickness of } \\
\text { about } 0.82 \mu \mathrm{m} \text {. }\end{array}$ & 343 \\
\hline $\begin{array}{l}\text { Chloroauric acid } \\
\left(\mathrm{HAuCl}_{4}, 15.7 \mathrm{~g} \mathrm{~L}^{-}\right. \\
\left.{ }^{1}\right) \text { in water with } \\
\mathrm{HCl}(0.5 \mathrm{M}) .\end{array}$ & $\begin{array}{l}\text { Indole }(10 \mathrm{~g} \\
\left.\mathrm{L}^{-1}\right) \text { in } \\
\text { dichloromet } \\
\text { hane (DCM) }\end{array}$ & $\begin{array}{l}\text { Polyindole was prepared by } \\
\text { slowly adding an aq. HAuCl4 } \\
\text { soltuion to the indole solution } \\
\text { in DCM. The polyindole was } \\
\text { collected by centrifugation }\end{array}$ & $\begin{array}{l}\text { Rod-like, semi- } \\
\text { crystalline } \\
\text { polyindole-Au } \\
\text { nanocomposites for } \\
\text { application in } \\
\text { electronic devices. } \\
\text { The gold } \\
\text { nanoparticles are } \\
\text { uniformly distributed } \\
\text { in the polymer. The } \\
\text { polymer displayed } \\
\text { switchable } \\
\text { photoluminescence. }\end{array}$ & $\begin{array}{l}344, \\
345\end{array}$ \\
\hline $\begin{array}{l}\text { Ammonium } \\
\text { peroxydisulphate } \\
\text { in water with } 10 \\
\text { mM CTAB }\end{array}$ & $\begin{array}{l}\text { Indole in } \\
\text { chloroform }\end{array}$ & $\begin{array}{l}\text { Polyindole nanocapsules were } \\
\text { prepared by adding } 0.35 \mathrm{~g} \\
\text { indole monomer to } 30 \mathrm{~mL} \text { of } \\
\text { CTAB in water and stirring for } \\
30 \mathrm{~min} \text {. Then } 0.68 \mathrm{~g} \\
\text { Ammonium peroxydisulphate } \\
\text { in in } 30 \mathrm{~mL} \text { water was added } \\
\text { dropwise. After } 24 \mathbf{h} \text { reaction } \\
\text { time at room temperature, the }\end{array}$ & $\begin{array}{l}\text { Polyindole } \\
\text { nanocapsules with } \\
\text { capsule diameters in } \\
\text { the range of } 1-3 \mu \mathrm{m} \\
\text { for electrochemical } \\
\text { applications. The } \\
\text { morphology and the } \\
\text { electrochemical } \\
\text { activity changed upon }\end{array}$ & 346 \\
\hline
\end{tabular}




\begin{tabular}{|c|c|c|c|c|}
\hline & & $\begin{array}{l}\text { polyindole was filtered and } \\
\text { washed with ethyl alcohol and } \\
\text { water. Finally, it was dried } \\
\text { under vacuum at } 40{ }^{\circ} \mathrm{C} \text { for } 48 \mathrm{~h} \text {. } \\
\text { Alternatively, Ammonium } \\
\text { peroxydisulphate in water was } \\
\text { added dropwise to an indole } \\
\text { solution in chloroform. }\end{array}$ & $\begin{array}{l}\text { addition of a } \\
\text { surfactant. }\end{array}$ & \\
\hline $\begin{array}{l}\text { Ferric chloride } \\
\left(\mathrm{FeCl}_{3}, 0.525 \mathrm{M}\right) \text { in } \\
\text { nitromethane or } \\
\text { acetonitrile. }\end{array}$ & $\begin{array}{l}\text { Thiophene } \\
(0.5 \mathrm{M}) \text { in } \\
\text { hexane }\end{array}$ & $\begin{array}{l}\text { Polthiophene microparticles } \\
\text { were prepared by dropwise } \\
\text { addition of a ferric chloride } \\
\text { solution in nitromethane or } \\
\text { acetonitrile to thiophene in } \\
\text { hexane, while stirring at } 20^{\circ} \mathrm{C} \\
\text { for } 24 \mathrm{~h} \text {. The polythiophene } \\
\text { particles were separated from } \\
\text { the liquid by centrifugation and } \\
\text { washing in ethanol. Finally, the } \\
\text { powder was dried at } 50^{\circ} \mathrm{C} \text { for } \\
24 \mathrm{~h} \text {. }\end{array}$ & $\begin{array}{l}\text { Polythiophene } \\
\text { microparticles with } \\
\text { diameters between } \\
2.67-3.95 \mu \mathrm{m} \text {. } \\
\text { Electrical } \\
\text { conductivity of the } \\
\text { polythiophene } \\
\text { microparticles } \\
\text { increases with } \\
\text { reducing } \\
\text { oxidant/monomer } \\
\text { ratio, polymerization } \\
\text { temperature, and the } \\
\text { monomer } \\
\text { concentration. }\end{array}$ & 347 \\
\hline
\end{tabular}

\section{Composites}

The conductive properties of conductive polymers such as polyaniline can be significantly improved by addition of nanoparticles. Examples include carbon nanotubes, ${ }^{345,348-350} \mathrm{C} 60,{ }^{351,352}$ gold nanoparticles, ${ }^{344,353}$ manganese oxide, ${ }^{346}$ and graphene. ${ }^{349,354,355}$ The dimensions of the polymer and metal domains of are controlled by the reaction conditions, with polymer dimensions of 50-180 $\mathrm{nm}$ and particle dimensions of 10-140 nm. In addition, polyelectrolytes such as poly(acryclic acid), ${ }^{356}$ poly(vinylsulfonate), ${ }^{357}$ and poly(sodium 4-styrene sulfonate $)^{358}$ have been added to the conductive polymer matrix.

\section{Outlook}

Conductive polymers such as polyaniline have promising properties for electrochemical applications in for example electrochemical conversion and sensors. Interfacial polymerization allows for synthesis of high surface areas of conductive polymer nanostructures or membrane layers with electrochemical properties. Relevant reaction conditions for polymer formation have been studied in detail. Future research on conductive polymers prepared via 
interfacial polymerization might focus on composites and covalent attachment of the polymers to a substrate or layer.

\subsubsection{ZIFs and MOFs}

\section{ZIF and MOF chemistry}

metal organic frameworks (MOFs) and Zeolite imidazolate frameworks (ZIFs) consist of coordination metals that are covalently bound with organic ligands. The large variety of organic ligands that can be used for the synthesis allows for tailoring of the MOF and ZIF properties. ${ }^{359}$ Layers of MOFs and ZIFs are commonly prepared by seeding of pre-synthesized crystals on top of a porous support, followed by a secondary growth step in a precursor solution. ${ }^{360,} 361$ The seeding step is required to create the interface on which crystal growth predominantly occurs. In this way, crystal growth can be directed to obtain suitable materials performance. The synthesis route allows for uniform film formation with layer thicknesses in the range of several $\mu \mathrm{m}$, suitable for membrane applications such as gas and vapor separation. ${ }^{362}$ Crystal defect formation inherently occurs, due to diffusion limitations of the crystal precursors molecules in inter-crystalline gaps that have a smaller size than the precursor. Membrane application of seeded MOF layers is limited by large penalty in selectivity due to inter-crystalline defects and by low permeance due to the relatively large thicknesses. Alternative synthesis routes that employ exfoliated MOF nanosheets have successfully been applied to decrease layer thicknesses to the nanometer range. ${ }^{363}$ However, the complex fabrication route of the exfoliated nanosheets and the limited yield of nanosheets of sufficient quality hamper large-scale implementation of these synthesis routes.

More recently, metal organic frameworks have been prepared in a single step via interfacial polymerization. By confining the crystal growth to a liquidliquid interface, pre-seeding is no longer required. In addition, film formation limits the reactant diffusion, allowing for uniform film growth of layers with thicknesses around $\sim 2 \mu \mathrm{m}$. The relatively large film thickness is required to obtain sufficiently large crystal sizes for a defect layer formation. Figure 1-11 shows scanning electron micrographs of the MOF and ZIF layers prepared via interfacial polymerization. Although the common precursors used for MOF and ZIF synthesis are more soluble in polar solvents, a number of reagents can be dissolved in apolar solvents. Currently, either a solvent with some degree of polarity (i.e., octanol) or the addition of a co-solvent is employed to obtain 
sufficiently high precursor solubilities, while preserving the stable liquid interface.
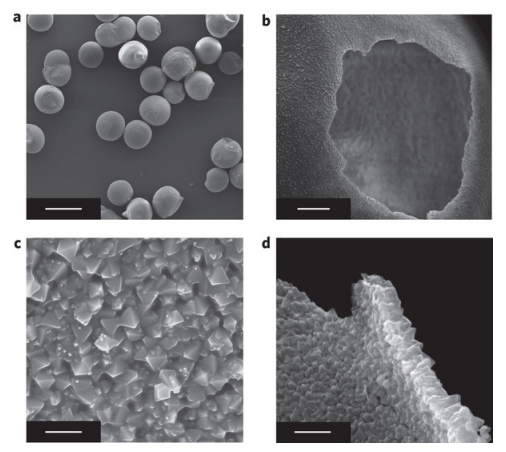
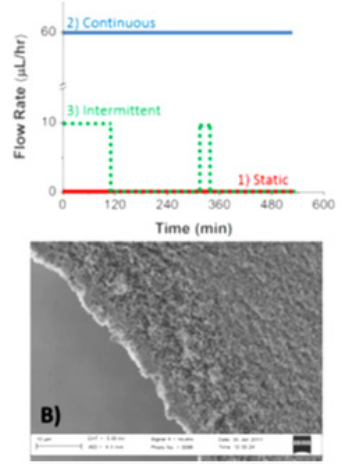
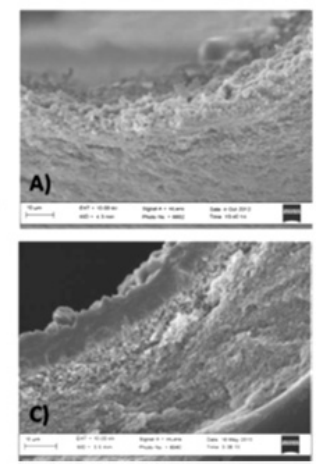

Figure 1-11. Left panels: (a) Overview of several MOF capsules illustrating their monodispersity. The capsules retain their spherical shape upon drying. Scale bar, $500 \mu \mathrm{m}$. (b) MOF capsule crushed with a needle tip showing its hollow interior. Scale bar, $25 \mu \mathrm{m}$. (c) Detail of the defect-free capsule wall. Gaps between larger crystals are sealed by intergrown smaller crystals. Scale bar, $2 \mu \mathrm{m}$. (d) Cross-sectional view of the capsule wall, showing its thin and uniform thickness. Scale bar, $2 \mu \mathrm{m} .{ }^{191}$ Copyright 2011. Adapted with permission from the Nature Publishing Group. Right panels: Bore flow rate profiles used to synthesize ZIF-8 membranes on the inner surface of Torlon hollow fibers. (A) Static growth, with a $\mathrm{Zn}^{2+} / \mathrm{H}_{2} \mathrm{O}$ bore solution and 2-methylimidazole/octanol shell solution, produced discontinuous coatings of particles at the fiber surface on the bore side. (B) A thin, continuous ZIF-8 membrane of $\sim 2 \mu \mathrm{m}$ thickness was obtained via growth under continuous bore flow of $60 \mu \mathrm{L} h^{-1}$. (C) A flow profile consisting of an initial continuous flow process followed by a static growth interrupted by a reactant replenishment step, led to a ZIF-8 membrane of $\sim 9 \mu \mathrm{m}$ thickness. ${ }^{364}$ Copyright 2014. Adapted with permission from the American Association for the Advancement of Science.

The film growth direction is predominantly towards the aqueous side, because most organic phase precursors solubilize well in the aqueous phase. Table 1-11 shows an overview of the reactants that are used for ZIF and MOF synthesis via interfacial polymerization. Both hollow capsules and supported layers have been prepared. The reaction times are usually in the range of several hours, because the precursor reactivity is not as high as in conventional interfacial polymerization syntheses. Catalysts such as tertiary amines are employed to improve the reactivity. ${ }^{191}$ To obtain sufficient film formation that limits the 
reactant diffusion to the opposite phase, much higher monomer concentrations are used as compared to for example polyamide synthesis.

Table 1-11. Precursors used for ZIFs and MOFs prepared via interfacial polymerization, the reaction conditions, and their applications. In bold: the reactant names, method of interfacial polymerization, reaction time and temperature and final polymer configuration.

\begin{tabular}{|c|c|c|c|c|}
\hline Aq. phase reactant & $\begin{array}{l}\text { Org. phase } \\
\text { reactant }\end{array}$ & Reaction conditions & Application & $\begin{array}{l}\mathrm{R} \\
\mathrm{e}\end{array}$ \\
\hline $\begin{array}{l}\text { Copper acetate }(7.2 \\
\mathrm{g}) \text { in } 100 \mathrm{~g} \text { water } \\
\text { with } 1-4 \mathrm{wt} \% \\
\text { polyvinyl alcohol } \\
(\mathrm{PVA}, 98 \% \\
\text { hydrolysed; } M_{w} \text {, } \\
13,000-23,000) \text {. Up } \\
\text { to } 20 \% \text { ethanol was } \\
\text { added for the } \\
\text { preparation of hollow } \\
\text { capsules. } \\
\text { Zinc nitrate } \\
\left(\mathrm{ZnNO} \mathrm{H}_{3} \cdot \mathrm{H}_{2} \mathrm{O}, \mathrm{g} \mathrm{L}^{-1}\right) \\
\text { in water. }\end{array}$ & $\begin{array}{l}\text { 1,3,5-Benzene } \\
\text { tricarboxylic } \\
\text { acid }(1.765 \\
\text { wt.\%) in } \\
\text { 1-octanol. } \\
\text { 2-Methyl } \\
\text { imidazole in } \\
\text { 1-octanol. }\end{array}$ & $\begin{array}{l}\mathrm{Cu}_{3}(\mathrm{BTC})_{2} \text { was prepared } \\
\text { from a copper acetate in aq. } \\
\text { PVA solution and 1,3,5- } \\
\text { benzenetricarboxylic acid } \\
\text { in 1-octanol. Cupric oxide } \\
\text { particles were removed by } \\
\text { centrifugation prior to } \\
\text { reaction. ZIF-8 was } \\
\text { prepared from a solution of } \\
\text { 2-methylimidazole 1- } \\
\text { octanol and zinc nitrate in } \\
\text { water. Film growth was } \\
\text { obtained by leaving the } \\
\text { interface to stand. Capsules } \\
\text { were prepared from an } \\
\text { emulsion prepared in a } \\
\text { microchannel. }\end{array}$ & $\begin{array}{l}\text { Membrane } \\
\text { nanofiltration } \\
\text { applications. } \\
\mathrm{Cu}_{3}(\mathrm{BTC})_{2} \mathrm{MOF} \\
\text { membrane showed } \\
\text { dye retention (Rose } \\
\text { Bengal). Capsules } \\
\text { were used as } \\
\text { carriers for the dye, } \\
\text { and showed no } \\
\text { leaching over time. } \\
\text { Upon capsule } \\
\text { breakage, the dye } \\
\text { could be released. }\end{array}$ & $\begin{array}{l}1 \\
9 \\
1\end{array}$ \\
\hline $\begin{array}{l}\text { Zinc nitrate } \\
\left(\mathrm{ZnNO}_{3} \cdot \mathrm{H}_{2} \mathrm{O}, 0.05-\right. \\
0.4 \mathrm{M}) \text { in dimethyl } \\
\text { formamide } \\
\text { 1,4-Benzene } \\
\text { dicarboxylic acid } \\
(\mathrm{TPA},) \text { in hexane. } \\
\text { The molar ratio of } \\
\mathrm{Zn}\left(\mathrm{NO}_{3}\right)_{2} \cdot 6 \mathrm{H}_{2} \mathrm{O} \text { to } \\
\mathrm{TPA} \text { was kept }\end{array}$ & $\begin{array}{l}\text { Trimethyl } \\
\text { amine (TEA) } \\
\text { in hexane. }\end{array}$ & $\begin{array}{l}\text { MOF layers were prepared } \\
\text { by adding TEA in hexane } \\
\text { to zinc nitrate and TPA in } \\
\text { DMF. Reaction times of } \mathbf{5} \\
\text { min to } 10 \text { h were used. } \\
\text { Membranes were collected } \\
\text { by a circle-shaped copper } \\
\text { wire. Particles were filtered } \\
\text { and washed with DMF } \\
\text { membranes, because it } \\
\text { caused curving in DMF. } \\
\text { Both membrane and } \\
\text { particle products were } \\
\text { dried in vacuum at } 70{ }^{\circ} \mathrm{C} \\
\text { for } 12 \mathrm{~h} \text {. }\end{array}$ & $\begin{array}{l}\text { Depending on the } \\
\text { precursor and } \\
\text { catalyst } \\
\text { concentrations, } \\
\text { microparticles or } \\
\text { membranes were } \\
\text { obtained. Estimated } \\
\text { Langmuir surface } \\
\text { areas were } 709 \mathrm{~m}^{2} \\
\mathrm{~g}^{-1} \text { for the } \\
\text { membrane and } 2115 \\
\mathrm{~m}^{2} \mathrm{~g}^{-1} \text { for the } \\
\text { particles, measured } \\
\text { with liquid } \mathrm{N}_{2} \text {. No } \\
\text { sorption hysteresis }\end{array}$ & $\begin{array}{l}3 \\
6 \\
5\end{array}$ \\
\hline
\end{tabular}




\begin{tabular}{|c|c|c|c|c|}
\hline constant at 2. & & & was observed. & \\
\hline $\begin{array}{l}\text { Zinc nitrate } \\
\left(\mathrm{ZnNO}_{3} \cdot \mathrm{H}_{2} \mathrm{O}, 15 \mathrm{~g} \mathrm{~L}^{-}\right. \\
\left.{ }^{1}\right) \text { in water. }\end{array}$ & $\begin{array}{l}\text { 2-Methyl } \\
\text { imidazole } \\
\text { hexane }+ \\
\text { ethanol as co- } \\
\text { solvent. }\end{array}$ & $\begin{array}{l}\text { PES membrane support } \\
\text { was impregnated with an } \\
\text { aq. zinc nitrate overnight. } \\
\text { Excess liquid was removed } \\
\text { from the support surface } \\
\text { using a rubber wiper. Next, } \\
\text { 2-methylimizazole in } \\
\text { hexane was gently poured } \\
\text { on the surface. The solution } \\
\text { was drained off after a } \mathbf{1} \mathbf{~ h} \\
\text { reaction } \\
\text { time. The membranes were } \\
\text { finally post-treated } \\
\text { overnight at } 100^{\circ} \mathrm{C} \text {. }\end{array}$ & 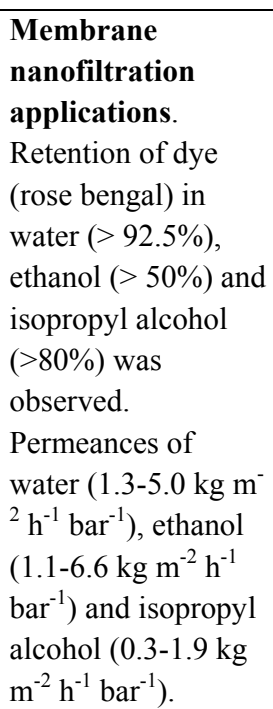 & $\begin{array}{l}3 \\
6 \\
6\end{array}$ \\
\hline $\begin{array}{l}\text { 2-Methylimidazole } \\
\text { (mIm, } 0.018 \mathrm{M}) \text { in } \\
\text { water }\end{array}$ & $\begin{array}{l}\text { Zinc nitrate } \\
\left(\mathrm{ZnNO}_{3} \cdot \mathrm{H}_{2} \mathrm{O}\right. \\
1.37 \mathrm{M}) \text { in } 1- \\
\text { octanol }\end{array}$ & $\begin{array}{l}\text { A Torlon hollow fiber, with } \\
\text { flow of the zinc nitrate in } \\
\text { octanol solution through } \\
\text { the bore, was immersed in } \\
\text { the aq. mIm solution. The } \\
\text { aqueous shell solution was } \\
\text { stirred at } 60 \text { rpm and } \\
\text { reacted for } 120 \text { min with } 30 \\
\text { min with continuous bore } \\
\text { solution flow. Another } 3.5 \\
\text { h static growth was } \\
\text { applied, followed by } \\
\text { another } 20 \text { min flow } \\
\text { through the bore and a final } \\
3.5 \text { h growth step. } \\
\text { Reactants were removed } \\
\text { with neat octanol on the } \\
\text { bore side and water at the } \\
\text { shell side. Methanol (shell } \\
\text { side), heptane and hexane } \\
\text { (bore side) were used to } \\
\text { exchange solvents before } \\
\text { evaporation. Shell and bore } \\
\text { side liquids and flow rates } \\
\text { were exchanged in } \\
\text { alternative synthesis cases. } \\
\text { PDMS sealing was used to } \\
\text { repair defects in the }\end{array}$ & $\begin{array}{l}\text { Membrane gas } \\
\text { separation } \\
\text { applications. } \mathrm{H}_{2} \\
\text { permeances of } \\
\text { around } 800 \mathrm{GPU} \\
\text { and } \mathrm{H}_{2} / \mathrm{C}_{3} \mathrm{H}_{6} \\
\text { separation factors } \\
\text { above } 200 \text { and } \\
\mathrm{C}_{3} \mathrm{H}_{6} / \mathrm{C}_{3} \mathrm{H}_{8} \\
\text { separation factors } \\
\text { above } 8 \text { at } \\
\text { temperatures from } \\
25-125{ }^{\circ} \mathrm{C} \text {. }\end{array}$ & $\begin{array}{l}6 \\
4\end{array}$ \\
\hline
\end{tabular}




\begin{tabular}{|c|c|c|c|c|}
\hline & & crystals. & & \\
\hline $\begin{array}{l}\text { Copper nitrate } \\
\left(\mathrm{Cu}\left(\mathrm{NO}_{3}\right)_{2}\right) \text { in } \mathrm{N}, \mathrm{N}- \\
\text { dimethyl formamide } \\
(\mathrm{DMF})\end{array}$ & $\begin{array}{l}\text { 1,4-Benzene } \\
\text { dicarboxylic } \\
\text { acid in } \mathrm{N}, \mathrm{N}- \\
\text { dimethyl } \\
\text { formamide } \\
\text { (DMF) }\end{array}$ & $\begin{array}{l}\text { The solution of } \mathrm{Cu}\left(\mathrm{NO}_{3}\right)_{2} \\
\text { (top) and of 1,4- } \\
\text { benzenedicarboxylic acid ( } \\
\text { bottom) are separated by an } \\
\text { intermediate solvent layer. } \\
\text { Diffusion of } \mathrm{Cu}^{2+} \text { cations } \\
\text { and 1,4- } \\
\text { benzenedicarboxylic acid } \\
\text { precursors into the middle } \\
\text { phase causes slow growth } \\
\text { of the MOF crystals. No } \\
\text { immiscible liquid phases } \\
\text { are involved, and it is } \\
\text { therefore technically no } \\
\text { interfacial polymerization. } \\
\text { Nonetheless, the reactants } \\
\text { are separated by means of a } \\
\text { multiphase system. }\end{array}$ & $\begin{array}{l}\text { Membrane gas } \\
\text { separation } \\
\text { applications. The } \\
\text { separation of } \mathrm{CO}_{2} \\
\text { from } \mathrm{CO}_{2} / \mathrm{CH}_{4} \\
\text { mixtures by } \\
\text { addition of the } \\
\text { MOF nanosheets to } \\
\text { a polyimide. The } \\
\text { composites showed } \\
\text { improved selectivity } \\
\text { towards } \mathrm{CO}_{2} \text {. }\end{array}$ & $\begin{array}{l}3 \\
6 \\
7\end{array}$ \\
\hline
\end{tabular}

\section{Outlook}

ZIFs and MOFs represent a class of materials with great potential for sorption and membrane separation processes. The development of facile interfacial polymerization procedures for the synthesis of layers and hollow capsules can potentially bring the large-scale application of MOFs a step closer. Further development of growth protocols, variation of the monomer reactants and catalysts that improve the reaction rate might open up possibilities to obtain sub- $\mu \mathrm{m}$ layer thicknesses and synthesis time. For example, pre-seeded crystals that assemble at the liquid-liquid interface can potentially be used to aid defect-free film formation. In addition, excellent work on the controlled growth of MOF nanosheets by separating the reactants by a third interface has been presented. ${ }^{367}$ Although the reaction occurs in a diffuse reaction zone instead of at the interface, and therefore it is technically no interfacial polymerization, the diffusion limitations of the multiphase system aid in control over the MOF crystal growth.

\subsubsection{Polysiloxanes}

\section{Polysiloxane chemistry}

Polysiloxanes are a class of materials that consist of a Si-O-Si backbone and are characterized by a good thermal and chemical stability. Polysiloxanes are conventionally prepared by sol—gel synthesis. The sol—gel route employs 
silanol precursors, which are commonly alkoxysilanes. The alkoxy groups hydrolyse in the presence of water to form silanol groups. Subsequent condensation of the silanol groups leads to the formation of siloxane bonds. The sol-gel route owes its success to the relatively mild reaction conditions and the good control over the colloid size and degree of branching. By controlling the temperature, $\mathrm{pH}$ and water concentration during sol preparation, both very dense and very porous polysiloxanes can be obtained. ${ }^{368}$

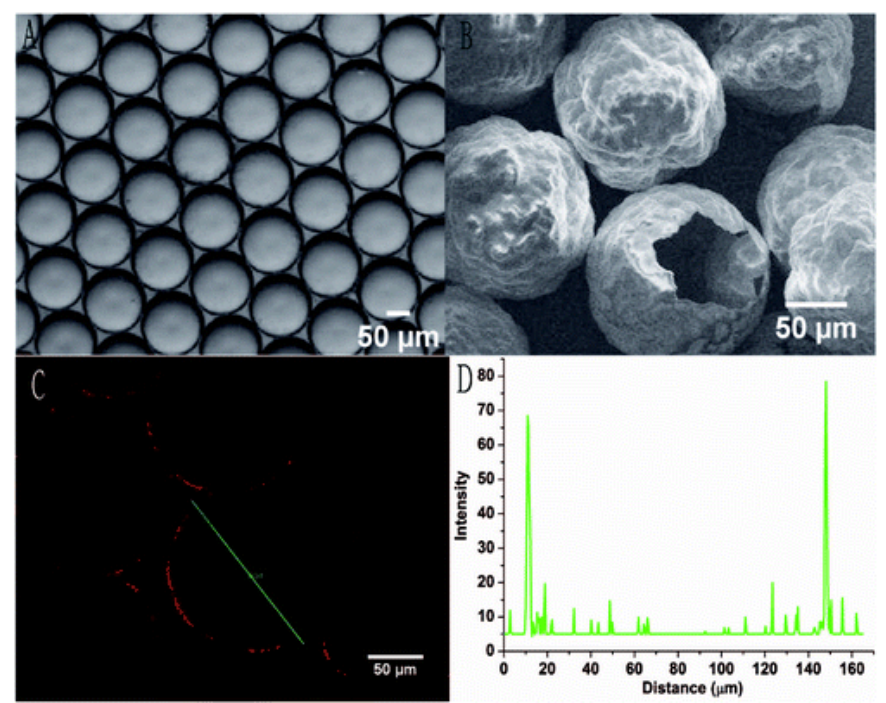

Figure 1-12. (A) Uniform droplets generated by microfluidic device. (B) Scanning electron micrograph of the as-synthesized hollow microspheres. (C) Confocal microscopy image of silica shells embedded with carboxytetramethylrhodamine. (D) Profile of luminescence intensity in a single microsphere. ${ }^{371}$ Copyright 2010. Adapted with permission from the American Chemical Society

Sol - gel can be combined with interfacial polymerization by dissolving the alkoxysilane in an organic phase. The aqueous phase provides the interface at which hydrolysis and condensation occurs, and acts as reagent for the polymerization. This approach is mainly employed to synthesize hollow silica nano- or microspheres, although planar layers have been prepared in the past. ${ }^{369,}{ }^{370}$ Figure 1-12 shows an example of silica microspheres that are synthesized from uniform droplets generated by a microfluidic device. The fluorescent marker embedded in the shell could be used to carefully determine the shell diameter. 
Table 1-12 shows an overview of the precursors that are used for the preparation of polysiloxanes. The alkoxysilane precursor, often tetraethoxysilane (TEOS), is dissolved in an organic phase such as hexane. Alkoxysilane hydrolysis occurs at the interface, in contact with a base or acid solution in water. The subsequent condensation does not require water as reactant, but is still more likely to occur at the interface due to the higher condensation rate in acid or base conditions.

Table 1-12. Precursors used for polysiloxanes prepared via interfacial polymerization, the reaction conditions, and their applications. In bold: the reactant names, method of interfacial polymerization, reaction time and temperature and final polymer configuration.

\begin{tabular}{|c|c|c|c|c|}
\hline $\begin{array}{l}\text { Aq. phase } \\
\text { reactant }\end{array}$ & Org. phase reactant & Reaction Conditions & Application & Ref. \\
\hline $\begin{array}{l}\text { Water (13.9 } \\
\text { g) with pH } \\
\text { adjusted to } 4 \text {. } \\
\text { A surfactant } \\
\text { was added for } \\
\text { emulsification } \\
\text { : Tween } 80 \text {, } \\
\text { Triton X-100, } \\
\text { Brij 78, } \\
\text { SDS, Pluronic } \\
\text { P123, Reax } \\
\text { 88B, or Reax } \\
\text { 88A. }\end{array}$ & $\begin{array}{l}\text { Tetraethylortho } \\
\text { silicate (TEOS, } \\
3.25-5.25 \mathrm{~g} \text { ) in } \\
\text { 1.5-3.75 g 1-butyl-3- } \\
\text { methylimidazolium } \\
\text { hexafluorophosphate } \\
\text { (ionic liquid, BMIm- } \\
\text { PF6) }\end{array}$ & $\begin{array}{l}\text { Silica capsules filled with } \\
\text { ionic liquid were prepared by } \\
\text { emulsification of BMIm- } \\
\text { PF6 in water using a } \\
\text { surfactant. Next, TEOS was } \\
\text { added dropwise and the } \\
\text { mixture was stirred for } \mathbf{1 2} \mathbf{h} \text {. } \\
\text { Finally, the silica } \\
\text { microcapsules were isolated } \\
\text { and washed by } \\
\text { centrifugation. }\end{array}$ & $\begin{array}{l}\text { Entrapment of } \\
\text { ionic liquid in } \\
\text { hollow silica } \\
\text { capsules. In } \\
\text { addition, } \\
\text { palladium } \\
\text { catalysts is } \\
\text { coated onto the } \\
\text { ionic liquid filled } \\
\text { capsules for the } \\
\text { hydrogenation of } \\
\text { alkynes. Reax } \\
\text { 88A was the only } \\
\text { surfactant that } \\
\text { resulted in } \\
\text { capsule } \\
\text { formation. }\end{array}$ & 372 \\
\hline $\begin{array}{l}\text { Water, } \\
\text { adjusted to } \\
\text { the correct pH } \\
\text { using } \\
\text { ammonium } \\
\text { hydroxide or } \\
\text { sodium } \\
\text { hydroxide }\end{array}$ & $\begin{array}{l}\text { Tetraethylortho } \\
\text { silicate (TEOS, } 0.5- \\
2.5 \mathrm{ml}) \\
\text { With Tegopren } 7008 \\
(1.0 \mathrm{v} . \%) \text { as } \\
\text { surfactant. }\end{array}$ & $\begin{array}{l}\text { Water was added to } \\
\text { Tegopren } 7008 \text { solution in } \\
\text { hexadecane and emulsified } \\
\text { at } 3000 \mathrm{rpm} \text { stirring for } 30 \\
\left.\text { min at } 20^{\circ} \mathrm{C}\right) \text {. Next, TEOS } \\
(0.5-2.5 \mathrm{ml}) \text { was added and } \\
\text { mixed for } 5 \mathrm{~min} \text {. Particles } \\
\text { were left to form for } \mathbf{1 - 2 4} \mathbf{h} \\
\text { reaction time. }\end{array}$ & $\begin{array}{l}\text { Hollow silica } \\
\text { capsules for } \\
\text { holding a liquid } \\
\text { core. More } \\
\text { robust shells } \\
\text { were found at } \\
\text { higher TEOS } \\
\text { concentrations. } \\
\text { Continued } \\
\text { inward growth of } \\
\text { the shell was } \\
\text { observed at high } \\
\text { TEOS }\end{array}$ & 146 \\
\hline
\end{tabular}




\begin{tabular}{|c|c|c|c|c|}
\hline & & & concentrations. & \\
\hline $\begin{array}{l}\text { Water, with } \\
2.0 \mathrm{M} \mathrm{HCl} \text {. } \\
\text { Added to } \\
\text { water with } \\
0.5 \text { wt.\% } \\
\text { PEO27- } \\
\text { PPO61- } \\
\text { PEO27 } \\
\text { surfactant }\end{array}$ & $\begin{array}{l}\text { Tetraethylortho } \\
\text { silicate (TEOS, } 30 \mathrm{~g}) \\
\text { in } 30 \mathrm{~g} \text { n-octadecane. }\end{array}$ & $\begin{array}{l}\text { An oil-in-water emulsion } \\
\text { was formed by dropping the } \\
\text { TEOS solution into } 300 \mathrm{ml} \\
\text { aq. surfactant solution at } \\
3000 \mathrm{rpm} \text { stirring for } 30 \mathrm{~min} \text {. } \\
\text { Next, the aq. } \mathrm{HCl} \text { solution } \\
\text { was added dropwise at } 500 \\
\text { rpm stirring. The reaction } \\
\text { was continued at continued } \\
\text { stirring at } \mathbf{3 5}{ }^{\circ} \mathbf{C} \text { for } \mathbf{4 8} \mathbf{h} \text { to. } \\
\text { The capsules were filtered, } \\
\text { washed by ethanol in water } \\
(30 \text { wt. } \% \text { ) and dried in an } \\
\text { oven at } 50^{\circ} \mathrm{C} \text { for } 24 \mathrm{~h} .\end{array}$ & $\begin{array}{l}\text { Hollow silica } \\
\text { capsules for } \\
\text { holding phase } \\
\text { change materials } \\
\text { (n-octadecane). } \\
\text { At pH } 2.89, \\
\text { compact silica } \\
\text { capsules with } \\
\text { fairly smooth } \\
\text { surface and mean } \\
\text { particle size of } \\
17.0 \mu \text { m were } \\
\text { obtained. }\end{array}$ & 373 \\
\hline $\begin{array}{l}\text { Water, } \\
\text { adjusted to } \\
\text { pH } 11 \text { with } \\
\text { ammonia } \\
(28 \%) \text { and } \\
\text { HCl. Added } \\
\text { to water with } \\
\text { cetyltrimethyl } \\
\text { ammonium } \\
\text { bromide } \\
\text { (CTAB, in } 2 \\
\text { mL water and } \\
2 \text { mL ethanol) } \\
\text { surfactant. }\end{array}$ & $\begin{array}{l}\text { Tetraethylortho } \\
\text { silicate. } \\
\text { (TEOS, } 160 \mu \mathrm{L} \text { and } \\
108 \mu \mathrm{L} \text { of } 100 \mu \mathrm{M} \\
\text { ([5-(and-6)- } \\
\text { Carboxytetramethyl } \\
\text { rhodamine] in } 2 \mathrm{~mL} \\
\text { carrier oil (DC } \\
\text { 5225C, } 40 \text { wt.\%) } \\
\text { Formulation Aid (DC } \\
749 \text { Fluid, } 30 \text { wt.\%) } \\
\text { Ar20 Silicone Oil (30 } \\
\text { wt.\%) }\end{array}$ & $\begin{array}{l}\text { The two phases were } \\
\text { supplied to microchannels } \\
\text { using syringe pumps. The } \\
\text { droplets collected were kept } \\
\text { at } \mathbf{3 5}{ }^{\circ} \mathbf{C} \text { for } \mathbf{2 4} \mathbf{h} \text { to form } \\
\text { hollow silica microspheres. } \\
\text { The final products were } \\
\text { washed with isopropanol and } \\
\text { acetone. }\end{array}$ & $\begin{array}{l}\text { Hollow silica } \\
\text { capsules filled } \\
\text { with } \\
\text { ethylbutyrate for } \\
\text { the extraction of } \\
\text { iodine. Shell } \\
\text { thickness } 500 \mathrm{~nm} \\
\text { and } 130 \mu \mathrm{m} \\
\text { diameter. The } \\
\text { microsphere } \\
\text { morphology } \\
\text { could be varied } \\
\text { from totally } \\
\text { hollow to partly } \\
\text { solid by either } \\
\text { increasing the } \\
\text { TEOS or } \\
\text { decreasing the } \\
\text { CTAB } \\
\text { concentrations. }\end{array}$ & 371 \\
\hline $\begin{array}{l}\text { Water with } \\
\mathrm{pH} \text { ranging } \\
\text { from } 1-13 \\
\text { Acid: } \mathrm{HCl} \text {, } \\
\mathrm{HNO}_{3} \text {, acetic } \\
\text { acid, formic } \\
\text { acid, citric } \\
\text { acid } \\
\text { Base: } \mathrm{NaOH} \\
\text { and ammonia }\end{array}$ & $\begin{array}{l}\text { Ethyl Silicate 40, (E- } \\
40,0.27 \mathrm{M}) \text { in } \\
\text { hexane }\end{array}$ & $\begin{array}{l}\text { Acid and base catalyzed } \\
\text { sol-gel at the liquid-liquid } \\
\text { interface. The reaction was } \\
\text { performed at } \mathbf{2 4} \mathrm{h} \text { reaction } \\
\text { time, followed by } 24 \mathrm{~h} \\
\text { drying at } 30^{\circ} \mathrm{C} \text { and } 24 \mathrm{~h} \text { at } \\
60^{\circ} \mathrm{C} \text {. Finally, the layers } \\
\text { were calcined for } 2 \mathrm{~h} \text { at } 400 \\
{ }^{\circ} \mathrm{C} \text {. }\end{array}$ & $\begin{array}{l}\text { Silica layers for } \\
\text { optical devices } \\
\text { such as } \\
\text { multiplexers. } \\
\text { The film growth } \\
\text { rate and density } \\
\text { depends on the } \\
\text { type of catalyst. } \\
\text { Crack-free } 1-20 \\
\mu \text { m thick films } \\
\text { could be formed. }\end{array}$ & $\begin{array}{l}369, \\
370, \\
374\end{array}$ \\
\hline
\end{tabular}




\section{Hybrid inorganic-organic}

Although hybrid inorganic-organic materials are fairly common in sol-gel science, only a few examples of silica-based hybrid materials have been prepared by sol-gel combined with interfacial polymerization. Table 1-13 shows the precursors that are used for hybrid inorganic-organic polysiloxanes, the reaction conditions and their applications. Covalent attachment of a catalyst in the porous surface of microcapsules allowed for large-surface areas of catalytically active hollow capsules. By tuning the properties of such materials, selective transport and catalysis could be combined in a single system.

Table 1-13. Precursors used for hybrid inorganic-organic polysiloxanes prepared via interfacial polymerization, the reaction conditions, and their applications. In bold: the reactant names, method of interfacial polymerization, reaction time and temperature and final polymer configuration.

\begin{tabular}{|c|c|c|c|c|}
\hline $\begin{array}{l}\text { Aq. phase } \\
\text { reactant }\end{array}$ & Org. phase reactant & Reaction Conditions & Application & Ref. \\
\hline $\begin{array}{l}\text { Water with } \\
\text { cetyltrimethyl } \\
\text { ammonium } \\
\text { chloride } \\
\text { (CTAC, } 8.7 \\
\text { wt.\%) }\end{array}$ & $\begin{array}{l}\text { Ru-TsDPEN catalyst } \\
\text { functionalized with a } \\
\text { trimethoxysilane group } \\
(0.12 \mathrm{wt} . \%) \\
\text { Tetraethylortho } \\
\text { silicate (TEOS, } 30 \\
\text { wt.\%) in chloroform }\end{array}$ & $\begin{array}{l}\text { The microcapsules were } \\
\text { prepared by emulsification } \\
\text { of an aq. CTAC solution to a } \\
\text { solution of TEOS and the } \\
\text { silyl functionalized Ru- } \\
\text { TsDPEN catalyst in } \\
\text { chloroform that contains } \\
\text { hydrophobic magnetic } \\
\text { nanoparticles. The mixture } \\
\text { was stirred at } 10,000 \text { rpm for } \\
4 \text { min and left to react for } \\
\mathbf{2 4} \mathbf{h} \text { while stirring } \\
\text { mechanically. The } \\
\text { microcapsules were } \\
\text { separated by using an } \\
\text { external magnetic field and } \\
\text { washed with water. }\end{array}$ & $\begin{array}{l}\text { Silica } \\
\text { microcapsules } \\
\text { with catalytic } \\
\text { activity for the } \\
\text { asymmetric } \\
\text { transfer } \\
\text { hydrogenation } \\
\text { of ketones. The } \\
\text { ruthenium } \\
\text { catalyst loading } \\
\text { was } 12 \mu \text { mol g- } \\
1 .\end{array}$ & 375 \\
\hline
\end{tabular}




\begin{tabular}{|c|c|c|c|c|}
\hline $\begin{array}{l}\text { Water with } \\
\text { sodium } \\
\text { hydroxide } \\
(\mathrm{NaOH}, 0.1 \\
\mathrm{M}) \text { or } \\
\text { hydrochloric } \\
\text { acid }(\mathrm{HCl} \text {, } \\
0.01 \mathrm{~mol} / \mathrm{L}) \\
\text { solution in } \\
\text { water. }\end{array}$ & $\begin{array}{l}\text { 3,30-Dichloro- } \\
\text { biphenylene-bridged } \\
\text { precursor (DPBS, } \\
0.09 \text { mmol) in toluene. } \\
\text { o. }\end{array}$ & $\begin{array}{l}\text { DPBS in toluene was slowly } \\
\text { added to an aq. acidic or } \\
\text { alkaline solution. The } \\
\text { formed solid was washed } \\
\text { with water and ethanol, and } \\
\text { then dried in vacuum. } \\
\text { Dichloro-biphenylene- } \\
\text { bridged silsesquioxanes was } \\
\text { also prepared under an acid } \\
\text { condition with a similar } \\
\text { procedure, using a dilute } \\
\text { sodium hydroxide solution. }\end{array}$ & $\begin{array}{l}\text { Synthesis of a } \\
\text { layered structure } \\
\text { of biphenylene- } \\
\text { bridged } \\
\text { silsesquioxanes. } \\
\text { The material } \\
\text { shows some } \\
\text { well-ordered } \\
\text { features with } \\
\text { lamellar spacing } \\
\text { in the range of } \\
0.25-0.30 \mathrm{~nm} \text {. }\end{array}$ & 376 \\
\hline
\end{tabular}

\section{Outlook}

Polysiloxanes can be readily prepared by performing sol—gel synthesis at the interface of two liquids. Although most research focused on hollow capsule synthesis, ${ }^{371,373}$ formation of free-standing or supported polysiloxane layers is well possible. ${ }^{369,} 370,374$ Although the number of hybrid inorganic-organic polysiloxanes prepared via interfacial polymerization is minor, there are countless options for hybrid precursors available from the well-developed field of sol-gel chemistry.

\subsection{Conclusions and future outlook}

In conclusion, the library of monomer precursors that are used for interfacial polymerization is expanding rapidly. The technique has proven to be useful for polymer synthesis with high surface areas of ultrathin layers on top of porous supports or nanosized structures such as fibers and capsules. The monomer reactants are generally highly reactive, but recent developments in polysiloxane and MOF layer synthesis show that smooth layer formation is even possible at lower reaction rates. Moreover, monomer reactivity does not necessarily limit the choice in reactants; reactions mediated by (homogeneous) catalysts, strong oxidizing agents and radicals can be combined readily with interfacial polymerization. The main limitation of the technique lies in the use of two immiscible solvents. The incompatibility of the solvent implicates that each of the reactants should be compatible with at least one of the phases. In 
addition, the large quantities of solvents that are required for synthesis involves purification and re-usage. Therefore, libraries of suitable precursors and fundamental knowledge on the role of synthesis parameters on material properties are crucial to future developments of interfacial polymerization based synthesis.

There are still many unexplored directions for the synthesis of low dimensional, large surface area structures via interfacial polymerization. More and more novel hybrid bio-organic and hybrid inorganic-organic layers are being presented in recent literature. In addition, composite materials can be obtained by assembly of nano- or micro-sized particles at the interface during interfacial polymerization, or by co-polymerization of a second component (e.g., the combined interfacial synthesis of a polyamide by polycondensation and silica synthesis via sol—gel). Such hybrid and composite materials allow for design of materials that display unique, synergistic properties. In membranes, hybrid materials are already used to build in additional rigidity and affinity groups. The performance of conducting polymers can be greatly improved by adding for example graphene nanosheets. Polyurethane capsules can be made stimuli-responsive by incorporating magnetic nanoparticles or light sensitive components. Interfacial polymerization allows us to focus all these material property combinations to the confined lateral dimensions of an interface.

\subsection{Acknowledgements}

This project has received funding from the European Union's Seventh Framework Programme for research, technological development and demonstration under CARENA grant agreement no. 263007. This is, in part, a project of the Dutch Institute for Sustainable Process Technology (ISPT).

\subsection{Thesis outline}

In this thesis, novel hybrid membranes prepared by interfacial polymerization are described. The outline of this thesis is schematically represented by the flowchart in Figure 1-13. 


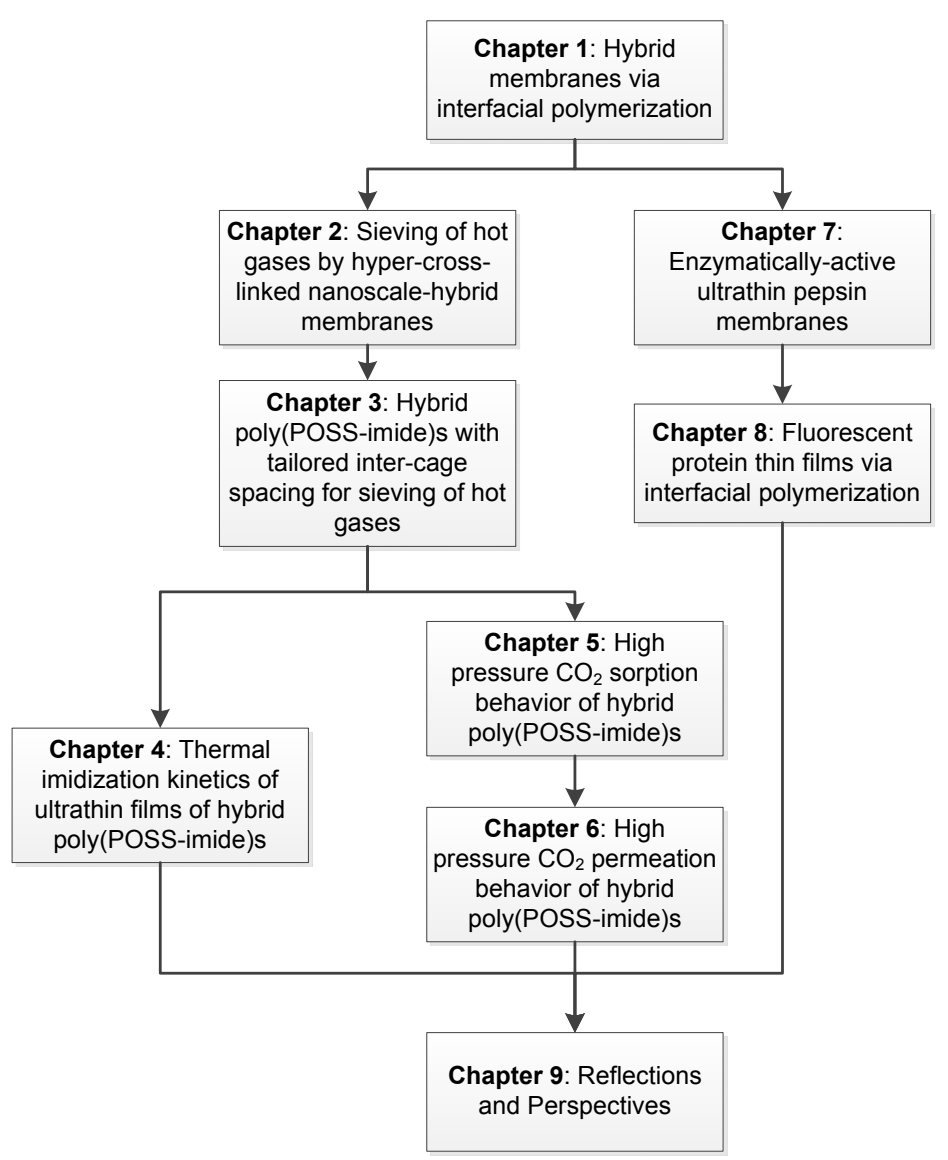

Figure 1-13. Schematic overview of the thesis outline.

Chapter 1 introduces the concept of hyper-cross-linked, hybrid membranes and gives an overview of the current trends in interfacial polymerization. The chapter demonstrates that interfacial polymerization can be used for the synthesis of ultrathin films that consist of a wide range of polymeric, inorganic and biological components. Chapter 1 provides the background for the two main directions of this thesis: hybrid inorganic-organic membranes for gas separation applications (chapters 2-6) and ultrathin biological hybrid films (chapters 7-8)

Chapter 2 reports on the synthesis of ultrathin films of novel hybrid polyhedral oligomeric silsesquioxanes-imides via interfacial polymerization. The nanoscale distribution of POSS and imide moieties is studied by atomic force microscopy. The hyper-cross-linked network characteristics of the hybrid material is used for sieving of hot gases. 
Chapter 3 extends the synthesis of poly(POSS-imide)s via interfacial polymerization that is presented in chapter 2 towards other imide bridges. The length and flexibility of the imide groups can be used to tailor the intercage spacing in the hyper-cross-linked network. The gas separation performance at elevated temperatures is studied in relation with the type of imide bridge.

In Chapter 4, the heat treatment required for the preparation of the poly(POSS-imides) presented in chapters 2 and 3 are studied. The influence of the length and flexibility of the organic group that connect the POSS-cages on the thermal imidization is determined. Changes in chemical and physical properties are monitored by a combination of thermal analysis techniques.

In Chapter 5 the sorption behavior of compressed $\mathrm{CO}_{2}$ and $\mathrm{CH}_{4}$ in hybrid poly(POSS-imides) is studied. Spectroscopic ellipsometry is used to determine the changes in thickness and refractive index in ultrathin polymer and hybrid network films. The sorbed gas concentrations and apparent molar volumes are estimated from the ellipsometry data.

In Chapter 6 the high pressure $\mathrm{CO}_{2}$ sorption and permeation of the hybrid poly(POSS-imide) membranes that are presented in Chapter 5 is studied.

Chapter 7 presents enzymatically-active ultrathin pepsin membranes that are prepared via interfacial polymerization. The ultrathin pepsin films are characterized with respect to enzymatic activity and membrane separation performance.

Chapter 8 continues with the cross-linked protein layer concept that is presented in Chapter 7. Here, fluorescent protein thin films are prepared via interfacial polymerization. The fluorescence recovery after photobleaching and fluorescent activity of the all-protein layers are studied.

Chapter 9 Reflects on all the chapters in this thesis and provides direction for future research on novel membrane materials, analysis of ultrathin membrane films and approaches for preparation of high surface-to-volume ratio membranes configurations for large-scale applications.

\subsection{References}

1. Baker, R. W., Membrane Technology and Applications. 2012.

2. Khayet, M.; Matsuura, T., Membrane distillation: principles and applications. Elsevier: 2011.

3. Wijmans, J. G.; Baker, R. W. Journal of Membrane Science 1995, 107, (1-2), 1-21

4. Raharjo, R. D.; Freeman, B. D.; Paul, D. R.; Sarti, G. C.; Sanders, E. S. Journal of Membrane Science 2007, 306, (1-2), 75-92 
5. Raharjo, R. D.; Freeman, B. D.; Sanders, E. S. Journal of Membrane Science 2007, 292, (1-2), 45-61

6. Gales, L.; Mendes, A.; Costa, C. Journal of Membrane Science 2002, 197, (1-2), 211222

7. Kim, H. J.; Nah, S. S.; Min, B. R. Advances in Environmental Research 2002, 6, (3), 255-264

8. Rebollar-Perez, G.; Carretier, E.; Lesage, N.; Moulin, P. Membranes 2011, 1, (1), 8090

9. Jiang, X.; Kumar, A. Journal of Membrane Science 2006, 286, (1-2), 285-292

10. Yeom, C. K.; Lee, S. H.; Song, H. Y.; Lee, J. M. Journal of Membrane Science 2002, 205, (1-2), 155-174

11. Ogieglo, W.; Wormeester, H.; Wessling, M.; Benes, N. E. Polymer (United Kingdom) 2014, 55, (7), 1737-1744

12. Ganesh, K.; Nagarajan, R.; Duda, J. L. Industrial and Engineering Chemistry Research 1992, 31, (3), 746-755

13. Jordan, S. S.; Koros, W. J. Macromolecules 1995, 28, (7), 2228-2235

14. Budd, P. M.; Elabas, E. S.; Ghanem, B. S.; Makhseed, S.; McKeown, N. B.; Msayib, K. J.; Tattershall, C. E.; Wang, D. Advanced Materials 2004, 16, (5), 456-459

15. Hashem, M.; Bezzu, C. G.; Kariuki, B. M.; McKeown, N. B. Polymer Chemistry 2011, 2, (10), 2190-2192

16. Budd, P. M.; McKeown, N. B.; Fritsch, D. Journal of Materials Chemistry 2005, 15, (20), 1977-1986

17. Bezzu, C. G.; Carta, M.; Tonkins, A.; Jansen, J. C.; Bernardo, P.; Bazzarelli, F.; McKeown, N. B. Advanced Materials 2012, 24, (44), 5930-5933

18. Nagel, C.; Günther-Schade, K.; Fritsch, D.; Strunskus, T.; Faupel, F. Macromolecules 2002, 35, (6), 2071-2077

19. Park, J. Y.; Paul, D. R. Journal of Membrane Science 1997, 125, (1), 23-39

20. Ree, M.; Kim, K.; Woo, S. H.; Chang, H. Journal of Applied Physics 1997, 81, (2), 698-708

21. Vanherck, K.; Koeckelberghs, G.; Vankelecom, I. F. J. Progress in Polymer Science 2013, 38, (6), 874-896

22. David, O. C.; Gorri, D.; Nijmeijer, K.; Ortiz, I.; Urtiaga, A. Journal of Membrane Science 2012, 419-420, 49-56

23. Berchtold, K. A.; Singh, R. P.; Young, J. S.; Dudeck, K. W. Journal of Membrane Science 2012, 415-416, (0), 265-270

24. Rezac, M. E.; Koros, W. J.; Miller, S. J. Journal of Membrane Science 1994, 93, (2), 193-201

25. Rezac, M. E.; Koros, W. J.; Miller, S. J. Industrial and Engineering Chemistry Research 1995, 34, (3), 862-868

26. Duthie, X.; Kentish, S.; Powell, C.; Nagai, K.; Qiao, G.; Stevens, G. Journal of Membrane Science 2007, 294, (1-2), 40-49

27. Wind, J. D.; Sirard, S. M.; Paul, D. R.; Green, P. F.; Johnston, K. P.; Koros, W. J. Macromolecules 2003, 36, (17), 6433-6441

28. Wessling, M.; Schoeman, S.; van der Boomgaard, T.; Smolders, C. A. Gas Sep. Purif. 1991, 5, (4), 222-228 
29. Scholes, C. A.; Chen, G. Q.; Stevens, G. W.; Kentish, S. E. Journal of Membrane Science 2010, 346, (1), 208-214

30. Ogieglo, W.; Wessling, M.; Benes, N. E. Macromolecules 2014, 47, (11), 3654-3660

31. Vandezande, P.; Gevers, L. E. M.; Vankelecom, I. F. J. Chem. Soc. Rev. 2008, 37, (2), 365-405

32. Han, S. H.; Misdan, N.; Kim, S.; Doherty, C. M.; Hill, A. J.; Lee, Y. M. Macromolecules 2010, 43, (18), 7657-7667

33. Han, S. H.; Kwon, H. J.; Kim, K. Y.; Seong, J. G.; Park, C. H.; Kim, S.; Doherty, C. M.; Thornton, A. W.; Hill, A. J.; Lozano, Á. E.; Berchtold, K. A.; Lee, Y. M. Physical Chemistry Chemical Physics 2012, 14, (13), 4365-4373

34. Sanders, D. F.; Smith, Z. P.; Ribeiro, C. P.; Guo, R.; McGrath, J. E.; Paul, D. R.; Freeman, B. D. Journal of Membrane Science 2012, 409-410, 232-241

35. Calle, M.; Doherty, C. M.; Hill, A. J.; Lee, Y. M. Macromolecules 2013, 46, (20), 8179-8189

36. Sarbu, T. T. E. J. Nature 2000, 405, (6783), 165

37. Consolati, G.; Genco, I.; Pegoraro, M.; Zanderighi, L. Journal of Polymer Science, Part B: Polymer Physics 1996, 34, (2), 357-367

38. Dorkenoo, K. D.; Pfromm, P. H. Macromolecules 2000, 33, (10), 3747-3751

39. Punsalan, D.; Koros, W. J. Journal of Applied Polymer Science 2005, 96, (4), 11151121

40. Punsalan, D.; Koros, W. J. Polymer 2005, 46, (23), 10214-10220

41. Huang, Y.; Paul, D. R. Journal of Membrane Science 2004, 244, (1-2), 167-178

42. Huang, Y.; Paul, D. R. Polymer 2004, 45, (25), 8377-8393

43. Huang, Y.; Paul, D. R. Macromolecules 2005, 38, (24), 10148-10154

44. Huang, Y.; Paul, D. R. Macromolecules 2006, 39, (4), 1554-1559

45. Cui, L.; Qiu, W.; Paul, D. R.; Koros, W. J. Polymer 2011, 52, (15), 3374-3380

46. Horn, N. R.; Paul, D. R. Polymer 2011, 52, (7), 1619-1627

47. Horn, N. R.; Paul, D. R. Macromolecules 2012, 45, (6), 2820-2834

48. Van Hoof, V.; Dotremont, C.; Buekenhoudt, A. Sep. Purif. Technol. 2006, 48, (3), 304-309

49. Agirre, I.; Arias, P. L.; Castricum, H. L.; Creatore, M.; ten Elshof, J. E.; Paradis, G. G.; Ngamou, P. H. T.; van Veen, H. M.; Vente, J. F. Separation and Purification Technology 2014, 121, (0), 2-12

50. Boeltken, T.; Belimov, M.; Pfeifer, P.; Peters, T. A.; Bredesen, R.; Dittmeyer, R. Chemical Engineering and Processing: Process Intensification 2013, 67, 136-147

51. Peters, T. A.; Stange, M.; Sunding, M. F.; Bredesen, R. Int. J. Hydrogen Energy 2015, 40, (8), 3497-3505

52. Katz, E.; Willner, I. Angewandte Chemie International Edition 2004, 43, (45), 60426108

53. Vendamme, R.; Onoue, S. Y.; Nakao, A.; Kunitake, T. Nature Materials 2006, 5, (6), 494-501

54. Zhang, Q.; Yang, W.; Ma, H.; Ma, P.; Xu, Q. Guangxue Xuebao/Acta Optica Sinica 2009, 29, (6), 1719-1723

55. Ko, Y. G.; Shin, S. S.; Choi, U. S. Journal of Colloid and Interface Science 2011, 361, (2), 594-602 
56. Witte, F.; Bartsch, I.; Willbold, E. Advances in biochemical engineering/biotechnology 2012, 126, 285-296

57. Klok, H. A. Journal of Polymer Science, Part A: Polymer Chemistry 2005, 43, (1), 117

58. Dušek, K.; Dušková, M.; Ilavský, M.; Stewart, R.; Kopeček, J. Biomacromolecules 2003, 4, (6), 1818-1826

59. Alcântara, A. C. S.; Aranda, P.; Darder, M.; Ruiz-Hitzky, E. Journal of Materials Chemistry 2010, 20, (42), 9495-9504

60. Descalzo, A. B.; Martínez-Máñez, R.; Sancenón, F.; Hoffmann, K.; Rurack, K. Angewandte Chemie - International Edition 2006, 45, (36), 5924-5948

61. Kickelbick, G. Progress in Polymer Science (Oxford) 2003, 28, (1), 83-114

62. Moore, T. T.; Koros, W. J. Journal of Molecular Structure 2005, 739, (1-3), 87-98

63. Goh, P. S.; Ismail, A. F.; Sanip, S. M.; Ng, B. C.; Aziz, M. Separation and Purification Technology 2011, 81, (3), 243-264

64. Le, N. L.; Wang, Y.; Chung, T. S. Journal of Membrane Science 2011, 379, (1-2), 174-183

65. Dai, Y.; Johnson, J. R.; Karvan, O.; Sholl, D. S.; Koros, W. J. Journal of Membrane Science 2012, 401-402, 76-82

66. Campbell, J.; Székely, G.; Davies, R. P.; Braddock, D. C.; Livingston, A. G. Journal of Materials Chemistry A 2014, 2, (24), 9260-9271

67. Cordes, D. B.; Lickiss, P. D.; Rataboul, F. Chemical Reviews 2010, 110, (4), 20812173

68. Hartmann-Thompson, C., Applications of Polyhedral Oligomeric Silsesquioxanes. 2011; Vol. 3.

69. Jeong, B. H.; Hoek, E. M. V.; Yan, Y.; Subramani, A.; Huang, X.; Hurwitz, G.; Ghosh, A. K.; Jawor, A. J. Membr. Sci. 2007, 294, (1-2), 1-7

70. Zou, H.; Wu, S.; Shen, J. Chemical Reviews 2008, 108, (9), 3893-3957

71. Jadav, G. L.; Singh, P. S. J. Membr. Sci. 2009, 328, (1-2), 257-267

72. Kong, C.; koushima, A.; Kamada, T.; Shintani, T.; Kanezashi, M.; Yoshioka, T.; Tsuru, T. Journal of Membrane Science 2011, 366, (1-2), 382-388

73. Chhabra, P.; Choudhary, V. Journal of Applied Polymer Science 2010, 118, (5), 3013 3023

74. Choi, J.; Lee, K. M.; Wycisk, R.; Pintauro, P. N.; Mather, P. T. Journal of the Electrochemical Society 2010, 157, (6), B914-B919

75. Kayser, M. J.; Reinholdt, M. X.; Kaliaguine, S. Journal of Physical Chemistry B 2010, $114,(25), 8387-8395$

76. Kumar, G. G.; kim, P.; kim, A. r.; Nahm, K. s.; Elizabeth, R. N. Materials Chemistry and Physics 2009, 115, (1), 40-46

77. Joshi, M.; Butola, B. S. Journal of Macromolecular Science - Polymer Reviews 2004, 44, (4), 389-410

78. Kopesky, E. T.; Haddad, T. S.; Cohen, R. E.; McKinley, G. H. Macromolecules 2004, 37, (24), 8992-9004

79. Kopesky, E. T.; McKinley, G. H.; Cohen, R. E. Polymer 2006, 47, (1), 299-309

80. Zhang, Y.; Lee, S.; Yoonessi, M.; Liang, K.; Pittman, C. U. Polymer 2006, 47, (9), 2984-2996 
81. Kang, S.; Hong, S. I.; Choe, C. R.; Park, M.; Rim, S.; Kim, J. Polymer 2001, 42, (3), 879-887

82. Tsagaropoulos, G.; Eisenberg, A. Macromolecules 1995, 28, (18), 6067-6077

83. Wu, C. L.; Zhang, M. Q.; Rong, M. Z.; Friedrich, K. Composites Science and Technology 2002, 62, (10-11), 1327-1340

84. Li, F.; Li, Y.; Chung, T. S.; Kawi, S. Journal of Membrane Science 2010, 356, (1-2), 14-21

85. Dasgupta, B.; Sen, S. K.; Banerjee, S. Materials Science and Engineering B: SolidState Materials for Advanced Technology 2010, 168, (1), 30-35

86. Raftopoulos, K. N.; Pielichowski, K. Progress in Polymer Science, (0),

87. Feng, Y.; Jia, Y.; Guang, S.; Xu, H. Journal of Applied Polymer Science 2010, 115, (4), 2212-2220

88. Hao, N.; Böhning, M.; Goering, H.; Schönhals, A. Macromolecules 2007, 40, (8), 2955-2964

89. Hao, N.; Böhning, M.; Wohlrab, S.; Schönhals, A. Macromolecular Symposia 2008, 267, (1), 69-73

90. Iyer, P.; Iyer, G.; Coleman, M. Journal of Membrane Science 2010, 358, (1-2), 26-32

91. Jackson, C. L.; Bauer, B. J.; Nakatani, A. I.; Barnes, J. D. Chemistry of Materials 1996, 8, (3), 727-733

92. Corriu, R. J. P. Angewandte Chemie - International Edition 2000, 39, (8), 1376-1398

93. Jones, J. R. Acta Biomaterialia 2013, 9, (1), 4457-4486

94. Watanabe, H.; Vendamme, R.; Kunitake, T. Bulletin of the Chemical Society of Japan 2007, 80, (3), 433-440

95. Wu, Y.; Wu, C.; Li, Y.; Xu, T.; Fu, Y. Journal of Membrane Science 2010, 350, (1-2), 322-332

96. Xie, Z.; Hoang, M.; Duong, T.; Ng, D.; Dao, B.; Gray, S. Journal of Membrane Science 2011, 383, (1-2), 96-103

97. Dell'Erba, I. E.; Williams, R. J. J. Journal of Thermal Analysis and Calorimetry 2008, 93, (1), 95-100

98. Strachota, A.; Whelan, P.; Křǐž, J.; Brus, J.; Urbanová, M.; Šlouf, M.; Matějka, L. Polymer 2007, 48, (11), 3041-3058

99. Pellice, S. A.; Fasce, D. P.; Williams, R. J. J. Journal of Polymer Science, Part B: Polymer Physics 2003, 41, (13), 1451-1461

100. Tanaka, K.; Chujo, Y. Journal of Materials Chemistry 2012, 22, (5), 1733-1746

101. Pielichowski, K.; Njuguna, J.; Janowski, B.; Pielichowski, J., Polyhedral Oligomeric Silsesquioxanes (POSS)-Containing Nanohybrid Polymers. In Supramolecular Polymers Polymeric Betains Oligomers, Springer Berlin Heidelberg: 2006; Vol. 201, pp 225-296.

102. Abe, Y.; Gunji, T. Progress in Polymer Science (Oxford) 2004, 29, (3), 149-182

103. Hartmann-Thompson, C., Applications of Polyhedral Oligomeric Silsesquioxanes. Springer: 2011; Vol. 3.

104. Asuncion, M. Z.; Laine, R. M. Journal of the American Chemical Society 2010, 132, (11), 3723-3736

105. Laine, R. M.; Roll, M. F. Macromolecules 2011, 44, (5), 1073-1109

106. Nischang, I.; Brüggemann, O.; Teasdale, I. Angewandte Chemie - International Edition 2011, 50, (20), 4593-4596 
107. Oaten, M.; Choudhury, N. R. Macromolecules 2005, 38, (15), 6392-6401

108. Wu, G.; Su, Z. Chemistry of Materials 2006, 18, (16), 3726-3732

109. Zhang, C.; Babonneau, F.; Bonhomme, C.; Laine, R. M.; Soles, C. L.; Hristov, H. A.; Yee, A. F. Journal of the American Chemical Society 1998, 120, (33), 8380-8391

110. Kanezashi, M.; Shioda, T.; Gunji, T.; Tsuru, T. AlChE J. 2012, 58, (6), 1733-1743

111. Dalwani, M.; Zheng, J.; Hempenius, M.; Raaijmakers, M. J. T.; Doherty, C. M.; Hill, A. J.; Wessling, M.; Benes, N. E. Journal of Materials Chemistry 2012, 22, (30), $14835-14838$

112. Sharma, K. P.; Collins, A. M.; Perriman, A. W.; Mann, S. Advanced Materials 2013, 25, (14), 2005-2010

113. Wang, H.; Chung, T. S.; Tong, Y. W.; Jeyaseelan, K.; Armugam, A.; Chen, Z.; Hong, M.; Meier, W. Small 2012, 8, (8), 1185-1190

114. Akira, S.; Takeda, K. Nature Reviews Immunology 2004, 4, (7), 499-511

115. Xu, L. C.; Siedlecki, C. A. Biomaterials 2007, 28, (22), 3273-3283

116. Chandramohan, A.; Nagendiran, S.; Alagar, M. Journal of Composite Materials 2012, 46, (7), 773-781

117. Huang, J.; He, C.; Liu, X.; Xu, J.; Tay, C. S. S.; Chow, S. Y. Polymer 2005, 46, (18), 7018-7027

118. Huang, J.; Xiao, Y.; Mya, K. Y.; Liu, X.; He, C.; Dai, J.; Siow, Y. P. Journal of Materials Chemistry 2004, 14, (19), 2858-2863

119. Sulaiman, S.; Brick, C. M.; De Sana, C. M.; Katzenstein, J. M.; Laine, R. M.; Basheer, R. A. Macromolecules 2006, 39, (16), 5167-5169

120. Leu, C. M.; Chang, Y. T.; Wei, K. H. Macromolecules 2003, 36, (24), 9122-9127

121. Leu, C. M.; Chang, Y. T.; Wei, K. H. Chemistry of Materials 2003, 15, (19), 37213727

122. Leu, C. M.; Reddy, G. M.; Wei, K. H.; Shu, C. F. Chemistry of Materials 2003, 15, (11), 2261-2265

123. Choi, J.; Tamaki, R.; Kim, S. G.; Laine, R. M. Chemistry of Materials 2003, 15, (17), 3365-3375

124. Huang, J. C.; He, C. B.; Xiao, Y.; Mya, K. Y.; Dai, J.; Siow, Y. P. Polymer 2003, 44, (16), 4491-4499

125. Devaraju, S.; Vengatesan, M. R.; Alagar, M. High Performance Polymers 2011, 23, (2), 99-111

126. Alonso, B.; Massiot, D.; Valentini, M.; Kidchob, T.; Innocenzi, P. Journal of NonCrystalline Solids 2008, 354, (15-16), 1615-1626

127. Chattopadhyay, D. K.; Zakula, A. D.; Webster, D. C. Progress in Organic Coatings 2009, 64, (2-3), 128-137

128. Vreugdenhil, A. J.; Gelling, V. J.; Woods, M. E.; Schmelz, J. R.; Enderson, B. P. Thin Solid Films 2008, 517, (2), 538-543

129. Brusatin, G.; Innocenzi, P.; Guglielmi, M.; Babonneau, F. Journal of Sol-gel Science and Technology 2003, 26, (1-3), 303-306

130. Brinker, C. J.; Scherer, G. W., Sol-gel science: the physics and chemistry of sol-gel processing. Academic press, inc.: 1990.

131. Li, G.; Kanezashi, M.; Tsuru, T. Journal of Membrane Science 2011, 379, (1-2), 287295 
132. Castricum, H. L.; Paradis, G. G.; Mittelmeijer-Hazeleger, M. C.; Kreiter, R.; Vente, J. F.; ten Elshof, J. E. Advanced Functional Materials 2011, 21, (12), 2319-2329

133. ten Hove, M.; Nijmeijer, A.; Winnubst, L. Separation and Purification Technology 2015,

134. Mascia, L. Trends in Polymer Science 1995, 3, (2), 61-66

135. Schubert, U.; Hüsing, N.; Lorenz, A. Chemistry of Materials 1995, 7, (11), 2010-2027

136. Wen, J.; Wilkes, G. L. Chemistry of Materials 1996, 8, (8), 1667-1681

137. Haas, K. H. Advanced Engineering Materials 2000, 2, (9), 571-582

138. Schottner, G. Chemistry of Materials 2001, 13, (10), 3422-3435

139. Kreiter, R.; Rietkerk, M. D. A.; Castricum, H. L.; Van Veen, H. M.; Ten Elshof, J. E.; Vente, J. F. Journal of Sol-gel Science and Technology 57, (3), 245-252

140. Paradis, G. G.; Kreiter, R.; van Tuel, M. M. A.; Nijmeijer, A.; Vente, J. F. Journal of Materials Chemistry 2012, 22, (15), 7258-7264

141. Tomczak, S. J.; Marchant, D.; Svejda, S.; Minton, T. K.; Brunsvold, A. L.; Gouzman, I.; Grossman, E.; Schatz, G. C.; Troya, D.; Sun, L.; Gonzalez, R. I. In Properties and improved space survivability of POSS (polyhedral oligomeric silsesquioxane) polyimides, 2005; 2005; pp 395-406.

142. Zhang, W.; Müller, A. H. E. Progress in Polymer Science 2013, 38, (8), 1121-1162

143. Choi, J.; Yee, A. F.; Laine, R. M. Macromolecules 2003, 36, (15), 5666-5682

144. Morgan, P. W., Interfacial Polymerization. In Encyclopedia of Polymer Science and Technology, John Wiley \& Sons, Inc.: 2002.

145. Huang, J.; Kaner, R. B. Journal of the American Chemical Society 2004, 126, (3), $851-855$

146. Bean, K.; Black, C. F.; Govan, N.; Reynolds, P.; Sambrook, M. R. Journal of Colloid and Interface Science 2012, 366, (1), 16-22

147. Liu, D.; Yu, B.; Jiang, X.; Yin, J. Langmuir 2013, 29, (17), 5307-5314

148. Sawhney, A. S.; Pathak, C. P.; Hubbell, J. A. Biomaterials 1993, 14, (13), 1008-1016

149. Scott, C.; Wu, D.; Ho, C. C.; Co, C. C. Journal of the American Chemical Society 2005, 127, (12), 4160-4161

150. Odian, G. G., Principles of polymerization. 2004; Vol. 3.

151. Morgan, P. W., Condensation Polymers: By interfacial and Solution Methods. 1965; p 190.

152. Ghosh, A. K.; Jeong, B. H.; Huang, X.; Hoek, E. M. V. J. Membr. Sci. 2008, 311, (12), 34-45

153. Jin, Y.; Su, Z. J. Membr. Sci. 2009, 330, (1-2), 175-179

154. Zhang, R. X.; Vanneste, J.; Poelmans, L.; Sotto, A.; Wang, X. L.; Van Der Bruggen, B. Journal of Applied Polymer Science 2012, 125, (5), 3755-3769

155. Huang, J.; Kaner, R. B. Chemical Communications 2006, (4), 367-376

156. Jegal, J.; Min, S. G.; Lee, K. H. J Appl Polym Sci 2002, 86, (11), 2781-2787

157. Frère, Y.; Danicher, L.; Gramain, P. European Polymer Journal 1998, 34, (2), 193-199

158. Chiang, Y. C.; Hsub, Y. Z.; Ruaan, R. C.; Chuang, C. J.; Tung, K. L. J. Membr. Sci. 2009, 326, (1), 19-26

159. Arai, Y.; Watanabe, M.; Sanui, K.; Ogata, N. Journal of polymer science. Part A-1, Polymer chemistry 1985, 23, (12), 3081-3093 
160. Marks, M. J.; Munjal, S.; Namhata, S.; Scott, D. C.; Bosscher, F.; De Letter, J. A.; Klumperman, B. Journal of Polymer Science, Part A: Polymer Chemistry 2000, 38, (3), 560-570

161. Chu, L. Y.; Park, S. H.; Yamaguchi, T.; Nakao, S. I. J. Membr. Sci. 2001, 192, (1-2), 27-39

162. Zhao, J.; Zhang, Y.; Su, Y.; Liu, J.; Zhao, X.; Peng, J.; Jiang, Z. Journal of Membrane Science 2013, 445, 1-7

163. Chai, G. Y.; Krantz, W. B. J. Membr. Sci. 1994, 93, (2), 175-192

164. Karode, S. K.; Kulkarni, S. S.; Suresh, A. K.; Mashelkar, R. A. Chemical Engineering Science 1997, 52, (19), 3243-3255

165. Munjal, S. Polymer Engineering and Science 1994, 34, (2), 93-101

166. Freger, V. Langmuir 2003, 19, (11), 4791-4797

167. Ghosh, A. K.; Hoek, E. M. V. J. Membr. Sci. 2009, 336, (1-2), 140-148

168. Zhang, Y.; Benes, N. E.; Lammertink, R. G. H. Lab on a Chip 2015, 15, (2), 575-580

169. Wu, D.; Huang, Y.; Yu, S.; Lawless, D.; Feng, X. Journal of Membrane Science 2014, 472, 141-153

170. Hung, W. S.; Lai, C. L.; An, Q.; De Guzman, M.; Shen, T. J.; Huang, Y. H.; Chang, K. C.; Tsou, C. H.; Hu, C. C.; Lee, K. R. J. Membr. Sci. 2014, 470, 513-523

171. Ahmad, A. L.; Ooi, B. S.; Choudhury, J. P. Separation Science and Technology 2004, 39, (8), 1815-1831

172. Karode, S. K.; Kulkarni, S. S.; Suresh, A. K.; Mashelkar, R. A. Chemical Engineering Science 1998, 53, (15), 2649-2663

173. Yashin, V. V.; Balazs, A. C. Journal of Chemical Physics 2004, 121, (22), 1144011454

174. Bouchemal, K.; Couenne, F.; Briançon, S.; Fessi, H.; Tayakout, M. AIChE Journal 2006, 52, (6), 2161-2171

175. Freger, V. Langmuir 2005, 21, (5), 1884-1894

176. Dhumal, S. S.; Wagh, S. J.; Suresh, A. K. Journal of Membrane Science 2008, 325, (2), 758-771

177. Kobašlija, M.; McQuade, D. T. Macromolecules 2006, 39, (19), 6371-6375

178. Hermans, S.; Bernstein, R.; Volodin, A.; Vankelecom, I. F. J. Reactive and Functional Polymers 2014, 86, 199-208

179. Lau, W. J.; Ismail, A. F.; Misdan, N.; Kassim, M. A. Desalination 2012, 287, 190-199

180. Mansourpanah, Y.; Madaeni, S. S.; Rahimpour, A. J. Membr. Sci. 2009, 343, (1-2), 219-228

181. Kim, S. H.; Kwak, S. Y.; Suzuki, T. Environmental Science and Technology 2005, 39, (6), 1764-1770

182. Du, J.; Zhang, J.; Han, B.; Liu, Z.; Wan, M. Synthetic Metals 2005, 155, (3), 523-526

183. Lei, J.; Liang, W.; Brumlik, C. J.; Martin, C. R. Synthetic Metals 1992, 47, (3), 351359

184. Qi, G.; Huang, L.; Wang, H. Chemical Communications 2012, 48, (66), 8246-8248

185. Wang, X.; Yeh, T. M.; Wang, Z.; Yang, R.; Wang, R.; Ma, H.; Hsiao, B. S.; Chu, B. Polymer (United Kingdom) 2014, 55, (6), 1358-1366

186. Sun, Q.; Deng, Y. Journal of the American Chemical Society 2005, 127, (23), 82748275 
187. McIlroy, D. A.; Blaiszik, B. J.; Caruso, M. M.; White, S. R.; Moore, J. S.; Sottos, N. R. Macromolecules 2010, 43, (4), 1855-1859

188. Gaudin, F.; Sintes-Zydowicz, N. Colloids and Surfaces A: Physicochemical and Engineering Aspects 2011, 384, (1-3), 698-712

189. Quevedo, E.; Steinbacher, J.; McQuade, D. T. Journal of the American Chemical Society 2005, 127, (30), 10498-10499

190. Yadav, S. K.; Suresh, A. K.; Khilar, K. C. AIChE Journal 1990, 36, (3), 431-438

191. Ameloot, R.; Vermoortele, F.; Vanhove, W.; Roeffaers, M. B. J.; Sels, B. F.; De Vos, D. E. Nature Chemistry 2011, 3, (5), 382-387

192. Raaijmakers, M. J. T.; Wessling, M.; Nijmeijer, A.; Benes, N. E. Chemistry of Materials 2014, 26, (12), 3660-3664

193. Dalwani, M.; Benes, N. E.; Bargeman, G.; Stamatialis, D.; Wessling, M. Journal of Membrane Science 2010, 363, (1-2), 188-194

194. Dalwani, M.; Benes, N. E.; Bargeman, G.; Stamatialis, D.; Wessling, M. J. Membr. Sci. 2011, 372, (1-2), 228-238

195. Buch, P. R.; Jagan Mohan, D.; Reddy, A. V. R. J. Membr. Sci. 2008, 309, (1-2), 36-44

196. Kawaguchi, T.; Tamura, H. J Appl Polym Sci 1984, 29, (11), 3359-3367

197. Shintani, T.; Matsuyama, H.; Kurata, N. Desalination 2007, 207, (1-3), 340-348

198. Han, R. Journal of Membrane Science 2013, 425-426, 176-181

199. Shin, D. H.; Kim, N.; Lee, Y. T. Journal of Membrane Science 2011, 376, (1-2), 302311

200. Jimenez Solomon, M. F.; Bhole, Y.; Livingston, A. G. J. Membr. Sci. 2012, 423-424, 371-382

201. Lee, K. P.; Arnot, T. C.; Mattia, D. J. Membr. Sci. 2011, 370, (1-2), 1-22

202. Hermans, S.; Mariën, H.; Van Goethem, C.; Vankelecom, I. F. J. Current Opinion in Chemical Engineering 2015, 8, (0), 45-54

203. Misdan, N.; Lau, W. J.; Ismail, A. F. Desalination 2012, 287, 228-237

204. Ismail, A. F.; Padaki, M.; Hilal, N.; Matsuura, T.; Lau, W. J. Desalination 2015, 356, 140-148

205. Hong, S.; Kim, I. C.; Tak, T.; Kwon, Y. N. Desalination 2013, 309, 18-26

206. Kim, C. K.; Kim, J. H.; Roh, I. J.; Kim, J. J. Journal of Membrane Science 2000, 165, (2), 189-199

207. Li, L.; Zhang, S.; Zhang, X.; Zheng, G. J. Membr. Sci. 2007, 289, (1-2), 258-267

208. Li, L.; Zhang, S.; Zhang, X.; Zheng, G. J. Membr. Sci. 2008, 315, (1-2), 20-27

209. Liu, M.; Wu, D.; Yu, S.; Gao, C. J. Membr. Sci. 2009, 326, (1), 205-214

210. Roh, I. J.; Greenberg, A. R.; Khare, V. P. Desalination 2006, 191, (1-3), 279-290

211. Xie, W.; Geise, G. M.; Freeman, B. D.; Lee, H. S.; Byun, G.; McGrath, J. E. J. Membr. Sci. 2012, 403-404, 152-161

212. Zuo, J.; Wang, Y.; Sun, S. P.; Chung, T. S. J. Membr. Sci. 2012, 405-406, 123-133

213. Arthur, S. D. J. Membr. Sci. 1989, 46, (2-3), 243-260

214. Yu, S.; Liu, M.; Lü, Z.; Zhou, Y.; Gao, C. J. Membr. Sci. 2009, 344, (1-2), 155-164

215. Liu, M.; Yao, G.; Cheng, Q.; Ma, M.; Yu, S.; Gao, C. J. Membr. Sci. 2012, 415-416, (0), 122-131

216. Oh, N. W.; Jegal, J.; Lee, K. H. Journal of Applied Polymer Science 2001, 80, (14), 2729-2736

217. Yoon, K.; Hsiao, B. S.; Chu, B. J. Membr. Sci. 2009, 326, (2), 484-492 
218. Mo, Y.; Tiraferri, A.; Yip, N. Y.; Adout, A.; Huang, X.; Elimelech, M. Environmental Science and Technology 2012, 46, (24), 13253-13261

219. Sundet, S. A.; Murphey, W. A.; Speck, S. B. Journal of Polymer Science 1959, 40, (137), 389-397

220. Trushinski, B. J.; Dickson, J. M.; Smyth, T.; Childs, R. F.; McCarry, B. E. J. Membr. Sci. 1998, 143, (1-2), 181-188

221. Kurth, C. J.; Kloos, S. D. Modified Sulfonamide Polymers. 2008.

222. Lind, M. L.; Jeong, B. H.; Subramani, A.; Huang, X.; Hoek, E. M. V. Journal of Materials Research 2009, 24, (5), 1624-1631

223. Lind, M. L.; Suk, D. E.; Nguyen, T. V.; Hoek, E. M. V. Environmental Science and Technology 2010, 44, (21), 8230-8235

224. Fathizadeh, M.; Aroujalian, A.; Raisi, A. J. Membr. Sci. 2011, 375, (1-2), 88-95

225. Huang, H.; Qu, X.; Ji, X.; Gao, X.; Zhang, L.; Chen, H.; Hou, L. Journal of Materials Chemistry A 2013, 1, (37), 11343-11349

226. Wang, Q.; Zhang, G. S.; Li, Z. S.; Deng, S.; Chen, H.; Wang, P. Desalination 2014, 352, 38-44

227. Duan, J.; Pan, Y.; Pacheco, F.; Litwiller, E.; Lai, Z.; Pinnau, I. J. Membr. Sci. 2015, 476, 303-310

228. Huo, J.; Marcello, M.; Garai, A.; Bradshaw, D. Advanced Materials 2013, 25, (19), $2717-2722$

229. Sorribas, S.; Gorgojo, P.; Téllez, C.; Coronas, J.; Livingston, A. G. Journal of the American Chemical Society 2013, 135, (40), 15201-15208

230. Haggenmueller, R.; Du, F.; Fischer, J. E.; Winey, K. I. Polymer 2006, 47, (7), 23812388

231. Jeong, J. Y.; Lee, H. J.; Kang, S. W.; Tan, L. S.; Baek, J. B. Journal of Polymer Science, Part A: Polymer Chemistry 2008, 46, (18), 6041-6050

232. Kim, H. J.; Lim, M. Y.; Jung, K. H.; Kim, D. G.; Lee, J. C. Journal of Materials Chemistry A 2015, 3, (13), 6798-6809

233. Kim, H. S.; Park, B. H.; Yoon, J. S.; Jin, H. J. Materials Letters 2007, 61, (11-12), 2251-2254

234. Zhao, H.; Qiu, S.; Wu, L.; Zhang, L.; Chen, H.; Gao, C. J. Membr. Sci. 2014, 450, 249-256

235. Zhao, Y.; Qiu, C.; Li, X.; Vararattanavech, A.; Shen, W.; Torres, J.; Hélix-Nielsen, C.; Wang, R.; Hu, X.; Fane, A. G.; Tang, C. Y. Journal of Membrane Science 2012, 423424, 422-428

236. Arslan, G.; Tor, A.; Cengeloglu, Y.; Ersoz, M. Journal of Hazardous Materials 2009, 165, (1-3), 729-735

237. Oleinikova, M.; González, C.; Valiente, M.; Muñoz, M. Polyhedron 1999, 18, (25), 3353-3359

238. Lee, S. Y.; Kim, H. J.; Patel, R.; Im, S. J.; Kim, J. H.; Min, B. R. Polymers for Advanced Technologies 2007, 18, (7), 562-568

239. Kalkan-Sevinc, Z. S.; Goettler, L. A. Polymer Engineering and Science 2012, 52, (11), 2410-2416

240. Duan, J.; Litwiller, E.; Pinnau, I. J. Membr. Sci. 2015, 473, 157-164

241. Zuo, J.; Chung, T. S. Journal of Materials Chemistry A 2013, 1, (34), 9814-9826

242. Langdon, C. J. Marine Biology 1989, 102, (2), 217-224 
243. Raaijmakers, M. J. T.; Schmidt, T.; Barth, M.; Tutus, M.; Benes, N. E.; Wessling, M. Angewandte Chemie International Edition 2015, n/a-n/a

244. Raaijmakers, M. J. T.; Schmidt, T.; Barth, M.; Tutus, M.; Benes, N. E.; Wessling, M. Angewandte Chemie International Edition 2015, 54, (20), 5910-5914

245. Majorek, K. A.; Porebski, P. J.; Dayal, A.; Zimmerman, M. D.; Jablonska, K.; Stewart, A. J.; Chruszcz, M.; Minor, W. Molecular Immunology 2012, 52, (3-4), 174182

246. Kollman, J. M.; Pandi, L.; Sawaya, M. R.; Riley, M.; Doolittle, R. F. Biochemistry 2009, 48, (18), 3877-86

247. Chang, H.; Khan, R.; Rong, Z.; Sapelkin, A.; Vadgama, P. Biofabrication 2010, 2, (3), 035002

248. Nair, G.; Gargiuli, J. F.; Shiju, N. R.; Rong, Z.; Shapiro, E.; Drikakis, D.; Vadgama, P. Chembiochem : a European journal of chemical biology 2006, 7, (11), 1683-9

249. Abad-Zapatero, C.; Rydel, T. J.; Erickson, J. Proteins 1990, 8, (1), 62-81

250. Royant, A.; Noirclerc-Savoye, M. Journal of structural biology 2011, 174, (2), 385-90

251. Strongin, D. E.; Bevis, B.; Khuong, N.; Downing, M. E.; Strack, R. L.; Sundaram, K.; Glick, B. S.; Keenan, R. J. Protein engineering, design \&amp; selection : PEDS 2007, 20, (11), 525-34

252. Kafka, A. P.; Kleffmann, T.; Rades, T.; McDowell, A. Molecular Pharmaceutics 2009, $6,(5), 1483-1491$

253. Kafka, A. P.; McLeod, B. J.; Rades, T.; McDowell, A. Journal of Controlled Release 2011, 149, (3), 307-313

254. Yúfera, M.; Pascual, E.; Fernández-Díaz, C. Aquaculture 1999, 177, (1-4), 249-256

255. Nordgreen, A.; Yúfera, M.; Hamre, K. Aquaculture 2008, 285, (1-4), 159-166

256. Zhang, Q.; Shi, Y.; Zhan, X.; Chen, F. Colloids and Surfaces A: Physicochemical and Engineering Aspects 2012, 393, 17-26

257. Su, J. F.; Wang, L. X.; Ren, L.; Huang, Z.; Meng, X. W. J Appl Polym Sci 2006, 102, (5), 4996-5006

258. Su, J.; Wang, S.; Huang, Z.; Liang, J., Polyurethane MicroPCMs containing Noctadecane applied in building materials synthesized by interfacial polycondensation: Thermal stability and heat absorption simulation. In Advanced Materials Research, 2010; Vol. 96, pp 121-127.

259. Su, J. F.; Wang, L. X.; Ren, L. Colloids and Surfaces A: Physicochemical and Engineering Aspects 2007, 299, (1-3), 268-275

260. Siddhan, F.; Jassal, M.; Agrawal, A. K. J Appl Polym Sci 2007, 106, (2), 786-792

261. Lu, S.; Xing, J.; Zhang, Z.; Jia, G. J Appl Polym Sci 2011, 121, (6), 3377-3383

262. Liang, C.; Lingling, X.; Hongbo, S.; Zhibin, Z. Energy Conversion and Management 2009, 50, (3), 723-729

263. Ley, S. V.; Ramarao, C.; Lee, A. L.; Østergaard, N.; Smith, S. C.; Shirley, I. M. Organic Letters 2003, 5, (2), 185-187

264. Crespy, D.; Stark, M.; Hoffmann-Richter, C.; Ziener, U.; Landfester, K. Macromolecules 2007, 40, (9), 3122-3135

265. Poe, S. L.; Kobašlija, M.; McQuade, D. T. Journal of the American Chemical Society 2007, 129, (29), 9216-9221

266. Ramarao, C.; Ley, S. V.; Smith, S. C.; Shirley, I. M.; DeAlmeida, N. Chemical Communications 2002, (10), 1132-1133 
267. Saihi, D.; Vroman, I.; Giraud, S.; Bourbigot, S. Reactive and Functional Polymers 2006, 66, (10), 1118-1125

268. Tatiya, P. D.; Hedaoo, R. K.; Mahulikar, P. P.; Gite, V. V. Industrial and Engineering Chemistry Research 2013, 52, (4), 1562-1570

269. Tsuda, N.; Ohtsubo, T.; Fuji, M. Advanced Powder Technology 2012, 23, (6), 724730

270. Takahashi, T.; Taguchi, Y.; Tanaka, M. Journal of Chemical Engineering of Japan 2005, 38, (11), 929-936

271. Hirech, K.; Payan, S.; Carnelle, G.; Brujes, L.; Legrand, J. Powder Technology 2003, 130, (1-3), 324-330

272. Gaudin, F.; Sintes-Zydowicz, N. Colloids and Surfaces A: Physicochemical and Engineering Aspects 2008, 331, (1-2), 133-142

273. Morral-Ruíz, G.; Melgar-Lesmes, P.; García, M. L.; Solans, C.; García-Celma, M. J. Polymer (United Kingdom) 2012, 53, (26), 6072-6080

274. Jinglei, Y.; Keller, M. W.; Moore, J. S.; White, S. R.; Sottos, N. R. Macromolecules 2008, 41, (24), 9650-9655

275. Yadav, S. K.; Khilar, K. C.; Suresh, A. K. J. Membr. Sci. 1997, 125, (2), 213-218

276. Baier, G.; Friedemann, K.; Leuschner, E. M.; Musyanovych, A.; Landfester, K. Macromolecular Symposia 2013, 331-332, (1), 71-80

277. Brochu, A. B. W.; Chyan, W. J.; Reichert, W. M. Journal of Biomedical Materials Research - Part B Applied Biomaterials 2012, 100 B, (7), 1764-1772

278. Bouchemal, K.; Briançon, S.; Perrier, E.; Fessi, H.; Bonnet, I.; Zydowicz, N. International Journal of Pharmaceutics 2004, 269, (1), 89-100

279. Chang, C. P.; Chang, J. C.; Ichikawa, K.; Dobashi, T. Colloids and Surfaces B: Biointerfaces 2005, 44, (4), 187-190

280. Dobashi, T.; Furukawa, T.; Ichikawa, K.; Narita, T. Langmuir 2002, 18, (16), 60316033

281. Dobashi, T.; Furukawa, T.; Narita, T.; Shimofure, S.; Ichikawa, K.; Chu, B. Langmuir 2001, 17, (15), 4525-4528

282. Patchan, M. W.; Fuller, B. W.; Baird, L. M.; Gong, P. K.; Walter, E. C.; Vidmar, B. J.; Kyei, I.; Xia, Z.; Benkoski, J. J. ACS Applied Materials and Interfaces 2015, 7, (13), 7315-7323

283. Fielding, L. A.; Armes, S. P. Journal of Materials Chemistry 2012, 22, (22), 1123511244

284. Wu, G.; An, J.; Sun, D.; Tang, X.; Xiang, Y.; Yang, J. Journal of Materials Chemistry A 2014, 2, (30), 11614-11620

285. Yang, Y.; Ning, Y.; Wang, C.; Tong, Z. Polymer Chemistry 2013, 4, (21), 5407-5415

286. Zhang, Q.; Yang, Y.; Wang, C. Y. Acta Polymerica Sinica 2014, (7), 997-1001

287. Li, J.; Hughes, A. D.; Kalantar, T. H.; Drake, I. J.; Tucker, C. J.; Moore, J. S. ACS Macro Letters 2014, 3, (10), 976-980

288. Yang, Y.; Wei, Z.; Wang, C.; Tong, Z. ACS Applied Materials \& Interfaces 2013, 5, (7), 2495-2502

289. Mookhoek, S. D.; Blaiszik, B. J.; Fischer, H. R.; Sottos, N. R.; White, S. R.; Van Der Zwaag, S. Journal of Materials Chemistry 2008, 18, (44), 5390-5394

290. Wolińska-Grabczyk, A.; Jankowski, A. Separation and Purification Technology 2007, 57, (3), 413-417 
291. Khosravi, A.; Sadeghi, M. Journal of Membrane Science 2013, 434, 171-183

292. Chattopadhyay, D. K.; Raju, K. V. S. N. Progress in Polymer Science (Oxford) 2007, $32,(3), 352-418$

293. Neumann, D.; Fisher, M.; Tran, L.; Matisons, J. G. Journal of the American Chemical Society 2002, 124, (47), 13998-13999

294. Raaijmakers, M. J. T.; Hempenius, M. A.; Schön, P. M.; Vancso, G. J.; Nijmeijer, A.; Wessling, M.; Benes, N. E. Journal of the American Chemical Society 2014, 136, (1), 330-335

295. Fu, B. X.; Zhang, W.; Hsiao, B. S.; Rafailovich, M.; Sokolov, J.; Johansson, G.; Sauer, B. B.; Phillips, S.; Balnski, R. High Performance Polymers 2000, 12, (4), 565571

296. Wahab, M. A.; Mya, K. Y.; He, C. Journal of Polymer Science, Part A: Polymer Chemistry 2008, 46, (17), 5887-5896

297. Wei, X.; Kong, X.; Yang, J.; Zhang, G.; Chen, J.; Wang, J. J. Membr. Sci. 2013, 440, $67-76$

298. Seman, M. N. A.; Khayet, M.; Hilal, N. J. Membr. Sci. 2010, 348, (1-2), 109-116

299. Wei, X. Z.; Zhu, L. P.; Deng, H. Y.; Xu, Y. Y.; Zhu, B. K.; Huang, Z. M. J. Membr. Sci. 2008, 323, (2), 278-287

300. Kwak, S. Y.; Yeom, M. O.; Roh, I. J.; Kim, D. Y.; Kim, J. J. J. Membr. Sci. 1997, $132,(2), 183-191$

301. Loría-Bastarrachea, M. I.; Aguilar-Vega, M. Industrial and Engineering Chemistry Research 2010, 49, (23), 12060-12066

302. Pascu, O.; Garcia-Valls, R.; Giamberini, M. Polymer International 2008, 57, (8), 995 1006

303. Arribas, P.; Khayet, M.; García-Payo, M. C.; Gil, L. Separation and Purification Technology 2014, 138, 118-129

304. Abu Seman, M. N.; Khayet, M.; Hilal, N. Desalination 2011, 273, (1), 36-47

305. Tang, B.; Huo, Z.; Wu, P. J. Membr. Sci. 2008, 320, (1-2), 198-205

306. Wu, H.; Tang, B.; Wu, P. J. Membr. Sci. 2013, 428, 425-433

307. Wu, H.; Tang, B.; Wu, P. J. Membr. Sci. 2013, 428, 301-308

308. Tang, B.; Zou, C.; Wu, P. J. Membr. Sci. 2010, 365, (1-2), 276-285

309. Wei, X. Z.; Yang, J.; Zhang, G. L. Polymers and Polymer Composites 2012, 20, (3), 261-270

310. Zhang, P.; Wu, L.; Bu, Z.; Li, B. G. J Appl Polym Sci 2008, 108, (6), 3586-3592

311. Zhang, Y.; Su, Y.; Peng, J.; Zhao, X.; Liu, J.; Zhao, J.; Jiang, Z. J. Membr. Sci. 2013, 429, 235-242

312. Wu, H.; Tang, B.; Wu, P. Journal of Physical Chemistry C 2010, 114, (39), 1639516400

313. Lee, K. P.; Zheng, J.; Bargeman, G.; Kemperman, A. J. B.; Benes, N. E. J. Membr. Sci. 2015, 478, (0), 75-84

314. Thurston, J. T.; Dudley, J. R.; Kaiser, D. W.; Hechenbleikner, I.; Schaefer, F. C.; Holm-Hansen, D. Journal of the American Chemical Society 1951, 73, (7), 2981-2983

315. Tsai, C. W.; Tsai, C.; Ruaan, R. C.; Hu, C. C.; Lee, K. R. ACS Applied Materials and Interfaces 2013, 5, (12), 5563-5568

316. Mikroyannidis, J. A. Journal of Polymer Science, Part A: Polymer Chemistry 1988, $26,(2), 583-593$ 
317. Rice, W. C.; Puglia, J. P. High performance composite membrane. 2001.

318. Perry, M.; Ginzburg, V.; Ginzburg, B.; Lapido, P. 2010,

319. Anon. Journal of Polymer Science, Part A: Polymer Chemistry 1990, 28, (13), 37873793

320. Kim, J. H.; Lee, K. H.; Kim, S. Y. Journal of Membrane Science 2000, 169, (1), 81-93

321. Chern, Y.-T.; Chen, L.-W. J Appl Polym Sci 1991, 42, (9), 2535-2541

322. Chern, Y.-T.; Chen, L.-W. J Appl Polym Sci 1992, 44, (6), 1087-1093

323. Yang, Z.; Zhang, L.; Zhang, G.; Li, C. Huagong Xuebao 2012, 63, (8), 2635-2641

324. Martin, C. R.; Liang, W.; Menon, V.; Parthasarathy, R.; Parthasarathy, A. Synthetic Metals 1993, 57, (1), 3766-3773

325. Michaelson, J. C.; McEvoy, A. J. Journal of the Chemical Society, Chemical Communications 1994, (1), 79-80

326. Parthasarathy, A.; Brumlik, C. J.; Martin, C. R.; Collins, G. E. Journal of Membrane Science 1994, 94, 249-254

327. Huang, J.; Virji, S.; Weiller, B. H.; Kaner, R. B. Journal of the American Chemical Society 2003, 125, (2), 314-315

328. Sawall, D. D.; Villahermosa, R. M.; Lipeles, R. A.; Hopkins, A. R. Chemistry of Materials 2004, 16, (9), 1606-1608

329. He, Y. Materials Science and Engineering B: Solid-State Materials for Advanced Technology 2005, 122, (1), 76-79

330. Wang, Y.; Jing, X. Journal of Physical Chemistry B 2008, 112, (4), 1157-1162

331. Li, R.; Chen, Z.; Li, J.; Zhang, C.; Guo, Q. Synthetic Metals 2013, 171, 39-44

332. Nuraje, N.; Su, K.; Yang, N. I.; Matsui, H. ACS Nano 2008, 2, (3), 502-506

333. Jia, Q. M.; Li, J. B.; Wang, L. F.; Zhu, J. W.; Zheng, M. Materials Science and Engineering A 2007, 448, (1-2), 356-360

334. Kuo, C. W.; Wen, T. C. European Polymer Journal 2008, 44, (11), 3393-3401

335. Virji, S.; Huang, J.; Kaner, R. B.; Weiller, B. H. Nano Letters 2004, 4, (3), 491-496

336. Zhao, M.; Wu, X.; Cai, C. Journal of Physical Chemistry C 2009, 113, (12), 49874996

337. Su, B.; Tong, Y.; Bai, J.; Lei, Z.; Wang, K.; Mu, H.; Dong, N. Indian Journal of Chemistry - Section A Inorganic, Physical, Theoretical and Analytical Chemistry 2007, 46, (4), 595-599

338. Huang, J.; Virji, S.; Weiller, B. H.; Kaner, R. B. Chemistry - A European Journal 2004, 10, (6), 1314-1319

339. Son, W. I.; Hong, J. M.; Kim, B. S. Korean Journal of Chemical Engineering 2005, 22, (2), 285-290

340. Yang, Q.; Hou, Z.; Huang, T. J Appl Polym Sci 2015, 132, (11),

341. Zhang, L.; Liu, P.; Ju, L.; Wang, L.; Zhao, S. Macromolecular Research 2010, 18, (7), 648-652

342. Wen, L.; Li, M.; Schlenoff, J. B. Journal of the American Chemical Society 1997, 119, (33), 7726-7733

343. Gupta, B.; Prakash, R. Synthetic Metals 2010, 160, (5-6), 523-528

344. Joshi, L.; Prakash, R. Materials Letters 2012, 66, (1), 250-253

345. Joshi, L.; Singh, A. K.; Prakash, R. Materials Chemistry and Physics 2012, 135, (1), $80-87$ 
346. Wang, Y. G.; Wu, W.; Cheng, L.; He, P.; Wang, C. X.; Xia, Y. Y. Advanced Materials 2008, 20, (11), 2166-2170

347. Li, X. G.; Li, J.; Meng, Q. K.; Huang, M. R. Journal of Physical Chemistry B 2009, 113, (29), 9718-9727

348. Liu, P.; Wang, X.; Li, H. Synthetic Metals 2013, 181, 72-78

349. Shen, J.; Yang, C.; Li, X.; Wang, G. ACS Applied Materials and Interfaces 2013, 5, (17), 8467-8476

350. Salvatierra, R. V.; Oliveira, M. M.; Zarbin, A. J. G. Chemistry of Materials 2010, 22, (18), 5222-5234

351. Wang, Q.; Wang, S.; Li, J.; Moriyama, H., Synthesis of C60-doped polyaniline nanoshuttles. In Advanced Materials Research, 2011; Vol. 284-286, pp 1010-1013.

352. Wang, Q.; Wang, S.; Li, J.; Moriyama, H. Journal of Polymer Science, Part B: Polymer Physics 2012, 50, (20), 1426-1432

353. He, J.; Perez, M. T.; Zhang, P.; Liu, Y.; Babu, T.; Gong, J.; Nie, Z. Journal of the American Chemical Society 2012, 134, (8), 3639-3642

354. Bora, C.; Dolui, S. K. Polymer International 2014, 63, (8), 1439-1446

355. Domingues, S. H.; Salvatierra, R. V.; Oliveira, M. M.; Zarbin, A. J. G. Chemical Communications 2011, 47, (9), 2592-2594

356. Ho, C.-H.; Liu, C.-D.; Hsieh, C.-H.; Hsieh, K.-H.; Lee, S.-N. Synthetic Metals 2008, $158,(15), 630-637$

357. Mafé, S.; Manzanares, J. A.; Reiss, H. The Journal of Chemical Physics 1993, 98, (3), 2408-2410

358. Kuo, C.-W.; Wen, T.-C. European Polymer Journal 2008, 44, (11), 3393-3401

359. Li, Y. S.; Bux, H.; Feldhoff, A.; Li, G. N.; Yang, W. S.; Caro, J. Advanced Materials 2010, 22, (30), 3322-3326

360. Hedlund, J.; Noack, M.; Kölsch, P.; Creaser, D.; Caro, J.; Sterte, J. Journal of Membrane Science 1999, 159, (1-2), 263-273

361. Li, Y. S.; Liang, F. Y.; Bux, H.; Feldhoff, A.; Yang, W. S.; Caro, J. Angewandte Chemie - International Edition 2010, 49, (3), 548-551

362. Li, J. R.; Sculley, J.; Zhou, H. C. Chemical Reviews 2012, 112, (2), 869-932

363. Peng, Y.; Li, Y.; Ban, Y.; Jin, H.; Jiao, W.; Liu, X.; Yang, W. Science 2014, 346, (6215), 1356-1359

364. Brown, A. J.; Brunelli, N. A.; Eum, K.; Rashidi, F.; Johnson, J. R.; Koros, W. J.; Jones, C. W.; Nair, S. Science 2014, 345, (6192), 72-75

365. Lu, H.; Zhu, S. European Journal of Inorganic Chemistry 2013, (8), 1294-1300

366. Li, Y.; Wee, L. H.; Volodin, A.; Martens, J. A.; Vankelecom, I. F. J. Chemical Communications 2015, 51, (5), 918-920

367. Rodenas, T.; Luz, I.; Prieto, G.; Seoane, B.; Miro, H.; Corma, A.; Kapteijn, F.; Llabrés i Xamena, F. X.; Gascon, J. Nat Mater 2015, 14, (1), 48-55

368. Brinker, C. J.; Scherer, G. W., Sol-gel science: the physics and chemistry of sol-gel processing. Academic press: 2013.

369. Schulze-Bergkamen, H.; Yamane, M. Journal of Sol-gel Science and Technology 1995, 5, (3), 185-191

370. Yamane, M. Journal of Sol-gel Science and Technology 1997, 8, (1-3), 483-487

371. Li, D.; Guan, Z.; Zhang, W.; Zhou, X.; Zhang, W. Y.; Zhuang, Z.; Wang, X.; Yang, C. J. ACS Applied Materials and Interfaces 2010, 2, (10), 2711-2714 
372. Weiss, E.; Dutta, B.; Kirschning, A.; Abu-Reziq, R. Chemistry of Materials 2014, 26, (16), 4781-4787

373. Zhang, H.; Sun, S.; Wang, X.; Wu, D. Colloids and Surfaces A: Physicochemical and Engineering Aspects 2011, 389, (1-3), 104-117

374. Yamane, M.; Shibata, S.; Yasumori, A.; Yano, T.; Uchihiro, S. Journal of Sol-gel Science and Technology 1994, 2, (1-3), 457-460

375. Zoabi, A.; Omar, S.; Abu-Reziq, R. European Journal of Inorganic Chemistry 2015,

376. Hu, R.; Zhu, Q.; Chen, W.; Liu, H.; Yao, B.; Zhan, J.; Hao, J.; Han, C. C. Polymer 2012, 53, (2), 267-271 


\section{Chapter 2 Sieving of hot gases by hyper-cross- linked nanoscale-hybrid membranes}

This chapter has been adapted from: Raaijmakers, M.J.T., Hempenius, M.A., Schön, P.M., Vancso, G.J., Nijmeijer, A., Wessling, M., Benes, N.E., Sieving of hot gases by hyper-cross-linked nanoscale-hybrid membranes. J. Am. Chem. Soc., 2014, 136 (1), pp. 330-335. (DOI:10.1021/ja410047u) 


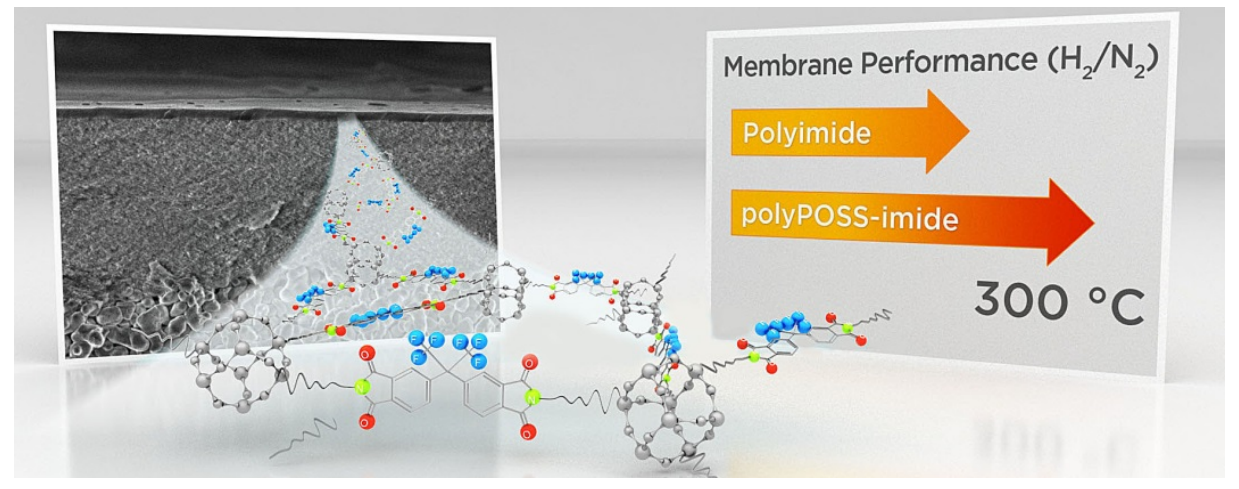

\begin{abstract}
Macromolecular networks consisting of homogeneously distributed covalently bonded inorganic and organic precursors are anticipated to show remarkable characteristics, distinct from those of the individual constituents. A novel hyper-cross-linked ultrathin membrane is presented, consisting of a giant molecular network of alternating polyhedral oligomeric silsesquioxanes and aromatic imide bridges. The hybrid characteristics of the membrane are manifested in excellent gas separation performance at elevated temperatures, providing a new and key enabling technology for many important industrial scale applications.
\end{abstract}




\subsection{Introduction}

Membrane separation of hot gases is a key enabling technique for many largescale chemical processes and advanced energy production technologies. ${ }^{1-3}$ Today, no membranes exist that allow selective separation of hot small gas molecules on a large scale. At elevated temperatures, state-of-the-art organic polymer membranes exhibit increased macromolecular dynamics, ${ }^{4,5}$ whereas a high polymer chain rigidity is a prerequisite for effective molecular sieving. ${ }^{6-9}$ The separation performance of even very rigid polymers, such as polyimides, subsides above $200{ }^{\circ} \mathrm{C} .{ }^{5,10}$ Development of novel high temperature polymers such as polybenzimidazoles, and thermally rearranged poly(benzoxazole)s and poly(benzoxazole-co-imides) have the potential to overcome the temperature limitations of polymers, but until now relatively few data is available for high temperature applications. ${ }^{11-14}$ Also, recent advances in nanoengineering of materials have resulted in radically different synthesis approaches for nanostructured membranes and thin films. ${ }^{15-19}$ These systems may well approach the ultimate gas separation performance, yet tremendous efforts are required to allow defect-free processing at the scale of industrially relevant applications. Here, we present a method for the facile production of ultrathin films of inorganic-organic hybrid materials that provide gas separation selectivity up to $300{ }^{\circ} \mathrm{C}$, in combination with chemical versatility and largescale defect-free processability. The unprecedented characteristics of these membranes originate from the hyper-cross-linked periodic network of covalently bound organic and POSS moieties.

The poly(POSS-imide) material presented consists of polyhedral oligomeric silsesquioxane (POSS) molecules, covalently linked by aromatic imide bridges. Cross-linked aromatic polyimides are considered high potential membrane materials. ${ }^{20}$ The POSS are silicon oxide cages with the basic formula $\mathrm{R}_{\mathrm{n}} \mathrm{Si}_{n} \mathrm{O}_{1.5 \mathrm{n}}(\mathrm{n}=6,8,12)$ and are decorated with various organofunctional groups. Their cubic symmetry and the availability of a large variety of functional groups allows for nanoscale assembly in three dimensions. ${ }^{21-25}$ The rigidness and bulky character of POSS cages is manifested by the free volume increase observed in systems where POSS is dispersed in the polymer matrix or covalently attached to the polymer main chain. ${ }^{26,27}$ However, such systems are still governed by the macromolecular dynamics of the polymer main chain. Instead, we propose to use the POSS cage as a main building block for the polymer network. We suggest the synthesis of hybrid poly(POSS-imide)s films using a two-step procedure: the interfacial 
polycondensation of an ammonium chloride salt-functionalized POSS and hexafluoroisopropylidene diphthalic anhydride (6FDA) based on a concept proposed by Dalwani et al., ${ }^{28}$ followed by thermal imidization. In the first step, a thin-film poly[POSS-(amic acid)] network is formed via a polycondensation reaction at the interface between two immiscible solvents, as shown in Scheme 1-1 (left panel). A water-soluble octa-ammonium POSS in alkaline solution and 6FDA in toluene were used as the amine and anhydride sources, respectively. In the second step, the amic acid groups are converted into cyclic imide groups via thermal imidization at temperatures up to $300^{\circ} \mathrm{C}$ in either air or an inert atmosphere, as shown in Scheme 1-1 (right panel).

a

b

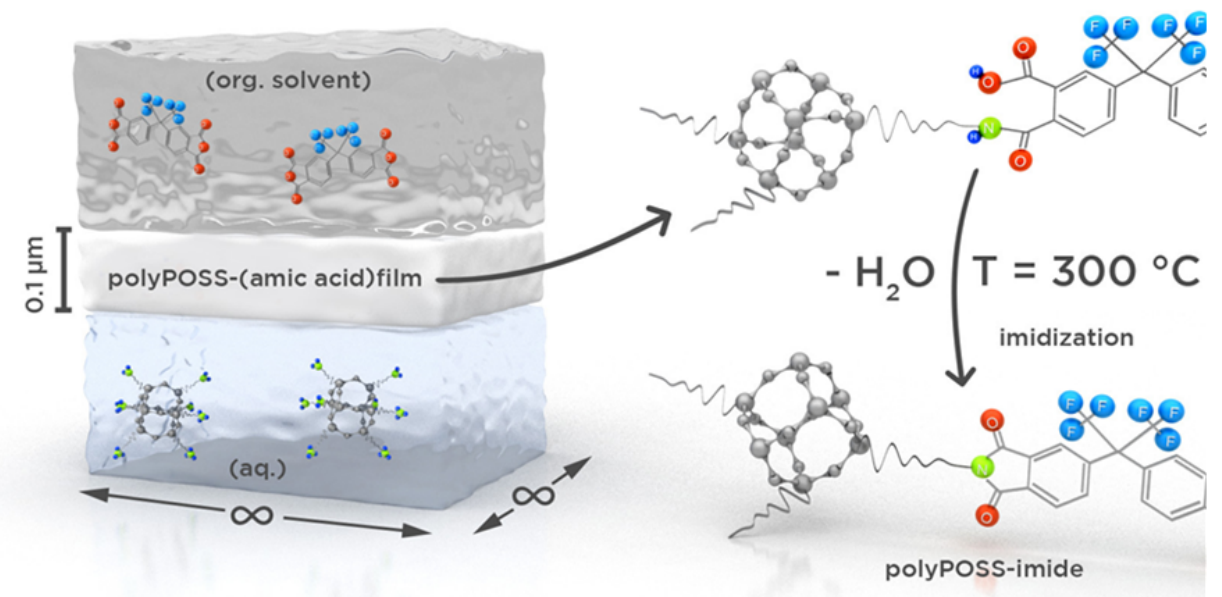

Scheme 1-1. The membrane synthesis process. (a) Interfacial polymerization reaction of octa-ammonium POSS in water and 6FDA in toluene. The ammonium groups are partially deprotonated to primary amines by sodium hydroxide $(\mathrm{NaOH}, \mathrm{pH}=9.9 \pm 0.3)$. The reaction occurs at the water-toluene interface, with final layer poly[POSS-(amic acid)] thicknesses of $\sim 0.1 \mu \mathrm{m}$ after $5 \mathrm{~min}$. (b) The subsequent conversion of the amic acid to cyclic imide (imidization) is performed via heat treatment at temperatures up to $300{ }^{\circ} \mathrm{C}$. 


\subsection{Experimental}

\subsubsection{Synthesis of poly(POSS-imide)s via interfacial polymerization}

Toluene (anhydrous 99.8 wt.\%, Sigma-Aldrich), 4,4-(hexafluoroisopropylidene) diphthalic anhydride (6FDA, Sigma-Aldrich), ammonium chloride salt functionalized POSS (OctaAmmonium POSS ${ }^{\circledR}$, Hybrid Plastics (USA)) and sodium hydroxide $\left(1.0 \mathrm{~mol} \mathrm{~L}^{-1}\right)$ were used as received. Freestanding hybrid films were prepared by adjusting the $\mathrm{pH}$ of an aqueous solution of 0.9 wt.\% octa-ammonium POSS, by adjusting the $\mathrm{pH}$ to 9.9 using sodium hydroxide $\left(0.1 \mathrm{~mol} \mathrm{~L}^{-1}\right)$, and subsequently contacting the aqueous solution with a 6FDA solution in toluene $(0.075 \mathrm{wt} . \%)$. The reaction at the interface between the aqueous POSS solution and 6FDA in toluene was confirmed by observing the thin-film formation. The mechanical integrity of the films was sufficient for their removal from the interface. The rapid kinetics of the polycondensation reaction allow for the production of a sufficient amount of freestanding film for bulk material characterization, such as infrared spectroscopy. Detailed thin-film characterization was performed on the supported thin films, that were produced directly on ceramic membranes $(\alpha-$ alumina discs with a $3-\mu \mathrm{m}$-thick $\gamma$-alumina layer). Film formation atop porous alumina supports was achieved by soaking the porous ceramic material in the aqueous POSS solution, followed by contacting with the 6FDA solution in toluene. The membrane was thermally imidized at $300{ }^{\circ} \mathrm{C}$ at a heating rate of $5{ }^{\circ} \mathrm{C} \mathrm{min}^{-1}$ under an air atmosphere.

\subsubsection{Material characterization.}

Static liquid/air contact angles were measured with a goniometer (OCA 15, Data Physics). Drops of $1 \mu \mathrm{L}$ milli-Q water were formed at the needle tip and contact angles were measured $5 \mathrm{~s}$ after placing the drop on the substrate.

Density measurements were performed using an AccuPyc II 1340 gas displacement density analyzer (Micromeritics, USA), with helium as gas source. The poly[POSS-(amic acid)] and poly(POSS-imide) samples were placed in a vacuum chamber, at $30{ }^{\circ} \mathrm{C}$, prior to the measurement to remove any water from the sample. The standard deviation was determined from 30 individual density measurements.

Scanning electron microscopy (SEM) images were obtained using a LEO-1550 Schottky field emission scanning electron microscope (Carl-Zeiss, Germany), with an accelerating voltage of $2.00 \mathrm{kV}$. Atomic Force Microscopy (AFM) 
measurements were performed using a Multimode 8 AFM instrument equipped with a NanoScope $\mathrm{V}$ controller, and a vertical engage J-scanner (Bruker AXS, Santa Barbara, CA). Membrane samples were glued to a metal support using a two component epoxy and dried overnight. Image processing and data analysis were performed with NanoScope software version 8.14 and NanoScope Analysis software version 1.40. Peak force tapping was done in air with Si tips on SiN cantilevers (SCANASYST-AIR, Bruker AXS, Camarillo, $\mathrm{CA}$, nominal spring constant $0.4 \mathrm{~N} \mathrm{~m}^{-1}$ ). Cantilever spring constants were determined with the thermal noise method. Imaging was done with a peak force tapping amplitude of $150 \mathrm{~nm}$ and at a scan rate of $0.97 \mathrm{~Hz}$.

Membrane single gas permeation experiments were performed in a dead-end mode at a trans-membrane pressure of $2 \mathrm{bar}$, and atmospheric pressure at the permeate side. Once the helium permeance remained constant, the other gases $\left(\mathrm{N}_{2}, \mathrm{CH}_{4}, \mathrm{H}_{2}\right.$, and $\mathrm{CO}_{2}$, consecutively) were measured at temperatures between 50-300 ${ }^{\circ} \mathrm{C}$.

\subsection{Results and discussion}

Film formation was confirmed using scanning electron microscopy (SEM) cross section images, and top-view atomic force microscopy (AFM) as depicted in Figure 2-2. The SEM micrograph reveals a distinct continuous film of approximately $0.1 \mu \mathrm{m}$ atop the ceramic support. The AFM top-view topography image of the poly[POSS-(amic acid)] reveals a smooth top layer with height differences $(0.1 \mu \mathrm{m})$ and a morphology less coarse compared to that of typical layers obtained via interfacial polymerization. ${ }^{29}$ Figure 2-2 (b) and 2-2 (d) correspond to the poly(POSS-imide) layer obtained after thermal imidization at $300{ }^{\circ} \mathrm{C}$. The SEM micrograph demonstrates that a distinct and continuous film remains on the support. The AFM images do exhibit a change in morphology resulting from stresses in the thin film confined on the porous support. Density measurements via helium pycnometry on the freestanding film material reveal that these stresses originate from densification, with the bulk density increasing from $1.5 \mathrm{~g} \mathrm{~cm}^{-3}$ to $1.67 \mathrm{~g} \mathrm{~cm}^{-3}$, induced by the chemical conversion of the amic acid groups to cyclic imides. However, no cracks appear to form in the ultrathin films. The high degree of crosslinking and the limited thickness of this layer prevent any pinhole or crack formation that could degrade the membrane's gas separation performance. 
a

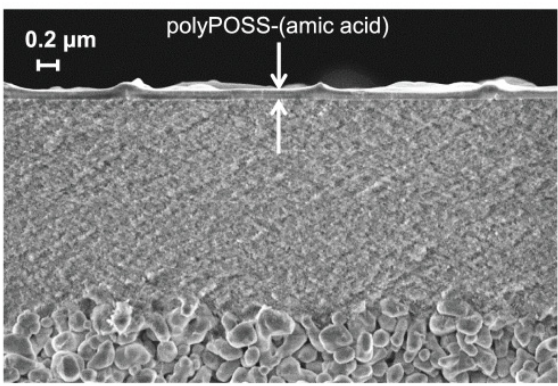

b

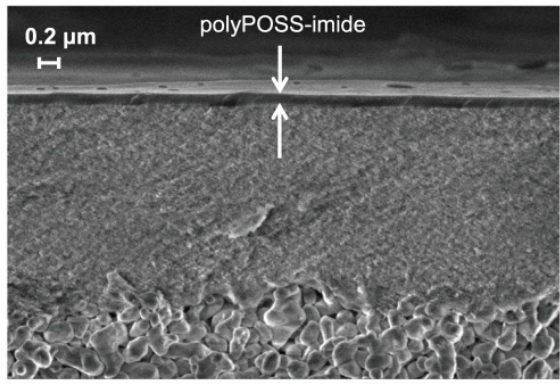

C

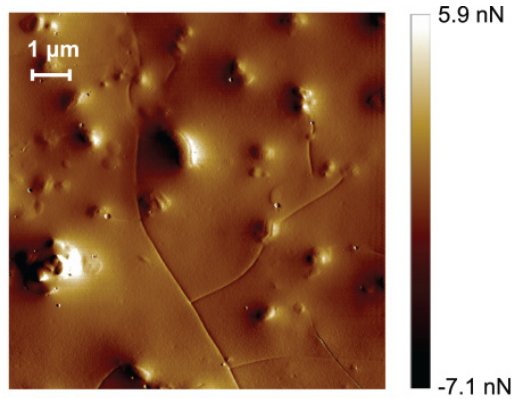

d

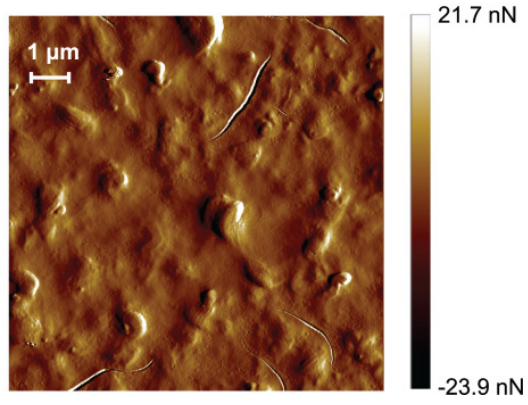

Figure 2-2: Heat treatment induced evolution of membrane layer morphology. (a-b) SEM micrograph of 0.1- $\mu \mathrm{m}$ poly[POSS-(amic acid)] and poly(POSS-imide) layers, on $\alpha$-alumina discs with a 3 - $\mu$ m-thick $\gamma$-alumina layer. The homogeneous supported films exhibit no apparent crack formation due to drying stresses or heat treatment. (c-d) The AFM peak force error images of the supported poly[POSS-(amic acid)] demonstrate that the film formation results in a smooth layer with hills and valleys of lateral dimensions up to $0.2 \mu \mathrm{m}$. The poly(POSS-imide) (d) layer exhibits a similar hill-valley structure. The heat-treatment step increases the intrinsic and thermal stress-induced surface roughness.

The formation of the poly[POSS-(amic acid)] and its subsequent conversion to poly(POSS-imide) via thermal treatment are confirmed using Fourier transform infrared spectroscopy with attenuated total reflectance (FTIR-ATR). Figure 2-3 (a) presents the spectra of the samples before and after thermal imidization at $300{ }^{\circ} \mathrm{C}$. The untreated sample exhibits two typical polyamide bands at 1620 and $1570 \mathrm{~cm}^{-1}$ that correspond to $\mathrm{C}=\mathrm{O}$ stretching and $\mathrm{N}-\mathrm{H}$ bending, respectively. After thermal treatment, these two bands vanish, and two distinct bands emerge at 1720 and $1780 \mathrm{~cm}^{-1}$ that can be attributed to polyimide $\mathrm{C}=\mathrm{O}$ symmetric and asymmetric stretching, respectively. The thermal conversion to polyimide is not inhibited by the presence of water, whereas trace water removal is a main challenge in the synthesis of polyimides via polymerization in aprotic polar solvents. ${ }^{30}$ Figure 2-3 (b) displays the 


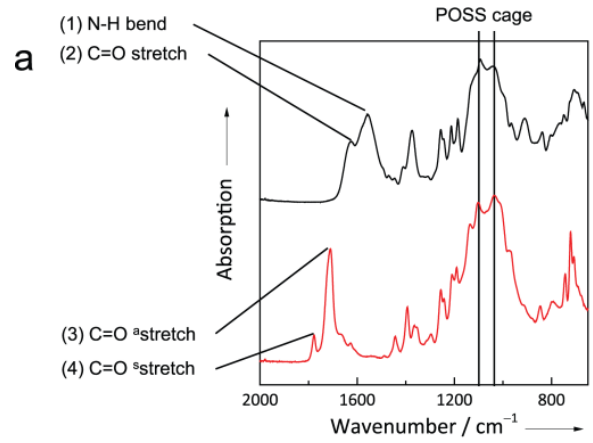

b

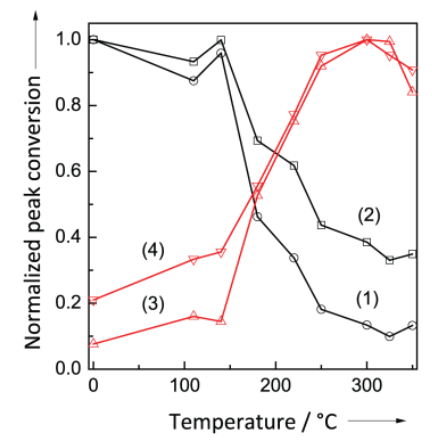

C
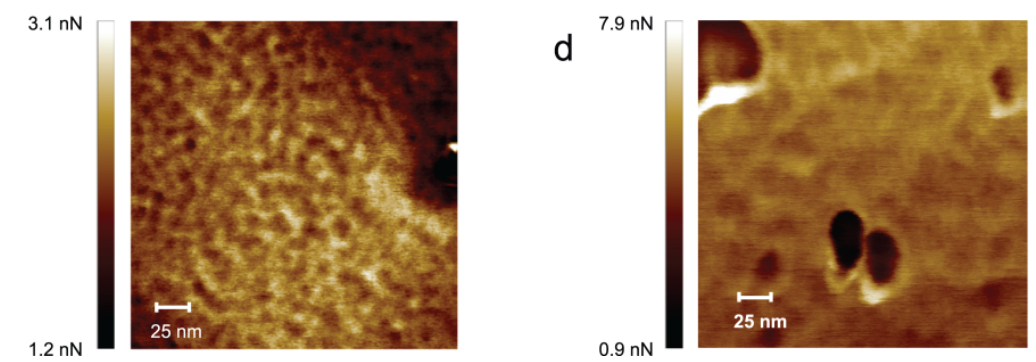

Figure 2-3: Heat treatment induced imidization. a, ATR-FTIR spectra of free-standing poly[POSS-(amic acid)] layers prior to (top line) and after heat treatment for $2 \mathrm{~h}$ in air at $300{ }^{\circ} \mathrm{C}$ (bottom line), normalized for the $\mathrm{CF}_{3}$ band at $1254 \mathrm{~cm}^{-1}$. The bands at 1620 and $1570 \mathrm{~cm}^{-1}$ are assigned to $\mathrm{N}-\mathrm{H}$ bending (1) and $\mathrm{C}=\mathrm{O}$ stretching (2) of the amic acid group. After heat treatment, the bands at 1620 and $1570 \mathrm{~cm}^{-1}$ are replaced by bands at 1720 and $1780 \mathrm{~cm}^{-1}$ that are assigned to $C=O$ asymmetric (3) and symmetric (4) stretching of the imide group, respectively. The sharp bands at 1125 and $1040 \mathrm{~cm}^{-1}$ can be attributed to the Si-O-Si asymmetric stretching vibrations of the polyhedral and ladder silsesquioxane structures, respectively. The results indicate complete conversion of the amic acid groups to cyclic imide groups, and suggest a concurrent partial cleavage of the POSS cage induced by the high $\mathrm{pH}$ during synthesis. ${ }^{31} \mathrm{~b}$, ATR-FTIR band intensities of (1) and (2) normalized with respect to their initial intensities and the band intensities of (3) and (4) normalized with respect to the imide band intensity of the $300{ }^{\circ} \mathrm{C}$-treated sample as a function of temperature. The results indicate that imidization is initiated at 140 $160{ }^{\circ} \mathrm{C}$, reaching a maximum conversion at $300^{\circ} \mathrm{C}$. c-d, AFM adhesion images of poly[POSS-(amic acid)] and poly(POSS-imide) layers. The images reveal homogeneously distributed areas of several nanometers in size with varying adhesion strength that correspond to regions with different chemical compositions. 
intensities of the two amic acid bands at 1570 (1) and $1620 \mathrm{~cm}^{-1}$ (2) and of the imide bands at 1720 (3) and $1780 \mathrm{~cm}^{-1}$ (4). The spectra are normalized with respect to the $\mathrm{C}-\mathrm{F}$ band intensity at $1254 \mathrm{~cm}^{-1}$. At temperatures below $140{ }^{\circ} \mathrm{C}$, no imidization occurs. The onset of imidization is observed between 140 and $160{ }^{\circ} \mathrm{C}$, and increases up to $300{ }^{\circ} \mathrm{C}$, above which a decrease in band intensity is observed that can be explained by de-imidization and polymer-bond degradation. This result is confirmed via thermogravimetric analysis (TGA) that indicates that there is no weight loss at temperatures up to $300{ }^{\circ} \mathrm{C}$ in either air or nitrogen atmospheres (Appendix, Figure A2-3). Figure 2-3 (c and d) present the adhesion-force images of poly[POSS-(amic acid)] and poly(POSS-imide). Peak force tapping AFM was used to map the adhesion forces of the poly[POSS-(amic acid)] and poly(POSS-imide) surfaces. The adhesion force was determined from the force-distance curves corresponding to an oscillating AFM tip that contacts the sample upon each oscillation at a rate well below the resonance frequency of the AFM cantilever. ${ }^{32}$ The images reveal 1-5-nm sized heterogeneities, bearing resemblance to two-dimensional periodic covalent organic frameworks, ${ }^{33}$ that can be attributed to the intrinsic molecular local ordering of inorganic and organic moieties. This local intrinsic ordering remains after the amic acid is converted into the imide; however, the force contrast diminishes. This result can be rationalized through the replacement of the strong polar amic acid with a weakly interacting imide. A comparison of the water contact angle measurements of the poly[POSS-(amic acid)] $\left(53^{\circ}\right)$ with those of the poly(POSS-imide) $\left(72^{\circ}\right)$ suggest a similar effect, supporting a nanoscale evolution in the adhesion force.

The hybrid characteristics of the material are manifested in the exceptional gas separation performance at elevated temperatures. Unprecedented performance at temperatures up to $300{ }^{\circ} \mathrm{C}$ (the practical limit of the measurement apparatus) is observed from individual gas permeation experiments. Figure 2-4 illustrates the gas permeation behavior of poly(POSS-imide) on $\alpha$-alumina discs with a 3- $\mu \mathrm{m}$-thick $\gamma$-alumina layer. Figure 2-4 (left panel) depicts a plot of the single gas permeance as a function of the gas molecule kinetic diameter (for $\mathrm{He}, \mathrm{H}_{2}$, $\mathrm{CO}_{2}, \mathrm{~N}_{2}$ and $\mathrm{CH}_{4}$ ) at 100,200 and $300{ }^{\circ} \mathrm{C}$. The permeance decreases with increasing gas molecule kinetic diameter, a trend typical of glassy polymers. Figure 2-4 (middle panel) depicts the Arrhenius plot of the permeance on a logarithmic scale as a function of $\mathrm{R}^{-1} \mathrm{~T}^{-1}$ reveals that the gas permeance is thermally activated. The activation energies for the measured gases are in the order $\mathrm{CH}_{4}>\mathrm{N}_{2}>\mathrm{H}_{2}>\mathrm{He}>\mathrm{CO}_{2}$. The poly(POSS-imide) activation energies 
for gas permeation are a factor 5-7 higher as compared to conventional polyimides. ${ }^{34}$ The relatively high activation energies for permeation underline the high energy barriers for gas diffusion in the rigid poly(POSS-imide) network.
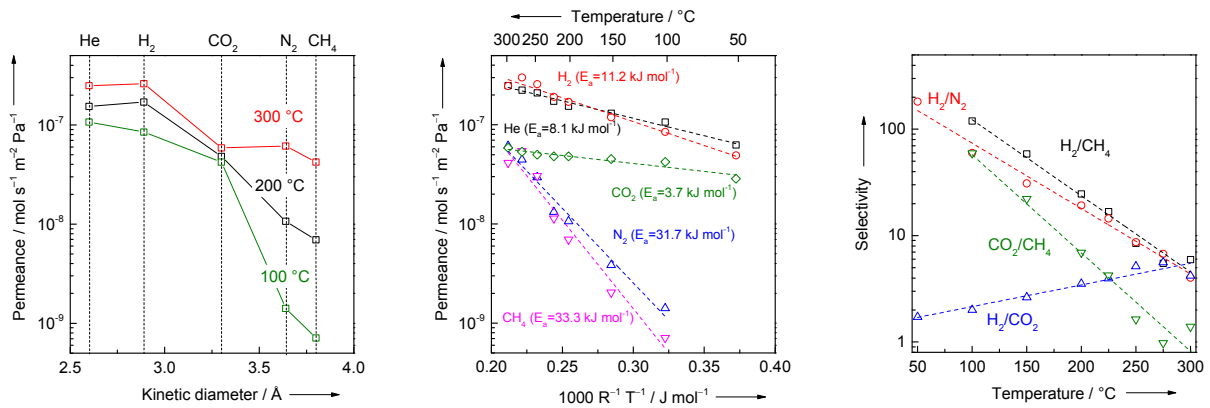

Figure 2-4: Gas permeation characteristics of poly(POSS-imide) membranes. (left panel) Permeance as a function of gas kinetic diameter. The decrease in permeance with increasing kinetic diameter is consistent with the glassy character of the poly(POSS-imide). (middle panel) Arrhenius plot of single gas permeances for $\mathrm{He}, \mathrm{H}_{2}, \mathrm{CO}_{2}, \mathrm{~N}_{2}$ and $\mathrm{CH}_{4}$. For all gases, activated transport is the dominant transport mechanism. The apparent activation energies for transport remain constant over temperatures ranging from $50-300{ }^{\circ} \mathrm{C}$, demonstrating that the membrane does not suffer from temperature-induced chain mobility. (right panel) Ideal selectivity of $\mathrm{H}_{2} / \mathrm{CH}_{4}, \mathrm{H}_{2} / \mathrm{N}_{2}, \mathrm{CO}_{2} / \mathrm{CH}_{4}$ and $\mathrm{H}_{2} / \mathrm{CO}_{2}$ as a function of temperature.

The low activation energy for the $\mathrm{CO}_{2}$ transport results from the high solubility of $\mathrm{CO}_{2}$ at low temperatures due to the presence of trifluoromethyl $\left(\mathrm{CF}_{3}\right)$ groups. At elevated temperatures, this solubility decreases, while the diffusivity increases, cancelling out the effect of temperature on the product of these processes. This is in agreement with gas sorption and diffusion data measured for other 6FDA based polyimide membranes. ${ }^{34-36}$ These studies show that, for increasing temperature, the $\mathrm{CO}_{2}$ permeation remains constant or even decreases. The correspondingly low activation energy is related to the simultaneous increase in gas diffusivity and decrease in gas sorption, at increasing temperatures. For the other gases, $\mathrm{He}, \mathrm{N}_{2}$ and $\mathrm{CH}_{4}$, the permeation does increase with temperature. The result is a decrease in selectivity of $\mathrm{CO}_{2}$ over these other gases. Conventional polyimides without $\mathrm{CF}_{3}$ groups do not display such behavior. ${ }^{37}$ The affinity towards $\mathrm{CO}_{2}$ implies that gas molecules 
diffuse in the organic part of the network, which is in agreement with the findings of molecular dynamics simulations. ${ }^{38}$

Unlike polymer membranes that suffer from chain-rearrangement-induced permeability loss at the elevated temperatures used in this study, this linear trend in the Arrhenius plot suggests that the activation energies of diffusion and sorption do not significantly depend on the temperature. The high thermal stability of the membrane can be rationalized by the large number of covalent bonds between the individual POSS cages. An average POSS/imide ratio of 3.8 was observed using X-ray photoelectron spectroscopy (XPS) of a poly(POSS-imide) membrane on an alumina support (Appendix).

Figure 2-4 (right panel) presents the ideal selectivities of the $\mathrm{H}_{2} / \mathrm{CH}_{4}, \mathrm{H}_{2} / \mathrm{N}_{2}$, $\mathrm{CO}_{2} / \mathrm{CH}_{4}$ and $\mathrm{H}_{2} / \mathrm{CO}_{2}$ gas pairs as a function of the temperature. The persistence of selectivity at elevated temperatures underlines the moderation of augmented macromolecular dynamics in the hyper-cross-linked poly(POSSimide) network. The dilation of the network is impeded by the high large number of organic bridges linking the rigid POSS cages, while molecular motions of the organic bridges allow diffusion of gas molecules. ${ }^{39}$ The selectivity as a function of temperature decreases due to the differences in the activation energies between gases, which results in an increase in the $\mathrm{H}_{2} / \mathrm{CO}_{2}$ selectivity with temperature and a decrease in the selectivities for the other gas pairs. Most surprisingly, the poly(POSS-imide) membrane retains gas selectivities of approximately 5 for $\mathrm{H}_{2} / \mathrm{CH}_{4}$ and $\mathrm{H}_{2} / \mathrm{N}_{2}$ at $300{ }^{\circ} \mathrm{C}$, which are unsurpassed by any other polymeric membrane. Moreover, the $\mathrm{CO}_{2} / \mathrm{CH}_{4}$ selectivities of approximately 60 at temperatures below $100{ }^{\circ} \mathrm{C}$ emphasize the applicability of the poly(POSS-imide) over a broad temperature range.

\subsection{Conclusion}

In summary, we have described the preparation of poly(POSS-imide) ultrathin gas separation membranes using interfacial polymerization followed by thermal imidization. The interfacial reaction results in an intrinsic homogeneous distribution of inorganic and organic constituents on the molecular scale. The subsequent heat treatment successfully converts the asformed amic acid into a cyclic imide at temperatures exceeding $180^{\circ} \mathrm{C}$. The hybrid character of the thin film is manifested in its excellent gas separation performance at elevated temperatures, which originate from the hyper-crosslinked periodic network of covalently bound rigid POSS and mobile organic moieties. The presented method can be easily extended to other dianhydride 
linkers to yield the next generation of potential gas separation membranes for elevated-temperature applications.

\subsection{Acknowledgements}

This project has received funding from the European Union's Seventh Framework Programme for research, technological development and demonstration under CARENA grant agreement no. 263007.

\subsection{Appendices}

\subsubsection{Poly(POSS-imide) synthesis}

Figure A2-1 shows the reaction scheme of poly[POSS-(amic acid)] and poly(POSS-imide) macromolecular network. Water soluble ammonium chloride salt functionalized POSS is first dissolved in an alkaline aqueous solution, allowing the conversion of ammonium to primary amine. 


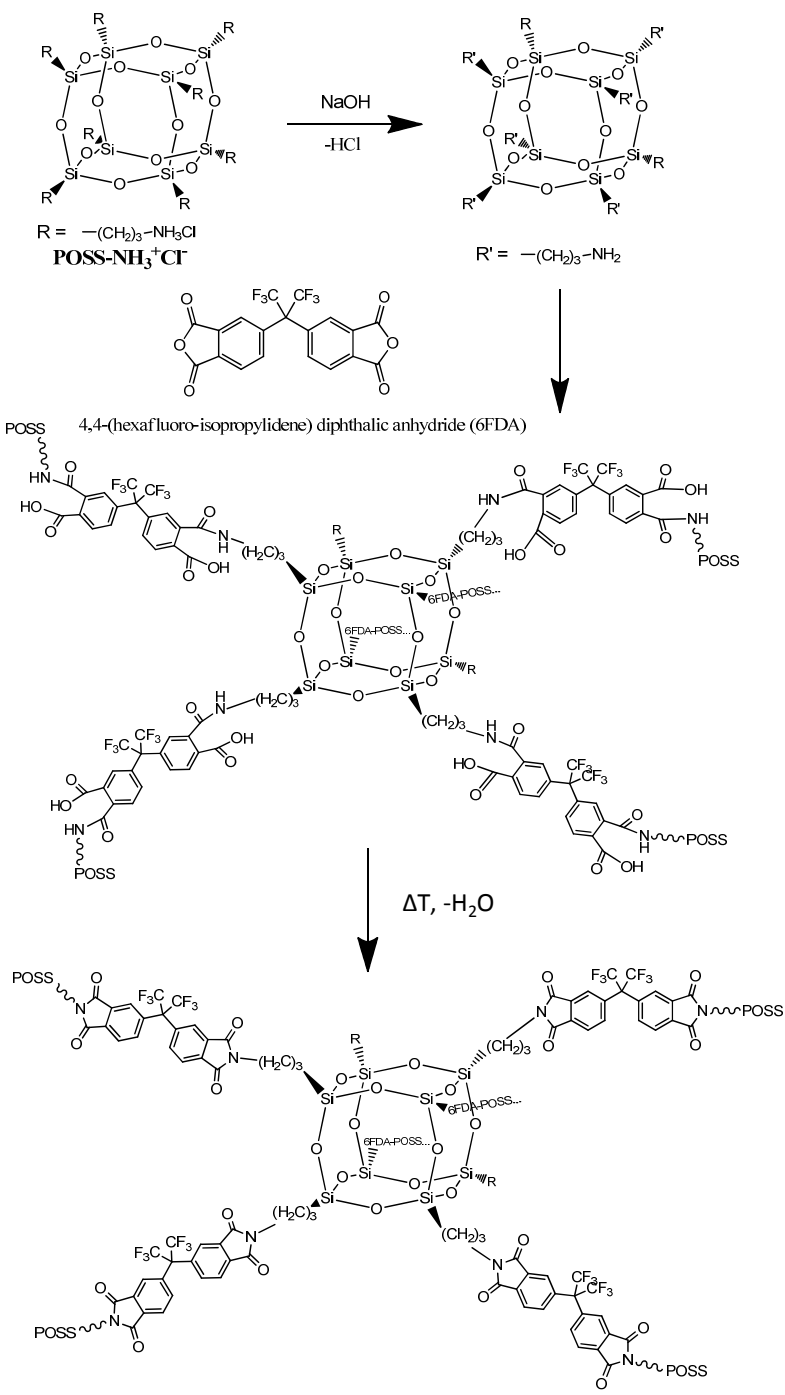

Figure A2-1. Interfacial polymerization reaction of partially deprotonated octa-ammonium POSS and 6FDA. The formed poly[POSS-(amic acid)] is subsequently converted to a poly(POSS-imide) by heat treatment.

The alkaline aqueous POSS solution is brought into contact with a 6FDA solution in toluene; the POSS and dianhydride react at the water/toluene interface, forming the thin film, hybrid poly[POSS-(amic acid)] network. Next, formation of poly(POSS-imide) is achieved by heat treatment at temperatures up to $300{ }^{\circ} \mathrm{C}$, converting the amic acid into cyclic imide bonds. Any unreacted POSS and 6FDA on the sample surface was removed by acetone and water 
washes. Samples were dried for 24 hours in dry nitrogen atmosphere to remove any toluene and unbound water.

Supported thin films were produced on $\alpha$-alumina discs coated with $3 \mu \mathrm{m}$ thick $\gamma$-alumina (porosity of $60 \%$ and a pore size of 2-3 nm). Pre-wetted discs, held fixed on a perforated plate by vacuum, were impregnated with the POSS solution. Following, the discs were left to dry in a nitrogen atmosphere for 30 min and subsequently submersed in the 6FDA in toluene solution (0.075 wt.\%).

\subsubsection{Material characterization}

\section{Differential scanning calorimetry}

Differential scanning calorimetry (DSC) was performed using a Perkin Elmer DSC 8000. Free standing poly(POSS-imide) was placed in an aluminum sample pan and cycled from 50 to $300{ }^{\circ} \mathrm{C}$ with a heating rate of $20{ }^{\circ} \mathrm{C} \mathrm{min}^{-1}$. Four subsequent heating and cooling cycles were used to prevent influence from sorbed water on the measurement.

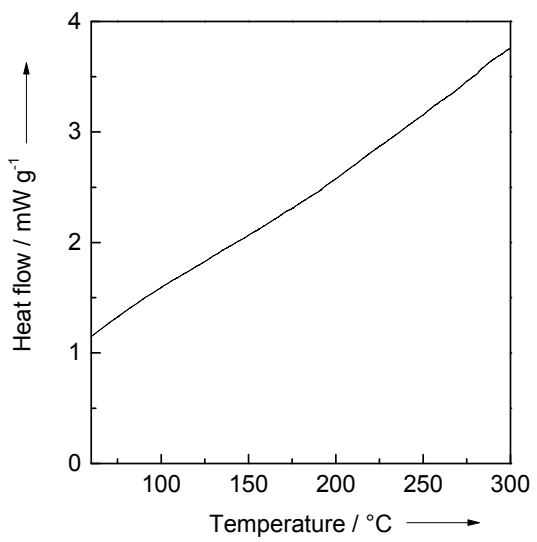

Figure A2-2: DSC analysis of a poly(POSS-imide) powder sample.

The heat flow as function of temperature shown in Figure A2-2 displays a steady increase of the heat flow with temperature. The absence of any peaks in the heat flow as a function of temperature evidences that there is no glass transition for temperatures up to $300^{\circ} \mathrm{C}$. 


\section{Thermal gravimetric analysis}

Thermal gravimetric analysis (TGA) was performed with NETZSCH STA 449 (Germany). Measurements were done on $1.5 \mathrm{mg}$ samples in alumina pans,

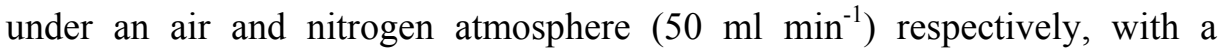
heating rate of $10{ }^{\circ} \mathrm{C}$. The thermal gravimetric evolution of freestanding poly(POSS-imide) shown in Figure A2-3 demonstrates that both under air and nitrogen the onset of weight loss is located above $300{ }^{\circ} \mathrm{C}$. In air the sample reaches a constant mass at around $600{ }^{\circ} \mathrm{C}$ while for nitrogen weight loss persists even at $1100{ }^{\circ} \mathrm{C}$, indicating two distinct degradation mechanisms. Both samples reach a final mass of $35 \%$ of the initial mass, having the appearance of a white powder in air atmosphere, and black powder in nitrogen atmosphere.

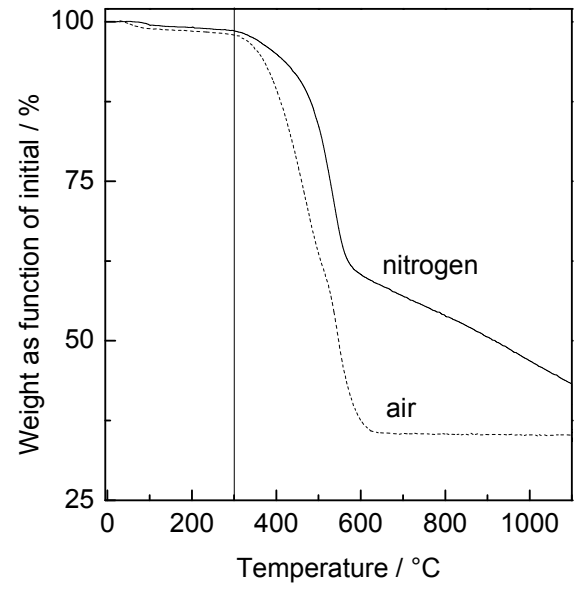

Figure A2-3: TGA analysis in air and nitrogen of a poly(POSS-imide) powder sample

\section{X-ray photoelectron spectroscopy}

$\mathrm{X}$-ray photoelectron spectroscopy measurements were performed on a Quantera SXM scanning XPS microprobe (Physical Electronics), using a monochromatic $\mathrm{Al} \mathrm{K} \alpha$ source $(1486.6 \mathrm{eV})$. The ratio of silica and fluorine elements indicates the presence of 1.9 dianhydride bridging molecules per POSS cage. Assuming complete conversion of the anhydride groups to cyclic imides, each POSS cage is connected with an average of 3.8 bridges. This assumption follows from the absence of anhydride and carboxylic acid peaks 
in the FTIR-ATR spectra and is in agreement with the nitrogen and carbon elemental fits.
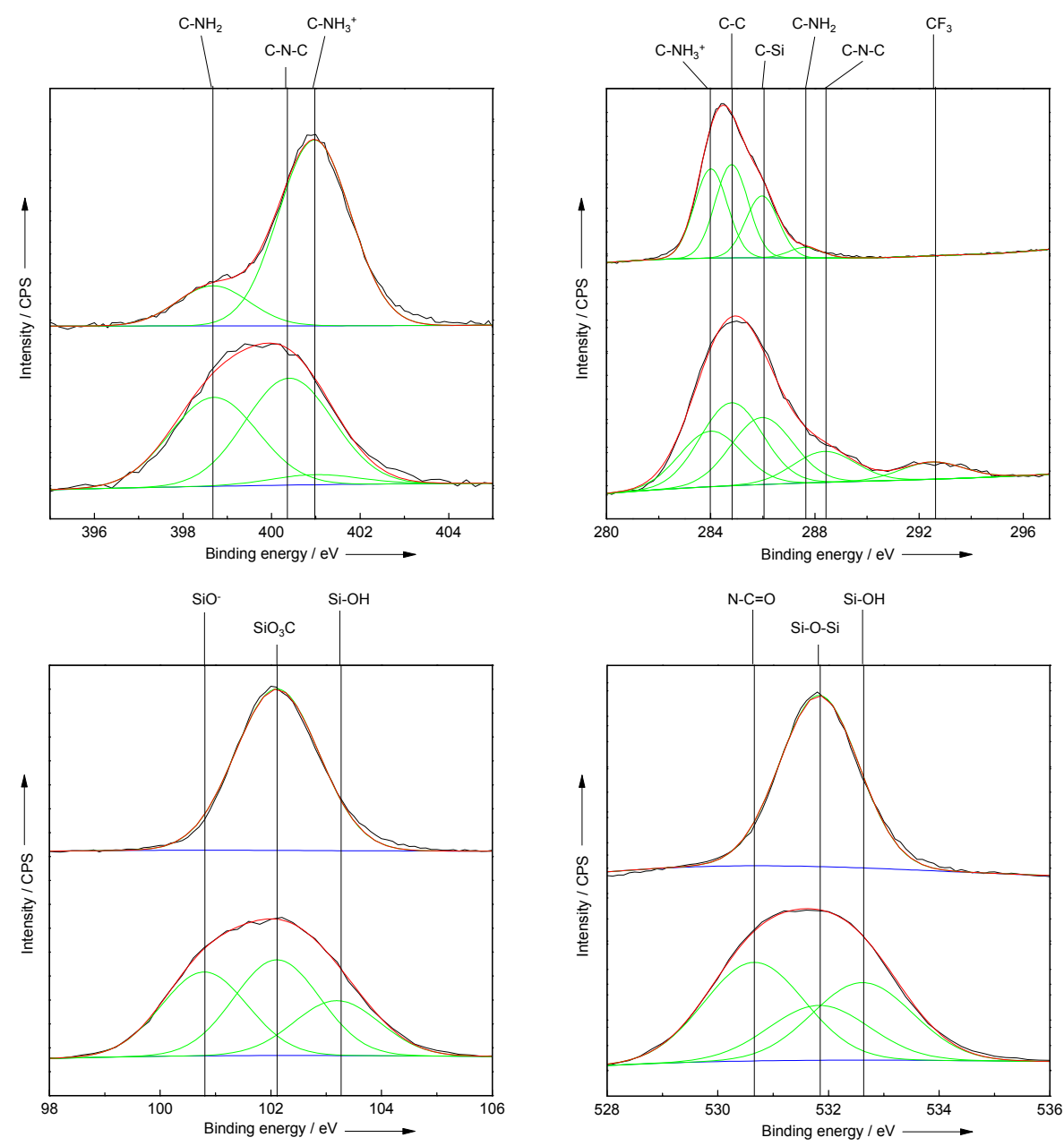

Figure A2-4: XPS elemental spectra for the N1s, C1s, Si2p and O1s signal. The data fitting has been performed using the peak analyzer function of Origin software. The peaks were fitted using Gaussians with similar FWHM values.

The nitrogen, carbon, oxygen and silica elemental fits of octa-ammonium POSS powder and poly(POSS-imide) on $\alpha$-alumina discs coated with $3 \mu \mathrm{m}$ thick $\gamma$-alumina are shown in Figure A2-4. The nitrogen elemental fit of octaammonium POSS shows two distinct peaks, attributed to the partially deprotonated ammonia groups. The binding energies of the amine and 
ammonia groups were fixed in the poly(POSS-imide) nitrogen peak fit, to determine the number of imide bonds per POSS molecule.

Table A2-1: XPS elemental composition for Octa-ammonium POSS and poly(POSS-imide) samples.

\begin{tabular}{|l|l|l|l|l|l|}
\hline & $\begin{array}{l}\text { Octa-NH } \\
\text { (theoretical) }\end{array}$ & $\begin{array}{l}\text { Octa-NH } \\
\text { POSS }\end{array}$ & $\begin{array}{l}\text { Poly(POSS- } \\
\text { imide) }\end{array}$ & \\
\hline & $\begin{array}{l}\text { Element concentration } \\
(\%)\end{array}$ & $\begin{array}{l}\text { Element } \\
\text { concentration } \\
(\%)\end{array}$ & $\begin{array}{l}\text { Standard } \\
\text { deviation } \\
(\%)\end{array}$ & $\begin{array}{l}\text { Element } \\
\text { concentration } \\
(\%)\end{array}$ & $\begin{array}{l}\text { Standard } \\
\text { deviation } \\
(\%)\end{array}$ \\
\hline $\mathrm{C}$ & 40 & 47.8 & 3.7 & 54.7 & 1.0 \\
\hline $\mathrm{N}$ & 13.33 & 9.8 & 1.1 & 5.0 & 0.4 \\
\hline $\mathrm{O}$ & 20 & 22.0 & 2.4 & 22.5 & 0.6 \\
\hline $\mathrm{Si}$ & 13.33 & 11.5 & 1.1 & 6.9 & 0.1 \\
\hline $\mathrm{F}$ & - & - & - & 9.8 & 0.1 \\
\hline $\mathrm{Cl}$ & 13.33 & 9.0 & 1.5 & - & - \\
\hline $\mathrm{Na}$ & - & 0.8 & 0.9 & 0.5 & 0.3 \\
\hline $\mathrm{C} / \mathrm{N}$ & 3 & 3.4 & & 10.9 & \\
\hline $\mathrm{F} / \mathrm{Si}$ & - & - & & 1.4 & \\
\hline $\mathrm{O} / \mathrm{N}$ & 1.5 & 1.6 & & 4.5 & \\
\hline $\mathrm{Cl} / \mathrm{N}$ & 1 & 0.9 & & - & \\
\hline
\end{tabular}

The resulting fit indicates that 4 out of 8 groups per POSS molecule have been converted to imide groups. The imide binding energy is in agreement with values found for other polyimides. ${ }^{40}$ The remaining unreacted groups mainly consist of amine groups, indicating that most ammonia groups are deprotonated upon interfacial polymerization. The binding energies of the octa-ammonium POSS were fixed in the carbon elemental fit of the poly(POSS-imide). The poly(POSS-imide) carbon elemental peak fit shows two additional peaks with respect to octa-ammonium POSS. These peaks are attributed to the imide bond $(288.6 \mathrm{eV})$ and $\mathrm{CF}_{3}$ groups $(292.5 \mathrm{eV})$, in accordance to typical binding energies found for these bonds. The ratio of the imide: $\mathrm{CF}_{3}$ peak fit area (approximately 2:1) is in good agreement with the supposition that both anhydride groups of the 6FDA are converted to cyclic imide bonds.

The silicon elemental fit of octa-ammonium POSS shows a single peak, attributed to the $\mathrm{SiO}_{3} \mathrm{C}$ groups of the POSS cage. The silicon elemental fit of 
the poly(POSS-imide) shows two additional peaks at a lower and higher binding energy. These peaks are associated with silanol and $\mathrm{SiO}^{-}$formed by partial hydrolysis of the POSS cage. ${ }^{41}$ The formation of silanol is known to both shift the binding energy, and broaden the XPS spectrum. ${ }^{42}$

The oxygen elemental spectrum of octa-ammonium shows a single peak associated with siloxane bonds in the POSS cages. The poly(POSS-imide) oxygen elemental spectrum shows an additional peak at a binding energy of $530.7 \mathrm{eV}$, and is associated with the $\mathrm{C}=\mathrm{O}$ of the imide group. The binding energy peak that emerged at $532.6 \mathrm{eV}$ is considered to be from silanol bonds, in agreement with the peak fit of silicon for the poly(POSS-imide) sample. In summary, the XPS spectra suggests a high degree of cross-linking between the POSS cages, with approximately 4 out 8 functional groups that have reacted with a dianhydride. Also, the data shows that the POSS cage is partially hydrolyzed during the interfacial polymerization reaction.

\section{Attenuated Total Reflection Fourier Transform Infrared Spectroscopy}

The chemical structures of the poly[POSS-(amic acid)] and poly(POSS-imide) were analyzed with Attenuated Total Reflection Fourier Transform Infrared Spectroscopy (ATR-FTIR) on free standing films using an ALPHA FT-IR Spectrometer (Bruker Optics Inc., Germany) equipped with a ZnSe crystal. All spectra were recorded at room temperature. Thermal imidization was done by heat treatment in air for two hours at temperatures ranging from $0-300{ }^{\circ} \mathrm{C}$. A detailed analysis of the poly[POSS-(amic acid)] and poly(POSS-imide) infrared absorption spectra is given in Table A2-2. The infrared data confirms the presence of the partially hydrolyzed POSS cage, in accordance with the XPS data. Presence of aliphatic carbon originating from octa-ammonium POSS, $\mathrm{CF}_{3}$ groups and phenyl groups of the 6FDA bridging molecule is confirmed by the infrared data. The differences between the spectra of the poly[POSS-(amic acid)] and poly(POSS-imide) originate solely from the conversion of the amic acid groups to cyclic imide. 
Table A2-2: FTIR-ATR peak analysis data for a poly[POSS-(amic acid)] and poly(POSS-imide) sample

\begin{tabular}{|c|c|c|c|c|}
\hline Wavenumber & $\begin{array}{l}\text { Poly[POSS- } \\
\text { (amic acid)] }\end{array}$ & $\begin{array}{l}\text { Poly(POSS- } \\
\text { imide) }\end{array}$ & & \\
\hline $\mathrm{cm}^{-1}$ & Intensity & Intensity & Bond & Vibrational mode \\
\hline 691 & high & shoulder & $\mathrm{CF}_{3}$ & def vib \\
\hline 706 & high & high & $\mathrm{NH}_{2}$ & def vib of primary amine \\
\hline 725 & shoulder & high & $\mathrm{CF}_{3}$ & def vib \\
\hline 750 & medium & medium & $\mathrm{CH}$ & $\begin{array}{l}\text { out of plane } 1,2,4, \\
\text { trisubstituted benzene }\end{array}$ \\
\hline 793 & shoulder & medium & $\mathrm{NH}_{2}$ & out of plane bend \\
\hline 846 & medium & medium & $\mathrm{NH}_{2}$ & out of plane bend \\
\hline 910 & medium & shoulder & $\mathrm{C}-\mathrm{C}$ & rocking \\
\hline 965 & medium & medium & $\mathrm{C}-\mathrm{C}$ & rocking \\
\hline 1000 & shoulder & shoulder & $\mathrm{C}-\mathrm{C}$ & rocking \\
\hline 1040 & high & high & Si-O cage & str \\
\hline 1093 & high & high & Si-O ladder & str \\
\hline 1122 & shoulder & high & $\mathrm{CF}_{3}$ & str \\
\hline 1185 & medium & medium & $\mathrm{CF}_{3}$ & str \\
\hline 1212 & medium & medium & $\mathrm{CF}_{3}$ & str \\
\hline 1245 & medium & medium & $\mathrm{CF}_{3}$ & str \\
\hline 1255 & medium & medium & $\mathrm{CF}_{3}$ & str \\
\hline 1393 & - & medium & $\mathrm{C}=\mathrm{O}$ or $\mathrm{C}-\mathrm{N}$ & str \\
\hline 1374 & high & - & $\mathrm{C}-\mathrm{N}$ & str \\
\hline 1445 & low & medium & $\mathrm{CH}_{2}$ & scissoring \\
\hline 1475 & low & low & $\mathrm{CH}_{2}$ & def vib \\
\hline 1560 & high & - & $\mathrm{N}-\mathrm{H}$ & bend amide \\
\hline 1627 & high & low & $\mathrm{C}=\mathrm{O}$ & str amide \\
\hline 1670 & - & shoulder & $\mathrm{C}=\mathrm{O}$ & str carboxylic acid \\
\hline 1710 & - & high & $\mathrm{C}=\mathrm{O}$ & asym str imide \\
\hline 1780 & - & low & $\mathrm{C}=\mathrm{O}$ & sym str imide \\
\hline 2886 & shoulder & - & $\mathrm{CH}_{2}$ & sym str \\
\hline 2939 & low & - & $\mathrm{CH}_{2}$ & asym str \\
\hline $3068-3235$ & broad & - & $\mathrm{H}_{2} \mathrm{O} / \mathrm{COOH}$ & bend \\
\hline 3380 & broad & broad & $\mathrm{NH}_{2}$ & asym str \\
\hline
\end{tabular}




\subsubsection{Membrane single gas permeation experiments}

Membrane single gas permeation experiments were performed in a dead-end mode at a trans-membrane pressure of 2 bar, and atmospheric pressure at the permeate side. Single gas permeation of $\mathrm{N}_{2}, \mathrm{CH}_{4}, \mathrm{H}_{2}$, and $\mathrm{CO}_{2}$ were measured at temperatures between $50-300{ }^{\circ} \mathrm{C}$. The apparent activation energy for gas permeance $\left(E_{p}\right)$ was determined using a linear fit using OriginPro 9 software. The activation energies were compared with those of conventional and 6FDA based polyimides, as shown in Table A2-3.

Table A2-3: gas permeance activation energy for polyimide membranes

\begin{tabular}{|c|c|c|c|}
\hline$E_{\mathrm{p}}\left(\mathrm{kJ} \mathrm{mol}^{-1}\right)$ & $E_{\mathrm{p}}\left(\mathrm{kJ} \mathrm{mol}^{-1}\right)$ & $E_{\mathrm{p}}\left(\mathrm{kJ} \mathrm{mol}^{-1}\right)$ & Reference \\
\hline $\mathrm{CO}_{2}$ & $\mathrm{~N}_{2}$ & $\mathrm{CH}_{4}$ & \\
\hline 3.7 & 31.7 & 33.3 & $\begin{array}{l}\text { Current } \\
\text { study }\end{array}$ \\
\hline-3.3 & 3.5 & & 34 \\
\hline-1.3 & & & 36 \\
\hline 0.2 & 4.45 & 7.25 & 35 \\
\hline 10.5 & 24.1 & & \multirow{3}{*}{37} \\
\hline 14.3 & 27.3 & & \\
\hline 21.0 & 31.2 & & \\
\hline
\end{tabular}

\subsection{References}

1. Niwa, S. I.; Eswaramoorthy, M.; Nair, J.; Raj, A.; Itoh, N.; Shoji, H.; Namba, T.; Mizukami, F. Science 2002, 295, (5552), 105-107

2. Jiang, H.; Cao, Z.; Schirrmeister, S.; Schiestel, T.; Caro, J. Angew. Chem. Int. Ed. 2010, 49, (33), 5656-5660

3. Choudhary, V. R.; Gaikwad, A. G.; Sansare, S. D. Angew. Chem. Int. Ed. 2001, 40, (9), 1776-1779

4. Wind, J. D.; Sirard, S. M.; Paul, D. R.; Green, P. F.; Johnston, K. P.; Koros, W. J. Macromolecules 2003, 36, (17), 6433-6441

5. $\quad$ Koros, W. J.; Woods, D. G. J. Membr. Sci. 2001, 181, (2), 157-166

6. Guiver, M. D.; Lee, Y. M. Science 2013, 339, (6117), 284-285

7. Carta, M.; Malpass-Evans, R.; Croad, M.; Rogan, Y.; Jansen, J. C.; Bernardo, P.; Bazzarelli, F.; McKeown, N. B. Science 2013, 339, (6117), 303-307

8. Du, N.; Park, H. B.; Robertson, G. P.; Dal-Cin, M. M.; Visser, T.; Scoles, L.; Guiver, M. D. Nat. Mater. 2011, 10, (5), 372-375

9. $\quad$ Song, Q.; Cao, S.; Zavala-Rivera, P.; Ping Lu, L.; Li, W.; Ji, Y.; Al-Muhtaseb, S. A.; Cheetham, A. K.; Sivaniah, E. Nat. Commun. 2013, 4,

10. Rezac, M. E.; Koros, W. J.; Miller, S. J. J. Membr. Sci. 1994, 93, (2), 193-201 
11. Calle, M.; Doherty, C. M.; Hill, A. J.; Lee, Y. M. Macromolecules 2013, 46, (20), 8179-8189

12. Calle, M.; Lozano, A. E.; Lee, Y. M. Eur. Polym. J. 2012, 48, (7), 1313-1322

13. Joseph, W. D.; Abed, J. C.; Mercier, R.; McGrath, J. E. Polymer 1994, 35, (23), 50465050

14. Kim, S.; Han, S. H.; Lee, Y. M. J. Membr. Sci. 2012, 403-404, 169-178

15. Angelova, P.; Vieker, H.; Weber, N. E.; Matei, D.; Reimer, O.; Meier, I.; Kurasch, S.; Biskupek, J.; Lorbach, D.; Wunderlich, K.; Chen, L.; Terfort, A.; Klapper, M.; Müllen, K.; Kaiser, U.; Gölzhäuser, A.; Turchanin, A. ACS Nano 2013, 7, (8), 64896497

16. Vendamme, R.; Onoue, S. Y.; Nakao, A.; Kunitake, T. Nat. Mater. 2006, 5, (6), 494501

17. Peinemann, K. V.; Abetz, V.; Simon, P. F. W. Nat. Mater. 2007, 6, (12), 992-996

18. Du, N.; Park, H. B.; Dal-Cin, M. M.; Guiver, M. D. Energy Environ. Sci. 2012, 5, (6), 7306-7322

19. Ho, B. P.; Chul, H. J.; Young, M. L.; Hill, A. J.; Pas, S. J.; Mudie, S. T.; Van Wagner, E.; Freeman, B. D.; Cookson, D. J. Science 2007, 318, (5848), 254-258

20. Vanherck, K.; Koeckelberghs, G.; Vankelecom, I. F. J. Prog. Polym. Sci. 2013, 38, (6), 874-896

21. Laine, R. M.; Roll, M. F. Macromolecules 2011, 44, (5), 1073-1109

22. Nischang, I.; Brüggemann, O.; Teasdale, I. Angew. Chem. Int. Ed. 2011, 50, (20), 4593-4596

23. Oaten, M.; Choudhury, N. R. Macromolecules 2005, 38, (15), 6392-6401

24. Wu, G.; Su, Z. Chem. Mater. 2006, 18, (16), 3726-3732

25. Zhang, C.; Babonneau, F.; Bonhomme, C.; Laine, R. M.; Soles, C. L.; Hristov, H. A.; Yee, A. F. J. Am. Chem. Soc. 1998, 120, (33), 8380-8391

26. Iyer, P.; Iyer, G.; Coleman, M. J. Membr. Sci. 2010, 358, (1-2), 26-32

27. Leu, C. M.; Chang, Y. T.; Wei, K. H. Chem. Mater. 2003, 15, (19), 3721-3727

28. Dalwani, M.; Zheng, J.; Hempenius, M.; Raaijmakers, M. J. T.; Doherty, C. M.; Hill, A. J.; Wessling, M.; Benes, N. E. Journal of Materials Chemistry 2012, 22, (30), 14835-14838

29. Freger, V. Langmuir 2003, 19, (11), 4791-4797.10.1021/la020920q

30. Sroog, C. E. Prog. Polym. Sci. 1991, 16, (4), 561-694

31. J. Feher, F.; D. Wyndham, K.; Soulivong, D.; Nguyen, F. J. Chem. Soc., Dalton Trans. 1999, (9), 1491-1498.10.1039/A807302C

32. Schön, P.; Bagdi, K.; Molnár, K.; Markus, P.; Pukánszky, B.; Julius Vancso, G. Eur. Polym. J. 2011, 47, (4), 692-698

33. Colson, J. W.; Dichtel, W. R. Nature Chem. 2013, 5, (6), 453-465

34. Duthie, X.; Kentish, S.; Powell, C.; Nagai, K.; Qiao, G.; Stevens, G. J. Membr. Sci. 2007, 294, (1-2), 40-49

35. Lin, W. H.; Chung, T. S. J. Membr. Sci. 2001, 186, (2), 183-193

36. Tanaka, K.; Okano, M.; Toshino, H.; Kita, H.; Okamoto, K.-I. J. Polym. Sci., Part B: Polym. Phys. 1992, 30, (8), 907-914

37. Villaluenga, J. P. G.; Seoane, B.; Hradil, J.; Sysel, P. J. Membr. Sci. 2007, 305, (1-2), $160-168$ 
38. Neyertz, S.; Gopalan, P.; Brachet, P.; Kristiansen, A.; Männle, F.; Brown, D. Soft Mater. 2014, 12, (1), 113-123

39. Lin, H.; Van Wagner, E.; Freeman, B. D.; Toy, L. G.; Gupta, R. P. Science 2006, 311, (5761), 639-642

40. Beamson, G.; Briggs, D., High Resolution XPS of Organic Polymers: The Scienta ESCA300 Database. John Wiley \& Sons: 1992.

41. Feher, F. J.; Wyndham, K. D.; Soulivong, D.; Nguyen, F. Journal of the Chemical Society - Dalton Transactions 1999, (9), 1491-1497

42. Simonsen, M. E.; Sønderby, C.; Li, Z.; Søgaard, E. G. J. Mater. Sci. 2009, 44, (8), 2079-2088 


\section{Chapter 3 \\ Hybrid poly(POSS-imide)s with tailored inter-cage spacing for sieving of hot gases}

This chapter has been adapted from: Raaijmakers, M.J.T., Hybrid polyhedral oligomeric silsesquioxanes-imides with tailored inter-cage spacing for sieving of hot gases, Chem. Mater., 2014, 26, (12), pp 3660-3664 (DOI: $10.1021 / \mathrm{cm} 500691 \mathrm{e})$ 

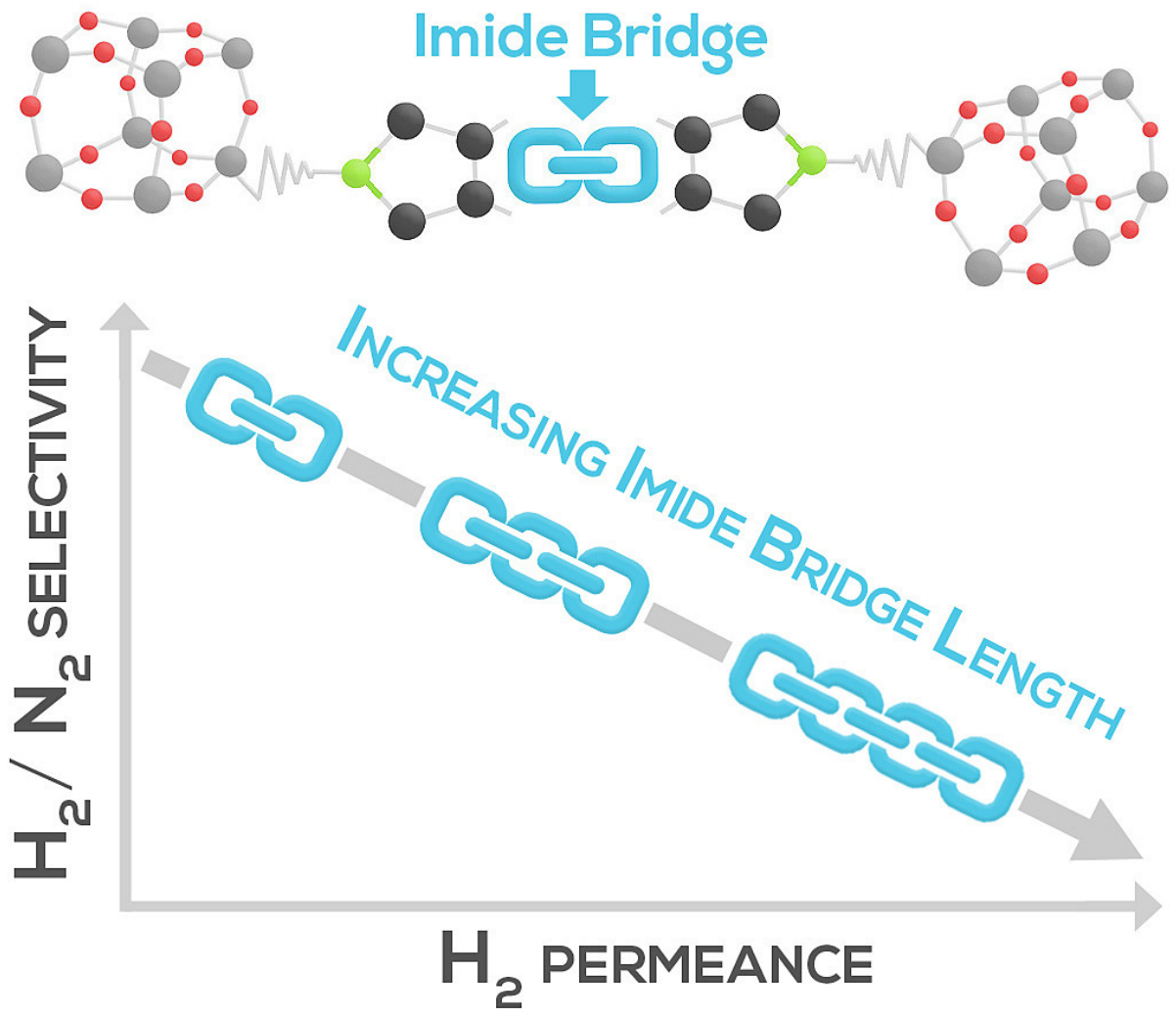

\begin{abstract}
Macromolecular network rigidity of synthetic membranes is essential for sieving of hot gases. Hyper-cross-linked poly(POSS-imide) membranes with tailored inter-cage spacing are presented. The length and flexibility of their imide bridges enables tuning of gas permeability and selectivity in a broad temperature range. The facile synthesis allows for large-scale production of membranes designed for specific process conditions.
\end{abstract}




\subsection{Introduction}

Sieving of hot gases requires membranes with moderated macromolecular dynamics at elevated temperatures. ${ }^{1}$ Recently, we have presented ultrathin poly(POSS-imide) hybrid membranes that allow gas separation in a broad temperature range. ${ }^{2}$ The poly(POSS-imide) membranes consist of a giant molecular network of polyhedral oligomeric silsesquioxanes (POSS), covalently linked by imide bridges. The hyper-cross-linked network characteristics allow persistence of gas separation performance up to $300{ }^{\circ} \mathrm{C}$. At such temperatures, size-sieving selectivity of organic polymeric membranes disappears due to the loss in their chain rigidity. ${ }^{3}$ Here, we demonstrate that we can tailor the gas sieving performance of nanoscale hybrid membranes via selection of the imide bridge that connects the POSS cages. The length and flexibility of the imide bridges directly affect the macromolecular dynamics and inter-cage distance of the giant network. In turn, this enables tuning of gas permeability and selectivity in a broad temperature range. The facile nature of the technique used for membrane synthesis allows for large-scale and defectfree membrane production, with properties tailored to fit the process requirements.

Hybrid materials allow integration of the superior thermo-mechanical properties of inorganic materials and versatile organic polymer segments. The physical dispersion of inorganic nanoparticles in polymers allows for materials synthesis with properties that are a combination of the individual components. ${ }^{4-7}$ Superior properties can be obtained by incorporation of nanoscale inorganic moieties as an intrinsic part of the polymeric network..$^{8-12}$ The octahedral symmetry of polyhedral oligomeric silsesquioxanes (POSS), and the wide array of functional groups they are decorated with, permit covalent bond formation in three dimensions. Here, we use a facile interfacial polymerization reaction that allows for production of nanoscale-hybrid ultrathin films. $^{2}, 13$ The hybrid membranes are prepared by interfacial polycondensation of octa-ammonium POSS in water and a dianhydride in toluene, resulting in the formation of a poly[POSS-(amic acid)] membrane layer. The high reactivity of the monomers allows for rapid formation of inherently defect-free membranes. Inhibition of reactant diffusion upon film formation impedes further film growth, limiting the film thickness to several hundred nanometers. 


\subsection{Experimental section}

\subsubsection{Synthesis of poly(POSS-imide)s via interfacial polymerization}

Toluene (anhydrous 99.8 wt.\%, Sigma-Aldrich), pyromellitic dianhydride (PMDA, Sigma-Aldrich), 3,3',4,4'-biphenyl tetracarboxylic dianhydride (BPDA, Sigma-Aldrich), 4,4'-oxydiphthalic anhydride (ODPA, Sigma-Aldrich), and 4,4'-(4,4'-Isopropylidenediphenoxy)bis(phthalic anhydride) (BPADA) 4,4-(Hexafluoroisopropylidene) diphthalic anhydride (6FDA, Sigma-Aldrich), ammonium chloride salt functionalized POSS (OctaAmmonium POSS ${ }^{\circledR}$, Hybrid Plastics (USA)) and sodium hydroxide (Sigma-Aldrich) were used as received. Free-standing films were prepared using ammonium chloride salt functionalized POSS, that is readily soluble in water. The $\mathrm{pH}$ of an aqueous solution of $0.9 \mathrm{wt} \%$ ammonium chloride salt functionalized POSS was adjusted using sodium hydroxide $\left(0.1 \mathrm{~mol} \mathrm{~L}^{-1}\right)$, and subsequently contacted with the dianhydride solution in toluene $(0.075 \mathrm{wt} . \%)$. Supported membranes were produced on ceramic membranes ( $\alpha$-alumina discs with a 3 - $\mu$ m-thick $\gamma$-alumina layer by pre-wetting the porous ceramic material under 0.5 bar vacuum in the aqueous POSS solution for $15 \mathrm{~min}$, followed by contacting with the dianhydride solution in toluene for $5 \mathrm{~min}$. The pore size of the $\gamma$-alumina is in the order of several $\mathrm{nm}$, and allows for defect-free interfacial polymerization membrane formation. The high hydrophilicity of the $\gamma$-alumina allows for facile wetting of the pores with the aqueous phase. Thermal conversion of the poly[POSS-(amic acid)] to poly(POSS-imide) was performed for 2 hours at $300{ }^{\circ} \mathrm{C}$ under an air atmosphere, at a heating rate of $5{ }^{\circ} \mathrm{C} \min ^{-1}$.

\subsubsection{Material characterization}

Membrane single gas permeation experiments were performed in a dead-end mode at a trans-membrane pressure of 2 bar, and atmospheric pressure at the permeate side. Once the helium permeance remained constant, the other gases $\left(\mathrm{N}_{2}, \mathrm{CH}_{4}, \mathrm{H}_{2}\right.$, and $\mathrm{CO}_{2}$, consecutively) were measured at temperatures between 50-300 ${ }^{\circ} \mathrm{C}$.

\subsection{Results and discussion}

After film formation by interfacial polymerization, the poly[POSS(amic acid)]s are converted to poly(POSS-imide)s by thermal treatment at $300{ }^{\circ} \mathrm{C}$. Figure 3-1 shows the Attenuated Total Reflection - Fourier Transform Infrared Spectroscopy (ATR-FTIR) spectra of the poly[POSS-(amic acid)] and 
poly(POSS-imide) materials. The poly[POSS-(amic acid)] spectra in Figure 3-1 (left panel) show common peaks at identical wave numbers, that can be attributed to the POSS cages, the amic acid groups, and the phenyl groups.
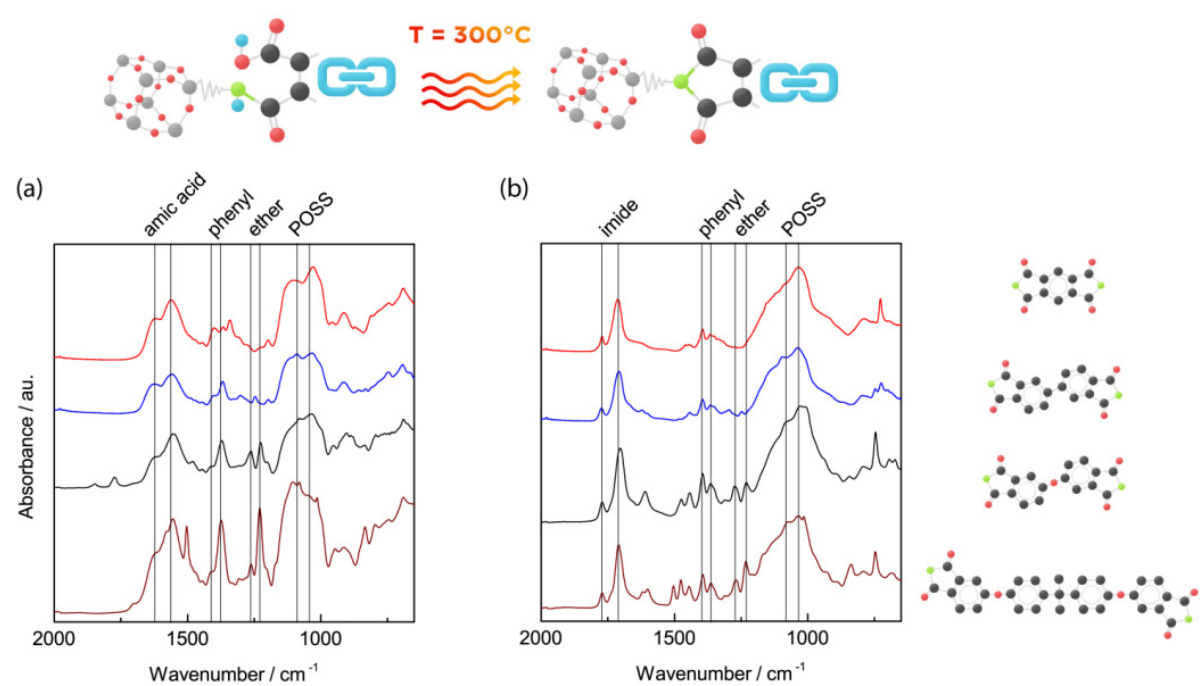

Figure 3-1: ATR-FTIR absorbance spectra of (left panel) poly[POSS-(amic acid)] and (right panel) poly(POSS-imide) (after $300{ }^{\circ} \mathrm{C}$ heat treatment) pre-pared using PMDA (-), BPDA (-), ODPA (-), BPADA (-). The bands at 1620 and $1570 \mathrm{~cm}^{-1}$ are assigned to $\mathrm{N}-\mathrm{H}$ bending (1) and $\mathrm{C}=\mathrm{O}$ stretching (2) of the amide group. After heat treatment the bands at 1620 and $1570 \mathrm{~cm}^{-1}$ are substituted by the bands at 1720 and $1780 \mathrm{~cm}^{-1}$, assigned to $\mathrm{C}=\mathrm{O}$ asymmetric (3) and symmetric (4) stretching of the imide group, respectively. The sharp bands at 1125 and $1040 \mathrm{~cm}^{-1}$ can be attributed to the Si-O-Si asymmetric stretching vibrations of polyhedral and ladder silsesquioxane structures, respectively. Partial cleavage of the POSS cages occurs due to hydrolysis by hydroxyl ions.

The differences between the poly[POSS-(amic acid)] spectra originate from the different functional groups of the dianhydrides; PMDA contains a 1,2,4,5-substituted phenyl, ODPA contains an ether, and BPADA has quaternary carbon and ether bonds (the complete peak analysis can be found in the Appendix, Table A2-1). After thermal treatment two distinct imide bands emerge at 1720 and $1780 \mathrm{~cm}^{-1}$, shown in Figure 3-1 (right panel) These peaks are attributed to the imide carbonyl symmetric and asymmetric stretching, respectively. The vanishing of the amic acid bands at 1620 and $1570 \mathrm{~cm}^{-1}$ 
indicates that complete conversion of the amic acid to imide groups is achieved. ${ }^{14}$ Also, the poly(POSS-imide) spectra lack carboxylic acid and dianhydride bands, implying that no detectable unreacted dianhydride moieties remain after imidization. The ratios between the POSS and imide peak intensities are similar for all poly(POSS-imide)s, implying that the number of imide groups on each POSS cage is not strongly affected by differences in reactivity and solubility of the dianhydrides.

The similar degree of POSS interconnectivity is confirmed by X-ray photoelectron spectroscopy (XPS) measurements of ceramic supported poly(POSS-imide) membranes (Appendix, Figure A2-4). Deconvoluted nitrogen elemental spectra reveal that, on average, 4 out of 8 functional groups on each POSS cage are converted to imides. The remaining unreacted functional groups are mostly primary amines, of which a slight fraction is protonated. The nitrogen, silica and carbon elemental compositions derived from the XPS measurement suggest a similar number of imide bridges per POSS molecule, assuming that no unreacted dianhydride groups remain. Both the infrared and XPS spectra reveal that partial hydrolysis of the POSS cage occurs. The wide range of dianhydrides suitable for the interfacial polycondensation of octa-ammonium POSS allows for production of gas separation membranes with a tailored inter-cage spacing. Figure 3-2 demonstrates the adaptability of the single gas permeance and selectivity over a broad temperature range, by the use of different imide bridges. Figure 3-2 (left panel) shows the gas sieving abilities of the membranes. The gas permeance follows a monotonic decrease with increasing kinetic diameter of the molecules, indicating that molecular separation occurs on basis of size exclusion. The diffusivity-controlled selectivity was also observed for the 6FDA based poly(POSS-imide)s, and originates from the hyper-cross-linked network characteristics. The permeance of each gas increases with increasing length of the imide bridges. This indicates that the larger spacing between the POSS cages results in increased permeation. The observation that transport occurs via the organic bridges of the hybrid material is supported by molecular dynamics simulations of gas transport in amino functionalized POSS. ${ }^{15}$ Figure 3-2 (right panel) shows that the inter-cage distance also affects the permselectivity. The $\mathrm{H}_{2} / \mathrm{N}_{2}$ selectivity as function of the $\mathrm{H}_{2}$ permeance shows the typical trade-off for molecular sieving membranes. A decrease in permeance, with decreasing length of the imide bridge, concurs with a 
substantial increase in the $\mathrm{H}_{2} / \mathrm{N}_{2}$ selectivity. At 100,200 and $300{ }^{\circ} \mathrm{C}$ a similar trade-off between selectivity and permeance can be observed.
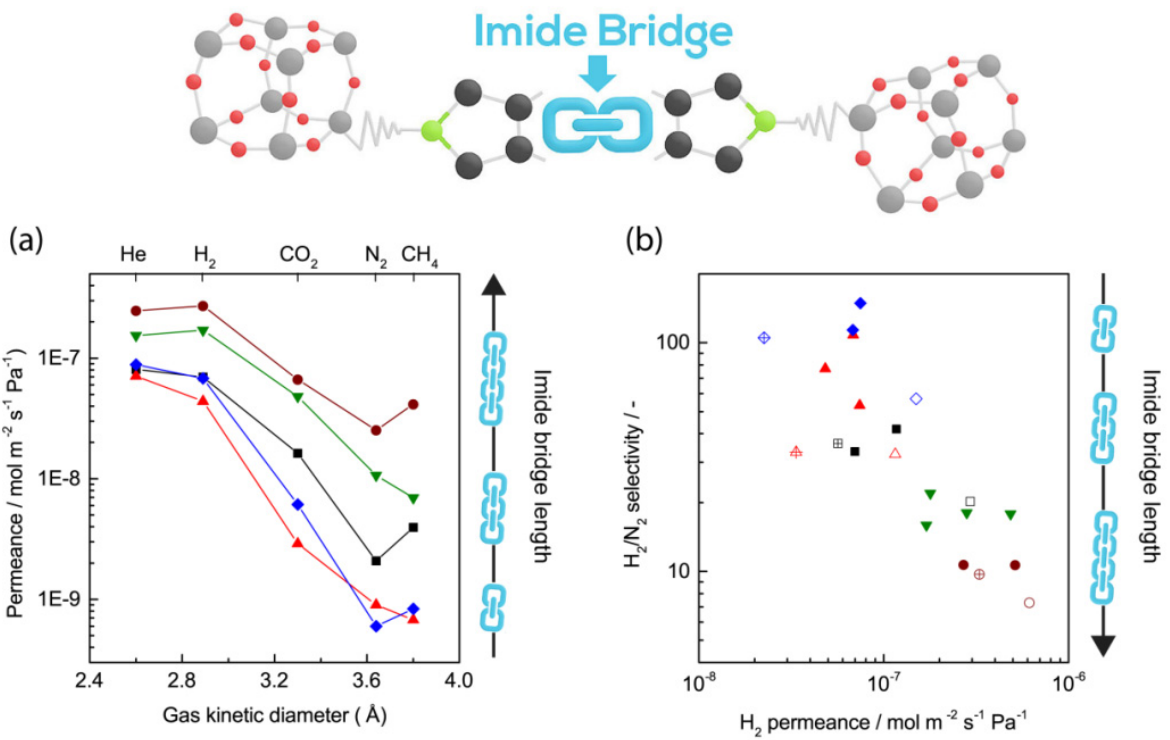

Figure 3-2: (left panel) Single gas permeance at $200^{\circ} \mathrm{C}$ as function of gas kinetic diameter for the poly(POSS-imide)s derived from PMDA $(\Delta)$, BPDA $(\diamond)$, ODPA ( $($ ), 6FDA $(\nabla)$ and BPADA $(\bullet)$. All poly(POSS-imide)s are selective towards smaller kinetic diameter gases. The gas permeance of all gases increases with increasing dianhydride molecular length, supporting the hypothesis that the inter-POSS spacing is a key parameter for the membrane characteristics. (right panel) $\mathrm{The}^{\mathrm{H}_{2}} / \mathrm{N}_{2}$ ideal gas selectivity as function of hydrogen permeance at $100{ }^{\circ} \mathrm{C}$ (open, crossed symbols), $200{ }^{\circ} \mathrm{C}$ (closed symbols) and $300{ }^{\circ} \mathrm{C}$ (open symbols) for the poly(POSS-imide)s derived from the different dianhydrides. The $\mathbf{H}_{2} / \mathbf{N}_{2}$ selectivity increases with decreasing imide bridge length, while $\mathrm{H}_{2}$ permeance is lower for the short imide bridges.

The gas permeation data as function of temperature demonstrates the hypercross-linked characteristics of the poly(POSS-imide)s. Figure 3-3 shows the Arrhenius plots for the membranes prepared with BPDA and BPADA. The Arrhenius plots for the membranes prepared with PMDA and ODPA are given in the Appendix. All membranes showed persistent gas selectivity in the temperature range of $50-300{ }^{\circ} \mathrm{C}$. Thermogravimetric analysis (Figure A3-2, Appendix) confirms that no material degradation occurs below $300{ }^{\circ} \mathrm{C}$ for all poly(POSS-imide)s. For all membranes the permeances increase with 
temperature, and an Arrhenius-type temperature dependence is observed for most gases. The membranes based on the shortest linkers, BPDA (Figure 3-3 (left panel)) and PMDA (Appendix, Figure A3-1), show similar apparent activation energies for all gases.

(a) Temperature $\left({ }^{\circ} \mathrm{C}\right)$

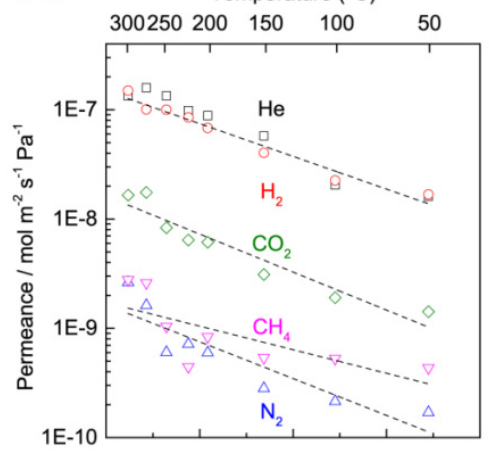

(b)

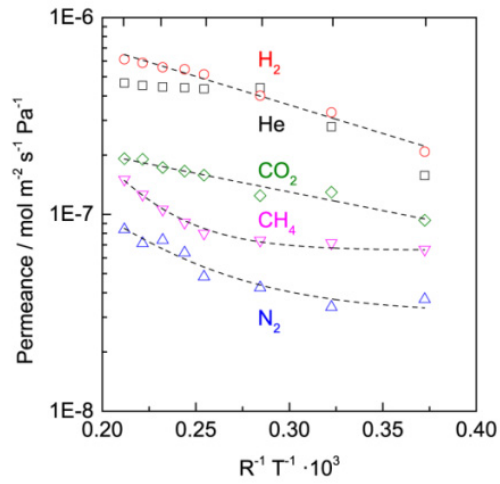

(c)

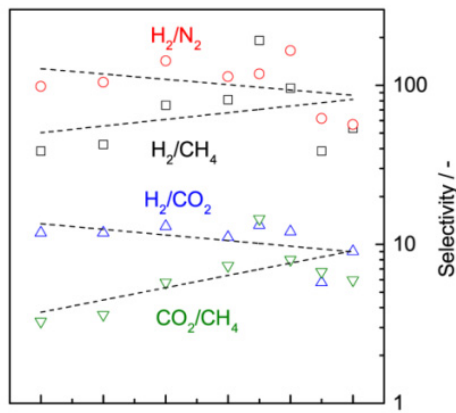

(d)

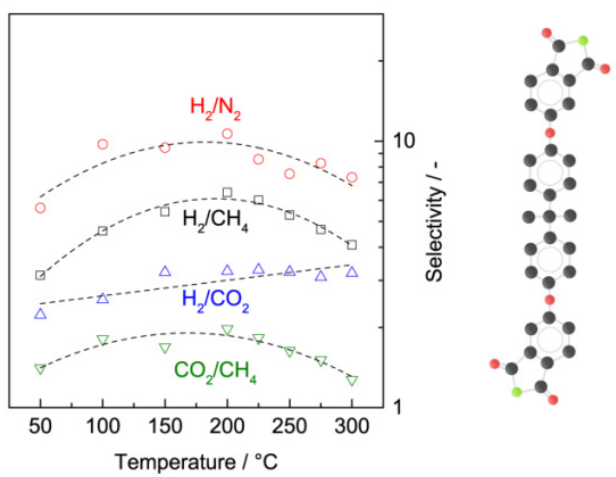

Figure 3-3: Arrhenius plot of the logarithm of the single gas permeance of He, $\mathrm{H}_{2}, \mathrm{CO}_{2}, \mathrm{~N}_{2}$ and $\mathrm{CH}_{4}$, as a function of $1000 \mathrm{R}^{-1} \mathrm{~T}^{-1}$ for the poly(POSS-imide)s derived from BPDA (a), and BPADA (b). The apparent activation energies for gas permeance are given in Table A3-1 in the Appendix, calculated from the slope of $\ln$ (permeance) as function of $R^{-1} T^{-1}$. The corresponding ideal gas selectivities of $\mathrm{H}_{2} / \mathrm{N}_{2}, \mathrm{H}_{2} / \mathrm{CH}_{4}, \mathrm{H}_{2} / \mathrm{CO}_{2}$ and $\mathrm{CO}_{2} / \mathrm{CH}_{4}$ as a function of temperature for the poly(POSS-imide)s derived from BPDA (c) and BPADA (d). The dashed lines are drawn as a guide to the eye.

The absence of any significant changes in the activation energy demonstrates the resilience of these membranes with respect to the operating temperature. This translates into the unsurpassed permselectivities that these membranes 
display at temperatures up to $300{ }^{\circ} \mathrm{C}$. Figure 3-3 (right panel) shows the corresponding permselectivities of $\mathrm{H}_{2} / \mathrm{N}_{2}, \mathrm{H}_{2} / \mathrm{CH}_{4}, \mathrm{H}_{2} / \mathrm{CO}_{2}$ and $\mathrm{CO}_{2} / \mathrm{CH}_{4}$ as a function of temperature. Single gas $\mathrm{H}_{2} / \mathrm{N}_{2}$ and $\mathrm{H}_{2} / \mathrm{CH}_{4}$ selectivities between 40-190 are observed for BPDA and 10-55 for PMDA based membranes, respectively. Most noteworthy, the $\mathrm{H}_{2} / \mathrm{N}_{2}$ and $\mathrm{H}_{2} / \mathrm{CH}_{4}$ selectivity predominantly increases with temperature. The $\mathrm{H}_{2} / \mathrm{CO}_{2}$ selectivities are above 10 over the complete temperature range of $50-300{ }^{\circ} \mathrm{C}$ for the BPDA based poly(POSS-imides). Relatively few membrane materials have been characterized in a similar temperature range, due to the limited membrane performance stability at elevated temperatures. In the last few years, data have become available on polybenzimidazole membranes. These membranes exhibit slightly higher selectivities, but significantly lower permeances. Also, interesting work has been performed on elevated temperature gas separation with polyimides and polyaramides. ${ }^{3,16}$ The performance of these materials is comparable to our hybrid materials, but does not persist above $200{ }^{\circ} \mathrm{C} .{ }^{17-19}$ There is a range of rigid polymers, such as poly(benzoxazole)s and poly(benzoxazole-co-imides), that have potential for high temperature gas separation. ${ }^{20-23}$ Yet, currently there is a lack of membrane performance data at high temperatures.

The poly(POSS-imide)s allow for facile tailoring of the rigidity and spacing of the segments that connect the POSS cages. The short imide bridges constrain macromolecular motions that would allow for permeation of larger kinetic diameter gas molecules. This is in contrast to longer imide bridges, ODPA and BPADA. These longer bridges display temperature-dependent apparent activation energies for the gas permeance of the larger molecules, $\mathrm{N}_{2}$ and $\mathrm{CH}_{4}$. At elevated temperature the molecular mobility of the longer bridges is more affected by an increase in temperature, as compared to the mobility of the short imide bridges. This in line with the variation in the coherence length found for conventional polyimides, obeying the order PMDA > BPDA > ODPA $>$ BPADA. $^{24}$ The augmented network mobility is manifested by a contribution to the apparent energy of activation, reflected by an increased permeation. This effect is most pronounced for the larger molecules that suffer the most from size exclusion. At lower temperatures the molecular motions of the network are less pronounced and their contribution to the apparent energy of activation diminishes. This is reflected by a lower apparent energies of activation of $\mathrm{N}_{2}$ and $\mathrm{CH}_{4}$ permeance at temperatures below $150{ }^{\circ} \mathrm{C}$. Differential scanning calorimetry (DSC) measurements on all 
poly(POSS-imide)s (Appendix) do not show any sharp transitions, indicating the network dynamics only change gradually. The absence of a glass transition at temperatures up to $300{ }^{\circ} \mathrm{C}$ can therefore not be the origin of the change in in apparent activation energy. The transition in activation energies results in a maximum selectivity of $\mathrm{H}_{2} / \mathrm{N}_{2}$ and $\mathrm{H}_{2} / \mathrm{CH}_{4}$ of ODPA (Appendix) and BPADA (Figure 3-3 (bottom left panel)) based poly(POSS-imide)s at a temperature around $150{ }^{\circ} \mathrm{C}$. The different selectivities of the poly(POSS-imide)s as function of temperature stresses the importance of the network dynamics for membrane performance, even in a system with relatively short flexible moieties. This understanding is essential for selecting the suitable imide bridge, and allows for a broad range of applications and operating conditions.

\subsection{Conclusion}

In conclusion, the poly(POSS-imide) membranes allow unprecedented gas sieving performance at elevated temperatures. Their facile synthesis allows for large-scale production of membranes designed for specific process conditions. The molecular sieving characteristics can be tailored by varying the inter-cage spacing, via the length of the imide bridge. The persistence of gas separation stability up to $300{ }^{\circ} \mathrm{C}$ underlines the hyper-cross-linked periodic network characteristics of the covalently bound rigid POSS. The simple and reliable synthesis method potentially allows for large-scale production of a new generation of tailor-made hybrid membranes for industrial scale applications that require sieving of hot gases.

\subsection{Acknowledgements}

This project has received funding from the European Union's Seventh Framework Programme for research, technological development and demonstration under CARENA grant agreement no. 263007.

\subsection{Appendices}

\subsubsection{Poly(POSS-imide) layer preparation}

Scheme A3-1 shows the formation of poly[POSS-(amic acid)] and poly(POSS-imide) network by interfacial polymerization. Ammonium chloride salt functionalized POSS is readily dissolved in water. Subsequently, the $\mathrm{pH}$ of the solution is adjusted using sodium hydroxide $(1 \mathrm{M})$ to allow the conversion of ammonium to primary amine functional groups. The alkaline aqueous POSS solution is contacted with a dianhydride solution in toluene for $5 \mathrm{~min}$. The polycondensation reaction at the interface results in rapid and defect-free layer 
formation of the hybrid poly[POSS-(amic acid)] network. After removal of the reactants, by flushing with acetone, the layers are heat treated at $300{ }^{\circ} \mathrm{C}$ in an air atmosphere to convert the poly[POSS-(amic acid)]s to poly(POSS-imide)s.

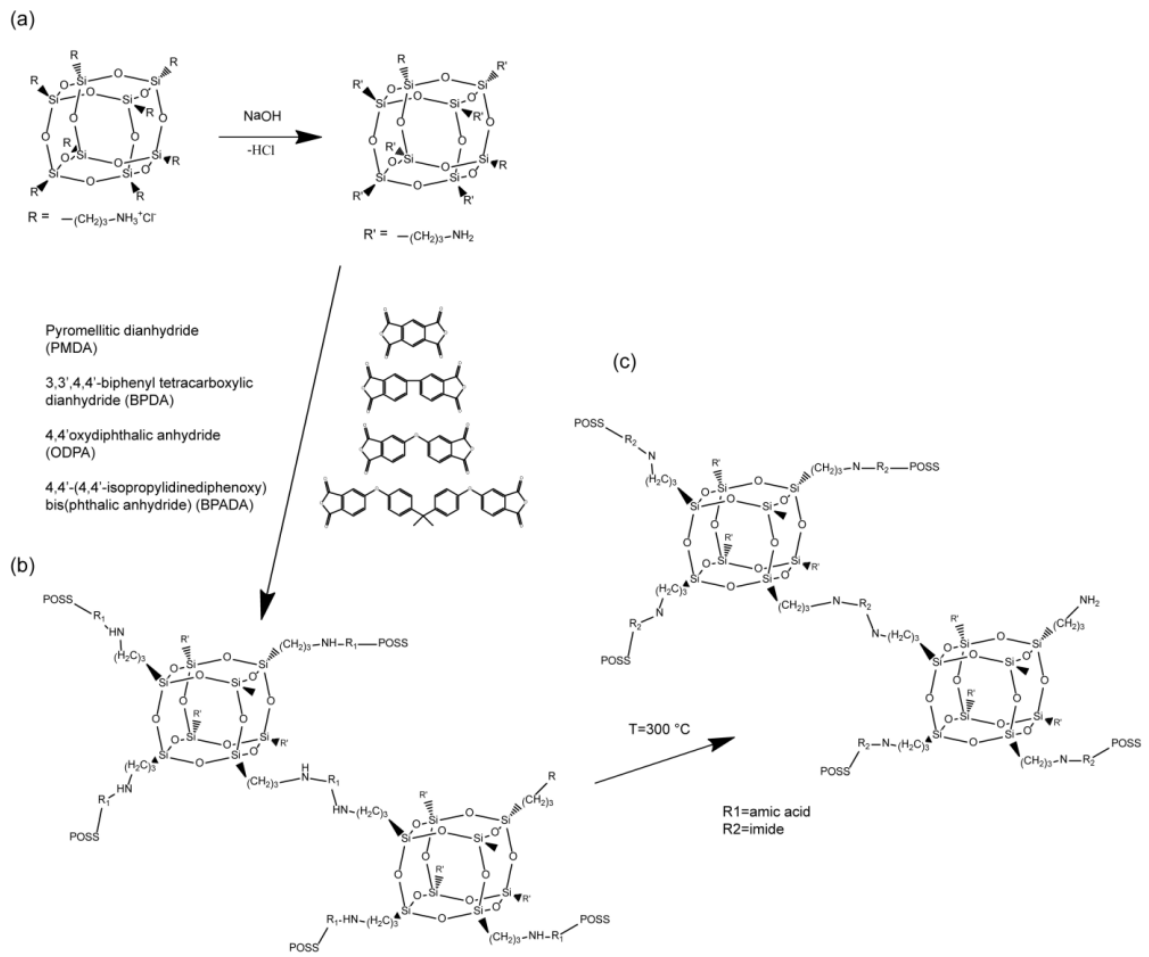

Scheme A3-1. Formation of poly[POSS-(amic acid)] and poly(POSS-imide) network by interfacial polymerization. (a) Partial deprotonation of the octa-ammonium POSS by sodium hydroxide to create amine functionalized functional groups. (b) Interfacial polycondensation reaction of the partially amine-functionalized POSS cage and the different dianhydrides, resulting in the formation of poly[POSS-(amic acid)]s. (c) thermal conversion

\subsubsection{Material characterization}

\section{Gas permeation analysis}

Membrane single gas permeation experiments were performed on an in-house developed gas permeation setup, using Kalrez ${ }^{\circledR}$ Spectrum 6375 O-rings. All membranes were measured in a dead-end mode at a trans-membrane pressure 
of $2 \mathrm{bar}$, and atmospheric pressure at the permeate side. The membranes were heated under helium atmosphere at a heating rate of $1.5{ }^{\circ} \mathrm{C} \mathrm{min}{ }^{-1}$. When the helium permeance reached a constant value, the other gases $\left(\mathrm{N}_{2}, \mathrm{CH}_{4}, \mathrm{H}_{2}\right.$, and $\mathrm{CO}_{2}$, consecutively) were measured at temperatures between $50-300{ }^{\circ} \mathrm{C}$. Equilibration time between measurements was at least $30 \mathrm{~min}$.

(a)

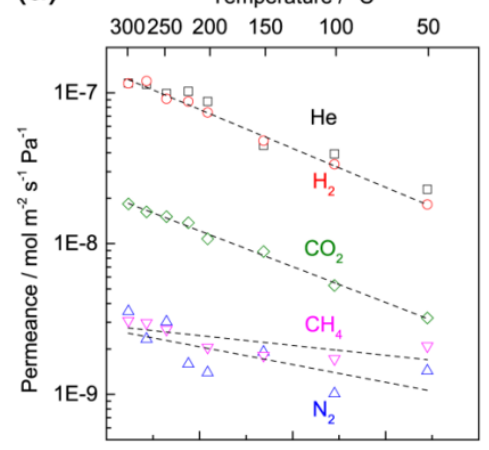

(b)

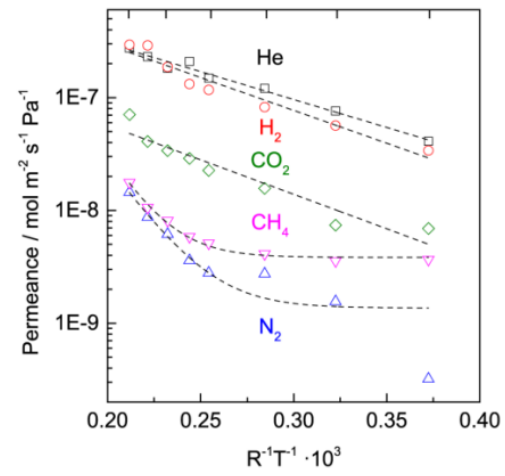

(c)

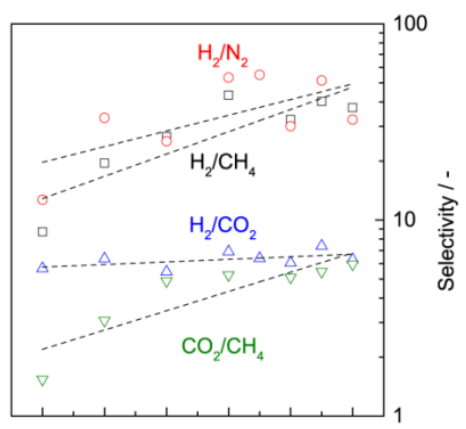

(d)

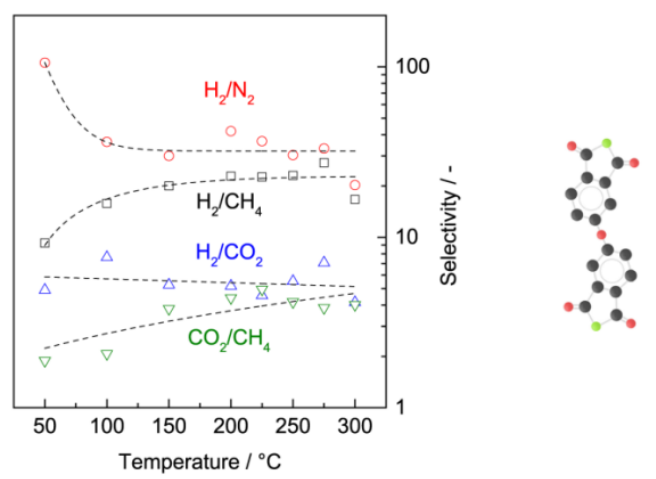

Figure A3-1. Arrhenius plot of the logarithm of the single gas permeance of $\mathrm{He}, \mathrm{H}_{2}, \mathrm{CO}_{2}, \mathrm{~N}_{2}$ and $\mathrm{CH}_{4}$, as a function of $\mathrm{R}^{-1} \mathrm{~T}^{-1} \cdot 10^{3}$ for the poly(POSS-imide)s derived from PMDA (a), and ODPA (b). The activation energies are calculated from the slope of the $\ln$ (permeance) as function of 1 $R^{-1} T^{-1}$. The corresponding ideal gas selectivities of $\mathrm{H}_{2} / \mathrm{N}_{2}, \mathrm{H}_{2} / \mathrm{CH}_{4}, \mathrm{H}_{2} / \mathrm{CO}_{2}$ and $\mathrm{CO}_{2} / \mathrm{CH}_{4}$ as a function of temperature for the poly(POSS-imide)s derived from PMDA (c) and ODPA (d). The dashed lines are drawn as a guide to the eye.

Figure 3-1 shows the Arrhenius plots of the $\log$ (permeance) as function of $\mathrm{R}^{-1} \mathrm{~T}^{-1} \cdot 10^{-3}$ for the membranes prepared with PMDA and ODPA. Both membranes show higher permeation rate with increasing temperatures. The 
activation energies for gas permeation through PMDA based poly(POSS-imide)s remain similar over the complete temperature range. The corresponding ideal gas selectivities of $\mathrm{H}_{2} / \mathrm{N}_{2}, \mathrm{H}_{2} / \mathrm{CH}_{4}, \mathrm{H}_{2} / \mathrm{CO}_{2}$ and $\mathrm{CO}_{2} / \mathrm{CH}_{4}$ as a function of temperature for the poly(POSS-imide)s derived from PMDA (d) show $\mathrm{H}_{2} / \mathrm{N}_{2}$ and $\mathrm{H}_{2} / \mathrm{CH}_{4}$ selectivities between 10-55. The low activation energy for $\mathrm{N}_{2}$ and $\mathrm{CH}_{4}$ substantiates that the short imide bridges do not exhibit macromolecular mobility that is required for transport of large kinetic diameter gases. This is in contrast to the apparent activation energies for $\mathrm{N}_{2}$ and $\mathrm{CH}_{4}$ for (c) BPADA poly(POSS-imide)s. The higher mobility of the large kinetic diameter gases originates from the larger imide bridge distance.

Table A3-1. The apparent activation energies for gas permeance for all poly(POSS-imide)s prepared with PMDA, BPDA, ODPA and BPADA. The activation for $\mathrm{N}_{2}$ and $\mathrm{CH}_{4}$ permeance of ODPA and BPADA based poly(POSS-imide)s were omitted due to changes in the apparent activation energy as function of temperature, in the temperature range of $50-300{ }^{\circ} \mathrm{C}$.

\begin{tabular}{|l|l|l|l|l|}
\hline & \multicolumn{4}{|l|}{ Activation energy / $\mathrm{kJ} \mathrm{mol}^{-1}$} \\
\hline $\mathrm{Gas}$ & PMDA & BPDA & ODPA & BPADA \\
\hline $\mathrm{He}$ & 10.7 & 16.2 & 13.4 & 8.4 \\
\hline $\mathrm{H}_{2}$ & 11.9 & 15.8 & 11.2 & 7.6 \\
\hline $\mathrm{CO}_{2}$ & 10.9 & 15.26 & 14.1 & 4.4 \\
\hline $\mathrm{N}_{2}$ & 5.4 & 13.17 & & \\
\hline $\mathrm{CH}_{4}$ & 3 & 7.78 & & \\
\hline
\end{tabular}

Table A3-1 shows the apparent activation energies for permeance for all poly(POSS-imide)s prepared with PMDA, BPDA, ODPA and BPADA. The apparent activation energies for permeance are relatively high compared to conventional polymeric membranes. BPDA based poly(POSS-imide)s show particularly high activation energies, and underlines the high energy barriers for gas diffusion due to rigidity of the short imide bridge.

\section{Thermogravimetric analysis}

Thermogravimetric analysis (TGA) was performed on a STA 449 F3 Jupiter ${ }^{\circledR}$ (Netzsch, Germany), equipped with a TG-only sample holder. Measurements were performed under $70 \mathrm{~mL} \mathrm{~min}^{-1}$ synthetic air $\left(20 \% \mathrm{O}_{2}\right.$ in $\left.\mathrm{N}_{2}\right)$ or $70 \mathrm{ml} \mathrm{min}^{-1}$ nitrogen from room temperature to $1000{ }^{\circ} \mathrm{C}$, with heating rates of $10^{\circ} \mathrm{C} \mathrm{min}^{-1}$. Temperature calibration was performed using melting standards. Blank corrections with an empty cup were carried under the same heating program. 
Sample weights were determined ex-situ. Figure A3-2 shows the relative weight normalized for the initial weight as function of temperature, for the poly(POSS-imide)s thermalized under air and nitrogen atmosphere. All poly(POSS-imide)s in air and nitrogen atmosphere show a similar degradation offset temperature at a temperature above $300{ }^{\circ} \mathrm{C}$. The initial mass loss at temperatures below $300{ }^{\circ} \mathrm{C}$ is likely due to evaporation of adsorbed water. The weight loss between $300-500{ }^{\circ} \mathrm{C}$ follows a similar degradation mechanism for all poly(POSS-imide)s. The weight loss rate under nitrogen atmosphere is significantly lower than under air atmosphere, suggesting that carbonaceous degradation products are only partially removed in the absence of oxygen. Above $500{ }^{\circ} \mathrm{C}$, the weight loss rate decreases. Under air atmosphere the weight loss stabilizes for all imide bridge types, except for BPADA based poly(POSSimide)s. The distinct degradation process of the BPADA based poly(POSSimide) can be rationalized by the presence of the relatively stable quaternary carbon groups that are not present in the other poly(POSS-imide)s. Under nitrogen weight loss persists for all poly(POSS-imide)s, suggesting the degradation kinetics are relatively low in the absence of nitrogen.
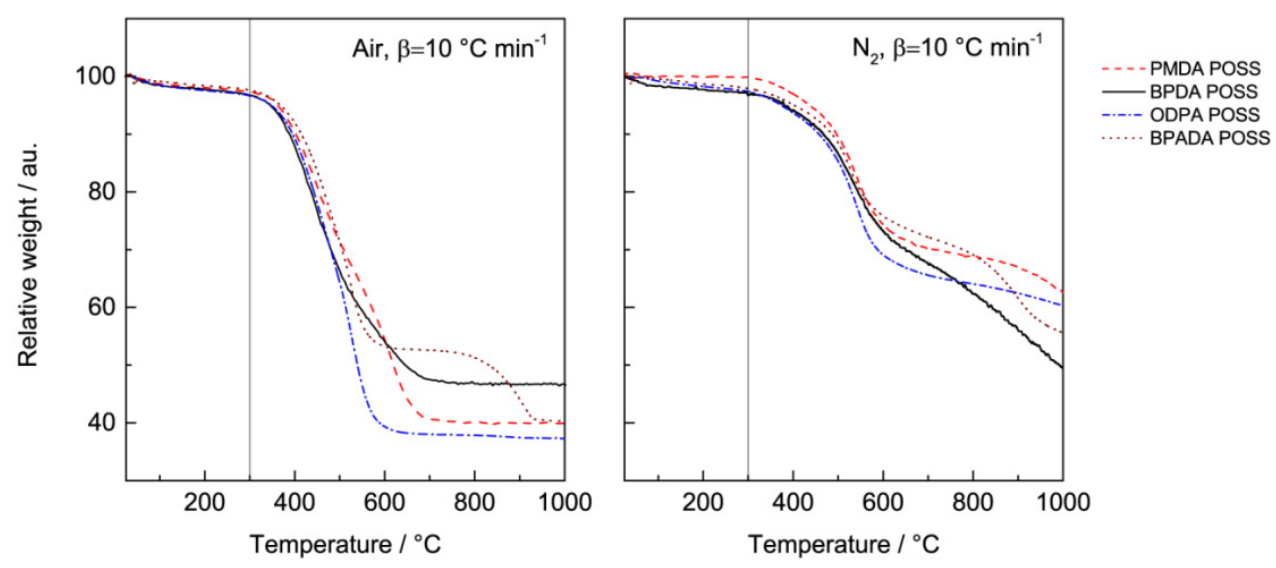

Figure A3-2. TGA mass loss curves of poly(POSS-imide)s prepared using PMDA, BPDA, ODPA and BPADA.

\section{Differential scanning calorimetry}

Differential scanning calorimetry (DSC) was performed on a DSC 8000 (Perkin Elmer, USA). Free-standing poly(POSS-imide) was placed in an aluminum sample pan and cycled from 50 to $300{ }^{\circ} \mathrm{C}$ with a heating rate of 20 
${ }^{\circ} \mathrm{C} \min ^{-1}$. Measurements were performed under $70 \mathrm{~mL} \min ^{-1}$ nitrogen. Temperature calibration was performed using melting standards. Blank corrections with an empty cup were carried under the same heating program. Sample weights were determined ex-situ. Four subsequent heating and cooling cycles were used to eliminate the influence of adsorbed water on the measurement. Figure A3-3 shows the heat flow of all poly(POSS-imide)s as function of temperature, corrected for a blank run and sample weight. The heat flow curves of all poly(POSS-imide)s display no transitions, underlining the lack of a glass transition in the material at temperatures up to $300{ }^{\circ} \mathrm{C}$. The heat capacity, represented by the slope of the curves, is largest for the BPDA based poly(POSS-imide). The ODPA based poly(POSS-imide) has the lowest calculated heat capacity. The PMDA and BPADA based poly(POSS-imide)s have similar heat flow profiles, suggesting the heat capacities are similar.

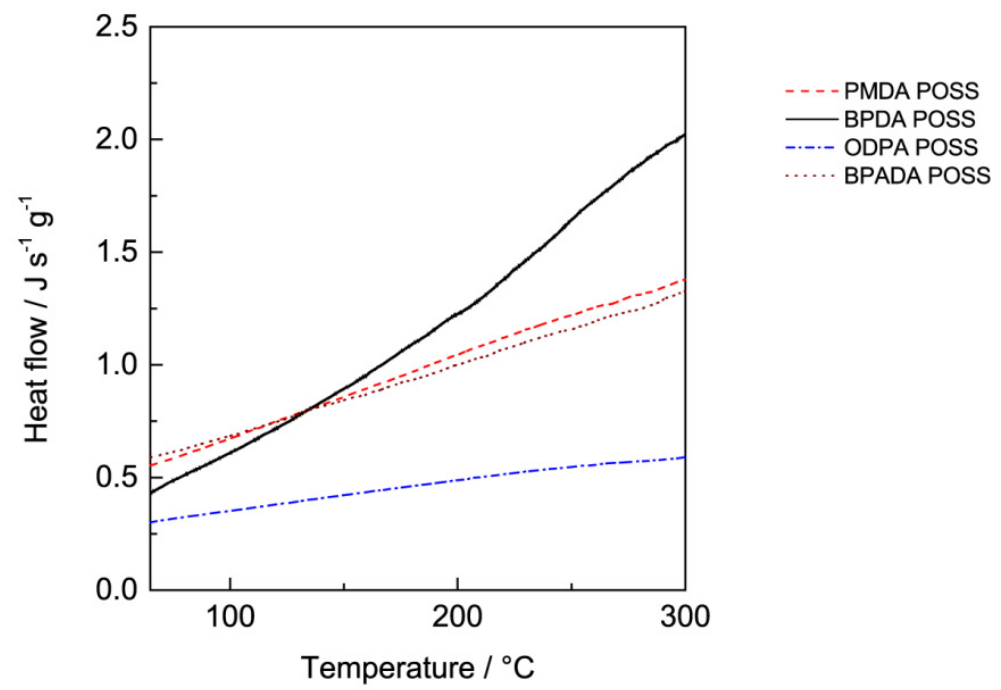

Figure A3-3. DSC curves of poly(POSS-imide) prepared using PMDA, BPDA, ODPA and BPADA.

\section{X-ray photoelectron spectroscopy}

$\mathrm{X}$-ray photoelectron spectroscopy measurements were performed on a Quantera SXM scanning XPS microprobe (Physical Electronics), using a monochromatic Al $\mathrm{K} \alpha$ source $(1486.6 \mathrm{eV})$. Octa-ammonium POSS powder and poly(POSS-imide) on $\alpha$-alumina discs coated with $3 \mu \mathrm{m}$ thick $\gamma$-alumina samples were measured. The elemental compositions of the poly(POSS- 
imide)s and octa-ammonium POSS powder are given in Table A3-2. For all poly(POSS-imide) samples an increase in carbon and oxygen content with respect to the POSS is observed, originating from imide bridge formation. The remaining sodium and chlorine are originating from the aqueous alkaline POSS solution.

Table A3-2 Elemental compositions of the poly(POSS-imide)s and octa-ammonium POSS powder.

\begin{tabular}{|l|l|l|l|l|l|l|}
\hline & \multicolumn{2}{|l|}{ Element } & \multicolumn{2}{l|}{} \\
\hline Sample & $\mathrm{C} 1 \mathrm{~s}$ & $\mathrm{~N} 1 \mathrm{~s}$ & $\mathrm{O} 1 \mathrm{~s}$ & $\mathrm{Na} 1 \mathrm{~s}$ & $\mathrm{C} 2 \mathrm{p}$ & $\mathrm{Si} 2 \mathrm{p}$ \\
\hline Octa-ammonium POSS & 47.8 & 9.8 & 22.0 & 0.8 & 9.0 & 11.5 \\
\hline $\begin{array}{l}\text { PMDA based poly(POSS- } \\
\text { imide) }\end{array}$ & 39.7 & 4.3 & 39.7 & 3.2 & 0.08 & 11.3 \\
\hline $\begin{array}{l}\text { BPDA based poly(POSS- } \\
\text { imide) }\end{array}$ & 42.7 & 4.8 & 37.8 & 2.5 & 0.1 & 10.3 \\
\hline $\begin{array}{l}\text { OPDA based poly(POSS- } \\
\text { imide) }\end{array}$ & 55.4 & 5.2 & 29.2 & 1.1 & 0.11 & 7.8 \\
\hline $\begin{array}{l}\text { ODPDA based poly(POSS- } \\
\text { imide) }\end{array}$ & 61.2 & 4.3 & 26.3 & 0.3 & 0.03 & 7.7 \\
\hline
\end{tabular}

The average number of imide bridged per POSS cage is calculated from the $\mathrm{Si} / \mathrm{C}, \mathrm{Si} / \mathrm{N}$ and $\mathrm{Si} / \mathrm{O}$ ratios of the poly(POSS-imide)s. For all poly(POSS-imide)s around 4 out of 8 functional groups on each POSS cage are bridged with an imide moiety. The absence of anhydride and carboxylic acid peaks in the FTIR-ATR spectra suggests that the imide bridges are connected with two POSS moieties. The carbon $(\mathrm{C} 1 \mathrm{~s})$ and nitrogen $(\mathrm{N} 1 \mathrm{~s})$ elemental spectra of octa-ammonium POSS powder and poly(POSS-imide)s are shown in Figure A3-4. The main differences between the C1s elemental spectrum of the poly(POSS-imide)s and the octa-ammonium POSS originates from the imide bonds and additional aliphatic and aromatic carbon groups. The emerged binding energy peak of the imide groups at $288 \mathrm{eV}$ is most pronounced. The deconvoluted peak surface area corresponds to a number of 4 imide groups per POSS cage. This in agreement with the N1s spectral data. The N1s elemental fit of octa-ammonium POSS shows two distinct peaks, attributed to the ammonia (401 eV) and amine (398.7) binding energies of the partially deprotonated ammonia groups. All poly(POSSimide) N1s spectra show a distinct shift towards lower binding energy groups. The shift can be attributed to an increase in amine and imide bond contribution to the N1s spectrum. About $50 \%$ of the nitrogen bonds in the deconvoluted N1s spectra 
can be attributed to imide groups. Table A3-3 gives the deconvoluted peak area distribution for the different binding energies associated with imide, amine and ammonia groups. The data suggests that around 4 out of 8 functional groups on each POSS cage are bridged with an imide moiety. This is in good agreement with the calculated numbers from the elemental ratios and with previously found results for 6FDA based poly(POSS-imide)s.

C1s

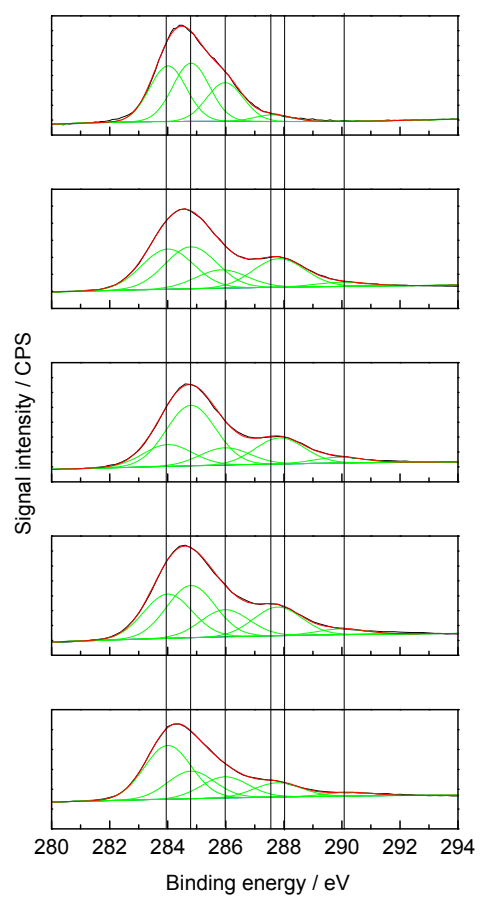

N1s

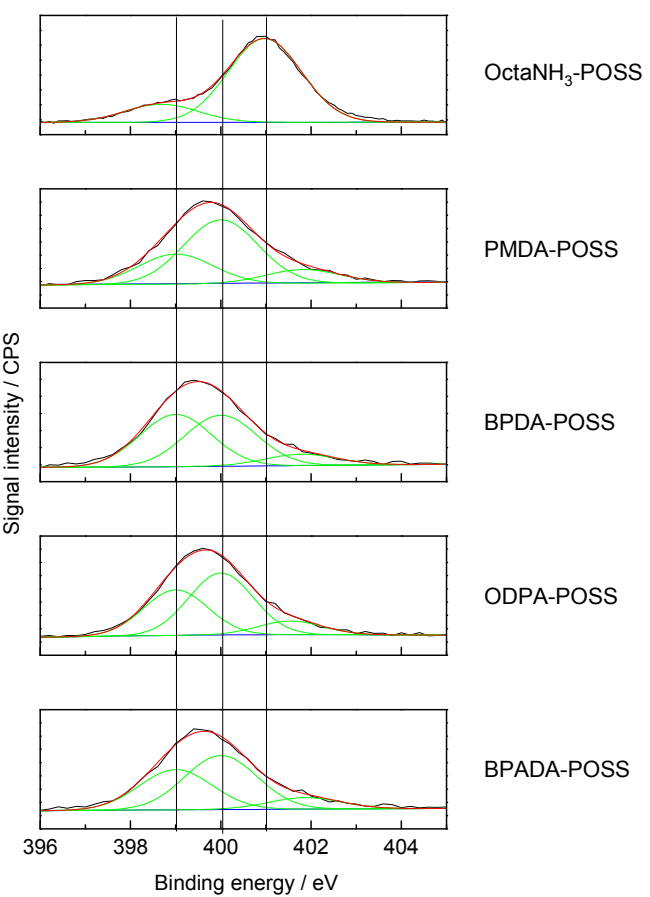

Figure A3-4. Deconvoluted XPS elemental spectra of C1s and N1s for poly(POSS-imide)s prepared using PMDA, BPDA, ODPA and BPADA.

Table A3-3. Deconvoluted XPS peak area distribution for the binding energies associated with amine, imide and ammonia binding energies

\begin{tabular}{|c|c|c|c|}
\hline & \multicolumn{3}{|c|}{ Deconvoluted peak area } \\
\hline & imide (\%) & amine (\%) & ammonia (\%) \\
\hline PMDA & 51.1 & 38.0 & 10.9 \\
\hline$\overline{B P D A}$ & 59.5 & 27.8 & 12.7 \\
\hline OPDA & 51.2 & 37.6 & 11.2 \\
\hline ODPDA & 44.5 & 45.6 & 9.9 \\
\hline Octa-NH 3 -POSS & 0 & 17.7 & 82.3 \\
\hline
\end{tabular}


Figure A3-5 shows the deconvoluted XPS elemental spectra of Si2p and O1s for octa-ammonium POSS and the poly(POSS-imide)s prepared with the different dianhydrides. The single binding energy of the Si2p spectrum of the octa-ammonium POSS corresponds to the attributed to the $\mathrm{SiO}_{3} \mathrm{C}$ groups of the POSS cage.
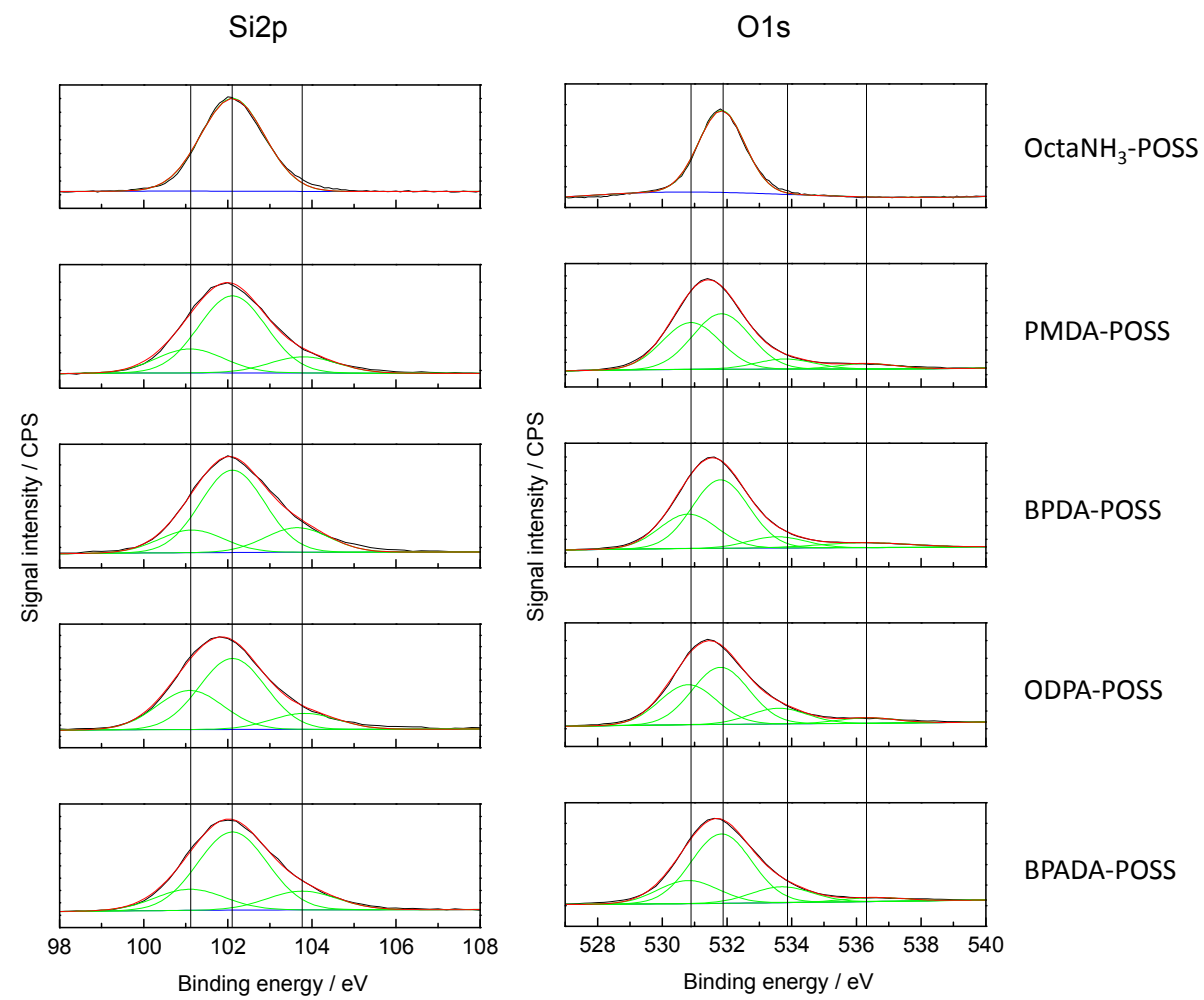

Figure A3-5. Deconvoluted XPS elemental spectra of Si2p and O1s for poly(POSS-imide)s prepared using PMDA, BPDA, ODPA and BPADA.

The poly(POSS-imide) Si2p spectra display a shift in binding energies towards both lower and higher binding energies. These peaks are associated with silanol and $\mathrm{SiO}^{-}$formed by partial hydrolysis of the POSS cage. The shift in binding energy and broadening of the XPS spectrum is mainly attributed to the formation of silanol groups. The single binding energy of the O1s spectrum of the octa-ammonium POSS corresponds to the siloxane bonds in the POSS cages. The O1s spectrum of the poly(POSS-imide)s show additional peaks at a binding energy of 530.7 and $532.6 \mathrm{eV}$, associated with the $\mathrm{C}=\mathrm{O}$ of the imide group and silanol bonds, respectively. The appearance of the silanol peak in 
the O1s spectrum is in agreement with the $\mathrm{Si} 2 \mathrm{p}$ spectrum of the poly(POSS-imide) samples.

\section{Attenuated Total Reflection - Fourier Transform Infrared Spectroscopy}

The chemical structures of the poly[POSS-(amic acid)] and poly(POSS-imide) were analyzed with Attenuated Total Reflection Fourier Transform Infrared Spectroscopy (ATR-FTIR) of free-standing films using an ALPHA FTIR Spectrometer (Bruker Optics Inc, Germany) equipped with a ZnSe crystal. All spectra were recorded at room temperature. Figure A3-6 shows the FTIRATR absorbance spectra of poly(POSS-imide)s prepared with PMDA, BPDA, ODPA and BPADA.

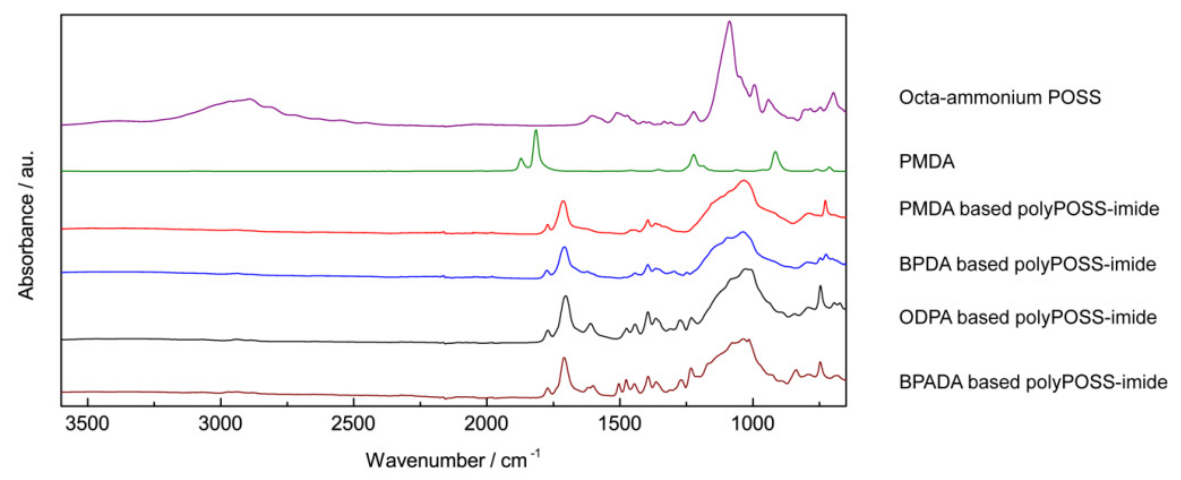

Figure A3-6 FTIR-ATR absorbance spectra of poly(POSS-imide)s prepared with PMDA, BPDA, ODPA and BPADA. The octa-ammonium POSS and PMDA spectra are given as reference. The PMDA spectrum is adapted from the NIST chemistry webbook. ${ }^{25}$

The octa-ammonium POSS and PMDA spectra are given as reference. The dianhydride peaks at 1820 and $1870 \mathrm{~cm}^{-1}$ for PMDA are not reflected in any of the poly(POSS-imide) spectra. The ammonia and water related peaks at $3200-2800 \mathrm{~cm}^{-1}$ are clearly visible in the octa-ammonium POSS spectrum. The poly(POSS-imide)s absorbance spectra only show slight absorbance in this region, underlining the absence of any carboxylic acid and ammonia groups in the poly(POSS-imide) layers. Table A3-4 and A3-5 show the bond and vibrational mode data as function of peak position for the poly[POSS-(amic acid)] and poly(POSS-imide)s respectively. 
Table A3-4. Poly[POSS-(amic acid)] bond and vibrational mode data as function of peak wavenumber position, for the poly(POSS-imide)s prepared with PMDA, BPDA, ODPA and BPADA.

\begin{tabular}{|c|c|c|c|c|c|c|}
\hline \multicolumn{7}{|c|}{ Poly[POSS-(amic acid)] } \\
\hline & PMDA & BPDA & ODPA & BPADA & & \\
\hline Wavenumber & Intensity & Intensity & Intensity & Intensity & Bond & Vibrational mode \\
\hline \multicolumn{7}{|l|}{$\mathrm{cm}^{-1}$} \\
\hline 693 & medium & medium & medium & medium & $\mathrm{C}-\mathrm{H}$ & out of plane bend \\
\hline 727 & shoulder & shoulder & shoulder & shoulder & & $\begin{array}{l}\text { O-substituted } \\
\text { benzene }\end{array}$ \\
\hline 746 & - & low & medium & medium & $\mathrm{CH}$ & $\begin{array}{l}\text { out of plane bend } \\
1,2,4 \text {, trisubstituted } \\
\text { benzene }\end{array}$ \\
\hline 773 & shoulder & shoulder & shoulder & shoulder & NH & def vib amide \\
\hline 798 & medium & medium & medium & medium & $\mathrm{NH} 2$ & $\begin{array}{l}\text { out of plane bend } \\
\text { of primary amine }\end{array}$ \\
\hline 837 & - & - & low & medium & $\mathrm{NH} 2$ & $\begin{array}{l}\text { out of plane bend } \\
\text { of primary amine }\end{array}$ \\
\hline 910 & shoulder & shoulder & shoulder & shoulder & $\mathrm{C}-\mathrm{C}$ & rocking \\
\hline 955 & shoulder & shoulder & shoulder & shoulder & $\mathrm{C}-\mathrm{C}$ & rocking \\
\hline 1000 & shoulder & shoulder & shoulder & shoulder & $\mathrm{C}-\mathrm{C}$ & rocking \\
\hline 1040 & high & high & high & high & Si-O cage & str \\
\hline 1093 & high & high & high & high & $\begin{array}{l}\text { Si-O } \\
\text { ladder }\end{array}$ & str \\
\hline 1120 & shoulder & shoulder & shoulder & shoulder & $\mathrm{C}-\mathrm{H}$ & in plane bending \\
\hline 1203 & medium & medium & medium & medium & $\mathrm{N}-\mathrm{H}$ & def \\
\hline 1228 & - & - & medium & high & $\begin{array}{l}\mathrm{C}-\mathrm{O} \\
\text { (ether) }\end{array}$ & str \\
\hline 1272 & - & - & medium & medium & $\begin{array}{l}\mathrm{C}-\mathrm{O}-\mathrm{C} \\
\text { (ether) }\end{array}$ & def vib \\
\hline 1370 & low & low & medium & high & $\begin{array}{l}\mathrm{C}=\mathrm{O} \text { or } \mathrm{C}- \\
\mathrm{N}\end{array}$ & str \\
\hline 1400 & medium & medium & high & high & $\begin{array}{l}\mathrm{C}=\mathrm{O} \text { or } \mathrm{C}- \\
\mathrm{N}\end{array}$ & str \\
\hline 1445 & low & low & medium & medium & $\mathrm{CH} 2$ & scissoring \\
\hline 1475 & - & - & medium & medium & $\mathrm{CH} 2$ & def vib \\
\hline 1504 & - & - & - & medium & $\mathrm{C}=\mathrm{C}$ & $\begin{array}{l}\text { srt (only for } \\
\text { electron donor } \\
\text { groups) }\end{array}$ \\
\hline 1560 & high & high & high & high & $\mathrm{N}-\mathrm{H}$ & bend amide \\
\hline
\end{tabular}




\begin{tabular}{|l|l|l|l|l|l|l|}
\hline 1620 & high & high & high & high & $\mathrm{C}=\mathrm{O}$ & str amide \\
\hline 1670 & high & high & high & high & $\mathrm{C}=\mathrm{O}$ & str carboxylic acid \\
\hline 1710 & - & - & - & - & $\mathrm{C}=\mathrm{O}$ & asym str imide \\
\hline 1770 & - & - & low & - & $\mathrm{C}-\mathrm{O}-\mathrm{C}$ & sym str \\
\hline 1845 & - & - & low & - & C-O-C & asym str \\
\hline 2878 & medium & medium & medium & medium & CH2 & sym str \\
\hline 2939 & medium & medium & medium & medium & CH2 & asym str \\
\hline 3068 & low & low & low & low & $\begin{array}{l}\mathrm{H} 2 \mathrm{O} / \mathrm{CO} \\
\text { OH }\end{array}$ & bend \\
\hline 3235 & broad & broad & broad & broad & $\begin{array}{l}\mathrm{H} 2 \mathrm{O} / \mathrm{CO} \\
\mathrm{OH}\end{array}$ & OH str \\
\hline 3380 & broad & broad & broad & broad & $\mathrm{NH} 2$ & asym str \\
\hline
\end{tabular}

Table A3-5. Poly(POSS-imide) bond and vibrational mode data as function of peak wavenumber position, for the poly(POSS-imide)s prepared with PMDA, BPDA, ODPA and BPADA.

\begin{tabular}{|c|c|c|c|c|c|c|}
\hline \multicolumn{7}{|c|}{ Poly(POSS-imide) } \\
\hline & PMDA & BPDA & ODPA & BPADA & & \\
\hline Wavenumber & Intensity & Intensity & Intensity & Intensity & Bond & Vibrational mode \\
\hline \multicolumn{7}{|l|}{$\mathrm{cm}^{-1}$} \\
\hline 693 & medium & medium & medium & medium & $\mathrm{C}-\mathrm{H}$ & out of plane bend \\
\hline 725 & medium & medium & low & low & $\mathrm{N}-\mathrm{H}$ & wagging \\
\hline 746 & - & low & medium & medium & $\mathrm{CH}$ & $\begin{array}{l}\text { out of plane } 1,2,4 \text {, } \\
\text { trisubstituted } \\
\text { benzene }\end{array}$ \\
\hline 773 & shoulder & shoulder & shoulder & shoulder & $\mathrm{NH}$ & def vib amide \\
\hline 793 & low & low & low & low & $\mathrm{NH} 2$ & $\begin{array}{l}\text { out of plane bend } \\
\text { of primary amine }\end{array}$ \\
\hline 837 & - & - & low & medium & $\mathrm{NH} 2$ & $\begin{array}{l}\text { out of plane bend } \\
\text { of primary amine }\end{array}$ \\
\hline 910 & shoulder & shoulder & shoulder & shoulder & $\mathrm{C}-\mathrm{C}$ & rocking \\
\hline 965 & shoulder & shoulder & shoulder & shoulder & $\mathrm{C}-\mathrm{C}$ & rocking \\
\hline 1000 & shoulder & shoulder & shoulder & shoulder & $\mathrm{C}-\mathrm{C}$ & rocking \\
\hline 1040 & high & high & high & high & Si-O cage & str \\
\hline 1093 & high & high & high & high & $\begin{array}{l}\text { Si-O } \\
\text { ladder }\end{array}$ & str \\
\hline 1120 & shoulder & shoulder & shoulder & shoulder & $\mathrm{C}-\mathrm{H}$ & in plane bending \\
\hline
\end{tabular}




\begin{tabular}{|c|c|c|c|c|c|c|}
\hline 1228 & - & - & high & high & $\begin{array}{l}\mathrm{C}-\mathrm{O} \\
\text { (ether) }\end{array}$ & str \\
\hline 1272 & - & - & medium & medium & $\mathrm{C}-\mathrm{O}-\mathrm{C}$ & def vib \\
\hline 1364 & low & low & medium & medium & $\begin{array}{l}\mathrm{C}=\mathrm{O} \text { or } \mathrm{C}- \\
\mathrm{N}\end{array}$ & str \\
\hline 1393 & medium & medium & high & high & $\begin{array}{l}\mathrm{C}=\mathrm{O} \text { or } \mathrm{C}- \\
\mathrm{N}\end{array}$ & str \\
\hline 1445 & low & low & medium & medium & $\mathrm{CH} 2$ & scissoring \\
\hline 1475 & - & - & medium & medium & $\mathrm{CH} 2$ & def vib \\
\hline 1504 & - & - & - & medium & $\mathrm{C}=\mathrm{C}$ & $\begin{array}{l}\text { srt (only for } \\
\text { electron donor } \\
\text { groups) }\end{array}$ \\
\hline 1610 & - & - & medium & medium & $\mathrm{C}=\mathrm{O}$ & str amide \\
\hline 1670 & - & - & - & - & $\mathrm{C}=\mathrm{O}$ & str carboxylic acid \\
\hline 1710 & high & high & high & high & $\mathrm{C}=\mathrm{O}$ & asym str imide \\
\hline 1770 & low & low & low & low & $\mathrm{C}=\mathrm{O}$ & sym str imide \\
\hline 2878 & medium & medium & medium & medium & $\mathrm{CH} 2$ & sym str \\
\hline 2939 & medium & medium & medium & medium & $\mathrm{CH} 2$ & asym str \\
\hline 3068 & low & low & low & low & $\begin{array}{l}\mathrm{H} 2 \mathrm{O} / \mathrm{CO} \\
\mathrm{OH}\end{array}$ & bend \\
\hline 3235 & broad & broad & broad & broad & $\begin{array}{l}\mathrm{H} 2 \mathrm{O} / \mathrm{CO} \\
\mathrm{OH}\end{array}$ & $\mathrm{OH}$ str \\
\hline 3380 & broad & broad & broad & broad & $\mathrm{NH} 2$ & asym str \\
\hline
\end{tabular}

\subsection{References}

1. Maier, G. Angewandte Chemie - International Edition 1998, 37, (21), 2961-2974

2. Raaijmakers, M. J. T.; Hempenius, M. A.; Schön, P. M.; Vancso, G. J.; Nijmeijer, A.; Wessling, M.; Benes, N. E. Journal of the American Chemical Society 2013, 136, (1), 330-335.10.1021/ja410047u

3. Koros, W. J.; Woods, D. G. Journal of Membrane Science 2001, 181, (2), 157-166

4. Le, N. L.; Chung, T. S. Journal of Membrane Science 2014, 454, 62-73

5. Lee, Y. J.; Huang, J. M.; Kuo, S. W.; Chang, F. C. Polymer 2005, 46, (23), 1005610065

6. Chua, M. L.; Shao, L.; Low, B. T.; Xiao, Y.; Chung, T. S. Journal of Membrane Science 2011, 385-386, (1), 40-48

7. Li, Y.; Chung, T. S. International Journal of Hydrogen Energy 2010, 35, (19), 1056010568

8. $\quad$ Laine, R. M.; Roll, M. F. Macromolecules 2011, 44, (5), 1073-1109

9. Nischang, I.; Brüggemann, O.; Teasdale, I. Angewandte Chemie - International Edition 2011, 50, (20), 4593-4596

10. Oaten, M.; Choudhury, N. R. Macromolecules 2005, 38, (15), 6392-6401 
11. Wu, G.; Su, Z. Chemistry of Materials 2006, 18, (16), 3726-3732

12. Zhang, C.; Babonneau, F.; Bonhomme, C.; Laine, R. M.; Soles, C. L.; Hristov, H. A.; Yee, A. F. Journal of the American Chemical Society 1998, 120, (33), 8380-8391

13. Dalwani, M.; Zheng, J.; Hempenius, M.; Raaijmakers, M. J. T.; Doherty, C. M.; Hill, A. J.; Wessling, M.; Benes, N. E. Journal of Materials Chemistry 2012, 22, (30), 14835-14838

14. Diaham, S.; Locatelli, M. L.; Lebey, T.; Malec, D. Thin Solid Films 2011, 519, (6), 1851-1856.

15. Neyertz, S.; Gopalan, P.; Brachet, P.; Kristiansen, A.; Männle, F.; Brown, D. Soft Materials 2014, 12, (1), 113-123

16. Rezac, M. E.; Koros, W. J.; Miller, S. J. Journal of Membrane Science 1994, 93, (2), 193-201

17. Berchtold, K. A.; Singh, R. P.; Young, J. S.; Dudeck, K. W. Journal of Membrane Science 2012, 415-416, 265-270

18. Kumbharkar, S. C.; Liu, Y.; Li, K. Journal of Membrane Science 2011, 375, (1-2), 231-240

19. Li, X.; Singh, R. P.; Dudeck, K. W.; Berchtold, K. A.; Benicewicz, B. C. Journal of Membrane Science 2014, 461, 59-68

20. Calle, M.; Doherty, C. M.; Hill, A. J.; Lee, Y. M. Macromolecules 2013, 46, (20), 8179-8189

21. Calle, M.; Lozano, A. E.; Lee, Y. M. European Polymer Journal 2012, 48, (7), 13131322

22. Joseph, W. D.; Abed, J. C.; Mercier, R.; McGrath, J. E. Polymer 1994, 35, (23), 50465050

23. Kim, S.; Han, S. H.; Lee, Y. M. Journal of Membrane Science 2012, 403-404, 169178

24. Ree, M.; Kim, K.; Woo, S. H.; Chang, H. Journal of Applied Physics 1997, 81, (2), 698-708.

25. Stein, S. E., Infrared Spectra. NIST Mass Spec Data Center. 
Chapter 4

\section{Thermal imidization kinetics of ultrathin films of hybrid poly(POSS-imide)s}

This chapter has been adapted from:

Raaijmakers, M.J.T., E.J. Kappert, A. Nijmeijer, N.E. Benes, Thermal imidization kinetics of ultrathin films of hybrid poly(POSS imide)s, Macromolecules, DOI 10.1021/acs.macromol.5b00473 


\section{$150^{\circ} \mathrm{C}<T_{\text {imidization }} 300^{\circ} \mathrm{C}$}

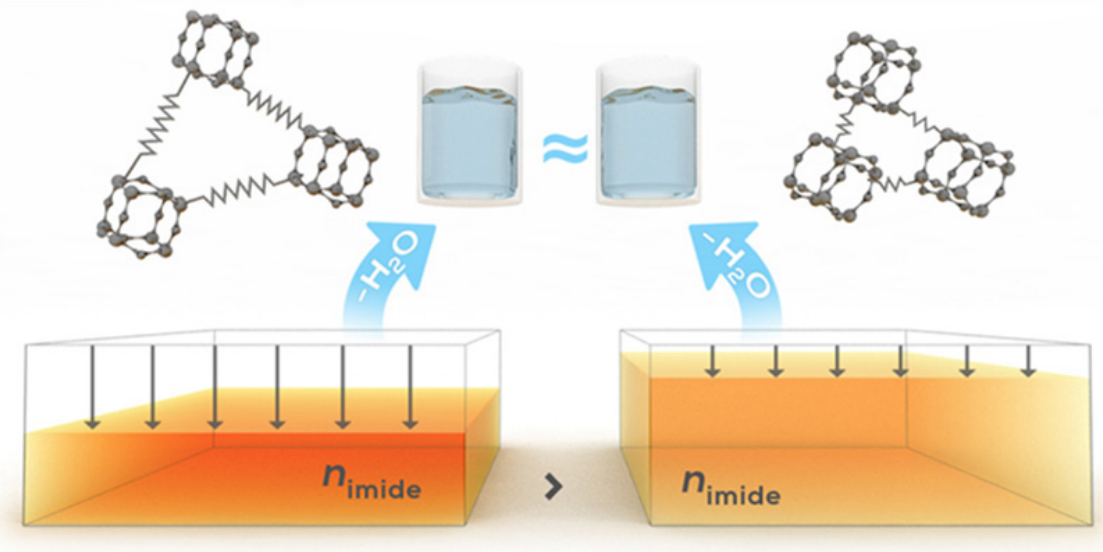

\section{Abstract}

In the thermal imidization of an alternating inorganic-organic hybrid network, there is an inverse relationship between the length and flexibility of the organic bridges and the extent of the layer shrinkage. The hybrid material studied here consists of polyhedral oligomeric silsesquioxanes that are covalently bridged by amic acid groups. During heat treatment, shrinkage of the materials occurs due to the removal of physically bound water, imidization of the amic acid groups, and silanol condensation. For five different bridging groups with different lengths and flexibilities, comparable mass reductions are observed. For the shorter bridging groups, the dimensional changes are hindered by the limited network mobility. Longer, more flexible bridging groups allow for much greater shrinkage. The imidization step can be described by a decelerating reaction mechanism with an onset at $150{ }^{\circ} \mathrm{C}$ and shows a higher activation energy than in the case of entirely organic polyimides. The differences in the imidization kinetics between hybrid and purely organic materials demonstrates the need for close study of the thermal processing of hybrid, hyper-cross-linked materials. 


\subsection{Introduction}

Hybrid network materials exhibit properties that are distinct from their individual organic and inorganic constituents. These unique properties are a result of the interplay between flexible organic bridges and rigid inorganic domains. ${ }^{1-3}$ Due to their chemical and thermal stability, aromatic imides are relevant candidates for the organic component in hybrid polymers. Most of these hybrid polyimides are based on sol-gel-derived silica-imide networks ${ }^{4,5}$ or polyhedral oligomeric silsesquioxane (POSS)-derived materials. These POSS-derived materials can consist of a network of alternating POSS and imide groups ${ }^{6-8}$ POSS cages that are covalently bound to oligomeric imides, ${ }^{9-}$ ${ }^{13}$ or POSS cages that are tethered to a polyimide main chain as side or end group. $^{14,15}$

To synthesize polyimide-based hybrid polymers, poly(amic acid) precursors are thermally processed to convert the amic acid groups to chemically and thermally robust imide groups. Compared to fully organic poly(amic acid)s, differences in the mobility of the functional groups in the hybrid material can strongly affect the imidization reaction kinetics and structural rearrangements. ${ }^{8}$ Therefore, a thermal processing strategy designed for an organic imide cannot simply be applied to its hybrid counterpart. Only a few studies have reported on the changes in the physical properties during thermal treatment of hybrid polyimides. ${ }^{10,16,17}$ Often, only the properties before and after the imidization step are measured, and the mechanisms of the thermally activated processes remain a black box.

Optimization of the thermal treatment step is crucial for obtaining a fully imidized material without significant decomposition of the organic moieties. Thermal imidization of hybrid imides most often needs to be performed in the solid state because of the limited solubility of the highly cross-linked networks. Solid-state thermal imidization has been studied ex situ using UV-vis, ${ }^{18,}{ }^{19}$ infrared, ${ }^{19}$ and Raman spectroscopy. ${ }^{20}$ In situ tracking of the imidization can be performed using TGA-MS, ${ }^{21}$ in situ infrared spectroscopy, ${ }^{22}$ and interferometry. ${ }^{23-25}$ The resulting data can be used to study the reaction kinetics. Past studies on these reactions unanimously agree on a decelerating reactivity, ${ }^{20,} 26-29$ first-order reaction models $\mathrm{s}^{26-28}$ and diffusion models ${ }^{29}$ have both been proposed. Most of these studies were performed on bulk materials, but in many applications, the materials are used as thin films. The length-scale confinement in ultrathin films can affect the time scale of diffusion-limited processes and, thus, result in different apparent kinetics. 
Here, we explore the concurrent imidization and structural rearrangements of ultrathin POSS-based hybrid materials using a combination of time-resolved techniques. The changes to the materials chemistry in the bulk have been studied via TGA-MS, allowing for the assignment of the mass loss processes to specific chemical reactions. Thermo-ellipsometric analysis (TEA) has been applied to follow the changes in the layer thickness and refractive index during thermal treatment. To assess the influence of the organic moiety on the behavior of the hybrid material, the five different organic linking groups given in Scheme 4-1 were studied. We conclude that the length and flexibility of the dianhydride precursor is an important factor that influences the network mobility during the imidization reaction, resulting in lower density films for shorter bridges.
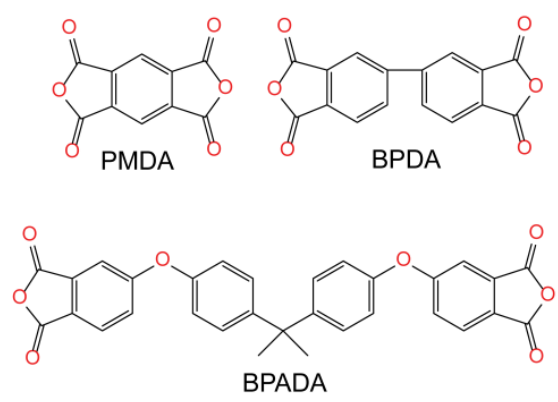
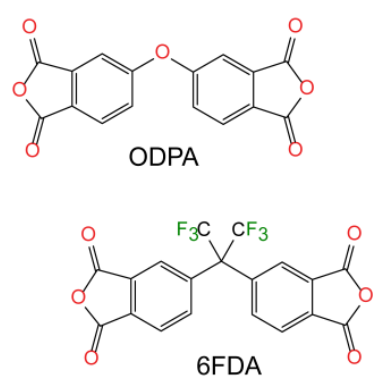

6FDA

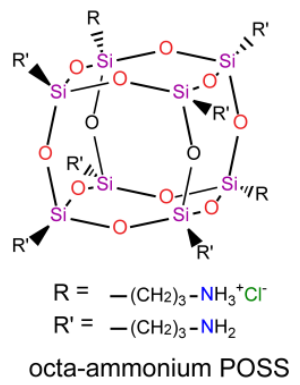

octa-ammonium POSS

Scheme 4-1. Structural formulas of the dianhydrides used as precursors for the crosslinking POSS-cages.

\subsection{Experimental section}

\subsubsection{Synthesis of poly[POSS-(amic acid)]s by interfacial polymerization.}

Toluene (anhydrous 99.8\%, Sigma-Aldrich), 4,4-(hexafluoroisopropylidene) diphthalic anhydride (6FDA, Sigma-Aldrich), pyromellitic dianhydride (PMDA, Sigma-Aldrich), 3,3',4,4'-biphenyl tetracarboxylic dianhydride (BPDA, Sigma-Aldrich), 4,4'-oxydiphthalic anhydride (ODPA, Sigma-Aldrich), 4,4'-(4,4'-isopropylidene diphenoxy) bis(phthalic anhydride) (BPADA, Sigma-Aldrich), ammonium chloride-functionalized POSS (octa-ammonium POSS $^{\circledR}$, Hybrid Plastics) and sodium hydroxide $(\mathrm{NaOH}$, Sigma-Aldrich) were used as received. The POSS was dissolved in water. To partially convert the ammonium groups to reactive amine groups, the $\mathrm{pH}$ was adjusted to 9.9 using $1 \mathrm{M} \mathrm{NaOH}$. Bulk poly[POSS-(amic acid)] was prepared by vigorously stirring a mixture of a 0.9 wt- $\%$ aqueous solution of 
octa-ammonium POSS and a 0.075 wt.\% dianhydride solution in toluene, which was filtered to remove any undissolved dianhydride. After reacting for several hours, the poly[POSS-(amic acid)] was removed from the toluene and water by vacuum filtration using a Büchner funnel, followed by rinsing with acetone to remove residual reactants. Poly[POSS-(amic acid)] membranes were prepared via interfacial polymerization on top of $\gamma$-alumina-coated $\alpha$-alumina discs. The $\alpha$-alumina discs were pre-wetted with the 0.9 wt.\% aqueous POSS solution for $15 \mathrm{~min}$ under a 500-mbar vacuum, followed by drying for $30 \mathrm{~min}$ at room temperature. Subsequently, a solution of the dianhydride in toluene was poured onto the discs. After $5 \mathrm{~min}$, the toluene was removed, and the samples were rinsed with acetone.

The structures and properties of the poly[POSS-(amic acid)] and poly(POSSimide) samples were determined using infrared spectroscopy, X-ray photoelectron spectroscopy, differential scanning calorimetry, atomic force microscopy and gas permeability at elevated temperatures in previous work on these hybrid materials. ${ }^{6,30}$

\subsubsection{Characterization of thin films.}

Thermogravimetric analysis (TGA) was performed using an STA 449 F3 Jupiter $^{\mathbb{B}}$ (Netzsch), equipped with a TG-only sample holder. Measurements were performed under $70 \mathrm{~mL} \mathrm{~min}{ }^{-1} \mathrm{~N}_{2}$ flow with a heating rate of $20{ }^{\circ} \mathrm{C} \mathrm{min}{ }^{-1}$ from 50 to $1200{ }^{\circ} \mathrm{C}$. Temperature calibration was performed using melting standards. Measurements were run sample-temperature controlled. The sample masses were determined using an internal balance exactly $30 \mathrm{~min}$ after inserting the sample. A consistent residence time in the purge gas prior to measurement was found to be a crucial parameter to obtain reproducible TGA graphs. The gases that evolved during the thermogravimetric analysis were transferred to a mass spectrometer (QMS 403 D Aëolos ${ }^{\circledR}$, Netzsch). TGA and MS start times were synchronized, but no correction was applied for the time offset caused by the transfer line time (estimated $<30 \mathrm{sec}$, systematic offset). First, a bar graph scan for $m / z=1-100 \mathrm{amu}$ was recorded for all poly(POSSamic acid) samples in the $\mathrm{N}_{2}$ atmosphere to determine the evolving $\mathrm{m} / \mathrm{z}$ numbers (data not shown). The detected $\mathrm{m} / \mathrm{z}$ numbers were selected and recorded more accurately in multiple-ion-detection mode with a dwell of 0.5 sec per $\mathrm{m} / \mathrm{z}$ value at a resolution of 50 . 


\subsubsection{Kinetic analysis}

The samples that were designated for kinetic analysis were stored under vacuum at $30{ }^{\circ} \mathrm{C}$ for 24 hours prior to analysis to remove any sorbed water. The measurements were performed using a $\mathrm{N}_{2}$ flow rate of $70 \mathrm{ml} \mathrm{min}^{-1}$ with heating rates $(\beta)$ of $5,10,15$, and $20^{\circ} \mathrm{C} \mathrm{min}^{-1}$ over the range from 50 to $1200{ }^{\circ} \mathrm{C}$. Blank corrections with an empty cup were performed at every heating rate. The mass loss was converted to the normalized conversion $(\alpha)$. The activation energies were determined using the modified advanced isoconversional method that allows for analyzing non-linear temperature programs and variations in the apparent activation energy with $\alpha .{ }^{31-33}$ The resulting activation energies were used as starting values for multivariate analysis of the kinetics using a multistep parallel reaction model described by

$$
\frac{\mathrm{d} \alpha_{i}}{\mathrm{~d} t}=A_{i} \exp \left[\frac{-E_{\mathrm{a}, i}}{R T(t)}\right] f_{i}(\alpha)
$$

Equation 4-1 was fit by minimizing the residual sum of squares (RSS) between the data and the fit using the patternsearch algorithm in Matlab. The individual steps were fitted with 14 different reaction models, ${ }^{34}$ and the resulting $R S S$ were used to determine the most accurate reaction model. Using the selected reaction models, all steps were fitted simultaneously, with $A_{i}, E_{\mathrm{a}, i}$, and $w_{i}$ as fitting parameters for every individual step $i$, where the sum of the weights $w_{\mathrm{i}}$ was set to 1 .

\subsubsection{Characterization of thin films by thermo-ellipsometric analysis (TEA)}

The thicknesses and refractive indices of the poly[POSS-(amic acid)] films were measured as a function of time and temperature to track the progress of the thermal imidization. Measurements were performed on an M2000-X ellipsometer (J.A. Woollam Co.) equipped with a temperature-controlled hot-stage (HCS622, INSTEC), calibrated using melting point standards. The spectroscopic ellipsometry measurements were conducted in the full wavelength range of $210-1000 \mathrm{~nm}$. For the room temperature measurements, spectra were recorded with $65^{\circ}, 70^{\circ}$, and $75^{\circ}$ angles of incidence; measurements at elevated temperatures were performed under a single angle of incidence of $70^{\circ}$. During the experiments, the hot stage was continuously purged with ultrapure $\mathrm{N}_{2}$. Prior to the thermal treatment, the films were held under vacuum in the measurement cell for two hours at $100{ }^{\circ} \mathrm{C}$, followed by a 
30-minute dwell at $50{ }^{\circ} \mathrm{C}$. Subsequently, the samples were heated to $300{ }^{\circ} \mathrm{C}$ at a heating rate of $5{ }^{\circ} \mathrm{C} \mathrm{min}^{-1}$. The sample was held at $300{ }^{\circ} \mathrm{C}$ for at least 6 hours to ensure completion of the imidization process. After the dwell, the sample was cooled to room temperature at the fastest attainable cooling rate $\left(>50^{\circ} \mathrm{C}\right.$ $\left.\min ^{-1}\right)$.

\title{
4.2.5. TEA data analysis
}

CompleteEASE (v.4.86, J.A. Woollam Co.) was used for the data analysis. The optical model used to model the layer on top of the $\gamma$-alumina-coated $\alpha$-alumina disc is visualized in Figure 4-2. The layered optical model was constructed by first measuring the bare substrate and, subsequently, measuring each individually applied layer. All layers are characterized by their thickness $d$ and their refractive index $n(\lambda)$. The wavelength-dependency of $n$ is modeled by an optical dispersion. Due to light scattering below $\lambda=500 \mathrm{~nm}$, the wavelength range was limited to $500-1000 \mathrm{~nm}$.

\section{SEM micrograph}

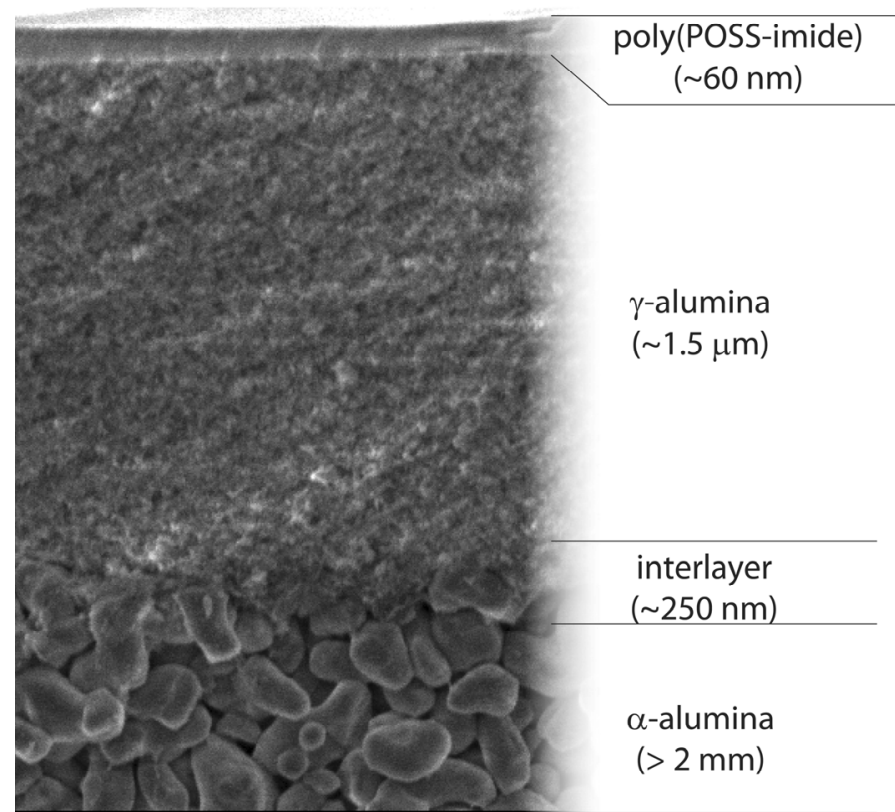

\section{Layer assignment}

\section{(fit parameter)}

Cauchy $[d, n(A, B)]$

\section{$\operatorname{EMA}\left(\Phi_{\text {void' }} d\right)$ of: Cauchy $[n(A, B, C)]$} Void

\author{
$\operatorname{EMA}\left(\Phi_{\text {void' }} d\right)$ of: \\ Cauchy $[n(A, B, C)]$ \\ Void \\ EMA-support ( $\left.\Phi_{\text {void }}\right)$ of: \\ Cauchy $[n(A, B, C)]$ \\ Void
}

Figure 4-2: Optical model of a poly(POSS-imide) layer on top of a $\gamma$-alumina-coated $\alpha$-alumina disc. The cross-section scanning electron micrograph of the supported layer shows the distinct morphology of the dense poly(POSS-imide) layer, the $1.5-\mu \mathrm{m} \quad \gamma$-alumina layer and the macroporous $\alpha$-alumina support. 
The $\alpha$-alumina disc was modeled using Bruggeman's Effective Medium Approximation (EMA) of alumina ${ }^{35}$ and void $(n=1)$ with porosity $\Phi_{\text {void,substrate. }}$ The roughness of the ceramic disc is modeled by a gradient in the porosity; ${ }^{36}$ this layer is converted to an intermix layer between the $\alpha$-alumina substrate and the $\gamma$-alumina coating to model infiltration of the coating layer into the substrate. The $\gamma$-alumina layer was also modeled using an EMA of alumina and void $(n=1)$ with porosity $\Phi_{\text {void }, \gamma \text {-alumina. }}$ The layer thickness and refractive index of the poly[POSS-(amic acid)] layers were modeled by a Cauchy optical dispersion, assuming transparency of the hybrid material in the wavelength range of 500-1000 nm. In the final fit, the thickness and optical dispersion were fit using the porosity of the $\gamma$-alumina layer and the porosity of the interlayer. Inclusion of the latter two parameters is required to correct for the changes in the residual water content in the $\gamma$-alumina pores.

\subsection{Results and discussion}

\subsubsection{Imidization and thermal stability of the poly[POSS-(amic acid)] groups}

The successful synthesis of poly[POSS-(amic acid)]s has been reported previously. ${ }^{6,30}$ The poly[POSS-(amic acid)] can be converted to poly(POSSimide)s by heating. The conversion of amic acid groups to imide groups is accompanied by the release of water [Scheme A4-1, Appendix]. Figure 4-3 shows the mass loss and the primary evolved gases upon heating for five different poly[POSS-(amic acid)]s. All five materials display a mass loss in four different mass steps, indicated by bold numerals (1, 2, 3, and 4) throughout the manuscript. Every step involves the loss of water from the material. The first three steps occur below $350{ }^{\circ} \mathrm{C}$ and are attributed to the removal of physically bound water (1), amic acid condensation and/or imidization (2), and dehydroxylation due to silanol condensation (3). A fourth step, recorded at temperatures exceeding $350{ }^{\circ} \mathrm{C}$, involves the thermal decomposition of the hybrid material (4). These four steps will be discussed in more detail.

The removal of physically bound water (1) occurs from room temperature to $\sim 250{ }^{\circ} \mathrm{C}$. The $\mathrm{CO}_{2}$ that is released during this step can originate from a decarboxylation reaction of either unreacted carboxylic acid groups or noncyclized amic acid groups. Additionally, $\mathrm{CO}_{2}$ may have been sorbed by the POSS-material, leading to $\mathrm{CO}_{2}$ release at low temperatures. 
The imidization of the material (2) occurs in the temperature range $150-300{ }^{\circ} \mathrm{C}$, agreeing well with previous observations by infrared spectroscopy of the imidization temperature range of these hybrid polyimides. ${ }^{6}$ This step can overlap with the condensation of amic acid moieties of hydrolyzed or partially reacted organic bridges. Subsequently, these newly formed amic acid groups are available as additional groups for imidization. Mainly water evolves during step $\mathbf{2}$. The water loss is higher than would be expected based on an imidization step alone. Because the drying overlaps with the imidization (2) step, the mass loss below $300{ }^{\circ} \mathrm{C}$ can be associated with both drying and imidization. For the ODPA and 6FDA-based samples, a small amount of organic components is also detected. These components may be the result of the sublimation of unreacted organic groups.

It is unlikely that the water release during step $\mathbf{3}$ corresponds to a distinct second imidization step. Although the imidization is reported to occur via a two-step reaction (see, e.g., ${ }^{27}$ ), these steps are reported to directly follow each other. This step would then be detected as a unimodal, non-Gaussian peak, rather than a bimodal peak. Therefore, we hypothesize that the water release originates from a condensation reaction of silanol groups. The silanol groups are formed via the partial hydrolysis of POSS cages in the presence of $\mathrm{NaOH}$ in the aqueous solution used for interfacial polymerization. ${ }^{6,37,38}$ The silanol condensation is supported by the observed disappearance of the silanol absorbance band and simultaneous manifestation of POSS cage and ladder bands in the attenuated total reflection Fourier transform infrared spectroscopy (ATR-FTIR) measurements (Scheme A4-2 and Figure A4-1, Appendix).

The onset of the decomposition (4) at $\sim 350{ }^{\circ} \mathrm{C}$ is found at the same temperature for all of the different organic materials. This observation suggests that the weakest link is found in the POSS-precursor. Theoretically, the aliphatic propyl-chain connecting the POSS-cage to the amine group is expected to have the lowest thermal stability. ${ }^{39}$ The detection of $\mathrm{C}_{3} \mathrm{H}_{x}$ components during the decomposition step in the TGA-MS analysis at lower temperatures than any other evolved organic components suggests that the propyl-group in the POSS-cage indeed forms the weakest link. Although the majority of the decomposition occurs between 350 and $650{ }^{\circ} \mathrm{C}$, a minor mass loss associated with the release of $\mathrm{CO}_{2}$ and methane is found to continue up to $1200{ }^{\circ} \mathrm{C}$, indicating that organic groups are still present at these temperatures. 

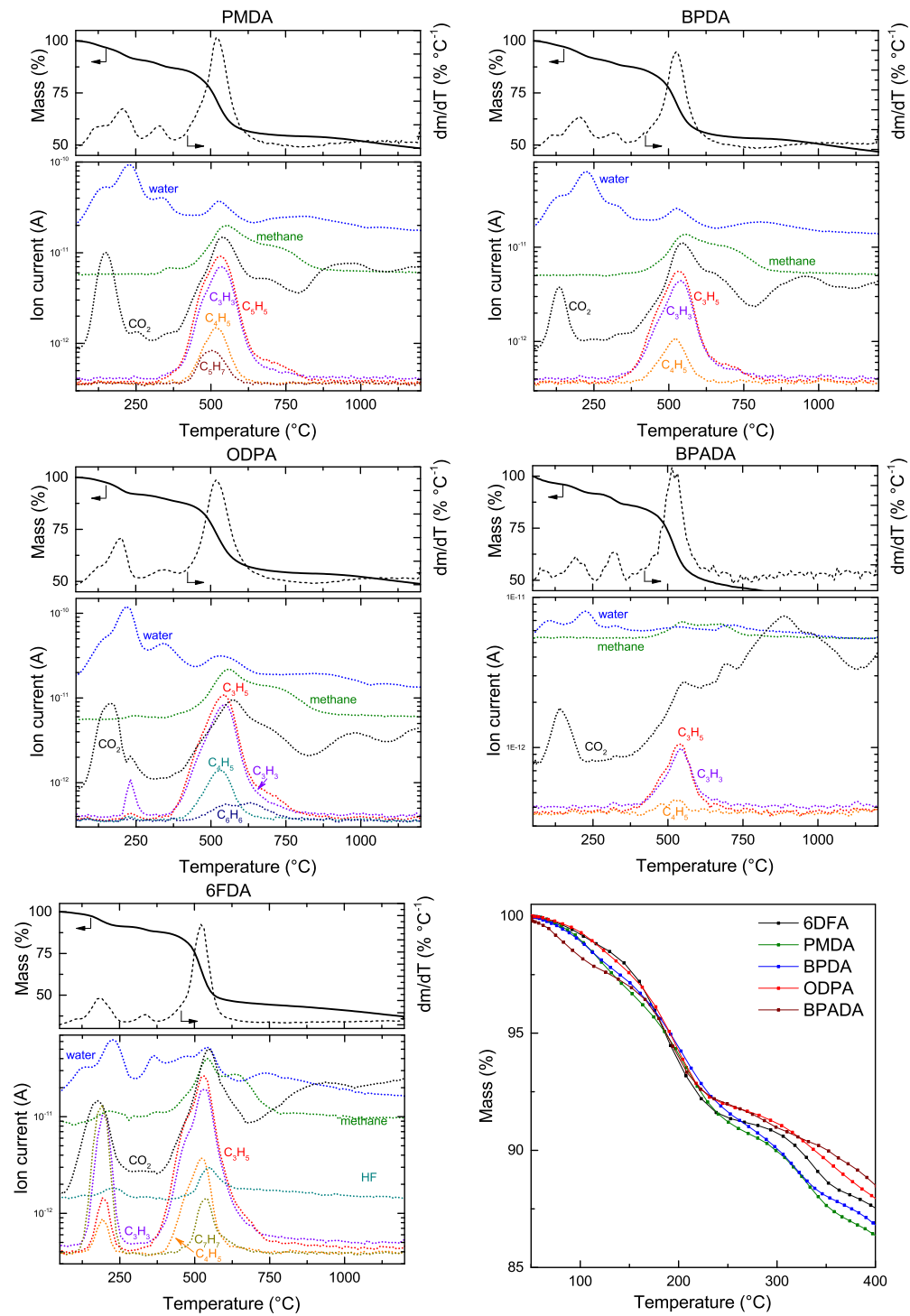

Figure 4-3: (all except for the bottom right graph) TGA-MS data: the relative mass and the differential mass loss (top panels) and the evolved gases (bottom panels) as a function of temperature for the poly[POSS-(amic acid)]s prepared using the different dianhydrides. All samples were heated under $\mathrm{N}_{2}$ at $20{ }^{\circ} \mathrm{C} \mathrm{min}^{-1}$. (bottom right graph) Comparison of the changes in sample mass as function of the temperature for the different bridging groups.

In Figure 4-3 (bottom right graph), the mass loss curve of the 5 different poly[POSS-(amic acid)]s are compared in the temperature range $50-400{ }^{\circ} \mathrm{C}$. 
The relative mass loss up to $300{ }^{\circ} \mathrm{C}$, which is associated with drying (1), imidization (2), and silanol condensation (3), is comparable for all of the poly[POSS-(amic acid)]s. The similarity in the mass losses can be rationalized by the similar number of amic acid, unreacted amine, and silanol groups in all samples, as was apparent from the XPS analysis in previous studies. ${ }^{30}$ Because the high molar mass of the POSS-cages dominates the mass of the polymer, the differences in the masses of the organic bridges will only have a marginal influence on the differences in the molecular weights of the synthesized network. As a result, the relative amount of mass released during imidization and silanol condensation will also be similar. Moreover, because the physisorbed water will mainly be present at the amic acid and amine groups and the number of these groups is similar for these materials, this amount will be comparable for all of the materials. Therefore, the sum of the drying, imidization, and silanol condensation processes result in similar mass losses, irrespective of which organic bridging groups is considered.

\subsubsection{Imidization of thin layers}

Accurate determination of the film thickness and density during thermal imidization is required to understand the mechanism of the imidization process in thin films. In particular, the role of the length and flexibility of the organic bridging group on the structural reorganizations is investigated. Figure 4-4 shows the relative changes in the thicknesses of the different poly[POSS-(amic acid)]s during heating under nitrogen.

Upon heating, the thicknesses of all of the layers decrease. The stepwise shrinkage is in agreement with the stepwise mass loss. The hybrid materials display a smaller shrinkage than their organic counterparts. ${ }^{40}$ For these organic polyimides, shrinkage is governed by the amount of residual solvent remaining after preparation by conventional solution polymerization and casting. In contrast, for the hybrid materials, the dense nature of the interfacial polymerization layer likely results in smaller amounts of residual solvent, resulting in the observed smaller shrinkages. The large degree of shrinkage outweighs the contributions from thermal expansion to the thickness. Only two distinct steps were recorded for the shrinkage: The drying step (1) recorded in the TGA experiment takes place during the pretreatment of the film at $100^{\circ} \mathrm{C}$ and is not recorded in this measurement. The onset of the first shrinkage is recorded at $125^{\circ} \mathrm{C}$, and the process continues up to $\sim 225^{\circ} \mathrm{C}$. A larger decrease in the thickness is recorded during further heating to $345^{\circ} \mathrm{C}$, resulting from the concurrent imidization (2) and silanol condensation (3). At this temperature, 
the reaction driving the shrinkage is kinetically hampered, as is evident from the shrinkage that persists for several hours of dwelling at $345^{\circ} \mathrm{C}$.

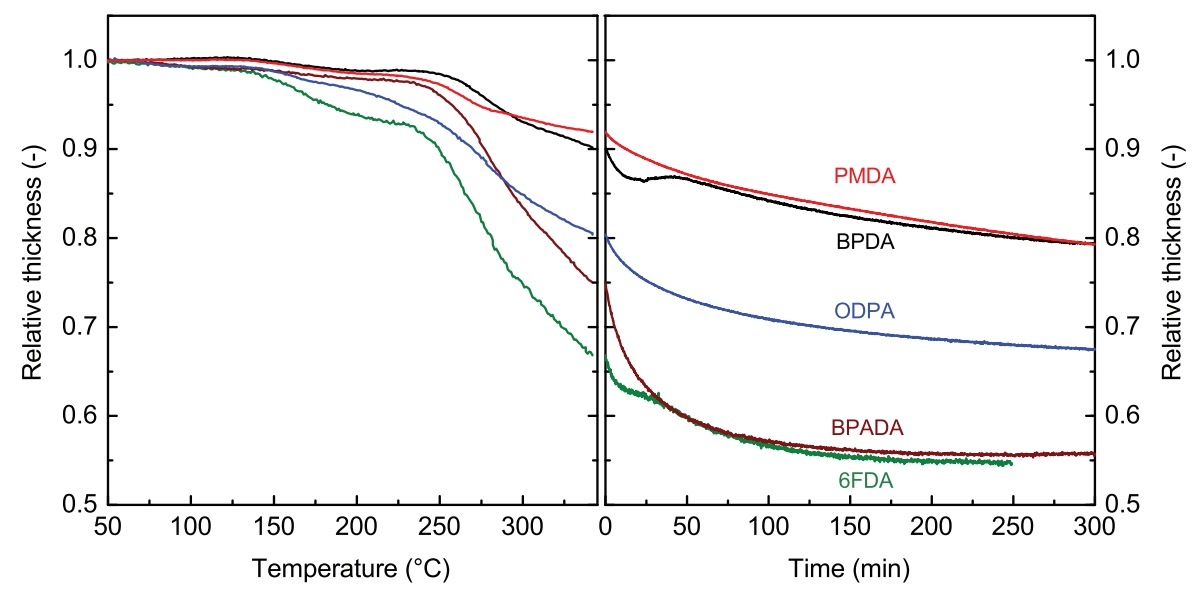

Figure 4-4: (left panel) Relative thickness during conversion of poly[POSS(amic acid)]s to poly(POSS-imide)s as function of temperature, and (right panel) dwell time at $345{ }^{\circ} \mathrm{C}$ after heating from 50 to $345{ }^{\circ} \mathrm{C}$ at a heating rate of $5{ }^{\circ} \mathrm{C} \mathrm{min}^{-1}$. The optical model is validated by a duplicate measurement of the ODPA based poly[POSS-(amic acid)] (not shown here).

The observation that the shrinkage rate decreases in time during the isothermal treatment is indicative of a decelerating reaction. ${ }^{41}$ For the layers prepared with short and rigid dianhydride bridges (PMDA, BPDA and ODPA), the thickness changes last for longer than 10 hours of dwell time (not shown in graph). In contrast, for the longer dianhydride bridges (BPADA, 6FDA), the changes in thickness stabilize within 4 hours of dwell time. The final relative thickness changes the most for 6FDA, followed by the others in the order 6FDA $\approx$ BPADA $>$ ODPA $>$ BPDA $\approx$ PMDA. The shrinkages are most pronounced for the longest bridging groups because the larger spacing between the POSScages and higher flexibility of the long groups allows for larger and faster structural rearrangements. The lengths of the functional units and flexibility of the chain has been determined for polyimide bridges by the coherence length along the chain axis. ${ }^{42}$ For the studied bridges, the coherence lengths from smallest to largest are PMDA $<$ BPDA $<$ ODPA $<$ BPADA. The coherence length for 6FDA is not measurable because its bulky character significantly distorts the chain of the polyimide. The differences in length and flexibility are also reflected in the linear thermal expansion coefficients that are larger for the longer bridges and smaller for the shorter bridges (Table A4-1, Appendix). For 
solid-state reactions, decelerating reactions are typically described using a reaction order or diffusion model. The strong dependency of the shrinkage on the length and flexibility of the dianhydride bridge could indicate that diffusional limitations are the main reason for the decelerating rate. ${ }^{43}$

The smaller shrinkage displayed by the layers with shorter bridging groups are indicative of more free volume in the imidized material, which is confirmed by a stronger decrease of the refractive index of the materials with short bridging groups. Figure 4-5 shows the evolution of the relative refractive index of the layers during heating. For all layers, the refractive index decreases upon heating. In agreement with the mass and thickness changes, the refractive index change occurs in a stepwise manner. The concurrent decreases in the refractive index and thickness are a typical indication of the removal of a component from a matrix

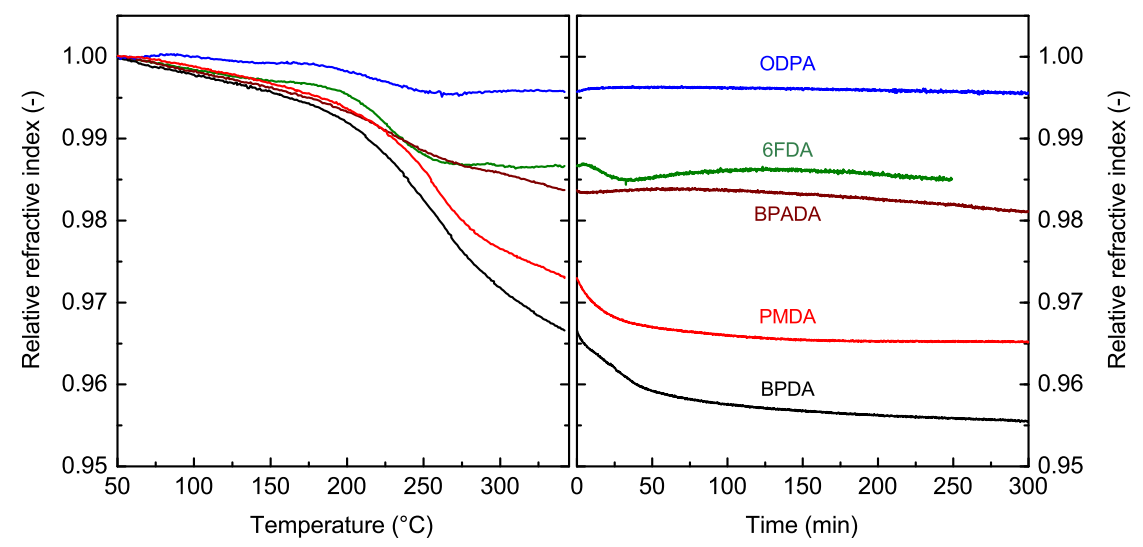

Figure 4-5: (Left panel) Relative refractive index at $632.8 \mathrm{~nm}$ wavelength of the poly[POSS-(amic acid)] as a function of the temperature and (right panel) the dwell time at $300{ }^{\circ} \mathrm{C}$ after heating from 50 to $300{ }^{\circ} \mathrm{C}$ at a heating rate of $5^{\circ} \mathrm{C} \mathrm{min}^{-1}$.

The relative refractive index changes differ significantly among the different layers. The relative changes in the refractive index are the largest for BPDA, followed by the others in the order BPDA $>$ PMDA $>$ BPADA $>6$ FDA $>$ ODPA. The changes in the refractive index due to chemical changes are expected to be similar for the different bridging groups. Therefore, the differences in the mobilities of the networks are the probable cause of the distinct changes in the refractive indices of the different bridging groups. For all networks, a similar amount of water is removed. However, in the more 
rigid networks of the BPDA- and PMDA-based layers, the shrinkage is less pronounced. This corresponds to a relatively high free volume in the imidized networks with the short bridging groups, which is further substantiated by a larger change in their refractive index during the imidization step..

\subsubsection{Density change upon imidization}

The densities of the poly[POSS-(amic acid)] films change during imidization due to shrinkage and water removal. Figure 4-6 shows a comparison of the changes in refractive index between the poly[POSS-(amic acid)]s and the poly(POSS-imide)s. All measurements were performed at $50{ }^{\circ} \mathrm{C}$ and, therefore, include any structural rearrangement that occurs during the cooling step that follows the imidization.

The refractive indices of the amic acids are similar $f$ or the materials prepared with the 5 different precursors. A strong decrease in the index was recorded for the short bridging groups PMDA and BPDA, whereas only a minor change was recorded for the BPADA, 6FDA and ODPA samples. Changes in the refractive index can occur due to chemical group conversion, removal of a component and densification. The changes in the refractive index due to imidization and water removal are similar because all materials display a similar mass loss and number of amic acid and silanol groups.

Therefore, the significant difference in layer shrinkage is the only explanation for the differences in the change in refractive index upon imidization. For the BPADA-, 6FDA-, and, to a lesser extent, ODPA-bridging groups, the shrinkage is significant.

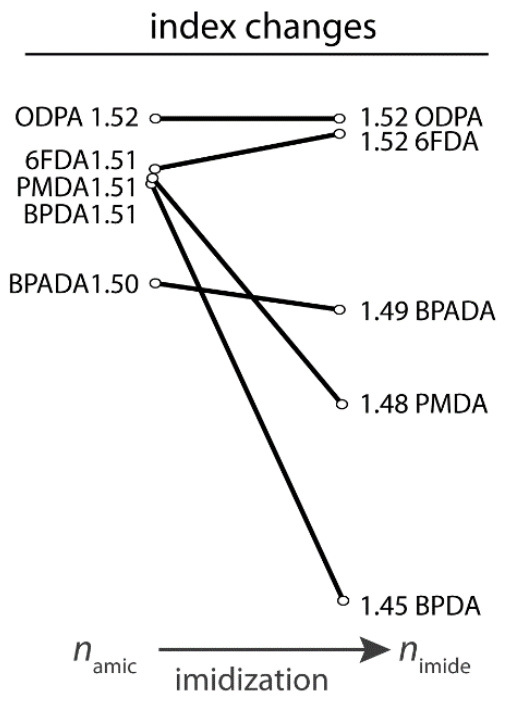

Figure 4-6: Changes in refractive index at $50{ }^{\circ} \mathrm{C}$ as a result of imidization, for 5 different dianhydride precursors.

For these materials, the overall changes in refractive index due to densification, chemical group conversion and water removal are negligible. For the PMDA- and BPDA-bridging groups, only minor shrinkage is observed because of the decreased mobility of the network. The absence of densification upon removal and chemical group conversion results in the formation of void space. The additional free volume that is created in the PMDA- and BPDA-based materials results in a decrease in the refractive index 


\subsubsection{Kinetic analysis of the reactions by isoconversional and multivariate analyses}

As discussed in the previous sections, upon heating to $600{ }^{\circ} \mathrm{C}$, four distinct steps are considered for the thermal evolution of the mass of the poly[POSS-(amic acid)]s: drying (1), imidization (2), silanol condensation (3), and decomposition of the organic moieties (4). The imidization step (2) significantly overlaps with the drying step (1); in the kinetic analysis, these steps will be considered a single step, referred to as step $\mathbf{1 + 2}$. Step $\mathbf{1 + 2}$ is responsible for $\sim 16 \%$ of the mass loss, and the imidization step may constitute only a small part of this mass loss. Step 3, which is responsible for $\sim 5 \%$ of the mass loss, is associated with water release from the condensation reactions of the silanol groups that were formed via the partial hydrolysis of the POSS cages during the synthesis. Step $\mathbf{3}$ may partially overlap with the final stages of the imidization reaction (2), but the condensation reactions are anticipated to dominate the observed mass loss. Step $\mathbf{4}$ is associated with the decomposition of the hybrid materials.

\section{Determination of the activation energy via an isoconversional analysis}

Here, the reaction kinetics of the poly(POSS-6FDA) material are analyzed. The reaction kinetics are typically expressed by three parameters for every step $i$ : the pre-exponential constant $A$, the reaction model $f(\alpha)$, and the activation energy $E_{\mathrm{a}}$ (see Equation 1). First, the activation energy as a function of mass loss is determined without assuming a reaction model, using a model-free isoconversional analysis method proposed in the literature. ${ }^{31-33}$ To accomplish this goal, the mass loss is converted to the normalized conversion $\alpha$. Drying and imidization $(\mathbf{1}+\mathbf{2})$ are detected in the range $\alpha=0-0.16$, silanol condensation (3) is detected for $\alpha=0.16-0.21$, and decomposition (4) for $\alpha=0.21-1$. The results of this analysis, shown in Figure A4-4 in the Appendix, clearly indicate the existence of the three different steps. The combined step $\mathbf{1}+\mathbf{2}$ and step $\mathbf{3}$ are associated with activation energies of $\sim 225 \mathrm{~kJ} \mathrm{~mol}^{-1}$ and $\sim 150 \mathrm{~kJ} \mathrm{~mol}^{-1}$, respectively. Step 4 shows an activation energy that gradually increases with conversion from 225 to $400 \mathrm{~kJ} \mathrm{~mol}^{-1}$.

In the analysis of step $\mathbf{1}+\mathbf{2}$, the resulting value for the activation energy will be an effective average of the activation energies for the removal of physisorbed water and the imidization reactions. Imidization can only occur after the removal of the physisorbed water from the amic acid group. The apparent activation energy determined in this study is significantly higher than the values typically obtained in previous imidization studies, which are on the 
order of $\sim 50$ to $100 \mathrm{~kJ} \mathrm{~mol}^{-1}{ }^{18,19,27-29}$ The use of a non-isothermal temperature program can be excluded as the cause of this difference, ${ }^{41}$ and the difference is too large to result solely from the assumption of a different reaction model. ${ }^{44}$ As the differences cannot be attributed to modeling artefacts, the hybrid nature of the material strongly increases the activation energy of the imidization reaction. It has been suggested that the rotation of the amic acid carbon towards the amide group could be the rate-limiting step during the imidization reaction. ${ }^{45}$ The rigid characteristics and the high degree of network interconnectivity of the POSS cage can hinder the rotational freedom of the amic acid groups.

\section{Determination of the kinetic triplet through a multivariate analysis of the kinetics}

The model-free values for the activation energy are subsequently used as inputs for a multivariate analysis of the kinetics, where Equation 1 is integrated for the 3 different reaction steps $(\mathbf{1}+\mathbf{2}, \mathbf{3}$, and $\mathbf{4})$. In the fitting approach, all steps are first fitted independently in their own temperature range: For step $\mathbf{1 + 2}$, this range is $50-250{ }^{\circ} \mathrm{C}$; for step $\mathbf{3}$, this range is $250-380^{\circ} \mathrm{C}$; and for step 4 , this range is $380{ }^{\circ} \mathrm{C}$ and above. The optimal fit parameters obtained for the individual reaction steps are subsequently combined and used as starting values for an overall fit of the data over the full temperature range. In this overall fit, the relative weights of the individual steps are included as a fit parameter as well.

\section{Fitting of the drying and imidization steps $(1+2)$}

For step $\mathbf{1}+\mathbf{2}$, when a single step reaction is fitted to the data in the range $\alpha=0.02-0.16$, none of the 14 reaction models given in Table A4-2 (Appendix) adequately capture the data. The reaction order model $\mathrm{F} 1$ and the diffusional models D2, D3, and D4 describe the shape of the curve better than the other models. The inadequacy of the fit, when assuming a single reaction step, is in line with the previous suggestion that, for imidization, a diffusional term needs to be added to the commonly employed F1-model. ${ }^{29}$ Fitting the data with two reactions in parallel also does not capture the data accurately. To improve the fit, a distributed activation energy can be assumed. This approach has been shown to be adequate for a wide range of parallel reactions. ${ }^{46}$ By combining the D4 reaction model (best description of the data from the first fitting attempt) with a Weibull distribution of the activation energy, the data can be fitted accurately. The mean activation energy of $\sim 225 \mathrm{~kJ} \mathrm{~mol}^{-1}$, obtained from 
the model fit, is in agreement with the value obtained from the isoconversional analysis. The suitability of the diffusional model can indicate that densification of the material limits the reaction rate with increasing conversion.

\section{Fitting of the silanol condensation (3)}

For the silanol condensation (3), when a single step reaction is fitted to the data in the range $\alpha=0.16-0.21$, the reaction-order model F1 most accurately describes the data. The corresponding activation energy is $\sim 150 \mathrm{~kJ} \mathrm{~mol}^{-1}$. The fit results are found to be completely independent of the starting values used for the fit. The suitability of the F1 model implies that the reactivity decreases due to a decrease in the concentration of reactive groups.

\section{Fitting of the decomposition (4)}

For the decomposition step (4), the strong dependency of the activation energy on the conversion hints at multiple processes taking place. Therefore, a distributed activation energy is required to properly fit the measured data. The onset of the decomposition processes is captured adequately using a Weibulldistributed activation energy. This approach does not accurately capture the complete degradation process. Because only the onset of decomposition is of interest in this study, no further attempts at optimizing a quantitative fit of the data were performed.

\section{Overall fit of the reaction kinetics}

The values obtained for the pre-exponential constant, activation energy, and reaction model for the individual steps were used as initial guess values for a fit of the data over the entire temperature and conversion ranges. In addition, the weights, $w_{\mathrm{i}}$, of the individual steps are included as an extra fit parameter, for which $w_{4}$ is set equal to $1-w_{1+2}-w_{3}$. The results of the overall fit are shown in Figure 4-7, and the values corresponding to the resulting fit are given in Table 4-1. The resulting values are insensitive to the starting values and do not deviate strongly from the values obtained when fitting the individual steps. This result supports the appropriateness of considering the individual steps in the analysis. The high weight of reaction $\mathbf{1 + 2}$ over reaction $\mathbf{3}$ confirms the strong mass losses during the drying and imidization steps. 


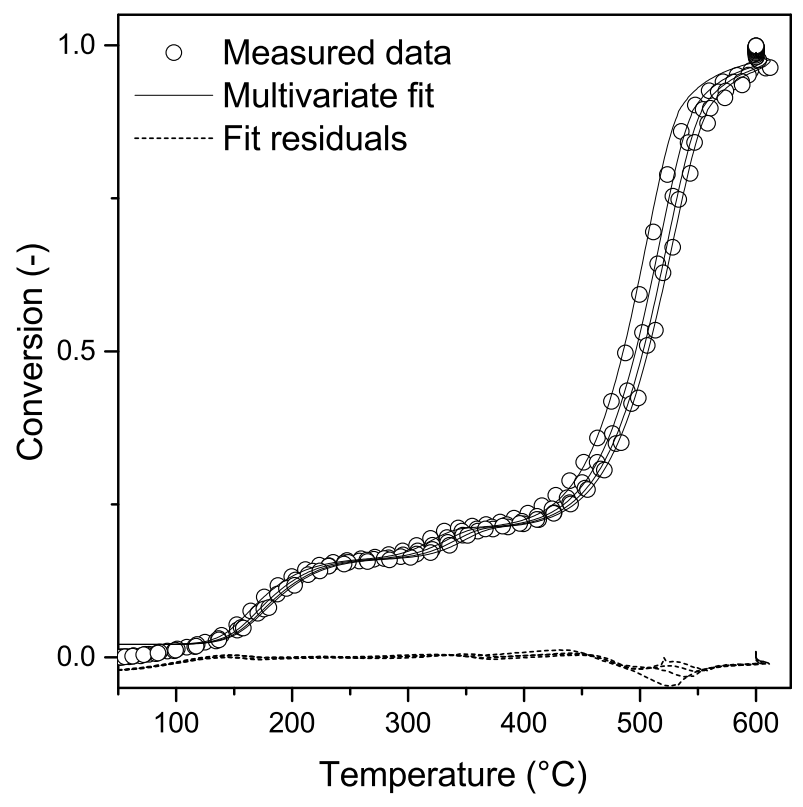

Figure 4-7: Multivariate fit for the thermal treatment of 6FDA-based poly[POSS-(amic acid)] under a $\mathrm{N}_{2}$ atmosphere. The symbols depict the experimental data and solid lines represent the fit; the dashed lines show the fit residuals.

Table 4-1: Kinetic parameters for the thermal treatment of 6FDA-based poly[POSS-(amic acid)] under a $\mathrm{N}_{2}$ atmosphere. Step 1+2 and 4 are fitted using a Weibull-distributed activation energy, and step 3 was fitted to an F1 reaction model.

\begin{tabular}{|c|c|c|c|}
\hline Conversion & $\begin{array}{l}\text { Drying and } \\
\text { imidization } \\
(1+2, w=0.141)\end{array}$ & $\begin{array}{l}\text { Silanol } \\
\text { condensation } \\
(3, w=0.054)\end{array}$ & $\begin{array}{l}\text { Decomposition } \\
(4, w=0.785)\end{array}$ \\
\hline $\mathrm{A}(\min -1)$ & $2.62 \cdot 1024$ & $5.12 \cdot 1012$ & $3.77 \cdot 1018$ \\
\hline $\begin{array}{l}\text { Ea threshold } \\
(\mathrm{kJ} \text { mol-1) }\end{array}$ & 200 & $\mathrm{n} / \mathrm{a}$ & 295 \\
\hline$(-)$ & 1.65 & $\mathrm{n} / \mathrm{a}$ & 3.29 \\
\hline$(\mathrm{kJ}$ mol-1) & 26.8 & $\mathrm{n} / \mathrm{a}$ & 4.9 \\
\hline Ea average $(\mathrm{kJ}$ mol-1)a & 224 & 151.4 & 299 \\
\hline Reaction model & $\frac{3}{2}(1-\alpha)^{2 / 3}\left[1-(1-\alpha)^{1 / 3}\right]$ & $1-\alpha$ & $\frac{3}{2}(1-\alpha)^{2 / 3}\left[1-(1-\alpha)^{1 / 3}\right]^{-1}$ \\
\hline
\end{tabular}

${ }^{\mathrm{a}}$ The activation energy indicated for step 2 is the single activation energy used for the fit 


\subsection{Conclusion}

Four steps were identified in the thermal processing of poly[POSS-(amic acid)]s: drying of physisorbed water (1), imidization (2), silanol condensation (3), and decomposition (4). The imidization was found to occur between 150 and $300{ }^{\circ} \mathrm{C}$, independent of the bridging group. Because of the comparatively low contribution of the organic bridging groups to the total mass of the material, the mass loss during all steps is similar. In contrast to the mass loss, the linking group does strongly influence the shrinkage and, therefore, the densification that occurs during imidization of the layer. The most pronounced shrinkage is found for the poly[POSS-(amic acid)]s with long bridges. In materials with short bridges, the network densification is hindered by the rigidity of the bridges. Therefore, the use of shorter bridges results in hybrid polyimides with significantly higher free volumes and, thus, lower densities.

A kinetic analysis of the imidization step reveals a very high value for the activation energy compared to imidization of fully organic poly(amic acid)s. This result is attributed to the high degree of interconnectivity and the rigidity of the POSS cages, which impedes the rate-limiting rotation of the amic acid groups. The appropriateness of the decelerating reaction model suggests that the decelerating reaction rate is due to network densification.

The combination of TGA-MS and TEA provides unique insights into the structural rearrangements in the hybrid materials that can be used for further optimization of thermal treatments of hybrid organic-inorganic network materials.

\subsection{Acknowledgements}

This project has received funding from the European Union's Seventh Framework Programme for research, technological development and demonstration under CARENA grant agreement no. 263007.

\subsection{Appendices}

\subsubsection{Conversion processes during thermal imidization}

During the heat treatment of the poly[POSS-(amic acid)]s, reaction steps associated with drying and imidization $(\mathbf{1}+\mathbf{2})$, silanol condensation (3) and decomposition (4) are observed. Scheme S2 shows the reaction mechanism of step 2 and 3 that occur. During step 2 of the heat treatment process, mainly conversion of amic acid to imide groups occurs (blue). 


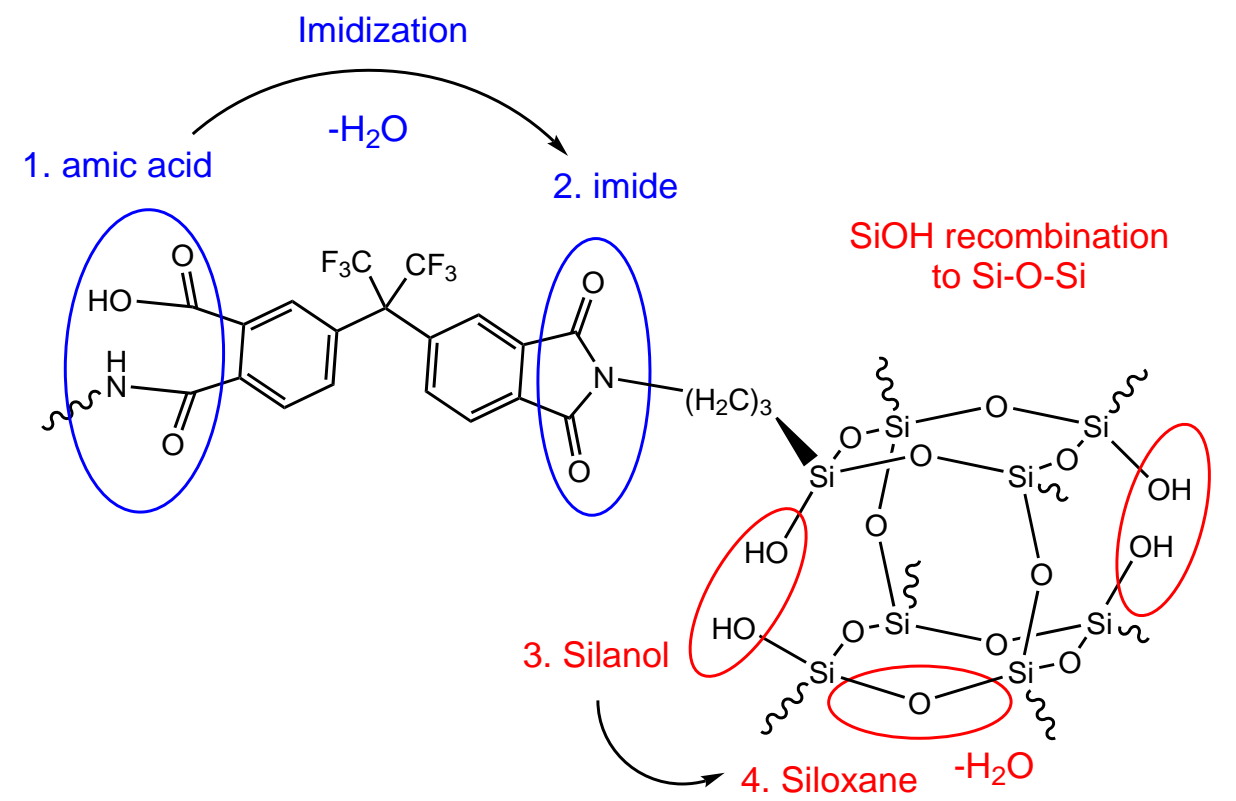

Figure 4-A9: Overview of the water loss originating from imidization and silanol condensation reactions.

During step 3, additional water loss is observed that originates from recombination of silanol groups to form siloxane groups (red). The silanol condensation reaction is observed from attenuated total reflection - Fourier transform infrared spectroscopy (ATR-FTIR) measurements of poly[POSS-(amic acid)] samples that were heat treated at different temperatures. Figure 4-A10 shows the relative intensity of infrared peaks that are characteristic for $\mathrm{Si}-\mathrm{O}$ bonds in a cage or ladder (i.e., a broken POSS cage) structure, and peaks that are characteristic for silanol groups. The peak at $3230 \mathrm{~cm}^{-1}$ could include vibrations from water present in the material. Although the scatter in the data makes a quantitative analysis difficult, the data shows a trend of increasing ladder and cage formation with increasing treatment temperatures, at the expense of silanol groups. 

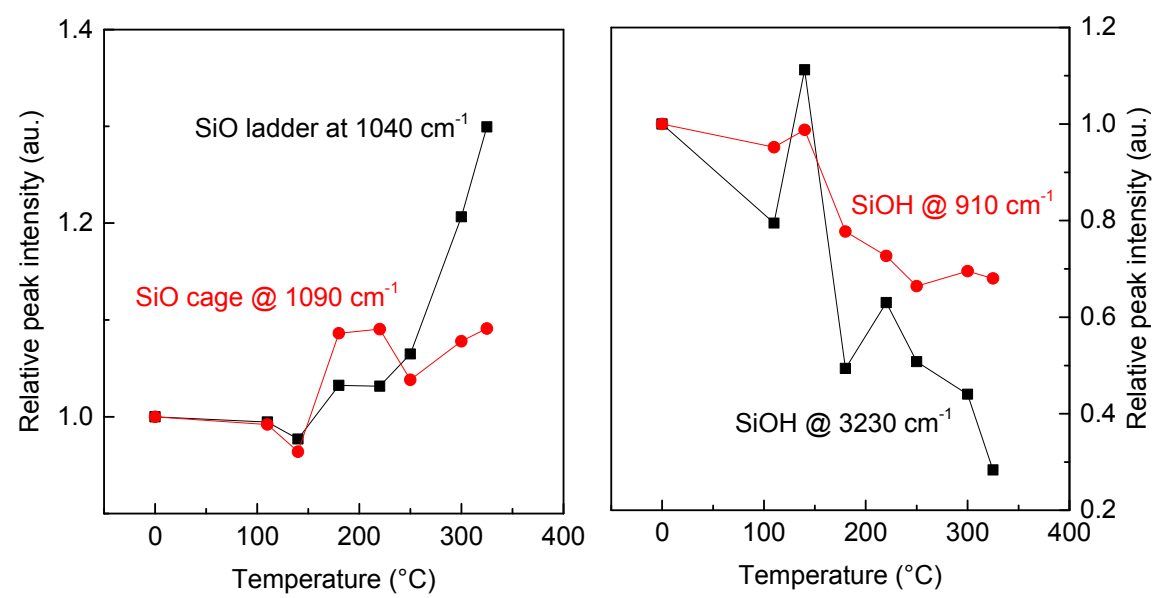

Figure 4-A10: (left panel) Relative intensity of the infrared peaks at 1040 and $1090 \mathrm{~cm}^{-1}$ for $6 \mathrm{FDA}$-based samples, corresponding to a Si-O-Si bond in ladder and cage configuration, respectively; (right panel) Relative intensity of the infrared peaks at 910 and $3230 \mathrm{~cm}^{-1}$, both corresponding to silanol groups. All infrared spectra were normalized with respect to the $\mathrm{CF}_{3}$ band at $1254 \mathrm{~cm}^{-1}$. All peak intensities are normalized with respect to their initial peak intensity.

\subsubsection{Thickness and refractive indices}

The thickness and refractive index have been measured using spectroscopic ellipsometry. Figure A4-2 shows the evolution of the thickness (top panels) and refractive index (bottom panels) of poly[POSS-(amic acid)]s prepared using PMDA, BPDA, ODPA, BPADA and 6FDA precursors, as function of temperature (left panel) and as function of time during the subsequent dwell at $345{ }^{\circ} \mathrm{C}$ (right panel). The data in Figure A4-2 correspond to the relative thickness data in Figure 4-3 and relative refractive index data in Figure 4-4. 

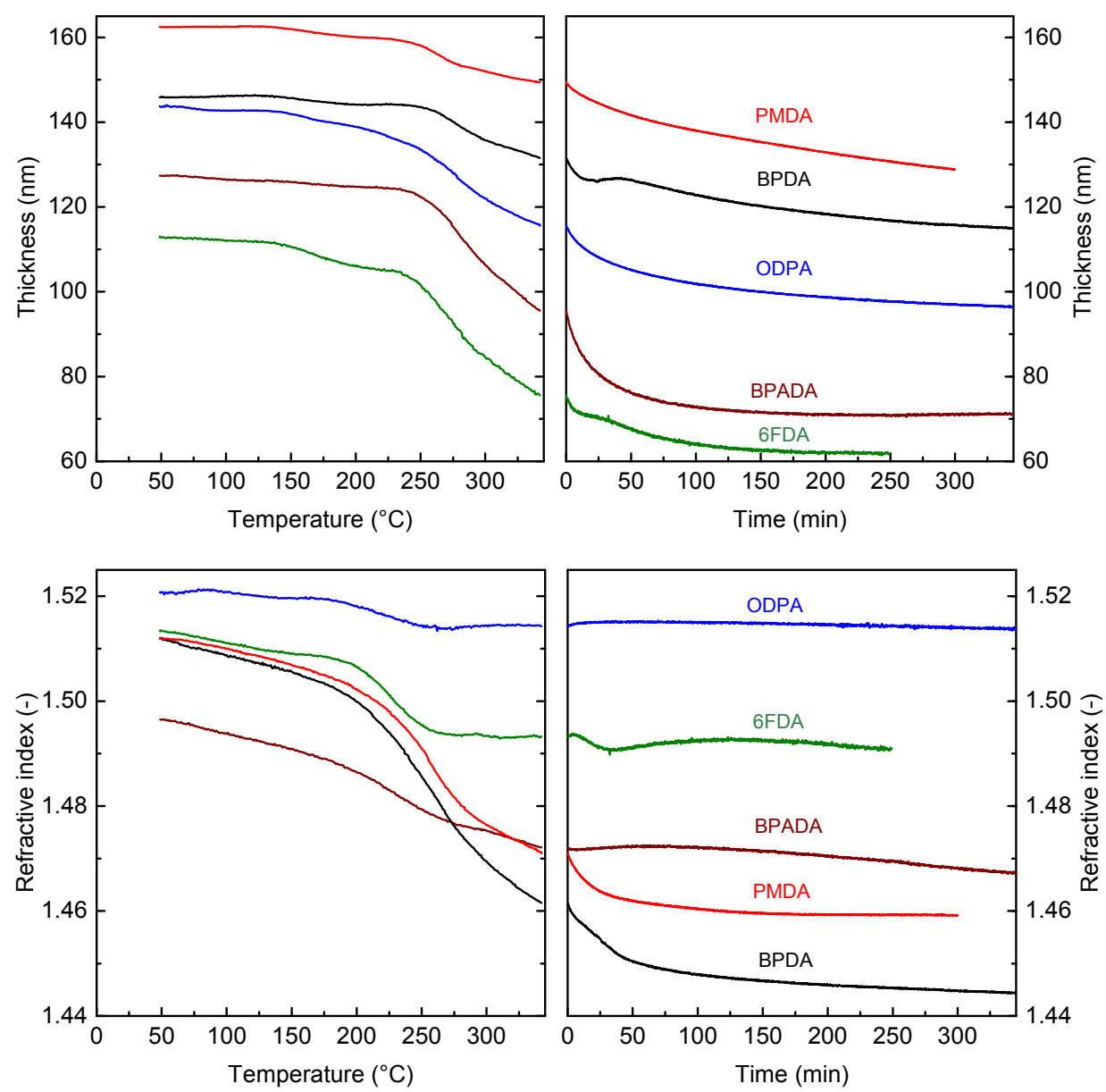

Figure A4-2. (top panels) Thickness and (bottom panels) refractive index of the poly[POSS-(amic acid)] layers as function of temperature (left), and dwell time at $345{ }^{\circ} \mathrm{C}$ after heating from 50 to $345{ }^{\circ} \mathrm{C}$ at a heating rate of $5^{\circ} \mathrm{C} \mathrm{min}^{-1}$. The poly[POSS-(amic acid)] layers were prepared atop a $\gamma$-alumina coated $\alpha$-alumina disc using PMDA, BPDA, ODPA, BPADA and 6FDA precursors.

Duplicate measurements were performed to validate the optical model of the spectroscopic ellipsometry measurements. Figure A4-3 shows the refractive index and thickness data of two poly[POSS-(amic acid)] prepared using ODPA (left panel). The data shows a similar evolution in thickness and refractive index. The absolute values of the thickness are slightly different, which can be related to the reproducibility of the interfacial polymerization reaction. 


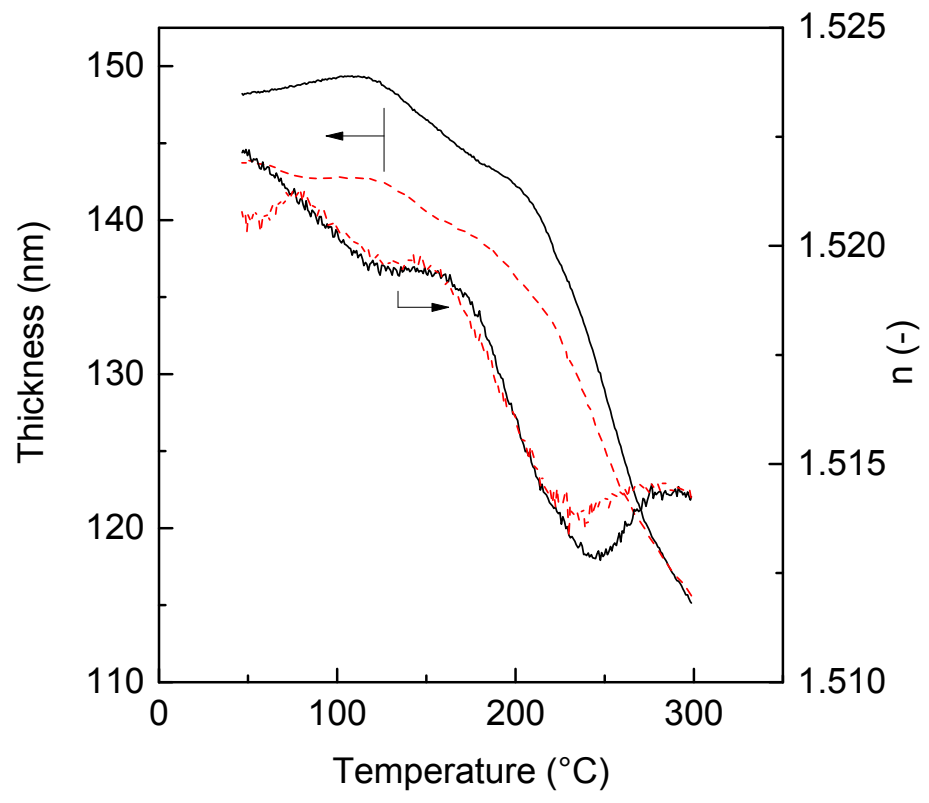

Figure A4-3. Refractive index and thickness data of two poly[POSS-(amic acid)]s prepared using ODPA (left panel).

The linear thermal expansion coefficient of the poly(POSS-imide)s has been determined by measuring the thicknesses between $50{ }^{\circ} \mathrm{C}$ and $345{ }^{\circ} \mathrm{C}$. Table A4-1 shows the linear thermal expansion coefficients of the poly(POSSimide)s.

Table A4-1. Linear thermal expansion coefficient of poly(POSS-imide)s prepared using PMDA, BPDA, ODPA, BPADA and 6FDA

\begin{tabular}{|l|l|l|l|}
\hline & $\begin{array}{l}\text { Thickness at 50 } \\
{ }^{\circ} \mathrm{C}\end{array}$ & $\begin{array}{l}\text { Thickness at 345 } \\
{ }^{\circ} \mathrm{C}\end{array}$ & $\begin{array}{l}\text { Linear thermal expansion } \\
\text { coefficient }\end{array}$ \\
\hline $\begin{array}{l}\text { Dianhydride } \\
\text { linker }\end{array}$ & $(\mathrm{nm})$ & $(\mathrm{nm})$ & $\left(10^{-6} \mathrm{C}^{-1}\right)$ \\
\hline PMDA & 118.6 & 121.3 & 76 \\
\hline BPDA & 113.2 & 114.6 & 44 \\
\hline ODPA & 91.9 & 95.7 & 141 \\
\hline BPADA & 64.4 & 70.5 & 317 \\
\hline 6FDA & 59.2 & 61.9 & 154 \\
\hline
\end{tabular}




\subsubsection{Kinetic analysis}

Figure A4-4 (left panel) shows the conversion of the mass loss of 6FDAPOSS as a function of temperature for heating rates $\beta=5,10,15$ and $20{ }^{\circ} \mathrm{C}$ $\mathrm{min}^{-1}$. The shift in the curves introduced by the different heating rates is an indication of kinetically limited processes. A plateau in the conversion curves is related to the absence of mass loss processes. The curves before and after the plateau can therefore be appointed to distinct, serial reaction steps. The conversion profile demonstrates 3 distinct mass loss steps: step 1 from $\alpha=0$ 0.16 , step 2 from $\alpha=0.16-0.21$, and step 3 from $\alpha=0.21-1$. The effective activation energy for mass loss as a function of the conversion can be calculated by performing an isoconversional analysis. ${ }^{41}$
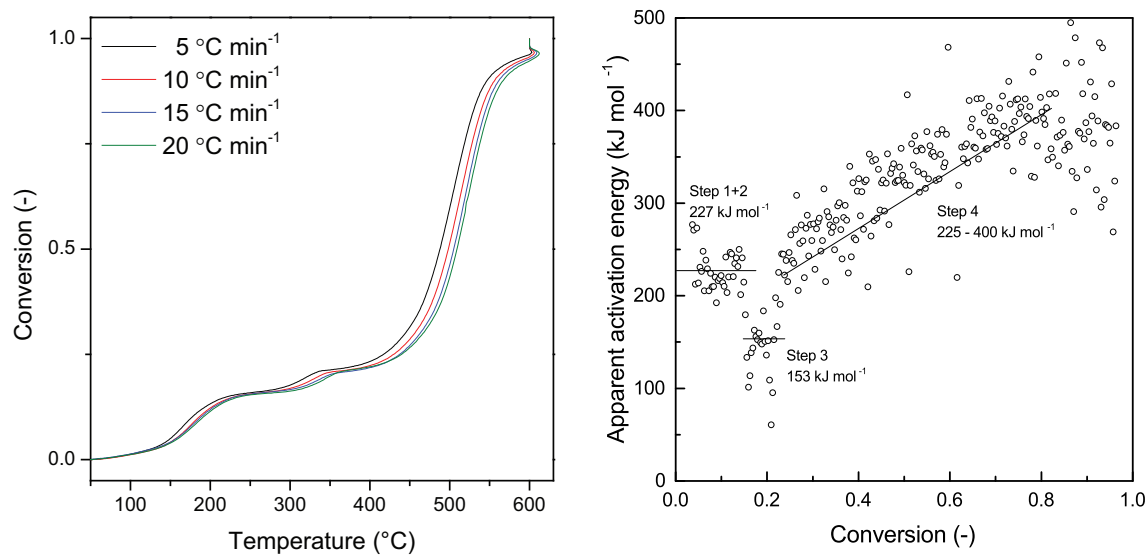

Figure A4-4. (left panel) Conversion of the mass loss of 6FDA-based poly[POSS-(amic acid)] as function of temperature, for heating rates $\beta=5,10,15$ and $20{ }^{\circ} \mathrm{C}$ min $^{-1}$ under $N_{2}$ atmosphere. (right panel) Apparent activation energy as function of conversion, determined by the isoconversional analysis of TGA-data for the thermal treatment of 6FDA based poly[POSS-(amic acid)].

This activation energy is referred to as an 'effective' activation energy, as it is in fact an average over the activation energies of the different reactions taking place at a specific value of the conversion. The occurrence of multiple reactions within the distinct steps is apparent from the release of different fragments that is observed in the TGA-MS data. Step 1 is dominated by the loss of water from the material, accompanied by the release of small amounts of $\mathrm{CO}_{2}$ and aromatic fragments. Step 2 is only coupled to the loss of water. In step 3, aromatics, $\mathrm{CO}_{2}$ and water are released. Figure A4-4 (right panel) 
shows the effective activation energy for the thermal imidization steps of poly(POSS-amic acid) prepared with 6FDA. The three distinct steps result in three plateaus in the effective activation energy: For step $1, E_{a} \sim 225 \mathrm{~kJ} \mathrm{~mol}^{-1}$; for step 2, $E_{a} \sim 150 \mathrm{~kJ} \mathrm{~mol}^{-1}$; for step 3, $E_{a}$ increased from $\sim 225$ to $\sim 400 \mathrm{~kJ} \mathrm{~mol}^{-}$

${ }^{1}$. Only an activation energy is insufficient for performing kinetic calculations, as the reaction rate is typically expressed as a function of $A$, the preexponential constant, and $f(\alpha)$. An overview of possible reaction models is given in Table A4-2.

Table A4-2. Overview of possible reaction models, taken from ${ }^{34}$

\begin{tabular}{|l|l|}
\hline Reaction model (name + abbreviation) & $\mathrm{f}(\alpha)$ \\
\hline Power law - P4 & $4 \alpha^{3 / 4}$ \\
\hline Power law - P3 & $3 \alpha^{2 / 3}$ \\
\hline Power law - P2 & $2 \alpha^{1 / 2}$ \\
\hline Power law - P2/3 & $2 / 3 \alpha^{1 / 2}$ \\
\hline Mampel (first order) - F1 & $1-\alpha$ \\
\hline Avrami-Erofeev - A4 & $4(1-\alpha)[-\ln (1-\alpha)]^{3 / 4}$ \\
\hline Avrami-Erofeev - A3 & $3(1-\alpha)[-\ln (1-\alpha)]^{2 / 3}$ \\
\hline Avrami-Erofeev - A2 & $2(1-\alpha)[-\ln (1-\alpha)]^{1 / 2}$ \\
\hline Contracting sphere - R3 & $3(1-\alpha)^{2 / 3}$ \\
\hline Contracting cylinder - R2 & $2(1-\alpha)^{1 / 2}$ \\
\hline One-dimensional diffusion - D1 & $1 / 2 \alpha^{-1}$ \\
\hline Two-dimensional diffusion - D2 & {$[-\ln (1-\alpha)]^{-1}$} \\
\hline Three-dimensional diffusion (Jander) - D3 & $3 / 2(1-\alpha)^{2 / 3}\left[1-(1-\alpha)^{1 / 3}\right]^{-1}$ \\
\hline Three-dimensional diffusion (Ginstling- & $3 / 2\left[(1-\alpha)^{-1 / 3}-1\right]^{-1}$ \\
Brounshtein) D4 & \\
\hline
\end{tabular}

In order to get insight into the reaction model, a temperature program containing isothermal dwells was ran. The temperatures of the isothermals were chosen such that in every isothermal step, one of the reactions was taking place. In line with previous observations, the profile of the conversion versus the time revealed a decelerating reaction profile that is commonly associated to the reaction order (F) or diffusion (D) models from Table A4-2. ${ }^{20,26-29}$

To determine which reaction model captures the data most adequately, and to obtain the value for the pre-exponential constant, the data given in Figure A4-4 (left panel) was fit by a multivariate kinetic model. To perform this analysis, the 3 steps in the activation energy were first fitted individually, using the activation energies obtained from Figure A4-4 right panel) as starting values. The data was fit 14 times, one time for each reaction models given in Table 
A4-2. These individual fits were followed by a combined fit of the full conversion range.

For the fitting of the first step, it was found that the data could not be captured using a single kinetic triplet $\left(A, E_{\mathrm{a}}\right.$, and $\left.f(\alpha)\right)$. This is of no surprise, as the MS-data gave clear evidence for multiple reactions occurring in this step. Surprisingly, however, fitting of the data with a combination of two individual reactions did not result in a good fit either. Therefore, it was tried to fit the data with a distributed activation energy. Here, a Weibull-distribution was chosen to model the distributed activation energy. For certain values of the parameters, this distribution can be mathematically equivalent to a Gamma-distributed activation energy or a $n$th order reaction. ${ }^{46}$ Using the Weibull-distribution, the data could be accurately fit, as long as the fitting was started from a conversion value of $\alpha=0.02$. Below this value, the individual curves do not demonstrate a shift with heating rate, implying a thermodynamic equilibrium. Step 2 could be captured accurately using a single kinetic triplet. Tests for the different reaction models revealed that a first order reaction (F1) model captured the data most accurately. For step 3, again a distribution in the activation energy was required for the fitting. Again this is with no surprise, since the degradation of the organic fragments typically consist of many different reactions, smeared out over a broad temperature range. These reaction distributions are commonly fit with distributed kinetic parameters. ${ }^{46}$

\subsection{References}

1. Pielichowski, K.; Njuguna, J.; Janowski, B.; Pielichowski, J., Polyhedral oligomeric silsesquioxanes (POSS)-containing nanohybrid polymers. In Advances in Polymer Science, 2006; Vol. 201, pp 225-296.

2. Ruiz-Hitzky, E.; Aranda, P.; Darder, M.; Ogawa, M. Chemical Society Reviews 2011, 40, (2), 801-828

3. Sanchez, C.; Soler-Illia, G. J. D. A. A.; Ribot, F.; Lalot, T.; Mayer, C. R.; Cabuil, V. Chemistry of Materials 2001, 13, (10), 3061-3083

4. Beecroft, L. L.; Johnen, N. A.; Ober, C. K. Polymers for Advanced Technologies 1997, 8, (5), 289-296

5. Khalil, M.; Saeed, S.; Ahmad, Z. Journal of Applied Polymer Science 2008, 107, (2), 1257-1268

6. Raaijmakers, M. J. T.; Hempenius, M. A.; Schön, P. M.; Vancso, G. J.; Nijmeijer, A.; Wessling, M.; Benes, N. E. Journal of the American Chemical Society 2014, 136, (1), 330-335

7. $\quad$ Asuncion, M. Z.; Laine, R. M. Macromolecules 2007, 40, (3), 555-562 
8. Choi, J.; Tamaki, R.; Kim, S. G.; Laine, R. M. Chemistry of Materials 2003, 15, (17), 3365-3375

9. Devaraju, S.; Vengatesan, M. R.; Alagar, M. High Performance Polymers 2011, 23, (2), 99-111

10. Huang, J. C.; He, C. B.; Xiao, Y.; Mya, K. Y.; Dai, J.; Siow, Y. P. Polymer 2003, 44, (16), 4491-4499

11. Leu, C. M.; Chang, Y. T.; Wei, K. H. Macromolecules 2003, 36, (24), 9122-9127

12. Leu, C. M.; Chang, Y. T.; Wei, K. H. Chemistry of Materials 2003, 15, (19), 37213727

13. Seçkin, T.; Köytepe, S.; Adigüzel, H. I. Materials Chemistry and Physics 2008, 112, (3), 1040-1046

14. Wright, M. E.; Petteys, B. J.; Guenthner, A. J.; Fallis, S.; Yandek, G. R.; Tomczak, S. J.; Minton, T. K.; Brunsvold, A. Macromolecules 2006, 39, (14), 4710-4718

15. Monticelli, O.; Fina, A.; Ullah, A.; Waghmare, P. Macromolecules 2009, 42, (17), 6614-6623

16. Wright, M. E.; Schorzman, D. A.; Feher, F. J.; Jin, R. Z. Chemistry of Materials 2003, $15,(1), 264-268$

17. Wright, M. E.; Petteys, B. J.; Guenthner, A. J.; Fallis, S.; Yandek, G. R.; Tomczak, S. J.; Minton, T. K.; Brunsvold, A. Macromolecules 2006, 39, (14), 47104718.10.1021/ma060372d

18. Pyun, E.; Mathisen, R. J.; Sung, C. S. P. Macromolecules 1989, 22, (3), 11741183.10.1021/ma00193a031

19. Dickinson, P. R.; Sung, C. S. P. Macromolecules 1992, 25, (14), 3758-3768

20. Seo, Y.; Lee, S. M.; Kim, D. Y.; Kim, K. U. Macromolecules 1997, 30, (13), 37473753.10.1021/ma961482v

21. Kim, B. H.; Park, H.; Park, H.; Moon, D. C. Thermochimica Acta 2013, 551, 184-190

22. Kim, S. K.; Kim, H. T.; Park, J. K. Polymer Journal 1998, 30, (3), 229-233

23. Ree, M.; Shin, T. J.; Park, Y. H.; Kim, S. I.; Woo, S. H.; Cho, C. K.; Park, C. E. Journal of Polymer Science, Part B: Polymer Physics 1998, 36, (8), 1261-1273

24. Kook, H. J.; Kim, D. Journal of Materials Science 2000, 35, (12), 2949-2954

25. Shin, T. J.; Ree, M. Langmuir 2005, 21, (13), 6081-6085

26. Yilmaz, T.; Güçlü, H.; Özarslan, Ö.; Yildiz, E.; Kuyulu, A.; Ekinci, E.; Güngör, A. Journal of Polymer Science, Part A: Polymer Chemistry 1997, 35, (14), 2981-2990

27. Seo, Y. Polymer Engineering and Science 1997, 37, (5), 772-776

28. Kim, Y. J.; Glass, T. E.; Lyle, G. D.; McGrath, J. E. Macromolecules 1993, 26, (6), 1344-1358

29. Lu, H.; Zhou, J.; He, T. Journal of Applied Polymer Science 2001, 79, (11), 20522059

30. Raaijmakers, M. J. T.; Wessling, M.; Nijmeijer, A.; Benes, N. E. Chemistry of Materials 2014, 26, (12), 3660-3664

31. Vyazovkin, S.; Dollimore, D. Journal of Chemical Information and Computer Sciences 1996, 36, (1), 42-45

32. Vyazovkin, S. Journal of Computational Chemistry 2001, 22, (2), 178-183

33. Vyazovkin, S. Journal of Computational Chemistry 1997, 18, (3), 393-402

34. Vyazovkin, S.; Chrissafis, K.; Di Lorenzo, M. L.; Koga, N.; Pijolat, M.; Roduit, B.; Sbirrazzuoli, N.; Suñol, J. J. Thermochimica Acta 2014, 590, 1-23 
35. Lichtenstein, T., Handbook of Thin Film Materials. College of Engineering and Applied Science, University of Rochester: University of Rochester. College of Engineering and Applied Science, 1979.

36. Ogieglo, W.; Wormeester, H.; Wessling, M.; Benes, N. E. ACS Applied Materials and Interfaces 2012, 4, (2), 935-943

37. J. Feher, F.; D. Wyndham, K.; Soulivong, D.; Nguyen, F. Journal of the Chemical Society, Dalton Transactions 1999, (9), 1491-1498.10.1039/A807302C

38. Dalwani, M.; Zheng, J.; Hempenius, M.; Raaijmakers, M. J. T.; Doherty, C. M.; Hill, A. J.; Wessling, M.; Benes, N. E. Journal of Materials Chemistry 2012, 22, (30), 14835-14838

39. Van Krevelen, D. W.; Te Nijenhuis, K., Properties of Polymers. 2009.

40. Unsal, E.; Cakmak, M. Macromolecules 2013, 46, (21), 86168627.10.1021/ma401361w

41. Vyazovkin, S.; Burnham, A. K.; Criado, J. M.; Pérez-Maqueda, L. A.; Popescu, C.; Sbirrazzuoli, N. Thermochimica Acta 2011, 520, (1-2), 1-19

42. Ree, M.; Kim, K.; Woo, S. H.; Chang, H. Journal of Applied Physics 1997, 81, (2), 698-708

43. Khawam, A.; Flanagan, D. R. The Journal of Physical Chemistry B 2006, 110, (35), 17315-17328.10.1021/jp062746a

44. Lesnikovich, A. I.; Levchik, S. V. Journal of Thermal Analysis 1983, 27, (1), 89-93

45. Ghosh, M. K.; Mittal, K. L., Polyimides : fundamentals and applications New York etc. : Marcel Dekker: 1996.

46. Burnham, A. K.; Braun, R. L. Energy \& Fuels 1999, 13, (1), 1-22.10.1021/ef9800765 


\section{Chapter 5}

\section{Sorption behavior of compressed $\mathrm{CO}_{2}$ and $\mathrm{CH}_{4}$ in ultrathin hybrid poly(POSS-imide) layers}

This chapter has been submitted for publication: Raaijmakers, M.J.T., Ogieglo, W., Wiese, M., Wessling M., Nijmeijer, A., Benes, N.E. Sorption behavior of compressed $\mathrm{CO}_{2}$ and $\mathrm{CH}_{4}$ in ultrathin hybrid poly(POSS-imide) layers 


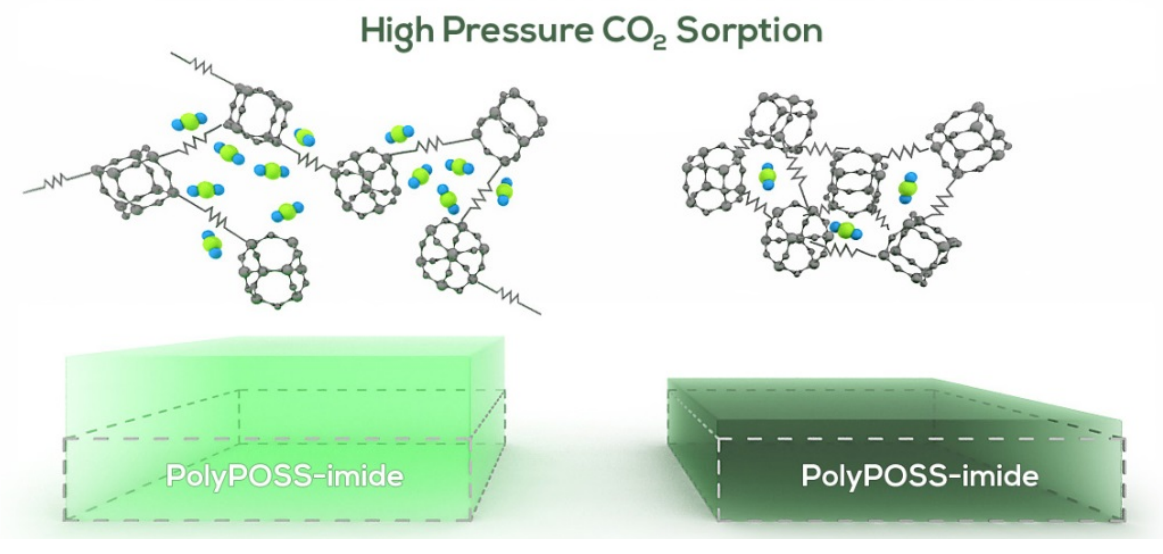

\begin{abstract}
Membrane gas separation of $\mathrm{CO}_{2}$ from other gases is a key enabling technique for carbon capture and storage as well as natural gas sweetening. Large-scale implementation of synthetic membranes for $\mathrm{CO}_{2}$ separation requires membranes with high $\mathrm{CO}_{2}$ permeability. Glassy polymeric membranes are suitable for $\mathrm{CO}_{2}$ separation applications, but in particular ultrathin polymeric films with high $\mathrm{CO}_{2}$ permeabilities suffer from penetrant induced changes such as plasticization and physical ageing. Here, we investigated the effects of high pressure $\mathrm{CO}_{2}$ and $\mathrm{CH}_{4}$ on the dilation and sorption behavior of ultrathin membrane layers of a hybrid inorganic-organic network material that consists of alternating polyhedral oligomeric silsesquioxane and imide groups. The imide precursor, containing fluoroalkane groups, provides affinity towards $\mathrm{CO}_{2}$ sorption, while the octa-functionalized silsesquioxane provides a high degree of cross-linking. The combination of these properties allows for extremely high sorption capacities, while maintaining the glassy characteristics of a network material. We succeeded to quantify the uptake of $\mathrm{CO}_{2}$ in the selective layer of a composite membrane only by determining the effective layer thickness and refractive index changes obtained by spectroscopic ellipsometry measurements at high $\mathrm{CO}_{2}$ and $\mathrm{CH}_{4}$ pressures. Spectroscopic ellipsometry can be used to accurately determine the sorption characteristics, whereas gravimetric or volumetric do not allow for accurate sorption measurements on swelling, ultrathin films. The sorption behavior of the ultrathin hybrid layers depends on the fluoroalkane group content. At low pressure, the apparent molar volume of the gases is low as compared to the liquid molar volume of $\mathrm{CO}_{2}$ and $\mathrm{CH}_{4}$, respectively. At high gas concentrations
\end{abstract}


in the polymer film, the apparent molar volume of $\mathrm{CO}_{2}$ and $\mathrm{CH}_{4}$ exceeds that of the liquid molar volume, and approaches that of the fluid phase. The high sorption capacity and network characteristics of the presented materials provide a new direction for membrane development for $\mathrm{CO}_{2}$ separation applications.

\subsection{Introduction}

Membrane gas separation is a key technology for $\mathrm{CO}_{2}$ separation and capture applications. ${ }^{1}$ Potential $\mathrm{CO}_{2}$ membrane separation applications range from post-combustion flue gas treatment, pre-combustion capture systems, oxy-fuel processes, natural gas sweetening and biogas refineries. ${ }^{2-6}$ Conventional techniques such as solvent scrubbing and physical adsorption processes are technologically well developed, but incur a large energy penalty on the $\mathrm{CO}_{2}$ capture. Membrane gas separation potentially lowers the energy requirements for $\mathrm{CO}_{2}$ removal, but large-scale implementation is hampered by the insufficient membrane permeability ${ }^{7}$ and the limited stability at high $\mathrm{CO}_{2}$ partial pressures. ${ }^{8-10}$

Polyimides currently represent the state-of-the-art for industrial membrane applications, owing to their rigid backbone that provides selectivity and stability at high pressures. ${ }^{11,12}$ Their stability at high pressure $\mathrm{CO}_{2}$ conditions is generally further improved by cross-linking and thermal annealing of polymers in the vicinity of the glass transition temperature. ${ }^{10,13-15}$ However, the improved stability is usually at the cost of permeability due to loss of free volume required for transport. Membrane developers therefore aim to further improve gas permeabilities, while maintaining the rigid characteristics of the glassy polymers. ${ }^{1}$ In recent years, the development of highly permeable polymers has brought about new classes of polymers, including polymers of intrinsic microporosity (PIMs), ${ }^{16-19}$ thermally rearranged (TR) polymers, ${ }^{20-23}$ hybrid inorganic-organic network polymers, ${ }^{24-27}$ polyethers ${ }^{28}$ and substituted polyacetylenes. ${ }^{29}$ Their high excess free volume (EFV) content and high affinity towards gases allows for high solubility and rapid diffusion of gases through the membrane layers. Especially polymeric membranes with high EFV suffer from penetrant induced changes such as plasticization and physical ageing, as a result of increased macromolecular dynamics. ${ }^{30}$ Moreover, the changes of membrane performance in time are particularly pronounced for ultrathin films that suffer from nano-confinement effects and accelerated aging. ${ }^{30-39}$ The increased macromolecular dynamics in highly permeable polymers are caused by the high solubility of a penetrant in the polymer 
matrix. Strategies to decelerate the macromolecular chain mobility include the use of hyper-cross-linked ${ }^{25,40}$ or interpenetrating networks ${ }^{41}$ and the physical dispersion of nanoparticles in the polymer. ${ }^{42}$ The hybridization allows for material synthesis that provides a synergistic combination of the highly permeable polymer and rigid inorganic constituents. ${ }^{43}$ Particularly hybrid networks that consist of alternating organic and inorganic groups allow for material design with properties that are distinct from those of the individual components. Here, we investigate the $\mathrm{CO}_{2}$ sorption and swelling behavior of an ultrathin hybrid network polymer using spectroscopic ellipsometry (SE). SE can be used to accurately determine the sorption, sorbed gas molar volume and penetrant-induced changes in the network polymer. Other gravimetric techniques used to determine sorption do not allow for accurate sorption measurements on ultrathin films, because the buoyancy correction that is required for calculation of the sorption depends on the polymer volume, which is an unknown parameter when strong swelling of the polymer occurs.

The network is based on polyhedral oligomeric silsesquioxanes (POSS) that are covalently bound by aromatic imide bridges. The POSS molecules restrict the macromolecular dynamics at elevated $\mathrm{CO}_{2}$ pressures, while the fluoroalkane-functionalized imide bridges provide affinity towards $\mathrm{CO}_{2}$ sorption. The properties of the ultrathin poly(POSS-imide) films have been systematically investigated with respect to their sorption, dilation and macromolecular dynamics at high $\mathrm{CO}_{2}$ pressures. We show that the degree of network connectivity is crucial for moderating dilation at very high $\mathrm{CO}_{2}$ concentrations. The presented poly(POSS-imide)s display very high $\mathrm{CO}_{2}$ sorption capacities, while the network rigidity restricts short- and long-term dynamics.

\subsection{Experimental}

\subsubsection{Membrane synthesis}

Network formation occurs via a facile interfacial polymerization reaction between an aqueous solution of POSS and a dianhydride solution in toluene. Here, the monomer concentration in the aqueous solution was varied to obtain films with different thicknesses and imide:POSS ratios. The $\mathrm{pH}$ of the POSS solution was fixed at 9.9, after optimization of the $\mathrm{pH}$ with respect to thickness and refractive index (Appendix, Figure A5-1). Poly(POSS-imide) membranes were prepared by interfacial polymerization of water-soluble ammonium chloride-functionalized POSS (octa-ammonium POSS ${ }^{\circledR}$, Hybrid Plastics) and a 
0.075 wt.\% 4,4-(hexafluoroisopropylidene) diphthalic anhydride (6FDA, Sigma-Aldrich) solution in toluene. The partial conversion of ammonium to primary amine groups was achieved by addition of $\mathrm{NaOH}$ until the solution reached a $\mathrm{pH}$ of 9.9. Supported thin films were produced on $\alpha$-alumina discs (Pervatech, Netherlands) coated with $1.5 \mu \mathrm{m}$ thick $\gamma$-alumina (porosity of $\sim 40$ $\%$ and a pore size of 2-3 nm). First, the $\alpha$-alumina discs, held fixed on a perforated plate by vacuum, were impregnated with the POSS solution. Next, the discs were left to dry in a nitrogen atmosphere for $30 \mathrm{~min}$ and subsequently submersed in the 6FDA in toluene solution. After $5 \mathrm{~min}$ reaction time the toluene was removed from the interface and the discs were washed with acetone to remove any residual reactants. After drying for at least 2 hours in air atmosphere the samples were heat-treated for 2 hours at $300{ }^{\circ} \mathrm{C}$ to achieve conversion of the amic acid groups to cyclic imide groups. The concentration of the POSS solution, a critical parameter in the interfacial polymerization reaction, were varied to obtain membranes with different thicknesses, refractive indices and chemical composition.

The Matrimid films were deposited on both silicon wafers and $\gamma$-aluminacoated discs to mimic the sample structure of the poly(POSS-imide)s. ${ }^{44}$ Matrimid membranes atop silicon wafers were prepared by spin coating (WS400B-6NPP/LITE, Laurell Technologies Corporation) of a 7 wt.\% Matrimid (type 5218, Huntsman) solution in cyclopentanone, under $\mathrm{N}_{2}$ atmosphere. Silicon wafers (100, front side polished, CZ test grade, Silchem) were used as a substrate for the spin-coated layer. The wafers were stored under clean-room conditions until being cut. The spin coating recipe consisted of a single step of 60 seconds at $3000 \mathrm{rpm}$. Matrimid membranes atop $\gamma$-alumina coated $\alpha$ alumina discs were prepared by floating of a spin coated, air-dried Matrimid layer deposited on a silicon wafer. ${ }^{44}$ Detachment of the Matrimid layer from the silicon wafer was accomplished by placing the sample in milli-Q water for $30 \mathrm{~min}$. A $\gamma$-alumina coated $\alpha$-alumina discs was carefully moved below the floating layer and moved upwards until full coverage of the disc was accomplished. Removal of water was accomplished by placing the samples in vacuum at $30{ }^{\circ} \mathrm{C}$ for at least 24 hours. In the ellipsometry cell, slight vacuum was applied on the substrate side to assure the presence of a sharp interface between Matrimid and the $\gamma$-alumina layer that was required for a resolvable ellipsometry model. The samples were annealed at $300{ }^{\circ} \mathrm{C}$ to remove any residual solvent and to improve the plasticization resistance. For samples that were not annealed, residual solvent results in non-physical $\mathrm{CO}_{2}$ sorption 
behavior. The thickness and refractive index data of non-annealed Matrimid are given in Figure A5-4 (Appendix).

\subsubsection{Spectroscopic ellipsometry}

The thickness and refractive index of poly(POSS-imide)s atop $\gamma$-alumina coated $\alpha$-alumina discs were determined using spectroscopic ellipsometry (M2000X, J.A. Woollam Co., Inc.). The psi $(\Psi)$ and delta $(\Delta)$ spectra were recorded over a wavelength range of 340-1000 nm, with a spectral resolution of about $2 \mathrm{~nm}$, using light reflected at $65^{\circ}, 70^{\circ}$ and $75^{\circ}$ angles of incidence. The optical model of the poly(POSS-imide) layer atop a $\gamma$-alumina coated $\alpha$-alumina disc is visualized in Figure 5-1.

\section{SEM micrograph}

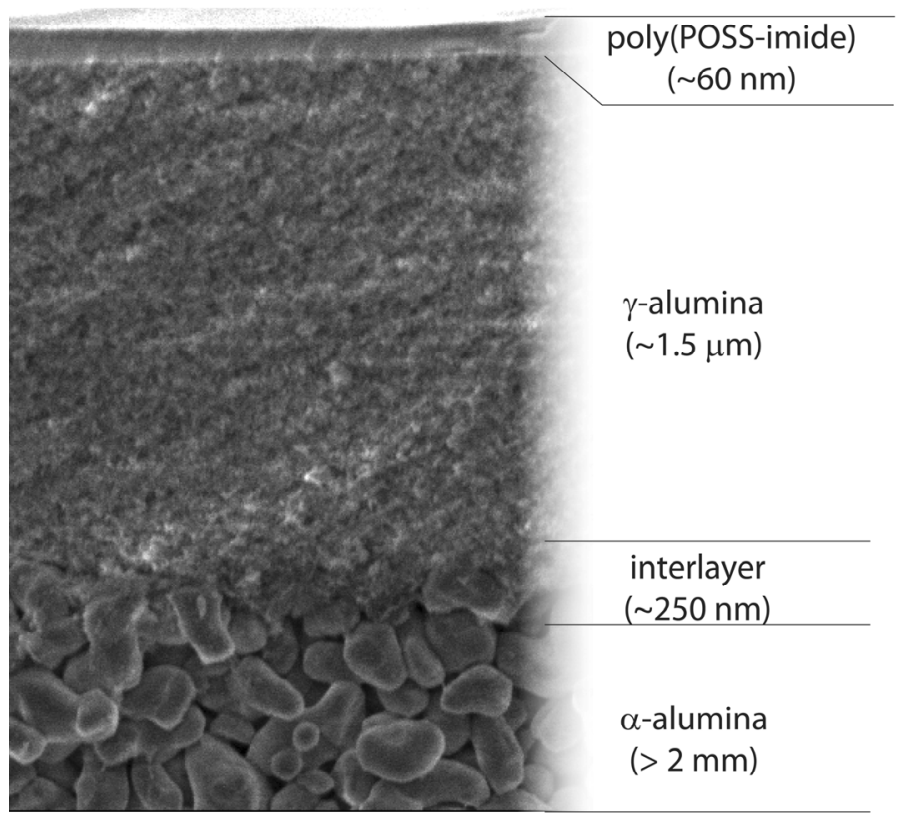

Layer assignment

\section{del (fit parameter) \\ Cauchy $[d, n(A, B)]$}

$\operatorname{EMA}\left(\Phi_{\text {void }} d\right)$ of: Cauchy $[n(A, B, C)]$ Void

Figure 5-1. Optical model of a poly(POSS-imide) layer atop a $\gamma$-alumina coated $\alpha$-alumina disc. The cross-section scanning electron micrograph of the membrane shows the distinct morphology of the dense poly(POSSimide) layer, $\gamma$-alumina and $\alpha$-alumina.

The layered optical model was constructed by a stepwise measurement of each individually added layer. The $\alpha$-alumina disc was modelled using an Effective Medium Approximation (EMA) of three-parameter Cauchy-type optical dispersion of $\mathrm{Al}_{2} \mathrm{O}_{3} \mathrm{n}(\lambda)=A+B / \lambda^{2}+C / \lambda^{4}$ with $A=1.751, B=0.00632 \mu \mathrm{m}^{2}, C$ 
$=-0.00010152 \mu \mathrm{m}^{45}$ and void $(n=1)$ with a graded EMA layer atop corresponding to the roughness of the ceramic disc. Justification for the optical model and its validation versus Atomic Force Microscopy and Mercury Porosimetry is given elsewhere ${ }^{44}$. The samples were again measured after coating of the $\gamma$-alumina layer. The interlayer between the $\gamma$-alumina and the $\alpha$-alumina was assumed to have a thickness similar to the thickness of the graded EMA layer that reflects the roughness of the $\alpha$-alumina disc, but its porosity was left as a fitting parameter accounting for the possible intrusion of the $\gamma$-alumina layer. The $\gamma$-alumina thickness and porosity were modelled using an EMA of $\mathrm{Al}_{2} \mathrm{O}_{3}$ and void. Finally, poly(POSS-imide) formation atop the $\gamma$-alumina was achieved by a procedure described in the synthesis section. The poly(POSS-imide) layer thickness and refractive index were determined using a two-parameter Cauchy optical dispersion (fit parameters $A$ and $B$ ), assuming transparency of the hybrid material in the used wavelength range. The porosity of the $\gamma$-alumina and the interlayer were set as fit parameters, to account for the water that remains in the $\gamma$-alumina after poly(POSS-imide) synthesis. The wavelength range for all optical models was limited to 500$1000 \mathrm{~nm}$ to reduce the influence of light scattering as a result of the nonuniformity of the porous $\alpha$-alumina discs. ${ }^{44}$

\subsubsection{Spectroscopic ellipsometry - high pressure $\mathrm{CO}_{2}$ sorption}

Spectroscopic ellipsometry measurements at elevated gas pressures were conducted with an Alpha-SE ${ }^{\circledR}$ ellipsometer (J.A. Woollam Co. Inc.). All measurements were done at a fixed angle of incidence $\left(70^{\circ}\right)$ in the wavelength range from 370 to $900 \mathrm{~nm}$. Samples were placed in a home-built stainless steel cell $\left(p_{\max }=20 \mathrm{MPa}, T_{\max }=473.15 \mathrm{~K}\right)$ equipped with a temperature and pressure control system, as depicted in Scheme 5-1. 


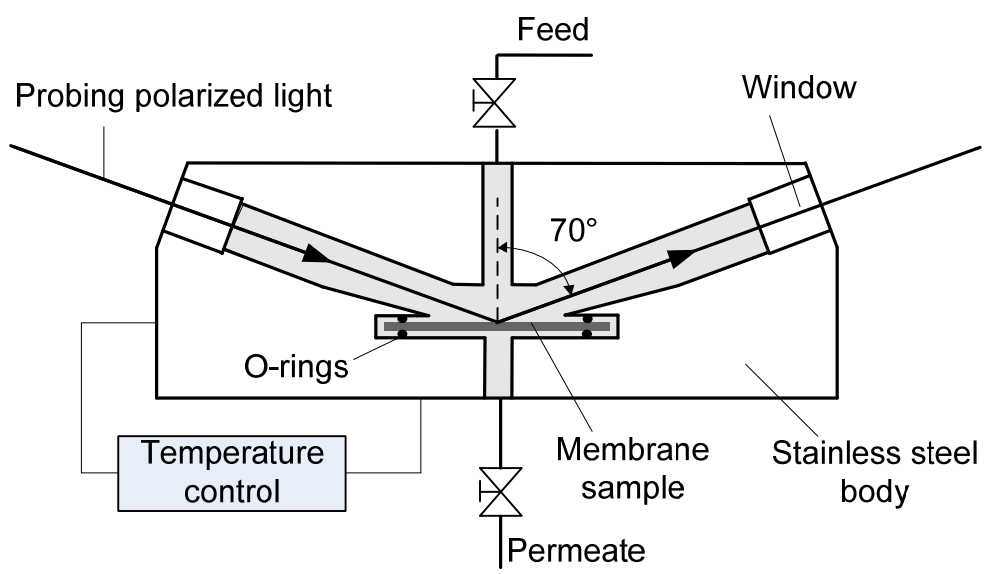

Scheme 5-1. Schematic of the stainless steel cell used in the spectroscopic ellipsometry analysis of $\mathrm{CO}_{2}$ adsorption and swelling dynamics of poly(POSS-imide)s and Matrimid membranes.

Accurate control and stability (within 0.1 bar) of the gas pressure was achieved using a syringe pump (Teledyne ISCO, 500D). The system temperature was maintained at $35{ }^{\circ} \mathrm{C}$ by a glycol bath connected to the cylinder of the syringe pump and by an induction heating belt connected to the measurement cell, in order to correct temperature changes due to $\mathrm{CO}_{2}$ Joule-Thompson effects upon incremental pressure change. Light entered and exited the cell through $1 \mathrm{~cm}$ thick quartz windows positioned perpendicular to the polarized light beam source and detector. Pressure induced birefringence of the cell windows was measured via a high-pressure helium calibration on a $25 \mathrm{~nm} \mathrm{SiO}_{2} / \mathrm{Si}$ wafer, and used for correction of during further high pressure measurements.

\subsubsection{Magnetic suspension balance}

The poly(POSS-imide) $\mathrm{CO}_{2}$ sorption isotherms were measured in $\mu \mathrm{g}$ resolution using a gravimetric sorption analyzer with magnetic suspension balance (Rubotherm). The temperature of the chambers was controlled at 35 ${ }^{\circ} \mathrm{C}$ by an external thermostat. In order to correct for drift, the magnetic suspension balance decouples the sample holder from the balance every $2 \mathrm{~min}$, measures the zero point and automatically corrects the deviation. To compensate the buoyancy effect introduced by quick changes of the reigning pressure in the pressure vessel, the precise volume of the sample container (filled and empty) is required. The determination of the sample container mass and volume starts with a degassing step at elevated temperatures. Sequential purging with helium guarantees the removing of all moisture and stable mass 
in the end. As soon as the mass is constant the temperature is regulated to the desired measurement temperature. The degassing step has been conducted for almost 2 days. Plotting the mass as a function of the gas density (helium) reveals the volume of the empty sample container which corresponds to the slope of the line. In addition the mass of the sample container is equal to the mass when no helium through flow is applied (interception at the y axis).

The density of helium and $\mathrm{CO}_{2}$ are calculated and integrated using ASPEN Properties. In order to determine the volume and mass of the sample container filled with sample, the same procedure is adapted. Before starting with the sorption and desorption measurements vacuum is applied to the pressure vessel and if necessary the temperature level corrected. The sorption and desorption measurements presented here are conducted at a constant temperature of $35^{\circ} \mathrm{C}$ and range between 0 and 30 bar. The gas chosen for the sorption is $\mathrm{CO}_{2}$. As mentioned above all measurements need to be corrected due to the buoyancy effect. Lorenz and Wessling derived the HSC algorithm which compensates this effect. ${ }^{46}$

\subsubsection{X-ray photoelectron spectroscopy}

Elemental composition and functional group binding energies were measured using X-ray photoelectron spectroscopy (XPS). The measurements were performed on a Quantera SXM scanning XPS microprobe (Physical Electronics), using a monochromatic $\mathrm{Al} \mathrm{K \alpha}$ source $(1486.6 \mathrm{eV})$ with a beam size of $200 \mu \mathrm{m}$. On every sample 4 different areas were probed with an area size of $300 \times 200 \mu \mathrm{m}$. XPS depth profiling was done by Argon ion sputtering at $2 \mathrm{kV}$, corresponding to a sputter speed of $5.4 \mathrm{~nm} \mathrm{~min}{ }^{-1}$ on $\mathrm{SiO}_{2}$.

\subsubsection{Scanning electron microscopy}

Scanning electron microscopy (SEM) images were obtained using a LEO-1550 Schottky field emission scanning electron microscope (Carl-Zeiss, Germany), with an accelerating voltage of $1.40 \mathrm{kV}$. The cross-section micrographs were used to determine the poly(POSS-imide) layer thickness.

\subsection{Results and discussion}

The poly(POSS-imide) membranes consist of a network of alternating POSS and imide moieties. The imide:POSS ratio, corresponding to the degree of network cross-linking, determines the membrane properties to a great extent. The layer growth and imide:POSS ratio are functions of the reactant concentration, reactivity, diffusivity and solubility in either phase. Figure 5-2 
(left panel) shows the reaction scheme of the formation of poly(POSS-imide) membranes by interfacial polymerization of octa-ammonium POSS and 6FDA. Each POSS cage is decorated with eight ammonium functional groups, that can potentially be converted to amine groups using a base such as sodium hydroxide. Formation of a poly[POSS-(amic acid)] layer is accomplished by contacting an aqueous solution of the partially deprotonated octa-ammonium POSS with a 6FDA solution in toluene. Finally, the amic acid groups are converted to cyclic imides by a heat treatment at $300{ }^{\circ} \mathrm{C} .{ }^{47}$ Figure 5-2 (right panel) shows the micrographs of the poly(POSS-imide) membranes atop ceramic discs, prepared with 5.0, 2.5 and 0.9 wt.\% POSS solutions.
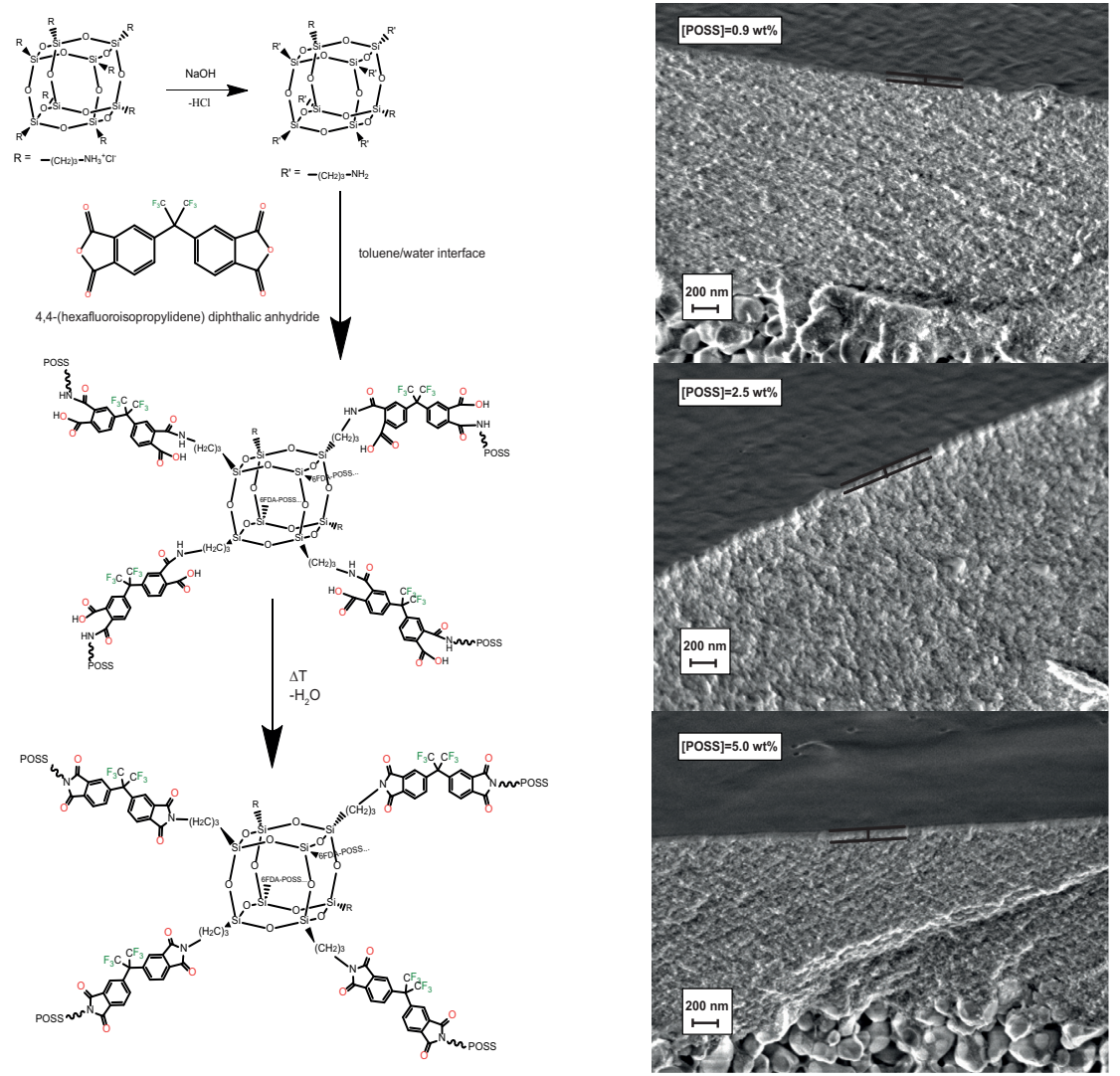

Figure 5-2. (left panel) Reaction scheme of the formation of poly(POSSimide) membranes by interfacial polymerization of octa-ammonium POSS in water and 6FDA in toluene. (right panel) Scanning electron micrographs of poly(POSS-imide)s prepared with 5.0, 2.5 and 0.9 wt.\% POSS solutions. 
The thickness of the poly(POSS-imide) layer increases with increasing concentration of the POSS solution used for synthesis. The poly(POSS-imide) layers display relatively smooth surfaces compared to conventional interfacial polymerization membranes. ${ }^{48}$ The regular surface is likely a result of the limited solubility of the charged POSS molecules in the organic phase, and limited diffusivity of the large reactants upon formation of the dense membrane layer. ${ }^{49}$ The irregularities found for films prepared with lower POSS concentrations likely originate from the roughness of the $\gamma$-alumina layer. For thicker poly(POSS-imide) layers, the fingerprint of the $\gamma$-alumina substrate fades.
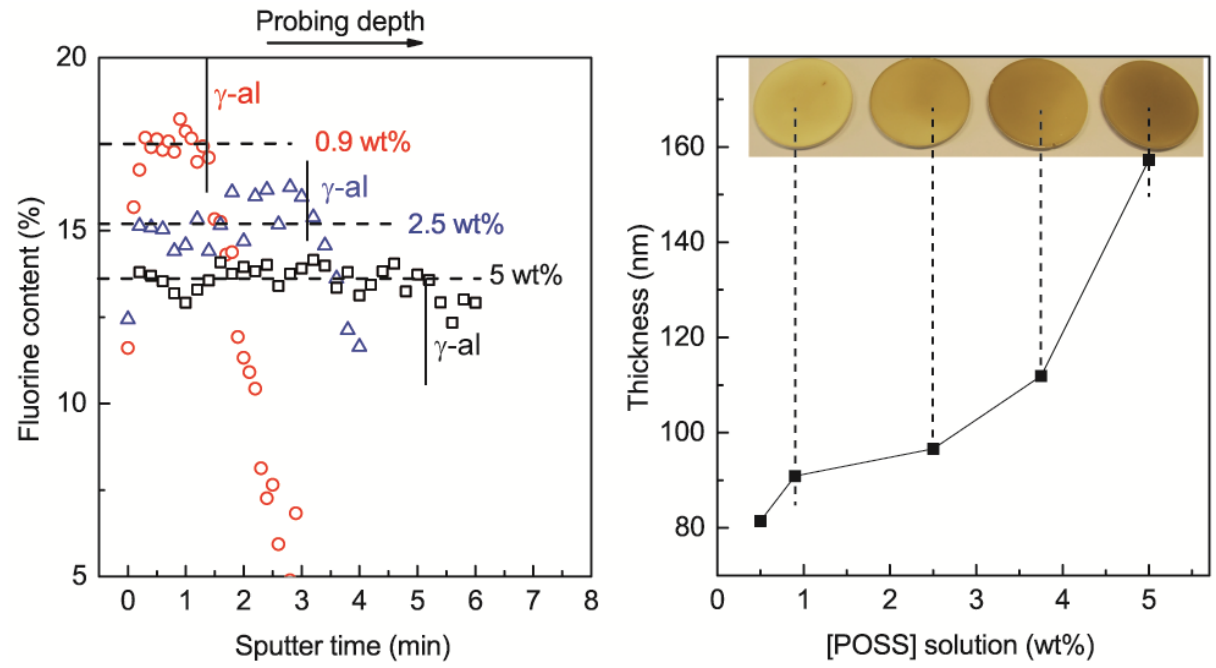

Figure 5-3. (left panel) The poly(POSS-imide) fluorine atom\%, determined by XPS as a function of etching time by argon ion sputtering. The sputter time is approximately proportional to the probing depth of the films. The sputtering depth at which the $\gamma$-alumina layer emerges in the XPS depth profile data is indicated with a horizontal line. (right panel) Poly(POSSimide) refractive index (red, open circles) and layer thickness (black, closed squares) as function of POSS concentration of the aqueous POSS solution used for interfacial polymerization. The photograph displays the top view of the ceramic discs with the corresponding poly(POSS-imide) layers. All lines are drawn as a guide for the eye.

The poly(POSS-imide)s prepared with different concentrations were further analyzed with respect to chemical composition and optical properties. Figure 5-3 (left panel) displays the ratio of fluorine content determined by $\mathrm{X}$-ray photoelectron spectroscopy as function of argon sputter time. The 
sputter time relates to the probing depth. The fluorine content data show that the number of imide groups is higher for the membranes prepared with lower POSS concentrations. The average number of imide groups per POSS cage, calculated from the fluorine content, equals about 3.7, 4.3 and 4.9 imide groups per POSS cage for the 5, 2.5 and 0.9 wt.\% layers, respectively. The imide:POSS group ratios are in accordance with the reactant stoichiometry during interfacial polymerization. Membranes prepared with higher POSS concentrations result in higher POSS content. Membranes prepared with lower POSS concentrations have a higher fluorine content.

The fluorine content of the poly(POSS-imide) membranes is relatively constant over the probing depth, indicating that the number of imide groups per POSS cage is similar throughout the membrane. This implies that the cross-linking density is independent of the side at which the reactants are offered during interfacial polymerization reaction, different from the gradients found in conventional interfacial polymerization membranes. ${ }^{50}$ However, because different elements display a different propensity towards removal by argon ion etching it is not possible to determine the imide:POSS ratio as function of etching depth with certainty. The differences in the rate of element removal by sputtering are reflected by the gradients in $\mathrm{Si} / \mathrm{F}$ and $\mathrm{C} / \mathrm{F}$ ratios as function of sputtering depth (Figure A5-2, Appendix). The observation with respect to the absence of gradients in the fluorine content should therefore be treated with caution.

The lower fluorine content in layers prepared with increasing wt.\% POSS solutions corresponds well with the thickness and refractive index data obtained from spectroscopic ellipsometry experiments. Figure 5-3 (right panel) displays the thicknesses and refractive indices of the poly(POSS-imide) films as a function of the POSS solution concentration used for synthesis. Both the thickness and the refractive index increase with increasing POSS solution concentration. The refractive index is a measure for the optical density of the material, and depends on the imide:POSS group ratio and the group packing density. The lower refractive index for layers prepared with lower concentrations is related to the higher imide group content and number of fluorine groups. High fluorine concentrations are known to result in a lower refractive index due to their large contribution to free volume elements. ${ }^{51}$ Because the fluorine content strongly influences the refractive index, a straightforward correlation of the refractive index and group packing density is not possible. However, the lower number of imide groups per POSS cage is 
indicative of a higher packing density. A similar effect has been reported for alkyl-POSS thin films, where the shorter alkyl groups led to higher refractive indices of the films due to higher packing densities. ${ }^{52}$ In summary, a high POSS concentration used for interfacial polymerization results in a more dense network, while a low POSS concentration results in a more open network.

The increase in thickness with increasing POSS concentration corresponds with the thickness trend found by SEM analysis of the same membranes. In addition, visual observation of the poly(POSS-imide) membranes reveals that membranes prepared with higher POSS concentrations have a darker color, indicative for a thicker layer. The lower thicknesses observed for films prepared with low POSS concentration solutions could indicate that the reaction is strongly limited due to depletion of reactants and reactant diffusion limitations upon layer formation. The absolute value of the thickness determined by ellipsometry are higher than those observed by SEM, which can be due to partial intrusion of the poly(POSS-imide) in the $\gamma$-alumina support layer. The layer intrusion, not easily discernable in SEM analysis, is confirmed by the gradual increase of aluminum and oxygen element concentrations with increasing etching depth, measured using XPS analysis (Figure A5-2 and A53, Appendix). Also, the complexity of the optical model might result in an overestimation of layer thickness. Nonetheless, the agreement between spectroscopic ellipsometry, XPS and SEM data supports the optical model used for modelling to poly(POSS-imide)s atop $\gamma$-alumina coated $\alpha$-alumina discs.

In conclusion, the poly(POSS-imide) layer formation can be controlled using the POSS concentration in the aqueous solution used for interfacial polymerization. The membrane thickness, the POSS and fluorine fractions and network density can be tailored to optimize membrane performance with respect to stability under high pressure conditions.

\subsection{1. $\mathrm{CO}_{2}$ and $\mathrm{CH}_{4}$ sorption isotherms - high pressure ellipsometry}

The $\mathrm{CO}_{2}$ sorption isotherms of Matrimid and poly(POSS-imide)s prepared at POSS concentrations of $0.9,2.5$ and 5 wt.\% were measured using high pressure SE. The change in polarization state of light upon reflection from the layers allows for precise measurement of changes in film thickness and refractive index as a function of pressure. From these changes, the concentration of the sorbed gas can be estimated using the Clausius - Mossotti approach. $^{39,53-55}$ 


\section{$\mathrm{CO}_{2}$ sorption in Matrimid 5218}

The $\mathrm{CO}_{2}$ sorption behavior of ultrathin Matrimid layers was measured for comparison with the poly(POSS-imide) samples. Matrimid was chosen because it is a high EFV, relatively plasticization-resistant glassy polymer widely used for gas separation. ${ }^{14,56-58}$ This polyimide can serve as a benchmark for other potential gas separation materials, since it is characterized by a relatively large $\mathrm{CO}_{2}$ sorption capacity and a good $\mathrm{CO}_{2} / \mathrm{CH}_{4}$ membrane selectivity. It is also known to respond well to annealing below and in the vicinity of its glass transition to improve plasticization resistance. ${ }^{14,}{ }^{59}$ The Matrimid films were deposited on both silicon wafers and $\gamma$-alumina-coated discs to mimic the sample structure of the poly(POSS-imide)s. ${ }^{44}$ The samples were annealed at $300{ }^{\circ} \mathrm{C}$ to remove any residual solvent and to improve the plasticization resistance. For samples that were not annealed, residual solvent resulted in non-physical $\mathrm{CO}_{2}$ sorption behavior. Figure 5-4 shows the thickness (left panel), refractive index (middle panel) and $\mathrm{CO}_{2}$ concentration (right panel) of annealed Matrimid on a silicon wafer (top panels) and a $\gamma$-alumina coated disc (bottom panels) as function of pressure upon sorption and desorption.
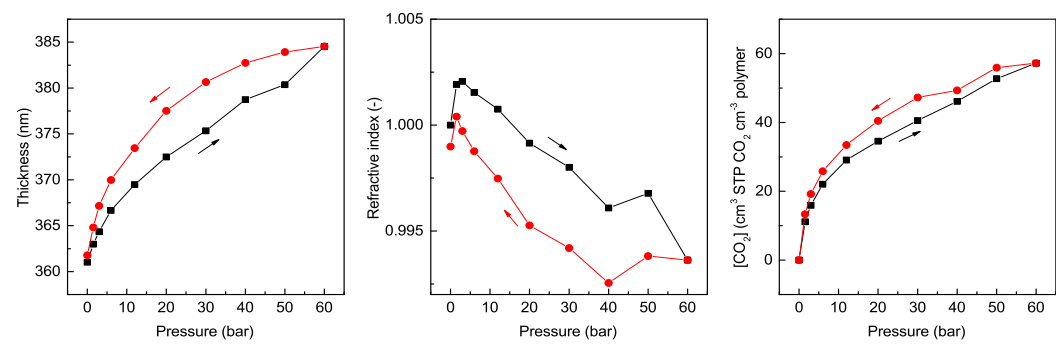

Matrimid on silicon wafer
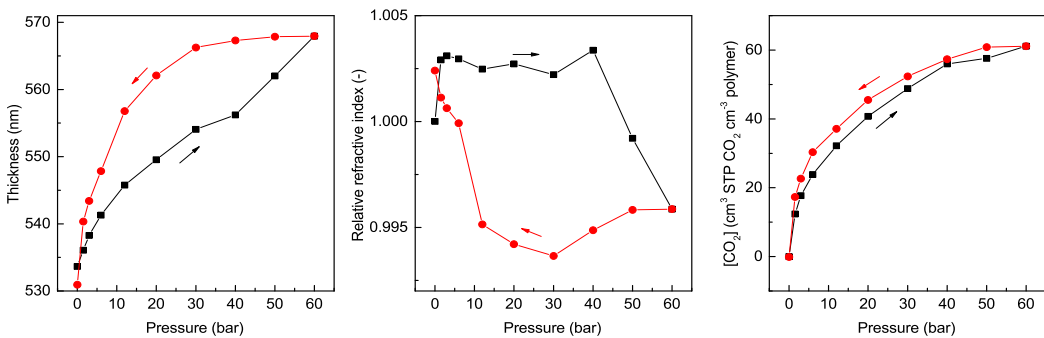

Matrimid on $\gamma$-alumina

Figure 5-4. (left panel) Thickness, (middle panel) relative refractive index and (right panel) $\mathrm{CO}_{2}$ concentration upon sorption ( $\square$ ) and desorption (•) of a $300{ }^{\circ} \mathrm{C}$ annealed Matrimid film on a silicon wafer (top panels) and a $\gamma$ alumina coated disc (bottom panels) as function of pressure. 
The more complex optical model for Matrimid on the $\gamma$-alumina-coated disc is validated by measurements of Matrimid on silicon wafers. The similarity between the thickness and refractive index data as function of pressure confirms the validity of the ellipsometry model for the Matrimid layer on top of the $\gamma$-alumina coated disc. Both thickness graphs display a concave shape of the isotherm, which is typical for gas sorption in glassy polymers, having a free volume distribution with frozen-in free volume. ${ }^{58,60}$ Upon increasing $\mathrm{CO}_{2}$ pressure from 0 to 1.5 bar, a simultaneous thickness increase and relative refractive index increase occurs. At higher $\mathrm{CO}_{2}$ pressures, the relative refractive index predominantly decreases. For a relative refractive index larger than 1, the frozen-in free volume elements of the polymer $(n=1.000)$ are being filled by the adsorbing gas molecules. A relative refractive index below 1 indicates predominant dissolution of the adsorbing gas molecules in the polymer matrix, and results in a reduction of the refractive index of the mixture. This is because the refractive index of the liquid $\mathrm{CO}_{2}$ (estimated at $n$ $\approx 1.23^{10,54,61,62}$ ) is much lower than the refractive index of the analyzed polymers. Matrimid displays predominantly free volume filling at low pressures, followed by dilation of the matrix at high $\mathrm{CO}_{2}$ pressures.

Upon desorption, the thickness and refractive index revert, without recovering to the original values that were found during sorption. The large hysteresis effect can be rationalized by the structural rearrangements upon dilation and lack of necessary chain mobility required to return the polymer to its original state. In fact, such hysteresis effects are known to be strongly depend on the sample's swelling history. ${ }^{63}$ The hysteresis effect in the refractive index are most pronounced for annealed Matrimid with respect to the non-annealed samples (Figure A5-4, Appendix). The suppressed mobility of the annealed Matrimid is likely related to the absence of residual solvent and chain reorganization upon heat treatment. The pronounced hysteresis in thickness and refractive index underline the non-equilibrium glassy nature of Matrimid.

The $\mathrm{CO}_{2}$ concentration in Matrimid as function of pressure, derived from the thickness and refractive index data, shows a typical glassy polymer sorption curve. Initially, a steep increase of $\mathrm{CO}_{2}$ concentration is observed, related to $\mathrm{CO}_{2}$ sorption in the easily accessible EFV of the polymer. At higher pressures, the sorption is dominated by $\mathrm{CO}_{2}$ uptake that requires polymer dilation. The $\mathrm{CO}_{2}$ sorption capacities of Matrimid agree very well with those reported in literature. ${ }^{39,53}$ 


\section{$\mathrm{CO}_{2}$ sorption in poly( $\mathrm{POSS}$-imide)s}

The poly(POSS-imide)s have properties that are distinct from organic polymers, due to their hyper-cross-linked network characteristics. As a consequence, the $\mathrm{CO}_{2}$ sorption behavior of poly(POSS-imide)s is completely different than that of Matrimid. Figure 5-5 shows the $\mathrm{CO}_{2}$ sorption-induced swelling (left panel), the relative refractive indices (middle panel) and adsorbed $\mathrm{CO}_{2}$ concentration (right panel) as function of pressure for poly(POSS-imide)s prepared with 0.9, 2.5 and 5 wt.\% POSS solutions. As a reference, the corresponding data for Matrimid and 6FDA-DAM:DABA-based polyimide are also shown.
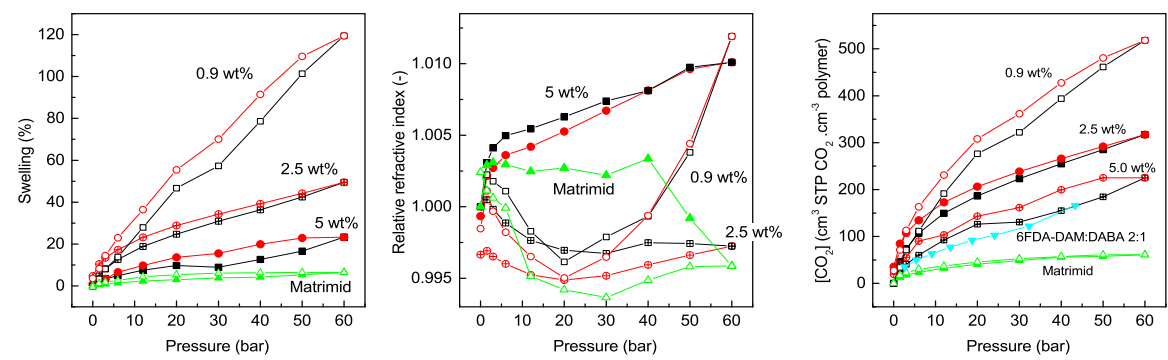

Figure 5-5. (left panel) Swelling degree, (middle panel) relative refractive index and (right panel) $\mathrm{CO}_{2}$ concentration as function of pressure for the poly(POSS-imide) membranes on $\gamma$-alumina coated discs, prepared at different POSS concentrations. Matrimid swelling degree, relative refractive index and sorption data and 6FDA-DAM:DABA-based polyimide sorption data are shown as reference. ${ }^{10}$

All poly(POSS-imide)s show significant degrees of swelling (left panel) that are associated with the high $\mathrm{CO}_{2}$ concentrations. The highest swelling is observed for the layers prepared with low POSS concentration solutions. The large degree of swelling, as much as $120 \%$ at 60 bar for the 0.9 wt.\% sample, demonstrates that the network has a flexible response to $\mathrm{CO}_{2}$ exposure. This is in contrast with the membranes prepared with high POSS concentrations that show a much less pronounced swelling.

The $\mathrm{CO}_{2}$ concentration data (right panel) shows that all three poly(POSSimide)s are characterized by $\mathrm{CO}_{2}$ sorption capacities that are much larger than that of Matrimid. The most pronounced $\mathrm{CO}_{2}$ sorption and swelling is observed for the poly(POSS-imide)s with the highest fluorine content. The high $\mathrm{CO}_{2}$ uptake, also observed for 6FDA based polymers, is attributed to the presence 
of $\mathrm{CF}_{3}$ groups in the structure. ${ }^{10,64,65}$ The data from Wind et al. for an ester modified 6FDA-DAM:DABA-based polyimide has a similar order of magnitude $\mathrm{CO}_{2}$ concentration. The magnitude of $\mathrm{CO}_{2}$ uptake increases with a decreasing concentration of the POSS solution used for the synthesis. The higher $\mathrm{CO}_{2}$ solubility can be rationalized by the higher concentration of fluorine for the layers prepared with lower POSS concentrations, as determined by SE in combination with XPS.

Despite the high swelling degrees, the swelling of all poly(POSS-imide)s under vacuum upon desorption returns very closely to the initial values before sorption. This indicates a good high pressure stability of the materials and is related to their highly cross-linked, giant macromolecular network character. The sorption-induced hysteresis of swelling, especially for 2.5 and $5 \mathrm{wt} . \%$ samples is comparable to that for Matrimid. In the case of the $0.9 \mathrm{wt} \% \%$ sample the hysteresis is larger. This might be due to the possibility of some macromolecular rearrangements as a result of the largest swelling and the lowest cross-linking density of this material.

The lack of significant sorption-desorption hysteresis for the poly(POSSimide)s, in comparison to Matrimid, is particularly evident from the refractive index isotherms. While the excess free volume structure of the Matrimid changes significantly in the course of the experiment, the poly(POSS-imide) based membranes seem remarkably stable. This again is in agreement with the highly cross-linked nature of the system, as opposed to the non-cross-linked structure of Matrimid, which allows for long range macromolecular rearrangements. The free volume characteristics of the poly(POSS-imide)s are therefore also different from conventional polymeric membranes. The free volume is not present as frozen-in free volume between the polymer chains, but as open spaces between the network elements.

The relative refractive index is calculated from the values of the refractive index of the $\mathrm{CO}_{2}$-exposed films divided by the refractive index of the films at vacuum. This type of sorption corresponds to the regular solution behavior. In the case of Matrimid, the refractive index during the sorption initially increases, corresponding to the filling of the EFV of the polymer. At higher pressures, the regular solution mechanism dominates and the index of the film decreases. Upon desorption, a pronounced, plasticization-related hysteresis is apparent as discussed earlier. In contrast, in the case of the $5 \mathrm{wt}$.\% poly(POSSimide) sample, the index increases during the sorption cycle up to the 
maximum reached pressure of 60 bar. This indicates, that even though this material swells about 4 times more than Matrimid, the regular sorption behavior still dominates the gas uptake. Such rather unusual behavior indicates the very high amount of penetrant-accessible open spaces in the network. This seems consistent with the observed significant increases of the free volume fractions for systems, where POSS is dispersed within the polymer network, as is determined from dielectric constant measurements. ${ }^{66}$ Nonetheless, such dispersions can also result in a decrease in sorption capacity, as is supported both by results of density and gas sorption measurements. ${ }^{67}$ The covalent bonds between the alternating POSS and imide groups in this work prevent loss of the open spaces in the network.

At lower POSS group concentrations, the network flexibility increases. The relative refractive index changes of the $2.5 \mathrm{wt} . \%$ sample, after showing an initial increase, decrease as function of pressure. The decrease in relative refractive index is indicative for strong dilation of the network, while a large part of the open spaces in the network have already been filled. Nonetheless, the dilation does have limitations: the refractive index of the $0.9 \mathrm{wt} . \%$ sample shows a strong increase above 20 bar. Such a behavior of the refractive index may be explained by a swelling-limiting effect of cross-links; the large affinity of the fluorine groups results in an increased sorption at higher pressures, but the matrix simply does not dilate further because the higher energy required for deformation.

\section{$\mathrm{CO}_{2}$ sorption isotherms - magnetic suspension balance}

The $\mathrm{CO}_{2}$ sorption isotherms of Matrimid and free-standing poly(POSS-imide) film prepared using a POSS concentrations of $0.9 \mathrm{wt} . \%$ were measured using a magnetic suspension balance (MSB). Figure A5-5 in the Appendix displays the $\mathrm{CO}_{2}$ sorption of (left panel) Matrimid and (right panel) poly(POSS-imide) powders as a function of $\mathrm{CO}_{2}$ pressure. For Matrimid, results are comparable to literature values are observed. For the poly(POSS-imide) samples, values that are much lower than those measured with $\mathrm{SE}$ are observed. A lower $\mathrm{CO}_{2}$ uptake in the poly(POSS-imide)s can be related to differences between powder reaction times (several hours reaction time are required to obtain sufficient powder volume for MSB measurements) and the change in reactant stoichiometries in the bulk can change the sample properties. More importantly, due to the swelling of the hybrid polymer, the calculations of the buoyancy effect are inherently incorrect (i.e., volume and mass calculations are dependent). The buoyancy correction requires precise knowledge of the 
sample volume. Since the volume is an unknown parameter for swelling samples such as the poly(POSS-imide)s, the gas sorption cannot be quantified from measurements based on volume displacement or mass changes.

\section{$\mathrm{CH}_{4}$ sorption in poly(POSS-imide)s}

Figure 5-6 (left panel) shows the swelling degree of the poly(POSS-imide) layers as function of $\mathrm{CH}_{4}$ pressure. The swelling degree increases with an increasing methane pressure, with swelling degrees up to about $60 \%$. The highest swelling is observed for the layers prepared with low POSS concentration solutions. The swelling degrees are significant compared to conventional polymers, but are less high as compared to swelling by $\mathrm{CO}_{2}$ at similar pressures.
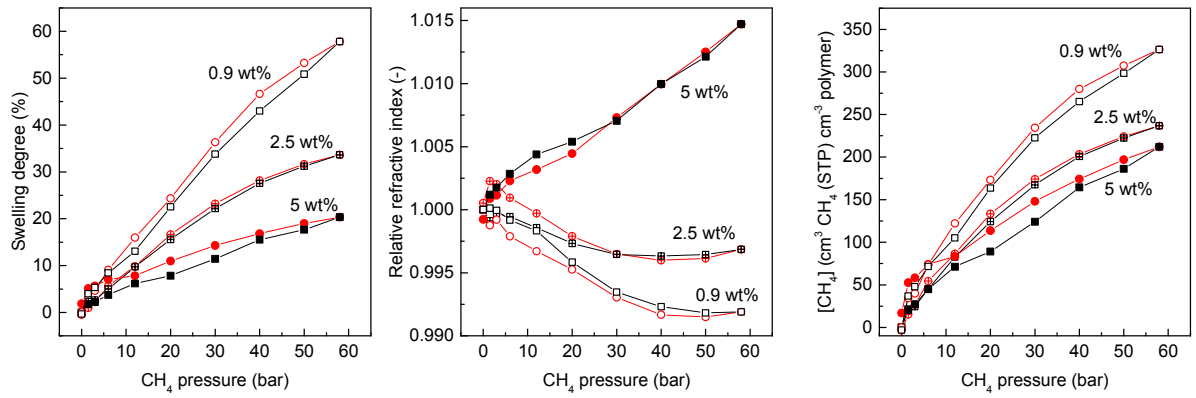

Figure 5-6. (left panel) Swelling degree, (middle panel) relative refractive index and (right panel) $\mathrm{CH}_{4}$ concentration upon sorption (a) and desorption (•) of poly(POSS-imide)s prepared with 0.9, 2.5 and 5.0 wt.\% POSS solutions and a $300{ }^{\circ} \mathrm{C}$ annealed Matrimid film, on $\gamma$-alumina coated discs, as function of pressure.

The $\mathrm{CH}_{4}$ concentration data, shown in Figure 5-6 (right panel), shows that all three poly(POSS-imide)s are characterized by $\mathrm{CO}_{2}$ sorption capacities that are much larger than that of conventional polyimides. The $\mathrm{CH}_{4}$ concentrations are about half of the $\mathrm{CO}_{2}$ concentrations, similar to other 6FDA-based polyimides. The high $\mathrm{CH}_{4}$ concentration originate from the large amount of open space in the poly(POSS-imide) network and the flexible response of the network upon $\mathrm{CH}_{4}$ exposure that results in swelling of the network. The most pronounced $\mathrm{CH}_{4}$ sorption and swelling is observed for the poly(POSS-imide)s with the highest fluorine content. The relative refractive index data for $\mathrm{CH}_{4}$ sorption is similar to that of the $\mathrm{CO}_{2}$ sorption data. For the samples with a low fluorine content, the relative refractive index increases over the complete pressure range. The increasing refractive index is indicative for a high degree of 
network rigidity. For the poly(POSS-imide)s with a higher fluor content, the relative refractive index slightly decreases, indicating that the network rigidity is lower.

\subsection{2. $\mathrm{CO}_{2}$ and $\mathrm{CH}_{4}$ partial molar volume and penetrant induced dynamics}

The apparent molar volumes, $V_{m}$, of the dissolved gases can be determined from the slope of the swelling versus the $\mathrm{CO}_{2}$ or $\mathrm{CH}_{4}$ concentrations. ${ }^{53}$ Figure 5-7 (top panels) shows the swelling degree as a function of the $\mathrm{CO}_{2}$ (left panels) and $\mathrm{CH}_{4}$ (right panels) concentrations in the poly(POSS-imide)s. Figure 5-7 (bottom panels) shows the apparent $V_{m}$ derived from the slope of the swelling as function of the gas concentration data, as a function of the $\mathrm{CO}_{2}$ (left panels) and $\mathrm{CH}_{4}$ (right panels) concentrations in the poly(POSS-imide)s. At low $\mathrm{CO}_{2}$ concentrations, the poly(POSS-imide)s follow the same trend as Matrimid. Consequently, the apparent $V_{m}$ at lower $\mathrm{CO}_{2}$ concentrations for the poly(POSS-imide)s and Matrimid are similar. The $V_{m}$ of $\mathrm{CO}_{2}$ at low concentrations is about $27 \mathrm{~cm}^{3} \mathrm{~mol}^{-1}$, which is less than the approximate $V_{m}$ value for liquid $\mathrm{CO}_{2}$. This value is typical for glassy polymers ${ }^{68}$, where gas molecules fill the space between the polymer chains (sorption into access free volume) as well as dilating the polymer matrix (regular solution sorption). In the absence of the former mechanism (e.g. sorption in rubbery polymers or liquids) the $\mathrm{CO}_{2} V_{m}$ would be close to its liquid value, as is found for PDMS. ${ }^{69}$

As the $\mathrm{CO}_{2}$ concentration increases, the slope of the curves inclines towards values that are close to the approximate $V_{m}$ value for $\mathrm{CO}_{2}$ in liquids of about $46 \mathrm{~cm}^{3} \mathrm{~mol}^{-1}$. At very high $\mathrm{CO}_{2}$ concentrations, the apparent $V_{m}$ increases to above that of liquid $\mathrm{CO}_{2}$. The same observations are made for apparent $V_{m}$ values of $\mathrm{CO}_{2}$ in PDMS and PES, albeit at different $\mathrm{CO}_{2}$ concentrations. In PES, similarly high molar volumes of $\mathrm{CO}_{2}$ are attributed to long range polymer matrix reorganizations, also referred to as plasticization. ${ }^{70}$ Because only a small amount of EFV is present in PES, the apparent $V_{m}$ reaches high values at relatively low $\mathrm{CO}_{2}$ concentrations. For the poly(POSS-imide) layers a much higher degree of open space is present, which is reflected by the low apparent $V_{m}$ values at high $\mathrm{CO}_{2}$ concentrations. In PDMS, the upswing in the $\mathrm{CO}_{2}$ molar volume is attributed to a change in $\mathrm{CO}_{2}$ activity at high concentrations, also observed for $\mathrm{CO}_{2}$ /butane mixtures near the critical point (which is at $31{ }^{\circ} \mathrm{C}$ for $\mathrm{CO}_{2}$ ). However, the explanation of the near-supercritical behavior of $\mathrm{CO}_{2}$ is not satisfactory to explain the apparent $V_{m}$ changes in the ultrathin poly(POSS-imide)s. 
$\mathrm{CO}_{2}$
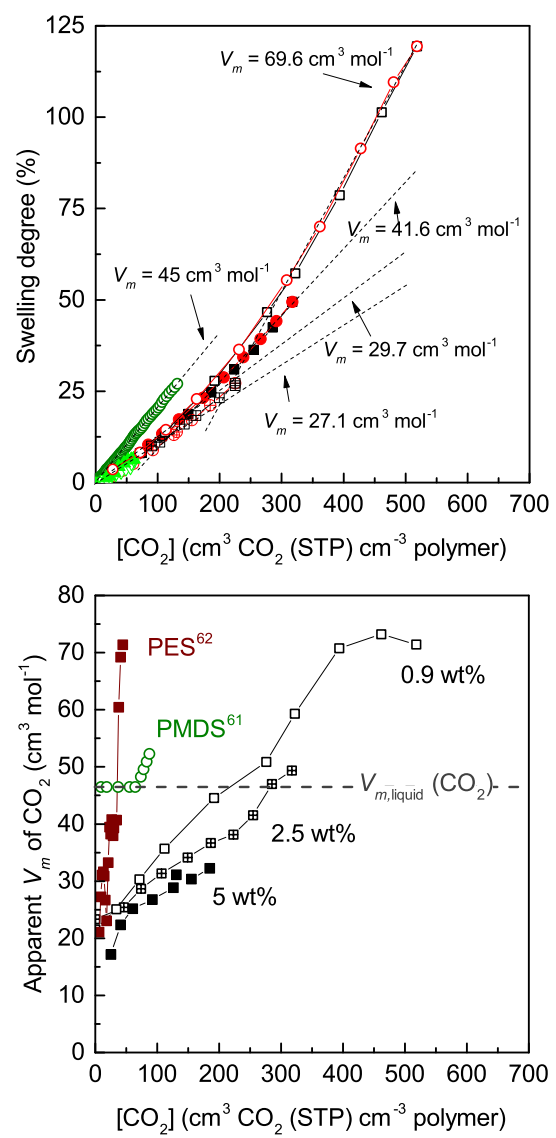

$\mathrm{CH}_{4}$
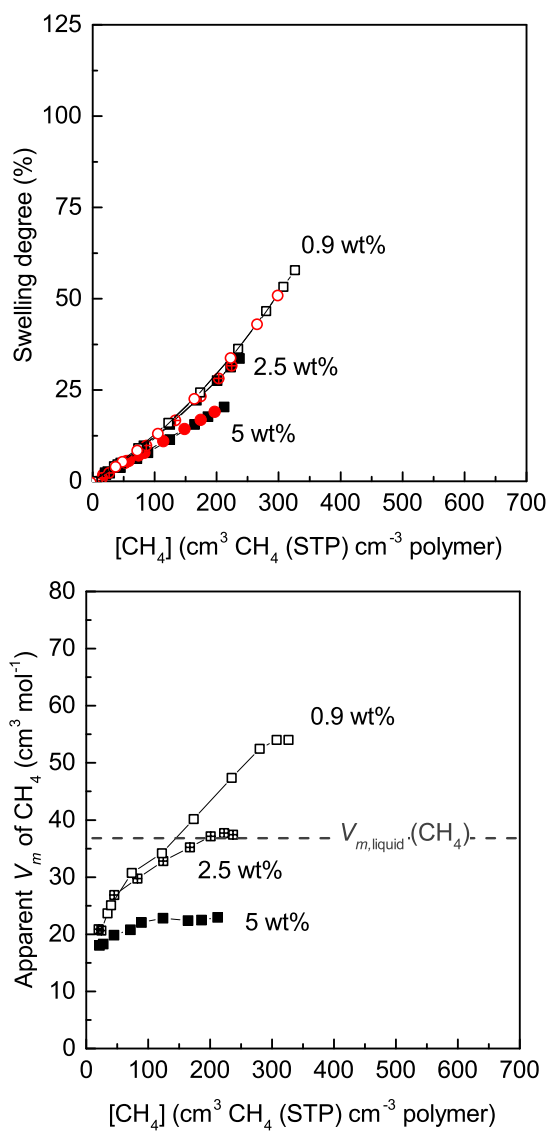

Figure 5-7. (top panels) Swelling as a function of the (left panel) $\mathrm{CO}_{2}$ and (right panel) $\mathrm{CH}_{4}$ concentrations in the poly(POSS-imide) layers prepared at (open symbols) 0.9, (crossed symbols) 2.5 and (closed symbols) 5.0 wt.\%, upon sorption (black squares) and desorption (red circles). Matrimid (light green triangles) and polydimethylsiloxane (PDMS, green circles, data from ${ }^{69}$ ) are added as a reference. (bottom panels) the $V_{m}$ of (left panel) $\mathrm{CO}_{2}$ and (right panel) $\mathrm{CH}_{4}$ as function of gas concentration in the poly(POSS-imide) layers prepared at different POSS concentrations. The $V_{m}$ of $\mathrm{CO}_{2}$ in PDMS (data from ${ }^{69}$ ) and polyethersulfone (PES, data from ${ }^{70}$ ) are added as a reference.

The apparent $V_{m}$ of $\mathrm{CH}_{4}$ displays a similar increase with increasing gas concentration. The apparent $V_{m}$ of $\mathrm{CH}_{4}$ similar as compared to $\mathrm{CO}_{2}$ at similar gas concentrations, except for the $5.0 \mathrm{wt} . \%$ that shows a lower $V_{m}$ value of $\mathrm{CH}_{4}$ as compared to $\mathrm{CO}_{2}$. The lower $V_{m}$ values might be related to the lower 
$V_{m}$ of liquid $\mathrm{CH}_{4}\left(37 \mathrm{~cm}^{3} \mathrm{~mol}^{-1}\right)$ as compared to $\mathrm{CO}_{2}\left(46 \mathrm{~cm}^{3} \mathrm{~mol}^{-1}\right)$. At high $\mathrm{CH}_{4}$ concentrations, the apparent $V_{m}$ increases to above that of liquid $\mathrm{CH}_{4}$, similar as the observations in $\mathrm{CO}_{2}$. The high $V_{m}$ values are not related to supercritical behavior, because $\mathrm{CH}_{4}$ at $35^{\circ} \mathrm{C}$ is not near its supercritical point. We suggest the changes in the $\mathrm{CO}_{2}$ and $\mathrm{CH}_{4}$ apparent $V_{m}$ are coupled to the high gas concentrations. When most of the initially available free volume has been filled, each $\mathrm{CO}_{2}$ or $\mathrm{CH}_{4}$ molecule added to the polymer matrix has to result in dilation. As the gas concentration increases, the interactions between $\mathrm{CO}_{2}$ or $\mathrm{CH}_{4}$ molecules and the polymer will become less relevant and the $V_{m}$ will approach that of the fluid phase. An infinitely diluted polymer matrix would approach the $V_{m}$ of $\mathrm{CO}_{2}$ or $\mathrm{CH}_{4}$ at a given pressure. For example, at 60 bar and $35{ }^{\circ} \mathrm{C}$ the $V_{m}$ of $\mathrm{CO}_{2}$ is about $280 \mathrm{~cm}^{3} \mathrm{~mol}^{-1}$ (calculated using ASPEN Properties 7.3, using a Soave-Redlich-Kwong property set for $\mathrm{CO}_{2}$ to predict the thermodynamic behavior of these gases within a range of 0 to 60 bars at 35 ${ }^{\circ} \mathrm{C}$ ), which is still much higher as the apparent $V_{m}$ of $\mathrm{CO}_{2}$ in the poly(POSSimide), PES or PDMS samples at 60 bar.

Unlike for the PES sorption, the increasing apparent $V_{m}$ of $\mathrm{CO}_{2}$ in the poly(POSS-imide)s is not related to time-dependent plasticization effects, since the sorption-desorption hysteresis is limited. This effect is particularly pronounced for the poly(POSS-imide) layer prepared with $5.0 \mathrm{wt} . \%$ POSS solution. The layer shows only a small increase in the apparent $V_{m}$, indicating that the network rigidity prevails over plasticizing effects of the gas. In addition, the lower $\mathrm{CH}_{4}$ concentrations and lesser extent of interactions between $\mathrm{CH}_{4}$ and the polymers might limit the plasticizing effect of the penetrant on the polymer matrix. Long-term, $\mathrm{CO}_{2}$-induced chain relaxations have been determined by the long-term thickness changes upon a sudden pressure increment. Figure 5-8 (left panel) displays the swelling degree as function of time for matrimid and poly(POSS-imide) thin films prepared at different POSS concentration on $\gamma$-alumina coated disc, after an incremental pressure increase from 0 to 50 bar $\mathrm{CO}_{2}$ pressure. Upon exposure to $50 \mathrm{bar}$ $\mathrm{CO}_{2}$, the layers almost instantaneously attain the high swelling degree. The swelling degrees are highest for 0.9 wt. $\%$ based poly(POSS-imide)s, followed by the others in the order 0.9 wt. $\%>2.5$ wt. $\%>5.0$ wt. $\%>$ Matrimid. The swelling degrees at 50 bar are in accordance with the stepwise sorption experiments displayed in Figure 5-4. Any slight discrepancies are probably caused by the difference in the $\mathrm{CO}_{2}$ exposure route. During the subsequent dwell, the thickness of the layers increases due to slow rearrangements of the 
network that are referred to as secondary relaxations. Figure 5-8 (right panel) displays the magnitude of secondary relaxations, given by the slope of the swelling change as function of the initial swelling value at 50 bar. The swelling change is obtained from a linear fit of the swelling degree data as function of time.
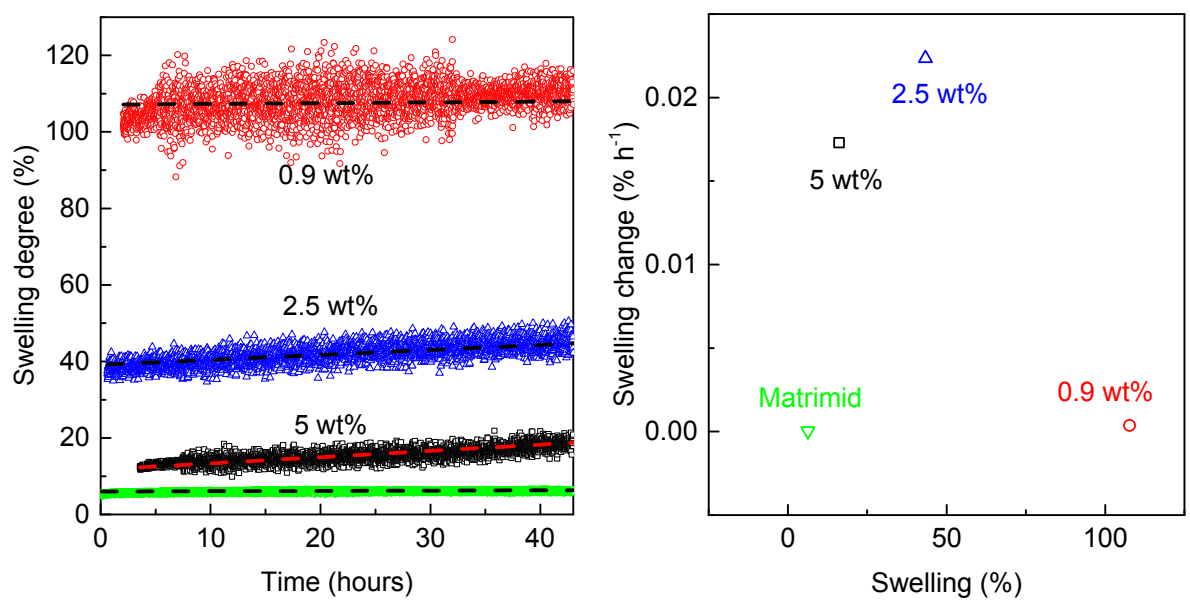

Figure 5-8. (left panel) Swelling degree as function of time for matrimid and poly(POSS-imide) thin films on $\gamma$-alumina coated disc prepared using 0.9, 2.5 and $5.0 \mathrm{wt} . \%$ POSS solutions, after an incremental pressure increase from 0 to 50 bar $\mathrm{CO}_{2}$ pressure. (right panel) Thickness increment of the slope of the swelling degree as function of time, as function of the initial swelling value at 50 bar.

The swelling change is most pronounced for the 2.5 and 5 wt.\% samples, indicating that these samples show the highest degree of secondary relaxations. For Matrimid and the $0.9 \mathrm{wt} . \%$ samples, secondary relaxations are much less pronounced. For Matrimid, the absence of large relaxations can be rationalized by the relatively low $\mathrm{CO}_{2}$ concentration as compared to the poly(POSS-imide) samples. The macromolecular mobility increases with $\mathrm{CO}_{2}$ concentration, and therefore shows a more pronounced change in the poly(POSS-imide) layers. For the 0.9 wt.\% sample, the high $\mathrm{CO}_{2}$ concentration likely accelerates the dynamics of the network to such an extent that the structure quickly attains a state close to equilibrium after exposure to 50 bar $\mathrm{CO}_{2}$. Thus any secondary relaxations are absent. 


\subsection{Conclusions}

Here, we compare the effects of high pressure $\mathrm{CO}_{2}$ and $\mathrm{CH}_{4}$ on the dilation and sorption behavior of ultrathin hybrid layers and conventional polyimide layers. The gas uptake was determined from thickness and refractive index changes obtained by spectroscopic ellipsometry measurements at high $\mathrm{CO}_{2}$ pressures. For the hybrid polymers we found sorption behavior that is distinct from the conventional polyimide. The dilation behavior hybrid polymers depends mainly on the fluorine group content. The $\mathrm{CO}_{2}$ and $\mathrm{CH}_{4}$ sorption in the hybrid poly(POSS-imides) are very high compared to conventional polyimides, due to the large amount of open space in the network and the flexible response of the network upon exposure to a high pressure gas. Because the open space gradually fills, additional sorption can only occur due to additional swelling. This large swelling degree prevents characterization of the sorption of these materials by using gravimetric methods that require accurate knowledge on the sample volume. Because of the gradual filling of the open space and increasing gas concentration in the poly(POSS-imide) films at higher pressures, the sorbing gases occupy an increasingly large molar volume. At high gas concentrations in the polymer film, the apparent molar volume of $\mathrm{CO}_{2}$ and $\mathrm{CH}_{4}$ exceeds that of the liquid molar volume, and approaches that of the fluid phase. The here determined structure-property relationship between the gas sorption behavior and hybrid material composition allows for optimization of the layers for $\mathrm{CO}_{2}$-related applications.

\subsection{Acknowledgements}

This project has received funding from the European Union's Seventh Framework Programme for research, technological development and demonstration under CARENA grant agreement no. 263007.

\subsection{Appendices}

\subsubsection{Spectroscopic ellipsometry}

The interfacial polymerization reaction parameters were analyzed using spectroscopic ellipsometry (SE) to determine the thickness and refractive index. Figure A5-1 shows the poly(POSS-imide) thickness and refractive index as function of $\mathrm{pH}$ of the aqueous POSS solution used for interfacial polymerization. 


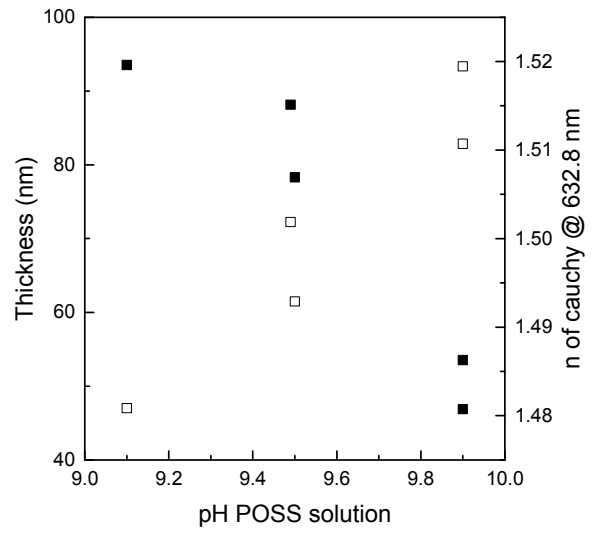

Figure A5-1. Thickness and refractive index as function of $\mathrm{pH}$, for poly(POSS-imide)s prepared with 0.9 wt.\% POSS solution.

With increasing $\mathrm{pH}$, the number of deprotonated ammonia group on each POSS cage increases, allowing more groups on each POSS cage to participate in the interfacial polymerization reaction. At low $\mathrm{pH}$ values, the lack of reactive amine groups on the POSS cages results in a high fraction of POSS cages with respect to the imide bridged groups. This is reflected by the high refractive index at low $\mathrm{pH}$ values. Alternatively, high $\mathrm{pH}$ values allow for many imide bridges to form on each POSS cage, resulting in a lower fraction of POSS cages. Because layer thicknesses need to be sufficiently high to resolve spectroscopic ellipsometry measurements at elevated pressures, only membranes prepared with a high $\mathrm{pH}$ were used for further analysis.

\subsubsection{X-ray photoelectron spectroscopy}

X-ray photoelectron spectroscopy (XPS) measurements were performed to determine the element concentration. XPS measurements were performed on a Quantera SXM scanning XPS microprobe (Physical Electronics), using a monochromatic Al $\mathrm{K} \alpha$ source $(1486.6 \mathrm{eV})$ with a beam size of $200 \mu \mathrm{m}$. XPS depth profiling was done by Argon ion sputtering at $2 \mathrm{kV}$, corresponding to a sputter speed of $5.4 \mathrm{~nm} \mathrm{~min}{ }^{-1}$ on $\mathrm{SiO}_{2}$. The element concentrations without Argon sputtering are given in Table A5-1. 
Table A5-1. Element concentrations and element ratios of poly(POSSimide) layers and powder prepared with different concentration POSS solutions. The element concentrations of 6FDA and octa-ammonium POSS are given as a reference.

\begin{tabular}{|c|c|c|c|c|c|c|}
\hline & $\begin{array}{l}\text { Poly(POSS- } \\
\text { imide) }(0.9 \\
\text { wt. } \%)\end{array}$ & $\begin{array}{l}\text { Poly(POSS- } \\
\text { imide) ( } 2.5 \\
\text { wt. } \%)\end{array}$ & $\begin{array}{l}\text { Poly(POSS- } \\
\text { imide) (5.0 } \\
\text { wt. } \%)\end{array}$ & $\begin{array}{l}\text { Poly(POSS- } \\
\text { imide) ( } 0.9 \\
\text { wt. } \%) \\
\text { powder }\end{array}$ & $6 \mathrm{FDA}$ & $\begin{array}{l}\text { Octa- } \\
\text { ammonium } \\
\text { POSS }\end{array}$ \\
\hline & $\begin{array}{l}\text { Element } \\
\text { concentration } \\
(\%)\end{array}$ & $\begin{array}{l}\text { Element } \\
\text { concentration } \\
(\%)\end{array}$ & $\begin{array}{l}\text { Element } \\
\text { concentration } \\
(\%)\end{array}$ & $\begin{array}{l}\text { Element } \\
\text { concentration } \\
(\%)\end{array}$ & $\begin{array}{l}\text { Element } \\
\text { concentration } \\
(\%)\end{array}$ & $\begin{array}{l}\text { Element } \\
\text { concentration } \\
(\%)\end{array}$ \\
\hline $\mathrm{C}$ & 44.2 & 44.4 & 48.2 & 44.0 & 65.5 & 47.8 \\
\hline $\mathrm{N}$ & 4.4 & 4.4 & 4.5 & 3.9 & & 9.8 \\
\hline $\mathrm{O}$ & 28.8 & 28.1 & 16.4 & 24.6 & 13.8 & 22 \\
\hline $\mathrm{Si}$ & 8.1 & 9.2 & 16.1 & 15.1 & & 11.5 \\
\hline $\mathrm{F}$ & 10.9 & 12.0 & 13.5 & 12.4 & 20.7 & - \\
\hline $\mathrm{Cl}$ & & & & & & 9 \\
\hline $\mathrm{Na}$ & 2.1 & 0.9 & 0.8 & & & \\
\hline $\mathrm{Al}$ & 1.5 & 1.0 & 0.6 & & & 0.8 \\
\hline $\begin{array}{l}\mathbf{C} / \\
\mathbf{N}\end{array}$ & 10.1 & 10.2 & 10.8 & 11.2 & & \\
\hline $\begin{array}{l}\text { F/S } \\
\text { i }\end{array}$ & 1.3 & 1.3 & 0.8 & 0.8 & & \\
\hline $\begin{array}{l}\text { C/ } \\
\text { F }\end{array}$ & 4.0 & 3.7 & 3.6 & 3.5 & 3.2 & \\
\hline
\end{tabular}

Figure A5-2 displays the ratio of carbon/fluorine (left panel) and silicon/fluorine ratio (right panel) as function of etching time by argon ion sputtering for poly(POSS-imide) layers prepared using 0.9, 2.5 and 5.0 wt.\% POSS solutions. 

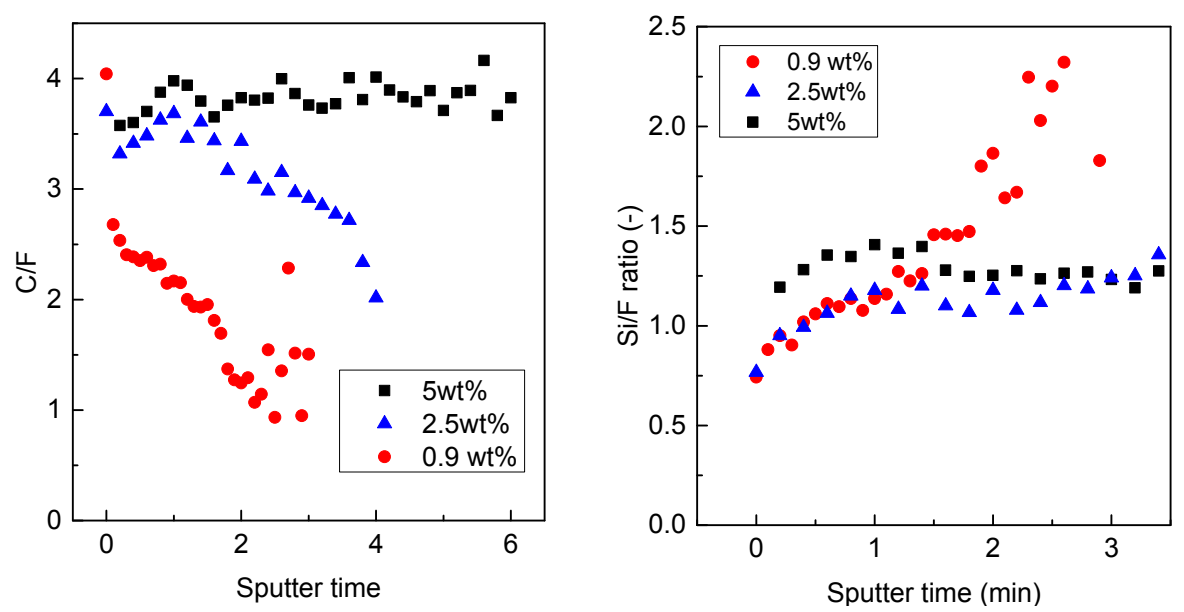

Figure A5-2. (left panel) ratio of carbon/fluorine and (right panel) silicon/fluorine ratio determined by XPS as function of etching time by argon ion sputtering for poly(POSS-imide) layers prepared using $0.9,2.5$ and 5.0 wt.\% POSS solutions.

Figure A5-3 shows the element concentration as function of etching time by argon sputtering for poly(POSS-imide) layers prepared using 0.9 (left panel), 2.5 (middle panel) and $5.0 \mathrm{wt} \%$ POSS solutions. The gradual concurrent increase of the $\mathrm{O} 1 \mathrm{~s}$ and $\mathrm{A} 12 \mathrm{p}$ signals as function of sputter time indicates that the poly(POSS-imide)s intrudes the $\gamma$-alumina layer.
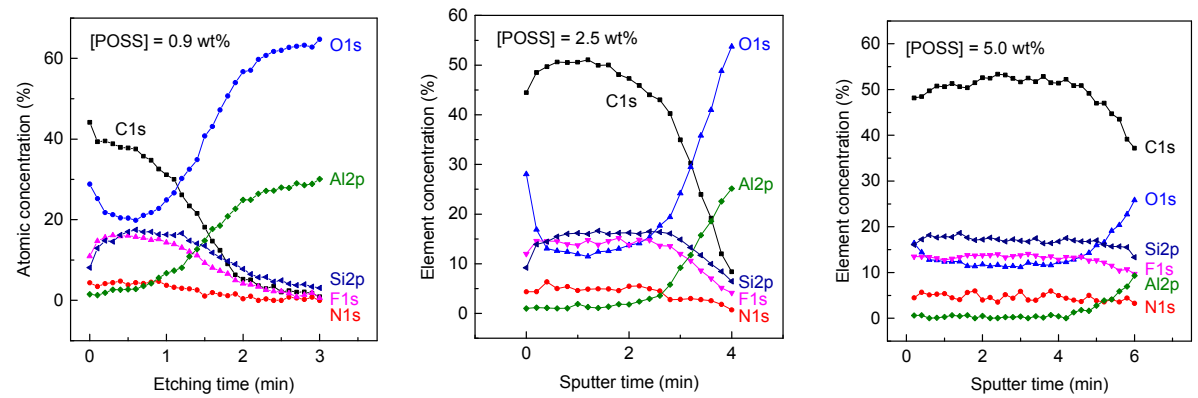

Figure A5-3. Element concentration determined by XPS as function of etching time by argon sputtering for poly(POSS-imide) layers prepared using 0.9 (left panel), 2.5 (middle panel) and 5.0 wt.\% POSS solutions.

Figure A5-4 shows the thickness and refractive index as a function of gas pressure for a non-annealed Matrimid film deposited on a silicon wafer and a $\gamma$-alumina coated disc, respectively. The more complex optical model for 
Matrimid on the $\gamma$-alumina-coated disc is validated by the similarity between the thicknesses and refractive indices as function of pressure. Both thickness graphs display a concave shape of the isotherm, which is typical for dual mode gas sorption in glassy polymers. ${ }^{58,71}$
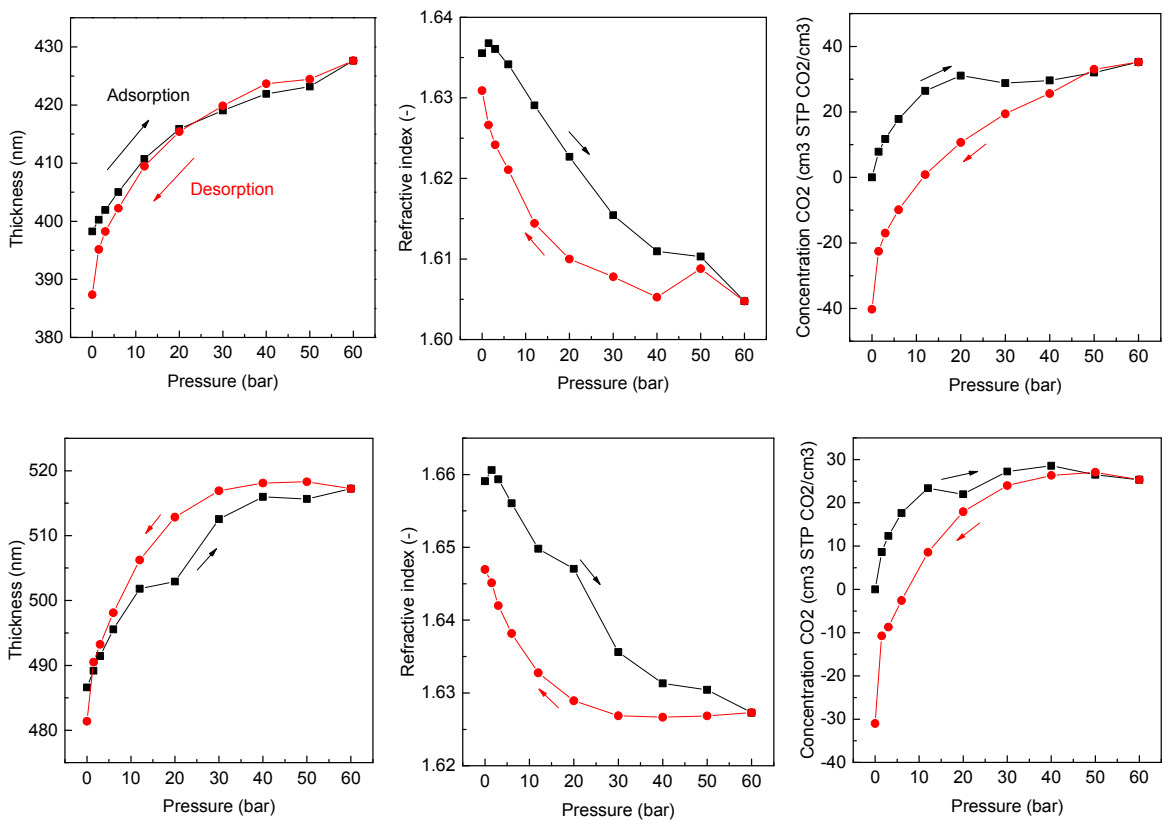

Figure A5-4. Thickness (left panel), refractive index (middle panel) and $\mathrm{CO}_{2}$ concentration upon sorption ( $(\bullet)$ and desorption $(\bullet)$ of non-annealed Matrimid on a silicon wafer (top panels) and $\gamma$-alumina coated disc (lower panels) as function of pressure.

Upon $\mathrm{CO}_{2}$ adsorption, a simultaneous thickness increase and refractive index decrease occurs, corresponding to dilation of the polymer matrix. Upon desorption, the thickness and refractive index revert, without recovering to the original values upon sorption. The large hysteresis effects can be rationalized by the structural rearrangements upon dilation and lack of necessary chain mobility required to return the polymer to its original state. Moreover, both thickness and refractive index are lower upon returning to vacuum. The difference in thickness and refractive index before and after sorption can only be explained by removal of residual solvent upon $\mathrm{CO}_{2}$ adsorption. Even under vacuum, the solvent used for spin coating remains trapped in the polymer matrix. Expansion of the polymer matrix by $\mathrm{CO}_{2}$ allows liberation of the kinetically trapped solvent. ${ }^{72}$ The solvent removal yields a polymer with larger 
excess fractional free volume as compared to the structure at the beginning of the sorption cycle. The pronounced non-equilibrium characteristics indicate the high tendency of the non-annealed Matrimid towards $\mathrm{CO}_{2}$-induced plasticization. The thickness mismatch at vacuum before and after the sorption measurements renders $\mathrm{CO}_{2}$ concentration calculations meaningless.

\subsection{3. $\mathrm{CO}_{2}$ sorption measurements measured by a magnetic suspension balance}

Sorption behavior was investigated in a magnetic suspension balance (MSB) with pressures up to 30 bars at $35^{\circ} \mathrm{C}$. Figure A5-5 displays the $\mathrm{CO}_{2}$ sorption of (left panel) Matrimid and (right panel) poly(POSS-imide) powders as a function of $\mathrm{CO}_{2}$ pressure. Both sorption isotherms display a steep initial incline in $\mathrm{CO}_{2}$ sorption that gradually flattens at higher pressure, as is typical for dual mode sorption.
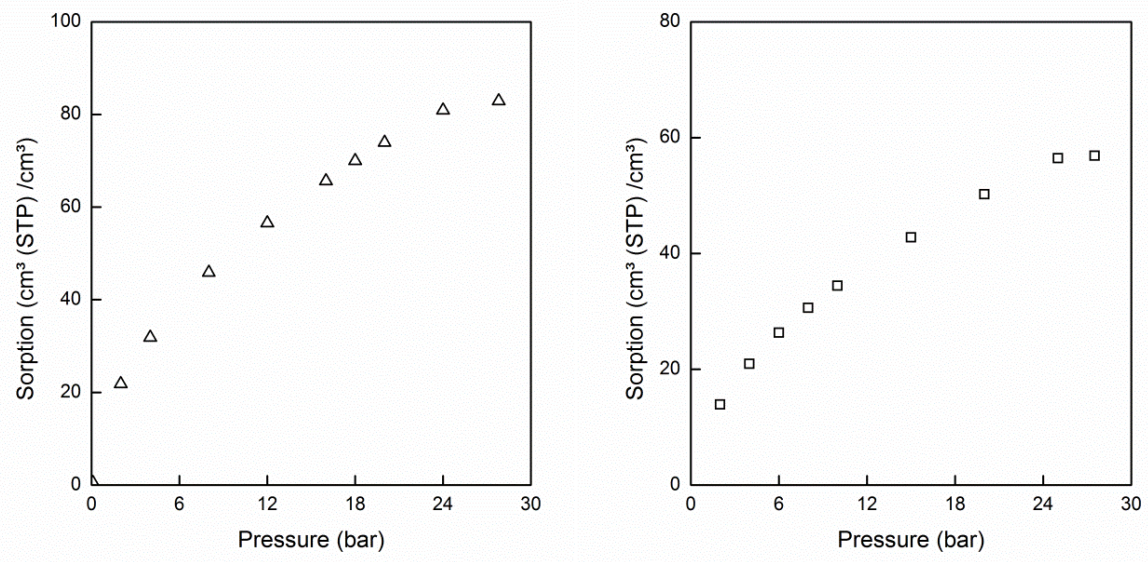

Figure A5-5. $\mathrm{CO}_{2}$ sorption as function of pressure for Matrimid (left panel) and poly(POSS-imide) powder (right panel), measured using a magnetic suspension balance.

For Matrimid the observed behavior and $\mathrm{CO}_{2}$ uptake of $\sim 80 \mathrm{~cm}^{3} \mathrm{CO}_{2}$ (STP) $\mathrm{cm}^{-3}$ polymer at 28 bar is in good agreement with literature results for powders. ${ }^{58}$ The $\mathrm{CO} 2$ sorption in Matrimid is higher as compared to the ellipsometry results (about 40\% higher as compared to spectroscopic ellipsometry results shown in Figure 4 (right panel), which has been observed by others ${ }^{38,} 39$ and can be attributed to the differences in layer thickness, measurement technique and polymer history. The results shown in The 
poly(POSS-imide) powder has a lower $\mathrm{CO}_{2}$ sorption as compared to the Matrimid sample and a much lower $\mathrm{CO}_{2}$ uptake as compared to the ellipsometry measurements in Figure 5 (right panel). The lower $\mathrm{CO}_{2}$ uptake in the poly(POSS-imide) can be related to several factors. Differences between powder reaction times (several hours reaction time are required to obtain sufficient powder volume for MSB measurements) and the change in reactant stoichiometries in the bulk can change the sample properties. The POSS powder used for $\mathrm{CO}_{2}$ measurements in the magnetic suspension balance was prepared with 0.9 wt.\% POSS solution. However, XPS data, shown in Table A5-1, indicates that the element composition resembled that of the poly(POSS-imide) layer prepared with a $5.0 \mathrm{wt} . \%$ POSS solution. Because the measurement depth of XPS is limited to several tens of nanometers, the powder composition can significantly differ from the layer composition. In addition, only a small amount of powder mass could be measured using the magnetic suspension balance. The sample mass was lower than the buoyancy effect of $\mathrm{CO}_{2}$, for which the measured weight needs to be corrected. Small discrepancies in the sample volume and mass will therefore significantly affect the calculated $\mathrm{CO}_{2}$ sorption. An underestimation of the buoyancy effect might lead to an underestimation of the sample volume, mass and $\mathrm{CO}_{2}$ uptake. Because the sample volume might change due to $\mathrm{CO}_{2}$ sorption, as observed by the large swelling degrees of the poly(POSS-imide)s, the buoyancy calculations are by definition incorrect. Because the magnetic suspension balance results are influenced by large number of experimental errors, the results should be interpreted with caution.

\subsection{References}

1. Du, N.; Park, H. B.; Dal-Cin, M. M.; Guiver, M. D. Energy and Environmental Science 2012, 5, (6), 7306-7322

2. $\quad$ Czyperek, M.; Zapp, P.; Bouwmeester, H. J. M.; Modigell, M.; Ebert, K.; Voigt, I.; Meulenberg, W. A.; Singheiser, L.; Stöver, D. Journal of Membrane Science 2010, 359, (1-2), 149-159

3. Favre, E.; Bounaceur, R.; Roizard, D. Journal of Membrane Science 2009, 328, (1-2), 11-14

4. Jones, C. W. Annual Review of Chemical and Biomolecular Engineering 2011, 2, 3152

5. Smart, S.; Lin, C. X. C.; Ding, L.; Thambimuthu, K.; Diniz Da Costa, J. C. Energy and Environmental Science 2010, 3, (3), 268-278

6. Scholz, M.; Melin, T.; Wessling, M. Renewable and Sustainable Energy Reviews 2013, 17, (0), 199-212

7. Blomen, E.; Hendriks, C.; Neele, F. In Capture technologies: Improvements and promising developments, Energy Procedia, 2009; 2009; pp 1505-1512. 
8. $\quad$ Baker, R. W., Membrane Technology and Applications. 2012.

9. Duthie, X.; Kentish, S.; Powell, C.; Nagai, K.; Qiao, G.; Stevens, G. Journal of Membrane Science 2007, 294, (1-2), 40-49

10. Wind, J. D.; Sirard, S. M.; Paul, D. R.; Green, P. F.; Johnston, K. P.; Koros, W. J. Macromolecules 2003, 36, (17), 6433-6441

11. Sridhar, S.; Veerapur, R. S.; Patil, M. B.; Gudasi, K. B.; Aminabhavi, T. M. Journal of Applied Polymer Science 2007, 106, (3), 1585-1594

12. Visser, T.; Masetto, N.; Wessling, M. Journal of Membrane Science 2007, 306, (1-2), 16-28

13. Duthie, X.; Kentish, S.; Pas, S. J.; Hill, A. J.; Powell, C.; Nagai, K.; Stevens, G.; Qiao, G. Journal of Polymer Science, Part B: Polymer Physics 2008, 46, (18), 1879-1890

14. Bos, A.; Pünt, I. G. M.; Wessling, M.; Strathmann, H. Separation and Purification Technology 1998, 14, (1-3), 27-39

15. Hillock, A. M. W.; Koros, W. J. Macromolecules 2007, 40, (3), 583-587

16. Budd, P. M.; Elabas, E. S.; Ghanem, B. S.; Makhseed, S.; McKeown, N. B.; Msayib, K. J.; Tattershall, C. E.; Wang, D. Advanced Materials 2004, 16, (5), 456-459

17. Hashem, M.; Bezzu, C. G.; Kariuki, B. M.; McKeown, N. B. Polymer Chemistry 2011, 2, (10), 2190-2192

18. Budd, P. M.; McKeown, N. B.; Fritsch, D. Journal of Materials Chemistry 2005, 15, (20), 1977-1986

19. Bezzu, C. G.; Carta, M.; Tonkins, A.; Jansen, J. C.; Bernardo, P.; Bazzarelli, F.; McKeown, N. B. Advanced Materials 2012, 24, (44), 5930-5933

20. Han, S. H.; Misdan, N.; Kim, S.; Doherty, C. M.; Hill, A. J.; Lee, Y. M. Macromolecules 2010, 43, (18), 7657-7667

21. Han, S. H.; Kwon, H. J.; Kim, K. Y.; Seong, J. G.; Park, C. H.; Kim, S.; Doherty, C. M.; Thornton, A. W.; Hill, A. J.; Lozano, Á. E.; Berchtold, K. A.; Lee, Y. M. Physical Chemistry Chemical Physics 2012, 14, (13), 4365-4373

22. Sanders, D. F.; Smith, Z. P.; Ribeiro, C. P.; Guo, R.; McGrath, J. E.; Paul, D. R.; Freeman, B. D. Journal of Membrane Science 2012, 409-410, 232-241

23. Calle, M.; Doherty, C. M.; Hill, A. J.; Lee, Y. M. Macromolecules 2013, 46, (20), 8179-8189

24. Raaijmakers, M. J. T.; Hempenius, M. A.; Schön, P. M.; Vancso, G. J.; Nijmeijer, A.; Wessling, M.; Benes, N. E. Journal of the American Chemical Society 2013, 136, (1), 330-335

25. Raaijmakers, M. J. T.; Wessling, M.; Nijmeijer, A.; Benes, N. E. Chemistry of Materials 2014, 26, (12), 3660-3664

26. Cornelius, C. J.; Marand, E. Journal of Membrane Science 2002, 202, (1-2), 97-118

27. Suzuki, T.; Yamada, Y.; Itahashi, K. Journal of Applied Polymer Science 2008, 109, (2), 813-819

28. Sarbu, T. T. E. J. Nature 2000, 405, (6783), 165

29. Consolati, G.; Genco, I.; Pegoraro, M.; Zanderighi, L. Journal of Polymer Science, Part B: Polymer Physics 1996, 34, (2), 357-367

30. Dorkenoo, K. D.; Pfromm, P. H. Macromolecules 2000, 33, (10), 3747-3751

31. Punsalan, D.; Koros, W. J. Journal of Applied Polymer Science 2005, 96, (4), 11151121

32. Punsalan, D.; Koros, W. J. Polymer 2005, 46, (23), 10214-10220 
33. Huang, Y.; Paul, D. R. Journal of Membrane Science 2004, 244, (1-2), 167-178

34. Huang, Y.; Paul, D. R. Polymer 2004, 45, (25), 8377-8393

35. Huang, Y.; Paul, D. R. Macromolecules 2005, 38, (24), 10148-10154

36. Huang, Y.; Paul, D. R. Macromolecules 2006, 39, (4), 1554-1559

37. Cui, L.; Qiu, W.; Paul, D. R.; Koros, W. J. Polymer 2011, 52, (15), 3374-3380

38. Horn, N. R.; Paul, D. R. Polymer 2011, 52, (7), 1619-1627

39. Horn, N. R.; Paul, D. R. Macromolecules 2012, 45, (6), 2820-2834

40. Raaijmakers, M. J. T.; Hempenius, M. A.; Schön, P. M.; Vancso, G. J.; Nijmeijer, A.; Wessling, M.; Benes, N. E. Journal of the American Chemical Society 2014, 136, (1), 330-335

41. Low, B. T.; Chung, T. S.; Chen, H.; Jean, Y. C.; Pramoda, K. P. Macromolecules 2009, 42, (18), 7042-7054

42. Gomes, D.; Nunes, S. P.; Peinemann, K. V. Journal of Membrane Science 2005, 246, (1), 13-25

43. Lau, C. H.; Nguyen, P. T.; Hill, M. R.; Thornton, A. W.; Konstas, K.; Doherty, C. M.; Mulder, R. J.; Bourgeois, L.; Liu, A. C. Y.; Sprouster, D. J.; Sullivan, J. P.; Bastow, T. J.; Hill, A. J.; Gin, D. L.; Noble, R. D. Angewandte Chemie - International Edition 2014, 53, (21), 5322-5326

44. Ogieglo, W.; Wormeester, H.; Wessling, M.; Benes, N. E. ACS applied materials \& interfaces 2012, 4, (2), 935-43

45. Lichtenstein, T.; Engineering, U. o. R. C. o.; Science, A., Handbook of Thin Film Materials. College of Engineering and Applied Science, University of Rochester: 1979.

46. Lorenz, K.; Wessling, M. Adsorption 2013, 19, (6), 1117-1125

47. Raaijmakers, M. J. T.; Kappert, E. J.; Nijmeijer, A.; Benes, N. E. Macromolecules 2015, 48, (9), 3031-3039

48. Pacheco, F. A.; Pinnau, I.; Reinhard, M.; Leckie, J. O. Journal of Membrane Science 2010, 358, (1-2), 51-59

49. Zhang, Y.; Benes, N. E.; Lammertink, R. G. H. Lab on a Chip 2015,

50. $\quad$ Freger, V. Langmuir 2003, 19, (11), 4791-4797

51. Hougham, G.; Tesoro, G.; Viehbeck, A. Macromolecules 1996, 29, (10), 3453-3456

52. Tanaka, K.; Chujo, Y. Journal of Materials Chemistry 2012, 22, (5), 1733-1746

53. Simons, K.; Nijmeijer, K.; Sala, J. G.; van der Werf, H.; Benes, N. E.; Dingemans, T. J.; Wessling, M. Polymer 2010, 51, (17), 3907-3917

54. Sirard, S. M.; Green, P. F.; Johnston, K. P. J Phys Chem B 2001, 105, (4), 766-772

55. Wind, J. D.; Sirard, S. M.; Paul, D. R.; Green, P. F.; Johnston, K. P.; Koros, W. J. Macromolecules 2003, 36, (17), 6442-6448

56. Rowe, B. W.; Freeman, B. D.; Paul, D. R. Macromolecules 2007, 40, (8), 2806-2813

57. Wessling, M.; Lidon Lopez, M.; Strathmann, H. Separation and Purification Technology 2001, 24, (1-2), 223-233

58. Visser, T.; Koops, G. H.; Wessling, M. Journal of Membrane Science 2005, 252, (12), 265-277

59. Dong, G.; Li, H.; Chen, V. Journal of Membrane Science 2011, 369, (1-2), 206-220

60. Wang, J. S.; Kamiya, Y. Journal of Polymer Science, Part B: Polymer Physics 2000, $38,(6), 883-888$ 
61. Sirard, S. M.; Ziegler, K. J.; Sanchez, I. C.; Green, P. F.; Johnston, K. P. Macromolecules 2002, 35, (5), 1928-1935

62. Sirard, S. M.; Castellanos, H.; Green, P. F.; Johnston, K. P. J Supercrit Fluid 2004, 32, (1-3), 265-273

63. Wessling, M.; Huisman, I.; Boomgaard, T.; Smolders, C. Journal of Polymer Science Part B: Polymer Physics 1995, 33, (9), 1371-1384

64. Cheng, S.-X.; Chung, T.-S.; Wang, R.; Vora, R. H. Journal of Applied Polymer Science 2003, 90, (8), 2187-2193

65. Duthie, X.; Kentish, S.; Powell, C.; Nagai, K.; Qiao, G.; Stevens, G. Journal of Membrane Science 2007, 294, (1-2), 40-49

66. Leu, C.-M.; Chang, Y.-T.; Wei, K.-H. Chemistry of Materials 2003, 15, (19), 37213727

67. Iyer, P.; Iyer, G.; Coleman, M. Journal of Membrane Science 2010, 358, (1-2), 26-32

68. Böhning, M.; Springer, J. Polymer 1998, 39, (21), 5183-5195

69. Fleming, G. K.; Koros, W. J. Macromolecules 1986, 19, (8), 2285-2291

70. Böhning, M.; Springer, J. Polymer 1998, 39, (21), 5183-5195

71. Scholes, C. A.; Chen, G. Q.; Stevens, G. W.; Kentish, S. E. Journal of Membrane Science 2010, 346, (1), 208-214

72. Ogieglo, W.; Upadhyaya, L.; Wessling, M.; Nijmeijer, A.; Benes, N. E. Journal of Membrane Science 2014, 464, 80-85 
Chapter 6

High pressure $\mathrm{CO}_{2}$ permeation behavior of hybrid poly(POSS-imide)s 


\begin{abstract}
Polyimide membranes based on fluoroalkanes display high $\mathrm{CO}_{2}$ permeances due to the sorption affinity of the fluorine groups towards $\mathrm{CO}_{2}$. Here, we studied the relationship between the $\mathrm{CO}_{2}$ sorption and permeability at high pressure differences across the membrane, for ultrathin fluoroalkane functionalized hybrid membranes. The hybrid membranes consist of a network of alternating imide and polyhedral oligomeric silsesquioxanes. The fluoroalkane groups on the imide bridge are responsible for the high sorption capacities, that range from $100-350 \mathrm{~cm}^{3} \mathrm{CO}_{2}$ (STP) $\mathrm{cm}^{-3}$ polymer at 26 bar. The $\mathrm{CO}_{2}$ permeability coefficient increases with increasing $\mathrm{CO}_{2}$ concentration in the membrane. The permeability coefficient increase is due to an increase in both solubility and diffusivity of the $\mathrm{CO}_{2}$ at higher pressures. The diffusivity of $\mathrm{CO}_{2}$ increases because the network swells, resulting in a higher apparent molar volume of $\mathrm{CO}_{2}$ and a reduced interaction of $\mathrm{CO}_{2}$ with the hybrid network. The presented work allows for optimization of the sorption behavior of the membrane with respect to the membrane permeability.
\end{abstract}




\subsection{Introduction}

Membrane gas separation is considered a key technology for carbon dioxide $\left(\mathrm{CO}_{2}\right)$ separation for carbon capture and sequestration applications, ${ }^{1-3}$ natural gas sweetening ${ }^{4-7}$ and biogas upgrading. ${ }^{8-10}$ Membranes that selectively permeate $\mathrm{CO}_{2}$ can be used for the removal of $\mathrm{CO}_{2}$ from high pressure gas mixtures such as methane or higher alkanes. ${ }^{6,} 11-13$ The valuable, retained component will remain at high pressure, while the permeated $\mathrm{CO}_{2}$ is at low pressure. In the development of highly permeable $\mathrm{CO}_{2}$ membranes the aim is to either increase the amount of excess free volume (EFV) in the polymer, or to improve the affinity of the polymer towards the permeating component. ${ }^{14}$ Examples of high EFV polymers include of polymers of intrinsic microporisity (PIMs), ${ }^{15}$ thermally rearranged (TR) polymers ${ }^{15-18}$ or substituted polyacetylenes such as poly[1-(trimethylsilyl)-1-propyne]. Although these materials show much promise due to their combination of high permeability and selectivity, inherent loss of EFV and permeance due ageing is observed. ${ }^{19}$

Incorporating affinity groups in the polymer matrix potentially allows for higher $\mathrm{CO}_{2}$ sorption, without the requirement of a high EFV content. The most common groups used for improved affinity towards $\mathrm{CO}_{2}$ are fluoroalkanes. The fluoroalkanes are usually incorporated by using 4,4'-(hexafluoro isopropylidene) diphthalic anhydride (6FDA) or 4,4'-(hexafluoro isopropylidene) dianiline (6FpDA) as precursors during synthesis. ${ }^{20-24}$ Polyimides that are functionalized with fluoroalkanes are known to have both a high permselectivity and permeability with respect to other polyimides. ${ }^{25}$ The electronegative character of the fluorine groups creates sites on the polyimide backbone that preferentially sorb $\mathrm{CO}_{2} \cdot{ }^{26}$ Nonetheless, the high sorption affinity for $\mathrm{CO}_{2}$ also makes the layers more sensitive towards plasticization and physical ageing effects, ${ }^{27-30}$ particularly for ultrathin films. ${ }^{30,31}$ To suppress these effects, chemical cross-linking ${ }^{20,32-34}$ and thermal annealing ${ }^{35-37}$ have been successfully applied, although at the cost of $\mathrm{CO}_{2}$ permeance. $^{20}$ Recently, we presented hybrid polyhedral oligomeric silsesquioxane-imides (poly(POSS-imide)s) ${ }^{38}$ that have permeances that are comparable PIMs and TR polymers, but have the network rigidity ${ }^{38,39}$ that is required to prevent plasticization and ageing effects. Here, we studied the $\mathrm{CO}_{2}$ sorption and permeation behavior of hybrid poly(POSS-imide)s that are functionalized with fluoroalkanes. The $\mathrm{CO}_{2}$ permeation depends strongly on the fluorine and POSS content of the membrane. Fundamental understanding of the structure-property-performance relationships of the membrane allows 
for optimization of the membrane properties for $\mathrm{CO}_{2}$ separation applications. Here, we studied the sorption behavior of ultrathin poly(POSS-imide) films in compressed $\mathrm{CO}_{2}$ atmospheres and determined the relationship between permeation and sorption data.

\subsection{Experimental}

\subsubsection{Poly(POSS-imide) membrane synthesis}

Poly(POSS-imide) membranes were prepared by interfacial polymerization of water-soluble ammonium chloride-functionalized POSS (octa-ammonium POSS, Hybrid Plastics) and a 0.075 wt.\% 4,4-(hexafluoroisopropylidene) diphthalic anhydride (6FDA, Sigma-Aldrich) solution in toluene. The partial conversion of ammonium to primary amine groups was achieved by addition of $\mathrm{NaOH}$ until the solution reached a $\mathrm{pH}$ of 9.9. Supported thin films were produced on $\alpha$-alumina discs (Pervatech, Netherlands) coated with $1.5 \mu \mathrm{m}$ thick $\gamma$-alumina (porosity of $\sim 40 \%$ and a pore size of $2-3 \mathrm{~nm}$ ). First, the $\alpha$-alumina discs, held fixed on a perforated plate by vacuum, were impregnated with the POSS solution. Next, the discs were left to dry in a $\mathrm{N}_{2}$ atmosphere for $15 \mathrm{~min}$ and subsequently submersed in the 6FDA in toluene solution. After $5 \mathrm{~min}$ reaction time, the toluene was removed from the interface and the discs were washed with acetone to remove any residual reactants. After drying for at least $2 \mathrm{~h}$ in air atmosphere the samples were heattreated for $2 \mathrm{~h}$ at $300{ }^{\circ} \mathrm{C}$ in air atmosphere to achieve conversion of the amic acid groups to cyclic imide groups. The concentration of the POSS solution, a critical parameter in the interfacial polymerization reaction, were varied to obtain membranes with different thicknesses, refractive indices and chemical composition. The concentrations of fluorine groups in the final polyPOSSimide layer was determined elsewhere. ${ }^{40}$

\subsubsection{Membrane characterization}

\section{Spectroscopic ellipsometry}

The thickness and refractive index of poly(POSS-imide)s atop $\gamma$-alumina coated $\alpha$-alumina discs were determined using spectroscopic ellipsometry (M2000X, J.A. Woollam Co., Inc.). The psi $(\Psi)$ and delta $(\Delta)$ spectra were recorded over a wavelength range of 340-1000 nm, with a spectral resolution of about $2 \mathrm{~nm}$, using light reflected at $65^{\circ}, 70^{\circ}$ and $75^{\circ}$ angles of incidence. The optical model of the poly(POSS-imide) layer atop a $\gamma$-alumina coated $\alpha$ alumina disc is visualized in Figure 6-1. The layered optical model was 
constructed by a stepwise measurement of each individually added layer. The $\alpha$-alumina disc was modelled using an Effective Medium Approximation (EMA) of three-parameter Cauchy-type optical dispersion of $\mathrm{Al}_{2} \mathrm{O}_{3}{ }^{41}$ with $n(\lambda)=A+B / \lambda^{2}+C / \lambda^{4}$ with $A=1.751, B=0.00632 \mu \mathrm{m}^{2}, C=-0.00010152 \mu \mathrm{m}^{4}$ and void $(n=1.000)$ with a graded EMA layer atop corresponding to the roughness of the ceramic disc.

\section{SEM micrograph}

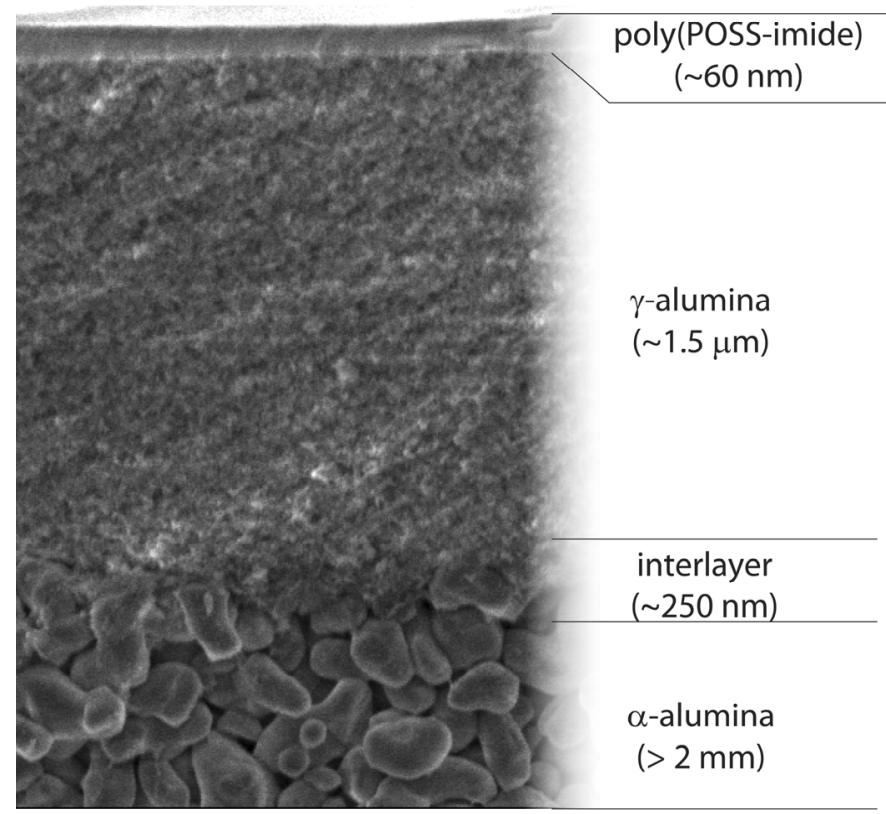

\section{Layer assignment}

Optical model

Cauchy $[d, n(A, B)]$

$\operatorname{EMA}\left(\Phi_{\text {void' }} d\right)$ of:

Cauchy $[n(A, B, C)]$

Void
EMA $\left(\Phi_{\text {void' }} d\right)$ of:
Cauchy $[n(A, B, C)]$
Void
EMA-support $\left(\Phi_{\text {void }}\right)$ of:
Cauchy $[n(A, B, C)]$
Void

Figure 6-1. Optical model of a poly(POSS-imide) layer atop a $\gamma$-alumina coated $\alpha$-alumina disc. The cross-section scanning electron micrograph of the membrane shows the distinct morphology of the dense poly(POSSimide) layer, $\gamma$-alumina and $\alpha$-alumina.

Justification for the optical model and its validation versus Atomic Force Microscopy and Mercury Porosimetry is given elsewhere. ${ }^{42}$ The samples were again measured after coating of the $\gamma$-alumina layer. The interlayer between the $\gamma$-alumina and the $\alpha$-alumina was assumed to have a thickness similar to the thickness of the graded EMA layer that reflects the roughness of the $\alpha$ alumina disc, but its porosity was left as a fitting parameter to account for the possible intrusion by $\gamma$-alumina. The $\gamma$-alumina thickness and porosity were modelled using an EMA of $\mathrm{Al}_{2} \mathrm{O}_{3}$ and void. Finally, poly(POSS-imide) formation atop the $\gamma$-alumina was achieved by a procedure described in the 
synthesis section. The poly(POSS-imide) layer thickness and refractive index were determined using a two-parameter Cauchy optical dispersion (fit parameters $A$ and $B$ ), assuming transparency of the hybrid material in the used wavelength range. The porosity of the $\gamma$-alumina and the interlayer were set as fit parameters, to account for the water that remains in the $\gamma$-alumina after poly(POSS-imide) synthesis. The wavelength range for all optical models was limited to $600-1000 \mathrm{~nm}$ to reduce the influence of light scattering as a result of the non-uniformity of the porous $\alpha$-alumina discs. ${ }^{42}$

\section{Spectroscopic ellipsometry - high pressure $\mathrm{CO}_{2}$ sorption}

Spectroscopic ellipsometry measurements at elevated gas pressures were conducted with an Alpha-SE ${ }^{\circledR}$ ellipsometer (J.A. Woollam Co. Inc.). All measurements were done at a fixed angle of incidence $\left(70^{\circ}\right)$ in the wavelength range from 370 to $900 \mathrm{~nm}$. Samples were placed in a home-built stainless steel cell $\left(p_{\max }=20 \mathrm{MPa}, T_{\max }=473.15 \mathrm{~K}\right)$ equipped with a temperature and pressure control system, as depicted in Scheme 6-1.

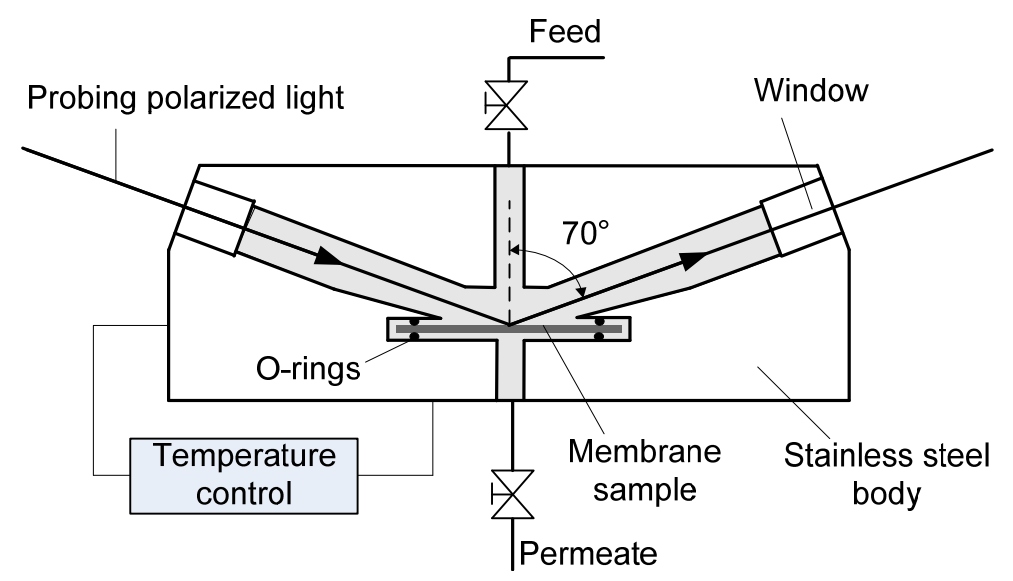

Scheme 6-1. Schematic of the stainless steel cell used in the spectroscopic ellipsometry analysis of $\mathrm{CO}_{2}$ adsorption and swelling dynamics of poly(POSS-imide)s and Matrimid membranes.

Accurate control and stability (within 0.1 bar) of the gas pressure was achieved using a syringe pump (Teledyne ISCO, 500D). The system temperature was maintained at $35{ }^{\circ} \mathrm{C}$ by a glycol bath connected to the cylinder of the syringe pump and by an induction heating belt connected to the measurement cell, in order to correct temperature changes due to Joule-Thompson effects upon incremental pressure change. Light entered and exited the cell through $1 \mathrm{~cm}$ thick quartz windows positioned perpendicular to the polarized light beam 
source and detector. Pressure induced birefringence of the cell windows was measured via a high-pressure helium calibration on a $25 \mathrm{~nm} \mathrm{SiO}_{2} / \mathrm{Si}$ wafer, and used for correction of the birefringence during further high pressure measurements. Static sorption experiments were performed by opening a valve between the feed and permeate side, equalizing the pressure on both sides of the membrane. Permeation experiments were performed by closing the valve between the feed and permeate side, and slowly opening the permeate side to atmosphere. ${ }^{43}$ The membrane permeance was determined by measuring the change in volume of $\mathrm{CO}_{2}$ in the syringe pump as function of time. The poly(POSS-imide) layer thickness and refractive index were determined using a two-parameter Cauchy optical dispersion (fit parameters $A$ and $B$ ), assuming transparency of the hybrid material in the used wavelength range. The porosity of the $\gamma$-alumina and the interlayer were set as fit parameters, to account for the water that remains in the $\gamma$-alumina after poly(POSS-imide) synthesis. The wavelength range for all optical models was limited to $600-900 \mathrm{~nm}$ to reduce the influence of light scattering as a result of the non-uniformity of the porous $\alpha$-alumina discs. ${ }^{42}$ The change in refractive index of $\mathrm{CO}_{2}$ at elevated pressures was taken into account by changing the ambient refractive index according to data from $^{44,45}$.

\subsubsection{Membrane $\mathrm{CO}_{2}$ permeability}

Figure 6-2 shows the $\mathrm{CO}_{2}$ permeance as function of the pressure difference across the ultrathin poly(POSS-imide) membranes. All poly(POSS-imide membranes have permeances between about $1-3 \cdot 10^{-7} \mathrm{~mol} \mathrm{~m}^{-2} \mathrm{~s}^{-1} \mathrm{~Pa}^{-1}$ (or 300$900 \mathrm{GPU}$ ), close to the permeance requirements for economically viable, large-scale $\mathrm{CO}_{2}$ membrane separation processes. ${ }^{46}$ The membrane thicknesses of the dry polymer are 93, 87 and $150 \mathrm{~nm}$ for the $0.9,2.5$ and $5.0 \mathrm{wt} . \%$ samples respectively. The lower permeance of the $5.0 \mathrm{wt} . \%$ as compared to the other samples is partly due to the higher layer thickness. The $\mathrm{CO}_{2}$ permeance of the poly(POSS-imide) membrane prepared with a $5.0 \mathrm{wt} . \%$ POSS solution remains constant for pressures differences up to 26 bar. For the membranes prepared with 2.5 and $0.9 \mathrm{wt} . \%$ POSS solutions, the $\mathrm{CO}_{2}$ permeance increases with increasing $\mathrm{CO}_{2}$ transmembrane pressure. The increasing $\mathrm{CO}_{2}$ permeances can be due to an increased solubility and/or diffusivity of $\mathrm{CO}_{2}$ at higher pressure. The permeance behavior is distinct from that of conventional fluoroalkane based polyimides, that show a pronounced minimum in the permeance at the so-called plasticization pressure. ${ }^{27,} 31,47$ Below the plasticization pressure, polymers become saturated by the gaseous penetrant. 
As a result, the permeability coefficient as function of pressure decreases. Above the plasticization pressure, the gas diffusivity increases due to plasticization of the matrix. The poly(POSS-imide)s differ from conventional polyimides: the solubility and/or diffusivity of $\mathrm{CO}_{2}$ likely increase with respect to pressure.

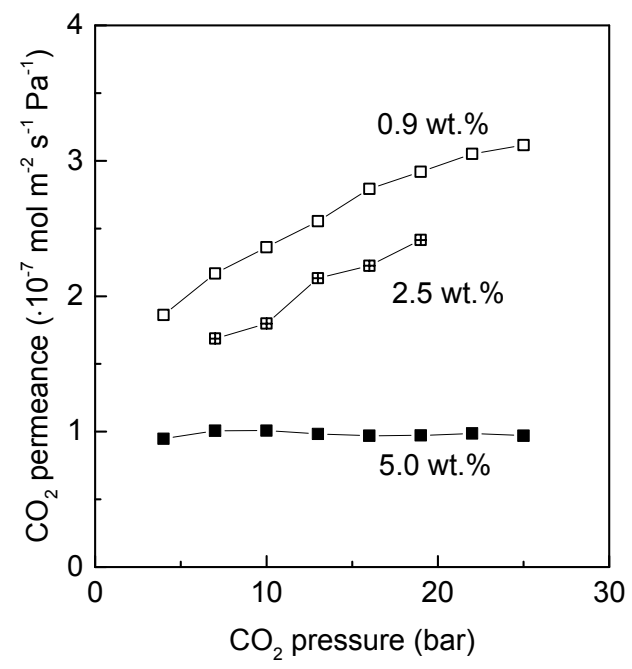

Figure 6-2. $\mathrm{CO}_{2}$ permeance at $35{ }^{\circ} \mathrm{C}$ as function of trans-membrane pressure for poly(POSS-imide)s prepared with 0.9, 2.5 and $5.0 \mathrm{wt} . \%$ POSS solutions. A permeance of $1 \cdot 10^{-7} \mathrm{~mol} \mathrm{~m}^{-2} \mathrm{~s}^{-1} \mathrm{~Pa}^{-1}$ equals about $300 \mathrm{GPU}$.

\subsubsection{Thickness, refractive index and $\mathrm{CO}_{2}$ concentrations}

The solubility and diffusivity of $\mathrm{CO}_{2}$ in the ultrathin poly(POSS-imide) layers has been determined by performing in-situ sorption measurements of a membrane, using spectroscopic ellipsometry. The thicknesses and refractive indices of the ultrathin poly(POSS-imide) layers are measured during static sorption experiments (i.e., no pressure difference across the membrane) and during permeation experiments (i.e., high pressure at the feed side and atmospheric pressure at the permeate side). Figure 6-3 (top left panel) shows the swelling degree as function of pressure of the poly(POSS-imide) membranes. The swelling degree of all poly(POSS-imide)s increases with increasing $\mathrm{CO}_{2}$ pressure. The swelling degrees are highest for the membranes prepared with 0.9 wt. $\%$ POSS solutions. 

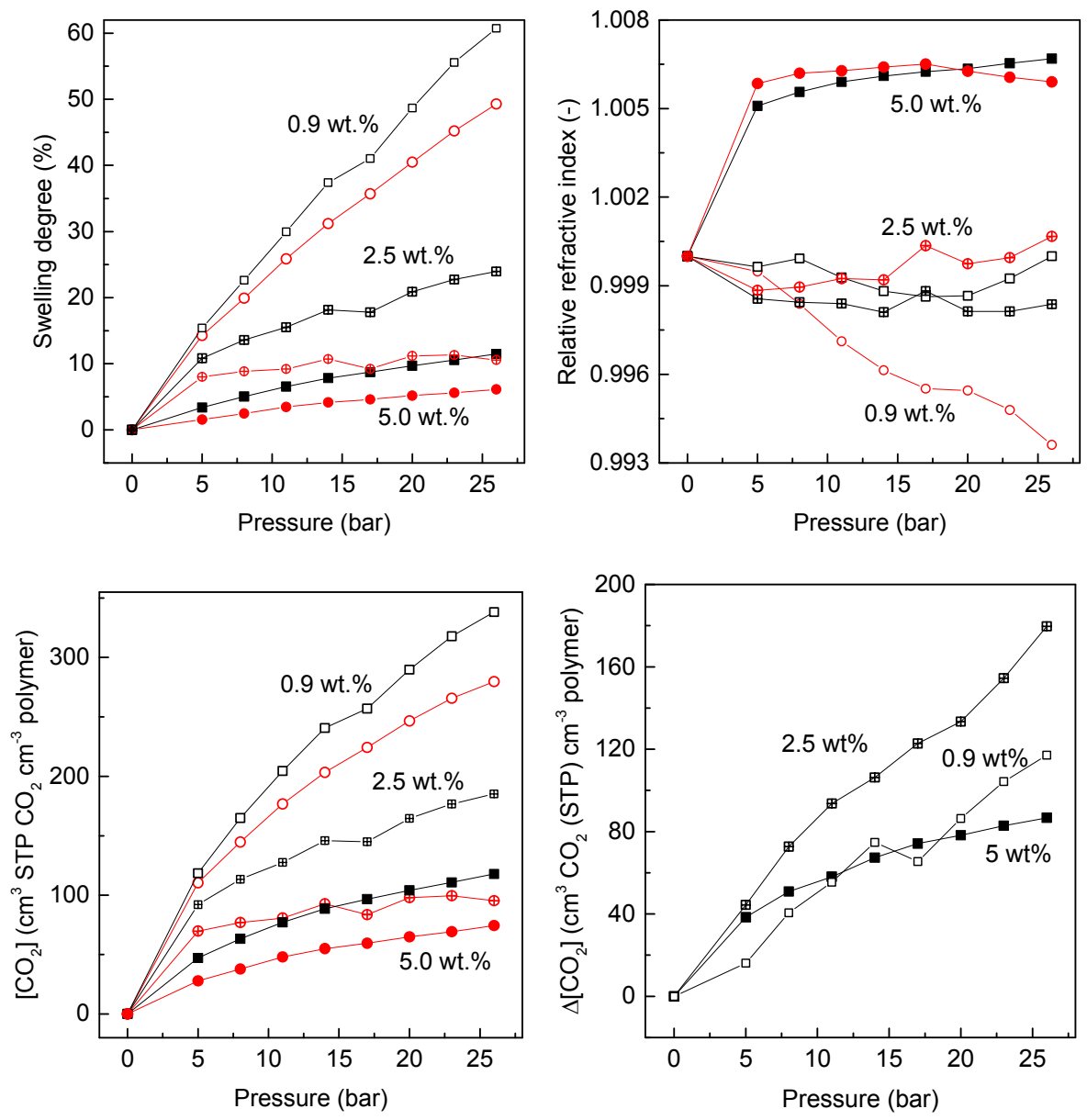

Figure 6-3. Top left panel: swelling degree as function of feed pressure of the membranes during static sorption (black squares) and permeation with atmospheric pressure at permeate side (red circles). Top right panel: relative refractive index of the membranes during static sorption (black squares) and permeation with atmospheric pressure at permeate side (red circles). Bottom left panel: $\mathrm{CO}_{2}$ concentrations as function of feed pressure, of the membranes during static sorption (black squares) and permeation with atmospheric pressure at permeate side (red circles). Bottom right panel: $\mathrm{CO}_{2}$ concentration gradient across the membrane layer as function of feed pressure, during the permeation experiment with atmospheric pressure at permeate side. The membranes were prepared using (open symbols) 0.9, (crossed symbols) 2.5 and (closed symbols) 5.0 wt.\% POSS solutions. 
The higher swelling degrees are associated with the larger fluorine content for the poly(POSS-imide)s prepared with lower concentration POSS solutions, which is discussed in detail elsewhere. ${ }^{40}$ The swelling degrees during a static sorption experiment are always higher as compared to the permeation experiment. During static sorption, the $\mathrm{CO}_{2}$ activity throughout the membrane layer is equal. The pressure difference across the membrane in permeation mode, resulting in a gradient in $\mathrm{CO}_{2}$ activity across the membrane, decreases the overall swelling degree of the membrane layers. The layers with lower swelling degrees display a higher relative refractive index, as shown in Figure 6-3 (top right panel). A relative refractive index above 1 indicates predominant filling of free volume spaces in the hybrid network, and results in an increase of the refractive index of the mixture. This is because the refractive index of the liquid $\mathrm{CO}_{2}$ (estimated at $n \approx 1.23^{48-51}$ ) is much higher than the refractive index of void space $(n=1)$. Relative refractive indices below 1 indicate predominant dilation of the network as compared to filling of free void spaces in the network. The layers prepared with $5.0 \mathrm{wt} . \%$ POSS solution show a relative refractive index higher than 1 that increases with increasing pressure. For the 0.9 wt. $\%$ sample, the relative refractive index decreases with increasing pressure, in line with the high swelling degrees. The differences in relative refractive index can be rationalized by differences in network composition: a higher POSS content increases the rigidity of the network and prevents dilation of the matrix upon $\mathrm{CO}_{2}$ sorption. The $\mathrm{CO}_{2}$ concentration as function of pressure, shown in Figure 6-3 (bottom left panel) display a concave isotherm shape that is typical for glassy polymers. ${ }^{52,53}$ The $\mathrm{CO}_{2}$ concentration is in the order, from high to low, for membranes prepared with $0.9>2.5>5.0 \mathrm{wt} \% \%$ POSS solution. The $\mathrm{CO}_{2}$ concentration measured during permeation is the average $\mathrm{CO}_{2}$ concentration. The complexity of the model used to fit the SE data does not allow for analysis of gradients in the $\mathrm{CO}_{2}$ concentration in the poly(POSS-imide) layers. However, assuming that the feed side concentration equals the $\mathrm{CO}_{2}$ sorption measured during static sorption, the SE data can be used to calculate a concentration profile across the membrane. By assuming that the concentration gradient is either linear or nonlinear, two concentration profiles can be estimated from the difference between the concentration measured during static sorption (feed side concentration) and the concentration determined during permeation (average concentration). Figure 6-3 (bottom right panel) shows the calculated differences $\mathrm{CO} 2$ in concentration between the retentate and permeate sides of the films, assuming linear concentration gradients inside the films. The 
concentration differences across the membrane are similar for the membranes prepared with 0.9 and 5.0 wt.\% POSS solutions. The highest concentration difference is observed for the $2.5 \mathrm{wt} . \%$ sample. For the membrane prepared with 0.9 wt.\% POSS the sorption isotherm of $\mathrm{CO}_{2}$ is the highest; in the absence of a transport resistance over the support this implies that for this membrane the highest concentration differences over the membrane are expected. The observed lower values indicate that the assumption of a linear concentration profile is not valid, or that the transport resistance through the ceramic support is not negligible. Because the permeances of the three membranes are in the same order of magnitude, and the negligible resistance of the ceramic support is confirmed by viscous flow calculations and permeance measurements of a bare support, it is most likely that non-linear concentration gradients exist across the membrane thickness.

Theoretical linear and non-linear concentration profiles across the layer thickness are visualized in Figure 6-4. The large discrepancy between the linear and non-linear profiles for the $0.9 \mathrm{wt} . \%$ based sample is apparent. For the 2.5 and $5.0 \mathrm{wt} . \%$ samples, the similarity between the concentration profiles indicate that the linear profile might well describe the $\mathrm{CO}_{2}$ concentration across the membrane layer. The difference in swelling degree change and concentration gradient profiles likely originates from differences in poly(POSS-imide) network rigidity: at high fluorine content, the network displays a high degree of flexibility that allows for high $\mathrm{CO}_{2}$ sorption. ${ }^{40}$ Consequently, a gradient in the $\mathrm{CO}_{2}$ concentration equals a gradient in the swelling degree, potentially resulting in large differences in solubility and diffusivity across the membrane. Because the membrane sorption is lower at the permeate side, lower dilation of the network occurs and the diffusivity of $\mathrm{CO}_{2}$ decreases. A higher $\mathrm{CO}_{2}$ diffusivity at higher concentrations, results in the absence of large concentration gradients at the feed side of the layer. For the other samples, sufficient network rigidity remains to prevent the excessive swelling differences across the layer. 

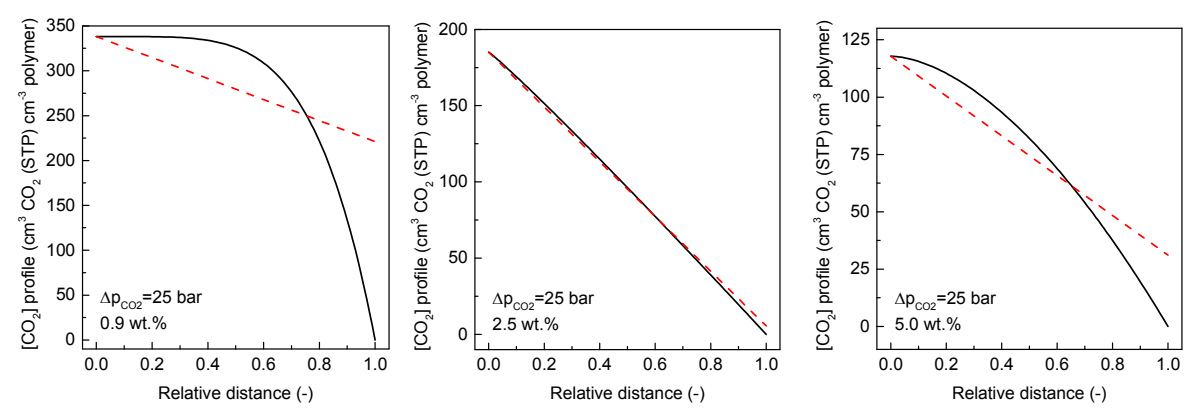

Figure 6-4. (top, left panel) Relative swelling degree change upon changing from static sorption to permeation. (other panels) $\mathrm{CO}_{2}$ concentration profile as function of relative distance across the membrane layer (feed side $=0$, permeate side $=1$ ) for poly(POSS-imide)s prepared with (top, right panel) 0.9, (bottom, left panel) 2.5 and (bottom, right panel) $5.0 \mathrm{wt} \%$ POSS solutions. The linear (dotted, red line) and non-linear (black, solid line) concentration profiles are calculated assuming that the $\mathrm{CO}_{2}$ concentration at the feed side equals that of the static sorption experiment, and that the average $\mathrm{CO}_{2}$ concentration is given by the $\mathrm{CO}_{2}$ concentration measured during permeation experiments.

\subsubsection{Apparent gas molar volumes}

The apparent molar volumes, $V_{m}$, of the dissolved gases can be determined from the slope of the swelling versus the $\mathrm{CO}_{2}$ concentrations. ${ }^{54}$ Figure 6-5 (left panel) displays the swelling degree as a function of the $\mathrm{CO}_{2}$ concentration in the poly(POSS-imide) membranes. For all membranes, the swelling degree as function of concentration during static sorption and permeation experiments follows the same increase in swelling as function of the $\mathrm{CO}_{2}$ concentration. The similarity between the sorption and permeation data indicates the absence of pronounced hysteresis effects upon changing from static sorption to a pressure gradient during permeation. Only the 0.9 wt.\% sample displays hysteresis, which is reflected by the higher $\mathrm{CO}_{2} V_{m}$ during permeation and the large difference in relative refractive index shown in Figure 3 (top, right panel). The $V_{m}$ of $\mathrm{CO}_{2}$, shown in Figure 6-5 (right panel) increases significantly, from 12.5 to $65 \mathrm{~cm}^{3} \mathrm{~mol}^{-1}$, with increasing $\mathrm{CO}_{2}$ concentration. The increase in $V_{m}$ can be rationalized by the progressive filling of the network. At low concentrations, the $\mathrm{CO}_{2}$ molecules can fill free spaces in the network without much dilation. At higher concentrations, sorption of the $\mathrm{CO}_{2}$ molecules requires additional dilation because the available free space is occupied more and more. Because the environment of the $\mathrm{CO}_{2}$ molecules 
changes, from a completely polymeric network to an environment that is partially filled with $\mathrm{CO}_{2}$, the $V_{m}$ will also progressively change. At high $\mathrm{CO}_{2}$ concentrations, the apparent $V_{m}$ values will start to resemble that of the fluid phase. $^{40}$
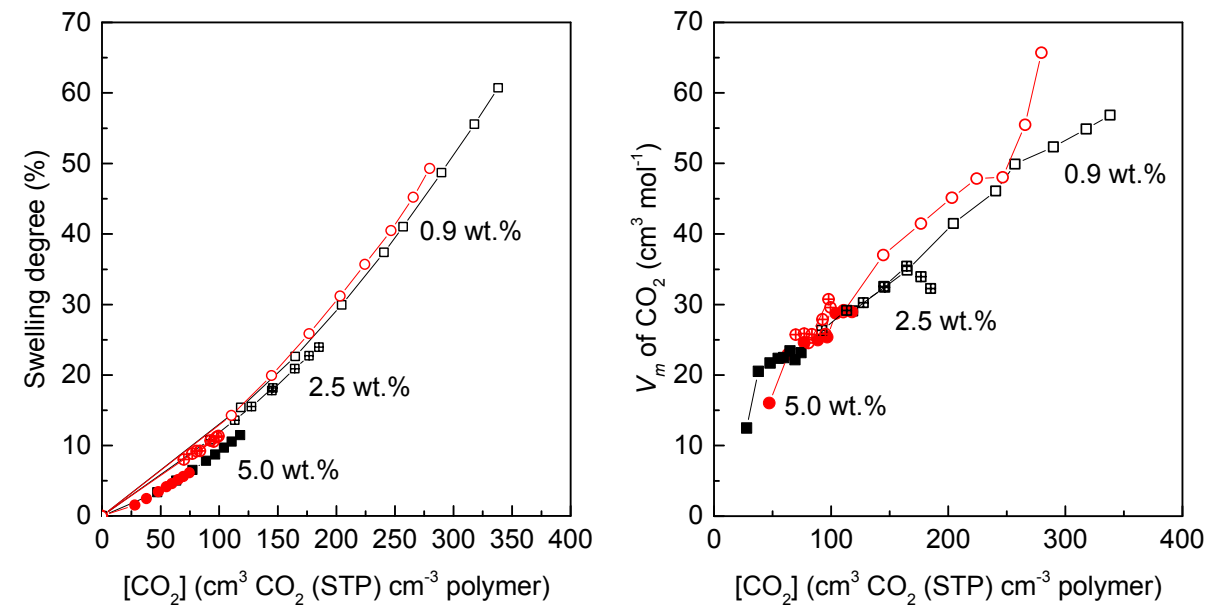

Figure 6-5. Swelling degree (left panel) and apparent $V_{m}$ of $\mathrm{CO}_{2}$ (right panel) as function of $\mathrm{CO}_{2}$ concentration, during static sorption experiments (black squares) and permeation experiments (red circles) for the poly(POSS-imide)s prepared with (open symbols) 0.9, (crossed symbols) 2.5 and (closed symbols) 5.0 wt.\% POSS solutions.

\subsection{6. $\mathrm{CO}_{2}$ permeability and diffusivity}

The change of the $V_{m}$ with $\mathrm{CO}_{2}$ concentration illustrates the influence of the penetrant on the nature of the network. The changes in network properties are reflected by the gas sorption and permeation behavior of the poly(POSSimide)s. Figure 6-6 (left panel) shows the permeability coefficient as function of $\mathrm{CO}_{2}$ concentration in the membranes. The permeability coefficient of $\mathrm{CO}_{2}$ is calculated from the permeance and thickness data measured by SE. The permeability coefficient increases with increasing $\mathrm{CO}_{2}$ concentration, due to the higher sorption and diffusion. Nonetheless, the slope of the curves is distinct for the different compositions. The $5.0 \mathrm{wt} . \%$ sample does not show an increase in permeability coefficient due to the high network rigidity. The 2.5 wt.\% sample does show a strong increase, without loss of network rigidity. The 0.9 wt.\% sample does result in much higher $\mathrm{CO}_{2}$ concentrations and permeability, but at the cost of network rigidity. Figure 6-6 (right panel) shows the diffusion coefficient of $\mathrm{CO}_{2}$ in the poly(POSS-imide) layer as 
function of sorbed $\mathrm{CO}_{2}$ concentration. The diffusion coefficients are in the range of about $2-12 \cdot 10^{-8} \mathrm{~cm}^{2} \mathrm{~s}^{-1}$, which is in a similar range as found for conventional polyimides. ${ }^{55}$ The diffusion coefficients increase with increasing $\mathrm{CO}_{2}$ concentration. The order of magnitude change of the diffusion coefficients as function of $\mathrm{CO}_{2}$ concentration are also observed for polybenzylmethacrylate, ${ }^{56}$ polysulfone,${ }^{57}$ natural methyl cellulose and sodium carboxymethyl cellulose, ${ }^{58}$ and carbon molecular sieve membranes. ${ }^{59}$
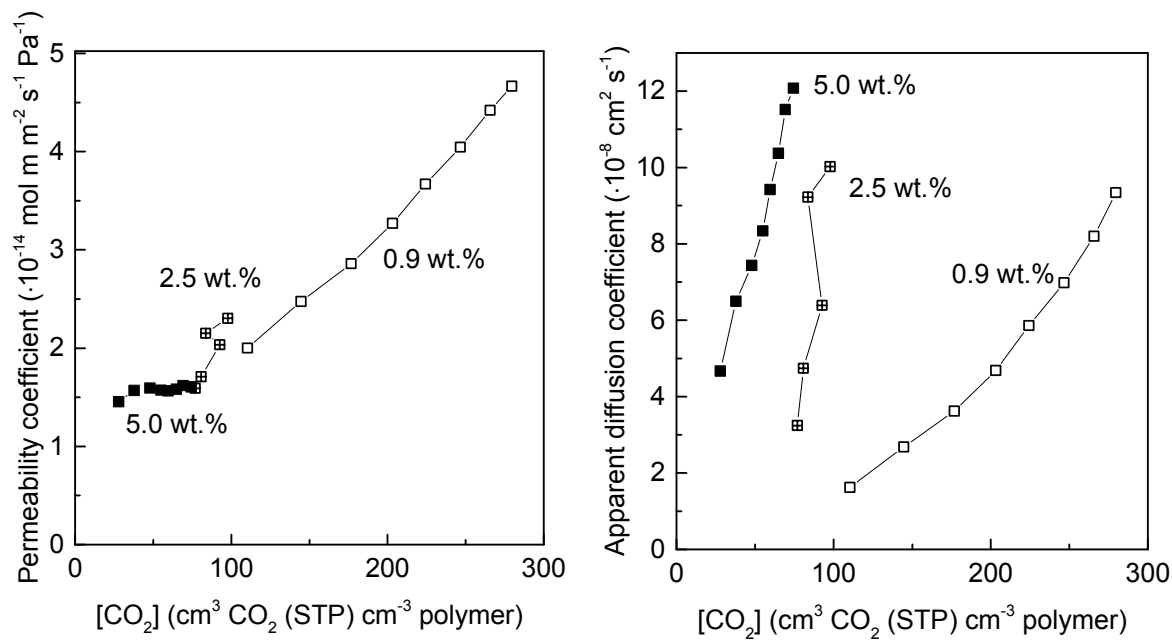

Figure 6-6. (left panel) $\mathrm{CO}_{2}$ concentration gradient as function of the average $\mathrm{CO}_{2}$ concentration during permeation. $1 \cdot 10^{-14} \mathrm{~mol} \mathrm{~m} \mathrm{~m}^{-2} \mathrm{~s}^{-1} \mathrm{~Pa}^{-1}$ equals about 30.3 barrer $\left(=10-10 \mathrm{~cm}^{3}(\mathrm{STP}) \mathrm{cm} \mathrm{cm}^{-2} \mathrm{~s}^{-1} \mathrm{cmHg}^{-1}\right)$. (right panel) Diffusion coefficient as function of the average $\mathrm{CO}_{2}$ concentration during permeation.

The increase in diffusion coefficient can be rationalized by the increased swelling and apparent $V_{m}$ at higher $\mathrm{CO}_{2}$ concentrations. The interactions of $\mathrm{CO}_{2}$ with the polymer network decrease, because the swollen, filled network starts to resemble the gas phase. The diffusion coefficient in the $0.9 \mathrm{wt} . \%$ sample are lower as compared to the 2.5 and $5.0 \mathrm{wt} . \%$ samples. Likely, the higher degree of cross-linking of the $0.9 \mathrm{wt} . \%$ sample reduces the diffusivity of the gas, even though the higher fluorine content results in a higher $\mathrm{CO}_{2}$ sorption.

\subsection{Conclusion}

In conclusion, the $\mathrm{CO}_{2}$ permeability in ultrathin poly(POSS-imide) membranes is determined by the sorption characteristics. The $\mathrm{CO}_{2}$ permeability coefficient 
increase with increasing $\mathrm{CO}_{2}$ concentration in the membrane. At high fluoroalkane content, the persistent increase in sorption due to flexibility of the network increases the permeability. Moreover, swelling of the network results in a higher apparent $V_{m}$ of $\mathrm{CO}_{2}$ and reduced interaction of $\mathrm{CO}_{2}$ with the hybrid network. As a result, the diffusion coefficient of $\mathrm{CO}_{2}$ increases strongly with increasing $\mathrm{CO}_{2}$ concentration. The fundamental understanding on the $\mathrm{CO}_{2}$ permeation allows for design of optimized membrane performance for $\mathrm{CO}_{2}$ separation applications.

\subsection{Acknowledgements}

This project has received funding from the European Union's Seventh

Framework Programme for research, technological development and demonstration under CARENA grant agreement no. 263007.

\subsection{References}

1. Czyperek, M.; Zapp, P.; Bouwmeester, H. J. M.; Modigell, M.; Ebert, K.; Voigt, I.; Meulenberg, W. A.; Singheiser, L.; Stöver, D. Journal of Membrane Science 2010, 359, (1-2), 149-159

2. Jones, C. W. Annual Review of Chemical and Biomolecular Engineering 2011, 2, 31 52

3. Smart, S.; Lin, C. X. C.; Ding, L.; Thambimuthu, K.; Diniz Da Costa, J. C. Energy and Environmental Science 2010, 3, (3), 268-278

4. Hao, J.; Rice, P. A.; Stern, S. A. Journal of Membrane Science 2008, 320, (1-2), 108122

5. Omole, I. C.; Adams, R. T.; Miller, S. J.; Koros, W. J. Industrial and Engineering Chemistry Research 2010, 49, (10), 4887-4896

6. Safari, M.; Ghanizadeh, A.; Montazer-Rahmati, M. M. International Journal of Greenhouse Gas Control 2009, 3, (1), 3-10

7. Wind, J. D.; Paul, D. R.; Koros, W. J. Journal of Membrane Science 2004, 228, (2), 227-236

8. Du, N.; Park, H. B.; Dal-Cin, M. M.; Guiver, M. D. Energy and Environmental Science 2012, 5, (6), 7306-7322

9. Favre, E.; Bounaceur, R.; Roizard, D. Journal of Membrane Science 2009, 328, (1-2), $11-14$

10. Scholz, M.; Melin, T.; Wessling, M. Renewable and Sustainable Energy Reviews 2013, 17, (0), 199-212

11. Bos, A.; Pünt, I. G. M.; Wessling, M.; Strathmann, H. Separation and Purification Technology 1998, 14, (1-3), 27-39

12. Hasan, R.; Scholes, C. A.; Stevens, G. W.; Kentish, S. E. Industrial and Engineering Chemistry Research 2009, 48, (11), 5415-5419

13. Reijerkerk, S. R.; Nijmeijer, K.; Ribeiro, C. P.; Freeman, B. D.; Wessling, M. Journal of Membrane Science 2011, 367, (1-2), 33-44 
14. Zhao, Y.; Qiu, C.; Li, X.; Vararattanavech, A.; Shen, W.; Torres, J.; Hélix-Nielsen, C.; Wang, R.; Hu, X.; Fane, A. G.; Tang, C. Y. Journal of Membrane Science 2012, 423424, 422-428

15. Swaidan, R.; Ma, X.; Litwiller, E.; Pinnau, I. Journal of Membrane Science 2013, 447, 387-394

16. Kim, S.; Jo, H. J.; Lee, Y. M. Journal of Membrane Science 2013, 441, 1-8

17. Kim, S.; Woo, K. T.; Lee, J. M.; Quay, J. R.; Keith Murphy, M.; Lee, Y. M. Journal of Membrane Science 2014, 453, 556-565

18. Scholes, C. A.; Ribeiro, C. P.; Kentish, S. E.; Freeman, B. D. Journal of Membrane Science 2014, 450, 72-80

19. Consolati, G.; Genco, I.; Pegoraro, M.; Zanderighi, L. Journal of Polymer Science, Part B: Polymer Physics 1996, 34, (2), 357-367

20. Cao, C.; Chung, T. S.; Liu, Y.; Wang, R.; Pramoda, K. P. Journal of Membrane Science 2003, 216, (1-2), 257-268

21. Cheng, S. X.; Chung, T. S.; Wang, R.; Vora, R. H. Journal of Applied Polymer Science 2003, 90, (8), 2187-2193

22. Duthie, X.; Kentish, S.; Powell, C.; Nagai, K.; Qiao, G.; Stevens, G. Journal of Membrane Science 2007, 294, (1-2), 40-49

23. Sanders, D. F.; Smith, Z. P.; Ribeiro, C. P.; Guo, R.; McGrath, J. E.; Paul, D. R.; Freeman, B. D. Journal of Membrane Science 2012, 409-410, 232-241

24. Suzuki, T.; Yamada, Y.; Itahashi, K. Journal of Applied Polymer Science 2008, 109, (2), 813-819

25. Matsumoto, K.; Xu, P. Journal of Membrane Science 1993, 81, (1-2), 23-30

26. Pandiyan, S.; Brown, D.; Neyertz, S.; Van Der Vegt, N. F. A. Macromolecules 2010, 43, (5), 2605-2621

27. Kawakami, H.; Nakajima, K.; Shimizu, H.; Nagaoka, S. Journal of Membrane Science 2003, 212, (1-2), 195-203

28. Neyertz, S.; Brown, D.; Pandiyan, S.; Van Der Vegt, N. F. A. Macromolecules 2010, 43, (18), 7813-7827

29. Neyertz, S.; Brown, D. Macromolecules 2013, 46, (6), 2433-2449

30. Kim, J. H.; Koros, W. J.; Paul, D. R. Journal of Membrane Science 2006, 282, (1-2), $32-43$

31. Cui, L.; Qiu, W.; Paul, D. R.; Koros, W. J. Polymer 2011, 52, (24), 5528-5537

32. Liu, Y.; Wang, R.; Chung, T. S. Journal of Membrane Science 2001, 189, (2), 231239

33. Ma, C.; Koros, W. J. Industrial and Engineering Chemistry Research 2013, 52, (31), 10495-10505

34. Eguchi, H.; Kim, D. J.; Koros, W. J. Polymer (United Kingdom) 2015, 58, 121-129

35. Kawakami, H.; Mikawa, M.; Nagaoka, S. Journal of Membrane Science 1996, 118, (2), 223-230

36. Duthie, X.; Kentish, S.; Pas, S. J.; Hill, A. J.; Powell, C.; Nagai, K.; Stevens, G.; Qiao, G. Journal of Polymer Science, Part B: Polymer Physics 2008, 46, (18), 1879-1890

37. Swaidan, R.; Ghanem, B.; Litwiller, E.; Pinnau, I. Journal of Membrane Science 2015, $475,571-581$ 
38. Raaijmakers, M. J. T.; Hempenius, M. A.; Schön, P. M.; Vancso, G. J.; Nijmeijer, A.; Wessling, M.; Benes, N. E. Journal of the American Chemical Society 2014, 136, (1), 330-335

39. Raaijmakers, M. J. T.; Wessling, M.; Nijmeijer, A.; Benes, N. E. Chemistry of Materials 2014, 26, (12), 3660-3664

40. Raaijmakers, M. J. T.; Ogieglo, W.; Wiese, M.; Wessling, M.; Nijmeijer, A.; Benes, N. E. Submitted 2015,

41. Lichtenstein, T.; Engineering, U. o. R. C. o.; Science, A., Handbook of Thin Film Materials. College of Engineering and Applied Science, University of Rochester: 1979.

42. Ogieglo, W.; Wormeester, H.; Wessling, M.; Benes, N. E. ACS applied materials \& interfaces 2012, 4, (2), 935-43

43. Ogieglo, W.; van der Werf, H.; Tempelman, K.; Wormeester, H.; Wessling, M.; Nijmeijer, A.; Benes, N. E. Journal of Membrane Science 2013, 437, 313-323

44. Michels, A.; Hamers, J. Physica 1937, 4, (10), 995-1006

45. Besserer, G. J.; Robinson, D. B. Journal of Chemical \& Engineering Data 1973, 18, (2), 137-140

46. Baker, R. W., Membrane Technology and Applications. 2012.

47. Cui, L.; Qiu, W.; Paul, D. R.; Koros, W. J. Polymer 2011, 52, (15), 3374-3380

48. Sirard, S. M.; Green, P. F.; Johnston, K. P. J Phys Chem B 2001, 105, (4), 766-772

49. Sirard, S. M.; Ziegler, K. J.; Sanchez, I. C.; Green, P. F.; Johnston, K. P. Macromolecules 2002, 35, (5), 1928-1935

50. Wind, J. D.; Sirard, S. M.; Paul, D. R.; Green, P. F.; Johnston, K. P.; Koros, W. J. Macromolecules 2003, 36, (17), 6433-6441

51. Sirard, S. M.; Castellanos, H.; Green, P. F.; Johnston, K. P. J Supercrit Fluid 2004, 32, (1-3), 265-273

52. Wang, J. S.; Kamiya, Y. Journal of Polymer Science, Part B: Polymer Physics 2000, $38,(6), 883-888$

53. Visser, T.; Koops, G. H.; Wessling, M. Journal of Membrane Science 2005, 252, (12), 265-277

54. Simons, K.; Nijmeijer, K.; Sala, J. G.; van der Werf, H.; Benes, N. E.; Dingemans, T. J.; Wessling, M. Polymer 2010, 51, (17), 3907-3917

55. Tanaka, K.; Kita, H.; Okano, M.; Okamoto, K. i. Polymer 1992, 33, (3), 585-592

56. Wang, J. S.; Naito, Y.; Kamiya, Y. Journal of Polymer Science, Part B: Polymer Physics 1996, 34, (12), 2027-2033

57. Wang, J. S.; Kamiya, Y. Journal of Membrane Science 1995, 98, (1-2), 69-76

58. Perko, T.; Markočič, E.; Knez, Z.; Škerget, M. Journal of Chemical and Engineering Data 2011, 56, (11), 4040-4044

59. Wang, K.; Suda, H.; Haraya, K. Industrial and Engineering Chemistry Research 2001, 40, (13), 2942-2946 


\section{Chapter 7 Enzymatically-active, ultrathin pepsin membranes}

This chapter has been adapted from: Raaijmakers, M.J.T., Schmidt, T., Barth, M., Tutus, M., Benes, N.E., Wessling, M. Enzymatically-active, ultrathin pepsin membranes, Angewandte Chemie Internation Edition. 


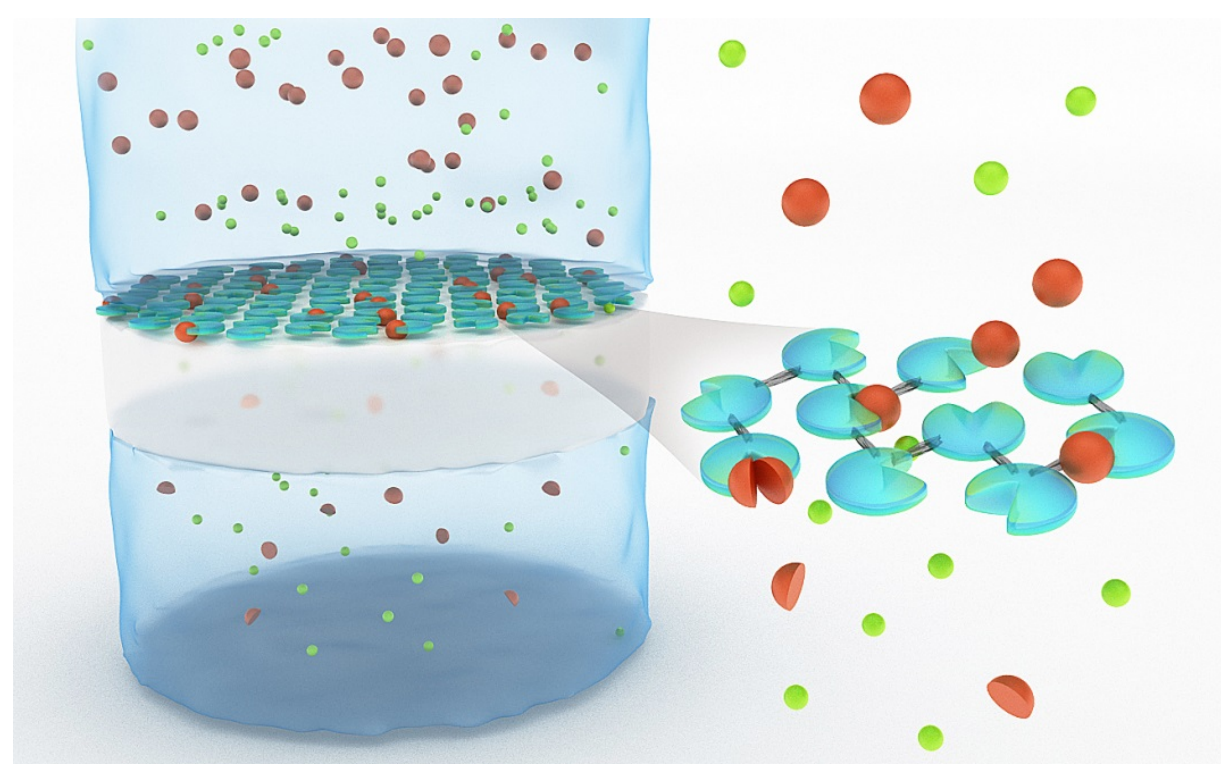

\section{Abstract}

Enzymatically active proteins enable efficient and specific cleavage reactions of peptide bonds. Covalent coupling of the enzymes permits immobilization, which in turn reduces autolysis-induced deactivation. Ultrathin pepsin membranes were prepared by facile interfacial polycondensation of pepsin and trimesoyl chloride. The pepsin membrane allows for simultaneous enzymatic conversion and selective removal of digestion products. The large water fluxes through the membrane expedite the transport of large molecules through the pepsin layers. The presented method enables the large-scale production of ultrathin, cross-linked, enzymatically active membranes.

\subsection{Introduction}

The unique architecture of enzymatic proteins allows for hydrolysis of peptide bonds in mild conditions. ${ }^{1}$ The high enzyme specificity and activity are attractive for isolation of peptides and in food upgrading processes. However, enzyme re-usage is complicated by self-cleavage induced deactivation and difficulties in recovery of dilute enzyme solutions used in relevant processes. ${ }^{2}$ Immobilized enzyme can be used instead, potentially reducing deactivation and increasing conversion specificity and activity. ${ }^{3-8}$ Enzyme mobility can be restricted by covalent coupling to a substrate or by self-cross-linking of the 
enzyme. Enzyme immobilization allows for simultaneous enzymatic conversion and removal of the converted products, while maintaining the enzyme activity of the immobilized proteins. ${ }^{9-11}$ The most common approach to achieve enzyme immobilization is formation of a polymer-protein bioconjugate. ${ }^{12-14}$ Current methods to make self-cross-linked freestanding or supported protein layers are based on template or self-assembly assisted crosslinking, generally using glutaraldehyde as cross-linking agent. Examples include freestanding protein films by assembly of proteins on sacrificial cadmium hydroxide templates for controlled drug release or nanofiltration purposes. ${ }^{15,16}$ More recently, enzymatically active protein films have been prepared based on hierarchical self-assembly of protein-polymer conjugates cross-linked in glutaraldehyde vapor, confirming that the native protein function can remain despite the high degree of covalent bonding between proteins. ${ }^{17}$ Nonetheless, the production of freestanding protein films in this manner is not easily scalable and a large amount of precious protein is required for small membrane surface areas.

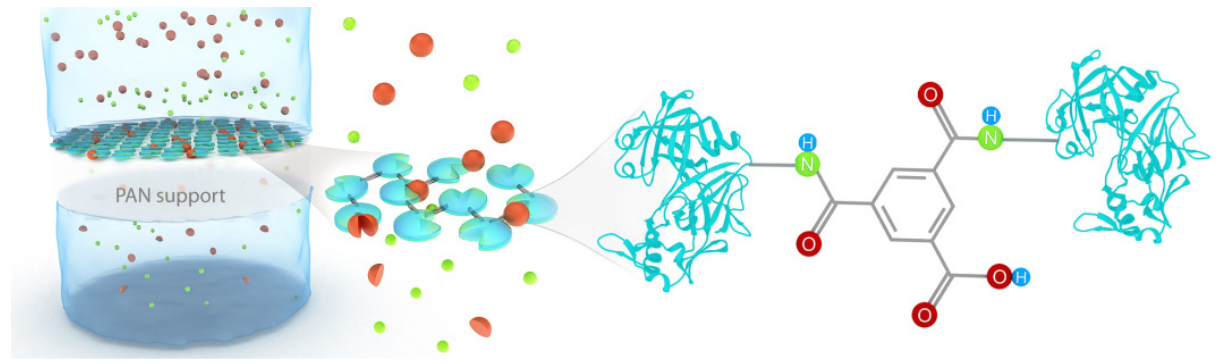

Scheme 7-1. Schematic representation of the pepsin membrane formation. The pepsin membrane is atop a porous PAN support, represented by the white area. The pepsin membrane consists of pepsin molecules that are randomly cross-linked by TMC, forming amide bridges between the pepsin molecules. The pepsin layer simultaneously acts as enzymatic surface and membrane sieve. The larger molecules are retained by the membrane and selectively cleaved by the pepsin. The large water flux through the membrane increases transport of solute molecules to the membrane surface area and removal of digestion product by membrane permeation.

Here, we propose to use a facile interfacial polycondensation reaction for the production of ultrathin enzymatically active pepsin membranes. ${ }^{18}$ Pepsin is a nonspecific acidic endopeptidase that preferentially cleaves proteins at carboxylic groups of aromatic amino acids such as phenylalanine, tryptophan, 
leucine and tyrosine. ${ }^{19}$ The ultrathin cross-linked pepsin membranes, with a thickness of 50-150 nm, show molecular retention for polyethylene glycol (PEG) at a molecular weight above $10 \mathrm{kDa}$ and exhibit enzymatic activity comparable to pristine pepsin. Scheme 7-1 shows the schematic representation of the pepsin membrane on top of a porous PAN support (left). The ultrathin pepsin layer allows simultaneous retention and selective cleavage of large molecules. The high water permeability allows for expeditious removal of digestion products.

\subsection{Experimental section}

Pepsin film formation by interfacial polymerization is achieved using a 0.46 $\mathrm{wt} \%$ pepsin in phosphate buffered saline (PBS, $\mathrm{pH}$ 7) solution and a trimesoyl chloride (TMC) solution in hexane. The $\mathrm{pH}$ of the buffer solution, reaction time and reactant concentrations were identified as critical parameters for effective film formation. Optimal pepsin and TMC concentrations were found to be higher than for conventional interfacial polymerization processes. This can be attributed to the large size of the pepsin, low reactivity of the functional groups and the nature of the formed film. In acidic environment the protein reactivity is limited by the high degree of protonated, unreactive ammonia groups. The neutral $\mathrm{pH}$ of the PBS buffer is critical for sufficient availability of reactive amines, while preventing permanent pepsin deactivation. Pepsin film formation atop a flat-sheet polyacrylonitril ultrafiltration membrane (PAN, SolSep, Netherlands) was achieved by prewetting the support with the aqueous pepsin solution and subsequent contacting the support with a solution of TMC in hexane.

\subsection{Results and discussion}

\subsubsection{Pepsin film formation}

Pepsin film formation was confirmed using X-ray photoelectron spectroscopy (XPS) and attenuated total reflection - Fourier transform infrared spectroscopy (ATR-FTIR). Figure 7-2 (left panel) shows the ATR-FTIR absorbance spectrum of pepsin powder and PAN supported ultrathin pepsin membranes prepared with 5 and 15 min reaction time. The absorbance spectra of pepsin membranes show peaks corresponding with the pepsin powder infrared absorbance signature, indicating the nature of the pepsin does not change upon crosslinking. As film formation advances, absorbance bands associated with phenyl rings and amide bonds emerge at 1240 and $1400 \mathrm{~cm}^{-1}$. The intensity of the pepsin related peaks increases with interfacial polymerization reaction 
time, which is due to the continued progress of the pepsin film growth. Film growth is sustained by the open character of the formed film that allows for diffusion of the monomer reactant. This is different from conventional interfacial polymerization film formation, where reactant diffusion inhibition limits film growth. ${ }^{20}$ The scanning electron micrographs shown in Figure 7-2 (right panel) substantiate film formation atop the porous PAN support. Whereas the PAN support top view micrograph clearly reveals pores, the pepsin membrane micrographs have the appearance of a dense layer with a distinct morphology that is unlike conventional interfacial polymerization membranes. Layer thickness determined from cross-section micrographs (Appendix, Figure A7-1) is in the range of 50-150 nm.
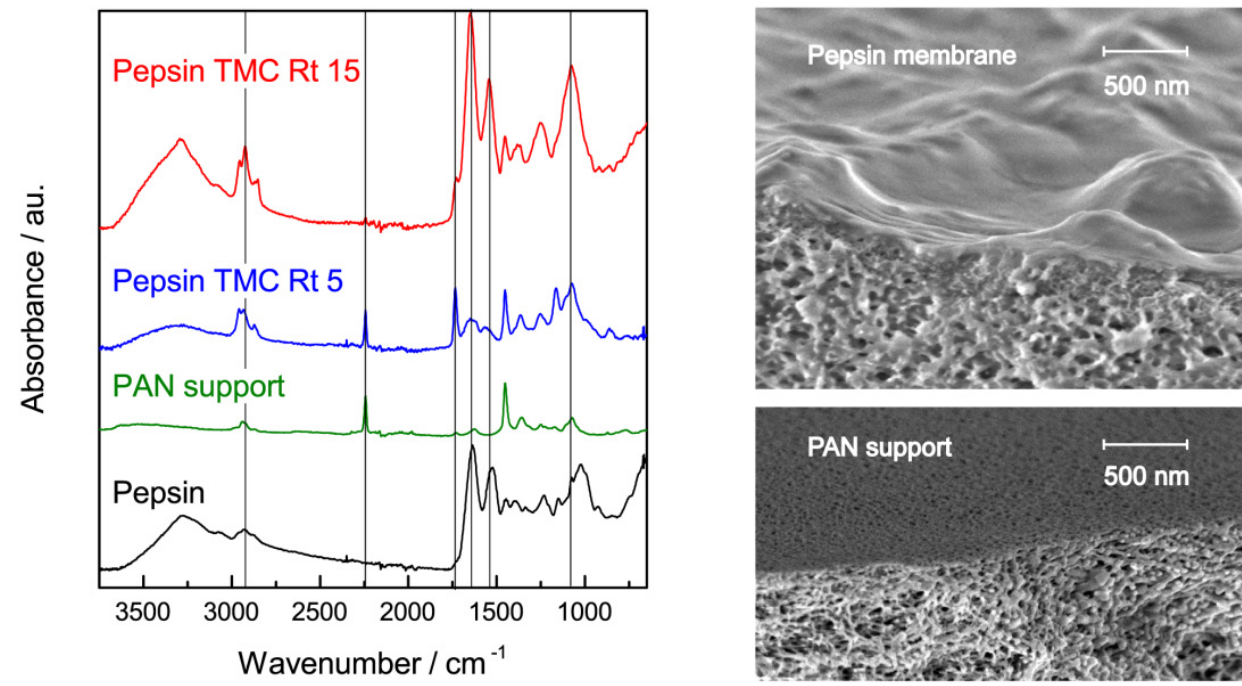

Figure 7-2. (left panel) ATR-FTIR absorbance spectrum of pepsin powder, PAN-PO supported ultrathin pepsin membranes prepared with 5 and 15 min reaction time (Rt). The absorbance peaks around $3000-3500 \mathrm{~cm}^{-1}$ represent the different $\mathrm{C}-\mathrm{C}, \mathrm{C}-\mathrm{H}$ and $\mathrm{O}-\mathrm{H}$ bonds present in the pepsin. Amino acid bonds are located at 1650 ( $\mathrm{N}-\mathrm{H}$ bending) and 1540 ( $\mathrm{C}=\mathrm{O}$ stretching) $\mathrm{cm}^{-1}$. (right panel) Scanning electron micrograph of a pepsin membrane atop a PAN support (top panel) and a bare PAN support (bottom panel). The pores present on the top side of the PAN support are not visible in the pepsin membrane PAN support. 


\subsubsection{Pepsin layer characterization}

A reaction time of 15 min was used to obtain sufficiently thick membranes for further characterization. The degree of pepsin crosslinking by the TMC groups was determined by XPS analysis of the supported films. Figure 7-3 shows the deconvoluted $\mathrm{C} 1 \mathrm{~s}$ and $\mathrm{O} 1 \mathrm{~s}$ binding energy spectrum of pepsin powder and pepsin membranes prepared by reacting presoaked PAN supports with 0.2 and 0.5 wt.\% TMC in hexane solutions, respectively. The $\mathrm{C} 1 \mathrm{~s}$ and $\mathrm{O} 1 \mathrm{~s}$ binding energy spectrum of the PAN support are given as a reference. The C1s spectra shown in Figure 7-3 (left panel) confirm the covalent bond formation between the pepsin and TMC atop the PAN support. The C1s binding energy peak locations of the pepsin membranes at 285, 286.5 and $288 \mathrm{eV}$, associated with saturated hydrocarbon, amine and amide groups, respectively correspond to the binding energy peaks of the pepsin powder. The increase of the binding energy peak surface area at $285 \mathrm{eV}$ (A) with respect to the 286.5 (B) and 288 $\mathrm{eV}$ peaks can be rationalized by an increase in aromatic carbon content. The degree of reaction between the pepsin and TMC can be calculated from the change in the $\mathrm{A} / \mathrm{B}$ ratio of the $\mathrm{C} 1 \mathrm{~s}$ peak surface areas. Moreover, the carbon to nitrogen elemental ratio gives an indication of the relative increase in aliphatic carbon in the pepsin membranes. The number of reacted TMC groups per pepsin molecule was estimated to be 40 for the pepsin membrane prepared using $0.2 \mathrm{wt} \% \mathrm{TMC}$ in hexane. The high degree of crosslinking results in effective immobilization of the pepsin, although it is unlikely that all TMC molecules connect two different pepsin molecules. This is reflected by the $\mathrm{C} 1 \mathrm{~s}$ binding energy peak at $285.8 \mathrm{eV}$ in the pepsin membrane spectra, associated with carbonyl groups that are formed by reaction of excess acyl chloride groups and water. The membranes prepared using $0.5 \mathrm{wt} \% \mathrm{TMC}$ in hexane have an estimated 5 reacted TMC groups per pepsin, which is significantly lower than membranes prepared with lower TMC concentrations. This is likely due to the acidification of the aqueous phase upon contact with the excess TMC monomers, hampering the amine group reactivity that is required for effective pepsin polycondensation. The absence of a peak in the pepsin membrane spectra at $287.1 \mathrm{eV}$, associated with the PAN C1s binding energy spectrum, indicates that the membrane layer thickness is above the X-ray beam penetration depth of $\sim 10 \mathrm{~nm}$. This observation is in accordance with the thickness observed from SEM analysis. The O1s spectra shown in Figure 7-3 (right panel) underline the partial conversion of acyl chloride groups to carboxylic acid groups upon interfacial polymerization. The peaks associated with carbonyl (531.5) and hydroxyl groups $(532.9 \mathrm{eV})$ increase with respect to 
the amide peaks upon pepsin membrane formation, suggesting that a relatively large fraction of the reactive groups on the TMC are converted to carboxylic acids. Nonetheless, the determination of the fraction of unconnected TMC groups is complicated by the pronounced shift in the fitted binding energy peak maxima and overlap in binding energy peaks of the different functional groups.
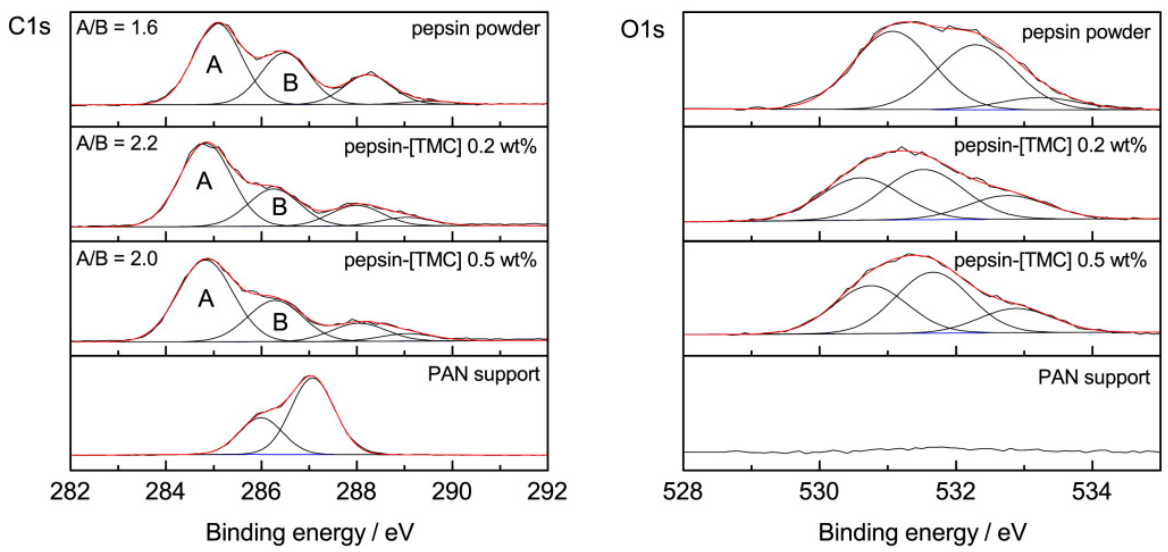

Figure 7-3. Deconvoluted C1s (left panel) and O1s (right panel) spectra of the PAN support, pepsin powder and PAN supported pepsin membranes prepared using 0.2 and $0.5 \mathrm{wt} \%$ TMC solutions in hexane with a reaction time of $15 \mathrm{~min}$. The spectra were fitted using Gaussians with similar full width at half maximum (FWHM) values. The complete C1, N1s and O1s binding energy relative peak areas analysis for pepsin powder, the PAN support and pepsin membranes prepared using 0.2 and 0.5 wt\% TMC solutions is given in the Appendix.

\subsubsection{Assay digestion}

Pepsin activity was tested in two consecutive digestion runs using hemoglobin and bovine serum albumin (BSA, fraction $\mathrm{V}$ ) as substrate, at a temperature of $37{ }^{\circ} \mathrm{C}$ and $\mathrm{pH} 2$ ( $\mathrm{HCl}$ adjusted). Multi angle laser light scattering (MALLS), ultraviolet light absorption (UV) and refractive index (RI) measurements are used to determine protein and digestion product molecular weight distribution. Hemoglobin and BSA digestion kinetics for the TMC cross-linked pepsin membranes on PAN support were compared with pepsin in solution. Figure 7-4 shows the molecular weight distribution of hemoglobin in solution after different contact times with the pepsin membranes prepared using 0.2 and 0.5 wt. $\%$ TMC solutions. The digestion kinetics of pepsin in solution have been determined as a reference (Appendix, Figure A7-3). To determine the 
degree of pepsin deactivation, two consecutive assay digestion runs were performed using the same membrane sample. The initial hemoglobin molecular weight distribution, represented by the dotted line at $\mathrm{t}=0$, is given by a single peak with a maximum at $36 \mathrm{kDa}$. After 1 hour, there is a significant decrease in the hemoglobin peak while a second peak at $8 \mathrm{kDa}$ emerges. Further evolution of the molecular weight distribution in time shows a continued decrease of hemoglobin concentration and increase in digestion product concentration. The membranes prepared with a 0.2 wt.\% TMC solution show the highest apparent activity. The low activity of the membranes prepared with a $0.5 \mathrm{wt} . \%$ TMC solution is likely a result of the lower pepsin reactivity, due to acidification of the aqueous solution during interfacial polymerization.
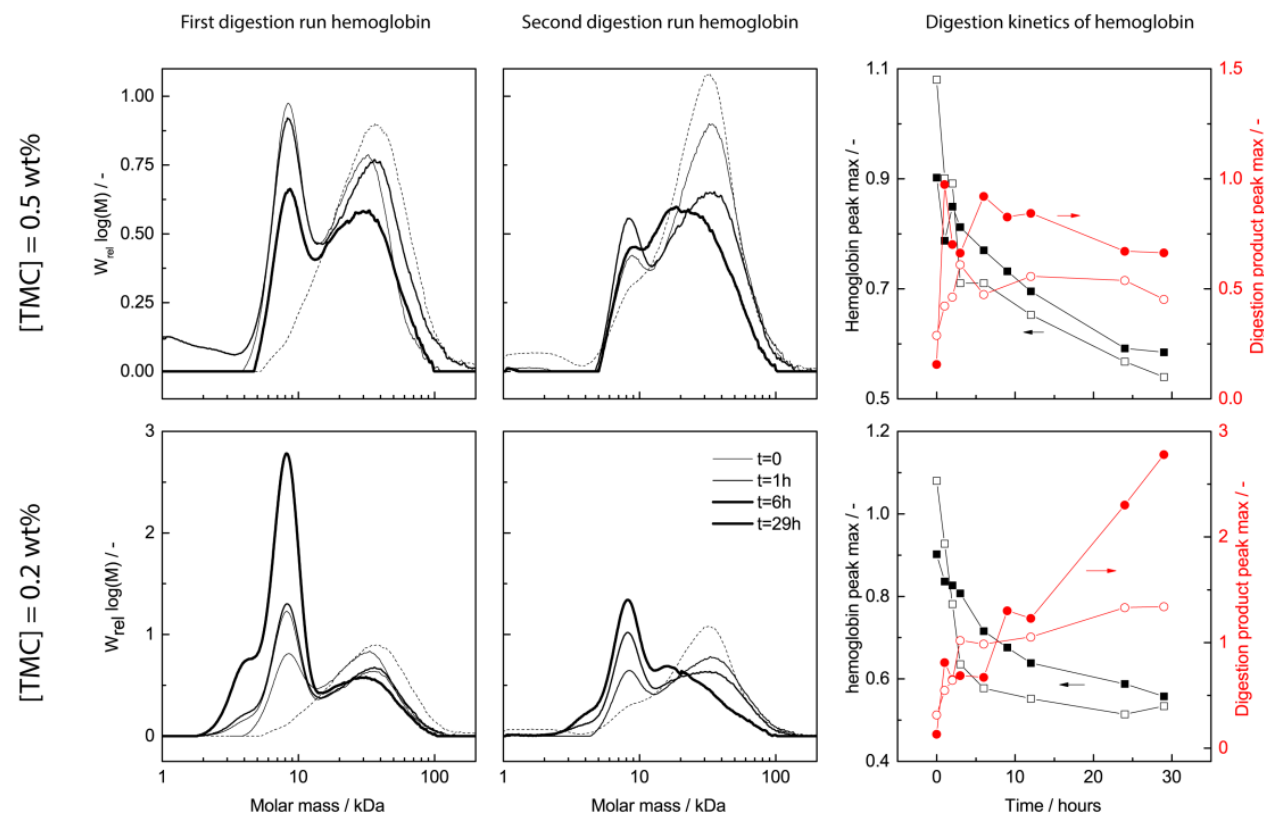

Figure 7-4. Molar mass distribution of hydrolysate products after 1, 6, 29 hours contact of a $1 \mathrm{~g} \mathrm{~L}^{-1}$ hemoglobin solution ( $\mathrm{pH} \mathrm{2,} \mathrm{HCl}$ adjusted) with a pepsin membrane at a temperature of $37^{\circ} \mathrm{C}$. Two consecutive runs were performed with membranes prepared using $0.5 \mathrm{wt} \%$ TMC (top panels) and $0.2 \mathrm{wt} \%$ TMC (bottom panels) on PAN support. To see the extent of pepsin deactivation the second runs (middle panels) were performed with the same membrane samples used in the first run (left panels). (right panels) Hemoglobin digestion kinetics as function of time, derived from the hemoglobin peak maximum ( $(\varpi)$ digestion product peak evolution ( $)$. 
Because it is not possible to quantify the amount pepsin in the layer, an exact determination of the degree of deactivation was not possible. However, the hemoglobin digestion for both layers is slightly higher in the second run compared to the first run, indicating that little deactivation occurs over the course of each run ( $\sim 30$ hours each). The digestion product formation, on the other hand, is more pronounced in the first runs ( $\bullet$ ) compared to the second runs (०). Moreover, the digestion product formation does not correspond to the continuous hemoglobin removal. The undervalued product formation is likely caused by absorption of digestion products to the membranes (Appendix, Figure A7-6). The digestion kinetics of BSA are similar to those measured for hemoglobin (Appendix, Figures A7-4 and A7-5).

\subsubsection{Pepsin layer membrane performance}

Molecular weight cut-off (MWCO) measurements of pepsin membranes on PAN support were performed using a stirred dead-end permeation cell. The feed and permeate concentrations were sampled to determine degree of retention of PEG molecules with a range of molar masses. The retention was calculated from the ratio of the concentration in the permeate over the concentration in the feed. A more detailed description of the setup is given in the Appendix. Permeation experiments were performed at 2 bar pressure difference using an aqueous feed solution of polyethylene glycol with mean molar masses of 2, 6, 8, 10, 20 and $40 \mathrm{kDa}$ respectively (each fraction $1 \mathrm{~g} \mathrm{~L}^{-1}$ ). Permeate composition was sampled after 30, 60, 90 and $120 \mathrm{~min}$. Gel permeation chromatography (GPC) was used for analysis of feed and permeate compositions. Figure 7-5 displays the molar mass distribution of the feed compared to two membranes prepared with 0.2 and $0.5 \mathrm{wt} \% \mathrm{TMC}$ solutions, respectively. The flux was around $50 \mathrm{~L} \mathrm{~m}^{-2} \mathrm{~h}^{-1}$ for all pepsin membranes and around $400 \mathrm{~L} \mathrm{~m}^{-2} \mathrm{~h}^{-1}$ for the PAN support layer. The concentration of PEG molecules in the feed at $120 \mathrm{~min}$ filtration time increases with respect to the initial PEG concentration of the feed. Also, the permeate concentration is lower than the feed concentration. The enrichment of the PEG molecules in the feed implicate that the pepsin membranes retain large molecules. The PAN support without pepsin layer does not show any retention for the same range of PEG molar masses (Appendix, Figure A7-7). The retention data, calculated for a permeation time of $120 \mathrm{~min}$, shows that the membranes prepared with a lower TMC concentration $(0.2$ wt.\%) show a stronger retention of large molecules compared to higher concentrations $(0.5 \mathrm{wt} . \%)$. The membranes prepared with 0.2 wt. $\%$ TMC solution retain $90 \%$ of the PEG with a molar 
mass above $9.5 \mathrm{kDa}$. The feed and permeate compositions for the PAN support were the same, implicating that the PEG molecule retention can be ascribed to the ultrathin cross-linked pepsin layer. This is in agreement with the XPS data that suggest a higher crosslink density for the membranes produced using lower TMC concentrations.
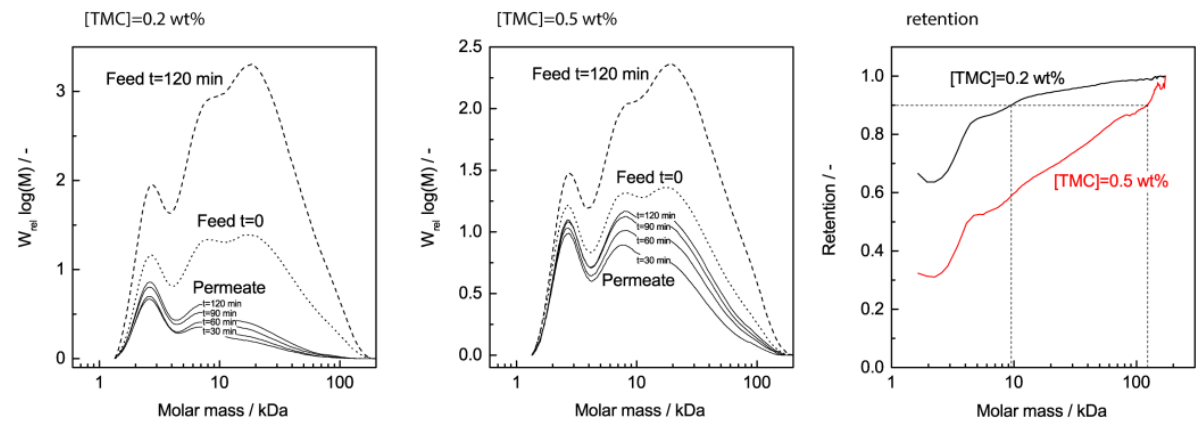

Figure 7-5. Molar mass distribution of the feed at $\mathrm{t}=0$ and $120 \mathrm{~min}$ and permeate samples taken every $30 \mathrm{~min}$ during dead-end filtration of an aqueous PEG solution with a mean molar masses of 2-40 kDa. Permeate compositions of the samples from membranes prepared with 0.2 (left panel) and $0.5 \mathrm{wt} \%$ (middle panel) TMC concentrations. (right panel) Retention as a function of PEG molar mass in the permeate fraction calculated from the molar mass distribution. The MWCO of the membranes prepared with 0.2 and 0.5 wt\% TMC are $9.5 \mathrm{kDa}$ and 120 kDa, respectively.

The range in which the membranes show retention is in the same range as the molecular weight of the proteins used for the digestion experiments. Integration of the protein thin film on a membrane support would allow for selective removal of enzymatic conversion products, while retaining larger molecules such as proteins.

\subsection{Conclusion}

In conclusion, we present a method to produce ultrathin pepsin membranes that show persistent enzymatic activity. Further study of the membrane formation process should be considered to determine the degree of active enzymes in the layer and the nanoscale enzyme distribution in the film. The interfacial polymerization technique can easily be applied to other proteins and other covalent organic linkers with different size, number of reactive groups and reactivity. 


\subsection{Acknowledgements}

MW, MB and MT acknowledge support through the Alexander von Humboldt Foundation. This work was performed in part at the Center for Chemical Polymer Technology CPT, which is supported by the EU and the federal state of North Rhine-Westphalia (grant no. EFRE 3000883 02).

\subsection{Appendix}

\subsubsection{Pepsin film formation}

Pepsin film formation by interfacial polymerization is achieved using a 0.46 wt\% pepsin (Carl Roth) in phosphate buffered saline (PBS, pH 7) and a trimesoyl chloride (TMC) solution in hexane. TMC concentrations of 0.2 and $0.5 \mathrm{wt} \%$ in hexane were used for the synthesis of the pepsin membranes. The membranes were prepared by interfacial polymerization atop porous polyacrylonitril (PAN, SolSep, Netherlands) supports, subsequently presoaked using an ethanol/water $(50 / 50 \mathrm{wt} \%)$ and the aqueous pepsin solution. In addition, the interfacial polymerization reaction was performed without the use of a substrate. The formation of a layer at the hexane-water interface could visually be confirmed. The free-standing layer had sufficient mechanical strength to be removed from the interface using tweezers. Scheme A7-1 shows the formation of a pepsin membrane by polycondensation of amino acid groups and trimesoyl chloride.
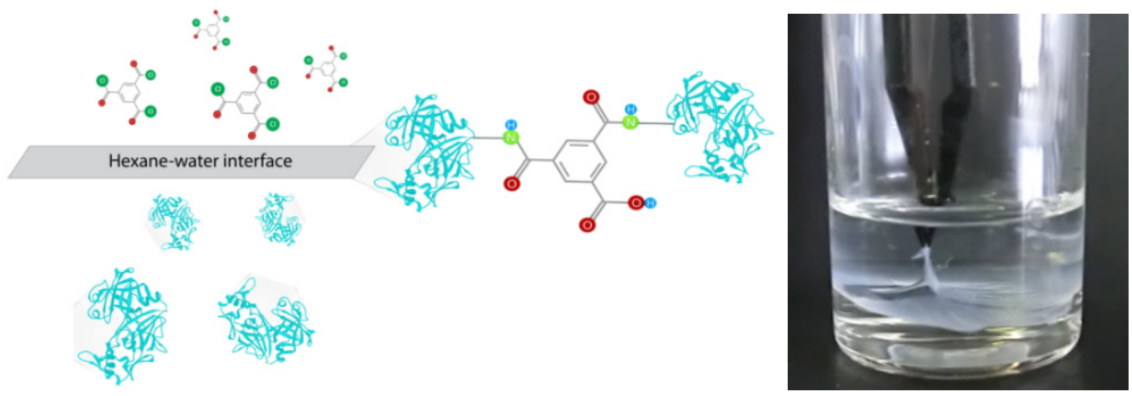

Scheme A7-1. (left) Formation of a pepsin membrane by interfacial polycondensation of an aqueous pepsin solution and a TMC solution in hexane. (right) Photograph of a cross-linked pepsin film formed at the hexane-water interface. 
Membranes were prepared with various concentrations of pepsin (aq. phase) and TMC (hexane). At low TMC concentrations, no layer formation could be observed by imaging using scanning electron microscopy. Low protein concentrations similarly resulted in absence of clear layer formation. Moreover, one would not expect strong absorption of pepsin on PAN, given that pepsin and the PAN support both have a negative zeta potential at $\mathrm{pH} 7$ (the conditions at which the interfacial polymerization reactions were performed).

\subsubsection{Pepsin layer characterization}

\section{Scanning electron microscopy}

Scanning electron microscopy (SEM) images were obtained using a LEO-1550 Schottky field emission scanning electron microscope (Carl-Zeiss, Germany), with an accelerating voltage of $2.00 \mathrm{kV}$. The membrane thickness was determined from cross-section micrographs of the PAN supported pepsin membranes.

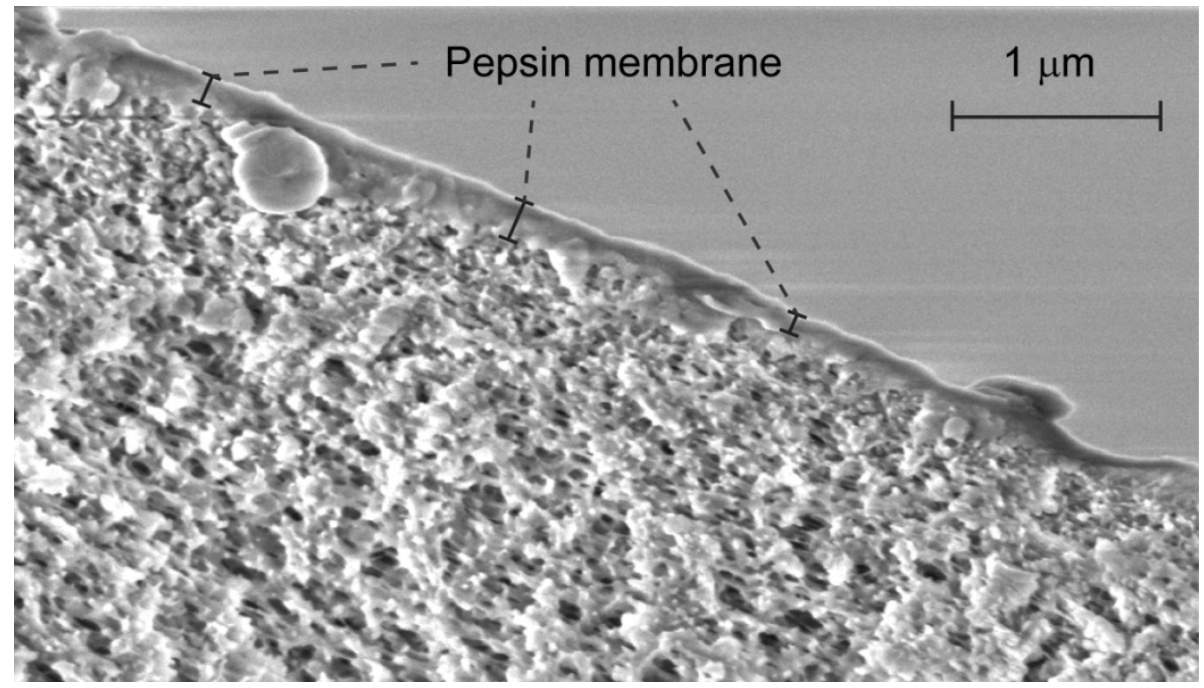

Figure A7-1. Cross-section scanning electron micrograph of a pepsin membrane atop a porous PAN support.

\section{Attenuated Total Reflection Fourier Transform Infrared Spectroscopy}

The chemical structures of the pepsin membrane were analyzed with Attenuated Total Reflection Fourier Transform Infrared Spectroscopy (ATRFTIR) on PAN supported membranes using an ALPHA FT-IR Spectrometer 
(Bruker Optics Inc, Germany) equipped with a ZnSe crystal. All spectra were recorded at room temperature. Pepsin films were prepared by interfacial polymerization of aqueous pepsin solution and a $0.2 \mathrm{wt} . \%$ TMC solution in hexane, with reaction times of 5 and $15 \mathrm{~min}$.

\section{X-ray photoelectron spectroscopy}

XPS (X-ray Photoelectron Spectroscopy) measurements were carried out in an Ultra AxisTM spectrometer, (manufactor: Kratos Analytical, Manchester UK). The samples were irradiated with monoenergetic $\mathrm{Al} \mathrm{K} * 1,2$ radiation (1486.6 $\mathrm{eV})$ and the spectra were taken at a power of $144 \mathrm{~W}(12 \mathrm{kV} \times 12 \mathrm{~mA})$. The aliphatic carbon (C-C, C-H) at a binding energy of $285 \mathrm{eV}$ (C1s photoline) was used to determine the charging. The spectral resolution - i.e., the Full Width of Half Maximum (FWHM) of the Ester carbon from PET - was better than $0.68 \mathrm{eV}$ for the elemental spectra. The information depth is about $10 \mathrm{~nm}$ for polymers. The elemental composition of the pepsin membranes, PAN support and pepsin powder are given in Table A7-1.

Table A7-1. Elemental composition of pepsin powder, bare PAN support and pepsin membranes on PAN prepared using 0.2 and $0.5 \mathrm{wt} \%$ TMC solutions. The element ratios are calculated from the elemental compositions.

\begin{tabular}{|c|c|c|c|c|}
\hline Element & $\begin{array}{l}\text { Pepsin membrane } \\
{[\mathrm{TMC}] 0.2 \mathrm{wt} \%}\end{array}$ & $\begin{array}{l}\text { Pepsin membrane } \\
{[\mathrm{TMC}] 0.5 \mathrm{wt} \%}\end{array}$ & PAN support & pepsin powder \\
\hline & \multicolumn{4}{|c|}{ Elemental fraction (\%) } \\
\hline $\mathrm{Na} 1 \mathrm{~s}$ & 1.09 & 0.72 & & \\
\hline O1s & 17.49 & 15.24 & 1.52 & 20.53 \\
\hline N1s & 9.76 & 11.53 & 21.88 & 11.16 \\
\hline $\mathrm{C} 1 \mathrm{~s}$ & 70.6 & 70.56 & 76.6 & 66.82 \\
\hline $\mathrm{Cl} 2 \mathrm{p}$ & 0.49 & 0.69 & - & 0.37 \\
\hline $\mathrm{Si} 2 \mathrm{p}$ & 0.58 & 1.27 & - & 0.77 \\
\hline \multirow[t]{2}{*}{$\mathrm{P} 2 \mathrm{p}$} & - & - & - & 0.36 \\
\hline & \multicolumn{4}{|l|}{ Element ratio } \\
\hline $\mathrm{O} / \mathrm{N}$ & 1.79 & 1.32 & 0.07 & 1.84 \\
\hline $\mathrm{C} / \mathrm{N}$ & 7.23 & 6.12 & 3.50 & 5.99 \\
\hline $\mathrm{C} / \mathrm{O}$ & 4.04 & 4.63 & 50.39 & 3.25 \\
\hline
\end{tabular}


The oxygen/nitrogen/carbon elemental ratios give an indication of the change in composition upon reaction of the TMC with the pepsin. The higher carbon/oxygen of the TMC groups compared to the pepsin powder attributes to the increase in carbon/nitrogen and carbon/oxygen ratio. Surprisingly, the oxygen/nitrogen elemental ratio is lower for the pepsin membranes compared to the pristine membranes. This can be due to a difference in the pepsin hydration state before and after membrane preparation, giving rise to uncertainty in the oxygen content. The carbon/nitrogen elemental ratio was used to estimate the number of TMC groups. The number of reacted TMC groups per pepsin molecule was estimated to be 40 for the pepsin membrane prepared using $0.2 \mathrm{wt} . \%$ TMC in hexane. The high number of TMC groups per pepsin molecule substantiates the immobile character of the pepsin in the ultrathin membrane layer. The membranes prepared using $0.5 \mathrm{wt} . \% \mathrm{TMC}$ in hexane have an estimated 5 reacted TMC groups per pepsin. These results are counterintuitive, as one would expect a higher crosslinking degree for membranes prepared with the higher TMC concentrations. The discrepancy between degree of crosslinking and reactant crosslinking can be rationalized by the acidic nature of the TMC groups. Hydrogen chloride liberated upon contact of TMC with the aqueous solution lowers the $\mathrm{pH}$ at the reaction interface, lowering the pepsin reactivity and resulting in a lower degree of crosslinking of the pepsin. This stresses the importance of the reactant stoichiometry for the pepsin membrane properties, and is in line with observations on the importance of reactant ratios in conventional interfacial polymerization processes. The minor fractions of sodium and chloride in the pepsin membrane are attributed to the PBS buffer used to prepare the pepsin solution for interfacial polymerization. It is unlikely that any acid chloride groups have remained on partially unreacted TMC, as the chloride group is readily exchanged with an hydroxyl group upon contact with water.

Figure A7-2 shows the deconvoluted N1s spectra of the PAN support, pristine pepsin powder and PAN supported pepsin membranes prepared using 0.2 and $0.5 \mathrm{wt} . \% \mathrm{TMC}$ in hexane. The binding energy for nitrogen atoms shifts from $396.98 \mathrm{eV}$ for pristine pepsin to 399 and $401 \mathrm{eV}$ for film 1 and 400 and $401 \mathrm{eV}$ for film 2 respectively. The $397 \mathrm{eV}$ binding energy is typically found for amino acids. The $399-400 \mathrm{eV}$ is associated with the amide bond $(\mathrm{N}-\mathrm{C}=\mathrm{O})$. The $401 \mathrm{eV}$ is associated with $\mathrm{NH}-\mathrm{Cl}$, which can be formed from liberation of $\mathrm{HCl}$ upon crosslinking with $\mathrm{TMC} . \mathrm{H}^{+}$protonates the amino acids, and simultaneously forms a ionic bond with the $\mathrm{Cl}$. 


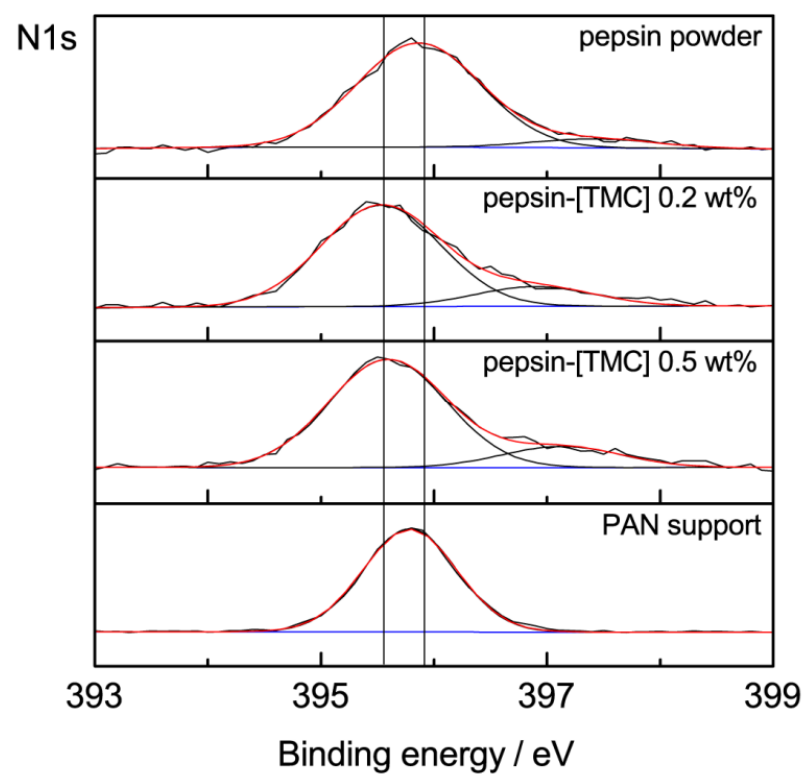

Figure A7-2. Deconvoluted N1s spectra of the PAN support, pristine pepsin powder and PAN supported pepsin membranes prepared using 0.2 and $0.5 \mathrm{wt} \%$ TMC in hexane. Both pepsin membranes were prepared using a reaction time of 15 min. The peaks were fitted using Gaussians with similar full width at half maximum (FWHM) values.

Table A7-2, A7-3 and A7-4 show the C1, N1s and O1s binding energy peak deconvolution areas for pepsin powder, PAN support and pepsin membranes prepared using 0.2 and $0.5 \mathrm{wt} \%$ TMC solutions. Minor shifts in the binding energy of the functional groups of the pepsin membranes with respect to pepsin are observed. This is likely related to the binding energy peak overlap that complicates the peak fitting procedure. 
Table A7-2. C1s binding energy peak deconvolution for pepsin powder, bare PAN support and pepsin membranes on PAN prepared using 0.2 and $0.5 \mathrm{wt} \%$ TMC solutions. The functional group associated with the binding energies are in accordance with literature values. ${ }^{21}$

\begin{tabular}{|c|c|c|c|c|c|c|c|}
\hline \multicolumn{8}{|c|}{$\mathrm{C} 1 \mathrm{~s}$ binding energy peak deconvolution } \\
\hline $\begin{array}{l}\text { Binding } \\
\text { energy }\end{array}$ & $\begin{array}{l}\text { pepsin } \\
\text { powder }\end{array}$ & $\begin{array}{l}\text { PAN } \\
\text { support }\end{array}$ & $\begin{array}{l}\text { Binding } \\
\text { energy }\end{array}$ & $\begin{array}{l}\text { Pepsin- } \\
\text { [TMC] } \\
0.2 \mathrm{wt}^{0} \%\end{array}$ & $\begin{array}{l}\text { Pepsin- } \\
{[\mathrm{TMC}]} \\
0.5 \mathrm{wt} \%\end{array}$ & \multicolumn{2}{|c|}{ Functional group } \\
\hline $\mathrm{eV}$ & \multicolumn{2}{|c|}{ peak surface area } & $\mathrm{eV}$ & \multicolumn{2}{|c|}{ peak surface area } & & \\
\hline 285.1 & 49.0 & - & 284.8 & 55.7 & 55.1 & $\mathrm{C} * \mathrm{C}$ & $\begin{array}{l}\text { saturated } \\
\text { hydrocarbon }\end{array}$ \\
\hline 286.0 & - & 32.4 & 286.0 & - & - & $\mathrm{C}^{*} \mathrm{C}-\mathrm{C} \equiv \mathrm{N}$ & $\begin{array}{l}\text { saturated } \\
\text { hydrocarbon }\end{array}$ \\
\hline 286.5 & 31.2 & - & 286.3 & 24.9 & 27.8 & $\mathrm{NH}_{2}$ & amine \\
\hline 287.1 & - & 67.6 & 287.1 & - & - & $\begin{array}{l}\mathrm{C}^{*} \mathrm{C} \equiv \mathrm{N} \\
\text { and } \mathrm{C} \equiv \mathrm{N}\end{array}$ & nitril \\
\hline 288.2 & 17.9 & - & 288.0 & 13.7 & 12.2 & $\mathrm{~N}-\mathrm{C}=\mathrm{O}$ & amide \\
\hline 289.5 & 2.0 & - & 289.1 & 5.7 & 5.0 & $\mathrm{COOH}$ & $\begin{array}{l}\text { carboxylic } \\
\text { acid }\end{array}$ \\
\hline
\end{tabular}

Table A7-3. N1s binding energy peak deconvolution for pepsin powder, PAN support and pepsin membranes on PAN prepared using 0.2 and 0.5 wt $\%$ TMC solutions. The functional group associated with the binding energies are in accordance with literature values. ${ }^{21}$

\begin{tabular}{|l|l|l|l|l|l|l|l|}
\hline \multicolumn{2}{|l}{ N1s binding energy peak deconvolution } \\
\hline $\begin{array}{l}\text { Binding } \\
\text { energy }\end{array}$ & $\begin{array}{l}\text { pepsin } \\
\text { powder }\end{array}$ & $\begin{array}{l}\text { PAN } \\
\text { support }\end{array}$ & $\begin{array}{l}\text { Binding } \\
\text { energy }\end{array}$ & $\begin{array}{l}\text { Pepsin-[TMC] } \\
0.2 \mathrm{wt} \%\end{array}$ & $\begin{array}{l}\text { Pepsin-[TMC] } \\
0.5 \mathrm{wt} \%\end{array}$ & Functional group \\
\hline $\mathrm{eV}$ & \multicolumn{2}{|l|}{ peak surface area } & $\mathrm{eV}$ & \multicolumn{2}{|l|}{ peak surface area } & \multicolumn{2}{l|}{} \\
\hline 527.5 & 50.9 & - & 527.0 & 36.9 & 35.9 & $\begin{array}{l}\mathrm{N}- \\
\mathrm{C}=\mathrm{O}\end{array}$ & amide \\
\hline 528.7 & 42.2 & - & 528.3 & 42.8 & 45.7 & $\mathrm{OH}$ & hydroxyl \\
\hline 529.7 & 6.9 & - & 528.9 & 20.3 & 18.4 & $\mathrm{C}=\mathrm{O}$ & carboxyl \\
\hline
\end{tabular}


Table A7-4. O1s binding energy peak deconvolution for pepsin powder, bare PAN support and pepsin membranes on PAN prepared using 0.2 and $0.5 \mathrm{wt}$ \% TMC solutions. The functional group associated with the binding energies are in accordance with literature values. ${ }^{21}$

\begin{tabular}{|l|l|l|l|l|l|l|l|}
\hline \multicolumn{2}{|l}{ N1s binding energy peak deconvolution } \\
\hline $\begin{array}{l}\text { Binding } \\
\text { energy }\end{array}$ & $\begin{array}{l}\text { pepsin } \\
\text { powder }\end{array}$ & $\begin{array}{l}\text { PAN } \\
\text { support }\end{array}$ & $\begin{array}{l}\text { Binding } \\
\text { energy }\end{array}$ & $\begin{array}{l}\text { Pepsin- } \\
{[\text { TMC }]} \\
0.2 \text { wt.\% }\end{array}$ & $\begin{array}{l}\text { Pepsin- } \\
{[\text { TMC }]} \\
0.5 \text { wt. } \%\end{array}$ & Functional group \\
\hline $\mathrm{eV}$ & peak surface area & $\mathrm{eV}$ & \multicolumn{2}{l|}{ peak surface area } & & amine \\
\hline 395.9 & 92.1 & - & 395.5 & 83.8 & 83.7 & $\mathrm{NH}_{2}$ & nitril \\
\hline 395.8 & - & 100 & 395.8 & - & - & $\mathrm{C} \equiv \mathrm{N}$ & amide \\
\hline 397.4 & 7.9 & - & 397.0 & 16.2 & 16.3 & $\mathrm{~N}-\mathrm{C}=\mathrm{O}$ & \\
\hline
\end{tabular}

\subsubsection{Assay digestion}

Assay digestion by the pepsin membranes on PAN and pepsin in solution were performed using hemoglobin (Horse, DWI Aachen, $36 \mathrm{kDa}, 1 \mathrm{~g} \mathrm{~L}^{-1}$ ) and bovine serum albumin (BSA, Sigma-Aldrich, fraction V, $66 \mathrm{kDa}, 1 \mathrm{~g} \mathrm{~L}^{-1}$ ). Control reactions were performed with pepsin in solution (Stock $5 \mathrm{~g} \mathrm{~L}^{-1}$, final conc. $0.3 \mathrm{~g} \mathrm{~L}^{-1}$ ) mixed with the solutions of hemoglobin and BSA respectively. All experiments were performed at $37^{\circ} \mathrm{C}$, in a pH 2 adjusted $0.2 \mathrm{M}$ buffer solution of sodium acetate ( $\mathrm{NaAc}$ trihydrate, Merck). Samples were taken at set sampling intervals. The sample volume was cooled to room temperature and the $\mathrm{pH}$ was raised to $\mathrm{pH} 7$ using sodium hydroxide $(0.1 \mathrm{M})$ to quench the digestive process. The composition of the digested assays was determined using gel permeation chromatography equipped with a Superose column (Superose 6 10/300 GL, GE Healthcare, USA). Multi angle laser light scattering (MALLS), ultraviolet light absorption (UV) and refractive index (RI) measurements were used to determine the molar mass distribution. The calibration curve for the Superose column was performed using $100 \mu \mathrm{L}$ injects of solutions of Vitamin B12 (13 $\left.\mathrm{mg} \mathrm{L}^{-1}\right)$, Insulin human $\left(9 \mathrm{mg} \mathrm{L}^{-1}\right)$, Ovalbumin C (8 mg L $\left.{ }^{-1}\right)$, Ribonuclease A (4 mg L $\left.{ }^{-1}\right)$, Myoglobin $\left(3 \mathrm{mg} \mathrm{L}^{-1}\right)$, Ovalbumin (6 $\left.\mathrm{mg} \mathrm{L}^{-1}\right)$, $\beta$-lactoglobulin $\left(14 \mathrm{mg} \mathrm{L}^{-1}\right)$, Covalbumin $\left(2 \mathrm{mg} \mathrm{L}^{-1}\right)$, Blue Dextran (12 $\left.\mathrm{mg} \mathrm{L}^{-1}\right)$. The $\mathrm{dn} / \mathrm{dc}$ values of BSA (0.1578), dextran (0.147) and casein $(0.1880)$ were used.

Digestion by pepsin in solution occurs by preferential cleavage of phenylalanine, tryptophan, leucine and tyrosine in position P1 or P1'. ${ }^{19}$ Cleavage is more specific at $\mathrm{pH} 1.3$, where pepsin preferentially cleaves at 
phenylalanine and leucine in position $\mathrm{P} 1$ with negligible cleavage for all other amino acids in this position. This specificity is lost at $\mathrm{pH}>2$. Figure A7-3 (left panel) shows the molar mass distribution of a $1 \mathrm{~g} \mathrm{~L}^{-1}$ hemoglobin solution ( $\mathrm{pH}$ 2, $\mathrm{HCl}$ adjusted) and pepsin at a temperature of $37{ }^{\circ} \mathrm{C}$ after $0,1,6,29$ hours. The initial molar mass distribution, represented by the dotted line at $\mathrm{t}=0$, is given by a single peak with a maximum at $50 \mathrm{kDa}$, corresponding to the hemoglobin. After $5 \mathrm{~min}$, a significant decrease in the hemoglobin peak is observed, while a second peak emerges at $29 \mathrm{kDa}$. The $\mathrm{M}_{\mathrm{w}}$ values are shifted to higher than hemoglobin in solution $(36 \mathrm{kDa})$, because of residual pepsin in the solution. Further evolution of the molar mass distribution in time shows a continued decrease of hemoglobin concentration and increase in digestion product concentration. Figure A7-3 (right panel) shows the hemoglobin digestion kinetics as function of time, derived from the peak maximum evolution as function of time.
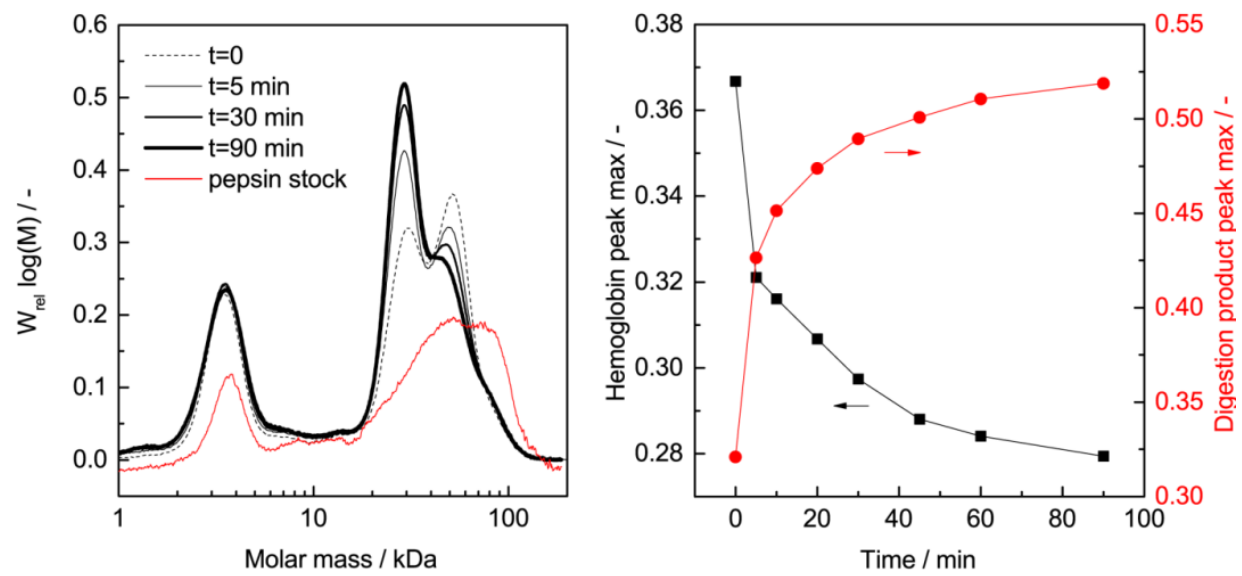

Figure A7-3. (left panel) Molar mass distribution of a $1 \mathrm{~g} \mathrm{~L}^{-1}$ hemoglobin solution (pH 2, $\mathrm{HCl}$ adjusted) and pepsin at a temperature of $37^{\circ} \mathrm{C}$ after $\mathrm{0}$, 5, 30, 90 min. (right panel) Hemoglobin digestion kinetics as function of time, derived from the peak maximum evolution as function of time. The hemoglobin peak evolution (c) and digestion product peak evolution (c) show pseudo-first order reaction kinetics.

The hemoglobin peak evolution (๘) and digestion product peak evolution (•) show pseudo-first order reaction kinetics. The increase in digestion product peak corresponds to the decrease in hemoglobin peak intensity, suggesting that hemoglobin is preferably cleaved at a single location. 
Figure A7-4 (left panel) shows the molar mass distribution of a $1 \mathrm{~g} \mathrm{~L}^{-1}$ BSA solution ( $\mathrm{pH} \mathrm{2,} \mathrm{HCl}$ adjusted) and pepsin at a temperature of $37{ }^{\circ} \mathrm{C}$ after 0,1 , 6, 29 hours. Membrane surface areas of the samples were; $2.6 \times 5.4 \mathrm{~cm}=$ $14.04 \mathrm{~cm}^{2}(\mathrm{BSA},[\mathrm{TMC}]=0.5 \mathrm{wt} \%) ; \mathrm{A}=2.8 \times 5.4 \mathrm{~cm}=15.12 \mathrm{~cm}^{2}$ (Hemoglobin, TMC 0.5wt\%); $2.3 \times 5.5 \mathrm{~cm}=12.65 \mathrm{~cm}^{2}($ BSA $[\mathrm{TMC}]=$ 0.2 wt. $\%$ ); $2.3 \times 5.5 \mathrm{~cm}=12.65 \mathrm{~cm}^{2}$ (Hemoglobin, $\left.[\mathrm{TMC}]=0.2 \mathrm{wt} . \%\right)$. The initial molar mass distribution, represented by the dotted line at $\mathrm{t}=0$, is given by a single peak with a maximum at $66 \mathrm{kDa}$, corresponding to the pristine BSA molar mass. After $5 \mathrm{~min}$, a significant decrease in the BSA peak can be observed, while a peak at $44 \mathrm{kDa}$ emerges. An additional broad peak with a maximum around $20 \mathrm{kDa}$ emerges. Further evolution of the molar mass distribution in time shows a continued decrease of BSA concentration and increase in digestion product concentration. Figure A7-4 (right panel) shows the BSA digestion kinetics as function of time, derived from the peak maximum evolution as function of time.
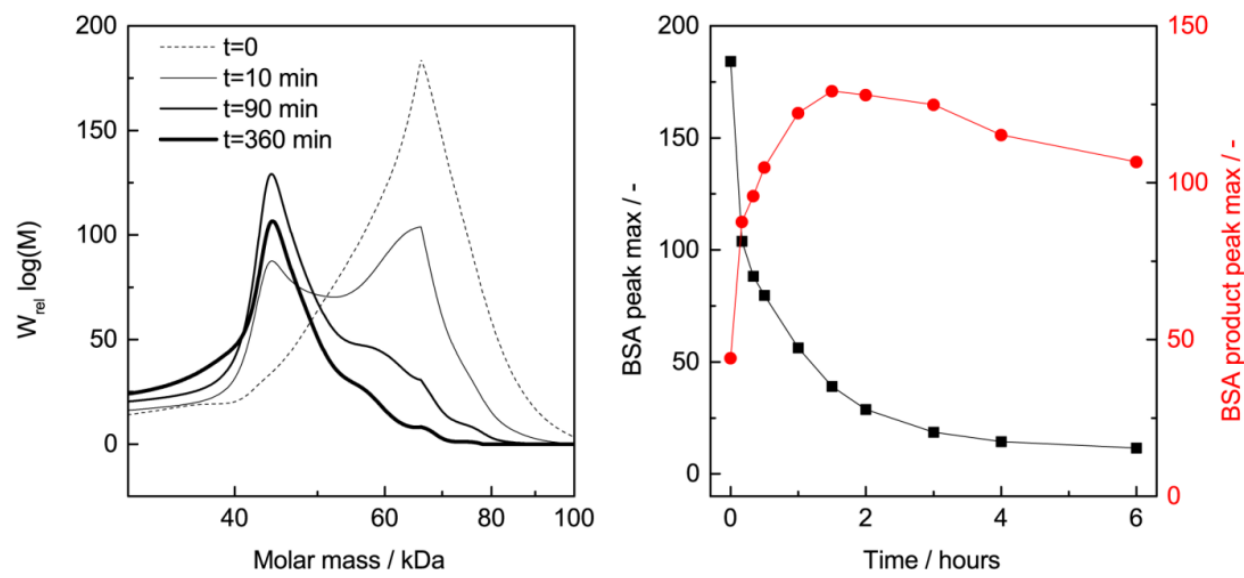

Figure A7-4. (left panel) Molar mass distribution of a $1 \mathrm{~g}$ L-1 hemoglobin solution (pH 2, $\mathrm{HCl}$ adjusted) and pepsin at a temperature of $37^{\circ} \mathrm{C}$ after $\mathrm{0}$, 1, 6, 29 hours. (right panel) Hemoglobin digestion kinetics as function of time, derived from the peak maximum evolution as function of time. The hemoglobin peak evolution (ש) and digestion product peak evolution (o) show pseudo-first order reaction kinetics.

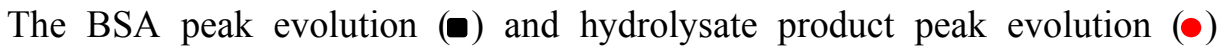
initially show pseudo-first order reaction kinetics. After long digestion times the $44 \mathrm{kDa}$ peak starts to decrease again, suggesting a number of cleavage routes are responsible for the digestion of BSA. The non-specific digestion of 
BSA at these conditions is in good agreement with the limited specificity of pepsin at $\mathrm{pH} 2$.

Figure A7-5 shows the molar mass distribution of a $1 \mathrm{~g} \mathrm{~L}^{-1}$ BSA solution ( $\mathrm{pH}$ 2, $\mathrm{HCl}$ adjusted) after $0,1,6$ and 29 hours contact with a pepsin membrane at a temperature of $37^{\circ} \mathrm{C}$.
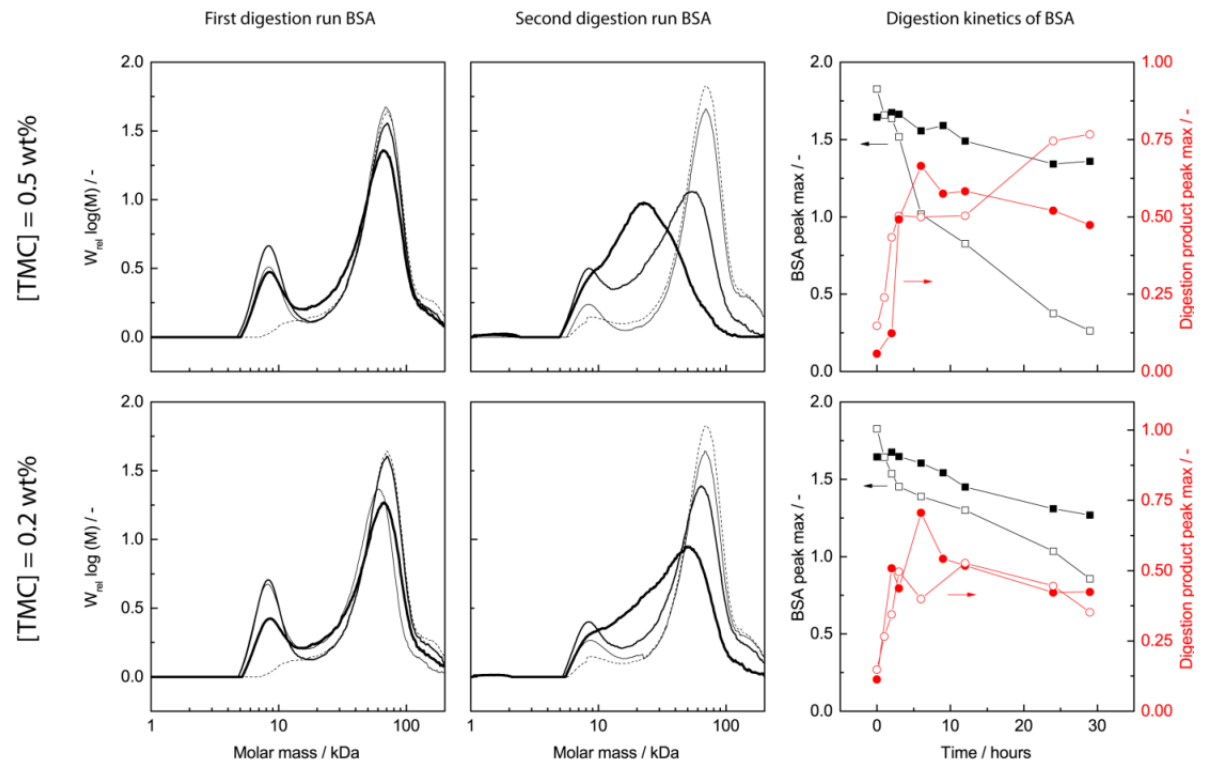

Figure A7-5. Molar mass distribution of a $1 \mathrm{~g} \mathrm{L-1} \mathrm{BSA} \mathrm{solution} \mathrm{(pH} \mathrm{2,} \mathrm{HCl}$ adjusted) after $0,1,6$ and 29 hours contact with a pepsin membrane at a temperature of $37{ }^{\circ} \mathrm{C}$. Two consecutive runs were performed with membranes prepared using 0.5 wt.\% TMC (top panels) and 0.2 wt.\% TMC (bottom panels) on PAN supports. The second runs (middle panels) were performed with the same membrane samples used in the first run (left panels), to see the extent of pepsin deactivation. (right panels) The BSA digestion kinetics derived from the peak maximum evolution as function of time. The first run (e) shows a more pronounced evolution of degradation product than the second run $(O)$. The hemoglobin peak evolution (a) on the other hand, shows a lower digestion rate for the first run than the second run $(\square)$.

Two consecutive runs were performed with membranes prepared using 0.2 wt.\% TMC (top panels) and $0.5 \mathrm{wt} . \%$ TMC (bottom panels) on PAN supports. The second runs (middle panels) were performed with the same membrane samples used in the first run (left panels), to see the extent of pepsin deactivation. The BSA digestion kinetics (right panels) are derived from the 
peak maximum evolution as function of time. The first run (๑) shows a more pronounced evolution of degradation product than the second run (O). The hemoglobin peak evolution (ש) on the other hand, displays a lower digestion rate for the first run compared to the second run ( $\square$ ).

Hemoglobin and BSA digestion by the pepsin membranes shows similar pseudo-first order digestion kinetics. However, the hemoglobin and BSA digestion product peaks shown in Figure 3 and Figure A7-5 do not show a corresponding increase in the digestion products. Visual observation of the membranes used for the assay digestion experiments revealed adsorption of digestion products. Figure A7-6 shows a PAN supported pepsin membrane after 29 hours of contact with hemoglobin in solution at a temperature of $37^{\circ} \mathrm{C}$ and $\mathrm{pH} 2$ ( $\mathrm{HCl}$ adjusted). The brown color originates from the hemoglobin digestion products that are adsorbed onto the membrane layer. The brownish colored layer could not be rinsed off with water. Energy-dispersive X-ray spectroscopy (EDX) analysis of the membranes showed the presence of iron atoms that originates from the hemoglobin and its digestion product, underlining the visual observations of Figure A7-6.

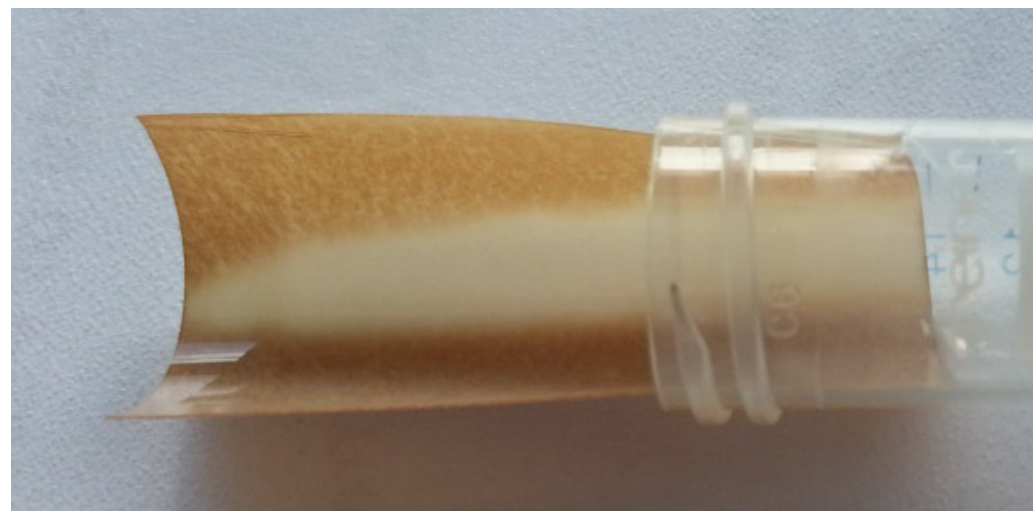

Figure A7-6. PAN supported pepsin membrane after 29 hours of contact with hemoglobin in solution at a temperature of $37^{\circ} \mathrm{C}$ and $\mathrm{pH} 2$ ( $\mathrm{HCl}$ adjusted). The brown color originates from the hemoglobin digestion products that are adsorbed into the membrane layer.

\subsubsection{Pepsin layer membrane performance}

Molecular weight cut-off (MWCO) measurements were evaluated using an aqueous solution of polyethylene glycols with mean molar masses of 2, 6, 8, 10,20 and $40 \mathrm{kDa}$ respectively (each fraction $1 \mathrm{~g} \mathrm{~L}^{-1}$ ). Gel permeation chromatography (GPC) was used for analysis of feed and permeate 
compositions. Figure A7-7 (left panel) shows the molar mass distribution of a PEG solution of 2, 6, 8, 10, 20 and $40 \mathrm{kDa}$. The higher molar mass PEG's have a higher molar mass than specified by the manufacturer. Figure A7-7 (right panel) shows the molar mass distribution of the feed, permeate and retentate samples taken after 15 min dead-end filtration with the PAN support using an aqueous PEG solution with a mean molar masses of 2-40 $\mathrm{kDa}$. There is no significant difference between the feed and permeate compositions, implicating that the PAN support has negligible PEG retention and a MWCO higher than $100 \mathrm{kDa}$.
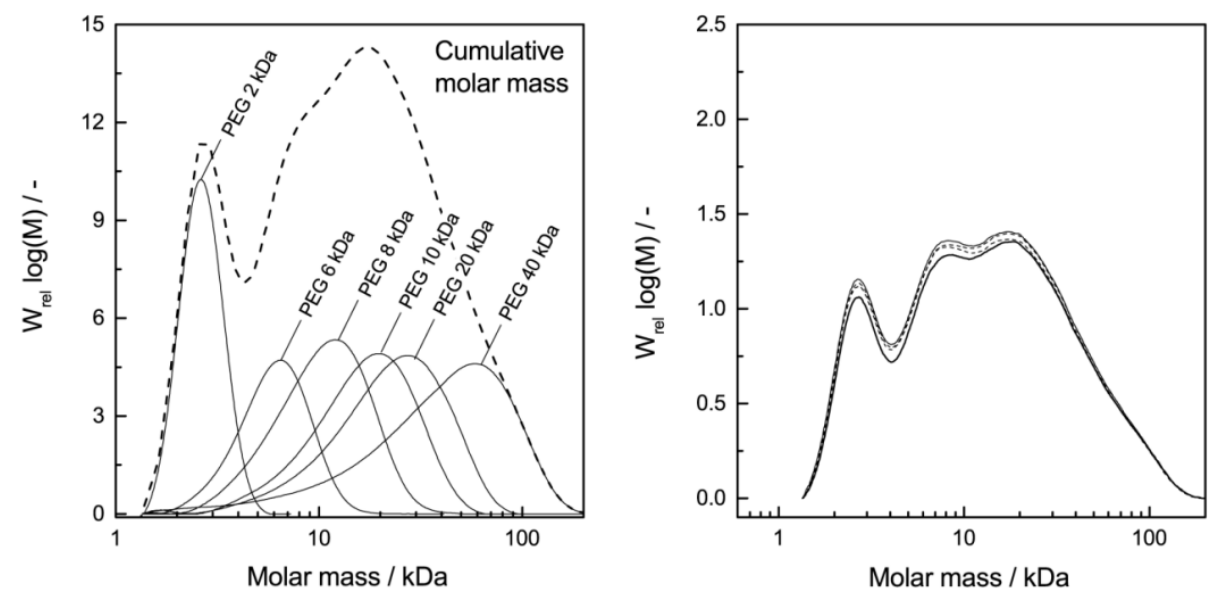

Figure A7-7. (left panel) Molar mass distribution of a PEG solution of 2, 6, 8, 10, 20 and $40 \mathrm{kDa}$. (right panel) Molar mass distribution of the feed and permeate samples taken after 15 min dead-end filtration with the PAN support using an aqueous PEG solution with a mean molar masses of 2-40 kDa.

The membrane dead-end permeation setup is shown in Figure A7-8. The feed solution is supplied to the stirred dead-end permeation cell by pressurizing a PEG solution in a feed tank using nitrogen back-pressure. 


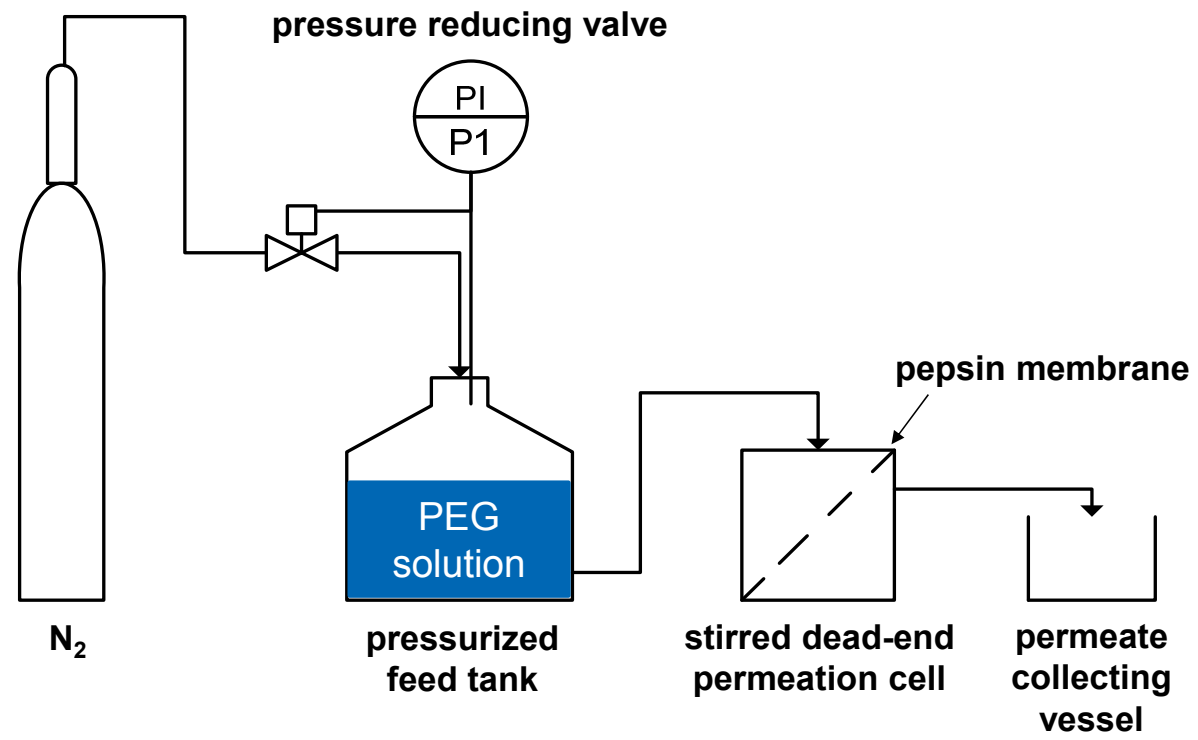

Figure A7-8. Schematic representation of the membrane dead-end permeation setup.

The permeated volume in the stirred dead-end permeation cell is replaced by the PEG solution from the feed tank. Because the PEG molecules are retained by the membrane, the concentration of PEG in the feed increases. The permeate collecting vessel, pressurized feed tank and stirred dead-end permeation cell are sampled for molar mass determination using GPC

\subsection{References}

1. Rao, M. B.; Tanksale, A. M.; Ghatge, M. S.; Deshpande, V. V. Microbiology and Molecular Biology Reviews 1998, 62, (3), 597-635

2. Qiao, Y.; Gumpertz, M.; Van Kempen, T. Journal of Food Biochemistry 2002, 26, (4), 355-375.10.1111/j.1745-4514.2002.tb00759.x

3. Chaitali, P. D.; Bahadur, A.; Shah, B. A. Cellulose Chemistry and Technology 1997, 31, (5-6), 315-320

4. Phadtare, S.; Vinod, V. P.; Wadgaonkar, P. P.; Rao, M.; Sastry, M. Langmuir 2004, 20, (9), 3717-3723

5. Shukla, S. P.; Devi, S. Journal of Applied Polymer Science 2005, 96, (5), 1544-1549

6. $\quad \mathrm{Hu}, \mathrm{J} . ; \mathrm{Li}, \mathrm{S}$.; Liu, B. Biotechnology Journal 2006, 1, (1), 75-79

7. Li, J.; Wang, J.; Gavalas, V. G.; Atwood, D. A.; Bachas, L. G. Nano Letters 2003, 3, (1), 55-58

8. Poojari, Y.; Palsule, A. S.; Clarson, S. J.; Gross, R. A. Silicon 2009, 1, (1), 37-45 
9. Broz, P.; Driamov, S.; Ziegler, J.; Ben-Maim, N.; Marsch, S.; Meier, W.; Hunziker, P. Nano Letters 2006, 6, (10), 2349-2353

10. Palivan, C. G.; Fischer-Onaca, O.; Delcea, M.; Itel, F.; Meier, W. Chemical Society Reviews 2012, 41, (7), 2800-2823.10.1039/C1CS15240H

11. Nardin, C.; Widmer, J.; Winterhalter, M.; Meier, W. European Physical Journal E 2001, 4, (4), 403-410

12. Tao, L.; Xu, J.; Gell, D.; Davis, T. P. Macromolecules 2010, 43, (8), 3721-3727

13. Phadtare, S.; Kumar, A.; Vinod, V. P.; Dash, C.; Palaskar, D. V.; Rao, M.; Shukla, P. G.; Sivaram, S.; Sastry, M. Chemistry of Materials 2003, 15, (10), 1944-1949

14. van Rijn, P.; Tutus, M.; Kathrein, C.; Mougin, N. C.; Park, H.; Hein, C.; Schürings, M. P.; Böker, A. Advanced Functional Materials 2014,

15. Peng, X.; Jin, J.; Ericsson, E. M.; Ichinose, I. Journal of the American Chemical Society 2007, 129, (27), 8625-8633

16. Peng, X.; Jin, J.; Nakamura, Y.; Ohno, T.; Ichinose, I. Nat Nano 2009, 4, (6), 353 357.http://www.nature.com/nnano/journal/v4/n6/suppinfo/nnano.2009.90_S1.html

17. Sharma, K. P.; Collins, A. M.; Perriman, A. W.; Mann, S. Advanced Materials 2013, 25, (14), 2005-2010.10.1002/adma.201204161

18. Zhao, J.; Zhang, Y.; Su, Y.; Liu, J.; Zhao, X.; Peng, J.; Jiang, Z. J. Membr. Sci. 2013, $445,1-7$

19. Keil, B., Specificity of proteolysis. Springer-Verlag Berlin-Heidelberg-NewYork: 1992; p 335.

20. Freger, V. Langmuir 2005, 21, (5), 1884-1894.10.1021/la048085v

21. Beamson, G.; Briggs, D., High Resolution XPS of Organic Polymers: The Scienta ESCA300 Database. John Wiley \& Sons: 1992. 


\section{Chapter 8 Fluorescent protein thin films via interfacial polymerization}

This chapter has been submitted for publication: Raaijmakers, M.J.T., Iyer, A., Subramaniam, V., Blum, C., Wessling, M., Benes, N.E., Fluorescent protein thin films by interfacial polymerization. 


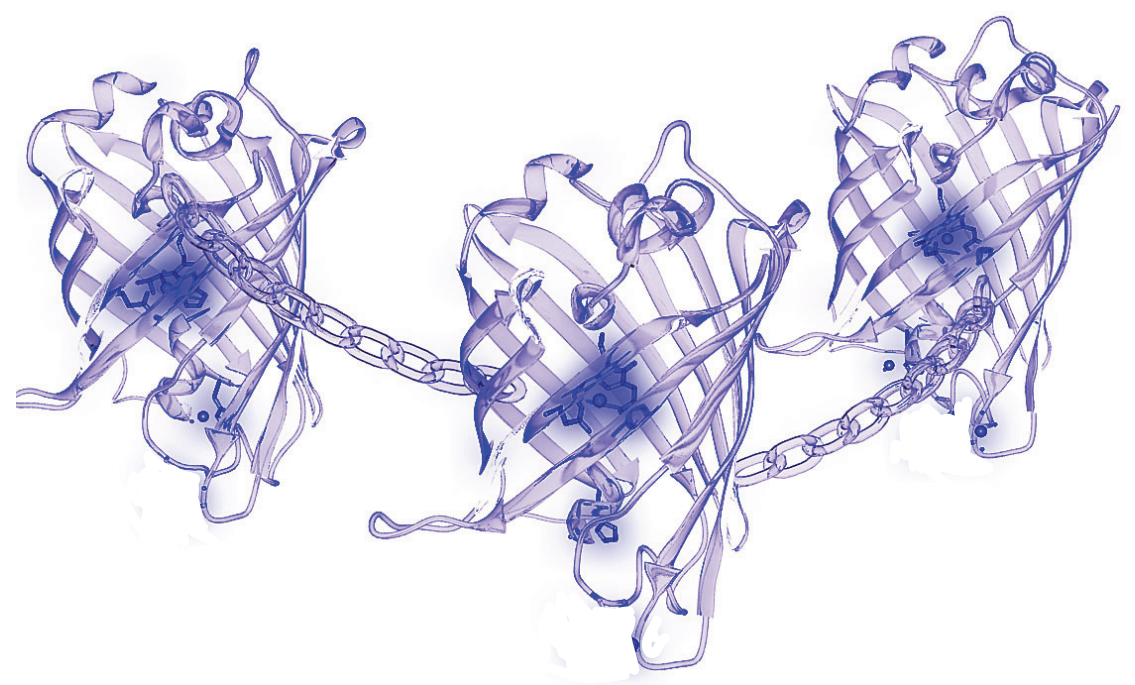

\begin{abstract}
We report the interfacial polymerization of proteins into a thin all-protein film with preservation of protein functionality. The intrinsic fluorescence of visible fluorescent proteins (VFPs) allows for visualization of their structural integrity upon cross-linking. The cross-linked fluorescent protein films made of EGFP and mRFP display a high degree of immobilization. The retention of significant fluorescence demonstrates that interfacial polymerization of proteins can be performed without major loss of the protein structural integrity. This proof that the protein tertiary structure is preserved during the film fabrication into all-protein films encourages the fabrication of new functional biomacromolecular thin films without the need for embedding of the protein into a protein-polymer conjugate.
\end{abstract}




\subsection{Introduction}

Hybrid assemblies of proteins permit design of interfaces with complex biological functionalities. ${ }^{1,2}$ Covalent immobilization of the proteins in a thin film is generally achieved by self-organization of the proteins at a suitable interface, followed by cross-linking using reagents such as glutaraldehyde. ${ }^{3}$ Examples include free-standing, highly water permeable, protein films by assembly of proteins on sacrificial cadmium hydroxide templates ${ }^{4}$ and freestanding fluorescent and enzymatic protein layers prepared via a partial charge-neutralization self-assembly mechanism. ${ }^{5}$ The protein functionalities are expressed by their biological activity, ${ }^{6}$ switchable properties as function of the surrounding medium ${ }^{7,8}$ and biocompatibility. ${ }^{9}$ The unique properties of these layers originate from the interplay between the protein functionality and their nanoscale assembly. Cross-linking the proteins into the integral films while maintaining protein functionality is however difficult: the immobilization is mainly based on conjugation of the proteins using blockcopolymers ${ }^{10,11}$ and Pickering emulsions. ${ }^{11,12}$ Both methods have limitations with respect to scalability towards the synthesis of thin films with large lateral dimensions. Moreover, typical cross-linking agents such as glutaraldehyde can affect protein function 5,13 and require accurate control of the process conditions for successful layer formation. ${ }^{3}$ Non-covalent strategies have been used to immobilize proteins without affecting their native conformation. Examples include the immobilization of EGFP by layer-by-layer assembly ${ }^{14}$ and nanoparticles ${ }^{15}$. Challenges of such non-covalent methods arise from limited binding capability of the protein structure to its surrounding, limiting the protein immobilization capability within the layer. ${ }^{14}$ Large-scale thin protein layer preparation, with preservation of the protein functionality upon immobilization, remains a major challenge. The techniques used for templating and cross-linking of proteins are relatively time-consuming and not easily scalable. These issues can potentially be overcome by using interfacial polymerization, a technique used for large-scale production of ultrathin films. The technique is based on the rapid polycondensation reaction that occurs at the interface of two immiscible liquids containing two reactive monomers. ${ }^{16}$ Commonly used monomers include diamines as aqueous phase reactant and acid chlorides in the organic phase. The reaction is used on large industrial scale to produce most of the desalination membranes. Recently, it was extended to more intricate reactions producing interfacially polymerized POSS-amides, POSS-imides and pepsin. ${ }^{17-20}$ Interfacial polymerization of 
proteins has also been demonstrated by polycondensation of bovine serum albumin ${ }^{8}$ and copolymerization of aquaporin with conventional m-phenyl diamine. ${ }^{21}$ However, it is unclear to what extent the protein structural integrity and functionality is influenced by the polymerization reaction. While pepsin maintained some of its enzymatic activity, the extent to which other proteins maintain their functionality is unknown. Here, we used the intrinsic fluorescence of visible fluorescent proteins (VFPs) to demonstrate the retention of structural integrity of the proteins upon cross-linking. VFPs possess a fluorophore that can absorb and emit light in a range of excitation and emission wavelengths. In VFPs the protein backbone forms a well-defined $\beta$-barrel structure around the fluorophores, whose structural integrity is essential for effective fluorescence emission. Denaturing the protein, resulting in destruction of the $\beta$-barrel structure, causes a loss of fluorescence. ${ }^{22,23}$ More subtle changes in the protein encapsulating the fluorophore result in changes in measurable photophysical properties (spectra, lifetimes) of the fluorophore. ${ }^{24-29}$ Single molecule experiments have shown that the fluorescence spectra of fluorescent proteins sensitively depend on the exact nature of the nanoenvironment of the fluorophore formed by the protein backbone. ${ }^{30,31}$ The intrinsic fluorescence of VFPs has thus been used as a convenient reporter of the structural integrity of the proteins. ${ }^{32}$ When confronted with denaturation or extensive conformational change the fluorophore activity will change or vanish, and is therefore an excellent check for the effect of cross-linking on protein function.

\subsection{Experimental section}

Film formation was accomplished by interfacial condensation of solutions of the VFPs enhanced green fluorescent protein (EGFP) and monomeric red fluorescent protein (mRFP) in water with and a trimesoyl chloride (TMC) solution in hexane. Hexane (anhydrous $99.8 \%$, Sigma-Aldrich) and 1,3,5-Benzenetricarboxylic acid chloride (TMC, Sigma-Aldrich) were used as received. EGFP and mRFP were recombinantly produced and purified according to standard protocols.

The TMC was stored and added to hexane in nitrogen atmosphere to prevent any hydrolysis of the acid chloride by moist from the air. Free-standing films were prepared by adding $10 \mathrm{~mL}$ of TMC solution in hexane $(0.05 \mathrm{wt} . \%)$ to $10 \mathrm{~mL}$ aqueous protein solution ( $0.087 \mathrm{wt} . \%$, Tris buffered). The thin films had sufficient mechanical strength to be transferred to a cuvette for fluorescence microscopy analysis. Figure 8-1 shows the reaction scheme of 
TMC and EGFP. Network formation at the interface of two immiscible solvents containing the monomer reactants occurs via a polycondensation reaction.

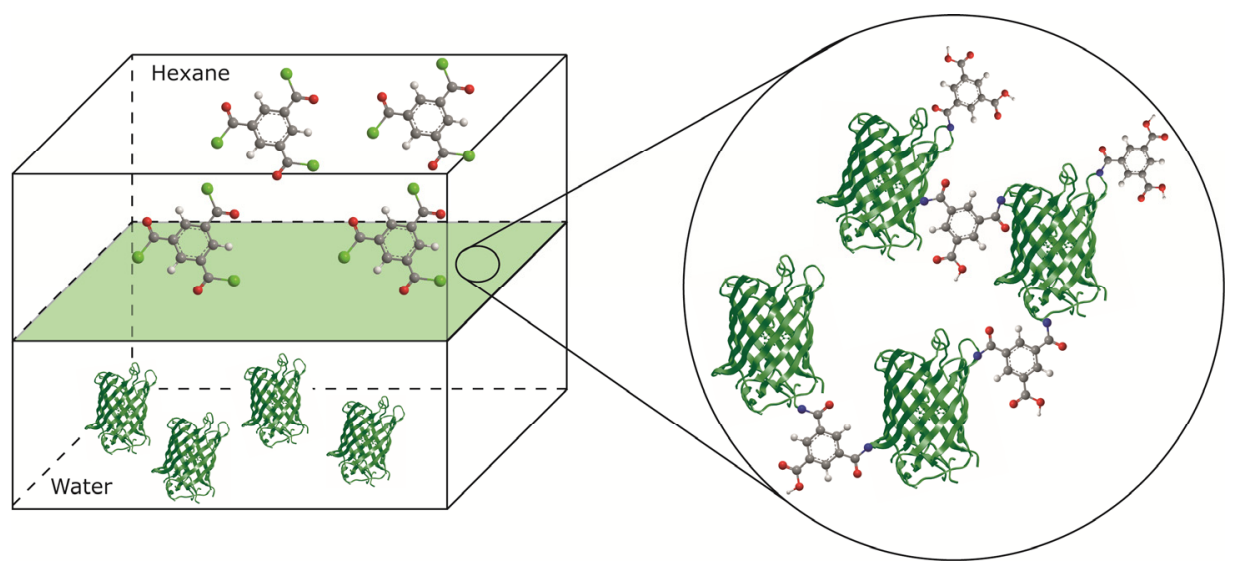

Figure 8-1. Reaction scheme of the interfacial polymerization reaction between EGFP and TMC.

The amine groups of the $\alpha$-amino acids of the two fluorescent proteins, EGFP and $\mathrm{mRFP}$, are prone to react with trimesoyl chloride (TMC)..$^{33}$ The abundance of amino acid residues enables high degree of cross-linking, fixating the proteins as a thin film. The TMC can react with one or more proteins, forming a covalent bridge that provides mechanical stability to the film. The films are sufficiently strong to be transferred from the interface to a silicon wafer or a second aqueous phase.

\subsubsection{Fluorescence Recovery After Photobleaching}

Fluorescence recovery after photobleaching (FRAP) was used to determine the diffusion coefficient within the thin film to gauge the cross linking efficiency. FRAP was performed with a Nikon A1 confocal microscope equipped with a Perfect Focus System. A 100-mW Argon ion laser (488 nm, Coherent, CA) was used to both bleach and monitor the protein fluorescence. In the FRAP experiment fluorescence from a circular region of interest (ROI) was bleached and the increase in fluorescence intensity in the ROI was monitored. Prior to the FRAP experiments the EGFP film was rinsed with Milli-Q water to remove any unreacted protein. During the experiment there was only a minimal drop in the fluorescence intensity in the reference ROI. All FRAP data were fitted using the Soumpasis fit which has been shown to better model 
membrane/protein diffusivity than a single exponential fit. ${ }^{34}$ This provides the diffusion coefficients and mobile fractions of the probed entity.

\subsubsection{Excitation and emission}

The excitation and emission spectra were measured using a FluoroMax-4 spectrofluorometer (Horiba Jobin Yvon) equipped with a $150 \mathrm{~W}$ xenon arc lamp as excitation source. The obtained spectra were analyzed using DAS6 software from Horiba Jobin Yvon. The emission and excitation spectra were recorded for EGFP and $\mathrm{mRFP}$ in solution and the interfacial polymerization layer that was cross-linked with TMC. The excitation spectra of EGFP and mRFP were measured by recording the emitted intensity at $510 \mathrm{~nm}$ and $610 \mathrm{~nm}$, respectively. The emission spectra of EGFP and mRFP were measured by excitation at $475 \mathrm{~nm}$ and $560 \mathrm{~nm}$, respectively.

\subsubsection{Lifetime spectroscopy}

Fluorescence decays of EGFP and mRFP were recorded by using a custom-built single-photon counting setup. Excitation of EGFP and mRFP by a pulsed laser was done at $475 \mathrm{~nm}$ and $560 \mathrm{~nm}$, respectively. ${ }^{35}$

\subsection{Results and discussion}

\subsubsection{Fluorescence recovery after photobleaching}

Upon cross-linking, the fluorescent molecules are immobilized by the covalent bonds between the proteins. The visual appearances of the protein films are light green and red for EGFP and mRFP, respectively. Figure 8-2 (left panel) shows the confocal microscopy image of the photobleached circular spot, the non-bleached fluorescent thin film and the background signal as reference. The brighter fluorescent spots in the thin protein layer are likely a result of thickness non-uniformity in the film. The thickness non-uniformity is also observed for conventional interfacial polymerization membranes. ${ }^{16,} 36$ Moreover, the propensity of proteins to lower the surface tension can increase the solubility of reactants in either phase. ${ }^{37}$ The reactant solubility and interface are known to influence layer morphology. ${ }^{38}$ Figure 8-2 (right panel) shows emitted light intensity from a photobleached spot before and after photobleaching and from a reference spot that was not photobleached. The bleached sample displays an exceedingly slow recovery of fluorescence as a function of time, confirming that the degree of cross-linking between the proteins almost completely immobilizes the proteins. The intensity of a non-bleached sample is added as reference to determine the photobleaching 
during measuring. When the intensity data is fitted using a Soumpasis fit model ${ }^{39}$ averaged over 4 measurements, an estimated immobile fraction of $78 \%$ is obtained. The mobile fraction has a with a diffusion value of $10 \mu \mathrm{m}^{2} \mathrm{~s}^{-1}$, which is higher than those found for the lateral diffusion of membrane proteins in lipids ${ }^{40}$, but much lower as compared to proteins in solution. ${ }^{41}$ This could be indicative of a small fraction of fluorescent proteins that are entrapped in the layer, while being only minimally cross-linked. The low level of recovery allowed for photobleaching of the logos of the MESA and MIRA institute. The confocal microscopy image demonstrates that even over a long time span of several hours there was only little observable recovery, indicating that the remaining active proteins cannot diffuse back due to their permanent immobilization in the protein network.
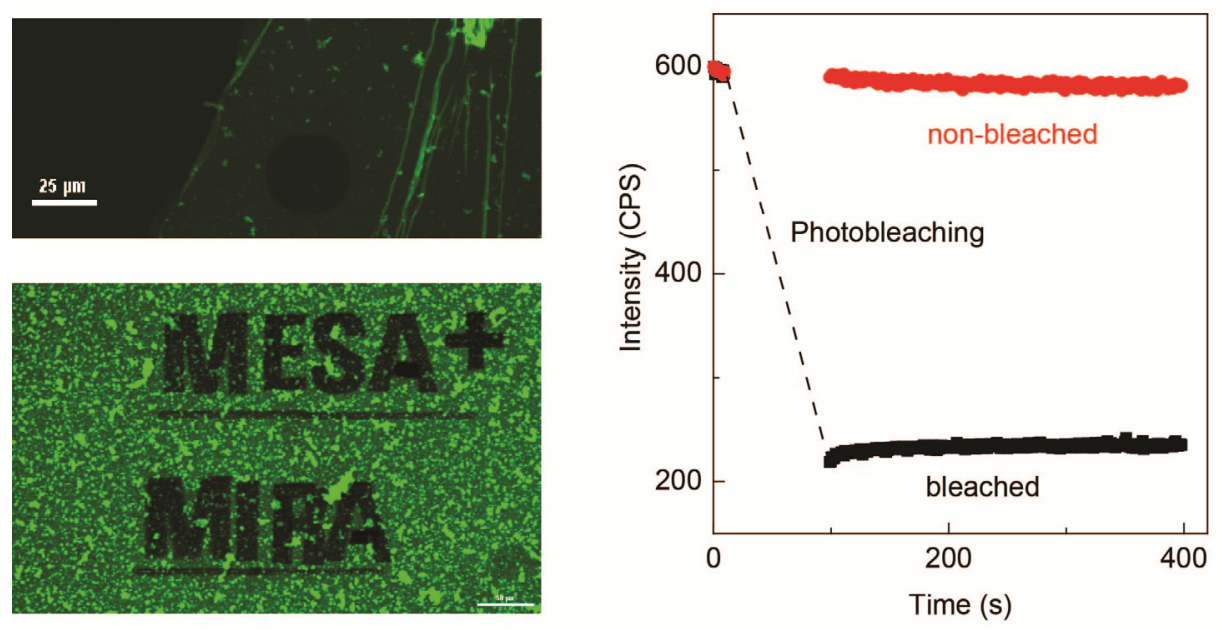

Figure 8-2. (left panel) Confocal microscopy image of a photobleached circular spot and logos of the $\mathrm{MESA}^{+}$Institute for Nanotechnology and MIRA Institute for Biomedical Technology and Technical Medicine. (right panel) Emitted light intensity as function of time before and after photobleaching of a $40 \mu^{2}$ diameter spot.

\subsubsection{Fluorescence spectroscopy; excitation and emission}

Excitation and emission spectra of TMC cross-linked EGFP and mRFP were taken to determine changes in the nature of the proteins' fluorescence. Changes in the fluorophores or the fluorophores nanoenvironment are known to result in substantial spectral shifts in the excitation and emission maxima. For mRFP, changes in the excitation at lower wavelengths with respect to the excitation maximum can be observed. Figure 8-3 shows the spectra of EGFP 
(left panel) and mRFP (right panel) in solution and after cross-linking. The excitation and emission peaks of EGFP and mRFP in solution are in good agreement with literature. ${ }^{42}$ Upon cross-linking, the excitation peak of EGFP remains at $489 \mathrm{~nm}$ and emission peak remain at $508 \mathrm{~nm}$, underlining that structural integrity of the VFP is not compromised. This is in contrast with changes in the excitation spectrum upon glutaraldehyde cross-linking, manifested by a partial conversion of the permanently ionized fluorophore of EGFP to a neutral ionization state. ${ }^{5}$ Small shifts in the excitation and emission maxima have been shown to be related to changes in the surroundings of the protein ${ }^{31,43}$ Cross-linking clearly changes the protein's environment compared to solution conditions, and we attribute small changes in the spectral maximum positions to the change induced in the environment of the protein and the fluorophore. Similar to EGFP, the excitation peak of mRFP at $580 \mathrm{~nm}$ and emission peak at $604 \mathrm{~nm}$ remain essentially unchanged after cross-linking. At lower wavelengths, mRFP shows an evident change in the shape of the excitation curve, which might be related to increased exposure of the fluorophore to a more polar environment ${ }^{43,44}$. The observed spectral changes indicate that some of the proteins undergo (partial) denaturation upon crosslinking.
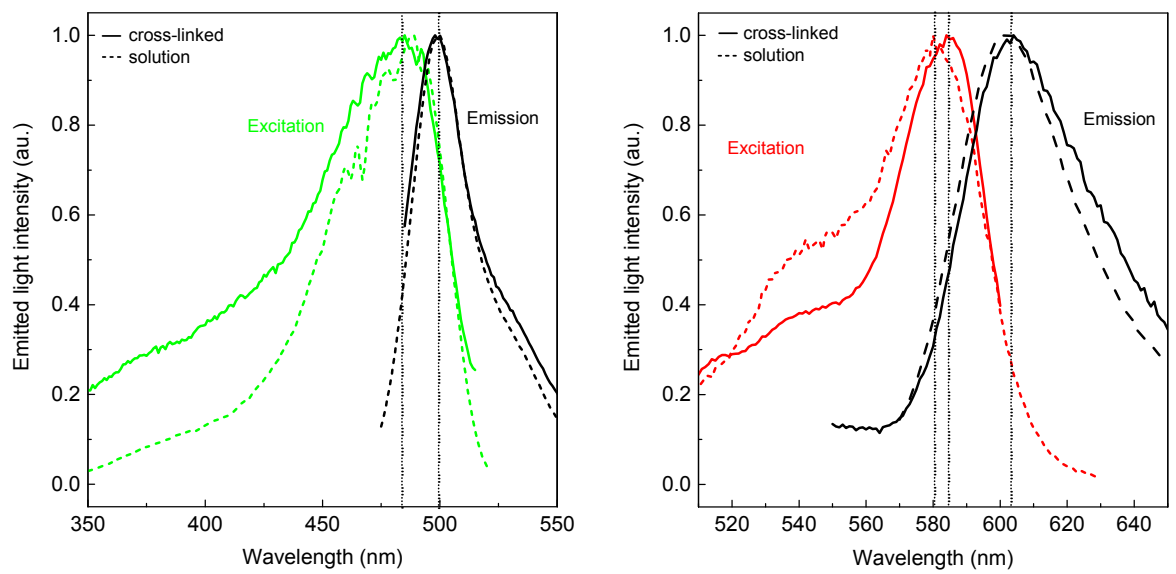

Figure 8-3. Normalized excitation and emission spectra of an EGFP solution and free floating EGFP (left panel) and mRFP (right panel) layers cross-linked with TMC. 


\subsubsection{Fluorescence lifetime spectroscopy}

Fluorescence lifetime spectroscopy was used to probe subtle changes in the protein encapsulating the fluorophore. Figure 8-4 (left panel) shows the fluorescence decay of EGFP in solution and of a free-floating EGFP cross-linked layer.
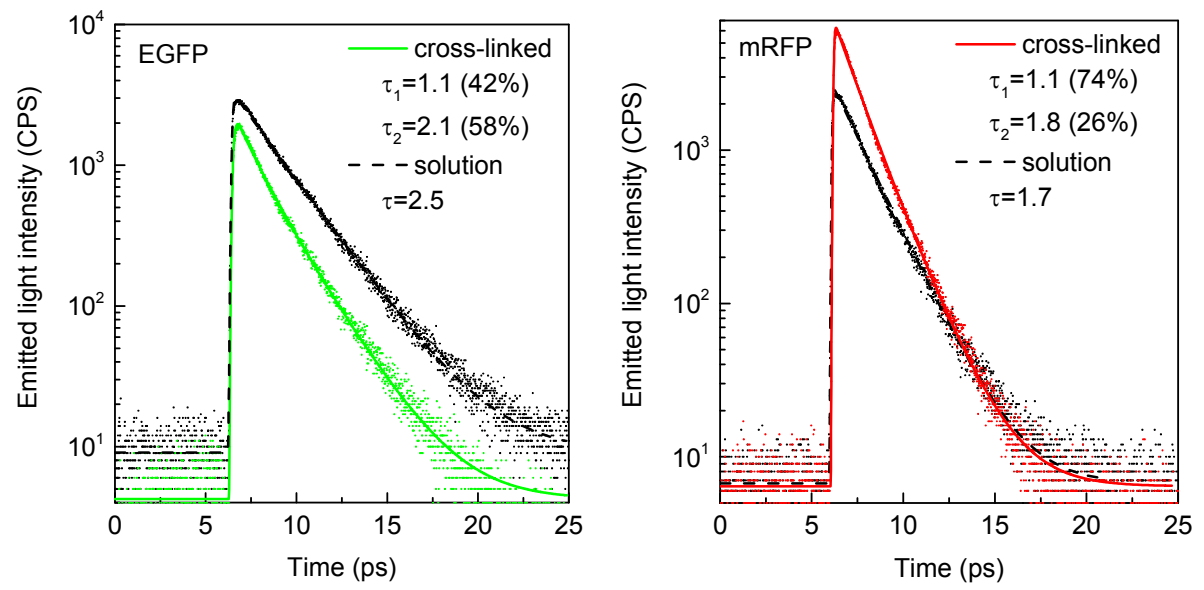

Figure 8-4. Lifetime spectra of an EGFP (left panel) and mRFP (right panel) in solution and cross-linked with TMC.

The intensity loss as function of time, represented by the slope of the fitted emission data, is a measure of the fluorophore lifetime. The lifetime for the EGFP solution is $2.5 \mathrm{~ns}$, which is in accordance with literature values. ${ }^{45}$ After cross-linking with TMC, we observe a decrease in fluorescence lifetime. To determine whether the heterogeneous population of cross-linked EGFP results in a number of in a number of different decay rates, we systematically fitted the data with single and multi-exponential decays. The lifetime data from the cross-linked EGFP could not be fitted using a single exponential decay. Fitting with a double exponential function gave lifetimes of $2.1 \mathrm{~ns}$ and $1.1 \mathrm{~ns}$. The TMC cross-linked mRFP layers display a similar decrease in fluorophore lifetime, as shown in Figure 8-4 (right panel). We find a double exponential decay with lifetimes of 1.1 and 1.8 nanoseconds for the TMC cross-linked mRFP, and a single exponential decay with lifetime of 1.7 nanoseconds for mRFP in solution. Fitting a third component did not increase the quality of the fit. However, it should be noted that especially the fast component is unlikely to arise from a uniform emitting species, but from a distribution of species of short lifetime. 
For both proteins the slow decay component agrees well with the lifetime measured from uncross-linked proteins in solution. The lifetime data thus suggests that the bulk of these proteins is not affected by the cross-linking, and that the structural integrity of these proteins is largely conserved. However, the appearance of a fast decaying component upon cross-linking shows that a fraction of the proteins is affected by the cross-linking and formation of the membrane. We see two possible mechanisms for the appearance of the fast decaying component. First, cross-linking could lead to subtle changes in the chromophore environment. Previous single molecule studies have shown that the emission properties sensitively depend on the nanoenvironment, that is, on the embedding of the fluorophore in the protein barrel. Although fluorescent proteins are known to be very stable, cross-linking might result in stress on the protein barrel that changes the flexibility and chemical environment of the chromophore, leading to the faster non-radiative decay of the fluorophore. Second, the fast decay observed might be related to the formation of quenched, dark fluorophores in the membrane. Denaturation of the fluorescent proteins results in these fully quenched, absorbing, but not emitting fluorophores. The close proximity of the concentrated fluorescent protein network allows for transfer of energy from the excited fluorophores to the dark fluorophores, resulting in the observed short decay component. In practice, both mechanisms are likely to play a role.

\subsection{Conclusions}

Interfacial polymerization can be used to produce ultrathin protein films without destroying or significantly diminishing the fluorescence of the fluorescent proteins immobilized in the protein network. The fluorescence recovery after photobleaching shows that there is a high degree of crosslinking between the proteins, restricting mobility of proteins within the layer. Fluorophore activity remains, although a fraction of the VFPs in the layer can be dark fluorophores as a result of partial denaturation. The presented method can potentially be extended for fabrication of new functional biomacromolecular thin films without the use of protein conjugates.

\subsection{References}

1. Tangirala, R.; Hu, Y.; Joralemon, M.; Zhang, Q.; He, J.; Russell, T. P.; Emrick, T. Soft Matter 2009, 5, (5), 1048-1054

2. Presley, A. D.; Chang, J. J.; Xu, T. Soft Matter 2011, 7, (1), 172-179 
3. Migneault, I.; Dartiguenave, C.; Bertrand, M. J.; Waldron, K. C. BioTechniques 2004, 37, (5), 790-802

4. $\quad$ Peng, X.; Jin, J.; Nakamura, Y.; Ohno, T.; Ichinose, I. Nat Nano 2009, 4, (6), 353-357

5. Sharma, K. P.; Collins, A. M.; Perriman, A. W.; Mann, S. Advanced Materials 2013, 25, (14), 2005-2010

6. Peng, X.; Jin, J.; Ericsson, E. M.; Ichinose, I. Journal of the American Chemical Society 2007, 129, (27), 8625-8633

7. Huang, H.; Yu, Q.; Peng, X.; Ye, Z. Journal of Materials Chemistry 2011, 21, (35), 13172-13179

8. Zhao, J.; Zhang, Y.; Su, Y.; Liu, J.; Zhao, X.; Peng, J.; Jiang, Z. Journal of Membrane Science 2013, 445, 1-7

9. Vaz, C. M.; Fossen, M.; Van Tuil, R. F.; De Graaf, L. A.; Reis, R. L.; Cunha, A. M. Journal of Biomedical Materials Research - Part A 2003, 65, (1), 60-70

10. Lin, Y.; Böker, A.; He, J.; Sill, K.; Xiang, H.; Abetz, C.; Li, X.; Wang, J.; Emrick, T.; Long, S.; Wang, Q.; Balazs, A.; Russell, T. P. Nature 2005, 434, (7029), 55-59

11. Jutz, G.; Böker, A. Journal of Materials Chemistry 2010, 20, (21), 4299-4304

12. Russell, J. T.; Lin, Y.; Böker, A.; Su, L.; Carl, P.; Zettl, H.; He, J.; Sill, K.; Tangirala, R.; Emrick, T.; Littrell, K.; Thiyagarajan, P.; Cookson, D.; Fery, A.; Wang, Q.; Russell, T. P. Angewandte Chemie - International Edition 2005, 44, (16), 2420-2426

13. Chui, W. K.; Wan, L. S. C. Journal of Microencapsulation 1997, 14, (1), 51-61

14. Kozlovskaya, V.; Ankner, J. F.; O'Neill, H.; Zhang, Q.; Kharlampieva, E. Soft Matter 2011, 7, (24), 11453-11463

15. Fuenzalida, J. P.; Weikert, T.; Hoffmann, S.; Vila-Sanjurjo, C.; Moerschbacher, B. M.; Goycoolea, F. M.; Kolkenbrock, S. Biomacromolecules 2014, 15, (7), 2532-2539

16. $\quad$ Freger, V. Langmuir 2003, 19, (11), 4791-4797

17. Dalwani, M.; Zheng, J.; Hempenius, M.; Raaijmakers, M. J. T.; Doherty, C. M.; Hill, A. J.; Wessling, M.; Benes, N. E. Journal of Materials Chemistry 2012, 22, (30), $14835-14838$

18. Raaijmakers, M. J. T.; Hempenius, M. A.; Schön, P. M.; Vancso, G. J.; Nijmeijer, A.; Wessling, M.; Benes, N. E. Journal of the American Chemical Society 2014, 136, (1), 330-335

19. Raaijmakers, M. J. T.; Wessling, M.; Nijmeijer, A.; Benes, N. E. Chemistry of Materials 2014, 26, (12), 3660-3664

20. Raaijmakers, M. J. T.; Benes, N. E. Submitted 2015,

21. Zhao, Y.; Qiu, C.; Li, X.; Vararattanavech, A.; Shen, W.; Torres, J.; Hélix-Nielsen, C.; Wang, R.; Hu, X.; Fane, A. G.; Tang, C. Y. Journal of Membrane Science 2012, 423424, 422-428

22. Ward, W. W.; Bokman, S. H. Biochemistry 1982, 21, (19), 4535-4540

23. Tsien, R. Y. Annual Review of Biochemistry 1998, 67, (1), 509-544

24. Vrzheshch, P. V.; Akovbian, N. A.; Varfolomeyev, S. D.; Verkhusha, V. V. FEBS Letters 2000, 487, (2), 203-208

25. Enoki, S.; Saeki, K.; Maki, K.; Kuwajima, K. Biochemistry 2004, 43, (44), 1423814248

26. Khan, F.; Kuprov, I.; Craggs, T. D.; Hore, P. J.; Jackson, S. E. Journal of the American Chemical Society 2006, 128, (33), 10729-10737 
27. Wielgus-Kutrowska, B.; Narczyk, M.; Buszko, A.; Bzowska, A.; Clark, P. L. Journal of Physics Condensed Matter 2007, 19, (28),

28. Huang, J. r.; Danny Hsu, S. T.; Christodoulou, J.; Jackson, S. E. HFSP Journal 2008, 2, (6), 378-387

29. Xie, J. B.; Zhou, J. M. Biochemistry 2008, 47, (1), 348-357

30. Blum, C.; Meixner, A. J.; Subramaniam, V. Journal of the American Chemical Society 2006, 128, (26), 8664-8670

31. Schleifenbaum, F.; Blum, C.; Subramaniam, V.; Meixner, A. J. Molecular Physics 2009, 107, (18), 1923-1942

32. Fabié, L.; Agostini, P.; Stopel, M.; Blum, C.; Lassagne, B.; Subramaniam, V.; Ondarçuhu, T. Nanoscale 2015, 7, (10), 4497-4504

33. Habeeb, A. F. S. A.; Hiramoto, R. Archives of Biochemistry and Biophysics 1968, $126,(1), 16-26$

34. Seu, K. J.; Cambrea, L. R.; Everly, R. M.; Hovis, J. S. Biophysical Journal 2006, 91, (10), 3727-3735

35. Blum, C.; Cesa, Y.; Escalante, M.; Subramaniam, V., Multimode microscopy: spectral and lifetime imaging. 2009; Vol. 6, p S35-S43.

36. Pacheco, F. A.; Pinnau, I.; Reinhard, M.; Leckie, J. O. Journal of Membrane Science 2010, 358, (1-2), 51-59

37. Beverung, C. J.; Radke, C. J.; Blanch, H. W. Biophysical Chemistry 1999, 81, (1), 5980

38. Zhang, Y.; Benes, N.; Lammertink, R. Lab on a Chip 2014,

39. Soumpasis, D. M. Biophysical Journal 1983, 41, (1), 95-97

40. Ramadurai, S.; Holt, A.; Krasnikov, V.; van den Bogaart, G.; Killian, J. A.; Poolman, B. Journal of the American Chemical Society 2009, 131, (35), 12650-12656

41. Petrášek, Z.; Schwille, P. Biophysical Journal 2008, 94, (4), 1437-1448

42. Shaner, N. C.; Steinbach, P. A.; Tsien, R. Y. Nature Methods 2005, 2, (12), 905-909

43. Abbyad, P.; Childs, W.; Shi, X.; Boxer, S. G. Proceedings of the National Academy of Sciences 2007, 104, (51), 20189-20194

44. Dong, J.; Solntsev, K. M.; Tolbert, L. M. Journal of the American Chemical Society 2006, 128, (37), 12038-12039

45. Jakobs, S.; Subramaniam, V.; Schönle, A.; Jovin, T. M.; Hell, S. W. FEBS Letters 2000, 479, (3), 131-135 
Chapter 9

Reflections \& Perspectives 


\subsection{Introduction}

This thesis deals with the design and characterization of novel hybrid (membrane) materials via interfacial polymerization. This chapter reflects on the general structure-property relationships of hybrid materials. In addition, it provides perspectives for future research on membrane material design and the structure-property-performance of hyper-cross-linked, hybrid network materials.

\subsection{Reflections}

\subsubsection{Reflections on hyper-cross-linked, hybrid materials}

Here, two types of hybrid materials have been studied: hybrid inorganic-organic network polymers and biological hybrids. Although the structure-properties of these two types of materials are dissimilar, the material concepts are complementary: ultrathin films that consist of hyper-cross-linked networks of two alternating moieties with a distinct functionality. The concept is easily extended towards other new materials, as is illustrated by Figure 9-1.

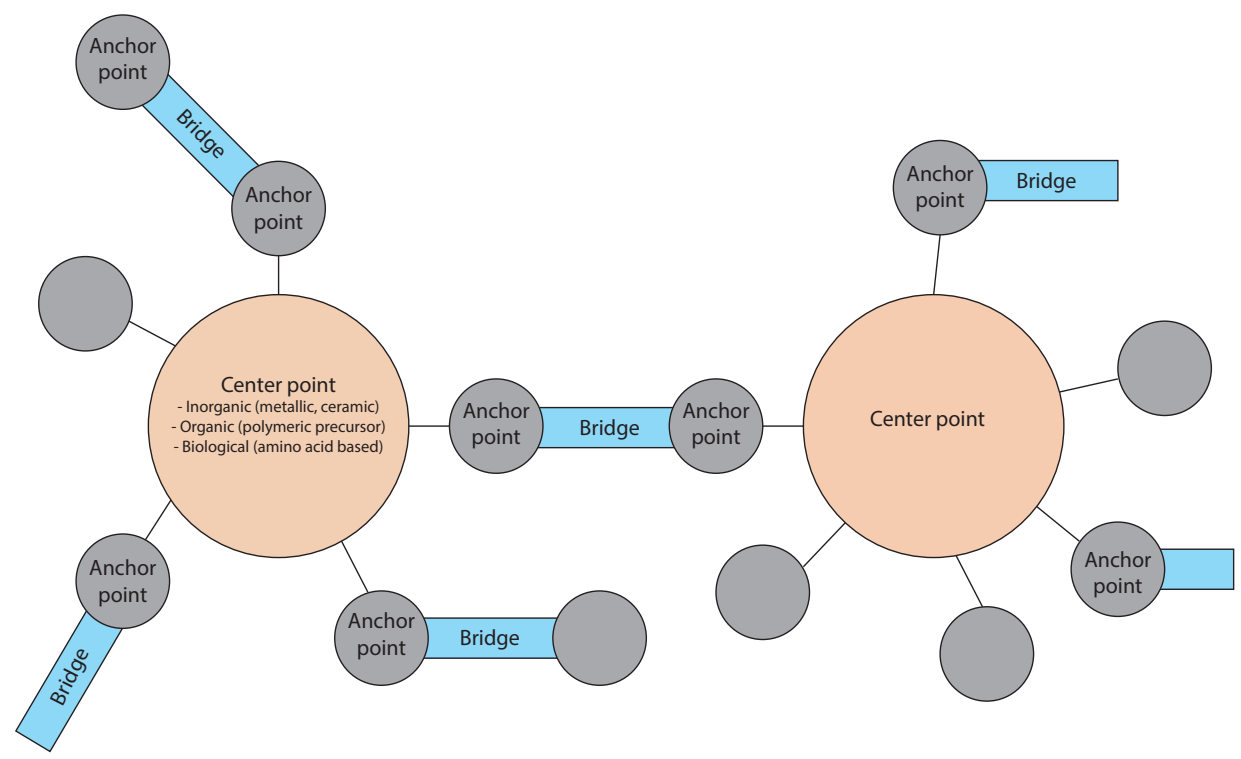

Figure 9-1. Conceptual structure of a hyper-cross-linked, hybrid material. The type of center point, anchor point and bridge moieties can be an inorganic, organic or biological group.

The center point of a hyper-cross-linked material is either an inorganic, organic or biological moiety with a multi-functionality that allows for covalent 
bond formation. This includes precursors such as polyhedral oligomeric silsesquioxanes, oligomers such as polyethyleneimine, and proteins. The center points are connected by a bridging moiety via an anchor point, that again have either an inorganic, organic or biological nature. The anchor point connecting the center point and bridging moieties can be any type covalent of bond. The overview on hybrid materials and the current trends in interfacial polymerization chemistry, that is given in Chapter 1, illustrates the broad range of suitable precursors and polymer types. The collection of polymers that can be synthesized via interfacial polymerization includes polyamides, polyurethanes, polyureas, polyanilines, polyimides, and polycarbonates. In addition, the technique has been used to prepare defect-free, ultrathin films of metal organic frameworks, organic-inorganic hybrids, and bio-hybrids. The properties of the center point, anchor point and bridge moieties can be selected to create materials with a distinct structure-property relationship, as is illustrated in Chapters 2-8.

\subsubsection{Reflections on structure-property relationships}

In this thesis, the selected center points are polyhedral oligomeric silsesquioxanes and proteins. The anchor points are imides (for the POSS based materials) and amides (for the protein based materials). The POSS provides rigidity that is required for membrane separation, while the proteins provide an active functionality (enzymatic or fluorescent activity) to the membrane layer.

\section{Poly(POSS-imide)s}

The structure-property relationships of the poly(POSS-imide)s are extensively studied in Chapters 2-6. Chapter 2 and 3 introduce the synthesis of a range of poly(POSS-imide)s. The length and flexibility of the imide bridge, given by the symbol $\mathrm{X}$ in Figure 9-2, can be varied by using different precursors during preparation. By doing so, the gas permeance and permselectivity at temperatures between $50-300{ }^{\circ} \mathrm{C}$ could be tailored. The systematic change of material structure-properties demonstrates how effective the synthesis approach is for membrane preparation. 


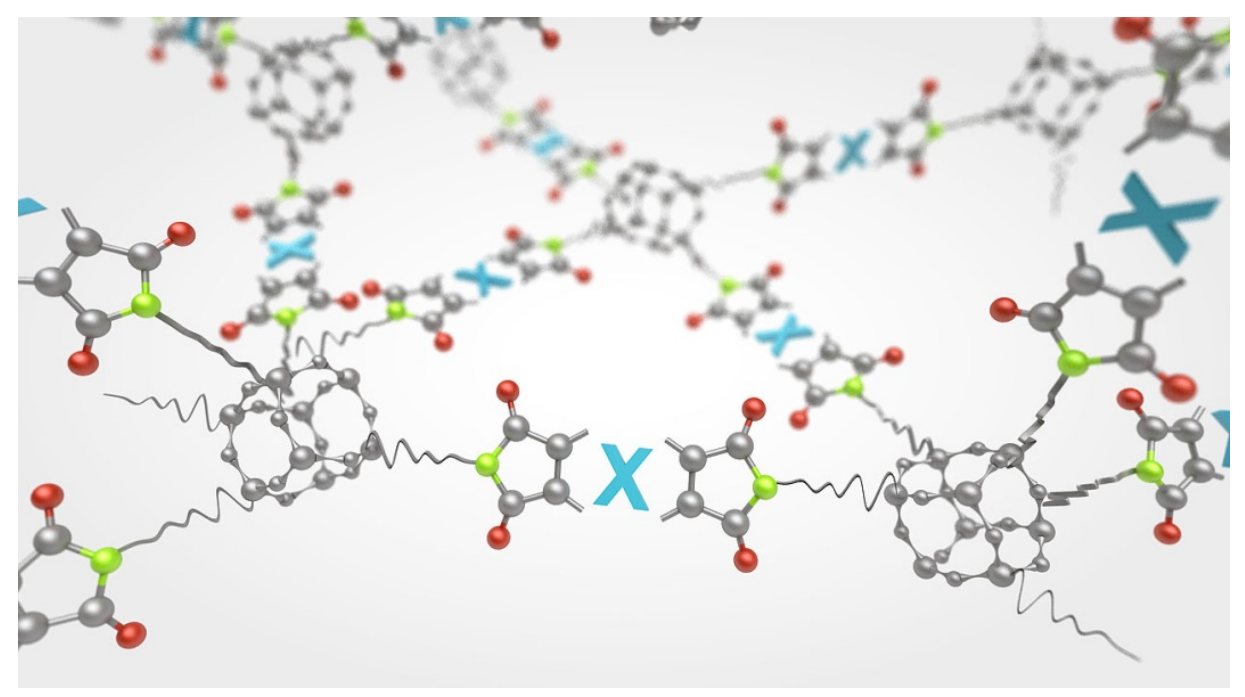

Figure 9-2. Poly(POSS-imide) network that is based on alternating POSS and imide groups.

The differences in structure-property relationships for the different bridges are further emphasized in Chapter 4. The changes in material properties during the heat treatment that is required to convert the poly[POSS-(amic acid)]s into poly(POSS-imide)s depend on the bridge length and flexibility. Moreover, the large change in chemical structure, layer thickness and refractive index demonstrates how important the heat treatment is for the properties of the poly(POSS-imide)s.

The general trend from Chapters 2-4 is clear: poly(POSS-imide)s with short imide bridges are glassy, rigid materials. Even at temperatures up to $300{ }^{\circ} \mathrm{C}$, macromolecular dynamics of the hybrid networks based on short imide bridges is limited. This is illustrated by the relatively small shrinkage during heat treatment of the poly[POSS-(amic acid)]s and the high permselectivities at a broad temperature range. Poly(POSS-imide)s with long, flexible imide bridges display a higher degree of network flexibility. Upon heat treatment, the layers allow for shrinkage that reaches up to $45 \%$ of the initial thickness. In addition, permselectivities drop at elevated temperatures due to enhanced macromolecular dynamics. Such observations are in line with other network polymers based on POSS. ${ }^{1}$

At elevated temperatures, the Van Der Waals interactions between small noncondensable gases and the membrane material are very small. At ambient temperatures, sorption of gases such as $\mathrm{CO}_{2}$ and $\mathrm{CH}_{4}$ plays a larger role in the 
gas separation properties. The temperature dependency of gas sorption is illustrated by the low apparent activation energies for $\mathrm{CO}_{2}$ permeation for a poly(POSS-imide) with an imide bridge that contains fluoroalkanes, shown in Chapter 2. The sorption behavior of the fluoroalkane based poly(POSS-imide) is further elaborated in Chapters 5 and 6 . The sorption behavior shows that the characteristics of the poly(POSS-imide)s are distinct from conventional polyimides. The membrane layers sorb large amounts of $\mathrm{CO}_{2}$ and $\mathrm{CH}_{4}$, up to an extent that the molar volume of the adsorbed gas exceeds that of the liquid molar volume of these gases. The exceedingly high gas concentrations, at elevated gas pressures, dilute the polymer matrix to such an extent, that the properties of the sorbed gas start to resemble that of the gas phase. The pronounced effect of the high $\mathrm{CO}_{2}$ sorption capacity is underlined by the increased gas diffusivity with increasing solubility, observed in Chapter 6: the swelling of the polymer decreases the resistance for diffusion, allowing for faster gas permeation.

In summary, the unique characteristics of the poly(POSS-imide)s originate from the hyper-cross-linked network structure. The spacing and molecular flexibility of the network can be adjusted by changing the imide bridge. The introduction of affinity groups such as fluoroalkanes has a pronounced influence on the behavior of the poly(POSS-imide)s. Although this thesis identifies a number of important structure-properties relationships, various questions remain. We have consistently compared to properties of the poly(POSS-imide)s with linear glassy polymers. However, it is not likely that the characteristics of network polymers are comparable to those of linear polymers. Linear glassy polymers display long-range relaxations due to the non-equilibrium state of the glassy state that decrease the free volume content in time. In network polymers, long-range reorganizations are constrained by the high degree of cross-linking, retaining the frozen-in free volume. Moreover, although the sorption isotherms at low concentrations of sorbed gas in the poly(POSS-imide) might resemble the concave sorption isotherm shape of a linear glassy polymer, completely distinct sorption phenomena are observed at high gas concentrations.

\section{Cross-linked protein layers}

Cross-linking of proteins via interfacial polymerization into an all-protein layer was performed to immobilize the proteins and to unite the protein activity with membrane performance. Both Chapter 7 and 8 demonstrate that the protein functionality can remain upon cross-linking. Chapter 7 
demonstrates that membrane performance and enzymatic activity can be combined into an ultrathin film with thicknesses around $50 \mathrm{~nm}$. The high water flux through the membranes allows for transport to the surface, where retained solutes can be degraded. Chapter 8 demonstrates that most of the proteins are immobilized (about $80 \%$ ), using similar reaction conditions as for the pepsin layers. The synthesis approach can easily be extended to other proteins, although for each individual protein careful assessment of the stability upon cross-linking is required: some proteins are more prone to unfold as compared to others.

In retrospect, the cross-linker that has been used (trimesoyl chloride) is not the most suitable one. The large number of residual carboxylic acid groups, formed by hydrolysis of unreacted acid chloride groups, indicates that steric hindrance of the proteins plays an important role in the film formation. Longer bridging molecules could potentially improve the cross-linking degree, although inter-molecular bond formation on a single protein could also increase.

The MWCO values are relatively high as compared to other nanofiltration membranes, and further optimization of the interfacial polymerization reaction conditions might be required. A simple way of improving membrane performance is the co-polymerization of other precursors that form membrane layers with a lower MWCO. In the latter case, optimization of reactant reactivity is of importance to obtain membrane layers with a desired protein content.

\subsection{Perspectives}

\subsubsection{Membrane material design for gas separation applications}

Design of a membrane material that is suitable for large-scale applications goes beyond the selection of a material with a high permeability and selectivity. Above all, the membrane material is only applicable in a membrane process if the following requirements are met:

- The membrane material must be suitable for relevant operating conditions.

- The technique used to prepare the membranes must be scalable for large surface areas. 
- Fundamental understanding of structure-property-performance relationships is required to optimize the membrane process performance.

Literature provides us with a wide array of membrane materials, of which only a very limited number is actually commercialized. In my opinion, it remains relevant to work on the development of new membrane materials. This does not only provide new candidates for membrane separation processes, but it also leads to a better fundamental understanding of the structure-property requirements for desired membrane performance. By systematically characterizing a large number of material candidates, we can come up with design rules for membranes that are fit for large-scale processes. Relevant work has been done in the past, including the realization that membranes display an inherent trade-off between permeability coefficient and selectivity (ref Robeson). The realization that the trade-off can be shifted by playing with the frozen-in free volume content of the material has surged the development of new material concepts such as polymers of intrinsic microporosity (PIMs), ${ }^{2-}$ 5 thermally rearranged (TR) polymers $^{6-9}$ and substituted polyacetylenes. ${ }^{10}$ Nonetheless, a number of membrane design criteria is often overlooked by solely focusing on high permeability and selectivity:

- Permeance is the permeability coefficient divided by thickness. Thus, a membrane needs to be ultrathin to minimize the membrane surface area required for permeation.

- The membrane layer must remain stable in the presence of penetrants over long periods of time. Particularly ultrathin films of highly permeable, high free volume polymers are prone to changes by physical ageing or plasticization.

- Permeability depends on temperature. With increasing temperature, the diffusivity increases, but the solubility decreases. Therefore, the changes in permeability with temperature are not straightforward.

These criteria impose a set of characteristics on the membrane; the high selectivity and permeability, in combination with long-term stability at high temperatures and high penetrant pressures, can only be accomplished by design of a membrane with an extremely glassy character. The high degree of frozen-in free volume that is required for membrane performance needs to be frozen in by the rigidity of the material matrix. This poses the ultimate challenge: how can we produce a defect-free, ultrathin membrane layer that 
has a large, frozen-in free volume. Here, interfacial polymerization is proposed as an ideal starting point to meet the demands of membrane preparation for gas separation applications. The technique allows for preparation of defect-free ultrathin layers that consist of polymer networks. The (hyper-cross-linked, hybrid) polymer network constrains long-range polymer chain reorganizations that are responsible for loss of membrane performance by ageing and plasticization in conventional polymeric membranes.

The preparation and optimization of a hyper-cross-linked network is not straightforward. In this thesis, we have optimized the gas separation performance with a number of parameters: monomer reactant type, concentration and reactivity. In addition, two completely different membrane types (i.e., hybrid inorganic-organic and bio-hybrids) have been prepared. Here, we identify a number of critical parameters that determine the properties of the network.

- Number of functional groups on each of the reactants. The degree of branching of the network depends strongly on the number of reactive groups on the monomer reactants. A higher degree of branching can be expected from reactants with a higher number of reactive groups. However, a higher number of reactive groups will also result in more unreacted groups. The poly(POSS-imide)s of Chapters 2-6 had around $50 \%$ unreacted amine groups. The pepsin-TMC layers contained a large number of unreacted carboxylic acid groups. The number of optimal groups might well be in between 2-4 functional groups per reactant. Preferably, one of the reactants should have only 2 reactive functional groups.

- Monomer reactivity. A high monomer reactivity will result in faster film formation. For monomer reactants with low reactivity, such as pepsin, the layer growth is slow. Therefore, higher reactant concentrations are generally required for successful film formation in case the monomer reactivity is low.

- Size of the reactant. The size of the reactants will be reflected in the membrane performance. Two large reactants will form a more open membrane layer due to steric hindrance of the reactants. This is reflected by the high MWCO of cross-linked pepsin membranes, whereas smaller molecules such as POSS allow separation performance in gas separation applications. 
- Monomer influence on the interface. Proteins consist of both hydrophilic and hydrophobic group, and are known to assemble at the interface. Layer formation and membrane properties are strongly dependent on the surfactant type and concentration. ${ }^{11}$

- Length and flexibility of the bridging group. Chapter 3 and 4 clearly illustrate the influence of the length and flexibility on membrane properties. Distinct properties can be expected from materials that have longer, more flexible bridges. While the poly(POSS-imide)s display glassy characteristics, one could design a more rubbery-like network using longer precursors.

- Side groups have a different effect on layer properties as bridging groups. In particular, side groups such as fluoroalkanes that influence the electronegativity will have a large impact on layer properties.

- Type of chemistry. The range of monomer reactants that can be used for interfacial polymerization is practically unlimited (Chapter 1). The center point, anchor point and bridge rigidity, hydrophilicity and chemical affinity can be predicted from polymeric counterparts. In addition, the chemical and thermal stability will depend on the type of groups, either aliphatic or with aromatic or other resonance structures.

Although these parameters provide guidelines for rational design of hypercross-linked networks, optimization of the reaction conditions for each individual combination of monomer reactants is required. Moreover, a fair comparison of membrane layers prepared via interfacial polymerization can only be accomplished by comparing structure-property-performance relationships, and not by solely comparing membrane performance data.

\subsubsection{Structure-property-performance relationships}

Fundamental knowledge on structure-property-performance relationships of the membrane material in a process is imperative for the determination of key material parameters. Often, a new membrane material is prepared and its permeability and selectivity are determined. This is particularly the case for membranes prepared via interfacial polymerization. Commonly, polyamides prepared via interfacial polymerization are characterized in terms of salt rejection or MWCO, water permeance, structure analysis by for example infrared spectroscopy or Rutherford backscattering spectrometry ${ }^{12}$ and layer morphology. This allows for empirical data analysis (e.g. a higher layer roughness results in higher water permeability, or precursor A gives better 
membranes than precursor B), but provides limited mechanistic insight into the membrane system. The difficulty in analysis of the membrane layers prepared via interfacial polymerization lies in the ultrathin nature of the films. Whereas most polymers can easily be prepared and analyzed as thin film and in bulk, preparation of mg sample masses of interfacial polymerization layers (of sub$\mu \mathrm{m}$ thickness) is already a tedious task. The systematic structure-property analysis is further complicated by the rough morphology and the asymmetric nature of such ultrathin films. Synthesis of free-standing films is possible, and allows for synthesis of larger samples masses. However, it is questionable whether the layer properties of a free-standing film are similar to a layer prepared on a porous support. While film formation on top of a porous support results in a $100 \mathrm{~nm}$ layer thickness, we could obtain $\mu \mathrm{m}$-thick films by free-standing film formation using similar reaction conditions. It is therefore preferential to characterize layers prepared via interfacial polymerization by using techniques that are applicable for thin films.

The only manner to obtain knowledge on the structure-property-performance relationships, is to combine membrane performance measurements with another in-situ characterization technique. Although simultaneous measurements are not a prerequisite, careful simulation of the membrane operating conditions is key to obtain accurate data. Because the temperature and presence of a penetrant (at a certain concentration and pressure) are of great influence on the membrane properties, we should accustom ourselves to measuring the membrane material properties at these conditions. In this thesis we have extensively analyzed the membrane thickness and refractive index (as an analogue to the layer density) by using spectroscopic ellipsometry at elevated temperature and pressure conditions (Chapters 4, 5 and 6). Although this provided useful insight on the membrane material properties in contact with a single component, the data will not reflect the membrane behavior under mixed feed conditions. The discrepancies between single and mixed gas experiments originates from effects such as:

- Competitive sorption and diffusion. The sorption and diffusion of a components is influenced by other components. Permeance of one component might decrease due to preferential sorption of the other component. Alternatively, the permeance might increase due to swelling induced by another component.

- Concentration polarization. Membranes preferentially permeate one component over the other. In doing so, the retained component is 
concentrated at the membrane surface. The concentration reduction of the permeating component decreases the driving force, and reduces process selectivity and permeability of the preferential component.

- Pressure ratio effects. when the ideal membrane selectivity is much larger than the pressure ratio across the membrane, the process can be in a pressure-ratio-limited regime. The process selectivity will therefore limit the separation, and the intrinsic membrane material selectivity will be irrelevant. ${ }^{13}$

- Stage-cut. The purity of the permeating and retained components are coupled by the membrane process selectivity. Along the length of the membrane, the selectivity can change due to competitive sorption, concentration polarization and pressure ratio effects. The driving force of the permeating component will only decrease across the membrane length, and therefore the permeance and selectivity will also drop along the membrane length. It is therefore crucial to establish the specifications of the retained and permeating components, and to verify whether these can be matched with the given process parameters.

Although membrane material researchers focus on ever-higher membrane permeance and selectivity, the process can be limiting the final membrane performance. It is therefore key to design a membrane material with respect to a specific process. Future research should focus more on the interaction of penetrants with the membrane material, at relevant temperatures and pressure conditions. Spectroscopic ellipsometry is an excellent tool to measure the changes in thickness and refractive index as function of time, temperature, pressure and penetrant type. The technique allows for estimation of penetrant fractions, molar volumes and changes in the polymer as function of time. Nonetheless, it does not give direct information on the physical properties such as macromolecular chain dynamics and the visco-elastic properties of the material. Techniques that allow for direct measurement of the physical properties of ultrathin films are:

- Atomic force microscopy (AFM) measures the interaction between a surface and a nano-sized probe. By using different modes (contact, tapping, non-contact) the surface roughness, mechanical properties and adhesion properties can be determined. AFM can be performed in an liquid or gas atmosphere, and can therefore be used to track in situ changes in ultrathin films. 
- Dielectric relaxation spectroscopy (DRS) measures the dielectric response of an ultrathin film at a broad frequency range $\left(10^{2}-10^{10} \mathrm{~Hz}\right)$. The dielectric response is a function of the electronic, atomic and molecular interactions within a system. In particular, the changes in inter- and intra-molecular chain interactions at elevated temperature and by presence of a penetrant provide mechanistic insight on physical behavior of (network) polymers.

- Quartz crystal microbalance (QCM) measures the visco-elastic response of a material that is coated on a resonating quartz crystal. The frequency dependency of the response can be measured in-situ and in the presence of a liquid or gas atmosphere.

In-situ measurement of the thin membrane film properties can be used for optimization of the membrane material properties. After optimization of the physical and chemical properties of the membrane, scale-up of the membrane preparation can be optimized.

\subsubsection{Scale-up the membrane production process}

All commercial membrane processes require a relatively large surface area. A single disposable hemodialysis module contains about $1.5 \mathrm{~m}^{2}$ of surface area, and yearly $>360$ million $^{14}$ of such modules are produced (with an ultrathin, defect free separation layer on a robust substrate with a high specific surface area!). Reverse osmosis plants operate modules of $35 \mathrm{~m}^{2}$ each, and total membrane surface areas can range up to multiple thousands of square meters.

- Membranes need to be defect-free to get a process selectivity that resembles the intrinsic membrane selectivity, for gas separation in particular. Defects are more likely to occur when the membrane layer is ultrathin.

- Ultrathin membranes need to be mechanically supported by a robust, porous substrate with a high specific surface area.

Interfacial polymerization allows for defect-free layer synthesis with potentially unlimited lateral dimensions. Membrane preparation via interfacial polymerization can be performed on hollow fibers and on planar supports that are used in spiral wound modules. Interfacial polymerization is most commonly employed for spiral wound membrane modules, because the layers are mainly used for aqueous applications. However, for gas separation 
applications a hollow fiber configuration is often more suitable, due to the higher surface-to-volume ratio of such a configuration.

Hollow fibers are commonly prepared via dry-wet spinning of a polymer solution into a non-solvent containing coagulation bath. At the right conditions, an asymmetric gas separation membrane that consists of a porous substructure and a thin, dense top layer can be obtained. Alternatively, one could prepare a gas separation membrane by using a porous hollow fiber or tube as a substrate for an interfacial polymerization reaction. For this purpose, we have done preliminary tests on membrane performance of poly(POSSimide)s prepared via interfacial polymerization on tubular ceramic supports. Figure 9-3 shows the hydrogen/nitrogen permselectivity as function of the hydrogen permeance. Clearly, the permselectivities that are obtained for tubular supports are lower as compared to the planar supports, while the permeances through the tubular supports are much higher.
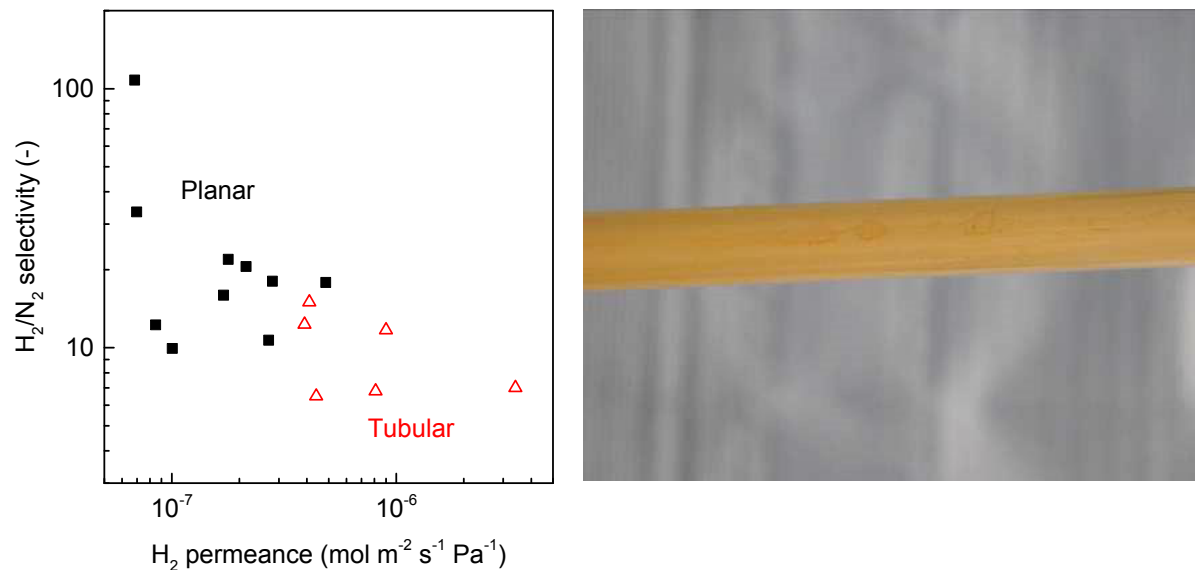

Figure 9-3. (left panel) Hydrogen/nitrogen permselectivity as function of the hydrogen permeance, for poly(POSS-imide)s prepared on planar (black squares) and tubular (red triangles). (right panel) Image of the $\gamma$-alumina coated $\alpha$-alumina tubes with a poly(POSS-imide layer). The yellow-brown color is characteristic for the poly(POSS-imide) layers. Layer thicknesses are about $50-300 \mathrm{~nm}$.

The differences in membrane performance can be caused by a number of reasons:

- The heat treatment of the planar supports was done on the same day as the membranes were prepared. The tubular supports were heat treated 
several days after preparation. In case of the tubular supports, poly(amic acid) hydrolysis could have altered the membrane performance. ${ }^{15}$

- The pore size distribution of the $\gamma$-alumina layers used on the tubular supports might be different from the planar membranes. The pore size is known to influence the membrane performance of layers prepared via interfacial polymerization. ${ }^{16}$

- The planar supports are coated with two $\gamma$-alumina layers, while the tubular supports are only coated with a single $\gamma$-alumina layer. The number of defects can therefore be higher in the tubular supports. Defects are detrimental for the membrane permselectivity.

Further optimization of interfacial polymerization reaction parameters will be required for the preparation of poly(POSS-imide) membranes on tubular supports. The critical parameters that determine the membrane performance have to be determined by systematic investigation of reactant concentrations, support pore size (distribution) and poly(amic acid) stability prior to the heat treatment.

Although tubular supports are suitable for membrane gas separation application, they have a relatively high cost price $^{17}$ and low surface-to-volume ratio with respect to hollow fibers. A higher surface to volume ratio can be accomplished using ceramic or metallic hollow fiber membranes. ${ }^{18,}{ }^{19}$ In addition, by substituting the heat treatment at $300{ }^{\circ} \mathrm{C}$ that is necessary to convert the poly[POSS-(amic acid)] precursor into poly(POSS-imide) with a chemical imidization $\operatorname{step}^{20}$ it is possible to use polymeric hollow fiber membranes as support.

\subsection{Conclusions}

Membrane development requires both fundamental material development and process knowledge. The integral design process is key for successful implementation of membranes in large-scale separation processes. In this thesis, we presented a generic synthesis route for preparation of hyper-crosslinked, hybrid membranes. Future research should move towards extension of the generic synthesis route for other material types and the testing of the membrane materials at relevant process conditions. 


\subsection{References}

1. Choi, J.; Tamaki, R.; Kim, S. G.; Laine, R. M. Chemistry of Materials 2003, 15, (17), 3365-3375

2. Budd, P. M.; Elabas, E. S.; Ghanem, B. S.; Makhseed, S.; McKeown, N. B.; Msayib, K. J.; Tattershall, C. E.; Wang, D. Advanced Materials 2004, 16, (5), 456-459

3. Hashem, M.; Bezzu, C. G.; Kariuki, B. M.; McKeown, N. B. Polymer Chemistry 2011, 2, (10), 2190-2192

4. Budd, P. M.; McKeown, N. B.; Fritsch, D. Journal of Materials Chemistry 2005, 15, (20), 1977-1986

5. Bezzu, C. G.; Carta, M.; Tonkins, A.; Jansen, J. C.; Bernardo, P.; Bazzarelli, F.; McKeown, N. B. Advanced Materials 2012, 24, (44), 5930-5933

6. Han, S. H.; Misdan, N.; Kim, S.; Doherty, C. M.; Hill, A. J.; Lee, Y. M. Macromolecules 2010, 43, (18), 7657-7667

7. Han, S. H.; Kwon, H. J.; Kim, K. Y.; Seong, J. G.; Park, C. H.; Kim, S.; Doherty, C. M.; Thornton, A. W.; Hill, A. J.; Lozano, Á. E.; Berchtold, K. A.; Lee, Y. M. Physical Chemistry Chemical Physics 2012, 14, (13), 4365-4373

8. Sanders, D. F.; Smith, Z. P.; Ribeiro, C. P.; Guo, R.; McGrath, J. E.; Paul, D. R.; Freeman, B. D. Journal of Membrane Science 2012, 409-410, 232-241

9. Calle, M.; Doherty, C. M.; Hill, A. J.; Lee, Y. M. Macromolecules 2013, 46, (20), 8179-8189

10. Consolati, G.; Genco, I.; Pegoraro, M.; Zanderighi, L. Journal of Polymer Science, Part B: Polymer Physics 1996, 34, (2), 357-367

11. Mansourpanah, Y.; Madaeni, S. S.; Rahimpour, A. Journal of Membrane Science 2009, 343, (1-2), 219-228

12. Matthews, T. D.; Yan, H.; Cahill, D. G.; Coronell, O.; Mariñas, B. J. Journal of Membrane Science 2013, 429, (0), 71-80

13. Wijmans, J. G. Journal of Membrane Science 2003, 220, (1-2), 1-3

14. Krause, B., Keynote lecture 1: "Membranes in Medical Applications". Gambro Dialysatoren GmbH: NMG-DMG-BMG meeting, Aachen, 2015.

15. Kreuz, J. A. Journal of Polymer Science Part A: Polymer Chemistry 1990, 28, (13), 3787-3793

16. Hermans, S.; Bernstein, R.; Volodin, A.; Vankelecom, I. F. J. Reactive and Functional Polymers 2014, 86, 199-208

17. Pera-Titus, M. Chemical Reviews 2014, 114, (2), 1413-1492

18. Luiten-Olieman, M. W. J.; Raaijmakers, M. J. T.; Winnubst, L.; Bor, T. C.; Wessling, M.; Nijmeijer, A.; Benes, N. E. Journal of Membrane Science 2012, 407-408, 155-163

19. Luiten-Olieman, M. W. J.; Raaijmakers, M. J. T.; Winnubst, L.; Wessling, M.; Nijmeijer, A.; Benes, N. E. Scripta Materialia 2011, 65, (1), 25-28

20. Kailani, M. H.; Sung, C. S. P. Macromolecules 1998, 31, (17), 5779-5784 


\section{Dankwoord}

Mijn proefschrift is mede tot stand gekomen door de productieve en prettige samenwerking met collega's van de vakgroep anorganische membranen en andere vakgenoten uit de hele wereld. In my personal view, the group of experts that has been closely involved in my research have been a great contribution to the originality and quality of this thesis.

Ik heb grote waardering voor de inspanningen van mijn begeleider, prof. dr. ir. Nieck Benes, die de basis heeft gelegd voor dit onderzoek. Nieck, je hebt een prachtig team aan onderzoekers weten te verzamelen, en een unieke infrastructuur op het lab opgebouwd waarmee inzicht in de fundamentele aspecten van dunne (membraan)lagen kan worden verkregen. De positie die je nu inneemt op de Universiteit Twente, als hoofd van de Films in Fluids groep, komt je dan ook terecht toe. Je bezit een scherpte die het mogelijk maakte om het meeste uit mezelf te halen, en je schroomde niet om de verwachtingen voor mij en mijn onderzoek hoog te houden. Nieck, your contributions are appreciatively acknowledged.

Mijn promotietraject binnen IM en het CARENA project is mede mogelijk gemaakt door prof. dr. ir. Arian Nijmeijer. Arian, je sterke management en positieve inslag hebben er altijd voor gezorgd dat er een goede, constructieve sfeer was binnen de groep. Het is mooi om te zien dat je altijd energie over had voor de groep (of juist ervan kreeg), naast je vele verantwoordelijkheden voor Shell op de meeste afgelegen locaties wereldwijd. Ik ken weinig mensen die zowel voet op een booreiland mogen zetten, en zich met enig gemak tussen de fundamentele wetenschappers begeven (als dat überhaupt al mogelijk is). Ik ben ervan overtuigd dat we elkaar in de toekomst nog met enige regelmaat zullen tegenkomen.

I have experienced much pleasure in working within the Inorganic Membranes group. My thanks go out to the staff, technical support and fellow researchers. Henny en Louis, ik heb altijd met interesse gevolgd wat jullie aan het onderzoek op het gebied van anorganische materialen bijdragen. Ondanks dat mijn onderzoek voor een groot deel op polymeerchemie is gebaseerd, heb ik toch vaak met jullie van gedachten kunnen wisselen. Mieke, met erg veel plezier heb ik onder jouw begeleiding mijn Master thesis op het gebied van stalen holle vezels afgerond. Het gemak waarmee je in het lab iets nieuws probeert en de energie die je toont om je praktische vaardigheden over te dragen zijn bemoedigend geweest voor een niet zo praktisch ingesteld persoon 
als ikzelf. Frank en Cindy, niet alleen bedankt voor de experimentele ondersteuning, maar ook voor de Twente grapjes (die ik vaak niet meteen begreep als Brabander), futsal, de Engelse drop en nog meer details die het dagelijks onderzoek aangenaam maakten.

All PhD's share a great deal of experiences, including the daily peaks and setbacks, surges of creativity and brilliance, and the difficulties of managing a multi-year project at your own responsibility. I have had the pleasure to work with a very mixed group of PhD's, which has taught me many things about the differences in intrinsic motivation, how one approaches problems and what you need for an effective cooperation. Emiel, by far you have been the largest contribution in all these learnings. The number of discussions we had are maybe only surpassed by the confusion our names caused (or did we cause the confusion?). Als "de Iels" waren we een team, altijd bereid om iets verder uit te denken en te optimaliseren. Ik genoot altijd van de momenten dat je zei: "Michiel, jij bent toch zo slim hè?" Om me uit te dagen binnen enkele minuten een vraagstuk op te lossen waar je zelf al een paar uur mee bezig was. Ondanks de substantiële afstand tussen Deventer en Frankfurt en het gegeven dat je voor de concurrent werkt, houden we zeker contact!

Wojciech, you definitely created an additional dimension to my path towards promotion (if not more than just one - if only we had the means to measure those!). You brought a lot of fun into the science we did, and you taught me so many things about polymers, physics and ellipsometry. Even at the end of my $\mathrm{PhD}$ you kept the learning curve steep, due to the vast knowledge you have gathered during your own scientific journey.

Evelien, you were the person that challenged me the most in the last year: you have an eye for detail and you always dare to ask (more) critical questions. Your strong rationale exemplifies how good a researcher you are, and I am sure you will manage just fine in these four (short) years. Keep up the enthusiasm you always show when working on something new, because it works contagiously. Kristianne, thanks for the positive attitude you have. It has been a pleasure teaching you the inside-outs of ellipsometry and polymer physics. Soon you will have more knowledge than I, and I will be the questioning you.

Marcel, thanks for always having my back during difficult experimental work and your patience to see whether things would work out. Bas, you are always down-to-earth (is that a regional thing?!) and I enjoyed that. You are always 
up for a good talk, topped with a good deal of humor and some sarcasm. Patrick, you always amazed me with the next unexpected thing you managed to do in the lab or out in the field. You always made office-life interesting and lively. Sushumna, I had a lot of fun working with you - and I am happy we can stay in touch over this long distance. Giri, Wei-Chen, Martin, Chung-Yul, Hammad, Ana, Rian, Cheryl - it has been interesting to work alongside you, and I took a great deal of learnings from the contact we had over the years. I have had the pleasure to supervise Bachelor and Master students during my PhD. Mitchel, Lynn and Wouter, many thanks for the useful insights you provided and the pleasant cooperation. I am proud of the work that you managed to do in the - too short - timespan of these assignments.

At the University of Twente I worked together with a number of researchers from other research groups. Harro, as fellow CARENA project $\mathrm{PhD}$ you were always first in line with figuring out the project procedures and the whether the targeted application of the membranes that we developed were in reach. Thanks for all the discussions and exchange of thoughts we had over the years. Yali, it was always a pleasure to work with you on interfacial polymerization related things, or just to have a fun conversation on the way to the coffee corner. Rob and Kitty, thanks for the time I could spend on the laboratories of your groups. Also thanks for your help in deciding whether and where I should do a PhD. All the other SFI and MST members, thanks for the enjoyable moments we shared.

My special thanks go to all the co-authors of the work that is presented in this thesis.. I have had the pleasure to work together with many researchers from the AVT-CVT and DWI of the RWTH Aachen in Germany. Thomas and Monika, thanks for your persistent effort in repeating experiments and discussing the results for the enzymatically active pepsin films. Martin and Burkhard, thanks for the help with the gas sorption equipment. Matthias, thanks for all the support in the discussion we had over the years, and the unlimited access you provided for working with your group and on your laboratories. Your enthusiasm and creativity have been an inspiration for me, and I appreciate all the scientific and personal feedback you have given me. Aditya, Martijn, Christian, Vinod, thanks for all the effort you placed in the fluorescent proteins layers. This was by far the area in which I was least comfortable at the start of the project, but you helped to overcome all the gaps in my knowledge 
All others from Aachen (Lars, John, Kurt, Serafin, Sebastian, Theresa, Tobias, Tim, Hans, Stefanie, Florian and more!), thanks for all the times I could stay in Aachen for work at the RWTH and enjoy dinner or party with you. You always gave me a genuine feeling of being welcome. I enjoyed all the Winterschool experiences we shared over the years. I hope we will stay in touch somehow - as colleagues within the field of chemical engineering and as friends.

Although not included in my thesis, I had the opportunity to work with researchers from TU Delft (Theo, Zeljka, Wouter), Institut Européen des Membranes (Anne, Martin), Université de Savoie (David, Sylvie), CSIRO (Anita). I would like to acknowledge the positive collaboration between our groups. Further help and learnings came from discussions with numerous fellow PhDs, and many, many others. Thanks to all of you!

Mijn familie is altijd een grote bron van ondersteuning en fijne momenten geweest door de jaren heen. Papa en mama, bedankt voor al het vertrouwen dat jullie altijd hebben in mij. Mijn broers, Erik, Paul, Ruud, bedankt voor de goede band die we delen. Ik geniet van alle tijd die we samen kunnen doorbrengen, ook met Melanie, Sandra \& Marleen en Hanneke.

Ik heb altijd veel steun ondervonden van mijn vrienden, die me altijd weer energie weten te geven met een leuke avond uit, een lang weekend rapujuhlat of gewoon een gezellig bezoek in Den Haag, Amsterdam, Deventer, Enschede of ergens anders in Nederland. In het bijzonder dank aan Inge, voor het ontwerp van de omslag van mijn proefschrift.

De meest belangrijke bijdrage aan mijn thesis is geleverd door Karin. Je bent de dierbaarste persoon in mijn leven. Alle energie die je me geeft is de grote drijvende kracht geweest achter mijn vasthoudendheid om mijn promotie tot een succes te maken. Je enthousiaste en slimme persoonlijkheid is een aanvulling op, en ook een voorbeeld voor mij. Het Michelangelo-effect gaat ook op voor doorzettingsvermogen, sociale vaardigheden en persoonlijke presentatie. Waar wij staan, is omdat we dat samen hebben bereikt - en dat belooft alleen maar goeds voor de toekomst! 


\section{Curriculum Vitae}

Michiel Raaijmakers was born on 11 May 1987 in Geldrop, the Netherlands. In 2005, he obtained his vwo-diploma at the Strabrecht College in Geldrop. In the same year, he started his bachelor studies in Chemical Engineering at the University of Twente. During these years, he was active as board member for the Erasmus Student Network Twente, worked for the International Office of the University of Twente for the Erasmus programme and was active in the organization of the study tour of C.T.S.G. Alembic to Malaysia and Singapore. For his contributions to the Erasmus programme in the Netherlands, he was awarded the Erasmus student award in 2012. In 2008, he performed his bachelor thesis at the Universitat de Barcelona in in Spain. After his bachelor studies he started with the master Chemical Engineering at the University of Twente, in the track Process Technology. In 2010, he performed a four-month professional internship at Vaperma Inc. in Quebec City, Canada. In 2011, he graduated cum laude from the University of Twente on a master thesis entitled: Development of stainless steel hollow fiber membranes with small radial dimensions. He was awarded the Unilever Research Price for his Master thesis.

Starting from November 2010, he has been working as a PhD candidate at the Inorganic Membranes group at the University of Twente, under the supervision of prof.dr.ir. Nieck E. Benes. He presented his research at multiple international conferences and workshops, including the International Membrane Science and Technology conference (IMSTEC, 2014) in Melbourne, Australia and Euromembrane (2015) in Aachen, Germany. In addition, he has co-organized a number of scientific meetings, including the Gordon Research Seminar (GRS, 2014) on Membranes, Materials and Processes. 


\section{List of publications}

Per August 2015

\section{Peer-reviewed international journals}

2015 Macromolecules. Thermal imidization kinetics of ultrathin films of hybrid poly(POSS imide)s. DOI: 10.1021/acs.macromol.5b00473

2015 Angewandte Chemie International Edition. Enzymatically Active Ultrathin Pepsin Membranes. DOI: 10.1002/anie.201411263

2015 Thermochimica Acta. Temperature calibration procedure for thin film substrates for thermo-ellipsometric analysis using melting point standards. DOI: 10.1016/j.tca.2014.12.017

2014 Chemistry of Materials. Hybrid polyhedral oligomeric silsesquioxanes-imides with tailored intercage spacing for sieving of hot gases. DOI: 10.1021/cm500691e

2014 Journal of the American Chemical Society. Sieving of hot gases by hyper-cross-linked nanoscale-hybrid membranes. DOI: $10.1021 / \mathrm{ja} 410047 \mathrm{u}$

2013 Patent. Highly crosslinked hybrid polyimide-silsesquioxane membranes. WO 2015030594 A1

2012 Journal of Materials Chemistry. Ultra-thin hybrid polyhedral silsesquioxane-polyamide films with potentially unlimited 2D dimensions. DOI: 10.1039/C2JM31941A

2012 Journal of Membrane Science. Towards a generic method for inorganic porous hollow fibers preparation with shrinkagecontrolled small radial dimensions, applied to $\mathrm{Al}_{2} \mathrm{O}_{3}, \mathrm{Ni}, \mathrm{SiC}$, stainless steel, and YSZ. DOI: 10.1016/j.memsci.2012.03.030

2011 Scripta Materialia. Porous stainless steel hollow fibers with shrinkage-controlled small radial dimensions. DOI: 10.1016/j.scriptamat.2011.03.023

2011 Ozone: Science \& Engineering. Influence of high salinity on the degradation of humic acid by $\mathrm{UV}_{254}$ and $\mathrm{H}_{2} \mathrm{O}_{2} / \mathrm{UV}_{254}$. DOI: 10.1080/01919512.2012.649998 


\section{Selected oral presentations}

\begin{tabular}{ll}
\hline 2015 & M.J.T. Raaijmakers, W. Ogieglo, M. Wessling, A. Nijmeijer, \\
& N.E. Benes, Hybrid inorganic-organic gas separation \\
& membranes, Euromembrane 2015, Aachen, Germany. \\
& M.J.T. Raaijmakers, Z. Maradzevic, W. Ogieglo E.J. Kappert, \\
T. Dingemans, N.E. Benes. Thermal imidization of \\
polyimides studied by in-situ thermal analyses. Workshop \\
Spectroscopic Ellipsometry 2015 (WSE 2015), Enschede, \\
Netherlands. \\
Nanostructured polyhedral oligomeric silsesquioxane hybrid \\
membranes, International Membrane Science and \\
Technology Conference (IMSTEC), Melbourne, Australia. \\
M.W.J. Luiten, M.J.T. Raaijmakers, A.J.A. Winnubst, T. Bor, \\
M. Wessling, A. Nijmeijer, N.E. Benes, Inorganic porous \\
hollow fiber membranes: generic method for small radial \\
dimensions, Euromembrane 2015, Londen, United Kingdom.
\end{tabular}

